UNIVERSIDADE DE SÃO PAULO

FRANCIELE PEREIRA CAMARGO

CARACTERIZAÇÃO TAXÔNOMICA E FUNCIONAL DA COMUNIDADE MICROBIANA ENVOLVIDA NA OBTENÇÃO DE BIOGÁS E OUTROS COMPOSTOS DE INTERESSE BIOTECNOLÓGICO A PARTIR DE RESÍDUOS DO PROCESSAMENTO DE CITROS/LARANJA 



\section{CARACTERIZAÇÃO TAXÔNOMICA E FUNCIONAL DA COMUNIDADE MICROBIANA ENVOLVIDA NA OBTENÇÃO DE BIOGÁS E OUTROS COMPOSTOS DE INTERESSE BIOTECNOLÓGICO A PARTIR DE RESÍDUOS DO PROCESSAMENTO DE CITROS/LARANJA}

Tese apresentada à Escola de Engenharia de São Carlos da Universidade de São Paulo, como parte dos requisitos necessários para obtenção do título de Doutora em Ciências: Engenharia Hidráulica e Saneamento.

Orientadora: Dra. Maria Bernadete Amâncio Varesche Co-orientadora: Dra. Iolanda Cristina Silveira Duarte

VERSÃO CORRIGIDA

São Carlos-SP 
AUTORIZO A REPRODUÇĀO TOTAL OU PARCIAL DESTE TRABALHO POR QUALQUER MEIO CONVENCIONAL OU ELETRÓNICO, PARA FINS DE ESTUDO E PESQUISA, DESDE QUE CITADA A FONTE.

Ficha catalográfica elaborada pela Biblioteca Prof. Dr. Sérgio Rodrigues Fontes da EESC/USP com os dados inseridos pelo(a) autor(a)

Camargo, Franciele pereira
c172c Caracterizaçăo taxônomica e funcional da

comunidade microbiana envolvida na obtençăo de biogás e outros compostos de interesse biotecnologico a partir

de residuos do processamento de citros/laranja /

Franciele pereira Camargo; orientadora Maria Bernadete

Amancio Varesche; coorientadora Iolanda Cristina

Silveira Duarte. Såo Carlos, 2021.

Tese (Doutorado) - Programa de pós-Graduaçăo em Engenharia Hidrálica e Saneamento e Area de

Concentraçao em Hidráulica e Saneamento -- Escola de Engenharia de sao Carlos da Universidade de sao Paulo, 2021 .

1. Acetogênese. 2. Biomassa lignocelul6sica. 3. Caracterizaça metataxonomica. 4. Limoneno. 5.

Metagenomica shotgun. 6. Planejamento Fatorial. I. Titulo.

Eduardo Graziosi Silva - CRB - 8/8907 


\section{FOLHA DE JULGAMENTO}

Candidato: Licenciada fRANCIELE PEREIRA CAMARGO.

Titulo da tese: "Caracterizaçāo taxônomica e funcional da oblençāo de biogás e outros compostos de interesse biotecnológico a partir de residuos do processamento de citros/laranja".

Data da defesa: $11 / 103 / 2021$

\section{Comissão Julgadora}

\section{Resultado}

Profa. Associada Maria Bernadete Amancio Varesche Silva (Orientadora)

(Escola de Engenharia de Sŏo Carlos/EESC-USP)

Prof. Titular Marcelo Zaiat

[Escola de Engenharia de Sōo Carlos/EESC-USP)

Profa, Dra. Tânia Forster Carneiro

(Universidade Estadual de Campinas/UNICAMP)

Profa. Dra, Silvana de Queiroz Silva

(Universidade Federal de Ouro Preto/UFOP)

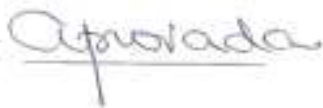

Profa. Dra. Fabiana Fantinatti Garboggini

(Universidade Estadual de Campinas/UNICAMP)
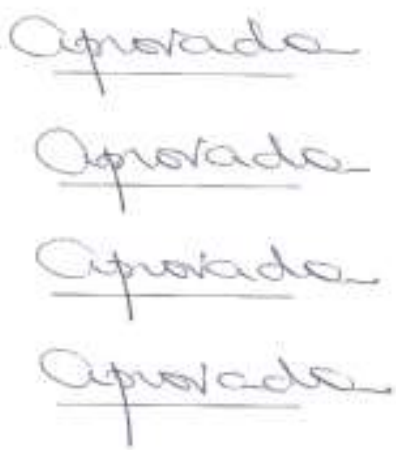

Coordenador do Programa de Pós-Graduaçào em Engenharia Hidrálica e Saneamento:

Prot. Dr. Eduardo Mario Mendiondo

Presidente da Comissão de Pós-Graduaçāo:

Prof. Titular Murilo Araujo Romero 



\section{Dedicatória}

A todos os brasileiros que, mesmo em tempos difíceis, continuam acreditando e lutando pela pesquisa científica e pelo ensino público de qualidade em nosso país. 



\section{AGRADECIMENTOS}

Aqueles que realizaram um doutorado sabem que nem sempre é fácil ou divertido, e que, definitivamente, não é possível ter sucesso sem muito apoio, ajuda, orientação, compreensão, companheirismo e incentivo das pessoas a seu redor. Mas estes sabem também que poucas coisas neste caminho são mais gratificantes que olhar para trás e ver que nada disso ficou em falta. Aproveito esta seção para humildemente mencionar as pessoas que me proporcionaram este enorme sentimento de gratidão.

À minha orientadora, Prof. Dr. Maria Bernadete Amâncio Varesche, pela confiança depositada em mim ao longo dos anos, correção minuciosa dos trabalhos e apoio nas dificuldades enfrentadas ao longo da pesquisa. À minha co-orientadora, Prof. Dr. Iolanda Silveira Duarte, a todo o auxílio prestado e a recomendação à Prof. Bernadete. Ao Prof. Dr. Edson Luiz Silva (Tininho), a grande participação em minha pesquisa e colaboração ao longo do processo de escrita.

Ao imensurável apoio técnico de Maria Ângela Adorno, Carolina Sabatini, Isabel Sakamoto, Eloisa Pozzi, Juliana Custódio e Fernando Moura, por toda ajuda, colaborações e agradável convivência nestes anos. Aos professores do Laboratório de Processos Biológicos (LPB), Prof. Dr. Eugênio Foresti e Marcelo Zaiat, as enriquecedoras discussões durante as pausas para o café.

A Université Paris-Saclay, Institut National de Recherche pour l'Agriculture, l'Alimentation et l'Environnement (IRSTEA/INRAE), e a todo grupo de pesquisa PRocédés biOtechnologiques au Service de l'Environnement (PROSE), a gentileza e carinho com que me acolheram ao longo de meu intercâmbio na França, especialmente à minha supervisora de estágio, Dr. Ariane Bize, e ao bioinformata Dr. Cédric Midoux, por toda paciência com que me ensinaram as ferramentas de bioinformática e auxiliaram na análise de dados de sequenciamento, nos artigos científicos e no idioma.

Ao Syndicat Interdépartemental Pour l'Assainissement de l'Agglomération Parisienne (SIAAP), a confiança e parceria no projeto Modélisation, Contrôle et Optimisation des Procédés d'Epuration des Eaux (MOCOPEE), e a todos os demais pesquisadores participantes, especialmente à responsável Dr. Céline Roose-Amsaleg.

Ao MIGALE Bioinformatics Facility (doi: 10.15454/1.5572390655343293E12), ao apoio concedido com as ferramentas computacionais armazenamento das sequências de metagenômica shotgun, especialmente aos bioestaticistas Dr. Mahendra Mariadassou, Dr. Valentin Loux e Dr. Cédric Midoux. 
A Usina São Martinho (Pradópolis- SP) por conceder o lodo granular termofílico de reator anaeróbio aplicado ao processamento de vinhaça de cana-de-açúcar, utilizado como inóculo nesta pesquisa, e aos colegas responsáveis por coletar este material.

À Prof. Dr. Maria do Carmo Calijuri e à técnica do Laboratório de Biotoxicologia de Águas Continentais e Efluentes (BIOTACE), Adriana Miwa, por gentilmente conceder acesso ao moinho de facas (Wiley TE-650/1).

Ao técnico da Central de Análises Químicas e Instrumentais (CAQI) do Instituto de Química de São Carlos (IQSC), Aldimar Constante, pelo auxilio no processamento das amostras de Espectrometria de Infravermelho por Transformada Fourier (FT-IR).

Ao Prof. Dr. Arnaldo Sarti e ao técnico Alberto Camilo Alécio, do Departamento de Bioquímica e Tecnologia Química, Instituto de Química, Universidade Estadual Paulista (UNESP Araraquara), a receptividade e auxilio nas análises de quantificação de limoneno.

A cuidadosa leitura e sugestões dos membros da minha banca de qualificação, Prof. Dr. Sandra Imaculada Maintinguer e Prof. Tit. Marcelo Zaiat. Aos membros títulares da banca de defesa desta tese, pelo pronto aceite e pelas colaborações que ajudaram na melhoria da versão final desta pesquisa: Prof. Dr. Tânia Forster Carneiro, Profa. Dra. Silvana de Queiroz Silva, Prof. Tit. Marcelo Zaiat e Prof. Dr. Fabiana Fantinatti Garboggini. Agradeço ainda aos membros suplentes pela disponibilidade.

Ao Dr. Tiago Palladino Delforno, a ajuda fornecida em todo o processo de intercâmbio, por facilitar o meu primeiro contato com minha supervisora do exterior, ajuda na elaboração do projeto de pesquisa, burocracias de visto, moradia e demais dificuldades relacionadas à estadia em Paris.

A todos os colegas do LPB/SHS, tanto aos que me ajudaram direta ou indiretamente incontáveis vezes na rotina do laboratório, quanto aos que, além disso, me ofereceram companheirismo e amizade. Agradeço aos amigos Jean Oliveira, Mirabelle Cunha, Rachel Costa, Adriana Maluf, Camila Rabelo, Alana Moura, Carol Granatto, Carol Garcia, Cristiane Arruda, Guilherme Soares, Elis W. Nogueira, Jamille Sandes, Tiago Cebola, Elias Neto, Felipe Augusto e Lídia Moura. Em especial, agradeço às "Bernadete's", Raissa Mazareli, Alejandra Villas e Fabrício Motteran, a amizade e ajuda inestimável no início e ao longo de minha pesquisa.

Aos amigos Henrique Dornelles (e nosso anexo felino, Mabel), Marina Gomes e Schayanna Macário, cuja amizade foi meu porto seguro enquanto estive em São Carlos, e cujo apoio e carinho foi o que me manteve forte nos eventuais obstáculos. 
Aos queridos amigos do intercâmbio, Tuğçe Katipoğlu, Subrata Dev, Aya Bahi, Lays Leonel, Stephane Benmaddi, Florent Bouchon e Francesc Puig-Castellví, os quais me ensinaram a conviver, respeitar e principalmente a rir muito de toda nossa bela diversidade cultural, pois agora sei que nunca estarei só em nenhum canto do mundo.

A todos os meus amigos e amigas, a compreensão com minhas ausências ao decorrer desta longa jornada acadêmica, e que continuaram ao meu lado em todos estes anos. Mais do que especialmente, agradeço à Luiza Alves, Daniela Martins Alves e Luis Salles, ao qual sou eternamente grata pois, além da valiosa amizade, sempre me socorreu em minhas dificuldades com estatística e linguagem de programação.

Aos meus pais, Alzira e Walter, minha irmã Ellen, meu cunhado André, e nossas preciosidades caninas Frida e Nina (em memória), ao apoio e compreensão que sempre tive em todas as decisões e caminhos que percorri em toda minha vida. Serei eternamente grata a confiança e amor irrestrito que sempre me ofereceram. Ser família de vocês sempre será meu título mais valioso.

As agências de fomento Coordenação de Aperfeiçoamento de Pessoal de Nível Superior (CAPES, código 001) e Conselho Nacional de Desenvolvimento Científico e Tecnológico (CNPq).

A Fundação de Amparo à Pesquisa do Estado de São Paulo (FAPESP), a bolsa de doutorado (processo ${ }^{\circ}$ 2017/01722-0), bolsa de Estágio em Pesquisa no Exterior (BEPE processo $\mathrm{n}^{\circ}$ 2018/26182-1), e suporte financeiro via Projeto Temático (processo $\mathrm{n}^{\circ}$ 2015/06246-7) concedidos, sem os quais esta pesquisa não seria possível.

Por fim, reforço que estar em um programa multidisciplinar nos obriga o tempo todo a sair da nossa zona de conforto, portanto, agradeço a todos onde encontrei este conforto e que me ajudaram de alguma forma na realização desta pesquisa e em minha trajetória. Muito obrigada!

"Se eu vi mais longe, foi por estar sobre ombros de gigantes". 

"Eu me seguro em minha palavra, em minha mão, em minha lavra" O Rappa 



\section{RESUMO}

CAMARGO, F. P. Caracterização taxônomica e funcional da comunidade microbiana envolvida na obtenção de biogás e outros compostos de interesse biotecnológico a partir de resíduos do processamento de citros/laranja. 312 p. Tese (Doutorado em Ciências) - Escola de Engenharia de São Carlos, Universidade de São Paulo, São Carlos, 2021.

A recuperação de energia a partir de biomassa lignocelulósica, como os resíduos sólidos de citros (RSC), vem sendo estudada como alternativa para seu reaproveitamento. O objetivo desta pesquisa foi avaliar a utilização de RSC como substrato para a obtenção de $\mathrm{H}_{2}$ e demais bioprodutos em reatores em batelada, bem como caracterizar a comunidade microbiana envolvida neste processo. Foi possível obter um consórcio autóctone por meio da autofermentação do RSC, além de isolar uma cepa similar à Enterococcus casseliflavus (99\%), e obter os parâmetros cinéticos de seu crescimento em glicose, como crescimento específico $(\mu=0,35 \mathrm{~h})$, tempo de geração celular $\left(\mathrm{Tg}=1,98 \mathrm{~h}^{-1}\right)$, potencial máximo de concentração de $\mathrm{H}_{2}\left(P=9,1 \mathrm{mmol} \mathrm{H} \mathrm{H}_{2} \cdot \mathrm{L}^{-1}\right)$, velocidade específica máxima de obtenção de $\mathrm{H}_{2}\left(R m=1,99 \mathrm{mmol} \mathrm{H} \mathrm{H}_{2} \mathrm{~L}^{-1}\right)$ e tempo de início da obtenção de $\mathrm{H}_{2}(\lambda=4,08 \mathrm{~h})$. Na etapa seguinte, foram avaliados dois diferentes pré-tratamentos, sendo que a maior concentração de $\mathrm{H}_{2}$ ocorreu nos reatores contendo $\mathrm{RSC}$ in natura $\left(13,31 \mathrm{mmol} \mathrm{H}_{2} \cdot \mathrm{L}^{-1}\right)$, quando comparado à hidrotermólise $\left(P=8,19 \mathrm{mmol} \mathrm{H}_{2} \cdot \mathrm{L}^{-1}\right)$ e deslignificação alcalina $(P=7,27$ mmol $\left.\mathrm{H}_{2} \cdot \mathrm{L}^{-1}\right)$. Por meio do método de Plackett \& Burman, foram avaliadas as variáveis $\mathrm{pH}$ $\left(5,5,7,0\right.$ e 8,5), temperatura $\left(30,37\right.$ e $\left.44^{\circ} \mathrm{C}\right)$, concentração de inóculo alóctone $(1,2$ e 3 gSTV.L $\left.{ }^{-1}\right)$ e de RSC (5, 10 e 15 g.L L $^{-1}$ ), volume do headspace (40, 50 e $60 \%$ ) e componentes do meio de cultura, como extrato de levedura (0, 0,5 e 1 g.L $\left.\mathrm{L}^{-1}\right), \mathrm{CaCO}_{3}\left(0,2,5\right.$ e 5 g.L $\left.{ }^{-1}\right)$, $\mathrm{NaCl}\left(0,2,5\right.$ e 5 g.L $\left.\mathrm{L}^{-1}\right)$ e peptona $\left(0,2,5\right.$ e 5 g. $\left.\mathrm{L}^{-1}\right) . \mathrm{O}$ pH, concentração de inóculo e substrato (RSC) foram as variáveis significativas. A condição ótima estabelecida por meio de Delineamento do Composto Central Rotacional foi de 4 gSTV.L ${ }^{-1}$ de inóculo (lodo granular aplicado ao processamento termofílico de vinhaça de cana-de-açúcar), 29,8 g.L -1 $^{-1}$ de RSC e pH 8,98, com $P=48,47 \mathrm{mmol} \mathrm{H}_{2} \cdot \mathrm{L}^{-1}$. A partir do sequenciamento shotgun, foi possível confirmar a partir da expressão gênica diferencial que as vias de degradação da celulose pela via acetogênica foram superexpressas nos reatores otimizados, sendo Clostridium e Paraclostridium os gêneros mais abundantes.

Palavras-chave: Acetogênese; Biomassa lignocelulósica; Caracterização metataxonômica; Limoneno; Metagenômica shotgun; Planejamento Fatorial. 



\begin{abstract}
CAMARGO, F. P. Taxonomic and functional characterization of the microbial community involved in obtaining biogas and other compounds of biotechnological interest from citrus peel waste. 312 p. Thesis (Doctor of Science) - São Carlos School of Engineering, Univesity of São Paulo, São Carlos, Brazil, 2021.
\end{abstract}

Energy recovery from lignocellulosic biomass, such as citrus peel waste (CPW), has been studied as an alternative to its reuse. This research aimed at evaluating the use of CPW as substrate to obtain $\mathrm{H}_{2}$ and other by-products in batch reactors, as well as characterizing the microbial community involved in this process. It was possible to obtain an autochthonous consortium through the self-fermentation of $\mathrm{CPW}$, in addition to isolating a strain similar to Enterococcus casseliflavus (99\%), as well as obtaining its growth kinetic parameters in glucose, namely specific growth $(\mu=0.35 \mathrm{~h})$, generation time $\left(\mathrm{Tg}=1.98 \mathrm{~h}^{-1}\right)$, maximum $\mathrm{H}_{2}$ concentration potential $\left(P=9.1 \mathrm{mmol} \mathrm{H}_{2} \cdot \mathrm{L}^{-1}\right)$, maximum $\mathrm{H}_{2}$ production rate $(R m=1.99$ mmol $\left.\mathrm{H}_{2} \cdot \mathrm{h}^{-1}\right)$ and starting time of $\mathrm{H}_{2}$ production $(\lambda=4.08 \mathrm{~h})$. The effect of hydrothermolysis $\left(180{ }^{\circ} \mathrm{C} ; 15\right.$ minutes) and alkaline delignification $\left(\mathrm{NaOH} 5 \mathrm{~mol} . \mathrm{L}^{-1} ; 1 \% \mathrm{H}_{2} \mathrm{O}_{2} ; 24\right.$ hours) pretreatments in CPW were evaluated, where it was observed that the $\mathrm{H}_{2}$ obtainment was higher in reactors containing fresh $\mathrm{CPW}\left(13.31 \mathrm{mmol} \mathrm{H}_{2} \cdot \mathrm{L}^{-1}\right)$ when compared to hydrothermolysis $\left(P=8.19 \mathrm{mmol} \mathrm{H}_{2} \cdot \mathrm{L}^{-1}\right)$ and alkaline delignification $\left(P=7.27 \mathrm{mmol} \mathrm{H}_{2} . \mathrm{L}^{-}\right.$ $\left.{ }^{1}\right)$. By means of applying the Plackett \& Burman statistical method, the variables pH (5.5, 7.0 and 8.5), temperature $\left(30,37\right.$ and $\left.44^{\circ} \mathrm{C}\right)$, inoculum $\left(1,2\right.$ and 3 gSTV.L $\left.{ }^{-1}\right)$ and CPW (5, 10 and 15 g.L $\mathrm{L}^{-1}$ ) concentrations, headspace volume (40, 50 and 60\%) and components of the culture medium were evaluated, namely yeast extract $\left(0,0.5\right.$ and 1 g. $\left.\mathrm{L}^{-1}\right), \mathrm{CaCO}_{3}, \mathrm{NaCl}$ and peptone $\left(0,2.5\right.$ and $\left.5 \mathrm{~g} . \mathrm{L}^{-1}\right)$ concentrations, with $\mathrm{pH}$, inoculum and $\mathrm{CPW}$ concentration the most significant variables. The optimal condition established by the Rotational Central Composite Design was 4 gSTV.L ${ }^{-1}$ of inoculum (sludge of sugarcane vinasse anaerobic treatment), 29.8 g. $\mathrm{L}^{-1}$ of $\mathrm{CPW}$ and $\mathrm{pH} 8.98$, with maximum production of $48.47 \mathrm{mmol} \mathrm{H}_{2} \mathrm{~L}^{-}$ 1. After the shotgun sequencing, it was possible to confirm, from differential gene expression, that the cellulose degradation acetogenic pathways were overexpressed in the optimized reactor, with Clostridium and Paraclostridium the most abundant genera.

Keywords: Acetogenesis; Lignocellulosic biomass; Metataxonomic characterization; Limonene; Shotgun metagenomics; Factorial design. 



\section{LISTA DE FIGURAS}

Figura 3.1. Conformação em cadeira da celulose e da hemicelulose e seus monômeros originados após hidrólise. 40

Figura 3.2. Estrutura química do limoneno. .45

Figura 3.3. Resumo dos principais métodos físicos, químicos e biológicos de tratamento da biomassa lignocelulósica 47

Figura 3.4. Esquematização simplificada do rompimento da estrutura lignocelulósica após pré-tratamento. 48

Figura 3.5. Principais gêneros de arqueias envolvidos no processo de metanogênese e suas respectivas ordens e famílias taxonômicas. 74

Figura 4.1. Fluxograma experimental com destaque para os ensaios fermentativos (em verde), metanogênicos (rosa) e as etapas de caracterização microbiana (em roxo). ...... 85

Figura 4.2. Esquema do reator hidrotérmico. 87

Figura 4.3. Fluxograma experimental de obtenção de consórcio celulolítico 89

Figura 4.4. Esquema da metodologia empregada para análise do consórcio celulolíticofermentativo, desde a determinação gravimétrica da degradação das fibras de celulose, isolamento de colônias em meio PCS até a avaliação da comunidade microbiana por meio de técnicas de Biologia molecular. .96

Figura 4.5. Esquema operacional do sistema de duas fases para digestão anaeróbia dos resíduos de citros, sendo (A) fase acidogênica a partir dos resíduos sólidos de citros e (B) fase metanogênica a partir da fração líquida do primeiro reator. 98

Figura 4.6. Esquema de amostragem estática do headspace. O conteúdo de biogás no espaço superior é coletado periodicamente (a cada 2 h) através da tampa de butila, usando seringa manual com trava. 103

Figura 4.7. Pipeline aplicado ao tratamento de sequências obtidas após o seqeenciamento shotgun via Plataforma Illumina HiSeq. 110

Figura 5.1. Características micromorfológicas das cascas (A-B) e bagaço (C-F) de citros em Microscopia Eletrônica de Varredura (MEV). As setas brancas indicam a presença de estruturas semelhantes a bactérias/bacilos aderidas à superfície do material. 115

Figura 5.2. Espectrograma vibracional na região do infravermelho (FT-IR) dos resíduos de citros (cascas e bagaço in natura) (A) utilizados na presente pesquisa e espectro comparativo de pectina de citros (B). 116 
Figura 5.3. Ácidos orgânicos e etanol nos ensaios de autofermentação dos resíduos de citros in natura.

Figura 5.4. Características micromorfológicas do consórcio celulolítico autóctone das cascas e bagaço de laranja in natura em microscopia de contraste de fase. As setas apontam as estruturas similares a endósporos. Aumento total de 1.000X. 120

Figura 5.5. Fibras de papel após o período de incubação. Ensaio controle (A) e ensaio contendo consórcio celulolítico isolado de resíduo de citros in natura (B).

Figura 5.6. Ácidos orgânicos é álcool no início e após $24 \mathrm{~h}$ dos ensaios em reator anaeróbio em batelada a $37{ }^{\circ} \mathrm{C}$ (A) e $55^{\circ} \mathrm{C}$ (B) com diferentes inóculos. 126

Figura 5.7. MEV da superfície do resíduo sólido de citros. Casca (A) e bagaço in natura (B), casca (C) e bagaço (D) após hidrotermólise e casca (E) e bagaço (F) após deslignificação alcalina. As setas indicam morfologias semelhantes a bactérias 127 Figura 5.8. Espectrograma vibracional na região do infravermelho (FT-IR) do resíduo sólido de citros, cascas (A) e bagaço in natura (B), após hidrotermólise e deslignificação alcalina.

Figura 5.9. Caracterização físico-química do resíduo sólido de citros (cascas e bagaço) antes e após diferentes pré-tratamentos.

Figura 5.10. Concentração de $\mathrm{H}_{2}$ a partir do resíduo de citros in natura $(\bullet)$, hidrotermólise (घ) e deslignificação alcalina ( $\mathbf{\Delta})$. 132

Figura 5.11. Ácidos orgânicos e etanol dos ensaios de diferentes pré-tratamentos. (A) ácido acético (HAc) e butírico (HBu); (B) ácido lático (HLac) e etanol (EtOH). 134

Figura 5.12. Parâmetros físico-químicos dos ensaios de comparação entre (I) resíduo sólido de citros in natura, (II) após deslignificação alcalina e (III) após hidrotermólise. (A) carboidratos totais, (B) ST, (C) fenóis totais e (D) STV. 136

Figura 5.13. Dendrograma do coeficiente de similaridade (Correlação Pearson) a partir do perfil de bandas do DGGE para o Domínio Bacteria. 137

Figura 5.14. Variação dos índices de diversidade de Shannon-Wiener e Dominância para o Domínio Bacteria. 138

Figura 5.15. Ideograma circular "Circos". Gêneros microbianos identificados nos resíduos in natura e após hidrotermólise. O círculo externo representa a abundância relativa em função do número de leituras. N.I= não identificado. 140

Figura 5.16. Rotas de conversão do resíduo sólido de citros (RSC) a carboidratos, AOV, $\mathrm{H}_{2}$ e $\mathrm{CH}_{4}$ e abundância relativa dos gêneros envolvidos nas diferentes etapas da digestão 
anaeróbia, sendo I= resíduo sólido de citros in natura e H= resíduo sólido de citros após hidrotermólise. $\mathrm{HAc}=$ Ácido acético; $\mathrm{HBu}=$ Ácido butírico; $\mathrm{HLac}=$ Ácido lático; $\mathrm{EtOH}=$ etanol. ( $\diamond$ Produtores de $\mathrm{H}_{2} ;(\diamond)$ Produtores de $\mathrm{CH}_{4}$ 146

Figura 5.17. Concentração acumulada de $\mathrm{H}_{2}$ dos ensaios de screening design para seleção de variáveis significativas por meio da matriz de Plackett \& Burman. 148

Figura 5.18. Diagramas de Pareto e significância das variáveis estudadas para o intervalo de confiança de $90 \%$. (A) $P$, (B) $R m$, (C) $\lambda$ e (D) HAc.

Figura 5.19. Parâmetros físico-químicos de carboidratos, $\mathrm{SSV}$ e $\mathrm{pH}$, obtidos para os ensaios screening design baseado na matriz de Plackett \& Burman (P\&B). 153

Figura 5.20. Análise de Componente Principal (PCA) dos parâmetros físico-químicos iniciais (concentração de fenol e carboidratos, SSV e pH) e respostas do modelo de Gompertz (modificado) para os ensaios de screening design. 154

Figura 5.21. Concentração de HAc (A) e HBu (B) e potencial máximo de concentração de $\mathrm{H}_{2}$ dos ensaios de delineamento de Plackett \& Burman. 156

Figura 5.22. Ideograma circular "Circos" representando os gêneros bacterianos identificados nos reatores R5 e R12 dos ensaios de screening design via delineamento de Plackett \& Burman. 159

Figura 5.23. Curvas de rarefação do RNAr $16 \mathrm{~S}$ via plataforma Illumina HiSeq para os reatores R5 e R12 160

Figura 5.24. Possíveis vias de conversão de resíduos sólidos de citros (RSC) em carboidratos, $\mathrm{AOV}$ e $\mathrm{H}_{2}$ e abundância relativa de gêneros relacionados aos inóculos alóctone e autóctone, hidrólise e acidogênese. Os valores entre parênteses representam abundância relativa nos ensaios R5 e R12, respectivamente. As setas vermelhas representam o efeito positivo $(\uparrow)$ ou negativo $(\downarrow)$ em cada variável (x1-x10) em diferentes respostas $(P, R m, \lambda, \mathrm{HAc})$. 165

Figura 5.25. Variação da concentração de hidrogênio dos ensaios de DCCR 166

Figura 5.26. Diagrama de Pareto ilustrando a significância dos resultados obtidos para a resposta $P$ para o intervalo de confiança de $90 \%$. 169

Figura 5.27. Relação entre os valores experimentais e valores preditos obtidos para a resposta $P$. 170

Figura 5.28. Superfície de resposta (A) e superfície de contorno (B) obtida para a interação entre as variáveis substrato $\left(\mathrm{g} . \mathrm{L}^{-1}\right)$ e $\mathrm{pH}$. 171

Figura 5.29. Diagrama de Pareto para $R m$ no intervalo de confiança de $90 \%$. 172 
Figura 5.30. Relação entre os valores experimentais e valores preditos obtidos para a resposta $R m$.

Figura 5.31. Diagrama de Pareto para a resposta $\lambda$ e intervalo de confiança de 90\%. 174

Figura 5.32. Relação entre os valores experimentais e valores preditos obtidos para a resposta $\lambda$.

Figura 5.33. Concentração acumulada de $\mathrm{H}_{2}$ no ensaio de validação. Otimizado ( $\bullet$; Não otimizado $(\bullet)$. Os desvios padrão foram calculados em cada condição para os resultados obtidos por meio do modelo de Gompertz. 176

Figura 5.34. Balanço de Massa da fase Solúvel (BMS) do reator nas condições otimizadas aplicadas à obtenção de $\mathrm{H}_{2}$ a partir de resíduos sólidos de citros 177

Figura 5.35. Concentração de AOV e alcoois ao longo do período operacional nos ensaios de DCCR (R01-R15), validação (Otim) e não otimizado (Não-Otim) 183

Figura 5.36. Abundância relativa dos filos (A) e gêneros (B) de bactérias mais abundantes no inóculo (Amostras 1-3) e amostras otimizadas (Amostras 4-6). NA = não identificado. As abundâncias relativas foram calculadas considerando o número total de leituras préprocessadas nas amostras. 188

Figura 5.37. Visão geral do número de genes para todos os níveis metabólicos entre as amostras analisadas e suas interseções por meio do gráfico Upset. 192

Figura 5.38. Abundância das vias metabólicas predominantes nas amostras de inóculo (Amostras 1-3) e do ensaio otimizado (Amostras 4-6) para os níveis de KEGG. 193

Figura 5.39. Abundância relativa das vias metabólicas predominantes nas amostras do inóculo (Amostras 1-3) e do ensaio de otimização (Amostras 4-6) para todos os níveis metabólicos (A) e filtradas para metabolismo de carboidratos (B). 194

Figura 5.40. Abundância relativa das vias metabólicas predominantes nas amostras de inóculo (A) e do ensaio de otimização (B) para a categoria de metabolismo de carboidratos, com as contribuições dos 10 gêneros mais abundantes. 195

Figura 5.41. Proporção dos $30 \mathrm{KO}$ mais abundantes nas amostras de inóculo (A) e do ensaio de otimização (B) para o metabolismo de carboidratos, com os 10 gêneros mais abundantes associados a estes KO. As proporções foram calculadas considerando o número total de leituras em triplicata. 196

Figura 5.42. Ação da piruvato formiato liase na clivagem do piruvato em formiato e acetilCoA. 197 
Figura 5.43. Proporções de $\mathrm{KO}$ relacionadas com a obtenção de $\mathrm{H}_{2}$ nas amostras de inóculo (A) e do ensaio de otimização (B), com os 10 gêneros associados mais abundantes... 199 Figura 5.44. Proporções das Enzimas Ativas por Carboidrato (CAZymes) das classes Atividades Auxiliares (AA) ou Hidrólise Glicosídica (GH) nas amostras de inóculo (A) e do ensaio de otimização (B), com os 10 gêneros mais abundantes associados. 201

Figura 5.45. Possíveis vias de conversão de resíduos sólidos de citros em $\mathrm{H}_{2}$ e $\mathrm{AOV}$ em condições otimizadas. Os números EC mostrados entre colchetes representam apenas os genes significativamente superabundantes nos reatores otimizados $(p \leq 0,005)$. Os valores entre parenteses representam a abundância relativa dos principais gêneros observados nos reatores otimizados. 204

Figura 5.46. Características micromorfológicas do consórcio celulolítico autóctone das cascas e bagaço de laranja in natura, após diluição seriada $\left(10^{-26}\right)$ em microscopia de contraste de fase. 205

Figura 5.47. Dendrograma de distância genética do gene RNAr $16 \mathrm{~S}$ de bactérias anaeróbias isoladas de resíduo sólido de citros in natura. A barra de escala representa o número de substituições por posição de nucleotídeo para cada dendrograma. Os números de acesso de cada sequência estão representados entre parênteses. Os valores dos nós representam os valores de bootstrap (1000 réplicas). Utilizou-se a sequência do gene RNAr $16 \mathrm{~S}$ de E. coli (X80725.1) como grupo externo ( $\bullet$..... 207

Figura 5.48. Tempo de geração (b) e relação entre massa seca e absorbância (b) para a cepa isolada (IS_2) 209

Figura 5.49. Produção de AOV e etanol a partir de diferentes fontes de carbono e potencial máximo de concentração de $\mathrm{H}_{2}(\downarrow)$ pela cepa isolada (IS_2). 210

Figura 5.50. Ácidos orgânicos e álcool ao longo do período de incubação com glicose (a) e xilose (b) para a cepa isolada (IS_2). 213

Figura 5.51. Concentração de $\mathrm{H}_{2}$ pela cepa isolada (IS_2) em função do tempo com diferentes concentrações de xilose. 216

Figura 5.52. Remoção de carboidratos totais $(\bullet)$ e potencial máximo de concentração de $\mathrm{H}_{2}$ do ensaio contendo glicose (๘), bioaumentação (resíduo sólido de citros + IS_2) (४) e autofermentação + bioaumentação (apenas resíduo sólido de citros) ( $\boldsymbol{\Delta}$ ) nos reatores em batelada inoculados com a cepa (IS_2) isolada de resíduo sólido de citros. 220

Figura 5.53. Compostos orgânicos a partir da glicose (A), autofermentação do resíduo sólido de citros + bioaumentação (B) e bioaumentação (C) ao longo do tempo de operação dos reatores em batelada. 
Figura 5.54. Possíveis vias de conversão de resíduo sólido de citros (RSC), polissacarídeos e monossacarídeos aos principais metabólitos observados na fermentação de E. casseliflavus. $\mathrm{HAc}=$ ácido acético; $\mathrm{HBu}=$ ácido butírico; $\mathrm{HPr}=$ ácido propiônico; $\mathrm{HLac}=$ ácido lático; $\mathrm{EtOH}=$ etanol.

Figura 5.55. Concentração de $\mathrm{H}_{2}$ na Fase I e obtenção de $\mathrm{H}_{2}$ e $\mathrm{CH}_{4}$ na Fase II 225

Figura 5.56. Ácidos orgânicos e etanol ao longo do período de incubação na Fase I (A) e Fase II (B) em diferentes amostrais temporais (CP1-3). Para as condições otimizadas, os pontos amostrais foram coletados no período entre $0-22 \mathrm{~h}$, enquanto para as condições não otimizadas as amostras foram coletadas entre 0-700 h. Ácido acético (HAc), ácido butírico $(\mathrm{HBu})$, ácido propiônico (HPr) e etanol (EtOH). 230

Figura 5.57. Características micromorfológicas da biomassa da Fase II ao final do período de incubação. As setas vermelhas indicam os bacilos e as setas pretas indicam os endósporos. Aumento total de 1600X.

Figura 5.58. Curvas de rarefação das sequencias obtidas após sequenciamento massivo do gene RNAr 16S via plataforma Illumina HiSeq para as amostras das fases I e II.

Figura 5.59. Ideograma circular "Circos" representando os gêneros de bactérias identificados nas fases I e II.

Figura 5.60. Ideograma circular "Circos" representando os gêneros de arqueias nas fases I e II.

Figura 5.61. Principais vias metabólicas inferidas para os diferentes níveis KEGG. Os percentuais apresentados foram calculados com base no número de correspondências para cada objeto KO observados para cada amostra (Fase I e Fase II).

Figura 5.62. KO mais abundantes inferidos para as amostras da Fase I e Fase II, relacionadas às etapas de hidrólise, acidogênese, acetogênese e concomitante obtenção de $\mathrm{H}_{2}$.

Figura 5.63. Principais KO inferidos e relacionados à metanogênese 241

Figura 5.64. Principais KO inferidos e relacionados à hidrólise, glicólise, acidogênese, acetogênese e obtenção de $\mathrm{H}_{2}$. Os percentuais foram calculados com base no número total de $\mathrm{KO}$ em cada amostra.

Figura 5.65. Possíveis vias de conversão de resíduos sólidos de citros à $\mathrm{CH}_{4} \mathrm{em}$ reatores em batelada operados em duas diferentes fases, sendo a Fase I referente às etapas de hidrólise, glicólise, acidogênese e acetogênese, e a Fase II majoritariamente referente à metanogênese. Os colchetes representam os números EC (Enzyme Commission Numbers) 
referentes aos KOs inferidos nas amostras. Os valores entre parenteses referem-se à abundância relativa dos principais gêneros observados nas fases I e II. 244

Figura 5.66. Curva de calibração do limoneno para 3,0;6,0;9,0;12,0;15,0;18,0 e 20,0 mg. $\mathrm{L}^{-1}$ de limoneno. 246

Figura 5.67. Cromatograma típico de solução padrão de limoneno (15 mg.L $\left.\mathrm{L}^{-1}\right)$ (A) e cromatograma obtido para ensaios com $17 \mathrm{mg} . \mathrm{L}^{-1}$ de limoneno (B) 247

Figura 5.68. Teor de limoneno inicial $(\mathrm{pI})$ e final $(\mathrm{pF})$ do processo de fermentação de reatores anaeróbios em batelada operados com diferentes concentrações de limoneno (sem adição de limoneno a $2000 \mathrm{mg} . \mathrm{L}^{-1}$ ) por cerca de 160 h. Adsorção (AD) e potencial máximo de concentração de $\mathrm{H}_{2}(P)$ 249

Figura 5.69. Concentração de $\mathrm{H}_{2}$ nos reatores anaeróbios controle e com diferentes concentrações de limoneno. 250

Figura 5.70. Ácidos orgânicos e álcoois dos reatores em batelada controle e com diferentes concentrações de limoneno. Ácido acético (HAc), ácido butírico (HBu), ácido propiônico (HPr) e etanol (EtOH) 253 



\section{LISTA DE TABELAS}

Tabela 3.1. Comparação entre os métodos físicos, químicos e biológicos de tratamento de biomassa lignocelulósica. 48

Tabela 3.2. Comparação da obtenção de metano em reator em batelada a partir de diferentes substratos e condições experimentais 53

Tabela 3.3. Comparação da obtenção de hidrogênio em reator em batelada a partir de diferentes substratos e condições experimentais 56

Tabela 3.4. Principais bactérias identificadas a partir de diferentes resíduos aplicados à obtenção de produtos de interesse biotecnológico em reatores em bateladas. .72

Tabela 3.5. Principais arquéias identificadas a partir de diferentes resíduos sólidos aplicados à obtenção de metano em reatores em batelada. 76

Tabela 3.6. Comparação entre técnicas de biologia molecular utilizadas em reatores anaeróbios. 78

Tabela 3.7. Principais ferramentas para análise massiva de dados de sequenciamento (shotgun ou metabarcoding) utilizados nesta pesquisa. .82

Tabela 4.1. Meio de cultivo Peptone Cellulose Solution (PCS) modificado e condições utilizadas no ensaio de autofermentação dos resíduos de citros in natura. 89

Tabela 4.2. Condições utilizadas nos ensaios de comparação entre resíduos de citros in natura e após diferentes pré-tratamentos (deslignificação alcalina e hidrotermólise). ..91

Tabela 4.3. Condições mínimas (-1), máximas (+1) e do ponto central (0) para as diferentes variáveis. 92

Tabela 4.4. Matriz de Plackett \& Burman codificada para o screening design com 16 condições experimentais e três repetições do ponto central. .93

Tabela 4.5. Matriz experimental com valores reais e valores codificados para os ensaios do DCCR de $2^{3}$, com 6 pontos axiais e 3 repetições no ponto central .94

Tabela 4.6. Condições experimentais dos ensaios de otimização da obtenção de $\mathrm{H}_{2}$ por meio do método de Delineamento Composto Central Rotacional (DCCR). 94

Tabela 4.7. Composição do meio de Zinder modificado, utilizado nos ensaios de obtenção de $\mathrm{CH}_{4} \mathrm{e}$ condições utilizadas nos ensaios em batelada. 99

Tabela 4.8. Composição da solução de metais traço .99

Tabela 4.9. Composição da solução de vitaminas. 100

Tabela 4.10. Análises físico-químicas utilizadas para o monitoramento dos reatores em batelada. 101 
Tabela 4.11. Fatores de equivalência utilizados para determinação da DQO equivalente. Os carboidratos totais foram considerados em termos de g-glicose. 102

Tabela 5.1. Caracterização físico-química dos resíduos de citros. 113

Tabela 5.2. Parâmetros de Gompertz dos ensaios de autofermentação dos resíduos de citros in natura para obtenção de $\mathrm{H}_{2}$ a partir de casacas e bagaço de citros 118

Tabela 5.3. Parâmetros de Gompertz modificado dos reatores anaeróbios com inóculos de diferentes origens, aplicados à obtenção de $\mathrm{H}_{2}$ a partir de resíduos de citros. 122

Tabela 5.4. Parâmetros físico-químicos dos reatores anaeróbios com inóculos de diferentes origens

Tabela 5.5. Parâmetros de Gompertz modificado dos ensaios após diferentes prétratamentos do resíduo sólido de citros. Potencial máximo de concentração de $\mathrm{H}_{2}(P)$, velocidade específica máxima de obtenção de $\mathrm{H}_{2}(\mathrm{Rm})$, tempo de início da obtenção de $\mathrm{H}_{2}$ $(\lambda)$ e $\mathrm{R}^{2}$ obtidos da equação de Gompertz modificada.

Tabela 5.6. Índices ecológicos das sequencias obtidas a partir do sequenciamento massivo do gene RNAr 16S via Plataforma Illumina HiSeq para amostra (1) ensaio com resíduo in natura e (2) ensaio após hidrotermólise

Tabela 5.7. Matriz de Plackett \& Burman codificada para o screening design com 16 condições experimentais e três repetições do ponto central $\left(\mathrm{x}_{1}-\mathrm{x}_{10}\right)$ e respostas obtidas para os ensaios cinéticos em batelada $\left(\mathrm{Y}_{1}-\mathrm{Y}_{4}\right)$. 148

Tabela 5.8. Dados estatísticos obtidos após a realização dos ensaios para seleção de variáveis significativas para as respostas $P, R m, \lambda$ e HAc para obtenção de $\mathrm{H} 2$ a partir de resíduos sólidos de citros.

Tabela 5.9. Efeito dos diferentes parâmetros na obtenção de $\mathrm{H}_{2}$, AOV em reatores em batelada com resíduo sólido de citros. 158

Tabela 5.10. Índices ecológicos para as sequencias do RNAr 16S via plataforma Illumina dos ensaios R5 e R12. 160

Tabela 5.11. Respostas relativas à obtenção de hidrogênio nos ensaios de DCCR..... 167

Tabela 5.12. Valores de significância para o intervalo de confiança de $10 \%$ das respostas para as variáveis dos ensaios de DCCR. 168

Tabela 5.13. Dados estatísticos (ANOVA) obtidos para os ensaios de DCCR, para a resposta $P$ e intervalo de confiança de $90 \%$.

Tabela 5.14. Dados estatísticos (ANOVA) dos ensaios de DCCR para a resposta $R m$ e intervalo de confiança de $90 \%$ 
Tabela 5.15. Dados estatísticos (ANOVA) dos ensaios de DCCR, para a resposta $\lambda$ e intervalo de confiança de $90 \%$.

Tabela 5.16. Teste ANOVA e valores ótimos para as respostas $P$ e $R m$ dos ensaios de DCCR 175

Tabela 5.17. Comparação entre os resultados para concentração de $\mathrm{H}_{2}(P)$ preditos pelo modelo obtido por meio de DCCR e os resultados experimentais obtidos. 176

Tabela 5.18. Parâmetros cinéticos e físico-químicos dos ensaios de DCCR e ensaio de validação (otimizado) 180

Tabela 5.19. Parâmetros estatísticos e de qualidade para as sequências brutas e filtradas obtidas a partir do inóculo (Amostras 1-3) e do ensaio otimizado (Amostra 4-6). 186

Tabela 5.20. Índices ecológicos (Observado, Chao-1, Shannon-Wiener e Simpson) para sequências filtradas obtidas a partir do inóculo (Amostras 1-3) e ensaio otimizado (Amostras 4-6). se = Erro Padrão calculado a partir de triplicatas. 187

Tabela 5.21. Remoção da fibra de papel filtro e $p$ valor obtido ${ }^{a}$ para a cepa isolada (IS_2), consórcio autofermentativo e ensaio controle (sem inóculo).

Tabela 5.22. Remoção de carboidratos e pH final dos reatores em batelada, operados com diferentes fontes de carbono para a cepa isolada (IS_2). 215

Tabela 5.23. Parâmetros de Gompertz modificado e densidade óptica da cepa isolada (IS_1) obtidos a partir de diferentes concentrações de xilose. 216

Tabela 5.24. Modelo de regressão e ANOVA para as respostas potencial máximo de concentração de $\mathrm{H}_{2}(P)$, velocidade máxima de obtenção de $\mathrm{H}_{2}(R m)$, tempo de início da obtenção de $\mathrm{H}_{2}(\lambda)$, $\mathrm{pH}$, densidade óptica $\left(\mathrm{OD}_{600}\right)$ e consumo de carboidratos nos ensaios em diferentes concentrações de xilose $\left(0,53\right.$ a 6,47 g. $\left.\mathrm{L}^{-1}\right)$ pela cepa isolada 218

Tabela 5.25. Parâmetros referentes ao modelo de Gompertz modificado ${ }^{\text {a }}$ para concentração de $\mathrm{H}_{2}$ para os ensaios com diferentes substratos (glicose e resíduo sólido de citros), bioaumentação e autofermentação. 219

Tabela 5.26. Concentração de $\mathrm{H}_{2}$ a partir de diferentes substratos e inóculos. 221

Tabela 5.27. Parâmetros cinéticos de obtenção de $\mathrm{H}_{2}$ e $\mathrm{CH}_{4}$ nas fases I e II, respectivamente. 225

Tabela 5.28. Parâmetros físico-químicos dos reatores do ensaio de potencial metanogênico ao final do período de operação da Fase I e Fase II. 228

Tabela 5.29. Índices ecológicos do gene RNAr $16 \mathrm{~S}$ para as fases I e II do ensaio acidogênico e metanogênico de resíduo sólido de citros. 232

Tabela 5.30. Especificações de operação do GC-MS 245 
Tabela 5.31. Parâmetros cinéticos de obtenção de $\mathrm{H}_{2}$ dos reatores anaeróbios controle e com diferentes concentrações de limoneno. Médias seguidas pela mesma letra não diferem entre si para o intervalo de confiança de $95 \%$ no teste de Kruskal-Wallis. 250

Tabela 5.32. Parâmetros físico-químicos dos reatores em batelada controle e com diferentes concentrações de limoneno no início $(\mathrm{pI})$ e final $(\mathrm{pF})$ 252

Tabela 6.1. Conclusões sobre as hipóteses iniciais da pesquisa e resumo sobre as principais condições operacionais e resultados de cada etapa 259 


\section{LISTA DE ABREVIATURAS E SIGLAS}

ADP

ANOVA

AOV

ATP

BLAST

BMS

CAZymes

CoA

$\mathrm{CoM}$

DCCR

DGGE

DNA

DQO

e.g.

EESC

EGSB

Eq.

et. al.

$\mathrm{EtOH}$

FT-IR

GC

GC-MS

H4SPT

HAc

$\mathrm{HAc}$

$\mathrm{HBu}$

$\mathrm{HBu}$

HCap

HLac

HLac

HMF

HPLC

HPr
Adenosina difosfato

Análise de Variância

Ácidos Orgânicos Voláteis

Trifosfato de Adenosina

Ferramenta Básica de Procura por Alinhamento Local

Balanço de Massa da fase Solúvel

Enzimas Ativas de Carboidratos

Coenzima A

Coenzima $\mathrm{M}$

Delineamento Composto Central Rotacional

Eletroforese em Gel com Gradiente Desnaturante

Ácido Desoxirribonucleico

Demanda Química de Oxigênio

por exemplo (do latim, exempli gratia)

Escola de Engenharia de São Carlos

Reator Anaeróbio de Leito Granular Expandido

Equação

e outros (do latim, et alia)

Etanol

Espectroscopia no Infravermelho por Transformada de Fourier

Citosina-Guanina

Cromatografia Gasosa acoplada à Espectrometria de Massas

Tetra-hidrossarcinapterina

Ácido acético

Ácido acético

Ácido butírico

Ácido butírico

Ácido caproico

Ácido lático

Ácido lático

Hidroximetilfurfural

Cromatografia Líquida de Alta Performance

Ácido propiônico 
HVal

KEGG

KO

LAS

LD

$\ln$

LPB

LQ

MEV

MSC

NAD+

$\mathrm{NADH}$

NCBI

NGS

OTU

$P$

P\&B

$\mathrm{pb}$

PCR

PCS

$\mathrm{pH}$

PIB

PID

q.s.p.

$R m$

RNA

RNAr

RSC

$\mathrm{Tg}$

THMPT

UASB

USP

Ácido valérico

Enciclopédia de Kyoto de Genes e Genomas

Banco de dados de ortologia KEGG

Alquilbenzeno Linear Sulfonado

Límite de Detecção

Logarítimo natural

Laboratório de Processos Biológicos

Limíte de Quantificação

Microscopia Eletrônica de Varredura

Massa Seca Celular

Dinucleótido de nicotinamida e adenina (forma oxidada)

Dinucleótido de nicotinamida e adenina (forma reduzida)

Centro Nacional de Informação Biotecnológica

Sequenciamento de Nova Geração

Unidade Taxonômica Operacional

Potencial máximo de concentração de $\mathrm{H}_{2}$

Plackett \& Burman

Pares de Base

Reação em Cadeia da Polimerase

Solução de Celulose e Peptona

Potencial Hidrogeniônico

Produto Interno Bruto

Painel de controle derivativo integral proporcional

Quantidade Suficiente Para

Velocidade máxima de obtenção de $\mathrm{H}_{2}$

Ácido Ribonucleico

Ácido Ribonucleico Ribossômico

Resíduo Sólido de Citros

Tempo de geração celular

Tetra-hidrometanopterina

Reatores Anaeróbios de Fluxo Ascendente com Manta de Lodo

Universidade de São Paulo 


\section{LISTA DE SÍMBOLOS}

\begin{tabular}{|c|c|}
\hline$\%$ & Porcentagem \\
\hline$\Delta \mathrm{G}$ & Energia livre de Gibbs \\
\hline$\leq$ & Menor ou igual \\
\hline$\geq$ & Maior ou igual \\
\hline${ }^{\circ} \mathrm{C}$ & Graus Celsius \\
\hline atm & atmosfera \\
\hline bar & unidade de pressão \\
\hline $\mathrm{cm}$ & Centímetros \\
\hline $\mathrm{d}$ & Dia \\
\hline $\mathrm{DQO}_{\text {filtrada }}$ & Demanda Química de Oxigênio de amostra filtrada \\
\hline $\mathrm{g}$ & Gramas \\
\hline g.dm ${ }^{3}$ & Grama por decímetro cúbico \\
\hline g.DQO.L $\mathrm{L}^{-1}$ & Grama de demanda química de oxigênio por litro \\
\hline g. $\mathrm{kg}^{-1}$ & Grama por quilo \\
\hline g. $\mathrm{L}^{-1}$ & Grama por litro \\
\hline g.SSV.L $\mathrm{L}^{-1}$ & Grama de sólidos suspensos voláteis por litro \\
\hline$g_{\text {glicose }} \cdot \mathrm{L}^{-1}$ & Grama de glicose por litro \\
\hline $\mathrm{g}_{\text {limoneno. }} \mathrm{L}^{-1}$ & Grama de limoneno por litro \\
\hline $\mathrm{g}_{\mathrm{msc}} \cdot \mathrm{L}^{-1}$ & Grama de massa seca celular por litro \\
\hline $\mathrm{gSS} . \mathrm{L}^{-1}$ & Grama de sólidos suspensos por litro \\
\hline gST.L $\mathrm{L}^{-1}$ & Grama de sólidos totais por litro \\
\hline gSTV.L $L^{-1}$ & Grama de sólidos totais voláteis por litro \\
\hline$g_{\text {xilose }} \cdot \mathrm{L}^{-1}$ & Grama de xilose por litro \\
\hline $\mathrm{h}$ & Hora \\
\hline $\mathrm{kg}$ & Quilograma \\
\hline $\mathrm{kJ}$ & Quilojoule \\
\hline $\mathrm{kWh}$ & Quilowatt-hora \\
\hline $\mathrm{L}$ & Litro \\
\hline L. $\mathrm{kg}^{-1}$ & Litro por quilo \\
\hline M & Molar \\
\hline $\mathrm{mg}$ & Miligramas \\
\hline $\mathrm{mg} \cdot \mathrm{kg}^{-1}$ & Miligrama por quilo \\
\hline $\operatorname{mg} . \mathrm{L}^{-1}$ & Milirama por litro \\
\hline
\end{tabular}




\begin{tabular}{|c|c|}
\hline mg EtOH.L $\mathrm{L}^{-1}$ & Miligramas de etanol por litro \\
\hline mg HAc. $\mathrm{L}^{-1}$ & Miligramas de ácido acético por litro \\
\hline mg HBu.L $\mathrm{L}^{-1}$ & Miligramas de ácido butírico por litro \\
\hline mg HLac.L $\mathrm{L}^{-1}$ & Miligramas de ácido lático por litro \\
\hline $\mathrm{mg}$ HPr. $\mathrm{L}^{-1}$ & Miligramas de ácido propiônico por litro \\
\hline $\min$ & Minutos \\
\hline $\mathrm{mL}$ & Mililitros \\
\hline $\mathrm{mm}$ & Milímetros \\
\hline mmol & Milomol \\
\hline mmol.h $\mathrm{h}^{-1}$ & Milimol por hora \\
\hline $\mathrm{mmol} . \mathrm{L}^{-1}$ & Milimol por litro \\
\hline $\mathrm{mmol} \mathrm{CH} 4 \cdot \mathrm{h}^{-1}$ & Milimol de metano por hora \\
\hline $\mathrm{mmol} \mathrm{CH} 4 \cdot \mathrm{L}^{-1}$ & Milimol de metano por litro \\
\hline $\mathrm{mmol} \mathrm{H}_{2} \cdot \mathrm{h}^{-1}$ & Milimol de hidrogênio por hora \\
\hline $\mathrm{mmol} \mathrm{H} \cdot \mathrm{L}^{-1}$ & Milimol de hidrogênio por litro \\
\hline Mpa & Megapascal \\
\hline Mt & Megatonelada \\
\hline $\mathrm{nm}$ & Nanômetros \\
\hline $\mathrm{OD}_{600}$ & Densidade óptica a 600 nanômetros \\
\hline $\mathrm{p}$ & Probabilidade de significância \\
\hline $\mathrm{R}^{2}$ & Coeficiente de determinação \\
\hline $\mathrm{rpm}$ & Revoluções Por Minuto \\
\hline$\alpha$ & Alfa \\
\hline$\beta$ & Beta \\
\hline$\gamma$ & Gama \\
\hline$\lambda$ & Tempo de início da obtenção de $\mathrm{H}_{2}$ \\
\hline$\mu$ & Crescimento específico \\
\hline$\mu \mathrm{L}$ & Microlitro \\
\hline$\mu \max$ & Velocidade máxima \\
\hline
\end{tabular}




\section{LISTA DE EQUAÇÕES}

$$
\begin{aligned}
& \mathrm{H}_{2} \mathrm{O}_{2} \leftrightarrow \mathrm{H}^{+}+\mathrm{HOO}^{-} \\
& \mathrm{H}_{2} \mathrm{O}_{2}+\mathrm{HOO}^{-} \rightarrow \mathrm{HO}^{-}+\mathrm{O}_{2}+\mathrm{H}_{2} \mathrm{O} \\
& \mathrm{C}_{6} \mathrm{H}_{12} \mathrm{O}_{6}+6 \mathrm{H}_{2} \mathrm{O} \rightarrow 2 \mathrm{CO}_{2}+2 \mathrm{CH}_{3} \mathrm{COOH}+4 \mathrm{H}_{2} \\
& \mathrm{C}_{6} \mathrm{H}_{12} \mathrm{O}_{6}+6 \mathrm{H}_{2} \mathrm{O} \rightarrow 2 \mathrm{CO}_{2}+\mathrm{CH}_{3} \mathrm{CH}_{2} \mathrm{CH}_{2} \mathrm{COOH}+2 \mathrm{H}_{2} \\
& \mathrm{C}_{6} \mathrm{H}_{12} \mathrm{O}_{6}+2 \mathrm{H}_{2} \rightarrow 2 \mathrm{CH}_{3} \mathrm{CH}_{2} \mathrm{COOH}+2 \mathrm{H}_{2} \mathrm{O} \\
& \mathrm{C}_{6} \mathrm{H}_{12} \mathrm{O}_{6} \rightarrow \mathrm{CH}_{3} \mathrm{CH}_{2} \mathrm{OH}+2 \mathrm{CO}_{2} \\
& \mathrm{CH}_{3} \mathrm{COO}^{-}+\mathrm{H}^{+} \rightarrow \mathrm{CH}_{4}+\mathrm{CO}_{2} \\
& 4 \mathrm{H}_{2}+\mathrm{CO}_{2} \rightarrow \mathrm{CH}_{4}+2 \mathrm{H}_{2} \mathrm{O} \\
& \text { Severidade }=\int_{0}^{t} \exp \left[\frac{T(t)-100}{14,75}\right] d \times t \\
& \text { Degradação (\%) }=\frac{\mathrm{M}_{\mathrm{t}}-\mathrm{M}_{\mathrm{r}}}{\mathrm{M}_{\mathrm{t}}} \times 100 \\
& T g=\frac{\ln 2}{\mu}=\frac{0,693}{\mu} \\
& B M S=\left(\frac{D Q O_{\text {metabólitos }}+D Q O_{\text {carboidratos }}+D Q O_{\text {fenóis }}}{D Q O_{\text {experimental }}}\right) \times 100 \\
& L D=3 \times \text { DesvPad } / m \\
& L Q=10 \times \mathrm{DesvPad} / \mathrm{m}
\end{aligned}
$$

(Eq.3.2) ............................59

(Eq. 3.3) ..........................65

(Eq. 3.4) ...........................65

(Eq. 3.5) ..........................66

(Eq. 3.6) ...........................67

(Eq. 3.7) …......................73

(Eq. 3.8) .........................73

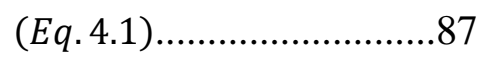

(Eq. 4.2).........................90

(Eq. 4.3)..........................97

(Eq. 4.4) ........................101

(Eq. 4.5) .........................105

(Eq. 4.6) ..........................105

Recuperação $(\%)=($ concentração estimada/teórica $) \times 100 \quad($ Eq.4.7) .................106

$Y(t)=P \cdot \exp \left\{-\exp \left(\frac{R m . e}{A}[\lambda-t]+1\right)\right\} \quad$ (Eq. 4.8) .......................112

$\mathrm{C}_{5} \mathrm{H}_{10} \mathrm{O}_{5}+1,67 \mathrm{H}_{2} \mathrm{O} \rightarrow 1,67 \mathrm{C}_{2} \mathrm{H}_{3} \mathrm{O}_{2}^{-}+1,67 \mathrm{H}^{+}+1,67 \mathrm{CO}_{2}+3,33 \mathrm{H}_{2}$ (Eq. 5.1) ................157

$\mathrm{C}_{5} \mathrm{H}_{10} \mathrm{O}_{5} \rightarrow 0,83 \mathrm{C}_{4} \mathrm{H}_{7} \mathrm{O}_{2}^{-}+0,83 \mathrm{H}^{+}+1,67 \mathrm{CO}_{2}+1,67 \mathrm{H}_{2} \quad$ (Eq. 5.2) .....................157

$Y_{1}=15,29+7,35 x_{2}-1,97 x_{2}^{2}+1,38 x_{3}+4,70 x_{2} x_{3} \quad$ (Eq. 5.3) ...................168

$Y_{2}=0,98+0,33 x_{2} \quad$ (Eq. 5.4) ....................171

$Y_{3}=12,55+3,21 x_{2} x_{3} \quad$ (Eq. 5.5) ....................174

$\mathrm{CH}_{3} \mathrm{CH}_{2} \mathrm{COOH}+3 \mathrm{H}_{2} \mathrm{O} \rightarrow \mathrm{CH}_{3} \mathrm{COOH}+7 \mathrm{HCO}_{3}^{-}+\mathrm{H}^{+}+3 \mathrm{H}_{2} \quad$ (Eq. 5.6) .......................182

6 fosfoßDglicosil(1,4) Dglicose $+H_{2} \leftrightarrow$ Dglicose + Dglicose6fosfato (Eq. 5.7)....197

Acetaldeído $+\mathrm{NAD}^{+}+\mathrm{CoA} \leftrightarrow$ AcetilCoA $+\mathrm{NADH}+\mathrm{H}^{+} \quad$ (Eq.5.8).......................198

Glicose $+2 \mathrm{ADP}+2 \mathrm{Pi} \rightarrow 2 \mathrm{EtOH}+2 \mathrm{CO}_{2}+2 \mathrm{ATP}+2 \mathrm{H}_{2} \mathrm{O} \quad$ (Eq. 5.9).....................198

$(S)$ - lactato $+\mathrm{NAD}^{+} \rightarrow$ piruvato $+\mathrm{NADH}+\mathrm{H}^{+} \quad$ (Eq.5.10)...................198

$\mathrm{CH}_{3} \mathrm{COOH}+2 \mathrm{H}_{2} \rightarrow \mathrm{CH}_{3} \mathrm{CH}_{2} \mathrm{OH}+4 \mathrm{H}_{2} \mathrm{O} \quad$ (Eq. 5.11).................212

$\mathrm{C}_{6} \mathrm{H}_{6} \mathrm{O}+5 \mathrm{H}_{2} \mathrm{O} \rightarrow 3 \mathrm{CH}_{3} \mathrm{COOH}+2 \mathrm{H}_{2} \quad$ (Eq. 5.12).................229

$A T P+$ acetato + Co $A \rightarrow A M P+$ difosfato + AcetilCoA $\quad$ (Eq. 5.13)....................229

AcetilCoA + fosfato $\leftrightarrow$ CoA + acetilfosfato $\quad$ (Eq.5.14)..................243 



\section{SUMÁRIO}

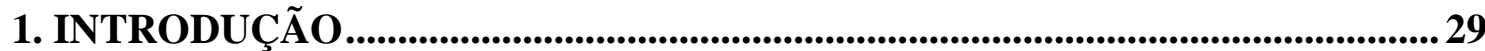

2. HIPÓTESES E OBJETIVOS ...........................................................................33

2.1 HIPÓTESE E OBJETIVO GERAL ................................................................... 33

2.1.1 Hipótese geral .............................................................................................................33

2.1.2 Objetivo geral ........................................................................................................... 33

2.2 HIPÓTESES E OBJETIVOS ESPECÍFICOS ………………………………..... 33

2.2.1 Hipótese e objetivo específico 1.......................................................................... 33

2.2.2 Hipótese e objetivo específico 2.......................................................................... 33

2.2.3 Hipótese e objetivo específico 3..........................................................................33

2.2.4 Hipótese e objetivo específico 4.........................................................................34

2.2.5 Hipótese e objetivo específico 5.......................................................................34

2.2.6 Hipótese e objetivo específico 6...............................................................................34

2.2.7 Hipótese e objetivo específico 7...........................................................................35

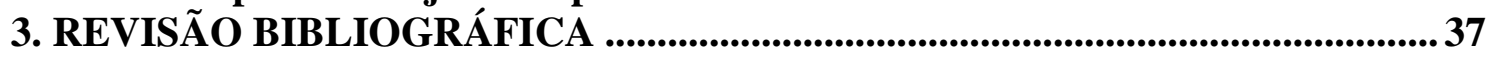

3.1 BIORREFINARIAS E BIOPRODUTOS .......................................................... 37

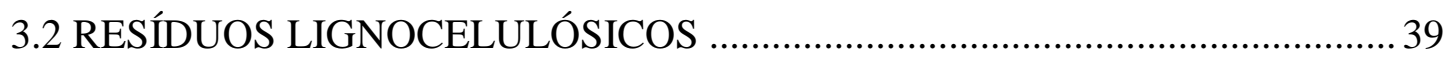

3.3 RESÍDUOS SÓLIDOS AGROIDUSTRIAIS..................................................... 41

3.4 RESÍDUOS DO PROCESSAMENTO DE CITROS ………………………….... 43

3.5 PRÉ-TRATAMENTOS DE RESÍDUOS LIGNOCELULÓSICOS........................ 46

3.5.1 Pré-tratamentos químicos ................................................................................57

3.5.2 Pré-tratamentos físicos .........................................................................................59

3.5.3 Pré-tratamentos biológicos.................................................................................62

3.6 MICRORGANISMOS FERMENTATIVOS E METANOGÊNICOS.................... 63

3.6.1 Bactérias fermentativas e celulolíticas .............................................................63

3.6.2 Arqueias metanogências.................................................................................72

3.7 TÉCNICAS DE BIOLOGIA MOLECULAR APLICADAS AO ESTUDO DE MICRORGANISMOS EM REATORES ANAERÓBIOS …………………………...76

3.7.1 Ferramentas de bioinformática aplicadas à metagenômica........................79

4. MATERIAL E MÉTODOS ..................................................................................83

4.1 ESQUEMA OPERACIONAL …………………………………………….... 83

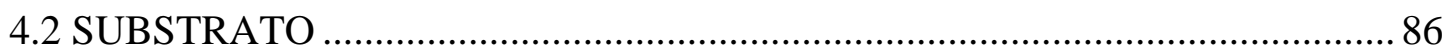

4.2.1 Resíduos de citros..................................................................................................86

4.2.2 Pré-tratamentos............................................................................................................ 86

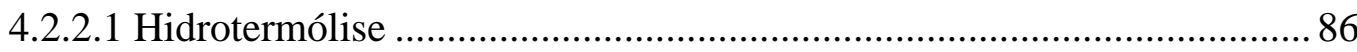

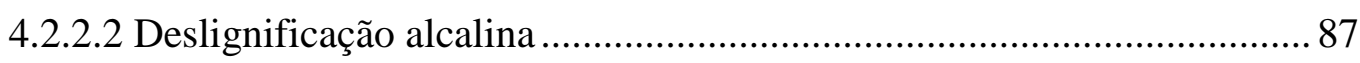

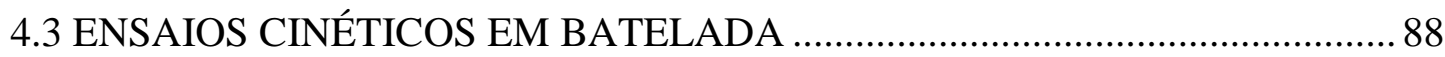

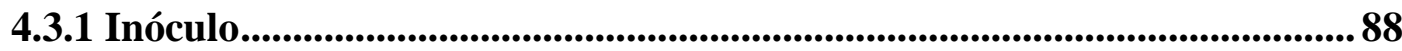

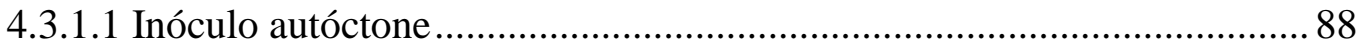

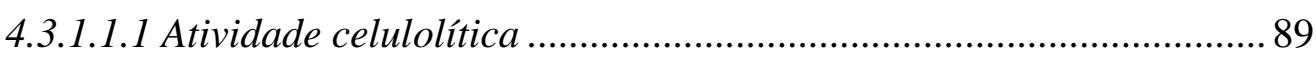

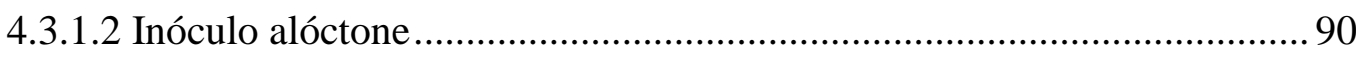

4.3.2 Faixa de temperatura .................................................................................90 
4.3.3 Ensaios de pré-tratamento ......................................................................

4.3.4 Ensaios fermentativos ....................................................................................91 91

4.3.4.1 Delineamento de Plackett \& Burman ................................................. 91

4.3.4.2 Delineamento Composto Central Rotacional........................................... 93

4.3.4.3 Obtenção de bactérias anaeróbias celulolíticas ....................................... 95

4.3.4.3.1 Caracterização da cepa isolada .................................................... 96

4.3.5 Ensaios metanogênicos ...........................................................................997

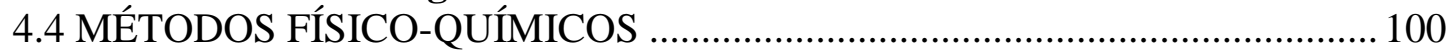

4.4.1 Análises físico-químicas e cromatográficas .............................................. 100

4.4.1.1 Caracterização de macro e microelementos......................................... 100

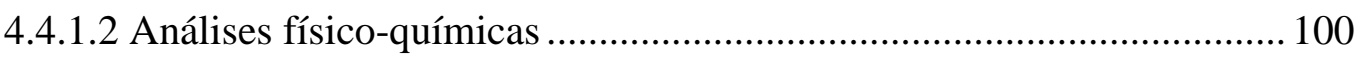

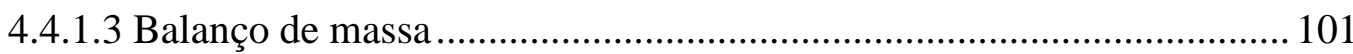

4.4.1.4 Análise da composição do biogás ..................................................... 102

4.4.1.5 Espectroscopia de Infravermelho com Transformada Fourier.............. 103

4.4.1.6 Microscopia Eletrônica de Varredura .................................................. 103

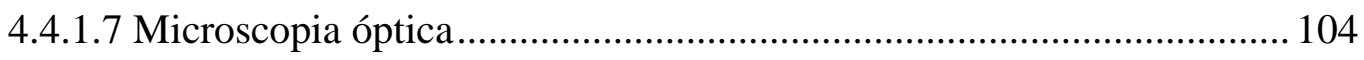

4.4.2 Determinação do teor de limoneno via GC-MS ...................................... 104

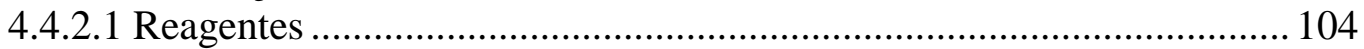

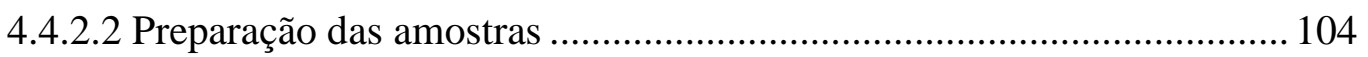

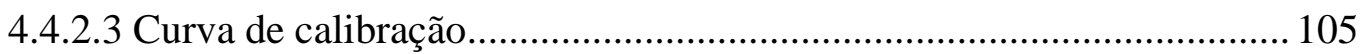

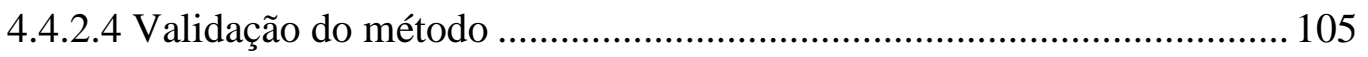

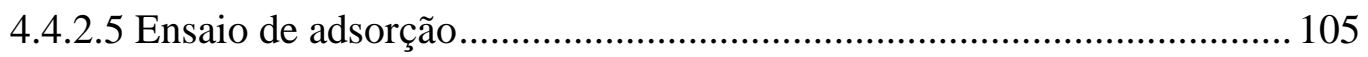

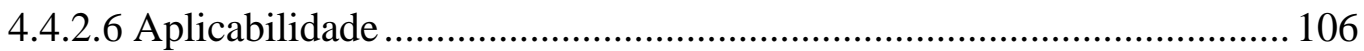

4.5 TÉCNICAS DE BIOLOGIA MOLECULAR ................................................. 106

4.5.1 Extração do DNA e amplificação da região-alvo .......................................... 107

4.5.2 Eletroforese em Gel de Gradiente Desnaturante ...................................... 108

4.5.3 Sequenciamento e bioinformática ....................................................... 108

4.10.3.1 Bactérias anaeróbias celulolíticas ................................................... 108

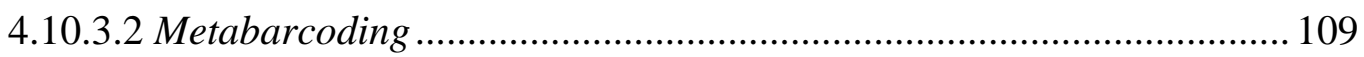

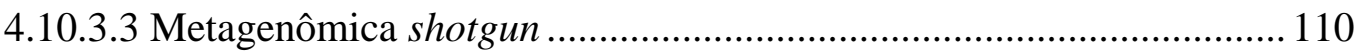

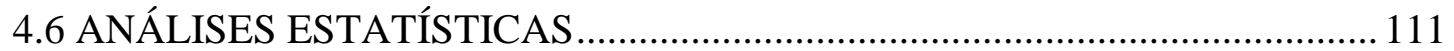

4.6.1 Ajuste dos dados experimentais............................................................ 112

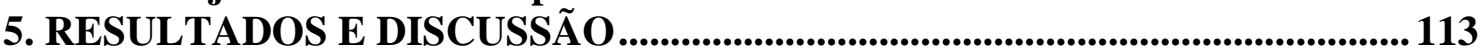

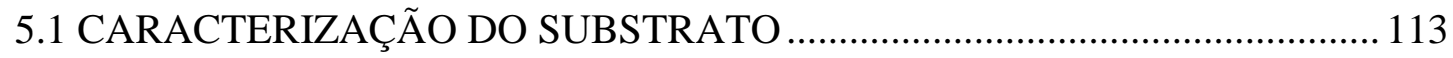

5.1.1 Caracterização físico química ................................................................................ 113

5.1.2 Exame Microscópico ................................................................................ 114

5.1.3 Espectroscopia de Infravermelho com Transformada de Fourier......... 115

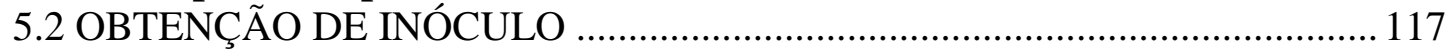

5.2.1 Inóculo autóctone .......................................................................................... 117

5.2.2 Inóculo alóctone ................................................................................................. 121

5.3 PRÉ-TRATAMENTOS APLICADOS AO RESÍDUO SÓLIDO DE CITROS 126

5.3.1 Efeitos dos pré-tratamentos nas características físico-químicas e morfológicas do substrato .................................................................................... 126 
5.3.2 Efeitos dos pré-tratamentos na obtenção de $\mathrm{H}_{2}$ e AOV .......................... 131

5.3.3 Análise da comunidade microbiana .............................................................. 136

5.4 SELEÇÃO DE VARIÁVEIS VIA PLACKETT \& BURMAN ......................... 146

5.4.1 Análise da comunidade microbiana ........................................................... 158

5.5 OTIMIZAÇÃO DA OBTENÇÃO DE $\mathrm{H}_{2}$ VIA DELINEAMENTO COMPOSTO

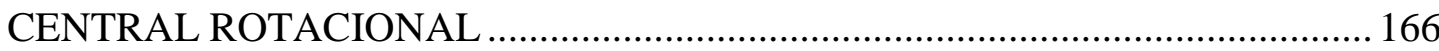

5.5.1 Delineamento Composto Central Rotacional (DCCR) ............................ 166

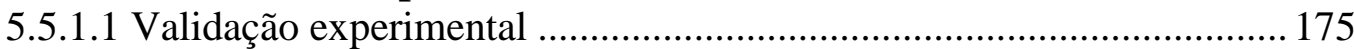

5.5.1.2 Parâmetros físico-químicos e AOV ................................................... 177

5.5.2 Caracterização microbiana ...................................................................184

5.5.2.1 Anotação funcional e mapeamento de vias metabólicas...................... 192

5.6 OBTENÇÃO DE BACTÉRIAS ANAERÓBIAS CELULOLÍTICAS ............... 205

5.6.1 Atividade celulolítica, isolamento e identificação .....................................205

5.6.2 Parâmetros cinéticos....................................................................................208

5.6.3 Vias fermentativas e metabolitos da cepa isolada.................................209

5.6.4 Efeito da concentração de xilose .........................................................2215

5.6.5 Aplicação em resíduo sólido de citros e bioaumentação.......................... 219

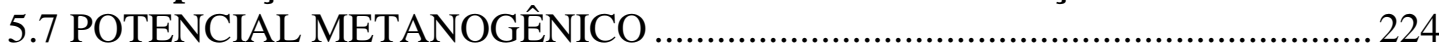

5.7.1 Obtenção de biogás e AOV .........................................................................224

5.7.2 Caracterização da comunidade microbiana ................................................ 230

5.7.3 Caracterização funcional................................................................................. 237

5.8 DETERMINAÇÃ̂ DO TEOR DE LIMONENO VIA GC-MS ........................ 245

5.8.1 Equipamentos e condições.........................................................................2245

5.8.2 Curva de calibração e validação de parâmetros ......................................2245

5.8.3 Ensaio de adsorção............................................................................24

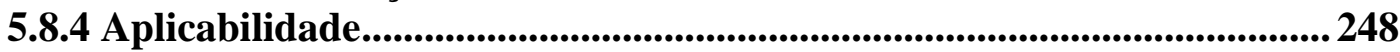

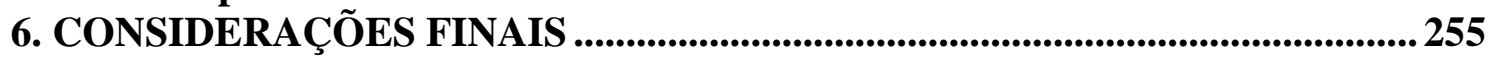

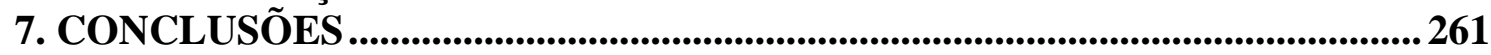

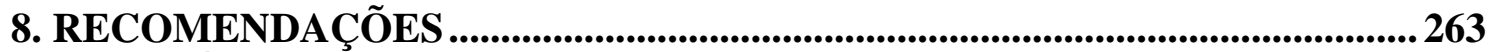

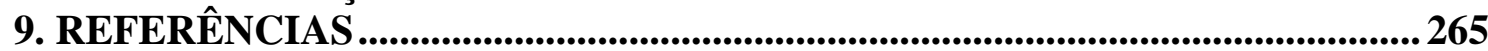

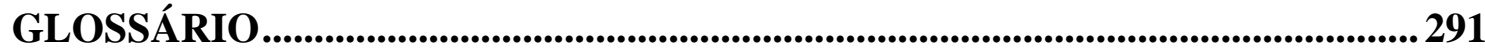

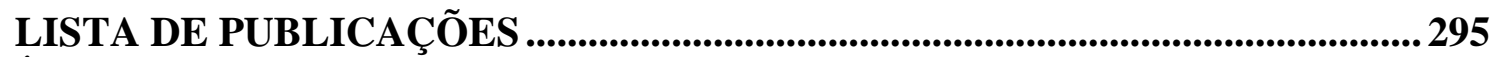

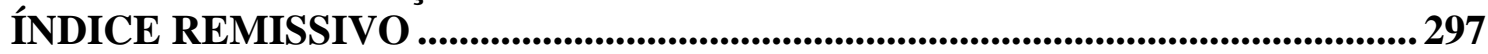





\section{INTRODUÇÃO}

O aumento populacional e o desenvolvimento da atividade econômica têm como consequência o acúmulo de resíduos de origem antrópica provenientes da atividade doméstica e industrial, como os resíduos agroidustriais. Além disso, surge com este desenvolvimento a necessidade de se buscar novas fontes de energia alternativas àquelas oriundas de combustíveis fósseis. A obtenção de produtos de interesse biotecnológico conciliada ao uso de biomassa residual é uma das propostas que vem ganhando destaque, minimizando os impactos ambientais de sua disposição direta no ambiente.

O uso de biocombustíveis, como o biogás (hidrogênio e metano), seria indicado para substituição dos combustíveis derivados do petróleo. Sua obtenção vem sendo estudada a partir de diversos inóculos e substratos, como resíduos alimentícios de restaurantes (FORSTER-CARNEIRO; PÉREZ; ROMERO, 2008), bagaço de cana-deaçúcar (LEITÃO et al., 2013), resíduos do processamento de citros (FORGÁCS et al., 2012; CALABRÒ et al., 2016; SU; TAN; XU, 2016), entre outros. Um dos obstáculos para a reutilização de resíduos sólidos orgânicos é a presença dos componentes de difícil degradação, como a celulose e a lignina, que podem restringir este processo devido a sua difícil assimilação pelos microrganismos (FRUNZO; PIROZZI, 2015). Desta forma, são necessárias novas possibilidades e também a otimização dos métodos físicos, químicos e biológicos de pré-tratamentos e hidrólise dos componentes lignocelulósicos dos resíduos orgânicos.

Os resíduos industriais do processamento de citros são potenciais substratos para a obtenção de bioprodutos, sendo o Brasil o principal produtor (CALABRÒ et al., 2016). O resíduo sólido de citros é composto por cascas e bagaço da fruta, sendo produzidas 500 toneladas (t) a cada $1.000 \mathrm{t}$ de fruta processadas (RUIZ; FLOTATS, 2016). Considerandose safra de aproximadamente 92,5 mil t de resíduos de frutas processadas, 44,8\% são direcionados à compostagem, reciclagem e coprocessamento/refinamento, enquanto o restante, aproximadamente 54,9\% do resíduo é considerado como excedente, sendo destinados à incineração, armazenamento local ou aterros sanitários (KOPPAR; PULLAMMANAPPALLIL, 2013; CITROSUCO, 2016). Uma vez que não há padronização para o reuso e disposição final do resíduo excedente (CALABRÒ et al., 2016), a abordagem de biorrefinaria vem ganhando destaque como possibilidade de destinação final, conciliando seu tratamento à obtenção de biogás (LÓPEZ; LI; THOMPSON, 2010). 
Calabrò et al. (2016) utilizaram diversos inóculos para a obtenção de metano a partir de resíduos de citros, tais como resíduos industriais e resíduos agroindustriais, sendo obtidos os melhores resultados em experimentos em condição mesófila e reatores em batelada; ou seja, de $33 \mathrm{mmol} \mathrm{CH}_{4} \cdot \mathrm{L}^{-1}$. Além disso, destaca-se também a obtenção de 0,01 mmol $\mathrm{CH}_{4} \cdot \mathrm{L}^{-1}$ utilizando resíduo pré-tratado de citros com inóculo de estrume de suíno e lodo de esgoto (SU; TAN; XU, 2016). Forgàcs et al. (2012) obtiveram concentração máxima de $247,7 \mathrm{mmol} \mathrm{CH}_{4} \cdot \mathrm{L}^{-1}$ utilizando resíduo de citros tratado por explosão a vapor com inóculo de reator de produção de biogás.

Outra possibilidade é o uso de resíduos sólidos de citros como substrato fermentativo para obtenção de compostos de interesse biotecnológico (FORGÁCS et al., 2012; RUIZ; FLOTATS, 2014; CALABRÒ et al., 2016). Todavia, destaca-se nestes resíduos a presença de inibidores, como compostos fenólicos e limoneno, os quais podem inibir o crescimento de algumas bactérias e arqueias metanogênicas (CALABRÒ et al., 2016). Sendo assim, a obtenção de microrganismos autóctones adaptados aos inibidores pode ser fundamental para o sucesso do processo fermentativo.

A determinação da prevalência de microrganismos presentes em citros torna-se informativa no estudo de grupos resistentes aos inibidores deste substrato, como a matriz lignocelulósica e, ainda, o limoneno, que vem sendo relatado como um dos obstáculos ao seu reuso. A possibilidade de uso de consórcios ao invés de culturas puras pode ser vantajosa, uma vez que há redução de custos em manutenção de cepas e meios específicos. Entretanto, o entendimento da composição do inóculo é fundamental, uma vez que as cepas isoladas podem ser aplicadas em processos de bioaumentação, como alternativa à melhoria de processos biotecnológicos e industriais e, recentemente, na produção biológica de $\mathrm{H}_{2}$ (MAINTINGUER et al., 2017).

A avaliação da comunidade microbiana, bem como a predição das enzimas envolvidas no processo fermentativo, é fundamental para o entendimento dos mecanismos de conversão da biomassa residual em produtos de valor agregado, como biogás e compostos orgânicos solúveis (COLOMBO et al., 2016). Uma vez que apenas uma pequena porcentagem de procariotos é cultivável, o uso de técnicas de biologia molecular, como o sequenciamento de nova geração (NGS) aplicados à amostras ambientais são úteis na caracterização destas comunidades, possibilitando o estudo de seu papel funcional e taxônomico na degradação de resíduos orgânicos (COLOMBO et al., 2016; KESKIN et al., 2018). 
As técnicas NGS podem ser aplicadas para o sequenciamento massivo do gene RNAr 16S (metabarcoding), ou ainda via metagenômica shotgun, por sequenciamento em plataforma Illumina (GUO et al., 2015), sendo as ferramentas meta-ômicas consideradas mais informativas para o entendimento da comunidade microbiana. Por meio da metagenômica shotgun, é possível acessar informações funcionais da comunidade, enquanto o sequenciamento massivo do gene RNAr 16S fornece informações diretas apenas sobre a identidade dos microrganismos. Além disso, por meio das ferramentas metaômicas tem-se a possibilidade de entendimento sobre como o consórcio microbiano se relaciona com as variáveis operacionais, e ainda sobre as rotas metabólicas envolvidas em sistemas complexos de aproveitamento de biomassa lignocelulósica (BRUCE et al., 2010; DELFORNO et al., 2017).

Além da composição do inóculo, outras variáveis são relevantes ao processo de obtenção de $\mathrm{H}_{2}$ em reatores anaeróbios, como temperatura, pH inicial, concentração de nutrientes e o tipo de substrato utilizado. Desta forma, o uso de ferramentas estatísticas torna-se útil no estabelecimento das condições operacionais ótimas para cada processo fermentativo. A obtenção de produtos de interesse biotecnológico pode ser otimizada a partir da manipulação das variáveis operacionais, bem como das condições nutricionais do meio de cultivo, a fim de obter condições economicamente viáveis e com maior produção do metabólito de interesse. Entretanto, uma vez que não há consenso sobre as condições ótimas para obtenção de biogás a partir de resíduos de citros, como $\mathrm{pH}$, temperatura (faixa mesofílica ou termofílica), condições nutricionais, concentração ideal de inóculo ou de substrato, se fazem necessários novos estudos acerca destas variáveis.

O método mais comum para seleção de variáveis operacionais é o unidimensional, ou também conhecido como "one factor at a time", em que se varia uma categoria por vez e as demais são mantidas como constantes (MATHUR et al., 2013; KORAYEM et al., 2015; WU et al., 2018). Entretanto, este método pode ser inviável quando há muitas variáveis a serem estudadas, além de não garantir que as melhores condições serão alcançadas (NAVEENA et al., 2005). O delineamento experimental de Plackett \& Burman (PLACKETT; BURMAN J.P., 1946) é ferramenta de screening de variáveis significativas e seus efeitos em diferentes processos (RODRIGUES; IEMMA, 2014).

Sitthikitpanya et al. (SITTHIKITPANYA; REUNGSANG; PRASERTSAN, 2018) analisaram o efeito de diferentes variáveis (concentração de substrato, enzima, inóculo, pH e temperatura) na obtenção de hidrogênio e metano a partir de biomassa lignocelulósica (tronco de óleo de palma) por Thermoanaerobacterium thermosaccharolyticum. Os autores 
observaram que o pH inicial e concentração de substrato foram as variáveis mais influentes no processo, enquanto as demais não foram significativas $(\mathrm{p} \leq 0,05)$ e fixadas em níveis menores, reduzindo os custos relacionados aos reagentes.

O Delineamento Composto Central Rotacional (DCCR) possibilita a obtenção de um modelo polinomial, que pode ser utilizado para descrever tanto o efeito de cada fator estudado, quanto a interação entre diferentes fatores em uma resposta de interesse (RODRIGUES; IEMMA, 2014), e.g., obtenção de $\mathrm{H}_{2}$. A partir do modelo de regressão, é possível estabelecer as condições ótimas de operação, a fim de maximizar a obtenção do subproduto de interesse. Villa-Montoya et al. (2020) obtiveram 29,46 mmol H $\mathrm{H}_{2} \cdot \mathrm{L}^{-1}$ após otimização usando DCCR em reatores em batelada, avaliando a concentração do substrato (resíduos de café), $\mathrm{pH}(4,82-8,18)$ e volume do headspace $(33,18-66,82 \%)$. As condições ótimas identificadas foram $\mathrm{pH}$ 7,0, com 7 g. $\mathrm{L}^{-1}$ de substrato e $30 \%$ de headspace, sendo que o ácido butírico foi o principal metabólito obtido (3.838 mg.L $\left.\mathrm{L}^{-1}\right)$.

Neste contexto, o objetivo geral desta pesquisa foi avaliar a utilização de resíduos sólidos de citros como substrato para a obtenção de produtos de interesse biotecnológico e biogás em reatores em batelada, além de isolar, identificar e caracterizar bactérias anaeróbias potencialmente celulolíticas a partir dos resíduos de citros in natura. Para tanto, utilizou-se os métodos estatísticos de Plackett \& Burman seguido de Delineamento Composto Central Rotacional (DCCR), além de técnicas de sequenciamento de nova geração (NGS) em plataforma Illumina HiSeq, via metagenômica metabarcoding e shotgun. 


\section{HIPÓTESES E OBJETIVOS}

\subsection{HIPÓTESE E OBJETIVO GERAL}

\subsubsection{Hipótese geral}

Os experimentos conduzidos foram baseados na hipótese geral de que os resíduos do beneficiamento de citros, tanto as cascas, quanto os bagaços, devido à sua composição rica em material lignocelulósico, podem ser usados como substratos na digestão anaeróbia em reatores em batelada, possibilitando a obtenção de produtos de interesse biotecnológico (ácidos orgânicos, álcoois e biogás), e como fonte de microrganismos fermentativos autóctones potencialmente celulolíticos.

\subsubsection{Objetivo geral}

O objetivo geral desta pesquisa foi avaliar a utilização de resíduos sólidos de citros como substrato para a obtenção de produtos de interesse biotecnológico e biogás em reatores em batelada, além de isolar, identificar e caracterizar bactérias anaeróbias potencialmente celulolíticas a partir dos resíduos de citros in natura.

\subsection{HIPÓTESES E OBJETIVOS ESPECÍFICOS}

\subsubsection{Hipótese e objetivo específico 1}

Hipótese 1- Os resíduos de citros in natura são fonte de microrganismos celulolíticos e fermentativos.

Objetivo 1.1- Avaliar consórcio fermentativo de bactérias anaeróbias celulolíticas e fermentativas a partir do enriquecimento de microbiota autóctone de resíduos de citros (cascas e bagaço in natura) em relação à obtenção de produtos de interesse biotecnológico.

Objetivo 1.2- Caracterizar bactérias anaeróbias potencialmente celulolíticas a partir do consórcio autofermentativo do resíduo de citros.

\subsubsection{Hipótese e objetivo específico 2}

Hipótese 2- Os grânulos de reatores UASB aplicados ao processamento de águas residuárias provenientes de avícolas ou vinhaça de cana-de-açúcar podem ser considerados fonte de microrganismos fermentativos e metanogênicos para obtenção de biogás e demais produtos de interesse biotecnológico, a partir da fermentação de resíduo de citros.

Objetivo 2.1- Comparar o efeito da adição de lodo granulado termófilico e mesofílico de reator UASB como fonte de biomassa anaeróbia na obtenção de produtos de interesse biotecnológico a partir de resíduos de citros, bem como avaliar a faixa de temperatura mais adequada para o processo. 


\subsubsection{Hipótese e objetivo específico 3}

Hipótese 3- O aumento da obtenção de biogás é possível por meio da aplicação de pré-tratamentos de hidrotermólise e deslignificação alcalina, com a finalidade de romper a estrutura lignocelulósica dos resíduos de citros e facilitar o acesso microbiano. A aplicação dos pré-tratamentos de hidrotermólise e deslignificação alcalina causa modificações na estrutura lignocelulósica das cascas e bagaço de citros, como a deslignificação, rompimento das fibras de hemicelulose e também de celulose cristalina.

Objetivo 3.1- Comparar e caracterizar morfologicamente a estrutura lignocelulósica após diferentes estratégias de rompimento da casca e bagaço dos resíduos sólidos de citros.

\subsubsection{Hipótese e objetivo específico 4}

Hipótese 4- É possível definir as condições operacionais ótimas à obtenção de biogás e outros produtos de interesse biotecnológico a partir de resíduos de citros por meio do método estatístico de Planejamento Experimental.

Objetivo 4.1- Avaliar as melhores condições para obtenção de produtos de interesse biotecnológico a partir de resíduos de citros por meio da ferramenta de screening design Plackett \& Burman para avaliação da significância de diferentes variáveis operacionais, e Delineamento Composto Central Rotacional (DCCR) para obtenção de superfície de resposta indicando as regiões ótimas para o processo.

\subsubsection{Hipótese e objetivo específico 5}

Hipótese 5- A obtenção de $\mathrm{H}_{2}$ a partir de resíduos sólidos de citros em reatores em batelada tem como consequência uma fração líquida rica em metabólitos, que podem ser utilizados como substrato por microrganismos sintróficos e/ou metanogênicos, como ácidos orgânicos voláteis (ácido acético, ácido butírico e ácido propiônico) e oligo/monossacarídeos oriundos da degradação dos resíduos lignocelulósicos.

Objetivo 5.1- Avaliar o potencial metanogênico da fração líquida acidificada obtida após a fermentação dos resíduos sólidos de citros em reatores em batelada, simulando um reator em batelada de dois estágios (fase acidogênica e fase metanogênica).

\subsubsection{Hipótese e objetivo específico 6}

Hipótese 6- É possível determinar via Cromatografia Gasosa acoplada à Espectrometria de Massas (GC-MS) o teor de limoneno, um dos principais inibidores da fermentação e metanogênese envolvidos na reutilização de resíduos sólidos de citros em reatores anaeróbios para recuperação de produtos de interesse biotecnológico. 
Objetivo 6.1- Desenvolver e validar um método de determinação do teor de limoneno em amostras líquidas via GC-MS, além de aplicar o método desenvolvido no monitoramento de reatores em batelada operados em temperatura mesofílica $\left(30^{\circ} \mathrm{C}\right)$ para obtenção de hidrogênio.

\subsubsection{Hipótese e objetivo específico 7}

Hipótese 7- As diferentes condições operacionais aplicadas em diferentes etapas da presente pesquisa influenciam diretamente a comunidade microbiana envolvida no processo, bem como as vias metabólicas predominantes.

Objetivo 7.1- Avaliar as comunidades microbianas envolvidas em diferentes etapas da fermentação de resíduos de citros, por meio de técnicas de sequenciamento de nova geração, bem como estimar sua contribuição nas diferentes etapas e vias metabólicas envolvidas na degradação de resíduos lignocelulósicos e digestão anaeróbia. 


\section{REVISÃO BIBLIOGRÁFICA}

\subsection{BIORREFINARIAS E BIOPRODUTOS}

Um dos grandes desafios da sociedade moderna é tornar-se mais sustentável, não apenas no que diz respeito à emissão e disposição de resíduos, mas também à exploração de recursos naturais. A biorrefinaria, cuja instalação visa a integração entre processos e equipamentos de conversão da biomassa para a obtenção de combustíveis, energia e produtos químicos a partir de biomassa residual, é considerada tecnologia emergente, implantada com a finalidade principal de impulsionar o desenvolvimento rural a partir do uso desta biomassa residual e integração entre os processos de obtenção de produtos de interesse biotecnológico a partir de resíduos. O objetivo deste processo é aproveitar ao máximo a matéria prima inicial bruta, bem como seus diferentes componentes e intermediários, maximizando seu valor agregado e diminuindo a emissão de resíduos (BORGES; COSTA, 2006; LÓPEZ; LI; THOMPSON, 2010).

Por meio da Agencia Internacional de Energia tem-se estimativa que até 2035 a demanda por combustíveis poderá aumentar em até 30\% (MARQUES et al., 2013). Desta forma, a obtenção de biocombustíveis e bioprodutos é uma das propostas que vem ganhando destaque, uma vez que permite conciliar a obtenção de energia à reutilização de resíduos, minimizando os impactos ambientais de sua disposição direta no ambiente. Os bioprodutos são produzidos a partir de matéria-prima biológica, por meio de reações termoquímicas ou bioquímicas que podem gerar etanol, metanol, butanol, óleos vegetais, biodiesel, biogás, entre outros, podendo ser aproveitados por meio da energia liberada em sua combustão direta ou para obtenção de energia elétrica (BALAT, 2011).

A alternativa mais indicada para a obtenção dos bioprodutos é a utilização de resíduos sólidos orgânicos, como os resíduos agroindustriais ou resíduos resultantes do processamento de alimentos, sendo que os resíduos alimentícios mais comuns provêm de vegetais, carnes, frutas, grãos e laticínios (KIRAN et al., 2014). A utilização de matériaprima orgânica não residual, a princípio, não é recomendada, pois pode acarretar na redução da quantidade de suprimentos e no aumento de seu preço, levando a instabilidade sociopolítica (SU; TAN; XU, 2016).

O uso de biocombustíveis, como o biogás, seria indicado para substituição dos combustíveis oriundos do petróleo (MARQUES et al., 2013). Sua obtenção vem sendo estudada a partir de diversos inóculos e substratos, como resíduos alimentícios de restaurantes (MASIH-DAS; TAO, 2018; JIANG et al., 2019), bagaço de cana-de-açúcar (LEITÃO et al., 2013; AHMAD et al., 2018; RABELO et al., 2018a; SOARES et al., 2018), 
banana (MAZARELI et al., 2020), resíduos do processamento de café (VILLA MONTOYA et al., 2020) e também os resíduos do processamento de citros (FORGÁCS et al., 2012; CALABRÒ et al., 2016; SU; TAN; XU, 2016).

A utilização do biogás resultante da fermentação de matéria orgânica como biocombustível pode ser considerada como uma via de duplo propósito, uma vez que além de promover a destinação adequada para diversos resíduos orgânicos, como as cascas e bagaço de citros, a captação desse gás impede sua liberação para a atmosfera (RUIZ; FLOTATS, 2016). Considera-se que este processo fomenta destinação mais adequada para os resíduos orgânicos, pois após a produção de biogás, o resíduo sólido resultante é rico em nutrientes, podendo ser utilizado como fertilizantes ou condicionantes do solo (LÓPEZ; LI; THOMPSON, 2010; KIRAN et al., 2014).

O metano, o hidrocarboneto mais simples e principal componente do biogás, vem sendo amplamente estudado como carreador energético, uma vez que produz mais energia

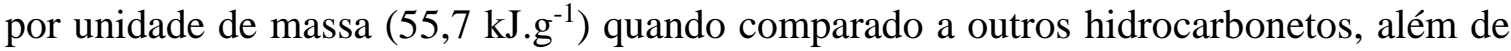
produzir menos dióxido de carbono como subproduto. Desta forma, o metano pode ser utilizado para produção de energia elétrica por meio de sua queima em turbinas de gás ou caldeiras de vapor, além de que, desde meados de 1930, seu uso sob a forma de gás natural comprimido como combustível em veículos vem ganhando destaque (AZMAN et al., 2015; SHEN et al., 2016; WEI; GENG, 2016).

O hidrogênio é o elemento mais abundante do universo, compreendendo aproximadamente três quartos de toda a matéria, sendo que a superfície terrestre contém cerca de $0,14 \%$ deste elemento na forma gasosa $\left(\mathrm{H}_{2}\right)$. Uma vez que o principal produto da combustão deste gás é a água e possui alto rendimento energético $\left(122 \mathrm{~kJ}_{\text {.g }}{ }^{-1}\right)$, pode ser considerado como um combustível não poluente e como alternativa ao uso de combustíveis fósseis (DAS; VEZIROGLU, 2001; ILGI KAPDAN; KARGI, 2006; SIVAGURUNATHAN et al., 2017).

$\mathrm{O}_{2}$ pode ser útil para o armazenamento e transmissão da energia gerada em sistemas nucleares ou de energia solar. Além disso, a hidrogenação tem outras aplicações além do uso como combustível, como eliminador de $\mathrm{O}_{2}$ a fim de prevenir a oxidação e corrosão de materiais ou também como refrigerante em geradores elétricos. $\mathrm{O} \mathrm{H}_{2}$ pode ser obtido a partir de combustíveis fósseis ou, alternativamente, a partir de biomassa, por meio de processos de eletrólise, fotólise, processos termoquímicos ou processos biológicos, foco deste estudo, que tem como principais vantagens a possibilidade de realização a 
temperaturas e pressões ambiente e, principalmente, o uso de biomassa residual como substrato de fermentação (DAS; VEZIROGLU, 2001; NIKOLAIDIS; POULLIKKAS, 2017).

\subsection{RESÍDUOS LIGNOCELULÓSICOS}

Os monossacarídeos podem ser estocados nas células animais e vegetais na forma de polímeros de alta massa molecular (glicogênio e amido, respectivamente) e que mantém a osmolaridade citosólica consideravelmente baixa, sendo liberadas e utilizadas para a síntese de ATP em situações de alta demanda energética, por meio do metabolismo aeróbio, em que o monossacarídeo será completamente oxidado a $\mathrm{CO}_{2}$ e água, ou também anaeróbio, por meio da fermentação destes açúcares a diversos produtos finais, como ácidos orgânicos e/ou álcoois, dependendo da rota metabólica favorecida (NELSON; COX, 2011). Entretanto, existem outros polissacarídeos abundantes nas células, que possuem função estrutural e não de armazenamento energético, mas que também podem conter elevada energia potencial.

A biomassa lignocelulósica, oriunda de atividades municipais, florestais e também agroindustriais, pode ser considerada como fonte abundante de recursos orgânicos, uma vez que grandes quantidades deste resíduo são acumulados anualmente (ZHENG et al., 2014). Um dos fatores limitantes da destinação destes resíduos como substrato é a sua difícil assimilação, o que impede a bioconversão direta desta biomassa à glicose (DE LA RUBIA et al., 2011). Sua composição é complexa, uma vez que é formada majoritariamente por celulose, hemicelulose e lignina, variando de acordo com fatores ambientais ou com as características vegetais, sendo que normalmente a proporção destes é em média 70-78\% de celulose e hemicelulose e 18-28\% de lignina (DEMÍRBAS, 2005; SUNDBERG, 2010; FRUNZO; PIROZZI, 2015), mas que podem variar de acordo com a origem do resíduo, sendo que resíduos agroflorestais geralmente possuem maior teor de lignina em relação aos resíduos agrícolas (SUNDBERG, 2010).

A celulose, principal componente dos materiais lignocelulósicos, é um biopolímero linear de celobiose (dissacarídeo de glicose), fortemente ligado e coberto por lignina nas estruturas lignocelulósicas, que por sua vez é um grande complexo aromático de heteropolímeros hidrofóbicos, o que confere a resistência do material à biodegradação (ZHENG et al., 2014). A resistência da lignina a torna a principal responsável pela dificuldade de se converter os polissacarídeos a monossacarídeos, entretanto, apesar de sua 
insolubilidade em água, a lignina pode se dissolver em temperaturas elevadas $\left(180{ }^{\circ} \mathrm{C}\right)$, condições ácidas ou alcalinas (GRABBER, 2005).

Sintetizada pelas plantas na magnitude de aproximadamente $10^{11}$ toneladas por ano, a celulose (Figura 3.1) é considerada um dos compostos mais abundantes da biosfera, e é um polissacarídeo polimérico linear e fibroso de celobiose, cuja principal função biológica é a função estrutural na parede celular vegetal (NELSON; COX, 2011). É formada por dissacarídeos de glicose, fortemente ligados via ligações glicosídicas $\beta-1,4$. As cadeias celulósicas possuem grande quantidade de grupos hidroxila, o que leva à formação de ligações de hidrogênio nestas mesmas cadeias ou em cadeias adjacentes, interligadas por ligações de hidrogênio e forças de Van der Waals, resultando em microfibras de alta resistência (ZHENG et al., 2014).

Outra característica que confere resistência à celulose são as diferentes possibilidades de orientação das moléculas ao longo das fibras, resultando em diferentes níveis de cristalinidade, podendo, ser subdividida em duas regiões principais: amorfa (baixa cristalinidade) e cristalina (alta cristalinidade), sendo que quanto mais cristalina a estrutura, mais resistente (ATALLA; VANDERHART, 1984; ZHENG et al., 2014).

Figura 3.1. Conformação em cadeira da celulose e da hemicelulose e seus monômeros originados após hidrólise.

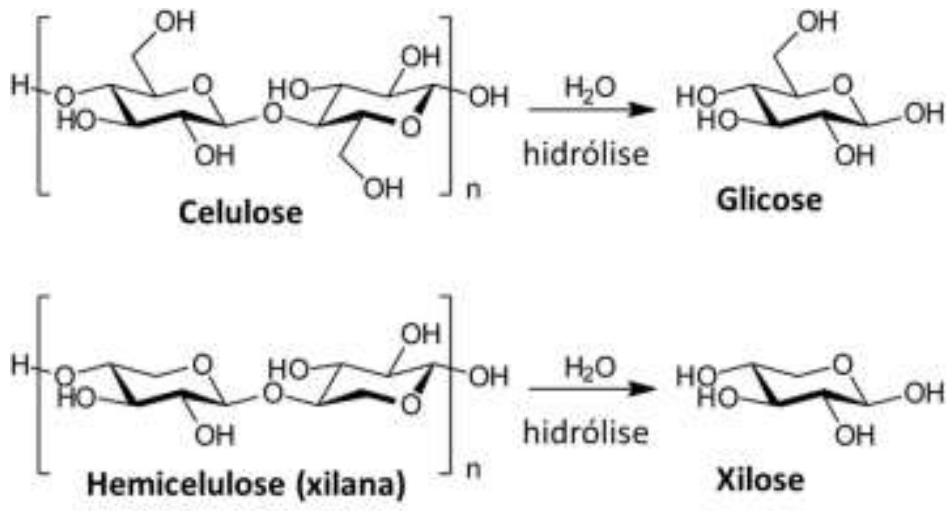

Fonte: Modificado de Kobayashi et al. (2016).

Outros homopolissacarídeos, como o amido, diferem da celulose devido a sua configuração molecular em $\alpha-1,4$ ao invés de $\beta-1,4$. Esta diferença é importante, uma vez que as enzimas produzidas pelos animais e pela maior parte dos microrganismos possuem afinidade por moléculas na configuração $\alpha$ (amilases e glicosidades) e apenas alguns microrganismos restritos a ambientes específicos (como o trato digestivo ou rúmem de herbívoros) ou decompositores de biomassa vegetal possuem enzimas celulases ou demais enzimas do complexo celulolítico (NELSON; COX, 2011). 
A hemicelulose, segundo componente mais abundante da estrutura lignocelulósica, difere em relação à celulose no que diz respeito a sua conformação e composição, pois são amorfas e também heterogêneas, compostas de várias pentoses, (como a xilose e a arabinose), hexoses (glicose, galactose, manose, ramnose) e também de ácidos (glucurônico, metil glucurônico e galacturônico). As cadeias de hemicelulose são as responsáveis pela interligação entre a celulose e a lignina, além de que são mais suscetíveis à hidrólise devido a sua estrutura amorfa (ZHENG et al., 2014).

Por fim, a lignina é um complexo aromático amorfo, hidrofóbico e heterogêneo, composto de unidades de fenilpropano (álcool coniferílico e sinapílico) com grupos hidroxila, metoxila e carbonila. A lignina é a responsável pela rigidez da estrutura tridimensional da lignocelulose (DE LA RUBIA et al., 2011; ZHENG et al., 2014). (GRABBER, 2005; LEITÃO et al., 2013). De acordo com Grabber (2005) e Leitão et al. (2013), a estrutura da lignina pode ser desestabilizada em altas temperaturas $\left(180^{\circ} \mathrm{C}\right) \mathrm{e} \mathrm{em}$ condições ácidas ou alcalinas.

A obtenção de bioprodutos depende da hidrólise dos resíduos lignocelulósicos a carboidratos mais assimiláveis, ou seja, a quebra das ligações glicosídicas dos polissacarídeos a monossacarídeos e oligossacarídeos (KIRAN et al., 2014), e também a diminuição da cristalinidade da estrutura celulósica (ZHENG et al., 2014) sendo para tanto, utilizados métodos físicos, químicos ou biológicos no pré-tratamento destes resíduos.

\subsection{RESÍDUOS SÓLIDOS AGROIDUSTRIAIS}

A agroindústria constitui uma das principais parcelas da economia, tanto para o abastecimento interno, quanto para exportação (SPADOTTO; RIBEIRO, 2007). As atividades da agroindústria podem provocar impactos ambientais consequentes do desmatamento, queimadas em pastagens e florestas, poluição relacionada ao uso de agrotóxicos, entre outros. No Brasil, dado seu potencial agrícola, a gestão dos resíduos da agroindústria é de vital importância. Em 2013, estima-se que o agronegócio foi responsável por 22,54\% do PIB nacional (CEPEA, 2013), ou seja, a atividade agrícola se traduz em benefícios ao país, com geração de empregos e maior contribuição ao desenvolvimento econômico e social (SCHNEIDER et al., 2012). Diversos motivos vêm incentivando as empresas a buscar alternativas para a disposição dos resíduos gerados durante o processamento de diferentes matérias primas, sendo que além dos riscos de danos ambientais, também podem ser citados os prejuízos financeiros advindos do não cumprimento da legislação ambiental vigente. 
Os resíduos agroidustriais podem ser divididos em inorgânicos e orgânicos, sendo os primeiros aqueles relacionados a embalagens de agrotóxicos e fertilizantes, além de insumos veterinários, enquanto os resíduos orgânicos, foco desta pesquisa, compreendem os resíduos agrícolas/agroindustriais (culturas permanentes ou temporárias), dejetos de animais e resíduos florestais/silviculturais (ABNT, 2004).

Quando analisadas as principais fontes de resíduos sólidos agroidustriais e orgânicos de culturas permanentes nacionais, Schneider et al. (2012) apontam que os resíduos de citros são os mais críticos (aproximadamente 8.825.276 t por ano), seguido pelo café (1.220.029 t por ano), coco-da-baía (405.009 t por ano), banana (99.640 t por ano) e castanha-de-caju (80.484 t por ano). Todos estes resíduos têm potencial para uso em reaproveitamento energético (FORSTER-CARNEIRO; PÉREZ; ROMERO, 2008; FORGÁCS et al., 2012; LEITÃO et al., 2013; CALABRÒ et al., 2016; SU; TAN; XU, 2016), embora ainda não haja legislações específicas para este fim. Estes dados compreendem apenas os resíduos do processamento industrial de citros, excluindo os resíduos de feiras e residências, pois estes são considerados junto aos resíduos urbanos, os quais não fazem parte do escopo deste estudo; além dos resíduos orgânicos gerados diretamente na atividade de agricultura, uma vez que estes são utilizados como complemento nutritivo aos solos no próprio local de produção, não sendo, portanto, indicado seu uso em outras finalidades (SCHNEIDER et al., 2012).

Uma das vantagens do uso dos resíduos sólidos orgânicos em sistemas de reaproveitamento energético é a consequente redução anual de material aterrado ou disposto de forma inadequada, diminuindo assim a necessidade de implantação de aterros sanitários em novas áreas. Além disso, a disposição de resíduos orgânicos de forma inadequada pode agravar a emissão de gases do efeito estufa, como o metano e dióxido de carbono (DEPPENMEIER, 2002). Desta forma, planos de gestão de resíduos cada vez mais adequados ambientalmente e vantajosos economicamente devem ser estudados, uma vez que as atividades agroidustriais não trazem apenas prejuízos para os estados e municípios que os abrigam, mas também benefícios proporcionais ao crescimento deste setor, portanto, não devem ser desestimuladas.

Com o desenvolvimento da atividade econômica e o crescente aumento populacional, problemas como o acúmulo de resíduos de origem antrópica provenientes da atividade doméstica e agroindustrial, e também a necessidade de novas fontes de energia renováveis e menos poluentes, ainda permanecem sem solução adequada. A obtenção de 
biocombustíveis e bioprodutos é uma das propostas que vem ganhando destaque, pois permite conciliar a produção de energia à utilização de resíduos, minimizando os impactos ambientais de sua disposição direta no ambiente.

\subsection{RESÍDUOS DO PROCESSAMENTO DE CITROS}

O Brasil é o principal produtor de citros do mundo, sendo responsável por aproximadamente $35 \%$ da produção mundial de laranja e $81,6 \%$ da exportação de suco concentrado (BORGES; COSTA, 2006; CALABRÒ et al., 2016), seguido pelos Estados Unidos da América, Índia e China. No Brasil, a atividade de exportação citrícola teve início na década de 80 no Estado do Rio de Janeiro. A partir de 1957, o Estado de São Paulo tornou-se o principal produtor devido as suas condições edafoclimáticas favoráveis (BORGES; COSTA, 2006).

A laranja (Citrus sinensis L.) pode ser considerada como uma das frutas mais cultivadas, sendo associada à obtenção de diversos produtos, como geleias, óleo essencial, mel de flor de laranjeira e conservas (LÓPEZ; LI; THOMPSON, 2010), entretanto, a sua principal destinação é a produção de suco, compreendendo 70\% do total (FAOSTAT, 2014; CALABRÒ et al., 2016), de 88 milhões de toneladas por ano.

Após o seu beneficiamento, entre 50-60\% do volume de frutas produzidas tornamse resíduos, incluindo suas cascas, bagaço, sementes e membranas, sendo que sua via de destinação mais comum é a sua utilização como matéria prima para a fabricação de ração para gado, compostagem ou incineração do resíduo excedente (LÓPEZ; LI; THOMPSON, 2010). Esses resíduos possuem em sua composição elevada quantidade de carboidratos, portanto, são considerados como potencial substrato para a obtenção de biogás e bioetanol, em biorrefinarias. Entretanto, a presença de limoneno e lignina tornam a degradação mais difícil, limitando a obtenção de produtos de interesse biotecnológico (POURBAFRANI et al., 2010).

Apenas no Brasil, estima-se que são produzidas aproximadamente $68 \mathrm{Mt}$ por ano, dos quais 25-30 Mt são convertidos em resíduos. Devido a sua composição, sendo 75-85\% de água, $17 \%$ de monossacarídeos solúveis, $0,8 \%$ de lignina $\left(\mathrm{C}_{10} \mathrm{H}_{11} \mathrm{O}_{3,5}\right), 9,2 \%$ de celulose $\left(\mathrm{CH}_{1,67} \mathrm{O}_{0,83}\right), 10,5 \%$ de hemicelulose $\left(\mathrm{CH}_{1,64} \mathrm{O}_{0,78}\right), 42,5 \%$ de pectina $\left(\mathrm{C}_{6} \mathrm{H}_{10} \mathrm{O}_{5}\right)_{n}$ e $0,3-$ 0,5\% de óleos essenciais, como o limoneno $\left(\mathrm{C}_{10} \mathrm{H}_{16}\right)$ (BICAS et al., 2008; LÓPEZ; LI; THOMPSON, 2010; CALABRÒ et al., 2016), os resíduos dos cultivares e do processamento de citros vem sendo estudados como matéria prima alternativa e de baixo custo para a obtenção de produtos de interesse biotecnológico. 
Forgàcs et al. (2012) obtiveram concentração máxima de 247,7 mmol CH $4 . \mathrm{L}^{-1}$ utilizando resíduo de citros tratado por explosão a vapor com inóculo de reator de planta de produção de biogás. Calabrò et al. (2016) utilizaram diversos inóculos para a obtenção de metano a partir de resíduos de citros, tais como resíduos industriais e resíduos agroindustriais, sendo obtidos os melhores resultados em experimentos em condição mesófila em reatores em batelada, com concentração de $33 \mathrm{mmol} \mathrm{CH}_{4} \cdot \mathrm{L}^{-1}$. Além disso,

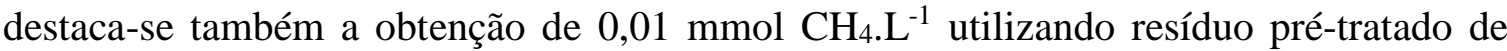
citros com inóculo de estrume suíno e lodo de esgoto (SU; TAN; XU, 2016).

Destaca-se que a obtenção de metano pode ser conciliada à obtenção de gás hidrogênio (FORSTER-CARNEIRO; PÉREZ; ROMERO, 2008; KIRAN et al., 2014) e que não apenas os resíduos sólidos do processamento de citros podem ser utilizados como substrato para a obtenção de biogás, mas também a água residuária oriunda de sua prensagem, processo realizado quando há o objetivo de redução do volume dos resíduos ou sua posterior destinação como matéria prima para ração animal (LÓPEZ; LI; THOMPSON, 2010).

Anjum et al. (2017) avaliaram o efeito da co-digestão de resíduos do processamento de citros e resíduos de restaurantes em reatores em batelada incubados por 80 dias a $30{ }^{\circ} \mathrm{C}$. Os autores verificaram que a proporção ideal seria de 1:1 de cada resíduo, a fim de reduzir a concentração de potenciais inibidores dos resíduos cítricos (e.g., limoneno) e aumentar a eficiência da obtenção de biogás. Saidi et al. (2018) obtiveram concentração máxima de $446 \mathrm{mmol} \mathrm{H} \mathrm{H}_{2} \cdot \mathrm{L}^{-1}$, em condições hipertermófilas $\left(80^{\circ} \mathrm{C}\right)$ em $\mathrm{pH}$ 7,0 e reator de tanque de agitação contínua, utilizando como inóculo cultura pura da bactéria Thermotoga maritima e resíduos de vegetais e frutas, incluindo citros/laranja, como fonte alternativa de carbono.

Além da difícil degradação dos componentes dos resíduos do processamento de citros, sua acidez e quantidades consideráveis de óleos essenciais (OEs), como o limoneno, podem inibir o desenvolvimento microbiano, uma vez que induz a lise celular (BAKKALI et al., 2008). Estima-se que a inibição microbiana pelo limoneno ocorra em concentrações acima de 25-75 mg. $\mathrm{L}^{-1} \mathrm{~d}^{-1}$, mas ainda sobre isso não há valores definidos (RUIZ; FLOTATS, 2016). Todavia, são poucas as pesquisas envolvendo a obtenção de hidrogênio a partir de resíduos de citros, bem como pesquisas sobre o efeito destes OE, como o limoneno, em processos fermentativos.

Os óleos essenciais (OEs) são compostos aromáticos naturais e voláteis, formados como metabólitos secundários por algumas espécies de plantas, compreendendo entre 0,3- 
0,5\% dos resíduos sólidos de citros in natura (CALABRÒ et al., 2016). Sua síntese ocorre em todos os órgãos das plantas (caule, flores, folhas, sementes, frutos, raízes, lenho) e é armazenada em células secretoras especializadas ou tricomas. Devido às suas propriedades medicinais, anti-sépticas e microbicidas, além de sua fragrância, os óleos essenciais são utilizados como aditivos em produtos farmacêuticos e da indústria de alimentos, como anestésicos, analgésicos, sedativos, anti-inflamatórios, entre outros (NEGRO et al., 2017; LOTITO et al., 2018).

Tendo em vista que os óleos essenciais são metabolizados principalmente como mecanismo de defesa das plantas, esses compostos podem ser tóxicos para outros organismos devido à sua afinidade lipofílica (JUSTINO DE ARAÚJO et al., 2020). Esta natureza lipofílica possibilita a passagem do óleo essencial pela parede celular e pela membrana citoplasmática, desestabilizando polissacarídeos e ácidos graxos, além de ocasionar a perda de íons nas células bacterianas, levando-os à lise (BAKKALI et al., 2008). O limoneno, um monoterpeno monocíclico conhecido como D-limoneno ou (R)(+)-4-isoproprenil-1-metilciclohexano (Figura 3.2), é o principal constituinte dos óleos essenciais na maioria das espécies cítricas, como limão, laranja, tangerina, limão e toranja (LOPRESTO, 2015; RUIZ; FLOTATS, 2016).

Figura 3.2. Estrutura química do limoneno.

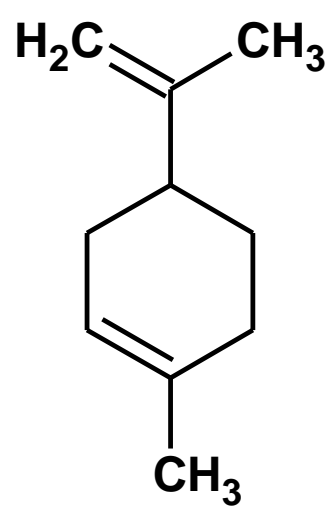

Fonte: Elaborada em ChemSketch (ACD, 2019).

O teor de limoneno nos resíduos de processamento de citros é considerado um dos principais obstáculos a sua reutilização na obtenção de biogás. Sua concentração mínima para inibição é estimada em aproximadamente 200 mg.kg-1 (POURBAFRANI et al., 2010; CALABRÒ et al., 2016; RUIZ; FLOTATS, 2016), e como as concentrações em resíduos sólidos de citros geralmente excedem esse limite, o efeito inibitório dessa substância é sempre esperado (RUIZ; FLOTATS, 2014). 
Em aerobiose, a degradação do limoneno ocorre em aproximadamente 14 dias, no entanto, não há dados sobre esse processo em condições anaeróbias. Sabe-se que em anaerobiose, o limoneno apresenta maior toxicidade; no entanto, os mecanismos ainda não são claros. A toxicidade do limoneno pode ser atribuída tanto à maior sensibilidade dos organismos anaeróbios quanto à baixa pressão parcial de oxigênio no sistema, resultando em menor oxidação deste composto (RUIZ; FLOTATS, 2014).

Calabrò et al. (2016) descreveram a formação de $p$-cimeno após a biodegradação do limoneno em condições anaeróbias, nos quais o limoneno é mais tóxico que o $p$-cimeno (DORMAN; DEANS, 2000), justificando o maior tempo de adaptação da biomassa, proporcional às maiores concentrações de limoneno e à adaptação microbiana após esse período. Os autores observaram maior tempo de início da obtenção de $\mathrm{H}_{2}(\lambda)$ em ensaios com maior concentração de limoneno; no entanto, a obtenção de metano atingiu valores finais de concentração ( $\left.33 \mathrm{mmol} \mathrm{CH}_{4} \cdot \mathrm{L}^{-1}\right)$ similares aos do controle.

Diversos métodos descritos na literatura podem ser utilizados para determinação do conteúdo de limoneno, como Espectroscopia de Absorção Molecular (UV-Vis) (AHRO et al., 2001), Cromatografia Gasosa com Detector por Ionização de Chama (GC-FID), Espectrometria de Mssa de Monitoramento de Íons Selecionados (SIM) (BLANCH; NICHOLSON, 1998), Cromatografia a Gás com Colunas Capilares de Vidro (SONG et al., 2000), Espectrometria de Mobilidade por Íons Ultravioleta (IMS) (VAUTZ; SIELEMANN; BAUMBACH, 2004), Cromatografia Líquida de Alta Performance (RPHPLC) (VILLA et al., 2007) e diferentes condições em Cromatografia em Fase Gasosa Acopladas à Espectrometria de Massa (GC-MS) (SONG et al., 2000; MARINE; CLEMONS, 2003; MILLER et al., 2008). De acordo com Adorno et al. (2014), métodos que envolvem análise direta do headspace são mais vantajosos quando comparados àqueles com injeção de amostra líquida na coluna cromatográfica, preservando seu tempo de vida.

Em pesquisas anteriores, o método via GC-MS foi utilizado para determinação de limoneno em amostras de citros (DAVIDOWSKI; DIMARCO, 2009), entretanto, ainda são escassos os dados referentes à sua aplicação em amostras de reatores anaeróbios, comumente alimentados com águas residuárias.

\subsection{PRÉ-TRATAMENTOS DE RESÍDUOS LIGNOCELULÓSICOS}

Diversos resíduos orgânicos podem ser utilizados para a obtenção de bioprodutos a partir da digestão anaeróbia da matéria orgânica, entretanto, um dos obstáculos é a presença dos componentes de difícil degradação, como a celulose e a lignina, que podem restringir 
este processo devido a sua difícil assimilação pelos microrganismos responsáveis pela decomposição (FRUNZO; PIROZZI, 2015). Desta forma, é necessária a aplicação de métodos físicos, químicos e biológicos de hidrólise dos componentes lignocelulósicos dos resíduos orgânicos. A Figura 3.3 sumariza os diferentes tipos de pré-tratamentos aplicáveis à biomassa lignocelulósica.

Figura 3.3. Resumo dos principais métodos físicos, químicos e biológicos de tratamento da biomassa lignocelulósica.

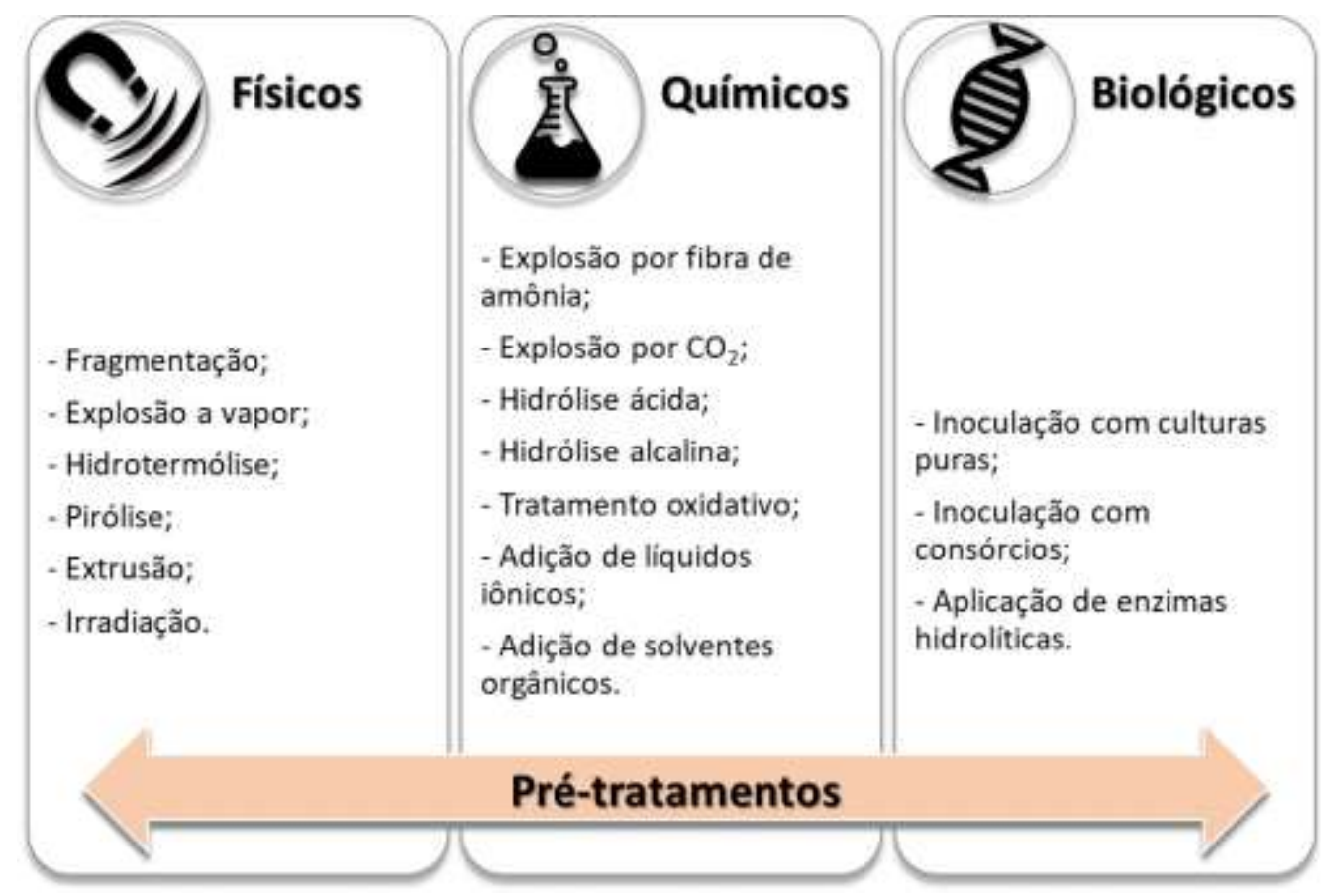

Fonte: Elaboração própria.

A obtenção de produtos de interesse biotecnológico a partir de diversos resíduos, entre eles os resíduos lignocelulósicos, vem sendo estudada como forma de solucionar, tanto a problemática de seu descarte inadequado, quanto à necessidade de se buscar novas fontes de carbono para a obtenção de produtos de interesse biotecnológico.

A etapa de pré-tratamento é importante para reduzir a rigidez da lignina (Figura 3.4), possibilitando a hidrólise da celulose e hemicelulose e, consequentemente, a conversão dos carboidratos poliméricos a monômeros fermentáveis (SUNDBERG, 2010). A eficiência da etapa de pré-tratamento depende de um orçamento positivo (HJORTH et al., 2011), uma vez que esta etapa é considerada a mais onerosa do processo de conversão de biomassa em açúcares fermentáveis para a obtenção de produtos de interesse biotecnológico (CABRERA et al., 2014), logo, faz-se necessário que o método mais eficiente seja escolhido. As principais vantagens e limitações de cada método estão descritas na Tabela 3.1. 
Figura 3.4. Esquematização simplificada do rompimento da estrutura lignocelulósica após pré-tratamento.

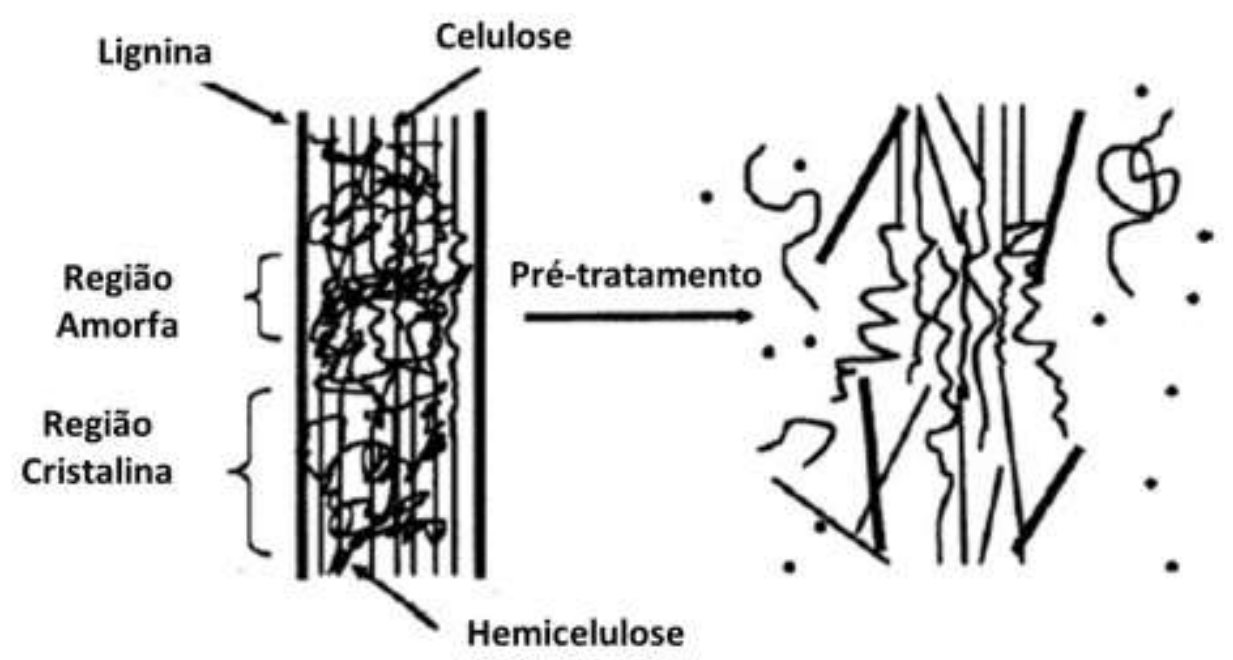

Fonte: Modificado de Mosier et al. (2005).

Tabela 3.1. Comparação entre os métodos físicos, químicos e biológicos de tratamento de biomassa lignocelulósica.

\begin{tabular}{ccc}
\hline Método & Pré-tratamento & Limitações \\
\hline \multirow{2}{*}{ Físico } & Trituração mecânica & - Consumo de energia \\
& Explosão a vapor & - Degradação da xilose \\
& Pirólise & - Geração de inibidores microbianos \\
& Hidrotermólise & - Consumo de energia \\
& Explosão por fibra de amônia & - Formação de cinzas \\
& Explosão de $\mathrm{CO}_{2}$ & - Consumo de energia \\
\hline \multirow{2}{*}{ Químico } & Ozonólise & - Baixa eficiência em biomassa com alto teor de \\
& Hidrólise ácida & - Onão afeta a lignina e a hemicelulose \\
& & - Alto custo de reagentes \\
& Hidrólise por alcalinização & - Risco de poluição secundária \\
& Biodegradação & - Longo tempo de exposição requerido \\
& Biológico & - Formação de sais irrecuperáveis \\
\hline
\end{tabular}

Fonte: Modificado de Balat (2011).

Ainda não há um consenso sobre o método mais adequado para o tratamento de resíduos orgânicos com composição lignocelulósica, uma vez que todos os métodos físicos, químicos e biológicos possuem vantagens e limitações (BALAT, 2011). Desta forma, maiores estudos sobre o potencial de diferentes métodos no pré-tratamento deste tipo de resíduo, entre eles os de citros, visando a posterior obtenção de produtos de interesse biotecnológico torna-se desejável. A importância de se reduzir o conteúdo lignocelulósico 
do substrato começa a ser evidenciada em meados da década de 80 com os trabalhos de Song e Lee (1984) e Sharma, Madan e Vasudevan (1989). Tais autores indicam que a obtenção de metano é maior quando são utilizados como substrato tecidos vegetais jovens, provavelmente devido à menor lignificação em relação aos tecidos adultos. Além disso, também fica evidente o aumento na concentração de glicose nos reatores após aplicação do método de hidrólise ácida do substrato lignocelulósico, tornando-o mais biodisponível.

A obtenção de biogás a partir de resíduos celulósicos/lignocelulósicos vem sendo avaliada pelo Grupo de Pesquisa em Processos Anaeróbios do Laboratório de Processos Biológicos (LPB) da Escola de Engenharia de São Carlos, Universidade de São Paulo campus São Carlos (EESC-USP). Botta et al. (2016), utilizaram consórcio microbiano obtido a partir de fluído de rumem pré-tratado com ácido, mantendo-se este fluido durante $24 \mathrm{~h}$ a $37^{\circ} \mathrm{C}$ e em pH 3,0, ajustado com $\mathrm{HCl} 3 \mathrm{M}$ e reajustado após este período para pH 7,0 com NaOH 1 mol.L $\mathrm{L}^{-1}$. O inóculo pré-tratado foi utilizado em bateladas com o objetivo de avaliar a obtenção de $\mathrm{H}_{2}$ a partir de resíduo de escritório (papel) como substrato. Além disso, os autores adicionaram celulase, a fim de aumentar a disponibilidade de açúcares fermentáveis a partir da celulose do papel, obtendo-se degradação de aproximadamente $65,5 \%$ do substrato com 5,51 mmol.g ${ }^{-1}$ DQO.

O bagaço de cana-de-açúcar foi avaliado como substrato após diferentes prétratamentos e diferentes inóculos (SOARES et al., 2017; AHMAD et al., 2020) para a obtenção de $\mathrm{H}_{2}$ e $\mathrm{CH}_{4}$. Soares et al. (2017a), avaliaram a obtenção de $\mathrm{H}_{2}$ a partir de bagaço de cana-de-açúcar após hidrotermólise $\left(200{ }^{\circ} \mathrm{C}, 10\right.$ minutos, 16 bar), em reatores em batelada em condições termofílicas $\left(60{ }^{\circ} \mathrm{C}\right)$. Os autores obtiveram concentração máxima de $17,7 \mathrm{mmol} \mathrm{H} 2 . \mathrm{L}^{-1}$, além de ácido acético (50,44 mg.L $\left.\mathrm{L}^{-1}\right)$, ácido butírico (209,71 mg.L $\left.\mathrm{L}^{-1}\right)$, etanol $\left(38,4 \mathrm{mg} \cdot \mathrm{L}^{-1}\right)$ e metano $\left(6,27 \mathrm{mmol} \mathrm{CH}_{4} \cdot \mathrm{L}^{-1}\right)$.

Rabelo et al. (2018b) avaliaram diferentes concentrações de bagaço de cana-deaçúcar $\left(0,8\right.$ a 9,2 g.L $\left.\mathrm{L}^{-1}\right)$ como substrato e $\mathrm{pH}$ inicial do meio reacional $\left(4,6\right.$ a 7,4 g.L $\left.\mathrm{L}^{-1}\right)$ a fim de otimizar a obtenção de $\mathrm{H}_{2}$. A partir do método estatístico de Delineamento Composto Central, os autores obtiveram 19,84 $\mathrm{mmol} \mathrm{H}_{2} \cdot \mathrm{L}^{-1}$ nas condições otimizadas, de $\mathrm{pH}$ inicial 7,2 e 7 g.L. $L^{-1}$ de substrato (bagaço de cana-de-açúcar). Além disso, os autores identificaram os microrganismos endógenos do bagaço de cana-de-açúcar, os quais foram semelhantes a Clostridium sp., Bacteroides sp., Paenibacillus sp.

Ahmad et al. (2020) também utilizaram o método de Delineamento Composto Central para otimização da obtenção de produtos de interesse biotecnológico a partir de bagaço de cana-de-açúcar. Neste estudo, o principal objetivo foi a avaliação dos efeitos da 
aplicação de pré-tratamento de deslignificação alcalina conciliado à hidrotermólise, a fim de promover a deslignificação do substrato. As variáveis operacionais estudadas foram temperatura do pré-tratamento $\left(160,180\right.$ e $\left.200{ }^{\circ} \mathrm{C}\right)$, tempo de exposição do substrato à hidrotermólise (5, 12 e 19 minutos) e concentração de peróxido de hidrogênio (2, 4 e 6\%). Os autores observaram que após o pré-tratamento otimizado $\left(180{ }^{\circ} \mathrm{C}, 12 \mathrm{~min}, 7,36 \% \mathrm{H}_{2} \mathrm{O}_{2}\right)$, houve $73,09 \%$ de deslignificação, $75,83 \%$ de remoção de xilose e $139,21 \%$ de aumento do conteúdo de glicanas. Além disso, obtiveram 13,1 mmol $\mathrm{CH}_{4} \cdot \mathrm{L}^{-1}$ para os resíduos prétratados.

Além dos trabalhos citados, novas pesquisas vêm sendo desenvolvidas com o objetivo de avaliar resíduos lignocelulósicos, tais como, cascas de frutas (banana), cascas de café e resíduos de cervejaria, como substratos para a obtenção de biogás e demais compostos de interesse biotecnológico (VILLA MONTOYA et al., 2019, 2020; MAZARELI et al., 2020), incluindo os resíduos de citros, foco desta pesquisa.

Uma das limitações associadas à aplicação de pré-tratamentos é a possível formação de inibidores. Os principais inibidores da fermentação são os ácidos fracos, furanos e compostos fenólicos. A geração destes compostos varia de acordo com o pH, tempo de exposição da biomassa ao pré-tratamento no processo de hidrólise e temperatura. Após a hidrólise, a hemicelulose é convertida em xilose, manose, galactose, glicose e ácido acético. Entretanto, Sundberg (2010) aponta que em pré-tratamentos sob temperaturas muito elevadas, acima de $200{ }^{\circ} \mathrm{C}$ há aumento da formação de compostos inibidores, como furfural e 5-hydroxymetil furfural (HMF), a partir da degradação da xilose e hexoses, respectivamente.

Com base nos dados apresentados na Tabela 3.2, pode-se observar para os resíduos de citros de forma geral, maior obtenção de metano, quando comparado aos demais resíduos, como o bagaço de cana-de-açúcar. Além disso, também é possível observar que entre os diversos tipos de pré-tratamento, a aplicação dos químicos (deslignificação ácida e alcalina) e físicos (moagem e trituração, hidrotermólise e explosão a vapor) oferecem melhores resultados em relação aos pré-tratamentos biológicos, como a biodegradação.

Observa-se ainda que os resíduos de citros já foram utilizados como substrato para a obtenção de metano a partir de diferentes pré-tratametos. Calabrò et al. (2016) utilizaram apenas a moagem e trituração em resíduos de citros e, ainda assim, obtiveram valores maiores em relação aqueles obtidos por Su, Tan e Xu (SU; TAN; XU, 2016), que utilizaram, também em resíduos de citros, a biodegradação por fungos das espécies 
Phanerochaete chrysosporium e Aspergillus niger. Forgàcs et al. (2012) utilizaram o método de hidrotermólise $\left(150^{\circ} \mathrm{C}\right.$ durante 20 minutos $)$ aplicado aos resíduos de citros que, de acordo com Zheng et al. (2014), é um dos métodos mais recomendados quando se tem como objetivo a obtenção de metano $\left(247,7 \mathrm{mmol} \mathrm{CH} \cdot \mathrm{L}^{-1}\right)$.

Além dos resíduos de citros, a obtenção de metano pode ser obtida a partir de outros resíduos lignocelulósicos, como resíduos do processamento de semente de girassol (DE LA RUBIA et al., 2011), bagaço de cana-de-açúcar (LEITÃO et al., 2013), palha e grama (HJORTH et al., 2011) e resíduos do processamento de farinha de milho, linho, palha de trigo, cânhamo (SCHROYEN et al., 2015).

De La Rubia et al. (2011) avaliaram a obtenção de $\mathrm{CH}_{4}$ em ensaios em batelada na faixa mesofílica $\left(35^{\circ} \mathrm{C}\right)$ e com lodo de esgoto anaeróbio como inóculo, a partir de resíduos do processamento de semente de girassol sem pré-tratamento, além da moagem e trituração do resíduo. Os autores compararam diferentes tamanhos de partículas dos resíduos, cujos melhores resultados foram aqueles dos ensaios contendo partículas maiores $(0,7,1,0,1,4 \mathrm{e}$ $2 \mathrm{~mm})$, em relação aqueles com partículas menores $(0,3$ e $0,5 \mathrm{~mm})$. Os autores atribuíram maior obtenção de $\mathrm{CH}_{4}$ nos ensaios com partículas de $2 \mathrm{~mm}$, e concentração máxima de $71,31 \mathrm{mmol} \mathrm{CH}_{4} \mathrm{~L}^{-1}$ à menor produção de ácido propiônico, ao contrário dos ensaios com partículas menores $(0,3 \mathrm{~mm})$, onde elevada produção do mesmo ácido e menor concentração de $\mathrm{CH}_{4}\left(60,93 \mathrm{mmol} \mathrm{CH} \cdot \mathrm{LL}^{-1}\right)$ foram reportadas.

Diferentes resíduos sólidos foram estudados por Hjorth et al. (2011) em reatores em batelada em temperatura mesofílica $\left(35^{\circ} \mathrm{C}\right)$, com estrume (suíno e bovino) como inóculo. Os autores obtiveram concentração máxima de aproximadamente $31,5 \mathrm{mmol} \mathrm{CH} 4 . \mathrm{L}^{-1}$ nos ensaios contendo resíduo de palha pré-tratado por extrusão após 28 dias de incubação, enquanto nos demais ensaios para as mesmas condições foi verificado $28,1 \mathrm{mmol} \mathrm{CH}_{4} . \mathrm{L}^{-1}$ para serrapilheira, 29,2 $\mathrm{mmol} \mathrm{CH} 4 . \mathrm{L}^{-1}$ para fração sólida de esterco (de bovinos e suínos), 22,5 $\mathrm{mmol} \mathrm{CH}_{4} \cdot \mathrm{L}^{-1}$ para fração sólida de esterco (de bovinos e suínos) prensado e 5,6 mmol $\mathrm{CH}_{4} \cdot \mathrm{L}^{-1}$ para grama.

Leitão et al. (2013) compararam pré-tratamentos químicos, como a deslignificação ácida e alcalina, além da hidrotermólise, aplicados ao bagaço de cana-de-açúcar, em reatores em batelada na faixa mesofílica $\left(35^{\circ} \mathrm{C}\right)$ contendo rúmen de caprinos, lodo UASB e efluente de cervejaria como inóculo. Os autores verificaram que a melhor concentração de metano $\left(66,12 \mathrm{mmol} \mathrm{CH}_{4} \cdot \mathrm{L}^{-1}\right)$ foi obtida nos ensaios contendo o resíduo pré-tratado em hidrotermólise, emquanto àqueles após deslignificação ácida e alcalina foram inferiores, de 40,91 e 46,47 $\mathrm{mmol} \mathrm{CH}_{4} \cdot \mathrm{L}^{-1}$, respectivamente. 
Schroyen et al. (2015) avaliaram a influência da adição de enzimas (lacase e peroxidase) em resíduos de farinha de milho, linho, palha de trigo, cânhamo, obtendo concentrações entre 21,5-25,71 $\mathrm{mmol} \mathrm{CH}_{4} \cdot \mathrm{L}^{-1}$, em bateladas incubadas em condições mesofílica $\left(27^{\circ} \mathrm{C}\right)$ com estrume bovino como inóculo. Além disso, os autores obtiveram concentração de $40 \mathrm{mmol} \mathrm{CH}_{4} \cdot \mathrm{L}^{-1}$ em reatores nas mesmas condições, com ensilagem de milho como substrato, atribuindo essa maior obtenção a partir deste resíduo, quando comparado aos resíduos de farinha de milho, linho, palha de trigo, cânhamo. 
Tabela 3.2. Comparação da obtenção de metano em reator em batelada a partir de diferentes substratos e condições experimentais.

\begin{tabular}{|c|c|c|c|c|c|c|c|c|}
\hline $\begin{array}{c}\text { Pré- } \\
\text { tratamento }\end{array}$ & mmol CH $4 \cdot \mathrm{L}^{-1}$ & Substrato & Pré-tratamento & Inóculo & $\begin{array}{c}\text { Volume } \\
\text { líquido }(\mathrm{mL})\end{array}$ & $\begin{array}{c}\text { Incubação } \\
\text { (dias) }\end{array}$ & $\begin{array}{c}\text { Temperatura } \\
\left({ }^{\circ} \mathrm{C}\right)\end{array}$ & Referência \\
\hline \multirow{6}{*}{ 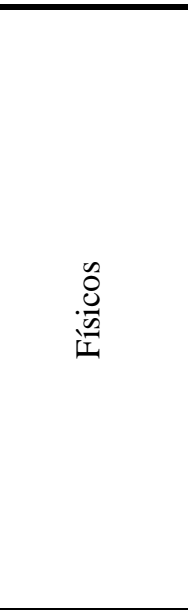 } & 33 & $\begin{array}{l}\text { Resíduos de } \\
\text { citros }\end{array}$ & $\begin{array}{l}\text { Moagem e } \\
\text { trituração }\end{array}$ & Estrume & 500 & 30 & 35 & $\begin{array}{l}\text { Calabrò et al. } \\
\text { (2016) }\end{array}$ \\
\hline & 66,1 & $\begin{array}{c}\text { Bagaço de } \\
\text { cana-de-açúcar }\end{array}$ & Hidrotermólise & $\begin{array}{c}\text { Rumem de caprinos, lodo } \\
\text { UASB, efluente de } \\
\text { cervejaria }\end{array}$ & 200 & 30 & 35 & $\begin{array}{l}\text { Leitão et al. } \\
\qquad(2013)\end{array}$ \\
\hline & 247,7 & $\begin{array}{l}\text { Resíduos de } \\
\text { citros }\end{array}$ & $\begin{array}{l}\text { Explosão a } \\
\text { vapor }\end{array}$ & $\begin{array}{l}\text { Resíduo de unidade de } \\
\text { biogás }\end{array}$ & 600 & 50 & 55 & $\begin{array}{l}\text { Forgàcs et al. } \\
\qquad(2012)\end{array}$ \\
\hline & 71,3 & $\begin{array}{l}\text { Resíduos do } \\
\text { processamento } \\
\text { de semente de } \\
\text { girassol }\end{array}$ & $\begin{array}{l}\text { Moagem e } \\
\text { trituração }\end{array}$ & $\begin{array}{l}\text { Lodo de esgoto } \\
\text { anaeróbio }\end{array}$ & 250 & 08 & 35 & $\begin{array}{l}\text { De La Rubia et } \\
\text { al. (2011) }\end{array}$ \\
\hline & 39,3 & Palha de trigo & Micro-ondas & $\begin{array}{l}\text { Estrume suíno e lodo de } \\
\text { esgoto }\end{array}$ & 500 & 26 & 35 & $\begin{array}{c}\text { Jackowiak et al. } \\
\text { (2011) }\end{array}$ \\
\hline & 31,5 & Palha & Extrusão & Estrume suíno e bovino & 450 & 28 & 35 & $\begin{array}{l}\text { Hjorth et al. } \\
(2011)\end{array}$ \\
\hline \multirow{2}{*}{$\frac{n}{0} \cdot \stackrel{0}{\Xi}$} & 40,9 & $\begin{array}{c}\text { Bagaço de } \\
\text { cana-de-açúcar }\end{array}$ & $\begin{array}{l}\text { Deslignificação } \\
\text { ácida }\end{array}$ & $\begin{array}{c}\text { Rumem de caprinos, lodo } \\
\text { UASB, efluente de } \\
\text { cervejaria }\end{array}$ & 200 & 30 & 35 & $\begin{array}{l}\text { Leitão et al. } \\
\qquad(2013)\end{array}$ \\
\hline & 46,5 & $\begin{array}{c}\text { Bagaço de } \\
\text { cana-de-açúcar }\end{array}$ & $\begin{array}{l}\text { Deslignificação } \\
\text { alcalina }\end{array}$ & $\begin{array}{c}\text { Rumem de caprinos, lodo } \\
\text { UASB, efluente de } \\
\text { cervejaria }\end{array}$ & 200 & 30 & 35 & $\begin{array}{l}\text { Leitão et al. } \\
\qquad(2013)\end{array}$ \\
\hline \multirow{2}{*}{$\begin{array}{l}0 \\
0 \\
00 \\
\frac{0}{00} \\
0\end{array}$} & 0,01 & Citros & Biodegradação & $\begin{array}{l}\text { Estrume suíno e lodo de } \\
\text { esgoto }\end{array}$ & 4000 & 30 & 25 & $\begin{array}{l}\text { Su, Tan e Xu } \\
\text { (2016) }\end{array}$ \\
\hline & 25,7 & $\begin{array}{l}\text { Farinha de } \\
\text { milho, palha de } \\
\text { trigo, cânhamo }\end{array}$ & $\begin{array}{l}\text { Enzimática } \\
\text { (lacase e } \\
\text { peroxidase) }\end{array}$ & Estrume bovino & 250 & 30 & 27 & $\begin{array}{l}\text { Schroyen et al. } \\
\text { (2015) }\end{array}$ \\
\hline
\end{tabular}

Fonte: Elaboração própria. 
Por fim, entre os pré-tratamentos mencionados, nota-se que os resultados obtidos por Calabrò et al. (2016), utilizando resíduos de citros sem outros pré-tratamentos além da moagem do resíduo, foram superiores em relação à obtenção de metano em comparação aos demais autores estudados. Entretanto, é importante salientar a influência do substrato utilizado, bem como de outras variáveis operacionais, como a origem do inóculo e faixa de temperatura.

Apesar do número reduzido de estudos com foco na obtenção de hidrogênio em comparação aos estudos voltados à obtenção de metano, é possível encontrar pesquisas nas quais sua obtenção é feita a partir do uso de resíduos do processamento de alimentos e biomassa lignocelulósica como substrato (Tabela 3.3).

Por exemplo, Rabelo et al. (2018) obtiveram 39,2 $\mathrm{mmol} \mathrm{H}_{2} \cdot \mathrm{L}^{-1}$ a partir de celulose $\left(5\right.$ g. $\left.\mathrm{L}^{-1}\right)$ como fonte de carbono em reatores em batelada sob condições mesofílicas $\left(37^{\circ} \mathrm{C}\right)$ ao longo de 16 dias de incubação. Os autores utilizaram lodo de lagoa facultativa de tratamento de efluente da indústria de papel como fonte de microrganismos celulolíticos e produtores de $\mathrm{H}_{2}$, sendo que após a caracterização filogenética deste inóculo por meio de ferramentas de biologia molecular (clonagem e sequenciamento) foram identificados gêneros relacionados à atividade celulolítica e fermentativa, como Clostridium, Klebsiella e Raoultella.

Apesar das vantagens relacionadas à aplicação de pré-tratamentos a fím de promover a deslignificação da biomassa e aumentar sua biodegradabilidade, uma de suas principais desvantagens é a formação de subprodutos potencialmente tóxicos e inibitórios ao processo fermentativo, como compostos fenólicos, furanos e 5-hydroxymetilfurfural (5HMF). Quéméneur et al. (2012) investigaram os efeitos de furfural, 5-HMF, fenol e ligninaKraft na obtenção de $\mathrm{H}_{2}$ a partir de xilose e lignina em reatores em batelada em condições mesofílicas $\left(37^{\circ} \mathrm{C}\right)$, utilizando lodo granulado anaeróbio pré-tratado por choque térmico (90 ${ }^{\circ} \mathrm{C}$ durante $10 \mathrm{~min}$ ) como inóculo. Os autores concluíram que apesar de que todos os compostos estudados foram considerados significativos em relação ao efeito inibitório na obtenção de $\mathrm{H}_{2}$, os furanos $\left(0,40-0,51 \mathrm{~mol} \mathrm{H}_{2}\right.$ por mol de xilose) foram relacionados a maiores impactos do que os compostos fenólicos (1,28-1,39 $\mathrm{mol} \mathrm{H}_{2}$ por mol de xilose), quando comparados ao controle contendo apenas xilose (1,67 $\mathrm{mol} \mathrm{H}_{2}$ por mol de xilose).

Soares et al. (2017a) aplicaram o método de superfície de respostas, a fim de obter as faixas operacionais ótimas em relação à temperatura de incubação e suplementação do meio reacional com extrato de levedura em reatores em batelada, utilizando bagaço de 
cana-de-açúcar pré-tratado por hidrotermólise e lodo granulado diluído $\left(10^{-4}\right)$ como inóculo. Os autores obtiveram $17,7 \mathrm{mmol} \mathrm{H}_{2} \cdot \mathrm{L}^{-1}$ nas condições otimizadas preditas pelo modelo de segunda ordem, a $60{ }^{\circ} \mathrm{C}$ e 3 g. $\mathrm{L}^{-1}$ de extrato de levedura.

Gonzales et al. (2017) avaliaram três diferentes substratos lignocelulósicos (casca de fruto de palmeira, cascas de arroz e pellet de madeira de pinheiro) pré-tratados por moagem $(\leq 2 \mathrm{~mm})$ e hidrólise ácida com $\mathrm{H}_{2} \mathrm{SO}_{4}(5 \%)$ em autoclave a $121{ }^{\circ} \mathrm{C}$ durante 60 minutos. Os ensaios foram realizados em batelada em faixa termofílica e lodo anaeróbio pré-tratado por choque térmico $\left(90{ }^{\circ} \mathrm{C}\right.$ durante $\left.30 \mathrm{~min}\right)$ como inóculo. A maior concentração de $\mathrm{H}_{2}$ observada foi de 44,9, 54,3 e 48,4 mmol $\mathrm{H}_{2} \cdot \mathrm{L}^{-1}$ para os resíduos de frutos de palmeira, casca de arroz e madeira de pinheiro, respectivamente.

Além da utilização de consórcios microbianos, a obtenção de $\mathrm{H}_{2}$ também é possível a partir da utilização de culturas puras como inóculo. Braga et al. (2017) utilizaram cepa de Clostridium cellulolyticum (atual Ruminiclostridium cellulolyticum) em reatores em batelada na faixa mesofílica $\left(37^{\circ} \mathrm{C}\right)$ utilizando bagaço de cana-de-açúcar como substrato e pré-tratado por hidrotermólise. Sob tais condições foi obtido 7,6 $\mathrm{mmol} \mathrm{H}_{2} \cdot \mathrm{L}^{-1}$. Zhao et al. (2012) utilizaram cultura pura de Thermoanaerobacterium thermosaccharolyticum como inóculo para obtenção de 71,6 mmol H $\mathrm{H}_{2} \mathrm{~L}^{-1} \mathrm{em}$ reatores em batelada com sabugo de milho como substrato, pré-tratado por meio da biodegradação durante 21 dias com os fungos Phanerochaete chrysosporium e Trichoderma viride, a $50{ }^{\circ} \mathrm{C}$ e $130 \mathrm{rpm}$ de agitação.

Com base no que foi mencionado, fica nítida a importância de se estudar cada processo com base em suas singularidades, como temperatura de incubação, composição do inóculo e especialmente no que diz respeito a origem do substrato e possíveis prétratamentos a serem aplicados na biomassa lignocelulósica, bem como a formação de compostos potencialmente tóxicos como consequência do processo de deslignificação. 
Tabela 3.3. Comparação da obtenção de hidrogênio em reator em batelada a partir de diferentes substratos e condições experimentais.

\begin{tabular}{|c|c|c|c|c|c|c|c|}
\hline $\begin{array}{c}\text { Pré- } \\
\text { tratamento }\end{array}$ & mmol $\mathbf{H}_{2} \cdot \mathrm{L}^{-1}$ & Substrato & Pré-tratamento & Inóculo & $\begin{array}{c}\text { Incubação } \\
\text { (dias) }\end{array}$ & $\begin{array}{c}\text { Temperatura } \\
\left({ }^{\circ} \mathbf{C}\right)\end{array}$ & Referência \\
\hline 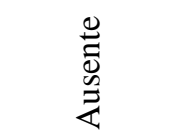 & 39,2 & Celulose & Nenhum & $\begin{array}{l}\text { Lodo de lagoa facultativa de } \\
\text { tratamento de efluente da } \\
\text { indústria de papel }\end{array}$ & 16 & 37 & $\begin{array}{l}\text { Rabelo et al. } \\
\qquad(2018)\end{array}$ \\
\hline \multirow{4}{*}{$\underbrace{\infty}_{0}$} & 29,2 & $\begin{array}{l}\text { Compostos } \\
\text { derivados da } \\
\text { lignocelulose } \\
\text { (xilose/lignina) }\end{array}$ & Nenhum & $\begin{array}{l}\text { Lodo granulado anaeróbio pré- } \\
\text { tratado por choque térmico ( } 90 \\
\left.{ }^{\circ} \mathrm{C} / 10 \mathrm{~min}\right)\end{array}$ & 50 & 37 & $\begin{array}{l}\text { Quéméneur et } \\
\text { al. (2012) }\end{array}$ \\
\hline & 17,7 & $\begin{array}{c}\text { Bagaço de } \\
\text { cana-de-açúcar }\end{array}$ & Hidrotermólise & $\begin{array}{l}\text { Lodo granulado termofílico } \\
\text { diluído }\left(10^{-4}\right)\end{array}$ & 16,6 & 60 & $\begin{array}{l}\text { Soares et al. } \\
(2017 \mathrm{a})\end{array}$ \\
\hline & 7,6 & $\begin{array}{c}\text { Bagaço de } \\
\text { cana-de-açúcar }\end{array}$ & Hidrotermólise & $\begin{array}{l}\text { Clostridium cellulolyticum } \\
\text { (atual R. cellulolyticum) }\end{array}$ & 16,6 & 37 & $\begin{array}{l}\text { Braga et al. } \\
\qquad(2017)\end{array}$ \\
\hline & 92,8 & Palha de milho & $\begin{array}{l}\text { Explosão a } \\
\text { vapor }\end{array}$ & $\begin{array}{l}\text { Lodo anaeróbio pré-tratado por } \\
\text { choque térmico }\left(220^{\circ} \mathrm{C} / 3 \mathrm{~min}\right)\end{array}$ & 2,5 & 35 & $\begin{array}{l}\text { Datar et al. } \\
\text { (2007) }\end{array}$ \\
\hline 芑 & 54,3 & Casca de arroz & Hidrólise ácida & $\begin{array}{l}\text { Lodo anaeróbio pré-tratado por } \\
\text { choque térmico }\left(90^{\circ} \mathrm{C} / 30 \mathrm{~min}\right)\end{array}$ & 03 & 35 & $\begin{array}{l}\text { Gonzales et al. } \\
\text { (2017) }\end{array}$ \\
\hline $\begin{array}{l}\stackrel{0}{60} \\
\frac{0}{0} \\
\frac{0}{0}\end{array}$ & 71,6 & $\begin{array}{l}\text { Sabugo de } \\
\text { milho }\end{array}$ & $\begin{array}{c}\text { Biodegradação } \\
\text { (Phanerochaete } \\
\text { chrysosporium) } \\
\text { + Enzimática } \\
\text { (Trichoderma } \\
\text { viride) }\end{array}$ & $\begin{array}{l}\text { Thermoanaerobacterium } \\
\text { thermosaccharolyticum }\end{array}$ & 1,4 & 60 & $\begin{array}{l}\text { Zhao et al. } \\
\text { (2012) }\end{array}$ \\
\hline
\end{tabular}

Fonte: Elaboração própria. 


\subsubsection{Pré-tratamentos químicos}

Os pré-tratamentos químicos geralmente envolvem a adição de reagentes, como a explosão por fibra de amônia, explosão por $\mathrm{CO}_{2}$, deslignificação ácida (SONG; LEE, 1984; LEITÃO et al., 2013) e alcalina (CHANDRA et al., 2012; KIM; HAN, 2012; LEITÃO et al., 2013), tratamento oxidativo (CABRERA et al., 2014), adição de líquidos iônicos e a adição de solventes orgânicos, a fim de alterar, tanto as características químicas, quanto físicas da biomassa. Os métodos de pré-tratamento químicos foram amplamente estudados para a produção de bioetanol, entretanto, sua aplicação para a obtenção de biogás ainda é reduzida (ZHENG et al., 2014).

Na explosão por fibra de amônia, a biomassa é exposta à amônia em estado líquido, quente e sob alta pressão, havendo a despressurização súbita e ocasionando a desestabilização da estrutura lignocelulósica, além da descristalização da celulose. Este método é indicado especialmente para o tratamento de biomassa de resíduos agrícolas, uma vez que tem pouco efeito sob a lignina e a hemicelulose, embora seu alto custo possa restringir sua aplicação. Uma alternativa ao método químico de explosão por fibra de amônia é a explosão por $\mathrm{CO}_{2}$, cuja metodologia é similar, porém o reagente utilizado é economicamente mais viável (SUNDBERG, 2010). Estes processos, apesar de extensivamente estudados para a produção de bioetanol, ainda não são aplicados no prétratamento para posterior obtenção de biogás (ZHENG et al., 2014).

O pré-tratamento ácido é considerado como um dos mais efetivos e, como o próprio nome sugere, envolve a adição de reagentes ácidos orgânicos ou inorgânicos, comumente o ácido sulfúrico $\left(\mathrm{H}_{2} \mathrm{SO}_{4}\right)$. Pode ser feito, tanto com ácidos em altas concentrações (30$70 \%$ ) e baixas temperaturas $\left(e . g ., 40{ }^{\circ} \mathrm{C}\right)$, quanto com baixas concentrações $(0,1 \%)$ e altas temperaturas (e.g., $\left.230{ }^{\circ} \mathrm{C}\right)$ (ZHENG et al., 2014).

$\mathrm{O}$ ácido pode ser adicionado à biomassa e ser aquecido indiretamente ou também via injeção direta de vapor, de forma similar ao método físico conhecido como explosão à vapor. Um dos maiores problemas relacionados a este método é a formação de resíduos ácidos que carecem de neutralização após o tratamento da biomassa (SUNDBERG, 2010), além da baixa fermentabilidade dos açúcares liberados após a hidrólise (SONG; LEE, 1984) e de sua toxicidade e corrosividade, requerendo, consequentemente, materiais caros para sua manipulação, armazenamento e utilização (ZHENG et al., 2014). 
Leitão et al. (2013) utilizaram o método de deslignificação ácida aplicado ao bagaço de cana-de-açúcar. O tempo de reação entre o ácido utilizado $(\mathrm{HCl} 0,63 \mathrm{M})$ foi de 6,4 minutos a $136{ }^{\circ} \mathrm{C}$, sendo que foram obtidos $40,9 \mathrm{mmol} \mathrm{CH}_{4} \cdot \mathrm{L}^{-1}$ após 30 dias de incubação em condições mesofílicas $\left(35^{\circ} \mathrm{C}\right)$, utilizando rúmem de caprinos, lodo de UASB e efluente de cervejaria como inóculos.

A deslignificação alcalina envolve a adição de bases, como o hidróxido de sódio $(\mathrm{NaOH})$, hidróxido de potássio $(\mathrm{KOH})$, hidróxido de cálcio $\left(\mathrm{Ca}(\mathrm{OH})_{2}\right)$ ou também hidróxido de amônio $\left(\mathrm{NH}_{4} \mathrm{OH}\right)$ a fim de promover a solubilização da lignina e também da hemicelulose (SUNDBERG, 2010), aumentando a porosidade do material e reduzindo o grau de polimerização da lignina com outros polímeros e de cristalinidade (KIM; HAN, 2012; ZHENG et al., 2014), além do aumento do grau de hidratação da celulose (CABRERA et al., 2014).

Entre as diversas possibilidades de bases que podem ser adicionadas ao substrato na deslignificação alcalina, a mais utilizada em estudos para obtenção de biogás é o hidróxido de sódio $(\mathrm{NaOH})$. Kim e Han (2012) obtiveram rendimento de glicose de 254,6 g.kg ${ }^{-1}$ de biomassa de palha de arroz após aplicação deslignificação alcalina com $\mathrm{NaOH}$ $\left(1,33\right.$ mol. $\left.\mathrm{L}^{-1}\right)$ a $80{ }^{\circ} \mathrm{C}$ durante 60 minutos, sendo que houve remoção de aproximadamente 43\% da lignina. Chandra et al. (2012) apontam que a eficiência da obtenção de metano a partir de palha de trigo aumentou até $112 \%$ após deslignificação alcalina com hidróxido de sódio $(\mathrm{NaOH})(4 \%$ dos $\mathrm{ST})$ a $37{ }^{\circ} \mathrm{C}$ durante cinco dias, aumentando de 3,5 para 7,4 mmol $\mathrm{CH}_{4} \cdot \mathrm{L}^{-1}$.

O pré-tratamento oxidativo ocorre por meio da adição de um composto oxidante, como oxigênio $\left(\mathrm{O}_{2}\right)$, peróxido de hidrogênio $\left(\mathrm{H}_{2} \mathrm{O}_{2}\right)$, ácido peracético $\left(\mathrm{CH}_{3} \mathrm{CO}_{3} \mathrm{H}\right)$ ou ozônio $\left(\mathrm{O}_{3}\right)$ na biomassa suspensa em água, sendo que seu principal efeito é a degradação da lignina. Um dos problemas relacionados a este pré-tratamento é a perda dos monossacarídeos, uma vez que a oxidação não é seletiva (SUNDBERG, 2010). Os peróxidos são transformados in situ em radicais hidroxil $\left(\mathrm{OH}^{*}\right)$ que por sua vez são mais potentes do que o peróxido em si. É mais comum no tratamento da biomassa com uso posterior de obtenção de bioetanol, havendo poucos estudos sobre sua aplicação para processos de obtenção de biogás (ZHENG et al., 2014).

A união dos métodos de deslignificação alcalina com o pré-tratamento oxidativo utilizando peróxido de hidrogênio $\left(\mathrm{H}_{2} \mathrm{O}_{2}\right)$ é um dos tratamentos químicos mais efetivos para resíduos agroindustriais, pois além de favorecer a quebra da lignina, é considerado um 
processo ambientalmente mais vantajoso, uma vez que o reagente utilizado não representa grandes riscos ambientais e é utilizado em baixas concentrações. As espécies superóxidas altamente reativas e radical hidroxila são formados de acordo com a Equação 3.1 e Equação 3.2 (CABRERA et al., 2014).

$$
\begin{aligned}
& \mathrm{H}_{2} \mathrm{O}_{2} \leftrightarrow \mathrm{H}^{+}+\mathrm{HOO}^{-} \\
& \mathrm{H}_{2} \mathrm{O}_{2}+\mathrm{HOO}^{-} \rightarrow \mathrm{HO}^{\cdot}+\mathrm{O}_{2}+\mathrm{H}_{2} \mathrm{O}
\end{aligned}
$$

O pré-tratamento via adição de solventes orgânicos, também conhecido como Organosolv, utiliza preferencialmente álcoois de baixo custo, como metanol e etanol. A adição de líquidos iônicos, como sais com cátions orgânicos ou ânions inorgânicos em baixas temperaturas, é um tipo de pré-tratamento químico promissor devido a sua grande eficiência na quebra da celulose e a possibilidade de recuperação de $100 \%$ do reagente utilizado ao término do tratamento. Entretanto, apesar de promissores, o Organosolv e os líquidos iônicos são considerados altamente dispendiosos e, portanto, pouco utilizados (SUNDBERG, 2010).

\subsubsection{Pré-tratamentos físicos}

Os tratamentos físicos são aqueles que não carecem de reagentes químicos e nem de microrganismos para promover a hidrólise da estrutura lignocelulósica (LEITÃO et al., 2013). Os tratamentos físicos mais recorrentes na literatura são a fragmentação (como a moagem e a trituração) (FORSTER-CARNEIRO; PÉREZ; ROMERO, 2008; DE LA RUBIA et al., 2011), a explosão de vapor (auto hidrólise) (JACQUET et al., 2011; FORGÁCS et al., 2012), aplicação de água em estado líquido em elevadas temperaturas (hidrotermólise) (LEITÃO et al., 2013), pirólise, extrusão e, por fim, a irradiação (ultrassom e micro-ondas) (JACKOWIAK et al., 2011). Os tratamentos físicos são favoráveis de aplicação para posterior obtenção de metano a partir de resíduos agroindustriais (ZHENG et al., 2014).

A fragmentação é um método utilizado como etapa anterior aos demais tipos de prétratamento, não havendo consenso na literatura se pode ser considerado por si só um tipo de pré-tratamento ou não, sendo empregada principalmente com a finalidade de reduzir o tamanho das partículas e facilitar o manuseio e armazenamento do resíduo, podendo aumentar sua superfície de contato. Os métodos de fragmentação mais comuns são os 
realizados por meio de máquinas de moagem ou trituração, como moinhos, martelo, facas, rolos e extrusores, dependendo do teor de umidade do substrato (ZHENG et al., 2014; CALABRÒ et al., 2016).

Kivaisi e Eliapenda (1994) afirmam que a redução das partículas de bagaço de coco de $5 \mathrm{~mm}$ para $0,85 \mathrm{~mm}$ aumentou a obtenção de metano a partir deste resíduo em até $30 \%$. Entretanto, outros autores como De La Rubia (2011) apontam redução na obtenção de metano proporcional à redução no tamanho das partículas da biomassa (resíduos do processamento de semente de girassol), sendo que nos ensaios com partículas entre 1,4-2,0 mm observaram-se maiores concentrações de metano (71,3 mmol $\left.\mathrm{CH}_{4} \cdot \mathrm{L}^{-1}\right)$, quando comparado aos ensaios com partículas entre $0,36-0,55 \mathrm{~mm}$ e $0,71-1,0 \mathrm{~mm}(62,2 \mathrm{mmol}$ $\mathrm{CH}_{4} \cdot \mathrm{L}^{-1}$ ), sendo uma possível explicação o aumento na produção de ácidos orgânicos voláteis. A partir destes resultados verifica-se a necessidade de considerar as diferenças entre o tipo de matéria-prima a ser tratada antes da escolha do pré-tratamento ideal, além de conciliar diferentes tipos de pré-tratamentos.

O método de explosão a vapor, um dos mais difundidos, consiste na submissão do substrato a elevadas temperaturas $\left(160-260{ }^{\circ} \mathrm{C}\right)$ e $(0,69-4,83 \mathrm{Mpa})$ durante curto intervalo de tempo, para que a pressão seja rapidamente reduzida, finalizando as reações e possibilitando a descompressão explosiva da biomassa, ocasionando a hidrólise da biomassa em açúcares (SUNDBERG, 2010; ZHENG et al., 2014).

A explosão a vapor vem sendo aplicada em diversos substratos como pré-tratamento para a obtenção de metano, entre eles o bagaço de citros. Forgàcs et al. (2012) obtiveram concentração máxima de $247,7 \mathrm{mmol} \mathrm{CH}_{4} \cdot \mathrm{L}^{-1}$ utilizando resíduo de citros tratado por explosão a vapor como substrato e lodo termófilo $\left(55^{\circ} \mathrm{C}\right)$ de unidade de biogás como inóculo. Além disso, estimou-se que houve redução de 94,3\% da concentração de óleo essencial (limoneno) no resíduo após o pré-tratamento, e a concentração de metano aumentou cerca de $426 \%$ em comparação com o resíduo sem pré-tratamento.

$\mathrm{Na}$ hidrotermólise, reatores pressurizados são utilizados para manter a água no estado líquido em elevadas temperaturas, geralmente em torno de $200{ }^{\circ} \mathrm{C}$, condição favorável à penetração da água na estrutura da biomassa, hidratando a celulose, solubilizando a hemicelulose e removendo a lignina, facilitando sua degradabilidade, além de prover produto final com menor concentração de inibidores. Nestas condições experimentais a água tem uma constante dielétrica elevada, agindo como um ácido e possibilitando a dissociação da hemicelulose e dissolução parcial da lignina (ZHENG et 
al., 2014). Apesar de sua demanda por energia elétrica, este método vem sendo apontado como uma possibilidade de pré-tratamento de biomassa lignocelulósica, uma vez que não carece de adição de reagentes químicos (SUNDBERG, 2010).

A hidrotermólise pode aumentar a produção de metano a partir de diversos substratos. Chandra et al. (2012) verificaram que a obtenção de metano a partir de palha de trigo aumentou $20 \%$ após o pré-tratamento via hidrotermólise $\left(200{ }^{\circ} \mathrm{C}\right.$ e $1,55 \mathrm{Mpa}$ durante 10 minutos). Em outro trabalho, Chandra, Takeuchi e Hasegawa (2012) também comparam a obtenção de metano nas mesmas condições, usando palha de arroz como substrato ao invés de palha de trigo. Sob tais condições, os autores obtiveram resultados melhores quando comparados aos do estudo anterior, uma vez que nos ensaios com substrato prétratado, concentrações de $\mathrm{CH}_{4}$ aproximadamente $222 \%$ superiores em relação ao substrato sem pré-tratamento. Essa variação ocorre devido às diferenças químicas e estruturais particulares de cada tipo de resíduo.

A hidrotermólise é promissora para aplicações futuras até mesmo em larga escala (ZHENG et al., 2014) e bons resultados tem sido observados para resíduos lignocelulósicos (LEITÃO et al., 2013). Este método foi escolhido para aplicação no pré-tratamento de resíduo de citros neste estudo.

O processo de extrusão, outro método físico de pré-tratamento, possibilita resultados similares aos da hidrotermólise, uma vez que a parede celular do material é quebrada após o alivio da pressão, causando a despolimerização da celulose, hemicelulose, lignina e também de proteínas. Hjorth et al. (2011) indicam que a eficiência na obtenção de metano a partir de biomassa agrícola (palha e grama) aumentou até $70 \%$ quando submetidas a este pré-tratamento.

Os métodos de irradiação incluem as micro-ondas, ultrassom, raios-gama e feixe de elétrons, sendo a primeira a mais estudada, na qual a energia é gerada por campo eletromagnético, fornecendo aquecimento rápido e uniforme com gradientes térmicos reduzidos. Possuem como vantagem a capacidade de aquecer rapidamente grandes volumes, levando a economia de energia, entretanto, são excessivamente onerosos (ZHENG et al., 2014). Jackowiak et al. (2011) obtiveram otimização de $28 \%$ na obtenção de metano a partir de palha de trigo após pré-tratamento com radiação micro-ondas utilizando lodo de esgoto e estrume como inóculo. 


\subsubsection{Pré-tratamentos biológicos}

Os pré-tratamentos biológicos geralmente envolvem o uso de culturas puras, consórcios microbianos ou também enzimas hidrolíticas (celulases, hemicelulases e lacases) produzidas por microorganismos, sendo este última possibilidade mais raramente aplicada por ser economicamente onerosa (ZHENG et al., 2014).

Os fungos filamentosos são os microrganismos mais estudados para aplicação no tratamento biológico, especialmente aqueles que são capazes de hidrolisar a biomassa lignocelulósica, mas utilizam principalmente lignina e hemicelulose, em vez da celulose, o que diminui a possibilidade de competição por substrato com as bactérias fermentativas (ZHENG et al., 2014; SU; TAN; XU, 2016). Além de microrganismos isolados, outra possibilidade é a utilização de consórcios, ou seja, microrganismos obtidos após a partir dos próprios materiais lignocelulósicos em decomposição.

Schroyen et al. (2015) utilizaram as enzimas lacase e peroxidase com o objetivo de degradar a lignina de resíduos de farinha de milho, linho, palha de trigo e cânhamo, em reatores batelada com estrume bovino e silagem de milho como inóculo. Os autores observaram concentrações de metano de até $40 \mathrm{mmol} \mathrm{CH}_{4} \cdot \mathrm{L}^{-1}$ para a silagem de milho após 30 dias de experimento. Para os demais substratos avaliados, a concentração de metano foi inferior, de aproximadamente $17,8 \mathrm{mmol} \mathrm{CH}_{4} \cdot \mathrm{L}^{-1}$. A biodegradação foi utilizada por $\mathrm{Su}$, Tan e Xu (2016) por meio da coinoculação de fungos Phanerochaete chrysosporium e Aspergillus niger com resíduos de citros como substrato e uma mistura de estrume suíno e lodo de esgoto como inóculo, resultando na concentração de $0,01 \mathrm{mmol} \mathrm{CH}_{4} \cdot \mathrm{L}^{-1}$.

Apesar das vantagens dos métodos de pré-tratamentos biológicos quando comparadas aos físicos e químicos, como a baixa demanda por energia e reagentes e a menor probabilidade de impacto ambiental, este tipo de pré-tratamento requere longo período de exposição entre microrganismo (ou enzima) e substrato, geralmente semanas ou meses, o que pode limitar seu uso em larga escala (ZHENG et al., 2014).

Neste cenário, optou-se pela aplicação do método de pré-tratamento físico por hidrotermólise e pré-tratamento químico de deslignificação alcalina, comparando seus efeitos na obtenção de biogás (hidrogênio e metano) a partir de resíduos de citros como substrato. 


\subsection{MICRORGANISMOS FERMENTATIVOS E METANOGÊNICOS}

\subsubsection{Bactérias fermentativas e celulolíticas}

Na digestão anaeróbia, é possível obter outros produtos de interesse biotecnológico como por exemplo, os ácidos orgânicos e álcoois produzidos na etapa fermentativa acidogênica e acetogênica, além do biogás. Os ácidos orgânicos comumente formados nestas etapas são os seguintes: acético, propiônico, isobutírico, butírico, isovalérico, valérico, lático, crotônico e caproico, além dos principais álcoois, tais como metanol, etanol e isobutanol. A formação destes produtos depende de diversos fatores, dentre eles a temperatura, tipo de substrato, $\mathrm{pH}$ do meio reacional e principalmente a origem do inóculo, uma vez que as populações microbianas presentes podem determinar as rotas metabólicas predominantes.

Miceli et al. (2018) relacionaram a diferentes doadores de elétrons (glicose, sacarose, lactato e melaço) com os principais metabólitos produzidos (ácido acético, ácido propiônico, ácido butírico, hidrogênio e metano) e as populações microbianas predominantes no processo. Os autores concluíram que o doador de elétrons é um dos principais fatores no estabelecimento dessas populações nos reatores anaeróbios.

O processo de obtenção biológica do gás hidrogênio envolve diferentes microrganismos, uma vez que pode ocorrer por meio da biofotólise da água usando algas e cianobactérias, pela fotodecomposição de compostos orgânicos por bactérias fotossintéticas ou também pela fermentação de compostos orgânicos. A obtenção de hidrogênio na via fermentativa é baseada na geração de elétrons em organismos heterotróficos a partir do crescimento oxidativo anaeróbio, no qual há a eliminação dos elétrons excedentes na forma de hidrogênio molecular devido à presença da enzima ferredoxina e também pela enzima hidrogenase, transferindo elétrons para o $\mathrm{H}^{+}(\mathrm{DAS}$; VEZIROGLU, 2001; SIVAGURUNATHAN et al., 2017).

Os principais microrganismos anaeróbios envolvidos no processo de obtenção de hidrogênio são as bactérias acidogênicas do gênero Clostridium, que inclui bactérias anaeróbias obrigatórias e fermentativas como C. cellobioparum (atual Ruminiclostridium cellobioparum), C. thermocellum, C. butyricum, entre outros (DAS; VEZIROGLU, 2001; YUTIN; GALPERIN, 2013), que podem atingir o balanço redox por meio da excreção de produtos da fermentação, como ácidos orgânicos e álcoois, ou pela produção de hidrogênio molecular. 
Uma vez que, tanto a obtenção de hidrogênio, quanto de ácidos orgânicos consiste de uma etapa intermediária da digestão anaeróbia, quando o objetivo do processo é a obtenção de um destes produtos finais, a reação deve ser interrompida nesta fase, caso contrário haverá consumo destes produtos como substrato para a metanogênese hidrogenotrófica e acetoclástica, respectivamente. Para tanto, é importante que as condições operacionais sejam bem estabelecidas e controladas, o que justifica a importância do estudo das faixas ideais de temperatura, $\mathrm{pH}$, condições nutricionais do meio, entre outros.

Em relação às principais populações envolvidas na fermentação, os clostrídios são acidogênicos e produtores de hidrogênio, sendo muito estudado, devido ao seu caráter ubíquo e diversidade metabólica. Entretanto, gêneros como Bacillus, Klebsiella e Enterobacter são associados ao processo de obtenção de produtos de interesse biotecnológico por meio de processos anaeróbios (MAINTINGUER et al., 2017; RABELO et al., 2018a; MAZARELI et al., 2019; RODRIGUES et al., 2019).

Converti e Perego (2002) avaliaram o uso de glicóse como fonte de carbono em condições de anaerobiose por espécie anaeróbia facultativa Enterobacter aerogenes, demonstrando que seu principal produto fermentativo, além do $\mathrm{H}_{2}$ foi o butanodiol. Kotay e Das (2007) obtiveram rendimento máximo de $\mathrm{H}_{2}$ (2,28 $\mathrm{mol} \mathrm{H}_{2}$ por mol de glicose) utilizando cepa isolada de lodo de esgoto anaeróbio, identificada como Bacillus coagulans, também anaeróbia facultativa, capaz de utilizar fontes alternativas de carbono, bem como resíduos lignocelulósicos, sendo relacionada à produção de ácido acético, ácido butírico e etanol, dependendo das condições do meio de cultivo.

López et al. (2010) relacionam o uso de resíduo sólido de citros como matéria prima principalmente para a produção de etanol de segunda geração, comumente em processos aeróbios, e ácido succinico em processos anaeróbios. Li et al. (2010) estudaram a produção de ácido succinico em batelada a partir de resíduos de citros pré-tratados com destilação a vapor como substrato, utilizando cepa celulolítica-fermentativa Fibrobacter succinogenes, obtendo 1,9 g.L. $\mathrm{L}^{-1}$ deste ácido.

Lin et al. (2007) avaliaram variadas espécies de clostrídios, como $C$. acetobutylicum, $C$. butyricum, $C$. tyrobutyricum e $C$. beijerinckii. Os autores verificaram para as condições experimentais com a última espécie melhor rendimento de $\mathrm{H}_{2}$ em relação as demais $\left(2,1 \mathrm{mmol} \mathrm{H}_{2}\right.$ por mmol de glicose). Os autores demonstraram ainda que os principais produtos da fermentação da glicose por espécies deste gênero são ácido butírico 
(0,37-0,67 mmol por mmol glicose) e acético (0,34-0,42 mmol por mmol glicose) em $\mathrm{pH}$ acima de 5, uma vez que abaixo deste valor, houve mudança da via metabólica de acético/butírico para láctico/etanol em algumas cepas, como C. butyricum.

Clostridium acetobutyricum é uma espécie conhecida por seu potencial de formação de solventes, como acetona, butanol e etanol, em pH igual ou abaixo de 5 e limitação de ferro e fosfato. Desta forma, para favorecer a via metabólica na qual há obtenção de hidrogênio, deve se manter o pH acima de 5 (HAWKES et al., 2002).

Ainda que Clostridium acetobutyricum seja conhecidamente anaeróbio, sabe-se que esta espécie é capaz de tolerar baixas concentrações de $\mathrm{O}_{2}$ no meio durante curtos períodos de exposição (entre 4 e 6 h), apesar de reduzir o consumo de açúcares e consequentemente a síntese de biomoléculas como DNA, RNA e proteínas, podendo causar danos celulares irreversíveis quando há exposição em longos períodos.

Espécies de Clostridium caracterizam-se pela produção de ácidos orgânicos voláteis em maior quantidade na fase exponencial do crescimento e álcoois na fase estacionária, provavelmente devido à diminuição do $\mathrm{pH}$ do meio, após a fase exponencial e consequente favorecimento de vias metabólicas redutoras. A espécie comumente conhecida como produtora de ácido propiônico é C. propionicum (atual Tyzzerella propionica) (DÜRRE, 1998; HAWKES et al., 2002; YUTIN; GALPERIN, 2013), além de bactérias do gênero Propionibacterium, que também produzem ácido propiônico como um dos principais produtos finais da fermentação, a partir de glicose ou lactato como substrato (SOLLI et al., 2014).

Quando o processo tem como principal objetivo a obtenção de hidrogênio como produto final, as rotas metabólicas desejáveis são as que produzem ácido acético e ácido butírico como principais produtos finais da fermentação, além da baixa produção de propiônico e de produtos finais reduzidos, como álcoois e ácido lático (HAWKES et al., 2002). Pela via do ácido acético tem-se rendimento de 4 moléculas de $\mathrm{H}_{2}$ para cada molécula de glicose (Equação 3.3), enquanto pela via do ácido butírico tem-se 2 moléculas de $\mathrm{H}_{2}$ para cada molécula de glicose (Equação 3.4).

$$
\begin{aligned}
& \mathrm{C}_{6} \mathrm{H}_{12} \mathrm{O}_{6}+6 \mathrm{H}_{2} \mathrm{O} \rightarrow 2 \mathrm{CO}_{2}+2 \mathrm{CH}_{3} \mathrm{COOH}+4 \mathrm{H}_{2} \\
& \mathrm{C}_{6} \mathrm{H}_{12} \mathrm{O}_{6}+6 \mathrm{H}_{2} \mathrm{O} \rightarrow 2 \mathrm{CO}_{2}+\mathrm{CH}_{3} \mathrm{CH}_{2} \mathrm{CH}_{2} \mathrm{COOH}+2 \mathrm{H}_{2}
\end{aligned}
$$


Na reação de oxidação da glicose a ácido acético, os átomos de hidrogênio são primeiramente transferidos para o dinucleótido de nicotinamida e adenina oxidado $\left(\mathrm{NAD}^{+}\right)$, que atua como carreador de elétrons em sua forma reduzida (NADH), sendo liberados como hidrogênio dissolvido (MOSEY, 1983). Em condições com excesso de energia disponível, há desvio das rotas metabólicas para a formação de compostos orgânicos mais reduzidos, consequentemente diminuindo a obtenção de hidrogênio (MOSEY, 1983; AQUINO; CHERNICHARO, 2005).

A produção de ácido propiônico está associada à baixa obtenção de hidrogênio, uma vez que há consumo de duas moléculas de hidrogênio para sua formação, como ilustrado na Equação 3.5 a partir da glicose como substrato.

$$
\mathrm{C}_{6} \mathrm{H}_{12} \mathrm{O}_{6}+2 \mathrm{H}_{2} \rightarrow 2 \mathrm{CH}_{3} \mathrm{CH}_{2} \mathrm{COOH}+2 \mathrm{H}_{2} \mathrm{O}
$$

Todavia, a formação de ácido propiônico pode ser desejável quando o objetivo do processo é a obtenção de metano como produto final, uma vez que o consumo de hidrogênio é necessário para manter a pressão parcial do reator dentro dos limites necessários para a atividade metanogênica (HAWKES et al., 2002).

Uma vez que a reação de produção de ácido acético gera dois mols deste ácido por mol de glicose, enquanto a produção de ácido butírico gera um mol de ácido por mol de glicose, fica claro que a predominância da rota metabólica acetogênica causa maior acidificação do meio. Além disso, a reação de formação de ácido acético é favorecida em menores concentrações de hidrogênio e desfavorecida quando a pressão parcial deste gás no meio torna-se elevada (acima de 0,0006 atm), momento em que as rotas de produção de ácido butírico e propiônico são mais favoráveis (MOSEY, 1983; MICELI; TORRES; KRAJMALNIK-BROWN, 2016). Isto ocorre como consequência da falta de $\mathrm{NAD}^{+}$no meio intracelular, e sua regeneração por meio de outras vias mais favoráveis nestas condições, nas quais a fermentação do ácido pirúvico acarreta na formação de ácido propiônico, lático e etanol, ou ainda pela fermentação do Acetil-CoA a ácido butírico.

É importante salientar que, como mencionado por Guo et al. (2014), nem sempre a produção de ácido acético está diretamente relacionada à obtenção de hidrogênio, uma vez que sua formação também pode ocorrer durante a homoacetogênese, via comum em reatores em batelada, na qual há consumo de $\mathrm{H}_{2}$ e $\mathrm{CO}_{2}$ ou também de monossacarídeos de hexose por bactérias do gênero Clostridium. 
A reação de formação do etanol (Equação 3.6), conhecida como via solvetogênica, é desvantajosa para o processo de obtenção de hidrogênio, apesar de não haver consumo direto de átomos de hidrogênio, a prevalência da via solvetogênica acarreta em competição pelo mesmo substrato necessário para a formação de hidrogênio nas vias acidogênica e acetogênica, sendo que sua produção ocorre a partir do composto intermediário comum às reações, Acetil-CoA.

$$
\mathrm{C}_{6} \mathrm{H}_{12} \mathrm{O}_{6} \rightarrow \mathrm{CH}_{3} \mathrm{CH}_{2} \mathrm{OH}+2 \mathrm{CO}_{2}
$$

A indústria de fabricação de ácido acético já é consolidada, movimentando entre 1200 a 1600 dólares no ano de 2015, o que corresponde a demanda de aproximadamente 13 milhões de toneladas deste produto puro. Sua principal aplicação é na produção oxidativa de monômero de acetato de vinil, usado como matéria prima para a fabricação de tintas e adesivos, além da produção de anidrido acético por meio de sua condensação, sendo utilizado para a produção do acetato de celulose, matéria prima da indústria têxtil e filmes fotográficos. O ácido acético glacial (livre de água) é um excelente solvente com diversas aplicações (PAL; NAYAK, 2017).

Os processos de obtenção biológica do ácido acético são comumente realizados utilizando bactérias aeróbias, especialmente as dos gêneros Acetobacter, Gluconobacter e Acidomonas oxidantes de açúcares, álcoois e etanol (YAMADA; HOSHINO; ISHIKAWA, 1997), que produzem ácido acético como produto final deste processo. O substrato preferencial de Acetobacter é etanol, que é um produto final valioso e utilizado como matéria prima em diversos processos industriais, gerando apenas $1 \mathrm{~mol}$ de ácido acético para cada mol de etanol oxidado (RASPOR; GORANOVIČ, 2008).

Apesar de a obtenção de ácido acético ser maior em processos oxidativo aeróbios em relação aos processos de fermentação, no primeiro caso, envolve mais gasto de operação, uma vez que as bactérias envolvidas são aeróbias obrigatórias e, portanto, carecem de oxigênio livre no sistema, acarretando em gastos com aeração constante (RASPOR; GORANOVIČ, 2008). Além disso, a possibilidade de uso de consórcio bacteriano na obtenção de ácido acético em processos anaeróbios ao invés de culturas puras também pode ser considerada como vantajosa, uma vez que reduz os gastos em meio de cultivos específicos e possibilita a obtenção de demais produtos de interesse biotecnológico conciliados ao processo, como o hidrogênio gasoso. 
Neste cenário, estudos sobre novas formas de obtenção de ácidos orgânicos e solventes a partir de processos biológicos anaeróbios vêm sendo estimulados, especialmente quando conciliadas à digestão anaeróbia, uma vez que há a possibilidade de obtenção de hidrogênio e/ou metano ao longo do processo, além do tratamento de resíduos orgânicos de difícil degradação, como os lignocelulósicos.

Em relação a conversão de biomassa lignocelulósica em produtos de interesse biotecnológico tem-se duas formas: (1) via hidrólise dos polissacarídeos a monossacarídeos fermentáveis ou (2) via fermentação dos açúcares em solventes, ácidos orgânicos e biogás (ZVERLOV; SCHWARZ, 2008). O papel dos microrganismos celulolíticos, bem como sua participação fundamental no ciclo do carbono, está intimamente relacionado com a primeira situação (WILSON, 2011).

Os microrganismos celulolíticos são capazes de hidrolisar a biomassa lignocelulósica em celulose e hemicelulose, que por sua vez, em ambientes anaeróbios, é catabolizada a celobiose e xilobiose e, posteriormente, hidrolisada por organismos fermentativos em ácidos graxos de cadeia curta (acético, propiônico e butírico) além de álcoois (etanol, butanol) e gases $\left(\mathrm{H}_{2}, \mathrm{CO}_{2}\right)$. Hidrogênio e ácido acético podem ser consumidos diretamente na metanogênese, enquanto os demais compostos requerem a atividade dos organismos sintróficos, que irá convertê-los em $\mathrm{H}_{2}, \mathrm{CO}_{2}$ e demais produtos, como ácido acético, etanol e ácido láctico (RATTANAPAN et al., 2019).

Estima-se que $90 \%$ da celulose presente na biomassa residual, em teoria, poderia ser convertida a metano (AZMAN et al., 2015). Desta forma, levando-se em consideração que a hidrólise da celulose é uma das etapas limitantes para o aproveitamento da maior parte da biomassa residual, a procura por fontes de obtenção de enzimas celulolíticas vem aumentando cada vez mais (SADHU; MAITI, 2013).

As celulases são enzimas responsáveis pela atividade celulolítica e compostas por exoglicanases, endoglicanases e $\beta$-glicosidases, variando de acordo com sua ação catalítica (SADHU; MAITI, 2013). A atividade celulolítica é comumente associada a microrganismos aeróbios, entretanto, bactérias semelhantes a Clostridium e Ruminiclostridium são conhecidas por sua eficiência em hidrolisar, em anaerobiose, os polissacarídeos que compõe os vegetais, por meio do celulossoma, um complexo enzimático extracelular responsável pela despolimerização da celulose, constituído por uma proteína integradora (cipA), que contém diversos compostos catalíticos e coenzimas (CHAPLEUR et al., 2016). 
Apesar de haver diferentes mecanismos de degradação biológica da celulose, sabese que as celulases são enzimas chave, presentes em todos estes mecanismos. Estas enzimas catalisam a reação de hidrólise das ligações $\beta-1,4$ entre as moléculas de glicose presentes nos polímeros de celulose. A maior diferença entre as celulases e demais enzimas, é que ao contrário das enzimas que catalisam reações com substratos que se ligam aos seus sítios ativos, as celulases catalisam reações com matrizes insolúveis, dependendo, portanto, da adesão do microrganismo celulolítico ao substrato, devido ao domínio conhecido como módulo de ligação de carboidratos (WILSON, 2011).

Estima-se que existem pelo menos onze famílias de celulases, sendo que a similaridade entre elas se baseia em sua sequência de aminoácidos, que determinam as dobras destas proteínas e sua especificidade, de acordo com diferentes tipos de substrato e diferentes níveis de cristalinidade da celulose. Em microrganismos anaeróbios, é comum a presença do complexo enzimático celulossoma, que apesar de não conter módulos de ligação de carboidratos, são anexados a proteínas "andaimes" que contém este sítio ativo (WILSON, 2011).

Diversos fatores podem afetar a atividade destas enzimas, como $\mathrm{pH}$ do meio reacional, temperatura de incubação e também a concentração de substrato e/ou produtos finais formados (celobiose e glicose) (SARATALE et al., 2008).

Os macronutrientes e micronutrientes, por exemplo, são elementos essenciais no metabolismo microbiano, necessários para o crescimento celular, tanto para sua composição (parede celular, membranas, DNA), e como também na forma de cofatores enzimáticos. Alguns destes micronutrientes, como $\mathrm{Ca}, \mathrm{Na}$ e $\mathrm{Fe}$, são imprescindíveis para o estabelecimento de populações de bactérias produtoras de hidrogênio (WU; CHU; SHEN, 2012). Da mesma forma, em concentrações elevadas, os micronutrientes podem ser tóxicos aos microrganismos envolvidos no processo de digestão anaeróbia, especialmente pelos metais $\mathrm{Cu}$ e Zn (LIN; SHEI, 2008), que apesar de essenciais aos processos fermentativos, podem apresentar efeitos inibitórios em concentrações acima de 250 e 400 mg.L ${ }^{-1}$, respectivamente (ZHENG; YU, 2004).

Uma das principais limitações para a compreensão dos aspectos fisiológicos dos microrganismos celulolíticos ocorre devido ao fato de que a maior parte destes microrganismos não são cultiváveis. Diversas espécies da ordem Clostridiales são associadas à atividade celulolítica de biomassa lignocelulósica residual, como polpa de 
papel, resíduos agroindustriais e bagaço de cana-de-açúcar (SADHU; MAITI, 2013). As espécies de clostrídios conhecidamente celulolíticas são: Clostridium thermocellum (atual Ruminiclostridium thermocellum), C. aldrichii (atual R. aldrichii), C. alkalicellulosi (atual R. alkalicellulosi), C. caenicola (atual R. caenicola), C. cellobioparum (atual $R$. cellobioparum), C. cellulolyticum (atual R. cellulolyticum), C. cellulosi (atual R. cellulosi), $C$. clariflavum (atual $R$. clariflavum), $C$. hungatei (atual $R$. hungatei), $C$. josui (atual $R$. josui), C. leptum (atual R. leptum), C. methylpentosum (atual R. methylpentosum), $C$. papyrosolvens (atual $R$. papyrosolvens), $C$. sporosphaeroides (atual $R$. sporosphaeroides), $C$. stercorarium (atual $R$. stercorarium), C. straminisolvens (atual $R$. straminisolvens), $C$. sufflavum (atual R. sufflavum), C. termitidis (atual R. termitidis), C. thermosuccinogenes (atual $R$. thermosuccinogenes) e $C$. viride (atual $R$. viride) (AZMAN et al., 2015). É possível notar, a maior parte das espécies celulolíticas anteriormente consideradas junto ao gênero Clostridium foram reclassificadas no gênero Ruminiclostridium (YUTIN; GALPERIN, 2013).

Guedon et al. (2002) estudaram a influência de subprodutos do metabolismo anaeróbio na atividade celulolítica, e verificaram que o acúmulo de ácido láctico inibiu o crescimento de C. cellulolyticum (atual Ruminiclostridium cellulolyticum) em ensaios contendo celulose como fonte de carbono, enquanto o acúmulo de ácido acético e etanol não representaram o mesmo efeito.

Rabelo et al. (2018) identificaram por sequenciamento massivo do gene 16S RNAr bactérias similares a Clostridium sp., Bacteroides sp., Paenibacillus sp., Lactobacillus paracasei, Escherichia hermannii e Enterobacter aerogenes em ensaios contendo bagaço de cana-de-açúcar como substrato para a obtenção de $\mathrm{H}_{2}$, sendo C. cellobioparum (atual Ruminiclostridium cellobioparum), C. sartagoforme e C. cellulolyticum (atual Ruminiclostridium cellulolyticum), bactérias tanto celulolíticas quanto produtoras de $\mathrm{H}_{2}$.

As bactérias mais comuns associadas à atividade hidrolítica em ambientes anaeróbios, especialmente em reatores, pertencem ao filo Firmicutes, tais como Clostridium, Ruminococcus, Caldicellulosiruptor, Caldanaerobacter, Butyrivibrio, Acetivibrio, Halocella e Eubacterium, além de outras pertencentes aos filos Bacteroidetes, Fibrobacter, Spirochaetes e Thermotogae (AZMAN et al., 2015).

Em relação aos habitats mais frequentes em que são encontrados organismos com potencial celulolítico, o rúmen é certamente o mais estudado, sendo que se estima que há cerca de $10^{10} \mathrm{NMP}$ por $\mathrm{mL}$, sendo $10 \%$ delas celulolíticas. Além do rúmen, as composteiras 
são outro tipo de ambiente amplamente estudado acerca de sua comunidade microbiana com potencial celulolítico, no qual a degradação da biomassa recalcitrante ocorre devido à atividade de bactérias celulolíticas termofílicas e mesofílicas, dependendo da etapa de degradação (WILSON, 2011).

Heerden et al. (2002) estudaram a microbiota do processo de compostagem contendo resíduos sólidos de citros. Os autores concluíram que os microrganismos predominantes do Domínio Bacteria durante a fase termofílica da compostagem foram semelhantes à Bacillus (B. licheniformis, B. macerans e B. stearothermophilus), além de Pseudomonas (P. aeruginosa, P. fluorescens e P. luteola). Bicas e Pastore (2008) também isolaram organismos predominantemente dos gêneros Bacillus e Pseudomonas em ensaios contendo resíduos de citros com até $0,1 \%$ de limoneno.

Há poucos relatos sobre o uso de resíduos sólidos de citros como substrato fermentativo para obtenção de compostos de interesse biotecnológico, especialmente biogás (hidrogênio e metano) (FORGÁCS et al., 2012; RUIZ; FLOTATS, 2014; CALABRÒ et al., 2016), especialmente sobre a comunidade microbiana autóctone deste material. Desse modo, justifica-se a realização de novos estudos acerca deste tema, especialmente em reatores anaeróbios, uma vez que os poucos dados existentes são relacionados apenas a comunidade microbiana aeróbia ou anaeróbia facultativa e passíveis de serem isoladas.

Lacava et al. (2006) realizaram a caracterização da comunidade bacteriana endofítica de citros, por meio das técnicas de isolamento e PCR/DGGE. Os autores identificaram bactérias semelhantes a Methylobacterium mesophilicum, Xyllela fastidiosa, Klebsiella sp., Pseudomonas sp., Enterobacter sp. e Bacillus spp.

Da mesma forma, Corrêa (2008) isolou organismos endofíticos de citros, sendo fungos filamentosos, leveduras e bactérias de diferentes partes da planta (folhas, ramos e fruto). Nesse último caso, verificaram que os fungos filamentosos contribuíram com $85,24 \%$ da abundância relativa deste vegetal, $0,75 \%$ de leveduras e, finalmente, $13,99 \%$ de bactérias da comunidade endofítica de citros, sendo 4,32\% nos frutos.

Desta forma, a determinação da prevalência de microrganismos em citros, bem como sua relação com inóculos alóctones utilizados em reatores anaeróbios, torna-se informativa no estudo de grupos resistentes aos potenciais inibidores deste substrato, como 
a matriz lignocelulósica e, ainda, o limoneno, que vem sendo relatado como um dos grandes obstáculos ao seu reuso.

A utilização de resíduos sólidos aplicada à obtenção de $\mathrm{H}_{2}, \mathrm{CH}_{4}$ e demais compostos orgânicos com potencial biotecnológico, como AOV e álcoois, vem sendo estudada pelo Grupo de Pesquisa em Processos Anaeróbios do LPB da EESC-USP, bem como os principais microrganismos associados à digestão anaeróbia destes resíduos (Tabela 3.4), sendo possível observar a ubiquidade dos clostrídeos. Entre os diversos resíduos sólidos estudados, destaca-se o bagaço de cana-de-açúcar (AHMAD et al., 2018; BRAGA et al., 2018; RABELO et al., 2018b; SOARES et al., 2020), banana (MAZARELI et al., 2020), e resíduos do processamento de café (VILLA MONTOYA et al., 2019).

Tabela 3.4. Principais bactérias identificadas a partir de diferentes resíduos sólidos aplicados à obtenção de produtos de interesse biotecnológico em reatores em bateladas.

\begin{tabular}{|c|c|c|c|c|c|c|}
\hline $\begin{array}{l}\text { Resíduo } \\
\text { sólido }\end{array}$ & $\underset{\text { inicial }}{\text { pH }}$ & ${ }^{\circ} \mathbf{C}$ & Inóculo & Principais bactérias & $\begin{array}{l}\text { Principais } \\
\text { compostos } \\
\text { orgânicos } \\
\end{array}$ & Referência \\
\hline $\begin{array}{l}\text { Bagaço } \\
\text { de cana- } \\
\text { de-açúcar }\end{array}$ & 6,0 & 37 & $\begin{array}{l}\text { Consórcio obtido a } \\
\text { partir de resíduo de } \\
\text { compostagem }\end{array}$ & $\begin{array}{c}\text { Dysgonomonas, } \\
\text { Coprococcus, } \\
\text { Sporomusa, } \\
\text { Bacteroides e } \\
\text { Sedimentibacter }\end{array}$ & $\begin{array}{c}\mathrm{H}_{2}, \mathrm{CH}_{4} \mathrm{e} \\
\mathrm{EtOH}\end{array}$ & $\begin{array}{l}\text { Soares et al. } \\
\quad(2020)\end{array}$ \\
\hline Banana & 7,5 & 44 & Autofermentação & $\begin{array}{l}\text { Clostridium e } \\
\text { Lactobacillus }\end{array}$ & $\begin{array}{c}\mathrm{H}_{2}, \mathrm{HAc}, \\
\mathrm{HBu}, \\
\mathrm{HLac} \text { e } \\
\text { EtOH }\end{array}$ & $\begin{array}{c}\text { Mazareli et al. } \\
\qquad(2020)\end{array}$ \\
\hline $\begin{array}{l}\text { Cascas } \\
\text { de café }\end{array}$ & 7,0 & 30 & Autofermentação & Clostridium & $\begin{array}{c}\mathrm{H}_{2}, \text { HAc e } \\
\text { HLac }\end{array}$ & $\begin{array}{l}\text { Villa-Montoya } \\
\text { et al. (2019) }\end{array}$ \\
\hline $\begin{array}{l}\text { Bagaço } \\
\text { de cana- } \\
\text { de-açúcar }\end{array}$ & 6,8 & 37 & $\begin{array}{l}\text { Consórcio obtido a } \\
\text { partir de efluente } \\
\text { da fabricação de } \\
\text { celulose e papel }\end{array}$ & $\begin{array}{c}\text { Clostridium, } \\
\text { Klebsiella, Routella e } \\
\text { Desulfovibrio }\end{array}$ & $\mathrm{H}_{2}$ e $\mathrm{HBu}$ & $\begin{array}{l}\text { Rabelo et al. } \\
\qquad(2018)\end{array}$ \\
\hline $\begin{array}{l}\text { Bagaço } \\
\text { de cana- } \\
\text { de-açúcar }\end{array}$ & 6,0 & 37 & $\begin{array}{l}\text { lodo UASB de } \\
\text { avícola }\end{array}$ & $\begin{array}{l}\text { Clostridium, } \\
\text { Enterococcus }\end{array}$ & $\begin{array}{c}\mathrm{H}_{2}, \mathrm{CH}_{4} \mathrm{e} \\
\mathrm{HAc}\end{array}$ & $\begin{array}{l}\text { Braga et al. } \\
\quad(2018)\end{array}$ \\
\hline $\begin{array}{l}\text { Bagaço } \\
\text { de cana- } \\
\text { de-açúcar }\end{array}$ & - & 37 & $\begin{array}{l}\text { lodo UASB de } \\
\text { avícola }\end{array}$ & $\begin{array}{l}\text { Thermotogaceae, } \\
\text { Anaerolinaceae, } \\
\text { Syntrophaceae, } \\
\text { Spirochaetaceae e } \\
\text { Clostridiaceae }\end{array}$ & $\begin{array}{l}\mathrm{CH}_{4} \mathrm{e} \\
\mathrm{HAc}\end{array}$ & $\begin{array}{c}\text { Ahmad et al. } \\
\text { (2018) }\end{array}$ \\
\hline
\end{tabular}

Nota: $(-)=$ Não especificado. Temperatura de incubação $\left({ }^{\circ} \mathrm{C}\right)$.

\subsubsection{Arqueias metanogências}

A metanogênese é a última etapa do processo de degradação anaeróbia e realizada por microrganismos do Domínio Archaea, que são anaeróbios estritos, cujo produto final é o gás metano $\left(\mathrm{CH}_{4}\right)$ e dióxido de carbono $\left(\mathrm{CO}_{2}\right)$, sendo um processo essencial para o ciclo do carbono. As arqueias metanogênicas podem ser encontradas em diversos ambientes 
anaeróbios e limitados em relação à luminosidade, nitrato e sulfato, mas com disponibilidade de compostos orgânicos complexos, como fontes termais, sedimentos de água doce, digestor anaeróbio e também no intestino de animais de sangue quente e rúmen (DEPPENMEIER, 2002).

A obtenção de metano ocorre ao final das reações realizadas por consórcio microbiano, de hidrólise, acidogênese, acetogênese, para que finalmente a matéria orgânica seja convertida em biogás na etapa de metanogênese, sendo que do total de biogás formado, geralmente $50-80 \%$ é metano (WALTER et al., 2016). A metanogênese pode ser acetoclástica (Equação 3.7), ou seja, realizada a partir do acetato gerado durante a acetogênese ou hidrogenotrófica (Equação 3.8), a partir do $\mathrm{H}_{2}$ e $\mathrm{CO}_{2}$ (DEPPENMEIER, 2002; ZHENG et al., 2014).

$$
\begin{array}{lr}
\mathrm{CH}_{3} \mathrm{COO}^{-}+\mathrm{H}^{+} \rightarrow \mathrm{CH}_{4}+\mathrm{CO}_{2} & \Delta G^{\prime 0}-36 \mathrm{~kJ} \cdot \mathrm{mol}^{-1} \text { (Eq.3.7) } \\
4 \mathrm{H}_{2}+\mathrm{CO}_{2} \rightarrow \mathrm{CH}_{4}+2 \mathrm{H}_{2} \mathrm{O} & \Delta G^{\prime 0}-131 \mathrm{~kJ} \cdot \mathrm{mol}^{-1} \text { (Eq.3.8) }
\end{array}
$$

Os organismos metanogênicos são diversos, tanto geneticamente quanto morfologicamente (DEPPENMEIER, 2002). Os principais gêneros associados à metanogênese em condições mesofílicas são Methanobacterium, Methanocaldococcus e Methanosarcina e, em condições termofílicas, os gêneros mais frequentes são Methanothermobacter e Methanoculleus, além da espécie Methanosarcina thermophilus (CHAPLEUR et al., 2016). As arqueias metanogênicas semelhantes a Methanosarcina são consideradas dominantes em reatores mesofílicos cujo inóculo ou substrato provém de estercos, uma vez que estes microrganismos possuem metabolismo versátil, podendo consumir $\mathrm{H}_{2}, \mathrm{CO}_{2}$, metanol, metilamina e também ácido acético como substrato (DEPPENMEIER, 2002; WALTER et al., 2016). As principais famílias e gêneros de arqueias metanogênicas, bem como os substratos utilizados para a metanogênese estão sumarizados na Figura 3.5. 
Figura 3.5. Principais gêneros de arqueias envolvidos no processo de metanogênese e suas respectivas ordens e famílias taxonômicas.

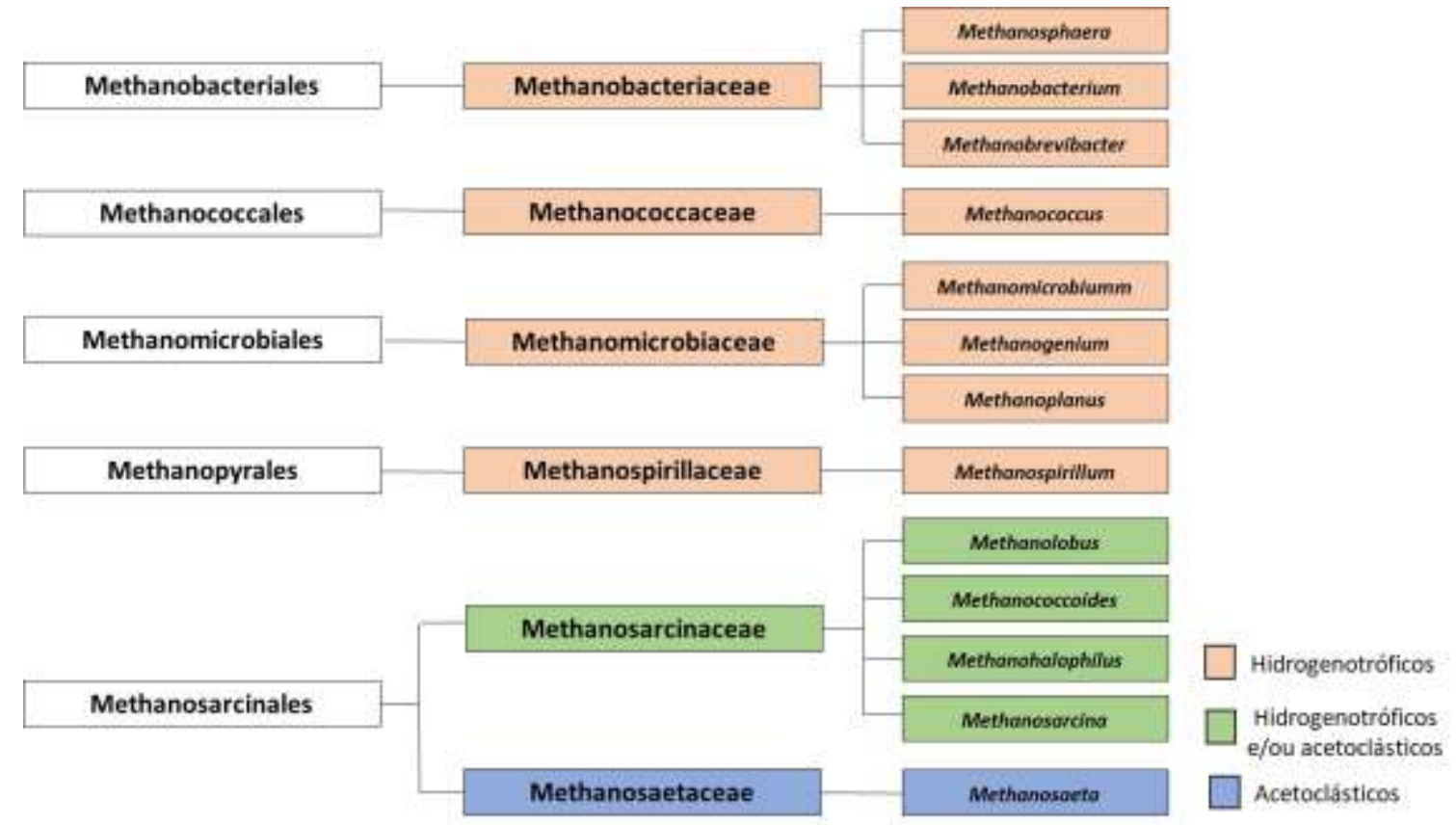

Fonte: Modificado de Deppenmeier (2002).

Apesar da diversidade de organismos hidrogenotróficos conhecida ser maior em relação aos acetoclásticos, com predominância de gêneros pertencentes à ordem Methanosarcinales, são os acetoclásticos os principais responsáveis pela metanogênese em reatores anaeróbios voltados à obtenção de biogás (SOLLI et al., 2014). Além disso, as arqueias hidrogenotróficas possuem velocidade de crescimento superior em relação às acetoclásticas (MERLIN CHRISTY; GOPINATH; DIVYA, 2014).

A temperatura pode influenciar a comunidade microbiana dos reatores anaeróbios durante a metanogênese (CHAPLEUR et al., 2016). No estudo realizado por Walter et al. (2016), utilizando estrume bovino como inóculo e resíduos da indústria de papel como substrato, os autores apontam que o desenvolvimento de arqueias semelhantes a Methanoculleus é favorecido em condições termofílicas. Além disso, os autores avaliaram a influência de seis diferentes pré-tratamentos (térmico, ultrassom, enzimático, biodegradação, deslignificação alcalina e ultrassom mais deslignificação alcalina) e observaram que o gênero dominante em todos os reatores utilizando os substratos prétratados foi Methanosarcina, acompanhado por consórcio de microrganismos hidrogenotróficos.

Os inóculos utilizados com mais frequência para favorecer a obtenção de biogás são lodos de diversos tipos de estação de tratamento de águas residuárias (FORSTERCARNEIRO; PÉREZ; ROMERO, 2008; FORGÁCS et al., 2012; LEITÃO et al., 2013; SU; 
TAN; XU, 2016), estrume (CALABRÒ et al., 2016; SU; TAN; XU, 2016) e também o rúmem de bovinos ou caprinos, na tentativa de prover consórcio rico em bactérias celulolíticas, fermentativas e metanogênicas (LEITÃO et al., 2013). Além da ampla variedade de inóculos aplicáveis aos processos metanogênicos tem-se verificado potencial de obtenção de $\mathrm{CH}_{4}$ a partir de resíduos sólidos, tais como aqueles provenientes do processamento de alimentos (JIANG et al., 2019; YUSOF et al., 2019) e bagaço de canade-açúcar (AHMAD et al., 2018; BRAGA et al., 2018) (Tabela 3.5). Entretanto, pesquisas acerca do potencial de obtenção de $\mathrm{CH}_{4}$ a partir de resíduos sólidos ainda são escassas na literatura, quando comparadas àquelas a partir de águas residuárias. 
Tabela 3.5. Principais arquéias identificadas a partir de diferentes resíduos sólidos aplicados à obtenção de metano em reatores em batelada.

\begin{tabular}{|c|c|c|c|c|c|}
\hline $\begin{array}{l}\text { Resíduo } \\
\text { sólido }\end{array}$ & $\begin{array}{c}\text { pH } \\
\text { inicial }\end{array}$ & $\begin{array}{c}\text { Temperatura } \\
\left({ }^{\circ} \mathrm{C}\right)\end{array}$ & Inóculo & Principais arquéias & Referência \\
\hline $\begin{array}{l}\text { Resíduos } \\
\text { de } \\
\text { alimentos }\end{array}$ & 7,0 & 35 & $\begin{array}{l}\text { esterco } \\
\text { de } \\
\text { avícola }\end{array}$ & Methanosaeta & $\begin{array}{l}\text { Yusof et al. } \\
\text { (2019) }\end{array}$ \\
\hline $\begin{array}{l}\text { Resíduos } \\
\text { de } \\
\text { alimentos }\end{array}$ & - & 37 & $\begin{array}{l}\text { lodo de } \\
\text { esgoto e } \\
\text { esterco } \\
\text { suíno }\end{array}$ & $\begin{array}{l}\text { Methanoculleus, } \\
\text { Methanosarcina }\end{array}$ & $\begin{array}{l}\text { Jiang et al. } \\
\text { (2018) }\end{array}$ \\
\hline $\begin{array}{l}\text { Bagaço } \\
\text { de cana- } \\
\text { de-açúcar }\end{array}$ & 6,0 & 37 & $\begin{array}{l}\text { lodo } \\
\text { UASB de } \\
\text { avícola }\end{array}$ & $\begin{array}{l}\text { Methanobacteriales, } \\
\text { Methanomassiliicoccales, } \\
\text { Methanomicrobiales e } \\
\text { Methanosarcinales }\end{array}$ & $\begin{array}{c}\text { Braga et al. } \\
\quad(2018)\end{array}$ \\
\hline $\begin{array}{l}\text { Bagaço } \\
\text { de cana- } \\
\text { de-açúcar }\end{array}$ & - & 37 & $\begin{array}{l}\text { lodo } \\
\text { UASB de } \\
\text { avícola }\end{array}$ & $\begin{array}{c}\text { Methanolinea, } \\
\text { Methanobacterium e } \\
\text { Methanosaeta }\end{array}$ & $\begin{array}{l}\text { Ahmad et } \\
\text { al. (2018) }\end{array}$ \\
\hline
\end{tabular}

Nota: (-)= Não especificado.

\subsection{TÉCNICAS DE BIOLOGIA MOLECULAR APLICADAS AO ESTUDO}

\section{DE MICRORGANISMOS EM REATORES ANAERÓBIOS}

Devido à ampla diversidade de microrganismos envolvidos na bioconversão de resíduos lignocelulósicos a produtos de valor agregado nas diferentes etapas do processo de digestão anaeróbia, como organismos sintróficos, celulolíticos, acidogênicos e acetogênicos, produtores de hidrogênio e metanogênicos, enfatiza-se a necessidade da aplicação de técnicas de biologia molecular para melhor entendimento do papel das diferentes comunidades microbianas envolvidas na assimilação de diferentes substratos, especialmente se tratando de biomassa residual complexa.

A caracterização da microbiota envolvida na degradação de resíduos sólidos é de grande importância para o entendimento deste processo, que pode ser conciliado à obtenção de produtos de interesse biotecnológico. Para identificação de microrganismos, comumente se utiliza como na análise comparativa os genes que codificam subunidades ribossômicas, envolvidos na tradução das informações do DNA em proteínas. Em procariotos os ribossomos são constituídos de três subunidades, a saber: $5 \mathrm{~S}, 16 \mathrm{~S}$ e 23S, com 120, 1.650 e 3.300 pares de base, respectivamente. O uso do gene que codifica a subunidade $16 \mathrm{~S}$ para classificação taxônomica de procariotos foi difundido, uma vez que este gene é observado em todos os microrganismos do Domínio Bacteria e Archaea, cuja região é conservada, 
além de possuir variações suficientes, possibilitando o cálculo de distâncias evolutivas (SCHLEIFER, 2009) e construção de dendrogramas de distância genética.

Uma vez que apenas $1 \%$ dos microrganismos conhecidos são cultiváveis em laboratório, técnicas baseadas em identificação por caracterização morfofisiológica e/ou biomolecular (amplificação do gene RNAr 16S), além de demandarem muito tempo, podem não fornecer resultados representativos acerca da comunidade envolvida em determinado processo (RAJENDHRAN; GUNASEKARAN, 2008).

As técnicas tradicionalmente utilizadas para identificação em larga escala de comunidades microbianas de amostras ambientais, como sequenciamento de Sanger (SANGER; COULSON, 1975) utilizando preparo de bibliotecas de clones, geram dados com menor robustez (1.000 bases por corrida), quando comparados às técnicas mais modernas, como os sequenciamentos de terceira geração (pirossequenciamento, $10^{9}-10^{12}$ bases por corrida) e sequenciamentos de nova geração (DANIEL, 2005).

Entre as técnicas de Biologia molecular mais frequentes aplicadas ao estudo de reatores anaeróbios, é possível citar aquelas conhecidas como fingerprint (impressão digital) por meio da Eletroforese em Gel de Gradiente Desnaturante (DGGE), e mais recentemente, as técnicas que envolvem o uso de sequenciamento de alta performance ou de nova geração, como o sequenciamento massivo do gene RNAr 16S (metabarcoding) ou, mais recentemente, o sequenciamento shotgun metagenômico, utilizando plataformas como Illumina HiSeq (GUO et al., 2015).

As técnicas de fingerprint, apesar de úteis para avaliação dos índices ecológicos microbianos de amostras de reatores, não possibilitam a caracterização microbiana das amostras de interesse, tampouco fornecem informações concretas sobre seu metabolismo ao longo do processo, como as enzimas produzidas e o potencial funcional do consórcio microbiano do inóculo utilizado em diferentes condições operacionais. Desta forma, se justifica a análise metagenômica da comunidade microbiana na avaliação de diferentes condições experimentais, especialmente em condições otimizadas para obtenção de produtos de interesse biotecnológico (VOGEL, 1996).

Em relação as técnicas citadas de sequenciamento de nova geração, o metabarcoding (sequenciamento massivo de um gene de interesse, como RNAr 16S) possibilita apenas informações acerca da identidade dos microrganismos em determinada comunidade (metataxonômia), além da avaliação dos índices ecológicos pertinentes, como 
índices de diversidade e dominância. Em contrapartida, o uso do shotgun metagenômico, assim como no metabarcoding tem-se acesso às informações para análise taxônomica e funcional da comunidade (BRUCE et al., 2010; COLOMBO et al., 2016). Por meio da técnica de shotgun, não se tem apenas sua identificação e estabelecimento de relações taxônomicas, mas também informações sobre genes codificadores de enzimas de interesse. Tal possibilidade é baseada no sequenciamento randômico do genoma, possibilitando o entendimento da diversidade fisiológica da microbiota do inóculo para possível relação com as variáveis operacionais em cada processo, e com as rotas metabólicas envolvidas na degradação da lignocelulose (BRUCE et al., 2010; COLOMBO et al., 2016; DELFORNO et al., 2017).

Apesar do estudo da comunidade microbiana envolvida no processo de digestão anaeróbia ser essencial para a compreensão do comportamento dos reatores anaeróbios sob diferentes condições operacionais e como estas afetam as vias metabólicas predominantes e consequentemente os metabólitos obtidos, além de informações acerca da resistência a potenciais agentes tóxicos e/ou recalcitrantes, diversas pesquisas ainda se baseiam apenas em dados físico-químicos para avaliação dos resultados obtidos (DATAR et al., 2007; MILLATI et al., 2018). Entretanto, é fundamental a obtenção de dados físico-químicos e biológicos para melhor compreensão de diferentes configurações de reatores anaeróbios. Encontram-se resumidas na Tabela 3.6 algumas das principais técnicas de Biologia molecular utilizadas com esta finalidade, bem como os gêneros mais abundantes em cada reator.

Tabela 3.6. Comparação entre técnicas de biologia molecular utilizadas em reatores anaeróbios.

\begin{tabular}{|c|c|c|c|c|c|c|}
\hline Substrato & $\begin{array}{r}\text { Gêneros } \\
\text { abunda }\end{array}$ & Aplicação & Reator & Inóculo & Técnica & Referência \\
\hline $\begin{array}{l}\text { Bagaço } \\
\text { de cana- } \\
\text { de-açúcar }\end{array}$ & $\begin{array}{l}\text { Clostridium, } \\
\text { Enterococcus }\end{array}$ & $\begin{array}{l}\text { Obtenção } \\
\text { de } \mathrm{H}_{2}, \mathrm{CH}_{4}\end{array}$ & Bate & $\begin{array}{l}\text { lodo } \\
\text { UASB/ } \\
\text { avícola }\end{array}$ & $\begin{array}{c}\text { Illumina } \\
\text { MiSeq (16S) }\end{array}$ & $\begin{array}{l}\text { Braga et al. } \\
\quad(2018)\end{array}$ \\
\hline $\begin{array}{l}\text { Bagaço } \\
\text { de cana- } \\
\text { de-açúcar }\end{array}$ & $\begin{array}{c}\text { Coprothermobacter, } \\
\text { Anaerobaculum }\end{array}$ & $\begin{array}{l}\text { Obtenção } \\
\text { de } \mathrm{H}_{2}\end{array}$ & Batelada & $\begin{array}{l}\text { lodo } \\
\text { UASB/ } \\
\text { vinhaça }\end{array}$ & $\begin{array}{c}\text { Illumina } \\
\text { MiSeq (16S) }\end{array}$ & $\begin{array}{l}\text { Soares et } \\
\text { al. }(2018)\end{array}$ \\
\hline Xilose & Clostridium & $\begin{array}{l}\text { Obtenção } \\
\text { de } \mathrm{H}_{2}\end{array}$ & Batelada & $\begin{array}{c}\text { lodo } \\
\text { anaeróbio } \\
\text { digerido }\end{array}$ & $\begin{array}{c}16 \mathrm{~S}+ \\
\text { Biblioteca de } \\
\text { clones }\end{array}$ & $\begin{array}{l}\text { Quéméneur } \\
\text { et al. } \\
\text { (2012) }\end{array}$ \\
\hline $\begin{array}{l}\text { Palha de } \\
\text { arroz }\end{array}$ & Ruminoc & $\begin{array}{l}\text { Produção } \\
\text { de Ácidos } \\
\text { Orgânicos }\end{array}$ & Bate & $\begin{array}{c}\text { Lodo } \\
\text { UASB } \\
\text { doméstico }\end{array}$ & $\begin{array}{l}\text { Pirosequencia- } \\
\text { mento }\end{array}$ & $\begin{array}{l}\text { Woo et al. } \\
\text { (2015) }\end{array}$ \\
\hline
\end{tabular}

Fonte: Elaboração própria. 
Quéméneur et al. (2012), avaliaram a influência de potenciais agentes inibidores comumente formados no processo de degradação de compostos lignocelulósicos em populações de cultura bacteriana mista (lodo anaeróbio digerido). Para tanto, os autores avaliaram a obtenção de $\mathrm{H}_{2}$ em reatores em batelada contendo xilose, furfural, 5-HMF (hidroxi metil furfural), furano, fenol e lignina (Kraft e Organosolv).

Toxicidade ao processo fermentativo foi observada para todos esses compostos, todavia, os mais inibitórios foram lignina e furanos, enquanto os fenóis os menos inibitórios. Além disso, os autores verificaram que os clostrídios foram predominantes independente do inibidor, e $C$. beijerinkii identificada em todos os ensaios, sendo considerada a cepa ideal para processos de obtenção de $\mathrm{H}_{2}$ a partir da lignocelulose. Todavia, espécies comumente associadas à obtenção de $\mathrm{H}_{2}$, como $C$. acetobutylicum e $C$. pasteurianum foram afetadas negativamente pela adição dos inibidores.

Braga et al. (2018) avaliaram a biomassa envolvida na obtenção de $\mathrm{H}_{2}$ (Fase I) e $\mathrm{CH}_{4}$ (Fase II) em reatores em batelada, sendo a Fase II alimentada com o efluente acidificado e rico em metabólitos gerado na Fase I, alimentada com bagaço de cana-deaçúcar. A partir do sequenciamento massivo do gene RNAr 16S foi possível identificar na Fase I gêneros produtores de celulases, como Clostridium e Enterococcus, enquanto na Fase II foram identificadas bactérias pertencentes as famílias Methanoregulaceae e Methanosaetaceae de arqueias metanogênicas. Este caso exemplifica como o estudo das comunidades microbianas envolvidas no processo de obtenção de biogás é relevante, possibilitando o ajuste das condições operacionais mais indicados para cada fase, bem como o enriquecimento prévio deste inóculo com a finalidade de obtenção de maior eficiência do processo.

\subsubsection{Ferramentas de bioinformática aplicadas à metagenômica}

O campo de estudos em ecologia microbiana vem sendo revolucionado por técnicas de sequenciamento de alto rendimento. Uma das maiores vantagens relacionadas a estas técnicas é a possibilidade de análise simultânea de centenas de comunidades, permitindo a análise de padrões anteriormente inacessíveis por técnicas de sequenciamento de menor rendimento. No entanto, sabe-se que há certa limitação de técnicas comuns para atribuição taxonômica e análise de dados de sequenciamento massivo (CAPORASO et al., 2010). 
A qualidade do sequenciamento é uma das barreiras na obtenção de uma análise precisa, uma vez que os possíveis problemas nesta etapa podem levar à superestimativa da diversidade microbiana. Este tipo de dado pode ser suscetível às falhas químicas e mecânicas ou contaminações, tanto no conteúdo do adaptador quanto no viés do conteúdo base, devido a problemas na obtenção de sequências e na preparação de bibliotecas. Desta forma, um dos principais passos na análise de dados de sequenciamento massivo é o controle da qualidade das sequências. Uma das ferramentas que podem ser usadas para o controle de qualidade de dados de sequenciamento massivo, como shotgun, é o Fastp, que fornece vários recursos, como qualidade da sequência base, pontuação da qualidade por sequência, conteúdo da sequência base, Conteúdo (GC), distribuição de comprimento de sequência, nível de duplicação de sequência, sequências super-representadas e conteúdo do adaptador, tanto para dados de sequenciamento paired-end quanto single-end (CHEN et al., 2018).

Em relação às sequências analisadas via metabarcoding, o Quantitative Insights Microbial Ecology (QIIME) é um pipeline que permite a análise de microbiomas a partir de sequências de DNA brutas, obtidas a partir de várias técnicas de sequenciamento, como Illumina, Ion Torrent, entre outros. Essa ferramenta é amplamente usada para desmultiplexação e filtragem de qualidade, coleta de OTU, atribuição taxonômica e reconstrução filogenética, além de análises e visualizações de diversidade (CAPORASO et al., 2010).

Um dos pipelines mais utilizados para atribuição taxonômica a partir de dados de metabolismo é o Find Rapidly OTU with Galaxy Solution (FROGS) (ESCUDIÉ et al., 2018), que inclui várias ferramentas de bioinformática para pré-tratamento, limpeza, desreplicação, remoção de quimera, agrupamento de OTUs e, finalmente, para anotação taxonômica de sequências. Após a anotação, o pacote phyloseq, usado na linguagem de programação $\mathrm{R}$, é uma alternativa à análise de dados metabarcoding já agrupados em Unidades Taxonômicas Operacionais (OTUs), permitindo sua importação, armazenamento, análise estatística e exibição gráfica de dados complexos de sequenciamento filogenético (MCMURDIE; HOLMES, 2013).

Em dados metagenômicos obtidos via shotgun, a avaliação da significância biológica (classificação e análise filogenética) pode ser realizada usando diversas ferramentas, como o SortMeRNA, no qual alinhamentos locais de alta qualidade das leituras de RNAr são comparados com banco de dados de RNAr, como BLASTn 
(KOPYLOVA; NOÉ; TOUZET, 2012), enquanto a anotação taxonômica pode ser realizada via Kaiju nr (MENZEL; NG; KROGH, 2016).

Além da significância biológica, a análise metagenômica via shotgun permite o estudo de genes e vias metabólicas, ou seja, uma oportunidade para elucidar a atividade e também interações ambientais. Para tanto, uma etapa importante na análise de dados é a montagem da sequência, ou seja, a montagem de reads (fragmentos curtos de RNA) em contigs (sequência montada), por meio de ferramentas como metaSPAdes e Quality Assessment Tool for Genome Assemblies (QUAST), para realização do controle de qualidade dos contigs e reads (GUREVICH et al., 2013; NURK et al., 2017).

Embora a etapa de montagem seja comumente aplicada, seu uso é controverso entre os bioinformatas, pois pode levar tempo e levar a erros na montagem do genoma. A FragGeneScan é uma ferramenta alternativa que permite a previsão de genes a partir de reads ao invés de contigs (RHO; TANG; YE, 2010), assim como o Bowtie (LANGMEAD, 2010), que alinha os reads por meio de um índice do genôma de referência (http://bowtiebio.sf.net).

Além da anotação taxonômica, por meio da técnica de metagenômica shotgun temse a anotação funcional, ou seja, a identificação e caracterização das regiões funcionais de um genoma. Para tanto, existem servidores de anotação automática, como o GhostKOALA (KANEHISA; SATO; MORISHIMA, 2016), nos quais as atribuições são feitas em comparação com o Kyoto Encyclopedia of Genes and Genomes (KEGG) e a base de dados KEGG Orthology (KO) (KANEHISA, 2000), sendo que a anotação do genoma é realizada por meio da atribuição de identificadores $\mathrm{KO}$ (número $\mathrm{K}$ ) às regiões de codificação. As vias metabolicas podem ser mapeadas, integradas e visualizadas a partir de diversas ferramentas, sendo o Pathview uma das mais utilizadas (LUO; BROUWER, 2013).

Por fim, os dados obtidos podem ser analisados em relação à sua relevância estatística e também visualizados graficamente por meio de pacotes especificos, como o ggplot2 (WICKHAM, 2009), tanto para dados de metabarcoding quanto shotgun. Dados de sequenciamento shotgun podem ser analisados estatisticamente quanto à variância média e à expressão diferencial baseada em modelo usando distribuição binomial negativa, através do pacote DESeq2 (LOVE; HUBER; ANDERS, 2014).

Uma vez que a análise de dados de sequenciamento massivo é um tópico emergente em bioinformática, nesta sessão apenas as principais ferramentas aplicadas nesta pesquisa 
foram mencionadas (Tabela 3.7). Além disso, é importante mencionar que as ferramentas utilizadas podem variar de acordo com a técnica de sequenciamento.

Tabela 3.7. Principais ferramentas para análise massiva de dados de sequenciamento (shotgun ou metabarcoding) utilizados nesta pesquisa.

\begin{tabular}{|c|c|c|c|}
\hline Ferramenta & Aplicação & Funcionalidade & Referência \\
\hline Fastp & Shotgun & filtragem, controle de qualidade & $\begin{array}{l}\text { Chen et al. } \\
\text { (2018) }\end{array}$ \\
\hline FROGS & Metabarcoding, Shotgun & $\begin{array}{c}\text { pré-tratamento, limpeza, } \\
\text { desreplicação, remoção de } \\
\text { quimera, agrupamento em OTU, } \\
\text { atribuição taxonômica }\end{array}$ & $\begin{array}{l}\text { Escudié et al. } \\
\qquad \text { (2018) }\end{array}$ \\
\hline metaSPAdes & Shotgun & $\begin{array}{c}\text { montagem de sequência (reads em } \\
\text { contigs) }\end{array}$ & $\begin{array}{l}\text { Nurk et al. } \\
\quad(2017)\end{array}$ \\
\hline Kaiju nr & Shotgun & anotação taxonômica & $\begin{array}{l}\text { Menzel, Ng, } \\
\text { Krogh }(2016)\end{array}$ \\
\hline GhostKOALA & Shotgun & anotação funcional & $\begin{array}{l}\text { Kaneshia et al. } \\
\qquad(2016)\end{array}$ \\
\hline DESeq2 & Metabarcoding, Shotgun & $\begin{array}{c}\text { visualização gráfica e análise } \\
\text { estatística }\end{array}$ & $\begin{array}{l}\text { Love et al. } \\
\quad(2014)\end{array}$ \\
\hline phyloseq & Metabarcoding & $\begin{array}{c}\text { visualização gráfica e análise } \\
\text { estatística }\end{array}$ & $\begin{array}{l}\text { McMurdie e } \\
\text { Holmes (2013) }\end{array}$ \\
\hline QUAST & Shotgun & controle de qualidade (contigs) & $\begin{array}{l}\text { Gurevich et al. } \\
\qquad(2013)\end{array}$ \\
\hline PathView & Shotgun & Mapeamento de vias metabólicas & $\begin{array}{l}\text { Luo e Brouwer } \\
\qquad(2013)\end{array}$ \\
\hline SortMeRNA & Shotgun & $\begin{array}{l}\text { controle de qualidade, } \\
\text { caracterização filogenética }\end{array}$ & $\begin{array}{l}\text { Kopylova et al. } \\
\text { (2012) }\end{array}$ \\
\hline QIIME & Metabarcoding, Shotgun & $\begin{array}{c}\text { desmultiplexação e filtragem de } \\
\text { qualidade, coleta de OTU, } \\
\text { atribuição taxonômica e } \\
\text { reconstrução filogenética e } \\
\text { análises e visualizações de } \\
\text { diversidade }\end{array}$ & $\begin{array}{l}\text { Caporas et al. } \\
\text { (2010) }\end{array}$ \\
\hline FragGeneScan & Shotgun & $\begin{array}{l}\text { alinhamento de sequência, } \\
\text { detecção e mapeamento de genes } \\
\text { (reads) }\end{array}$ & $\begin{array}{l}\text { Rho, Tang, Ye } \\
\text { (2010) }\end{array}$ \\
\hline Bowtie & Shotgun & $\begin{array}{c}\text { alinhamento de sequência, } \\
\text { detecção e mapeamento de genes }\end{array}$ & $\begin{array}{l}\text { Langmeand } \\
\quad(2010)\end{array}$ \\
\hline ggplot2 & Metabarcoding, Shotgun & $\begin{array}{l}\text { visualização gráfica e análise } \\
\text { estatística }\end{array}$ & Wickham (2009) \\
\hline
\end{tabular}

Fonte: Elaboração própria. 


\section{MATERIAL E MÉTODOS}

\subsection{ESQUEMA OPERACIONAL}

A fim de avaliar o potencial de uso de resíduos sólidos de citros para obtenção de produtos de interesse biotecnológico, como $\mathrm{H}_{2}, \mathrm{CH}_{4}$, AOV e álcoois, foram realizados ensaios fermentativos e ensaios metanogênicos em diferentes condições operacionais. Primeiramente, foram realizados ensaios fermentativos a fim de comparar diferentes inóculos (autóctones, como o consórcio autofermentativo, e alóctones, como lodos de reator UASB de diferentes origens), diferentes faixas de temperatura (mesofílica, a $37^{\circ} \mathrm{C}$, e termofílica, a $55{ }^{\circ} \mathrm{C}$ ) e, finalmente, duas diferentes formas de pré-tratamento do substrato utilizado (via hidrotermólise, desliginificação alcalina ou in natura). Além disso, realizouse o isolamento e caracterização de bactérias anaeróbias potencialmente celulolíticas a partir do consórcio autofermentativo.

Após estes ensaios preliminares, onde adotou-se os inóculos, faixa de temperatura e substrato cuja maior obtenção de $\mathrm{H}_{2}$ foi observada, foram realizados novos ensaios fermentativos utilizando o método estatístico de Planejamento Sequencial (Plackett \& Burman e Delineamento Composto Central Rotacional- DCCR). Nos ensaios de Plackett \& Burman, avaliaram-se dez diferentes variáveis operacionais (temperatura, $\mathrm{pH}$, concentração de inóculo autóctone e alóctone, concentração de substrato, volume do headspace, e concentração dos componentes do meio reacional: $\mathrm{NaCl}, \mathrm{CaCO}_{3}$, extrato de levedura e peptona. As variáveis que foram consideradas mais significativas para obtenção de $\mathrm{H}_{2}$ a partir dos resíduos de citros foram adotadas para os ensaios de DCCR ( $\mathrm{pH}$, concentração de inóculo alóctone e substrato), onde faixa ótima para estas variáveis por meio de superfície de resposta foi estimada e posteriormente confirmada por meio de um ensaio de validação.

Os ensaios metanogênicos foram realizados após a fermentação dos resíduos sólidos de citros, utilizando como substrato a fração líquida obtida após acidificação, a fim de simular um sistema de duas fases (acidogênica e metanogênica).

Diferentes técnicas de biologia molecular foram empregadas para caracterização microbiana das diferentes etapas da pesquisa. Sequenciamento de Sanger (gene RNAr 16S) foi utilizado para afiliação filogenética da bactéria anaeróbia celulolítica isolada a partir do consórcio autofermentativo dos resíduos de citros, enquanto sequenciamento massivo do gene RNAr 16S (metabarcoding) foi utilizado para caracterização das comunidades 
microbianas envolvidas nos ensaios fermentativos contendo resíduo sólido de citros após diferentes pré-tratamentos (in natura moído e após hidrotermólise), bem como para comparação entre a fase acidogênica (Fase I) e fase metanogênica (Fase II) a partir da fração líquida da Fase I. Por fim, utilizou-se a técnica de metagenômica shotgun para avaliar a comunidade microbiana e as vias metabólicas envolvidas no ensaio de validação da condição otimizada, em comparação com o inóculo alóctone utilizado nestas condições (lodo UASB/vinhaça).

A comparação entre os diferentes ensaios foi realizada por meio de dados obtidos pela caracterização do conteúdo de biogás $\left(\mathrm{H}_{2}, \mathrm{CH}_{4}\right)$, compostos orgânicos ( $\mathrm{AOV}$, álcoois), carboidratos totais e fenóis. Além disso, realizou-se a quantificação do teor de limoneno na fração líquida dos diferentes ensaios, a partir de metodologia via Cromatografia Líquida Gasosa acoplada à Espectrometria de Massas (GC-MS), desenvolvida e validada no presente estudo. Encontra-se resumida na Figura 4.1 as diferentes etapas da pesquisa. 
Figura 4.1. Fluxograma experimental simplificado, com destaque para os ensaios fermentativos (em verde), metanogênicos (rosa) e as etapas de caracterização microbiana (em roxo).

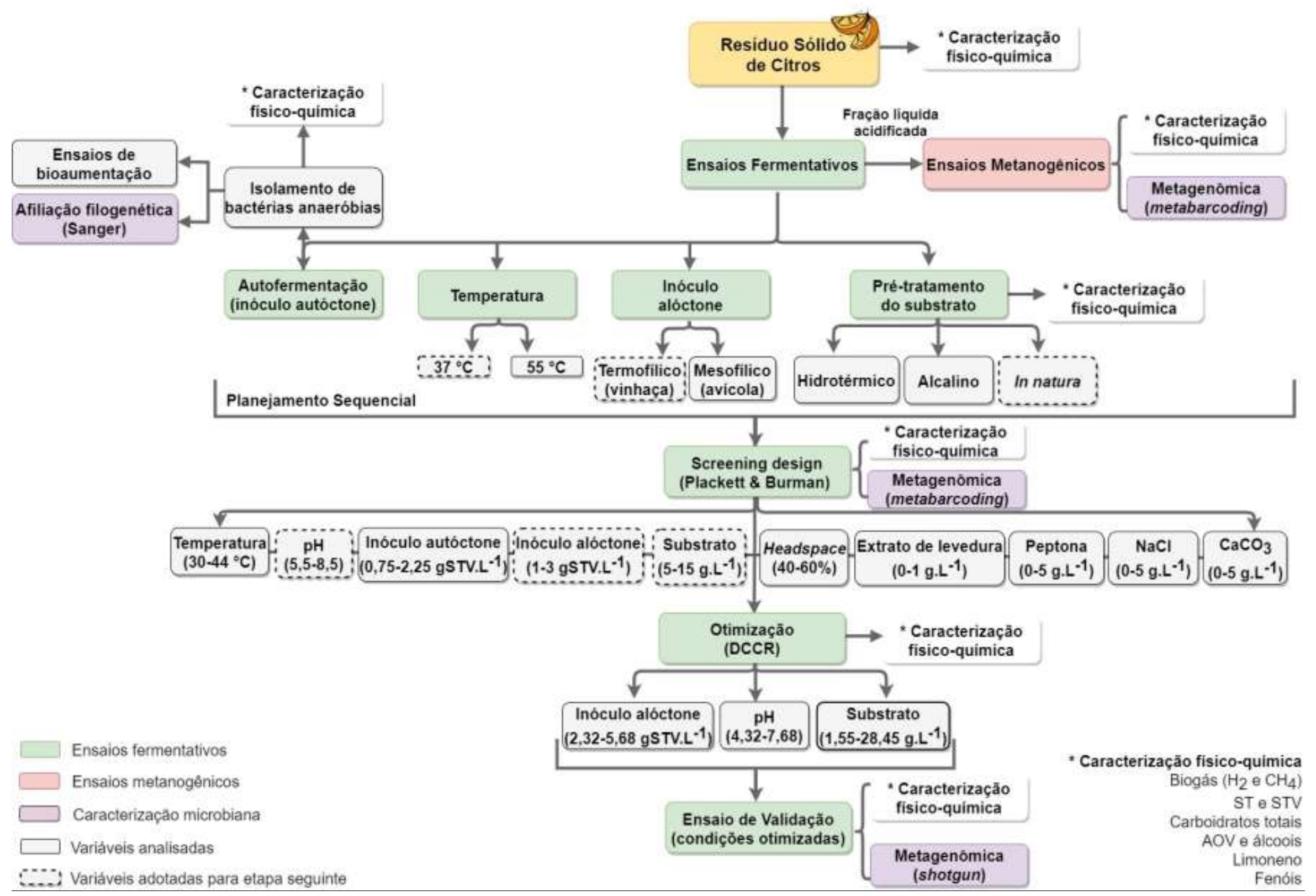




\subsection{SUBSTRATO}

\subsubsection{Resíduos de citros}

Os resíduos de citros in natura, utilizados como substrato para obtenção de inóculo autóctone e para os ensaios de obtenção de biogás, foram produzidos no Laboratório de Processos Biológicos da Universidade de São Paulo, campus São Carlos, espremendo laranjas do tipo pera (Citrus sinensis L. Osbeck, var. Pera-Rio), frescas e maduras, para remoção do suco e das sementes e separando suas cascas e bagaços, a fim de obter um resíduo semelhante ao das plantas industriais.

O armazenamento foi realizado conforme descrito em Calabrò et al. (2016), sendo o resíduo desidratado em estufa de secagem a $50{ }^{\circ} \mathrm{C}$ durante 24 h e depois moído em moinho de facas (tipo Wiley TE-650/1) até que partículas $\leq 1 \mathrm{~mm}$ fossem obtidas e acondicionadas em frascos plásticos a $4{ }^{\circ} \mathrm{C}$ até o momento de sua utilização.

\subsubsection{Pré-tratamentos}

Os resíduos (cascas e bagaço) foram submetidos aos pré-tratamentos de hidrotermólise e deslignificação alcalina. Após aplicação desses pré-tratamentos, a separação do resíduo foi realizada por filtração em membrana com porosidade de $0,1 \mathrm{~mm}$. A fração sólida foi lavada com água ultrapura para remoção dos açúcares residuais e utilizada nos ensaios subsequentes.

Ensaios em reatores anaeróbios em batelada foram conduzidos com os resíduos prétratados e ensaios controle com resíduos sem pré-tratamento utilizando as mesmas proporções $\left(15\right.$ g.L $\left.\mathrm{L}^{-1}\right)$ de resíduo de citros.

\subsubsection{Hidrotermólise}

O pré-tratamento do resíduo (cascas e bagaço) por meio de hidrotermólise foi realizado em reator de bancada, sob pressão de 10 bar a $180{ }^{\circ} \mathrm{C}$ por período de 15 minutos e com a massa total de $1,5 \%$ de substrato, como descrito em Jacquet et al. (2011) e Soares et al. (2017a). Após a explosão, a fração sólida foi levada para secagem em estufa a $50{ }^{\circ} \mathrm{C}$ e a fração líquida foi armazenada em frascos plásticos a $-20{ }^{\circ} \mathrm{C}$.

O reator hidrotérmico utilizado (Figura 4.2) foi desenvolvido em parceria entre o Laboratório de Processos Biológicos (LPB) da Escola de Engenharia de São Carlos da Universidade de São Paulo (EESC-USP) e o Departamento de Engenharia Mecânica da mesma escola. Este reator foi confeccionado em aço e é composto pelo reservatório, com capacidade total de $200 \mathrm{~mL}$, no qual ocorre o aquecimento da água e da biomassa na 
temperatura programada via painel de controle derivativo integral proporcional (PID); e do ciclone, no qual ocorre a separação da fração sólida e líquida após a abertura da válvula de explosão, sendo o resíduo pré-tratado coletado no funil de captação. A pressão máxima alcançada neste equipamento é de 50 bar.

Figura 4.2. Esquema do reator hidrotérmico.

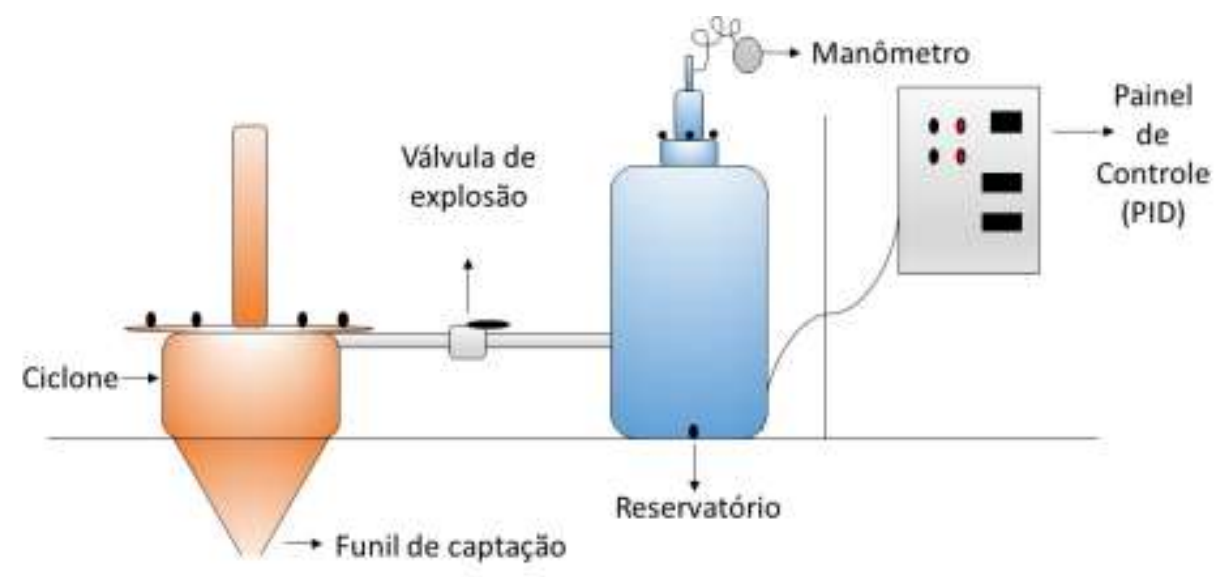

Fonte: Elaboração própria.

A severidade do tratamento foi calculada de acordo com Jacquet et al. (2011), por meio da Equação 4.1

Severidade $=\int_{0}^{t} \exp \left[\frac{T(t)-100}{14,75}\right] d \times t$

sendo,

$\mathrm{t}=$ tempo $(\min )$,

$\mathrm{T}=$ temperatura $\left({ }^{\circ} \mathrm{C}\right)$.

\subsubsection{Deslignificação alcalina}

Os ensaios de deslignificação alcalina foram realizados de acordo com Cabrera et al. (2014). Para tanto, adicionou-se 2,5 g de resíduo a solução de hidróxido de sódio $(\mathrm{NaOH})$ e $1 \%$ de peróxido de hidrogênio $\left(\mathrm{H}_{2} \mathrm{O}_{2}\right)$, ajustada para pH $11,5( \pm 0,2) \mathrm{com} \mathrm{NaOH}$ 5 mol. $L^{-1}$ durante $24 \mathrm{~h}$. A proporção de sólido/líquido utilizada foi de 1:20 (peso/volume). A fração sólida obtida após centrifugação foi utilizada como substrato nos ensaios para obtenção de biogás. 


\subsection{ENSAIOS CINÉTICOS EM BATELADA}

\subsubsection{Inóculo}

\subsubsection{Inóculo autóctone}

A obtenção do inóculo autóctone foi realizada a partir da autofermentação das cascas e bagaço in natura, separadamente e em conjunto foi realizada com o intuito de avaliar a hipótese de que o próprio resíduo de citros pode ser utilizado como fonte natural de microrganismos autóctones celulolíticos/produtores de biogás e adaptados aos potenciais agentes inibidores.

A estratégia utilizada para a obtenção do inóculo autofermentativo foi adaptada de Haruta et al. (2002) e Wang et al. (2011), sendo que a fonte de carbono foi substituída por 20 g.L. $\mathrm{L}^{-1}$ de resíduo de citros in natura (cascas, bagaço e cascas + bagaço) em frascos de $500 \mathrm{~mL}$ com volume reacional de $250 \mathrm{~mL}$ contendo meio Peptone Cellulose Solution (PCS) (Tabela 4.1) em pH ajustado para 7,0 com HCl 1 mol.L $\mathrm{L}^{-1}$ e NaOH 1 mol.L ${ }^{-1}$.

Os reatores anaeróbios em batelada foram submetidos a atmosfera de $\mathrm{N}_{2} / \mathrm{CO}_{2}$ (70/30\%) durante 20 minutos (FORGÁCS et al., 2012) e fechados com tampa de butila e rosca plástica. Os frascos foram incubados em estufa com temperatura ajustada a $37^{\circ} \mathrm{C}$ e a concentração de biogás foi o parâmetro adotados como indicador do crescimento microbiano. Amostras de aproximadamente $500 \mu \mathrm{L}$ do headspace foram coletadas periodicamente, a cada duas horas durante 48 horas ou até a estabilização da concentração de $\mathrm{H}_{2}$, utilizando seringas gastight equipadas com trava. 
Tabela 4.1. Meio de cultivo Peptone Cellulose Solution (PCS) modificado e condições utilizadas no ensaio de autofermentação dos resíduos de citros in natura.

\begin{tabular}{ccc}
\hline Componentes & $\begin{array}{c}\text { Quantidades - q.s.p. 1000 } \\
\text { mL de água ultrapurificada }\end{array}$ & Batelada (500 mL) \\
\hline Peptona $(\mathrm{g})$ & 5,0 & 1,25 \\
Extrato de levedura $(\mathrm{g})$ & 1,0 & 0,25 \\
$\mathrm{CaCO}_{3}(\mathrm{~g})$ & 5,0 & 1,25 \\
$\left.\mathrm{NaCl}^{\mathrm{g}}\right)$ & 5,0 & 1,25 \\
Fonte de carbono $(\mathrm{g}) *$ & 20 & 5,0 \\
\hline Condições & & 50 \\
headspace $(\%)$ & - & 250 \\
volume reacional $(250 \mathrm{~mL})$ & - & 37 \\
temperatura $\left({ }^{\circ} \mathrm{C}\right)$ & - & 7,0 \\
pH & - & 5
\end{tabular}

Fonte: Adaptado de Haruta et al. (2002). *Fonte de carbono= cascas e/ou bagaço de citros.

A fim de aumentar a densidade microbiana do inóculo, o meio foi transferido para tubos Falcon de $50 \mathrm{~mL}$ e centrifugado durante 5 minutos a $5000 \mathrm{rpm}$. O sobrenadante foi descartado e a biomassa recuperada transferida para um novo frasco contendo meio PCS fresco, nas mesmas condições reacionais definidas anteriormente, bem como mesmo volume reacional. Repetiu-se o procedimento aproximadamente cinco vezes (Figura 4.3).

Figura 4.3. Fluxograma experimental de obtenção de consórcio celulolítico-fermentativo.

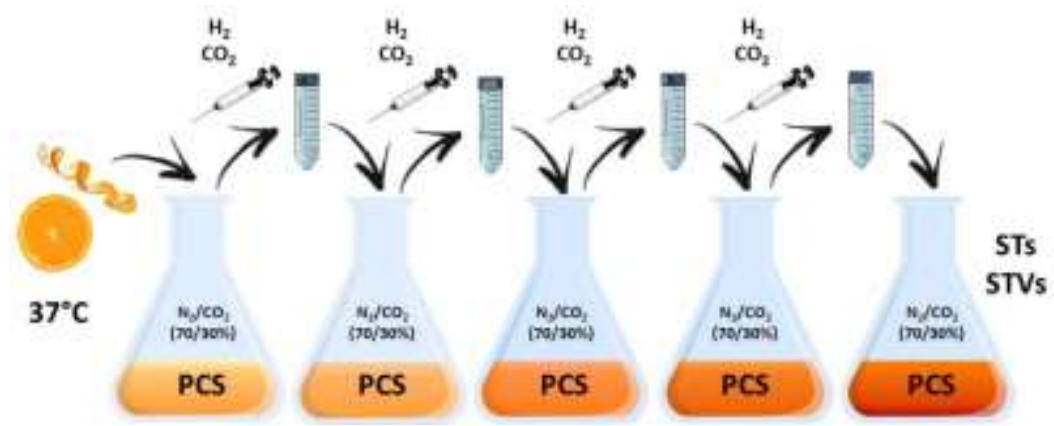

Fonte: Elaboração própria.

\subsection{Atividade celulolítica}

A atividade celulolítica potencial do consórcio bacteriano fermentativo foi estimada. Para tanto, volume de $10 \%$ do consórcio obtido foi transferido para frascos de antibiótico com capacidade de $100 \mathrm{~mL}$ e $50 \%$ de volume reacional contendo o meio PCS em anaerobiose, contendo 5 g. $\mathrm{L}^{-1}$ de papel filtro de celulose $\left(0,3 \mathrm{~cm}^{2}\right)$ como única fonte de carbono, sendo que a atividade celulolítica foi avaliada por meio da desintegração da fibra 
de papel filtro após 21 dias de incubação. Para tanto, a cultura foi filtrada e a fração sólida ressuspendida em $100 \mathrm{~mL}$ de solução de ácido acético-ácido nítrico (1:1) aquecida a 100 ${ }^{\circ} \mathrm{C}$ por período de 30 minutos, a fim de remover o material biológico.

$\mathrm{O}$ ensaio controle foi realizado substituindo-se o inóculo por água destilada. $\mathrm{O}$ material celulósico restante foi lavado repetidas vezes com água destilada e, após a lavagem, o material foi centrifugado e o percentual de degradação foi determinado por análise gravimétrica, de acordo com a Equação 4.2.

Degradação $(\%)=\frac{M_{t}-M_{r}}{M_{t}} \times 100$

sendo,

Mt= Massa Total de material celulósico;

$\mathrm{Mr}=$ Massa Residual.

\subsubsection{Inóculo alóctone}

Utilizou-se como inóculo o lodo granulado proveniente de reator UASB operado a $55{ }^{\circ} \mathrm{C}$ aplicado ao processamento de vinhaça de cana-de-açúcar e cedido pela Usina São Martinho (Pradópolis, São Paulo). Além disso, foi avaliado o potencial do mesmo lodo, porém proveniente do tratamento de águas residuárias de abatedouro de aves em temperatura mesofílica, cedido pela Avícola Dacar, Tietê, São Paulo, a fim de comparar sua eficiência na obtenção de biogás a partir de resíduos de citros.

Os inóculos foram transportados das empresas ao Laboratório de Processos Biológicos em recipientes plásticos com capacidade de $30 \mathrm{~L}$ e armazenados a $4{ }^{\circ} \mathrm{C}$ a fim de reduzir sua atividade biológica e química, até o momento do uso. Antes de sua utilização, o inóculo foi submetido à trituração em liquidificador doméstico a fim de promover a desestruturação dos grânulos.

\subsubsection{Faixa de temperatura}

Ensaios nas faixas de temperatura mesofílica $\left(37^{\circ} \mathrm{C}\right)$ e termofílica $\left(55^{\circ}\right)$ foram realizados com os diferentes inóculos exógenos descritos (lodo granulado de reator UASB aplicado às avícolas e à vinhaça de cana-de-açúcar), a fim de estabelecer a faixa ideal para os ensaios subsequentes.

O potencial de obtenção de biogás em relação aos inóculos em adição ao consórcio celulolítico autóctone obtido a partir da autofermentação dos resíduos de citros foi avaliado. Para tanto, utilizou-se 15 g.L $\mathrm{L}^{-1}$ do substrato de citros in natura moído em frascos Duran de 
$250 \mathrm{~mL}$, com $50 \%$ de headspace e $50 \%$ de volume reacional contendo meio PCS, em pH ajustado para 7,0 com $\mathrm{HCl} 1 \mathrm{~mol} . \mathrm{L}^{-1}$ e NaOH 1 mol.L-1. A concentração de inóculo adicionada foi de 2 gSTV.L $\mathrm{L}^{-1}$ de consórcio alóctone e 1,5 g STV.L $\mathrm{L}^{-1}$ de consórcio autóctone. Os reatores anaeróbios em batelada foram submetidos a atmosfera de $\mathrm{N}_{2} / \mathrm{CO}_{2}(70 / 30 \%)$ durante 20 minutos (FORGÁCS et al., 2012) e fechados com tampa de butila e rosca plástica. Amostras de $500 \mu \mathrm{L}$ do headspace foram coletadas em intervalos de duas horas durante aproximadamente 48 horas ou até que a concentração de biogás se estabilizasse, utilizando seringas de gastight equipadas com trava.

\subsubsection{Ensaios de pré-tratamento}

Ensaios preliminares foram realizados para definição do pré-tratamento mais adequado com resíduos de citros. Os ensaios foram conduzidos em reatores em batelada contendo 15 g.L - $^{-1}$ de substrato de citros moído pré-tratado ou sem pré-tratamento, de acordo com as condições descritas na Tabela 4.2. Os reatores foram mantidos a $37{ }^{\circ} \mathrm{C}$ até a estabilização da concentração de $\mathrm{H}_{2}$.

Tabela 4.2. Condições utilizadas nos ensaios de comparação entre resíduos de citros in natura e após diferentes pré-tratamentos (deslignificação alcalina e hidrotermólise).

\begin{tabular}{cccc}
\hline Componentes & In natura & $\begin{array}{c}\text { Deslignificação } \\
\text { alcalina }\end{array}$ & Hidrotermólise \\
\hline Peptona $\left(\mathrm{g} . \mathrm{L}^{-1}\right)$ & 1,25 & 1,25 & 1,25 \\
Extrato de levedura $\left(\mathrm{g} . \mathrm{L}^{-1}\right)$ & 0,25 & 0,25 & 0,25 \\
$\mathrm{CaCO}\left(\mathrm{g} . \mathrm{L}^{-1}\right)$ & 1,25 & 1,25 & 1,25 \\
$\mathrm{NaCl}\left(\mathrm{g} . \mathrm{L}^{-1}\right)$ & 1,25 & 1,25 & 1,25 \\
Fonte de carbono $\left(\mathrm{g} . \mathrm{L}^{-1}\right)^{*}$ & 3,75 & 3,75 & 3,75 \\
\hline Condições & & & \\
\cline { 1 - 2 } Volume do reator $(\mathrm{mL})$ & 500 & 500 & 500 \\
Headspace $(\%)$ & 50 & 50 & 50 \\
Volume reacional $(250 \mathrm{~mL})$ & 250 & 250 & 250 \\
Temperatura $\left({ }^{\circ} \mathrm{C}\right)$ & 37 & 37 & 7,0 \\
pH & 7,0 & 7,0 & 2 \\
Inóculo alóctone $\left(\mathrm{gSTV} . \mathrm{L}^{-1}\right)$ & 2 & 2 & 1,5 \\
Inóculo autóctone $\left(\mathrm{gSTV} . \mathrm{L}^{-1}\right)$ & 1,5 & 1,5 &
\end{tabular}

\subsubsection{Ensaios fermentativos}

\subsubsection{Delineamento de Plackett \& Burman}

Para avaliação da obtenção de produtos de interesse biotecnológico, utilizou-se o método estatístico de Planejamento Experimental, por meio da superfície de respostas, 
baseado na matriz de Plackett \& Burman (P\&B) (RODRIGUES; IEMMA, 2014). Foram realizados ensaios para avaliação do efeito da temperatura $\left(30-44{ }^{\circ} \mathrm{C}\right), \mathrm{pH}$ inicial $(5,5-8,5)$, concentração de inóculo autóctone (0,75-2,25 gSTV.L $\left.{ }^{-1}\right)$ e alóctone (1-3 gSTV.L $\left.{ }^{-1}\right)$, substrato (5-15 g.L $\mathrm{L}^{-1}$ ) e volume do headspace (40-60\%).

As concentrações dos componentes do meio de cultura foram avaliadas, sendo extrato de levedura (0-1 g.L $\left.\mathrm{L}^{-1}\right), \mathrm{CaCO}_{3}\left(0-5\right.$ g.L $\left.\mathrm{L}^{-1}\right), \mathrm{NaCl}\left(0-5\right.$ g.L $\left.\mathrm{L}^{-1}\right)$ e peptona $\left(0-5\right.$ g.L $\left.\mathrm{L}^{-1}\right)$. Todos os ensaios foram realizados sob condições estáticas. As condições mínimas e máximas para cada parâmetro avaliado (Tabela 4.3) foram estabelecidas com base em trabalhos anteriores realizados pelo Grupo de Pesquisa em Processos Anaeróbios (LPB/EESC/USP) (SOARES et al., 2017; VILLA MONTOYA et al., 2019; MAZARELI et al., 2020).

Optou-se por utilizar um planejamento de três níveis $(-1,0,+1)$, resultando em uma matriz com 16 condições experimentais (Tabela 4.4). A escolha desta matriz se deu devido à necessidade de atender o mínimo de quatro ensaios a mais do que o número de variáveis (10) a serem estudadas no processo, a fim de garantir os graus de liberdade necessários para o cálculo do erro padrão (RODRIGUES; IEMMA, 2014).

Tabela 4.3. Condições mínimas (-1), máximas (+1) e do ponto central (0) para as diferentes variáveis.

\begin{tabular}{lcccc}
\hline & Variável & $\mathbf{- 1}$ & $\mathbf{0}$ & $\mathbf{+ 1}$ \\
\hline $\mathrm{X}_{1}$ & Temperatura $\left({ }^{\circ} \mathrm{C}\right)$ & 30 & 37 & 44 \\
$\mathrm{X}_{2}$ & $\mathrm{pH}$ & 5,5 & 7 & 8,5 \\
$\mathrm{X}_{3}$ & Consórcio $\left(\mathrm{gSTV} . \mathrm{L}^{-1}\right)$ & 0,75 & 1,5 & 2,25 \\
$\mathrm{X}_{4}$ & Lodo $\left(\mathrm{gSTV} . \mathrm{L}^{-1}\right)$ & 1 & 2 & 3 \\
$\mathrm{X}_{5}$ & Substrato $\left(\mathrm{g} . \mathrm{L}^{-1}\right)$ & 5 & 10 & 15 \\
$\mathrm{X}_{6}$ & Headspace $(\%)$ & 40 & 50 & 60 \\
$\mathrm{X}_{7}$ & Extrato de levedura $\left(\mathrm{g} . \mathrm{L}^{-1}\right)$ & 0 & 0,5 & 1 \\
$\mathrm{X}_{8}$ & $\mathrm{CaCO}\left(\mathrm{g} . \mathrm{L}^{-1}\right)$ & 0 & 2,5 & 5 \\
$\mathrm{X}_{9}$ & $\mathrm{NaCl}\left(\mathrm{g} . \mathrm{L}^{-1}\right)$ & 0 & 2,5 & 5 \\
$\mathrm{X}_{10}$ & Peptona $\left(\mathrm{g} . \mathrm{L}^{-1}\right)$ & 0 & 2,5 & 5 \\
\hline
\end{tabular}


Tabela 4.4. Matriz de Plackett \& Burman codificada para o screening design com 16 condições experimentais e três repetições do ponto central.

\begin{tabular}{ccccccccccc}
\hline \multirow{2}{*}{ Ensaios } & \multicolumn{10}{c}{ Variáveis } \\
\cline { 2 - 10 } & $\mathbf{x}$ 1 & $\mathbf{x} 2$ & $\mathbf{x 3}$ & $\mathbf{x}$ 4 & $\mathbf{x}$ 5 & $\mathbf{x 6}$ & $\mathbf{x}$ 7 & $\mathbf{x} 8$ & $\mathbf{x 9}$ & $\mathbf{x 1 0}$ \\
\hline R1 & +1 & -1 & -1 & -1 & 1 & -1 & -1 & +1 & +1 & -1 \\
R2 & +1 & +1 & -1 & -1 & -1 & +1 & -1 & -1 & +1 & +1 \\
R3 & +1 & +1 & +1 & -1 & -1 & -1 & +1 & -1 & -1 & +1 \\
R4 & +1 & +1 & +1 & +1 & -1 & -1 & -1 & +1 & -1 & -1 \\
R5 & -1 & +1 & +1 & +1 & +1 & -1 & -1 & -1 & +1 & -1 \\
R6 & +1 & -1 & +1 & +1 & +1 & +1 & -1 & -1 & -1 & +1 \\
R7 & -1 & +1 & -1 & +1 & +1 & +1 & +1 & -1 & -1 & -1 \\
R8 & +1 & -1 & +1 & -1 & +1 & +1 & +1 & +1 & -1 & -1 \\
R9 & +1 & +1 & -1 & +1 & -1 & +1 & +1 & +1 & +1 & -1 \\
R10 & -1 & +1 & +1 & -1 & +1 & -1 & +1 & +1 & +1 & +1 \\
R11 & -1 & -1 & +1 & +1 & -1 & +1 & -1 & +1 & +1 & +1 \\
R12 & +1 & -1 & -1 & +1 & +1 & -1 & +1 & -1 & +1 & +1 \\
R13 & -1 & +1 & -1 & -1 & +1 & +1 & -1 & +1 & -1 & +1 \\
R14 & -1 & -1 & +1 & -1 & -1 & +1 & +1 & -1 & +1 & -1 \\
R15 & -1 & -1 & -1 & +1 & -1 & -1 & +1 & +1 & -1 & +1 \\
R16 & -1 & -1 & -1 & -1 & -1 & -1 & -1 & -1 & -1 & -1 \\
R17 & 0 & 0 & 0 & 0 & 0 & 0 & 0 & 0 & 0 & 0 \\
R18 & 0 & 0 & 0 & 0 & 0 & 0 & 0 & 0 & 0 & 0 \\
R19 & 0 & 0 & 0 & 0 & 0 & 0 & 0 & 0 & 0 & 0 \\
\hline
\end{tabular}

Nota: Variáveis codificadas de acordo com a Tabela 4.2

\subsubsection{Delineamento Composto Central Rotacional}

Após o screening design para determinação das variáveis significativas para o processo de obtenção de $\mathrm{H}_{2}$ a partir de resíduos de citros via delineamento de Plackett \& Burman, foram realizados nesta etapa da pesquisa os ensaios de otimização via Delineamento Composto Central Rotacional (DCCR) (RODRIGUES; IEMMA, 2014).

A influência das variáveis independentes de concentração de inóculo ( $\mathrm{x}_{1} ; 2,32-5,68$ gSTV.L $\left.{ }^{-1}\right)$, concentração de substrato $\left(\mathrm{x}_{2} ; 1,55-28,45\right.$ g.L $\left.\mathrm{L}^{-1}\right)$ e $\mathrm{pH}\left(\mathrm{X}_{3} ; 4,32-7,68\right)$ foi estimada por meio de um delineamento fatorial completo de $2^{3}$, incluindo 6 pontos axiais e 3 repetições no ponto central, totalizando 17 ensaios (Tabela 4.5). 
Tabela 4.5. Matriz experimental com valores reais e valores codificados para os ensaios do DCCR de $2^{3}$, com 6 pontos axiais e 3 repetições no ponto central, totalizando 17 ensaios.

\begin{tabular}{ccccccc}
\hline & \multicolumn{3}{c}{ Valores reais } & \multicolumn{3}{c}{ Valores codificados } \\
\cline { 2 - 7 } Ensaios & $\begin{array}{c}\text { Inóculo } \\
\left(\mathrm{gSTV} . \mathrm{L}^{-1}\right)\end{array}$ & $\mathrm{pH}$ & $\begin{array}{c}\text { Substrato } \\
\left(\mathrm{g} . \mathrm{L}^{-1}\right)\end{array}$ & $\begin{array}{c}\text { Inóculo } \\
\left(\mathrm{gSTV} . \mathrm{L}^{-1}\right)\end{array}$ & $\mathrm{pH}$ & $\begin{array}{c}\text { Substrato } \\
\left(\mathrm{g} . \mathrm{L}^{-1}\right)\end{array}$ \\
\hline E1 & 3,0 & 7,0 & 4,5 & -1 & -1 & -1 \\
E2 & 5,0 & 7,0 & 4,5 & 1 & -1 & -1 \\
E3 & 3,0 & 23,0 & 4,5 & -1 & 1 & -1 \\
E4 & 5,0 & 23,0 & 4,5 & 1 & 1 & -1 \\
E5 & 3,0 & 7,0 & 7,5 & -1 & -1 & 1 \\
E6 & 5,0 & 7,0 & 7,5 & 1 & -1 & 1 \\
E7 & 3,0 & 23,0 & 7,5 & -1 & 1 & 1 \\
E8 & 5,0 & 23,0 & 7,5 & 1 & 1 & 1 \\
E9 & 2,3 & 15,0 & 6,0 & $-1,68$ & 0 & 0 \\
E10 & 5,7 & 15,0 & 6,0 & 1,68 & 0 & 0 \\
E11 & 4,0 & 1,5 & 6,0 & 0 & $-1,68$ & 0 \\
E12 & 4,0 & 28,5 & 6,0 & 0 & 1,68 & 0 \\
E13 & 4,0 & 15,0 & 3,5 & 0 & 0 & $-1,68$ \\
E14 & 4,0 & 15,0 & 8,5 & 0 & 0 & 1,68 \\
E15 & 4,0 & 15,0 & 6,0 & 0 & 0 & 0 \\
E16 & 4,0 & 15,0 & 6,0 & 0 & 0 & 0 \\
E17 & 4,0 & 15,0 & 6,0 & 0 & 0 & 0 \\
\hline
\end{tabular}

Encontram-se resumidas na Tabela 4.6 as condições experimentais adotadas para os ensaios de otimização da obtenção de $\mathrm{H}_{2}$, sendo que a concentração de inóculo, pH inicial e concentração de substrato foram as variáveis adotadas, enquanto a concentração de consórcio celulolítico, temperatura de incubação, volume do headspace e os parâmetros já citados relacionados às condições nutricionais do meio foram fixadas de acordo com os resultados obtidos no ensaio de screening design.

Tabela 4.6. Condições experimentais dos ensaios de otimização da obtenção de $\mathrm{H}_{2}$ por meio do método de Delineamento Composto Central Rotacional (DCCR).

\begin{tabular}{|c|c|c|c|c|c|c|}
\hline & Variável & $-1,68$ & -1 & $\mathbf{0}$ & +1 & $+1,68$ \\
\hline $\mathrm{X}_{1}$ & Inóculo alóctone (gSTV.L ${ }^{-1}$ ) & 2,32 & 3 & 4 & 5 & 5,68 \\
\hline $\mathrm{x}_{2}$ & $\mathrm{pH}$ & 4,32 & 5 & 6 & 7 & 7,68 \\
\hline $\mathrm{x}_{3}$ & Substrato (g. $\left.\mathrm{L}^{-1}\right)$ & 1,55 & 7 & 15 & 23 & 28,45 \\
\hline & Condições fixas & & & \multicolumn{3}{|c|}{ Concentração } \\
\hline & óculo autóctone (gSTV.L ( $\left.^{-1}\right)$ & & & \multicolumn{3}{|c|}{2,25} \\
\hline & Temperatura $\left({ }^{\circ} \mathrm{C}\right)$ & & & \multicolumn{3}{|c|}{30} \\
\hline & Headspace (\%) & & & \multicolumn{3}{|c|}{40} \\
\hline & Peptona (g.L $\left.\mathrm{L}^{-1}\right)$ & & & \multicolumn{3}{|c|}{5} \\
\hline
\end{tabular}

O ensaio de validação foi planejado de acordo com as condições otimizadas de acordo com a superfície de resposta obtida, sendo: 4 gSTV.L ${ }^{-1}$ de inóculo alóctone, 29,8 
g. $\mathrm{L}^{-1}$ de resíduo de citros in natura e $\mathrm{pH}$ 8,98, além das mesmas condições fixas descritas na Tabela 4.6. Para fins comparativos entre os resultados da validação experimental nas condições otimizadas após DCCR, considerou-se como condições não otimizadas as anteriores aos ensaios de Plackett \& Burman e DCCR e com inóculo, tratamento do substrato e temperatura similares. Desta forma, as condições não otimizadas foram: 15 g.L ${ }^{-}$ ${ }^{1}$ de resíduo de citros in natura, 2 gSTV.L ${ }^{-1}$ de inóculo alóctone, $\mathrm{pH} 7,0,30{ }^{\circ} \mathrm{C}$ e meio de cultura PCS (HARUTA et al., 2002), onde se obteve 13,31 mmol $\mathrm{H}_{2} \cdot \mathrm{L}^{-1}$.

\subsubsection{Obtenção de bactérias anaeróbias celulolíticas}

Após a obtenção do consórcio celulolítico-fermentativo a partir da autofermentação das cascas e bagaço de citros in natura, as bactérias fermentativas produtoras de hidrogênio potencialmente celulolíticas foram isoladas de acordo com Wang et al. (2011) (Figura 4.4). Para tanto, realizou-se diluições seriadas $\left(10^{-1}\right.$ a $\left.10^{-30}\right)$ do consórcio em frascos de antibiótico contendo meio PCS, submetidos ao fluxo de $\mathrm{N}_{2}$ por período de cinco minutos, com volume reacional de $50 \%$ e incubados sob condição estática e anaeróbia a $37{ }^{\circ} \mathrm{C}$ por período de $24 \mathrm{~h}$.

Alíquotas de $500 \mu 1$ do headspace foram analisadas em cromatografia gasosa após o período de incubação, e a presença de $\mathrm{H}_{2}$ foi adotada como parâmetro, uma vez que a maior diluição na qual houve concentração de $\mathrm{H}_{2}$ foi plaqueada em meio sólido (meio PCS acrescido de 1,5\% de ágar bacteriológico) por meio da técnica de pour plate. 
Figura 4.4. Esquema da metodologia empregada para análise do consórcio celulolítico-fermentativo, desde a determinação gravimétrica da degradação das fibras de celulose, isolamento de colônias em meio PCS até a avaliação da comunidade microbiana por meio de técnicas de Biologia molecular.

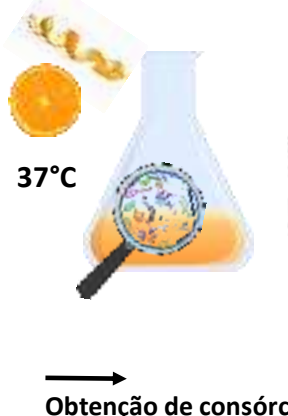

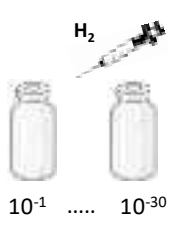

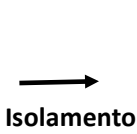

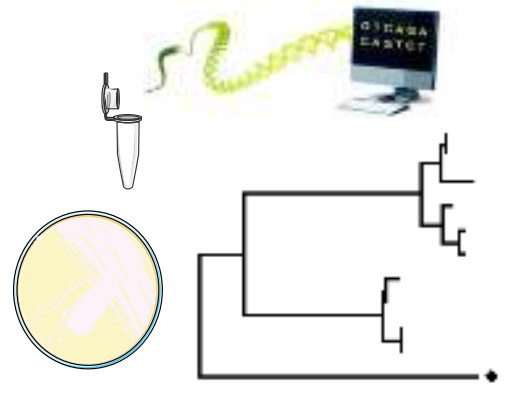

0.05

Afiliação filogenética

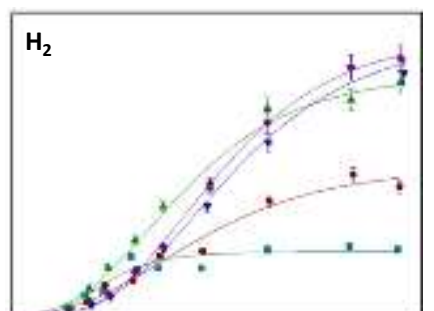

Caracterização cinética e nutricional

Fonte: Elaboração própria.

As placas foram incubadas em Jarra Gas-Pack com sache de anaerobiose (Oxoid ${ }^{\mathrm{TM}}$ AnaeroGen ${ }^{\mathrm{TM}}$ ) durante 48 h. Diferentes colônias foram transferidas do meio sólido para frascos Duran contendo meio PCS líquido e incubadas novamente por período de $48 \mathrm{~h}$ sob condições estáticas.

A biomassa dos ensaios com produção de $\mathrm{H}_{2}$ foram novamente plaqueadas em meio sólido, a fim de verificar a pureza da cultura. As características micromorfológicas da cultura isolada foram observadas a partir do preparo de lâminas a fresco (com ágar 2\%) e coloração de Gram, em microscópio óptico Olympus BX60 com câmera acoplada (software Olympus cellSens Dimension) em aumento total de 1000x. As amostras foram armazenadas em glicerina $(1: 1)$ a $-80{ }^{\circ} \mathrm{C}$, após lavagem com tampão PBS $(\mathrm{NaCl} 8 \%, \mathrm{KCl}$ 0,2\%, $\mathrm{Na}_{2} \mathrm{HPO}_{4}$ 1,44\%, $\mathrm{KH}_{2} \mathrm{PO}_{4}$ 0,24\%) (GREEN; SAMBROOK, 2012).

\subsection{Caracterização da cepa isolada}

Após a etapa de isolamento, a cepa de bactéria anaeróbia fermentativa produtora de hidrogênio e com maior atividade celulolítica foi caracterizada como descrito em Maintinguer et al. (2017) quanto aos seus requerimentos nutricionais. Foram realizados ensaios em batelada com diferentes fontes de carbono (glicose, frutose, sacarose, xilose, amido, glicerol, celobiose, celulose e lactose), além do resíduo sólido de citros, em meio PCS modificado, contendo 3 g. $\mathrm{L}^{-1}$ da respectiva fonte de carbono e utilizando $10 \%$ da cultura isolada como inóculo.

Ao final dos ensaios, foram quantificados os metabólitos produzidos (ácidos orgânicos e/ou álcoois), enquanto a concentração acumulada de $\mathrm{H}_{2}$ foi analisada ao longo 
de período de aproximadamente $30 \mathrm{~h}$. Além disso, realizou-se a caracterização da fase líquida após o período de incubação quanto à matéria orgânica (DQO $\left.\mathrm{Diltrada}_{\mathrm{a}}\right)$, teor de sólidos suspensos totais (SST) e sólidos suspensos voláteis (SSV), quantificação de carboidratos totais e fenóis totais, bem como a determinação do consumo de substrato.

Após o estabelecimento do substrato no qual houve maior obtenção de hidrogênio foram realizados novos ensaios cinéticos a fim de determinar o efeito de sua concentração. Foram avaliadas entre $0,5-6,5$ g. $\mathrm{L}^{-1}$ da respectiva fonte de carbono, utilizando as condições de isolamento $\left(37^{\circ} \mathrm{C}\right.$; e meio reacional PCS com $\left.\mathrm{pH} 7,0\right)$.

Os valores foram estabelecidos a fim de avaliar a condição ótima de crescimento da cepa em relação à variável fonte de carbono, por meio do método estatístico de Planejamento Experimental, de acordo com (RODRIGUES; IEMMA, 2014), totalizando 4 condições experimentais e 3 repetições do ponto central para que fosse possível obter os graus de liberdade necessários para o cálculo do erro padrão do experimento, obtenção do modelo de regressão e ANOVA dos resultados obtidos.

Os parâmetros cinéticos foram estabelecidos por meio de ensaios em batelada a fim de verificar a velocidade de crescimento $(R m)$, concentração máxima de $\mathrm{H}_{2}(P)$ e tempo necessário para início da obtenção de $\mathrm{H}_{2}(\lambda)$ do microrganismo isolado, a partir do modelo de Gompertz modificado (ZWIETERING et al., 1994).

Construiu-se curva de crescimento microbiano relacionando a biomassa produzida (densidade óptica ou massa seca). A partir do logaritmo natural (ln) da fase exponencial do ensaio cinético, o crescimento específico $(\mu)$ obtido por dados experimentais sobre a concentração celular $\left(\mathrm{OD}_{600}\right)$ em função do tempo foi ajustado com curvas polinomiais $\left(R^{2}=0,9882\right)$, a partir das quais se obteve um conjunto de valores de $X=f(t)$, por meio do qual foi estimado o $\mu$ da reação $\left(0,35 \mathrm{~h}^{-1}\right)$. Além disso, a partir da relação da densidade óptica com a massa seca celular, calculou-se o tempo de geração celular ( $T g$ ) da cepa utilizada (Equação 4.3). O valor obtido foi de 1,98 h.

$$
\operatorname{Tg}=\frac{\ln 2}{\mu}=\frac{0,693}{\mu}
$$

\subsubsection{Ensaios metanogênicos}

Uma vez que após o período de incubação necessário para a obtenção de hidrogênio a partir de resíduos de citros, há como consequência a geração de diversos metabólitos, 
como ácidos orgânicos, álcoois e oligo/monossacarídeos, verificou-se o potencial desta fração líquida na obtenção de gás metano, simulando um sistema de digestão anaeróbia de duas fases (fase acidogênica a partir de resíduos sólidos de citros + fase metanogênica a partir da fração líquida do primeiro reator) (Figura 4.5).

As condições experimentais aplicadas na Fase I foram as mesmas do reator R5, descritos nos ensaios de Plackett \& Burman, sendo: 15 g.L $\mathrm{L}^{-1}$ de resíduos de citros in natura, 2,25 gSTV.L ${ }^{-1}$ e 3 gSTV.L ${ }^{-1}$ de inóculo autóctone e alóctone, respectivamente, 5 g.L ${ }^{-1}$ de $\mathrm{NaCl}, 40 \%$ de headspace, $\mathrm{pH} 8,5$ e temperatura $30{ }^{\circ} \mathrm{C}$.

Figura 4.5. Esquema operacional do sistema de duas fases para digestão anaeróbia dos resíduos de citros, sendo (A) fase acidogênica a partir dos resíduos sólidos de citros e (B) fase metanogênica a partir da fração líquida do primeiro reator.

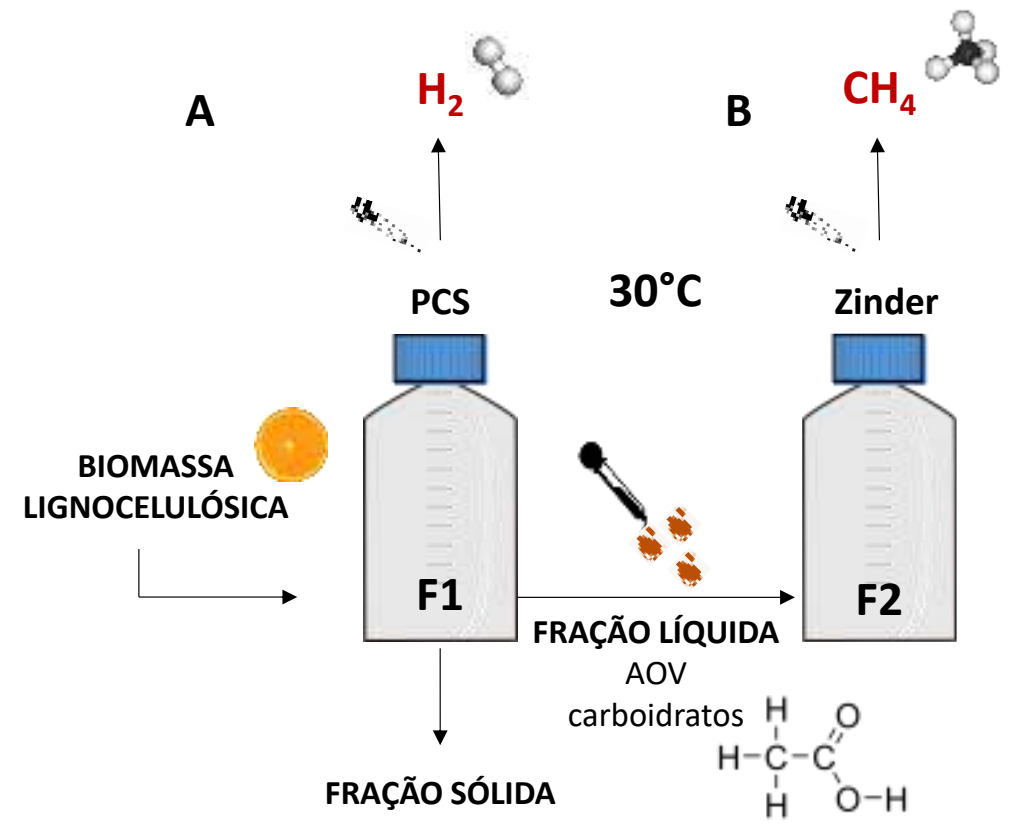

Fonte: Elaboração própria.

Após a Fase I, o conteúdo do reator foi filtrado em membrana de $<0,1 \mathrm{~mm}$, sendo a fração sólida descartada e a fração líquida utilizada como substrato na Fase II, sendo os ensaios realizados em frascos Duhran com volume total de $500 \mathrm{~mL}$, sendo $250 \mathrm{~mL}$ de volume reacional e $50 \%$ de headspace.

A fração líquida resultante da Fase I foi suplementada com a mesma composição do meio mineral de Zinder (ZINDER; KOCH, 1984) (Tabela 4.7) acrescido de solução traço de metais (Tabela 4.8) e de solução traço de vitaminas (Tabela 4.9). 
Tabela 4.7. Composição do meio de Zinder modificado, utilizado nos ensaios de obtenção de $\mathrm{CH}_{4}$ e condições utilizadas nos ensaios em batelada.

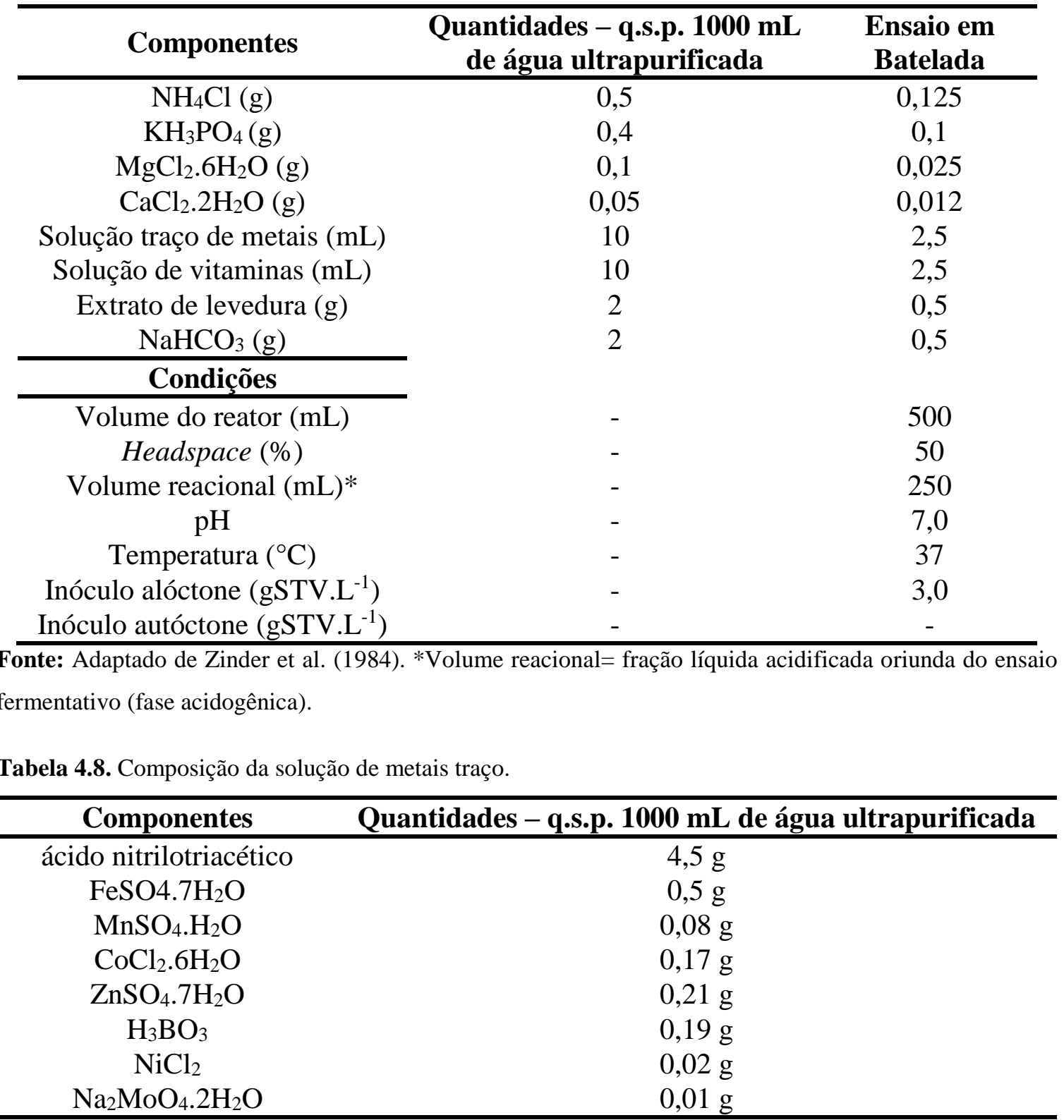

Fonte: Adaptado de Hirasawa et al. (2007). 
Tabela 4.9. Composição da solução de vitaminas.

\begin{tabular}{cc}
\hline Componentes & Quantidades - q.S.p. 1000 mL de água ultrapurificada \\
\hline Biotina & $0,002 \mathrm{~g}$ \\
Ácido fólico & $0,002 \mathrm{~g}$ \\
Piridoxina $\mathrm{HCl}$ & $0,010 \mathrm{~g}$ \\
Tiamina $\mathrm{HCl} .2 \mathrm{H}_{2} \mathrm{O}$ & $0,005 \mathrm{~g}$ \\
Riboflavina & $0,005 \mathrm{~g}$ \\
Ácido nicotínico & $0,005 \mathrm{~g}$ \\
D-pantotenato de cálcio & $0,005 \mathrm{~g}$ \\
Vitamina B12 & $0,0001 \mathrm{~g}$ \\
Ácido p-aminobenzoico & $0,005 \mathrm{~g}$ \\
Ácido lipoico & $0,005 \mathrm{~g}$ \\
\hline
\end{tabular}

Fonte: Adaptado de Hirasawa et al. (2007).

Após a inoculação com 3 gSTV.L $\mathrm{L}^{-1}$ de lodo UASB, o pH foi ajustado para 7,0 com $\mathrm{NaOH}$ ou $\mathrm{HCl} 1 \mathrm{~mol} . \mathrm{L}^{-1}$. Os ensaios foram realizados em frascos Duhran de $250 \mathrm{~mL}$, com $50 \%$ de headspace e $50 \%$ de volume reacional. Fluxionou-se $\mathrm{N}_{2} / \mathrm{CO}_{2}(70 / 30 \%)$ nos frascos (FORGÁCS et al., 2012), os quais foram fechados com tampa de butila e rosca plástica e incubados em condição mesofílica $\left(30^{\circ} \mathrm{C}\right)$ sob condições estáticas.

Os reatores foram monitorados quanto à composição do biogás (hidrogênio e metano) ao longo de aproximadamente 700 h, a fim de calcular os parâmetros de concentração máxima de $\mathrm{CH}_{4}(P)$, velocidade máxima da reação $(R m)$ e tempo de início da obtenção de $\mathrm{CH}_{4}(\lambda)$ a partir do modelo de Gompertz modificado (ZWIETERING et al., 1994). Amostras para quantificação dos metabólitos formados e produtos consumidos foram coletadas ao longo do processo.

\subsection{MÉTODOS FÍSICO-QUÍMICOS}

\subsubsection{Análises físico-químicas e cromatográficas}

\subsubsection{Caracterização de macro e microelementos}

A determinação do teor total dos elementos $\mathrm{Ca}, \mathrm{Cu}, \mathrm{Fe}, \mathrm{Mg}, \mathrm{Mn}, \mathrm{Ni}, \mathrm{K}, \mathrm{Na}$ e $\mathrm{Zn}$, bem como da concentração total de fósforo $(\mathrm{P})$ e nitrogênio $(\mathrm{N})$ foi realizada pela empresa Bioagri Ambiental, de acordo com o método descrito em EPA 6010 D-3051 (USEPA, 2014).

\subsubsection{Análises físico-químicas}

As análises físico-químicas de monitoramento dos reatores em batelada, sua periodicidade e métodos de referência, encontram-se resumidos na Tabela 4.10. Os Sólidos Totais (ST) e Sólidos Totais Voláteis (STV) foram quantificados de acordo com os métodos 2540B e 2540E, respectivamente (APHA/AWWA/WEF, 2012). A determinação dos ácidos 
orgânicos voláteis (AOV) acético (HAc), propiônico (HPr), butírico (HBu), caproico (HCap) valérico (HVal) e etanol $(\mathrm{EtOH})$ foi conduzida em cromatógrafo de gás Shimadzu ${ }^{\circledR}$ (2010) de acordo com Adorno et al. (2014).

Ao início e final de cada ensaio, analisou-se o teor de Sólidos Suspensos Totais e Voláteis (SST e SSV) e pH (APHA/AWWA/WEF, 2012), além de carboidratos totais (DUBOIS et al., 1956), fenóis (BUCHANAN; NICELL, 1997; APHA/AWWA/WEF, 2012), (APHA/AWWA/WEF, 2012) e ácido lático (TAYLOR, 1996).

Tabela 4.10. Análises físico-químicas utilizadas para o monitoramento dos reatores em batelada.

\begin{tabular}{ccc}
\hline Análise & Frequência da análise & Referência \\
\hline $\mathrm{pH}$ & Inicial e final & APHA/AWWA/WEF (2012) \\
$\mathrm{DQO}$ & Inicial e final & APHA/AWWA/WEF (2012) \\
SS e SSV & Inicial e final & APHA/AWWA/WEF (2012) \\
Ácidos orgânicos e álcoois & Inicial, intermediários e final & Adorno et al. (2014) \\
Ácido lático & Inicial, intermediários e final & Taylor (1996) \\
Fenóis totais & Inicial e final & Buchanan e Nicell (1997) \\
\hline
\end{tabular}

\subsubsection{Balanço de massa}

O balanço de massa da condição otimizada foi realizado em termos de DQO, a partir da caracterização do efluente acidificado dos reatores. O balanço de massa da fase solúvel (BMS) foi realizado de acordo com a Equação 4.4 (MAZARELI, 2019).

$$
B M S=\left(\frac{D Q O_{\text {metabólitos }}+D Q O_{\text {carboidratos }}+D Q O_{\text {fenóis }}}{D Q O_{\text {experimental }}}\right) \times 100
$$

Sendo,

$\mathrm{BMS}=$ balanço de massa da fase solúvel $(\%)$;

$\mathrm{DQO}_{\text {metabólitos }}=\mathrm{DQO}$ equivalente à soma dos metabólitos solúveis $\left(\mathrm{mg} . \mathrm{L}^{-1}\right)$;

$\mathrm{DQO}_{\text {carboidratos }}=\mathrm{DQO}$ equivalente aos carboidratos totais da fase solúvel $\left(\mathrm{mg} . \mathrm{L}^{-1}\right)$;

$\mathrm{DQO}_{\text {fenóis }}=\mathrm{DQO}$ equivalente aos fenóis totais $\left(\mathrm{mg} \cdot \mathrm{L}^{-1}\right)$;

$D_{\text {Q }}$ experimental $=$ DQO determinada experimentalmente.

Encontram-se resumidos na Tabela 4.11 os fatores de equivalência utilizados para determinação da DQO equivalente, de acordo com o descrito em Mazareli (2019). 
Tabela 4.11. Fatores de equivalência utilizados para determinação da DQO equivalente. Os carboidratos totais foram considerados em termos de g-glicose.

\begin{tabular}{|c|c|c|}
\hline Metabólito solúvel & Reação de oxidação & Fator de equivalência \\
\hline Ácido lático & $\mathrm{C}_{3} \mathrm{H}_{6} \mathrm{O}_{3}+3 \mathrm{O}_{2} \rightarrow 3 \mathrm{CO}_{2}+3 \mathrm{H}_{2} \mathrm{O}$ & $1,07 \mathrm{gDQO}^{-\mathrm{g}^{-1}}$ \\
\hline Ácido acético & $\mathrm{C}_{2} \mathrm{H}_{4} \mathrm{O}_{2}+\mathrm{O}_{2} \rightarrow 2 \mathrm{CO}_{2}+2 \mathrm{H}_{2} \mathrm{O}$ & $1,07 \mathrm{gDQO}^{-1} \mathrm{~g}^{-1}$ \\
\hline Ácido propiônico & $\mathrm{C}_{4} \mathrm{H}_{6} \mathrm{O}_{5}+3 \mathrm{O}_{2} \rightarrow 4 \mathrm{CO}_{2}+3 \mathrm{H}_{2} \mathrm{O}$ & $1,51 \mathrm{gDQO}^{-\mathrm{g}^{-1}}$ \\
\hline Ácido butírico & $\mathrm{C}_{4} \mathrm{H}_{8} \mathrm{O}_{2}+5 \mathrm{O}_{2} \rightarrow 4 \mathrm{CO}_{2}+4 \mathrm{H}_{2} \mathrm{O}$ & 1,82 gDQO.g ${ }^{-1}$ \\
\hline Ácido valérico & $\mathrm{C}_{5} \mathrm{H}_{10} \mathrm{O}_{2}+6,5 \mathrm{O}_{2} \rightarrow 5 \mathrm{CO}_{2}+5 \mathrm{H}_{2} \mathrm{O}$ & $2,04 \mathrm{gDQO} \cdot \mathrm{g}^{-1}$ \\
\hline Ácido caproico & $\mathrm{C}_{6} \mathrm{H}_{12} \mathrm{O}_{2}+8 \mathrm{O}_{2} \rightarrow 6 \mathrm{CO}_{2}+6 \mathrm{H}_{2} \mathrm{O}$ & $2,21 \mathrm{gDQO} \cdot \mathrm{g}^{-1}$ \\
\hline Etanol & $\mathrm{C}_{2} \mathrm{H}_{6} \mathrm{O}+3 \mathrm{O}_{2} \rightarrow 2 \mathrm{CO}_{2}+3 \mathrm{H}_{2} \mathrm{O}$ & $2,09 \mathrm{gDQO} \cdot \mathrm{g}^{-1}$ \\
\hline Fenóis & $\mathrm{C}_{6} \mathrm{H}_{6} \mathrm{O}+4 \mathrm{O}_{2} \rightarrow 3 \mathrm{CO}_{2}+3 \mathrm{H}_{2} \mathrm{O}$ & $1,36 \mathrm{gDQO} \cdot \mathrm{g}^{-1}$ \\
\hline Carboidratos totais & $\mathrm{C}_{6} \mathrm{H}_{12} \mathrm{O}_{6}+6 \mathrm{O}_{2} \rightarrow 6 \mathrm{CO}_{2}+6 \mathrm{H}_{2} \mathrm{O}$ & 1,07 gDQO.g $\mathrm{g}^{-1}$ \\
\hline
\end{tabular}

\subsubsection{Análise da composição do biogás}

A análise da composição do biogás em relação à concentração de gás hidrogênio, metano e dióxido de carbono foi realizada em cromatógrafo de gás Shimadzuß (2010), equipado com detector de condutividade térmica (DCT). A coluna utilizada foi a Carboxen 1010 PLOT, $30 \mathrm{~m}$ x 0,53 mm. A temperatura do injetor, do forno e do detector foram 220 ${ }^{\circ} \mathrm{C}, 130{ }^{\circ} \mathrm{C}$ e $230{ }^{\circ} \mathrm{C}$, respectivamente. Utilizou-se gás argônio como gás de arraste, com fluxo na coluna de 5,66 mL. $\mathrm{min}^{-1}$ com volume de Make-up de $12 \mathrm{~mL} \cdot \mathrm{min}^{-1}$. As amostras de biogás do headspace foram coletadas periodicamente (a cada 2 h) com uma tampa de butila usando seringa manual com trava (Figura 4.6). 
Figura 4.6. Esquema de amostragem estática do headspace. O conteúdo de biogás no espaço superior é coletado periodicamente (a cada 2 h) através da tampa de butila, usando seringa manual com trava.

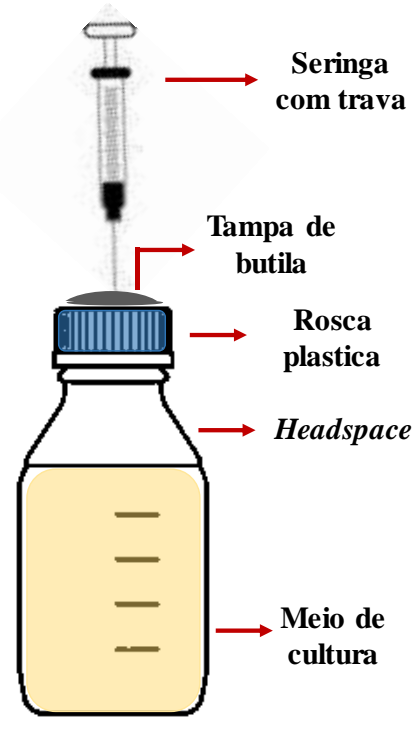

Fonte: Elaboração própria.

4.4.1.5 Espectroscopia de Infravermelho com Transformada Fourier A caracterização dos grupos funcionais presentes dos resíduos foi feita por meio do método qualitativo de FT-IR (Fourier Transform Infrared Spectroscopy) na faixa entre 4000-400 $\mathrm{cm}^{-1}$ e 32 scans, utilizando pastilhas de brometo de potássio (KBr) na concentração de $1 \%$. A análise foi realizada com o resíduo seco em estufa a $40{ }^{\circ} \mathrm{C}$ até peso constante. As análises foram realizadas na Central de Análises Químicas e Instrumentais (CAQI) do Instituto de Química de São Carlos (IQSC), Universidade de São Paulo (USP) campus São Carlos. A verificação dos grupos funcionais correspondentes às bandas foi realizada de acordo com Silverstein e Webster (1981).

\subsubsection{Microscopia Eletrônica de Varredura}

Os resíduos de citros, tanto cascas quanto bagaço, antes e após os pré-tratamentos empregados, foram submetidos à análise microscópica em Microscopia Eletrônica de Varredura (MEV), de acordo com o método descrito em Nation (1983) e Soares (2017). Para tanto, as amostras foram fixadas em solução tampão fosfato $(0,1 \mathrm{M}, \mathrm{pH} 7,3) \mathrm{com}$ glutaraldeído (2,5\%) por um período de $12 \mathrm{~h}$ a $4{ }^{\circ} \mathrm{C}$ e lavadas em tampão fosfato $(0,1 \mathrm{M}$, pH 7,3) durante 10 minutos e desidratadas em solução de etanol no gradiente de 
concentrações de 50\%, 70\%, 80\%, 90\%, 95\% e 100\% durante 10 minutos em cada concentração. Procedeu-se a secagem das amostras em estufa a $60{ }^{\circ} \mathrm{C}$ durante aproximadamente duas horas fixadas em stub por meio de fitas de carbono e revestidas com uma camada de $10 \mathrm{~nm}$ ouro.

As análises microscópicas foram realizadas em Microscópio Eletrônico de Varredura ZEISS modelo SIGMA equipado com canhão de elétrons por emissão de campo (MEV-FEG) modelo DSM-960 do Laboratório de Microscopia Eletrônica e Análise (LMEA) do Instituto de Física de São Carlos (IFSC), Universidade de São Paulo (USP) campus São Carlos.

\subsubsection{Microscopia óptica}

As características micromorfológicas do consórcio obtido foram observadas a partir do preparo de lâminas a fresco (com ágar 2\%) e coloração de Gram, em microscópio óptico Olympus BX60 com câmera acoplada (software Olympus cellSens Dimension) em aumento total de 1000X. As amostras foram armazenadas em glicerina (1:1) sob refrigeração de $-80{ }^{\circ} \mathrm{C}$ após lavagem com tampão PBS ( $\mathrm{NaCl} 8 \%, \mathrm{KCl}$ 0,2\%, $\mathrm{Na}_{2} \mathrm{HPO}_{4}$ 1,44\%, $\mathrm{KH}_{2} \mathrm{PO}_{4}$ 0,24\%) (GREEN; SAMBROOK, 2012).

\subsubsection{Determinação do teor de limoneno via GC-MS}

\subsubsection{Reagentes}

A solução padrão de limoneno foi feita com (R)-(+)-limoneno $\left(\mathrm{C}_{10} \mathrm{H}_{16}\right)$ com $90 \%$ de pureza (Sigma Aldrich-62122). Todos os demais reagentes (etanol e n-hexano) utilizados foram de pureza analítica $(\geq 98 \%)$.

\subsubsection{Preparação das amostras}

Amostras liquidas de reator anaeróbio foram coletadas no final do período de incubação e centrifugadas a $9000 \mathrm{rpm}$ por 5 minutos e preservadas a $-20^{\circ} \mathrm{C}$, sem adição de qualquer substância. As amostras foram diluídas em água MilliQ® conforme necessário, para análises posteriores na curva de calibração desenvolvida e descrita nos itens subsequentes. 


\subsubsection{Curva de calibração}

A curva de calibração da solução padrão de limoneno foi realizada em triplicata. As diluições foram realizadas em água ultra-purificada. Etanol p.a. foi utilizado como solvente para obter concentrações de 3,$0 ; 6,0 ; 9,0 ; 12,0 ; 15,0 ; 18,0$ e 20,0 mg.L $\mathrm{L}^{-1}$.

\subsubsection{Validação do método}

A linearidade, precisão instrumental e limites de detecção e quantificação foram estabelecidos de acordo com as recomendações de Ribani et al. (2004), Duarte et al. (2006) e Adorno et al. (2014), seguindo especificações da Agência Nacional de Vigilância Sanitária (ANVISA, 2003).

A linearidade da resposta do detector para a curva de calibração foi avaliada por regressão linear, a partir de amostras com concentrações de 3 a $20 \mathrm{mg} . \mathrm{L}^{-1}$ de limoneno. Três réplicas de cada nível padrão foram usadas para elaboração da curva analítica. A precisão instrumental (coeficiente de variação, CV\%) foi estimada pelo tempo de retenção de nove injeções repetidas da solução padrão com $12 \mathrm{mg} . \mathrm{L}^{-1}$ de limoneno.

O limite de detecção (LD) foi calculado de acordo com a Equação 4.5.

$$
L D=3 \times \operatorname{DesvPad} / m
$$

Sendo:

DesvPad= desvio padrão;

$\mathrm{m}=$ coeficiente angular.

A menor concentração possível de medida foi estabelecida pelo limite de quantificação (LQ), calculado de acordo com a Equação 4.6.

$$
L Q=10 \times \operatorname{DesvPad} / \mathrm{m}
$$

Sendo:

DesvPad = desvio padrão;

$\mathrm{m}=$ coeficiente angular.

\subsubsection{Ensaio de adsorção}

Para estimar o potencial de adsorção do limoneno à matéria orgânica, sua recuperação foi medida pela adição da concentração conhecida $\left(2000 \mathrm{mg} . \mathrm{L}^{-1}\right)$ ao lodo de 
esgoto usado como inóculo em reatores anaeróbios. Os resultados foram calculados pela Equação 4.7.

Recuperação $(\%)=($ concentração estimada/teórica $) \times 100$

A adsorção de limoneno foi estimada de acordo com Calabrò et al. (2016), em uma amostra controle (com água ultrapura ao invés de lodo de esgoto) e em uma amostra com $2.000 \mathrm{mg} . \mathrm{L}^{-1}$ de limoneno. A fim de extrair este composto, $1 \mathrm{~mL}$ de $\mathrm{n}$-hexano (de pureza analítica $\geq 98 \%$ ) foi adicionado a cada $1 \mathrm{~mL}$ de biomassa e agitado no vórtex por 5 minutos, e o procedimento foi repetido três vezes. A fração orgânica foi coletada e a porcentagem de recuperação estimada pela razão entre a concentração estimada na fase orgânica e a concentração teórica.

\subsubsection{Aplicabilidade}

Os ensaios foram conduzidos em batelada, com 5 g.L $\mathrm{L}^{-1}$ de glicose em frascos Duhran de $250 \mathrm{~mL}$, com $50 \%$ de headspace e $50 \%$ de volume reacional, em condições estáticas a $30^{\circ} \mathrm{C}$. O meio de cultivo utilizado foi meio PCS (HARUTA et al., 2002), com pH ajustado para 7,0 com $\mathrm{NaOH}$ ou $\mathrm{HCl} 1$ mol.L $\mathrm{L}^{-1}$, com adição de 0 a 2.000 mg.L $\mathrm{L}^{-1}$ de limoneno (sem adição de limoneno; 50; 100; 250; 500; 1.000; 1500 e 2.000 mg.L. de $^{-1}$ limoneno). O inóculo utilizado foi o lodo de reator UASB aplicado ao processamento termofílico de vinhaça da cana-de-açúcar $\left(2\right.$ gSTV.L $\left.L^{-1}\right)$.

Após a inoculação, uma mistura de $\mathrm{N}_{2} / \mathrm{CO}_{2}(70 / 30 \%)$ foi fluxionada nos reatores, que foram fechados com tampa de butila e rosca plástica. A concentração de limoneno foi estimada em amostras líquidas no início e no final do tempo de operação.

\subsection{TÉCNICAS DE BIOLOGIA MOLECULAR}

A comunidade microbiana envolvida na digestão anaeróbia de resíduos sólidos de citros foi avaliada por meio de diferentes ferramentas de biologia molecular. A análise de Eletroforese em Gel de Gradiente Desnaturante foi aplicada em diferentes amostras (inóculos autóctone e alóctone, biomassa após hidrotermólise e deslignificação alcalina, e biomassa de citros in natura) a fim de observar o efeito de pré-tratamentos por meio dos índices de diversidade obtidos. Além disso, a técnica de sequenciamento massivo do gene 16S RNAr via Plataforma Illumina foi aplicada nas amostras onde foram observadas maiores concentrações de $\mathrm{H}_{2}$ (resíduo in natura e após hidrotermólise) a fim de caracterizar e comparar sua comunidade microbiana. 
As amostras de reatores aplicados à matriz de Plackett \& Burman nas condições nas quais houve maior concentração de $\mathrm{H}_{2}$ (R5 e R12) também foram análisadas via técnica de sequenciamento massivo do gene 16S RNAr (metabarcoding) via Plataforma Illumina, bem como do reator aplicado à obtenção de metano a partir do efluente acidificado dos ensaios otimizados. As colônias isoladas a partir da autofermentação do resíduo de citros in natura foram identificadas a partir do sequenciamento do gene RNAr16S via técnica de Sanger.

Por fim, tanto o inóculo alóctone (lodo UASB) quanto a biomassa do reator de validação das condições otimizadas via DCCR foram analisadas pela técnica de metagenômica shotgun via Plataforma Illumina, a fim de comparar sua comunidade microbiana e os genes que codificam enzimas relevantes para o processo.

\subsubsection{Extração do DNA e amplificação da região-alvo}

Após os ensaios cinéticos em batelada, as amostras para extração do DNA genômico foram coletadas após o término dos experimentos e mantidas sob refrigeração $\left(-20{ }^{\circ} \mathrm{C}\right)$. Aproximadamente $50 \mathrm{~mL}$ do produto final de cada um dos reatores foram coletados e transferidos para tubos Falcon e centrifugados a $9000 \mathrm{rpm}$ em microcentrifuga durante 5 minutos. O sobrenadante foi descartado e o pellet formado foi lavado em tampão fosfatosalino (PBS) $\left(\mathrm{NaCl} 8 \%, \mathrm{KCl} 0,2 \%, \mathrm{Na}_{2} \mathrm{HPO}_{4}\right.$ 1,44\%, $\mathrm{KH}_{2} \mathrm{PO}_{4}$ 0,24\%) (GREEN; SAMBROOK, 2012) e utilizado nas etapas posteriores. O DNA foi extraído utilizando o kit Powersoil DNA (Mobio, Solana Beach, CA, USA), seguindo as recomendações do fabricante.

A identificação das colônias celulolíticas e produtoras de hidrogênio isoladas do consórcio autofermentativo foi realizada via análise Amplicon 16S do DNA genômico, utilizando para extração do DNA genômico o kit Pure Link TM Microbiome DNA Purification Kit (Invitrogen) e para amplificação da região de RNAr correspondente ao gene $16 \mathrm{~S}$ os primers $27 \mathrm{~F}$ e $1492 \mathrm{R}$.

O material genético amplificado foi purificado utilizando o kit Wizard ${ }^{\circledR}$ Genomic DNA Purification (Promega), de acordo com as recomendações do fabricante. Os resultados foram observados em eletroforese em gel de agarose $(1 \% ; 80 \mathrm{~V} ; 1$ hora), sendo que o produto da amplificação foi observado por meio de comparações utilizando o Low 
DNA Mass Ladder (Thermo Fisher Scientific ${ }^{\circledR}$ ) e o DNA foi quantificado utilizando método espectrométrico (Nanodrop 2000).

\subsubsection{Eletroforese em Gel de Gradiente Desnaturante}

A região de RNAr do gene $16 \mathrm{~S}$ dos do Domínio Archaea e Bacteria foi amplificada em reação em cadeia da polímeras (PCR) com os iniciadores 1100FGC - 1400R e 968FGC1401R, respectivamente, de acordo com o descrito por Ahmad et al. (2020). Os resultados foram observados em eletroforese em gel de agarose $(1,2 \%)$ e o marcador usado foi o Low

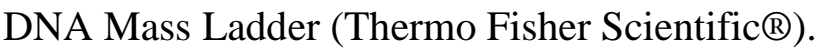

O produto da PCR foi separado por eletroforese em gel de poliacrilamida contendo gradiente desnaturante de $45 \%$ a $65 \%$ a temperatura constante de $60{ }^{\circ} \mathrm{C}$ e $75 \mathrm{~V}$ durante 16 h (MUYZER; WAAL; UITIERLINDEN, 1993). O DGGE (Eletroforese em Gel de Gradiente Desnaturante), foi realizado no DCode ${ }^{\mathrm{TM}}$ Universal Mutation Detection System (Bio-Rad).

Após a eletroforese, aplicou-se o corante brometo de etídeo no gel por um período de 15 minutos, para que as bandas fossem visualizadas em exposição UV (254 nm) e documentadas a partir do fotodocumentador L. PixTouch (Loccus Biotechnology) (AHMAD et al., 2020).

A similaridade entre as bandas foi calculada com o coeficiente de correlação de Pearson e apresentadas em dendograma, usando o software BioNumerics versão 7.3 (Applied Maths). Os índices de diversidade foram calculados utilizando o software Past versão 2.17c (HAMMER; HARPER; RYAN, 2001).

\subsubsection{Sequenciamento e bioinformática}

4.10.3.1 Bactérias anaeróbias celulolíticas

O sequenciamento das colônias celulolíticas e produtoras de hidrogênio isoladas do consórcio autofermentativo foi realizado pelo Centro de Genômica Funcional, do Departamento de Zootecnia da Escola Superior de Agricultura "Luiz de Queiroz" da Universidade de São Paulo campus Piracicaba (ESALQ/USP). As sequências obtidas foram analisadas e alinhadas com o software BioEdit e foram comparadas com sequências disponíveis em bancos de dados através da ferramenta BLAST (Basic Local Alignment Search Tool) do NCBI (National Center for Biotechnology Information).

As sequencias mais similares encontradas nesta base de dados (maior identidade, menor E-valor e maior cobertura) foram incluídas para fins comparativos na análise 
filogenética. A fim de aumentar a representatividade da análise filogenética, também foram incluídas sequências relacionadas em trabalhos similares, nos quais foram analisados consórcios autofermentativos de resíduos lignocelulósicos.

Para inferência das relações do dendrograma de distância genética, utilizou-se a abordagem de estimativa por máxima verossimilhança (ML), por meio do software MEGA versão 6 e com ramificações calculadas utilizando 1000 replicatas de bootstrap. O modelo de substituição foi escolhido via Critério de Informação Akaike (AIC), ainda via MEGA versão 6. O grupo externo foi escolhido de acordo com a similaridade com os gêneros obtidos. As sequencias obtidas foram submetidas ao banco de dados NCBI sob os números de acesso MH999447 (IS_1), MH999448 (IS_02) e MH999449 (IS_3).

\subsubsection{Metabarcoding}

As amostras de RNAr analisadas por sequenciamento massivo do gene $16 \mathrm{~S}$ das regiões V3 e V4 foram processadas na plataforma Illumina HiSeq PE250, com 2x250 pb ciclos, 100 reads e utilizando os primers universais para o domínio Bacteria 341F (5'CCTACGGGNGGCWGCAG -3`) e 806 R (5'- GGACTACNNGGGTATCTAAT-3`). As OTUs foram montadas com $97 \%$ de identidade e $80 \%$ de confiança na identificação dos táxons. As sequências referentes aos ensaios de screening design e potencial metanogênico foram submetidas ao banco de dados NCBI sob os números PRJNA526842 e PRJNA642905, respectivamente.

A inferência dos perfis funcionais nos ensaios de potencial metanogênico foi realizada por meio do pipeline Piphillin (http://secondgenome.com/Piphillin/) (IWAI et al., 2016) para a base de dados Kyoto Encyclopedia of Genes and Genomes (KEGG) de outubro de 2018, com identidade de 97\%. Esta ferramenta de inferência metagenômica é baseada no conteúdo funcional de genes de microrganismos com base em informações conhecidas do genoma dos organismos mais próximos taxonomicamente (IBEKWE et al., 2020).

Os $\mathrm{KO}$ de interesse foram filtrados por meio de comandos básicos da linguagem $\mathrm{R}$ (https://www.R-project.org/) e analisados por meio do pacote ggplot2 (WICKHAM, 2009). Os KO de interesse para a via metanogênica foram filtrados de acordo com Macedo et al. (2020). Os mapas metabólicos foram inferidos com base na ferramenta KEGG Mapper Reconstruct Pathway (KANEHISA; SATO; MORISHIMA, 2016). Os números EC (Enzyme Commission Numbers) referentes à cada $\mathrm{KO}$ foram analisados na plataforma The 
Comprehensive Enzyme Information System (BRENDA) (https://www.brendaenzymes.org/).

\subsubsection{Metagenômica shotgun}

A preparação da biblioteca e o sequenciamento metagenômico foram realizados pela empresa GenOne Biotechnologies (Rio de Janeiro, Brasil) em Plataforma Illumina HiSeq (2x150 pb), seguindo as diretrizes do fabricante. As sequências no formato FASTAQ obtidas após o sequenciamento via plataforma Illumina HiSeq foram processadas, de acordo com o esquema simplificado de pipeline na Figura 4.7. As sequências foram submetidas no banco de dados NCBI sob o número PRJNA605706.

Figura 4.7. Pipeline aplicado ao tratamento de sequências obtidas após o seqeenciamento shotgun via Plataforma Illumina HiSeq.

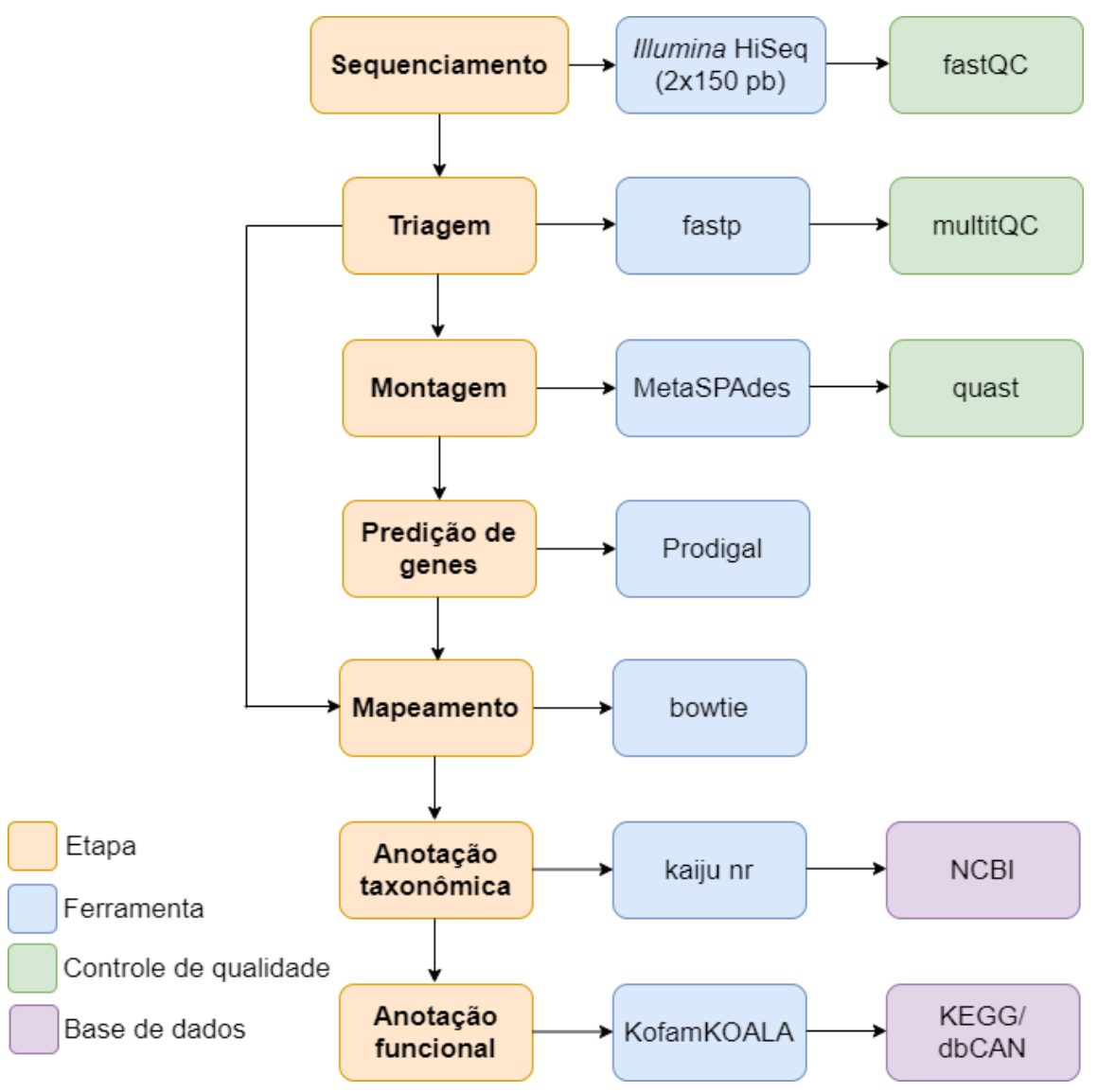

Fonte: Elaboração própria.

O controle de qualidade da sequência foi realizado por meio de análises em FastQC e MultiQC em relação aos seguintes parâmetros: qualidade da sequência por base, escores de qualidade da sequência, conteúdo da sequência base, conteúdo de GC por sequência, conteúdo $\mathrm{N}$ por base, distribuição de comprimento de sequência, nível de duplicação de 
sequência, sequências super-representadas e conteúdo do adaptador. Os parâmetros foram avaliados de acordo com Ewels et al. (2016).

As bases consideradas fora do padrão de qualidade mínimo foram filtradas via Fastp (CHEN et al., 2018), removendo as caudas de PoliG e PoliX nas extremidades de 3'. Após a triagem, as sequências curtas (reads) foram montadas em contigs através da montagem comparativa metaSPAdes (NURK et al., 2017), com reconstrução do genoma a partir dos dados obtidos e uma sequência comparativa específica. O controle de qualidade dos contigs foi realizado por meio do Quality Assessment Tool for Genome Assemblies (QUAST) em relação ao seu tamanho e porcentagem de GC, de acordo com Gurevich (2013).

A ferramentas bowtie (LANGMEAD, 2010) foi aplicada para mapeamento de genes. A anotação taxonômica foi realizada via kaiju nr (MENZEL; NG; KROGH, 2016) em comparação às sequências disponíveis no banco de dados NCBI. A anotação foi realizada com um ponto de corte $1 \mathrm{E}-5$ para o $E$-value e uma identidade $\geq 60 \%$.

A anotação funcional e metabólica foi realizada via GhostKOALA (KANEHISA; SATO; MORISHIMA, 2016) em comparação com Kyoto Encyclopedia of Genes and Genomes (KEGG), KEGG Orthology (KO) (KANEHISA, 2000) e Carbohydrate-Active Enzymes (CAZymes) (http://www.cazy.org/) via servidor HMMER. As vias metabólicas foram mapeadas pelo banco de dados KEGG, utilizando o pacote Pathview (LUO; BROUWER, 2013).

As análises de expressão gênica diferencial com base na distribuição binomial negativa foram realizadas usando o pacote DESeq2 (LOVE; HUBER; ANDERS, 2014), enquanto a visualização de dados foi realizada com o pacote ggplot2 (WICKHAM, 2009) e funções básicas R (https://www.R-project.org/).

\subsection{ANÁLISES ESTATÍSTICAS}

O teste de normalidade Shapiro-Wilk foi aplicado nos dados obtidos, a fim de verificar sua parametricidade, ou seja, se possuem distribuição normal $(p \geq 0,05)$ ou distribuição não normal ( $\mathrm{p} \leq 0,05)$, possibilitando assim a escolha dos testes estatísticos mais adequados a serem utilizados posteriormente.

Os dados de distribuição normal e de amostras não pareadas foram comparados por meio da Análise de Variância (ANOVA) e via Teste de Tukey ou Teste t-Student, avaliando-se desta forma sua relevância estatística, adotando-se um intervalo de confiança 
de $95 \%$, enquanto dados de distribuição não normal de amostras não pareadas foram comparados por meio do teste de Kruskal-Wallis para o mesmo intervalo de confiança. Os dados experimentais foram ajustados para valores médios obtidos de réplicas de reatores e interpretados usando o software PAST versão 2.17c (HAMMER; HARPER; RYAN, 2001).

\subsubsection{Ajuste dos dados experimentais}

Os dados experimentais foram ajustados para valores médios obtidos de réplicas (duplicatas ou triplicatas) dos ensaios em batelada realizados, sendo que os dados de concentração acumulada de hidrogênio foram obtidos a partir do modelo cinético sigmoidal de Gompertz modificado por Zwieterin et al. (1994), específico para a modelagem preditiva de crescimento microbiano, sendo que os parâmetros foram calculados por meio da Equação 4.8 no software OriginPro 9.0.

$$
Y(t)=P \cdot \exp \left\{-\exp \left(\frac{R m \cdot e}{P}[\lambda-t]+1\right)\right\}
$$

sendo,

$\mathrm{Y}(\mathrm{t})=$ razão logarítmica entre a concentração de $\mathrm{H}_{2}$ no tempo t e a concentração inicial, $R m=$ velocidade específica máxima de obtenção de $\mathrm{H}_{2}\left(\mu \mathrm{max} / \mathrm{mmol} \mathrm{H}_{2} \cdot \mathrm{h}^{-1}\right)$, $e=$ constante de Euler $(2,71828182)$ $\lambda$ = tempo de início da obtenção de $\mathrm{H}_{2}(\mathrm{~h})$, $P=$ potencial máximo de concentração de $\mathrm{H}_{2}\left(\mathrm{mmol} \mathrm{H}_{2} \cdot \mathrm{L}^{-1}\right)$. 


\section{RESULTADOS E DISCUSSÃO}

\subsection{CARACTERIZAÇÃO DO SUBSTRATO}

\subsubsection{Caracterização físico química}

Realizou-se a caracterização físico-química do resíduo de citros, após moagem, em relação a sólidos totais (ST), sólidos totais voláteis (STV), macronutrientes e micronutrientes (Tabela 5.1). Foram quantificados $\mathrm{Ca}, \mathrm{Cu}, \mathrm{Fe}, \mathrm{Mg}, \mathrm{Mn}, \mathrm{Ni}, \mathrm{K}, \mathrm{Na}, \mathrm{Zn}$, além nitrogênio total e fósforo total comparando-se composição similar aos resíduos de citros já relatados na literatura (MARTÍN et al., 2010; ANJUM et al., 2017).

Após a caracterização físico-química dos resíduos de citros, foi possível notar que as cascas possuem maior concentração de ST (300 g. $\left.\mathrm{kg}^{-1}\right)$ e STV (284,3 g.kg-1), nitrogênio $\left(8.200 \mathrm{mg} \cdot \mathrm{kg}^{-1}\right), \mathrm{Fe}\left(50,1 \mathrm{mg} \cdot \mathrm{kg}^{-1}\right), \mathrm{Mn}\left(9,97 \mathrm{mg} \cdot \mathrm{kg}^{-1}\right), \mathrm{K}\left(10.700 \mathrm{mg} \cdot \mathrm{kg}^{-1}\right)$ e $\mathrm{Na}(428$ mg. $\left.\mathrm{kg}^{-1}\right)$ quando comparadas ao bagaço, no qual foram observados valores inferiores para ST (121,5 g.kg $\left.{ }^{-1}\right)$ STV (117,9 g.kg $\left.{ }^{-1}\right)$, nitrogênio (5.810 mg. $\left.\mathrm{kg}^{-1}\right), \mathrm{Fe}\left(42,9 \mathrm{mg} \cdot \mathrm{kg}^{-1}\right), \mathrm{Mn}$ (8,99 mg. $\left.\mathrm{kg}^{-1}\right), \mathrm{K}\left(8.440 \mathrm{mg} \cdot \mathrm{kg}^{-1}\right)$ e $\mathrm{Na}\left(345 \mathrm{mg} \cdot \mathrm{kg}^{-1}\right)$. Em relação a fósforo, $\mathrm{Ca}, \mathrm{Cu}, \mathrm{Mg}$ e Zn observadas verificou-se valores maiores para bagaço, de 5.650, 99, 1.270 e 26,6 mg.kg-

1 , respectivamente, enquanto para a casca os valores obtidos foram de 4.930, 25,9, $977 \mathrm{e}$ 20,4 mg. $\mathrm{kg}^{-1}$, respectivamente.

Tabela 5.1. Caracterização físico-química dos resíduos de citros.

\begin{tabular}{ccc}
\hline Sólidos $\left(\mathbf{g}_{\mathbf{k g}} \mathbf{- 1}\right)$ & Cascas & Bagaço \\
\hline $\mathrm{ST}$ & 300,6 & 121,5 \\
$\mathrm{STV}$ & 284,3 & 117,9 \\
\hline \multicolumn{3}{c}{ Macro e micronutrientes $\left(\mathbf{m g . k \mathbf { k g } ^ { - 1 } )}\right.$} \\
\hline Nitrogênio Total & 8.200 & 5.810 \\
Fósforo Total & 847 & 917 \\
$\mathrm{Ca}$ & 4.930 & 5.650 \\
$\mathrm{Cu}$ & 25,9 & 99,0 \\
$\mathrm{Fe}$ & 50,1 & 42,9 \\
$\mathrm{Mg}$ & 977 & 1.270 \\
$\mathrm{Mn}$ & 9,97 & 8,99 \\
$\mathrm{Ni}$ & $\leq 1$ & $\leq 1$ \\
$\mathrm{~K}$ & 10.700 & 8.440 \\
$\mathrm{Na}$ & 428 & 345 \\
$\mathrm{Zn}$ & 20,4 & 26,6
\end{tabular}

Nota: $\mathrm{ST}=$ sólidos totais, $\overline{\mathrm{STV}}=$ sólidos totais voláteis, $\mathrm{Ca}=$ cálcio, $\mathrm{Cu}=$ cobre, $\mathrm{F} e=$ ferro, $\mathrm{Mg}=$ magnésio, $\mathrm{Mn}=$ manganês, $\mathrm{Ni}=$ níquel, $\mathrm{K}=$ potássio, $\mathrm{Na}=$ sódio, $\mathrm{Zn}=$ zinco. 
Tanto, nas cascas, quanto no bagaço de citros foi possível quantificar nitrogênio (8.200 e $5.810 \mathrm{mg} \cdot \mathrm{kg}^{-1}$, respectivamente) e fósforo (847 e $917 \mathrm{mg} \cdot \mathrm{kg}^{-1}$, respectivamente). Resíduos orgânicos com concentrações expressivas de $\mathrm{N}$ e $\mathrm{P}$, como observado para os resíduos de citros, não devem ser dispostos diretamente no solo, devido ao risco de agravamento de impactos ambientais, como eutrofização, ou inibição das populações microbianos do solo com prejuízo para a sua diversidade. Além disso, a incineração tampouco é recomendada, uma vez que não elimina os metais potencialmente tóxicos (CECILIA et al., 2019).

Sabe-se que diversos macro e micronutrientes observados nos resíduos sólidos de citros são de grande relevância para processos de digestão anaeróbia, como Fe (42,9-50,01 mg.kg-1 $), \mathrm{Cu}\left(25,9-99,0\right.$ mg.kg $\left.{ }^{-1}\right), \mathrm{Zn}\left(20,4-26,6\right.$ mg.kg $\left.{ }^{-1}\right), \mathrm{Mn}\left(8,99-9,97 \mathrm{mg} \cdot \mathrm{kg}^{-1}\right), \mathrm{Mg}$ (977-1.270 mg.kg-1 $), \mathrm{Ni}\left(\leq 1 \mathrm{mg} \cdot \mathrm{kg}^{-1}\right), \mathrm{Ca}\left(4.930-5.650\right.$ mg. $\left.\mathrm{kg}^{-1}\right)$ e K (8.840-10.700 mg.kg${ }^{1}$ ). Especificamente, o Fe é essencial para bactérias fermentativas produtoras de $\mathrm{H}_{2}$, que carecem deste elemento para atividade de suas enzimas que contém ferro ou enxofre (RUGGERI; TOMMASI; SANFILIPPO, 2015).

Entretanto, elevadas concentrações de Fe podem levar à inibição do processo fermentativo (FITZGERALD et al., 2019). A concentração de Fe nas cascas (50,01 mg.kg$\left.{ }^{1}\right)$ e no bagaço de citros $\left(42,9 \mathrm{mg} \cdot \mathrm{kg}^{-1}\right)$ foram consideradas abaixo do limite considerado inibitório para a produção biológica de $\mathrm{H}_{2}$ (LEE et al., 2009). Até o momento, não há relatos sobre o efeito da concentração de Fe em reatores anaeróbios contendo especificamente resíduos sólidos de citros como substrato. Lee et al. (2009) avaliaram os efeitos de íons metálicos na obtenção de $\mathrm{H}_{2}$ em reatores anaeróbios, utilizando glicose como fonte de carbono (16 g. $\left.\mathrm{L}^{-1}\right)$. Os autores mencionados observaram redução da atividade da hidrogenase e consequente redução da obtenção de $\mathrm{H}_{2}$ em concentrações de $\mathrm{Fe}$ acima de $125 \mathrm{mg} \cdot \mathrm{kg}^{-1}$.

Da mesma forma, $\mathrm{Na}\left(345-428 \mathrm{mg} \cdot \mathrm{kg}^{-1}\right)$ e $\mathrm{Ca}\left(4.930-5.650 \mathrm{mg} \cdot \mathrm{kg}^{-1}\right)$, apesar de associados à inibição do crescimento microbiano em processos fermentativos foram observados na presente pesquisa abaixo do limite inibitório indicado por Khanna et al. (2011) em 10 g.L $\mathrm{L}^{-1}$ de glicose, de $27.000 \mathrm{mg} \cdot \mathrm{kg}^{-1}$ para Na e $10.000 \mathrm{mg} \cdot \mathrm{kg}^{-1}$ para Ca.

\subsubsection{Exame Microscópico}

Por meio da análise de MEV do bagaço de citros (Figura 5.1 C-F), foi possível notar diferença estrutural quando comparado às cascas, uma vez que este resíduo possui superfície mais fibrosa em relação às cascas, onde foi possível observar superfície mais 
regular (Figura 5.1 A-B), bem como diferença na presença de microrganismos aderidos a sua superfície e reentrâncias, com destaque para a presença de bacilos e cocos, provavelmente de microrganismos autóctones do bagaço. Em relação às cascas, não foram observadas estruturas semelhantes a células microbianas em sua superfície.

Figura 5.1. Características micromorfológicas das cascas (A-B) e bagaço (C-F) de citros em Microscopia Eletrônica de Varredura (MEV). As setas brancas indicam a presença de estruturas semelhantes a bactérias/bacilos aderidas à superfície do material.

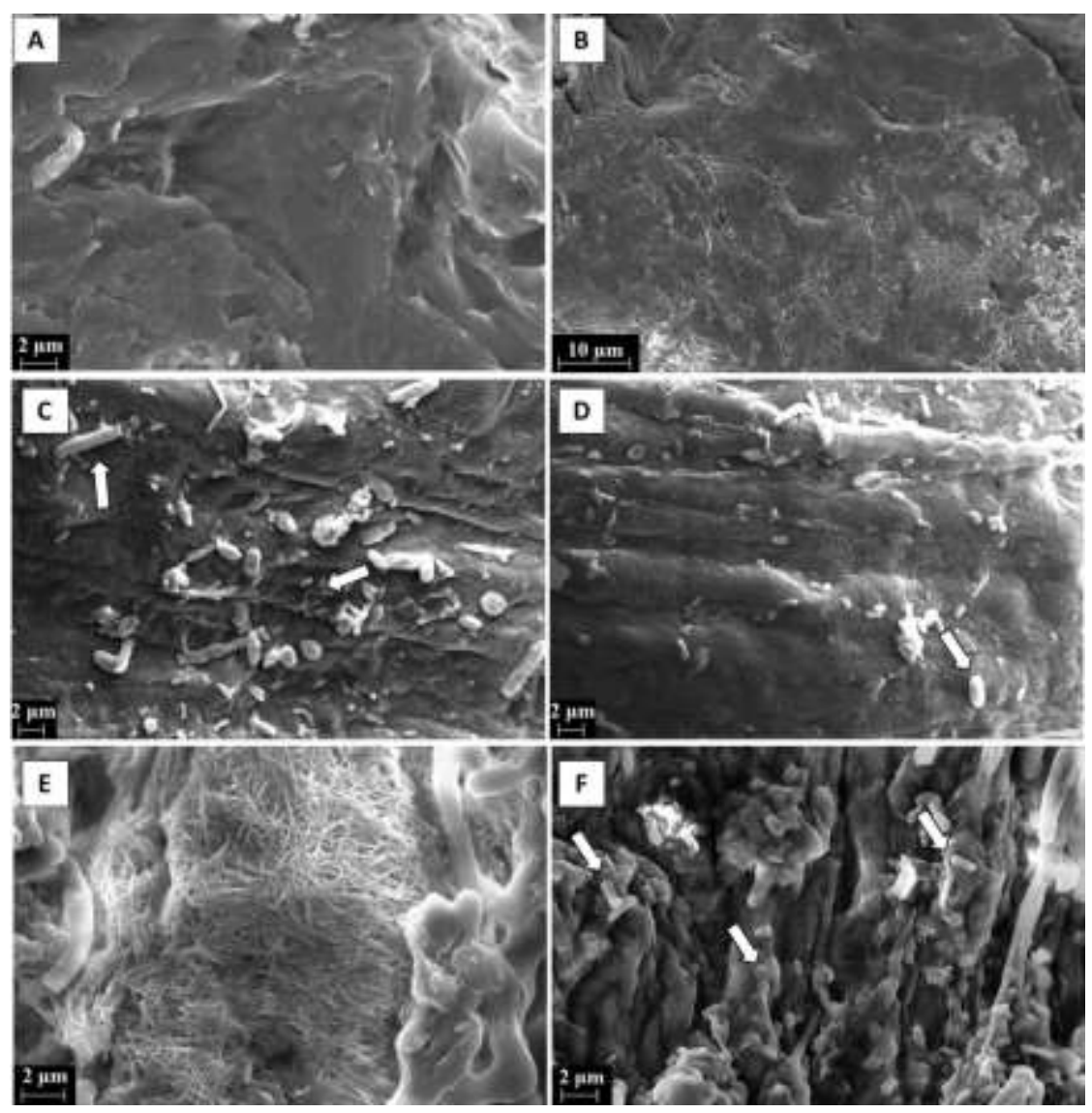

5.1.3 Espectroscopia de Infravermelho com Transformada de

\section{Fourier}

Os espectros de FT-IR das cascas e bagaço de laranja in natura (Figura 5.2) foram obtidos a fim de observar possíveis diferenças em sua composição e estrutura, para que posteriormente pudessem ser comparados aos espectros dos resíduos após os prétratamentos adotados, indicando possíveis alterações destas matrizes, especialmente em picos de grupos funcionais característicos para presença de celulose, hemicelulose e 
lignina. Utilizou-se como base comparativa o espectro referente à estrutura da pectina de citros. Os resultados são apresentados na frequência de 4.000 a $400 \mathrm{~cm}^{-1}$.

Figura 5.2. Espectrograma vibracional na região do infravermelho (FT-IR) dos resíduos de citros (cascas e bagaço in natura) (A) utilizados na presente pesquisa e espectro comparativo de pectina de citros (B).
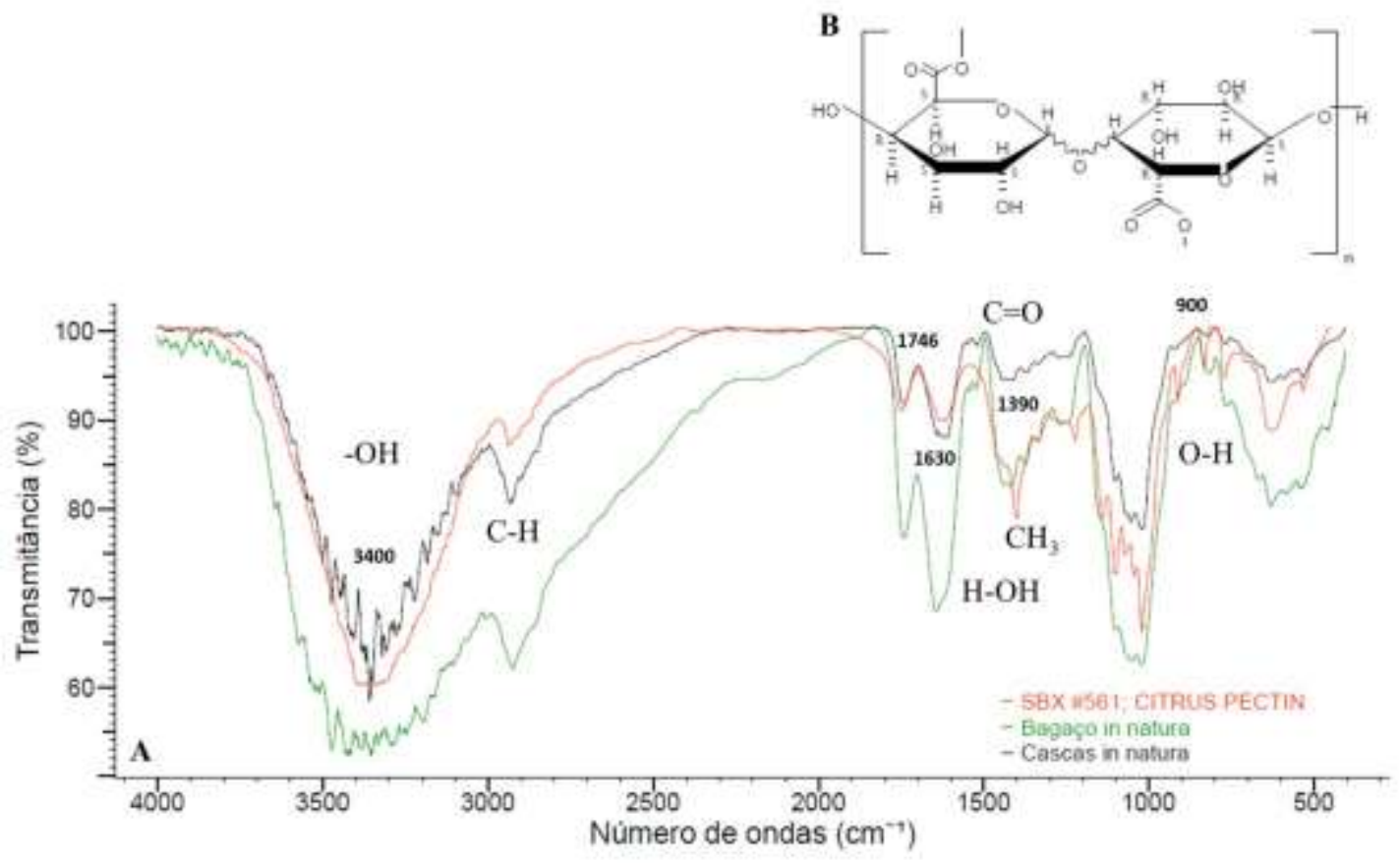

Em relação a região entre $3.800 \mathrm{~cm}^{-1}$ e $2.800 \mathrm{~cm}^{-1}$ foi verificada duas bandas principais, sendo que a primeira zona de absorção forte e larga em aproximadamente 3.400 $\mathrm{cm}^{-1}$, representa o alongamento de grupos $-\mathrm{OH}$ devido a ligações de hidrogênio inter e intramoleculares, e a faixa de $2.900 \mathrm{~cm}^{-1}$ representa o alongamento $\mathrm{C}-\mathrm{H}$, sendo $\mathrm{CH}, \mathrm{CH}_{2} \mathrm{e}$ $\mathrm{CH}_{3}$. Esta região é comumente associada às vibrações de deformação axial nos átomos de hidrogênio ligados a carbono, oxigênio e nitrogênio (C-H, O-H e N-H).

Picos entre 2.848 a $2.912 \mathrm{~cm}^{-1}$ em resíduos alimentares estão relacionadas as vibrações de estiramento assimétricas e simétricas de $\mathrm{CH}_{2}$ e $\mathrm{CH}_{3}$ de óleos vegetais, ácidos graxos, ésteres, aldeídos de alto peso molecular e cetonas. Também é possível notar picos característicos relacionados a lignina, uma vez que sua resolução é na faixa de 1.510 a 1.650 $\mathrm{cm}^{-1}$ (NANDA et al., 2016). Bandas na região entre 2.300-1.900 $\mathrm{cm}^{-1}$ não foram observadas, sendo típicas de vibrações de deformação axial de triplas ligações e duplas acumuladas.

A absorção entre 1.500 a $600 \mathrm{~cm}^{-1}$ é associada a diversos tipos de vibração, como deformações axiais e angulares de ligações $\mathrm{C}-\mathrm{O}, \mathrm{C}-\mathrm{N}, \mathrm{C}-\mathrm{C}$ e $\mathrm{C}-\mathrm{X}$. A presença de hemicelulose, no espectro correspondente às cascas e bagaço, pode ser notada a 
aproximadamente $1.700 \mathrm{~cm}^{-1}$. Os picos na faixa entre 900 e $1.200 \mathrm{~cm}^{-1}$ são relacionados a ocorrência de álcoois (O-H), ácido carboxílico, ésteres e éteres em resíduos de alimentos. Picos entre 800 e $900 \mathrm{~cm}^{-1}$ sugerem a presença de ligações $\mathrm{C}-\mathrm{H}$ aromáticas e os picos em aproximadamente $700 \mathrm{~cm}^{-1}$, de C-H alcanos (NANDA et al., 2016).

Em $1.718 \mathrm{~cm}^{-1}$ notou-se uma banda que pode ser atribuída às cetonas não conjugadas de carbonilas $(\mathrm{C}=\mathrm{O})$, que são frequentes e importantes grupos funcionais das cadeias laterais da estrutura da lignina. A faixa que compreende o pico em aproximadamente $1.350 \mathrm{~cm}^{-1}$ é atribuída ao alongamento com fenol hidroxila. As deformações em aproximadamente $1.630 \mathrm{~cm}^{-1}$ são associadas à absorção de água $(\mathrm{H}-\mathrm{OH})$ na amostra estudada. Por fim, a presença de bandas próximas a $1.320 \mathrm{~cm}^{-1}$ pode ser atribuída as vibrações de $\mathrm{CH}_{2}$ de celulose e hemicelulose, enquanto em $1.160 \mathrm{~cm}^{-1}$ é representativa para os grupos $\mathrm{C}-\mathrm{O}-\mathrm{C}$, presentes na celulose e hemicelulose. Picos na região entre 1.200 e $900 \mathrm{~cm}^{-1}$ são característicos de glicose, frutose e sacarose (ABID et al., 2017). Bandas similares foram encontradas em espectros de citros analisados em Abid, Cheikhrouhou, et al. (2017), He, Pang, et al. (2008) e Nanda, Isen, et al. (2016).

\subsection{OBTENÇÃO DE INÓCULO}

\subsubsection{Inóculo autóctone}

As cascas e bagaço de laranja (separadamente e em conjunto) foram utilizados como fonte de microrganismos fermentativos e potencialmente celulolíticos, autóctones dos resíduos de citros, por meio de ensaios de autofermentação e aumento da biomassa. Os ensaios foram realizados em temperatura mesofílica $\left(37^{\circ} \mathrm{C}\right) \mathrm{em} \mathrm{pH}$ do meio de cultivo (meio PCS) ajustado para 7,0.

Após a obtenção das curvas de concentração de hidrogênio, foi possível comparar com base nos parâmetros do modelo de Gompertz modificado (Tabela 5.2), as combinações de inóculo para os quais obtiveram-se os melhores resultados. A maior concentração de hidrogênio $(P)$ de $7,78 \mathrm{mmol} \mathrm{H}_{2} \cdot \mathrm{L}^{-1}$ foi obtida no ensaio contendo a mistura de cascas e bagaço de citros in natura. 
Tabela 5.2. Parâmetros de Gompertz dos ensaios de autofermentação dos resíduos de citros in natura para obtenção de $\mathrm{H}_{2}$ a partir de casacas e bagaço de citros.

\begin{tabular}{cccc}
\hline \multirow{2}{*}{ Parâmetro } & \multicolumn{3}{c}{ Substrato } \\
\cline { 2 - 4 } & Cascas & Bagaço & Cascas + Bagaço \\
\hline$P\left(\mathrm{mmol} \mathrm{H}_{2} \mathrm{~L}^{-1}\right)$ & 7,05 & 6,70 & 7,78 \\
$R m\left(\mathrm{mmol} \mathrm{H}_{2} \mathrm{~h}^{-1}\right)$ & 0,23 & 0,68 & 0,58 \\
$\lambda(\mathrm{h})$ & 4,75 & 9,13 & 8,08 \\
$\mathrm{R}^{2}$ & 0,97 & 0,98 & 0,95 \\
\hline
\end{tabular}

Nota: Potencial máximo de concentração de $\mathrm{H}_{2}(P)$, velocidade específica máxima de obtenção de $\mathrm{H}_{2}(R m)$, tempo de início da obtenção de $\mathrm{H}_{2}(\lambda)$ e $\mathrm{R}^{2}$ obtidos da equação de Gompertz modificada.

Aplicou-se o Teste de Tukey com intervalo de confiança de $95 \%$ a fim de avaliar a obtenção de $\mathrm{H}_{2}$ nos ensaios autofermentativos contendo cascas, bagaço e cascas e bagaço em conjunto. Considerou-se que a diferença da concentração de $\mathrm{H}_{2}$ observada não foi significativa ( $p \geq 0,05)$. Assim sendo, optou-se por utilizar a mistura entre cascas e bagaço de citros como fonte de microrganismos, uma vez que neste ensaio verificou-se maior concentração média de hidrogênio $\left(7,78 \mathrm{mmol} \mathrm{H} 2 \cdot \mathrm{L}^{-1}\right)$.

Em relação aos AOV e álcoois obtidos após a fermentação (Figura 5.3), verificouse predominância de HAc (80,27 mg.L $\left.\mathrm{L}^{-1}\right)$ e HLac $\left(39 \mathrm{mg} . \mathrm{L}^{-1}\right)$ no início dos ensaios, sendo que após a fermentação $(24 \mathrm{~h})$ verificou-se aumento do HLac para $61,1 \mathrm{mg} . \mathrm{L}^{-1}$, e diminuição da concentração de HAc para 68,22 mg.L $\mathrm{L}^{-1}$. Além disso, verificou-se HBu $(22,1$ mg. $\left.\mathrm{L}^{-1}\right)$ e EtOH (15,65 mg. $\left.\mathrm{L}^{-1}\right)$. Por meio da autofermentação de resíduos de banana em reatores em batelada ( $\mathrm{pH} \mathrm{7,5} \mathrm{e} 44^{\circ} \mathrm{C}$ ), Mazareli et al. (2020) obtiveram compostos similares aos do presente estudo a partir da autofermentação de resíduos de citros, sendo HAc (20720 mg.L $\left.{ }^{-1}\right), \mathrm{HBu}\left(30-2.660 \mathrm{mg} . \mathrm{L}^{-1}\right)$, HLac (260-5.140 mg.L $\left.{ }^{-1}\right)$ e EtOH (80-640 mg.L $\left.{ }^{-1}\right)$. A maior concentração destes compostos orgânicos a partir dos resíduos de banana provavelmente ocorreu devido à maior disponibilidade de carboidratos solúveis neste resíduo (15 g.L $\left.\mathrm{L}^{-1}\right)$ em comparação aos resíduos sólidos de citros $\left(1,2\right.$ g.L $\left.\mathrm{L}^{-1}\right)$. 
Figura 5.3. Ácidos orgânicos e etanol nos ensaios de autofermentação dos resíduos de citros in natura.

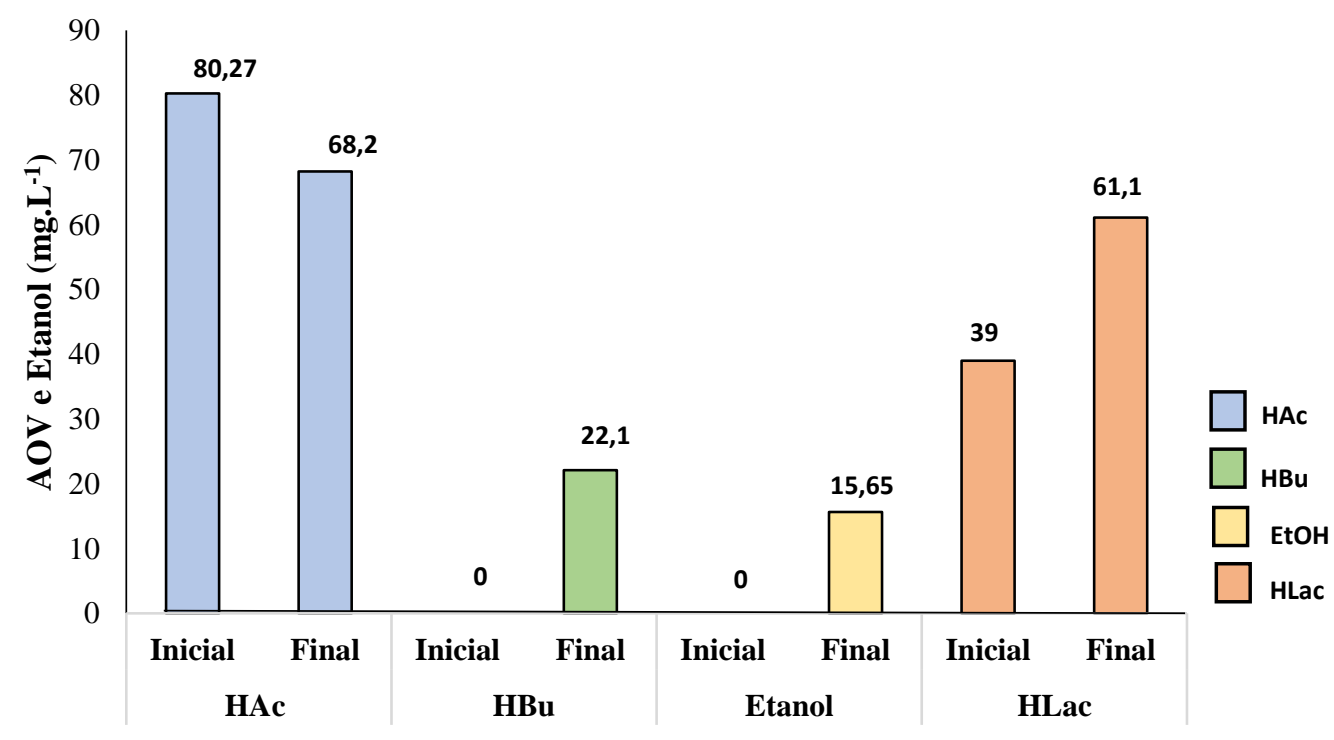

Por meio de exames microscópicos foi possível observar a prevalência de bactérias Gram-positivas, morfologicamente caracterizadas como bacilos, de aproximadamente 5x1 $\mu \mathrm{m}$, além de diversas estruturas similares a endósporos, endósporos ovais e terminais (Figura 5.4).

Apesar de não ser possível afirmar apenas por meio de observações morfológicas em microscopia óptica, sabe-se que bactérias do filo Firmicutes, especialmente do gênero Clostridium e Bacillus, são ubíquos e abundantes em condições de anaerobiose, além de serem formadores de endósporos (GALPERIN, 2013) e muitas vezes celulolíticos (WANG et al., 2011; GALPERIN, 2013), que podem ser encontrados comumente em matéria orgânica em decomposição (ZVERLOV; SCHWARZ, 2008), estando muitas vezes relacionados à produção de hidrogênio (LIN; SHEI, 2008). 
Figura 5.4. Características micromorfológicas do consórcio celulolítico autóctone das cascas e bagaço de laranja in natura em microscopia de contraste de fase. As setas apontam as estruturas similares a endósporos. Aumento total de 1.000X.

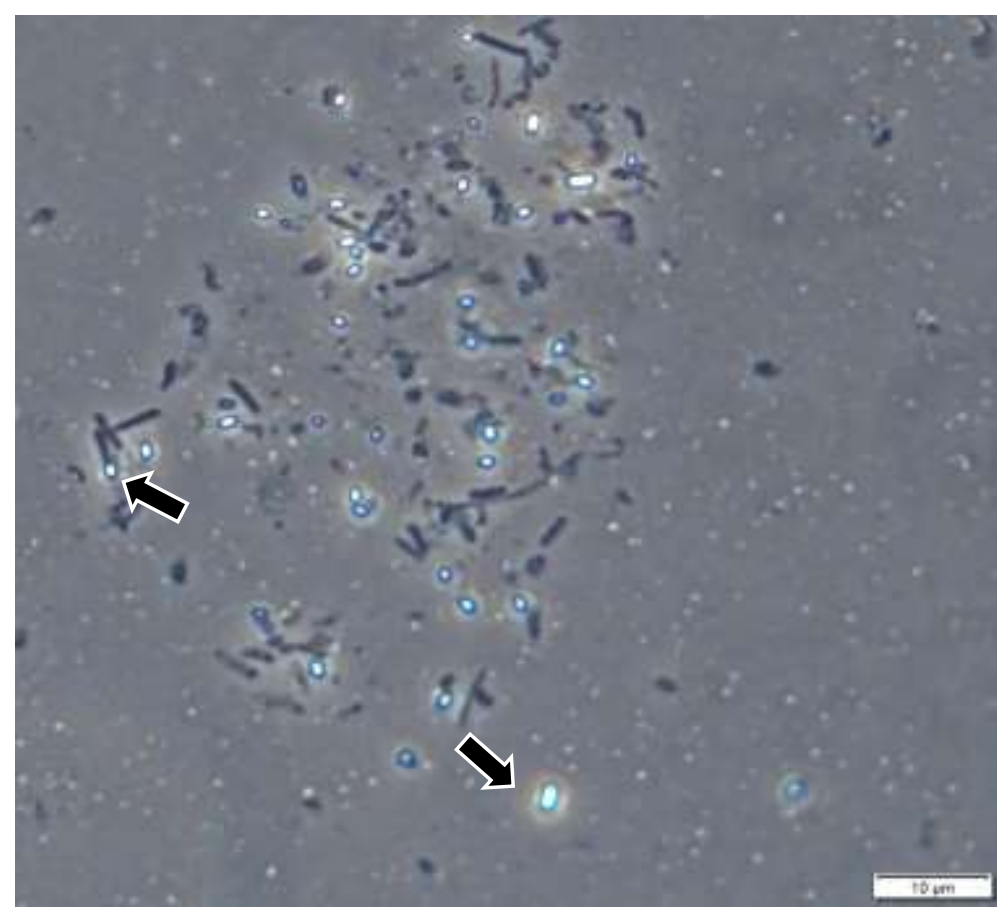

O consórcio autóctone obtido a partir da autofermentação dos resíduos de citros também foi caracterizado em relação à sua atividade celulolítica, por meio da análise gravimétrica da desintegração de fibra de papel filtro. Após período de 21 dias de incubação, estimou-se 13,44\% de desintegração da fibra de papel para os ensaios contendo o consórcio autofermentativo como inóculo e 3,5\% para os ensaios controle (sem inóculo).

Após a comparação de médias via Teste $t$-Student, considerou-se que a diferença obtida foi significativa $(\mathrm{p} \leq 0,05)$ para o intervalo de confiança adotado $(95 \%)$. Além disso, também se observou a mudança de coloração nas fibras de papel após o período de incubação (Figura 5.5), uma vez que as fibras dos ensaios controle mantiveram-se com a coloração original (brancas) e as fibras dos ensaios contendo o consórcio celulolítico tornaram-se amareladas. 
Figura 5.5. Fibras de papel após o período de incubação. Ensaio controle (A) e ensaio contendo consórcio celulolítico isolado de resíduo de citros in natura (B).
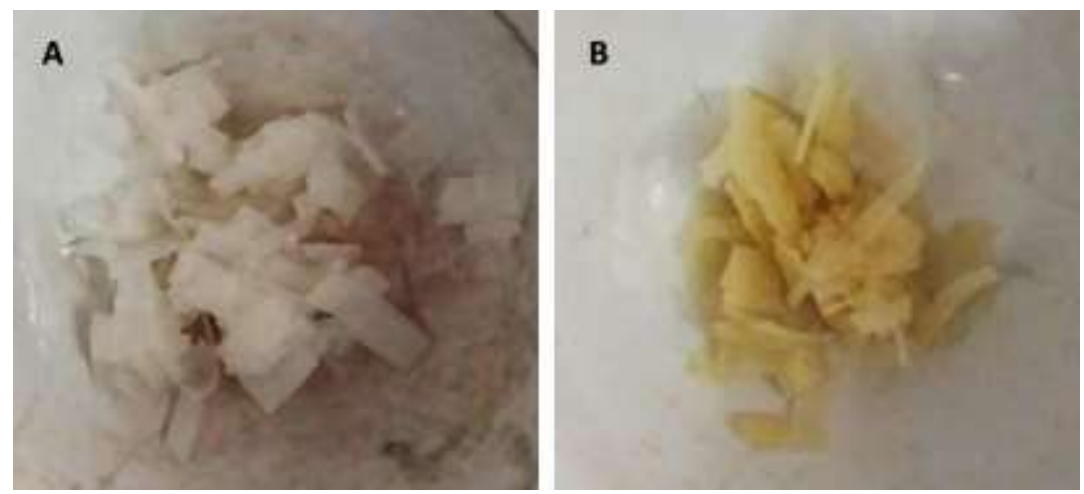

A partir dos resultados obtidos nesta etapa optou-se por utilizar o consórcio obtido a partir da autofermentação dos resíduos de citros in natura como inóculo autóctone nos ensaios subsequentes, a fim de aumentar a densidade de bactérias potencialmente celulolíticas e adaptadas aos resíduos de citros no processo.

\subsubsection{Inóculo alóctone}

O objetivo desta etapa foi comparar dois diferentes consórcios microbianos alóctones, os lodos granulados de reator UASB aplicado ao tratamento mesofílico e termofílico de águas residuárias de abatedouro de aves e vinhaça de cana-de-açúcar, respectivamente. Além disso, também foram avaliadas diferentes faixas de temperatura de operação dos reatores em batelada, mesofílica $\left(37^{\circ} \mathrm{C}\right)$ e termofílica $\left(55^{\circ} \mathrm{C}\right)$, a fim de determinar as melhores condições de operação para os ensaios subsequentes.

Em todos os ensaios realizados com esses inóculos não foi verificado concentração significativa de metano, ou seja, os valores observados foram inferiores a 1,27 mmol (limite de quantificação de metano do método utilizado). Desta forma, optou-se por prosseguir os ensaios com o foco voltado para a obtenção de hidrogênio e demais produtos de interesse biotecnológico, como ácidos orgânicos e álcoois.

Estima-se que o consórcio ideal para degradação de celulose é quando se tem ampla diversidade de bactérias celulolíticas e não celulolíticas, assim como ocorre no ambiente. Recentemente, a estratégia de uso de inóculos autofermentativo aplicados a material celulósico/lignocelulósico, conciliado a consórcios alóctones a fim de potencializar a obtenção de biogás $\left(\mathrm{CH}_{4}\right.$ e/ou $\left.\mathrm{H}_{2}\right)$ vem sendo amplamente difundida (BRAGA et al., 2018; RABELO et al., 2018a; MAZARELI et al., 2020; SOARES et al., 2020; VILLA 
MONTOYA et al., 2020). Desta forma, optou-se por utilizar consórcio complexo, sendo uma mistura de bactérias autóctones/endógenas dos resíduos de citros, provavelmente, adaptadas a seus potenciais inibidores e capazes de utilizar este resíduo complexo como substrato, aliado ao consórcio alóctone, rico em bactérias fermentativas produtoras de biogás, como o lodo de reator UASB.

Após a obtenção das curvas de concentração de hidrogênio foi possível comparar com base nos parâmetros do modelo de Gompertz modificado (Tabela 5.3) as combinações de inóculo com melhores resultados, a fim de determinar qual o melhor consórcio microbiano alóctone para obtenção de hidrogênio.

Notou-se que $P$ e $R m$ foram maiores nos ensaios a $37{ }^{\circ} \mathrm{C}$, embora a maior concentração observada tenha sido obtida com o Lodo UASB/vinhaça (12,54 mmol H2.L$\left.{ }^{1}\right)$, bem como a maior velocidade $\left(2,64 \mathrm{mmol} \mathrm{H}_{2} \cdot \mathrm{h}^{-1}\right)$. A partir da comparação de médias realizada via Teste de Tukey foi possível afirmar que a diferença de resultados obtidos em diferentes temperaturas foi significativa ( $\mathrm{p} \leq 0,05)$, sendo assim, optou-se pelo Lodo UASB oriundo do UASB de tratamento de vinhaça de cana-de-açúcar para dar andamento aos ensaios de obtenção de hidrogênio nas etapas subsequentes.

Tabela 5.3. Parâmetros de Gompertz modificado dos reatores anaeróbios com inóculos de diferentes origens, aplicados à obtenção de $\mathrm{H}_{2}$ a partir de casacas e bagaço de citros.

\begin{tabular}{|c|c|c|c|c|c|c|}
\hline \multirow[b]{3}{*}{ Parâmetros } & \multicolumn{6}{|c|}{ Ensaios } \\
\hline & \multicolumn{3}{|c|}{$37^{\circ} \mathrm{C}$} & \multicolumn{3}{|c|}{$55^{\circ} \mathrm{C}$} \\
\hline & $\begin{array}{c}\text { Lodo } \\
\text { UASB/ } \\
\text { avícola }\end{array}$ & $\begin{array}{c}\text { Lodo } \\
\text { UASB/ } \\
\text { vinhaça }\end{array}$ & $\begin{array}{l}\text { Consórcio } \\
\text { autóctone }\end{array}$ & $\begin{array}{c}\text { Lodo } \\
\text { UASB/ } \\
\text { avícola }\end{array}$ & $\begin{array}{c}\text { Lodo } \\
\text { UASB/ } \\
\text { vinhaça }\end{array}$ & $\begin{array}{l}\text { Consórcio } \\
\text { autóctone }\end{array}$ \\
\hline$P\left(\mathrm{mmol} \mathrm{H}_{2} \cdot \mathrm{L}^{-1}\right)$ & 8,46 & 12,54 & 6,93 & 3,33 & 5,19 & 1,51 \\
\hline$R m\left(\mathrm{mmol} \mathrm{H}_{2} \cdot \mathrm{h}^{-1}\right)$ & 1,07 & 2,64 & 1,69 & 0,06 & 0,39 & 0,15 \\
\hline$\lambda(\mathrm{h})$ & 3,50 & 4,72 & 7,14 & 0,18 & 5,10 & 16,46 \\
\hline $\mathrm{R}^{2}$ & 0,99 & 0,98 & 0,94 & 0,89 & 0,84 & 0,95 \\
\hline
\end{tabular}

Nota: Potencial máximo de concentração de $\mathrm{H}_{2}(P$,$) , velocidade específica máxima de obtenção de \mathrm{H}_{2}(R m$,), tempo de início da obtenção de $\mathrm{H}_{2}(\lambda)$ e $\mathrm{R}^{2}$ obtidos da equação de Gompertz modificada.

Uma vez que a produção de metano não foi significativa, optou-se por não realizar nenhum tipo de pré-tratamento do inóculo, tendo em vista que esta etapa não apenas inibe a atividade metanogênica, mas também a atividade de bactérias celulolíticas-fermentativas e produtoras de hidrogênio (REN et al., 2008; RATTI et al., 2015).

Assim como neste estudo, Lazaro et al. (2014) também observaram maior concentração de hidrogênio em reatores em batelada contendo vinhaça de cana-de-açúcar 
como substrato e lodo de reator UASB como inóculo, na faixa mesofílica, quando comparado à faixa termofílica, obtendo 28,4 e $6,7 \mathrm{mmol} \mathrm{H}_{2} \cdot \mathrm{L}^{-1}$, respectivamente.

Verificou-se para o Lodo UASB/vinhaça maior $P\left(12,54 \mathrm{mmol} \mathrm{H}_{2} \cdot \mathrm{L}^{-1}\right)$ a partir do resíduo de citros em relação ao Lodo UASB/avícola $\left(8,46 \mathrm{mmol} \mathrm{H}_{2} \cdot \mathrm{L}^{-1}\right)$, ambos incubados à $37^{\circ} \mathrm{C}$. Harada et al. (1996) relataram que em comparação com lodos oriundos de tratamento mesofílico, os lodos termofílicos comumente contém maiores concentrações de compostos orgânicos tóxicos, o que pode justificar seu maior potencial de obtenção de biogás a partir de substratos como os resíduos de citros, uma vez que os microrganismos autóctones deste tipo de lodo estão mais adaptados a potenciais inibidores orgânicos. De acordo com Harada et al. (1996), a temperatura ótima para a atividade microbiana depende do substrato e dos produtos de interesse, justificando a melhor faixa de obtenção de biogás na faixa mesofílica $\left(37^{\circ} \mathrm{C}\right)$.

Na Tabela 5.4 estão incluídos os resultados referentes aos parâmetros físicoquímicos dos reatores incubados com o Lodo UASB/avícola, Lodo UASB/vinhaça e consórcio autofermentativo a $37{ }^{\circ} \mathrm{C}$ e $55^{\circ} \mathrm{C}$. A partir da comparação da variação inicial e final dos diferentes parâmetros, notou-se que não houve um padrão entre o aumento ou redução de sólidos, matéria orgânica, carboidratos totais e fenóis totais, uma vez que se obteve diferentes respostas para os diferentes ensaios.

Após comparação via Kruskal-Wallis, foi possível observar diferença significativa para a variação na concentração de ST e STV para todos os ensaios realizados na faixa de $37{ }^{\circ} \mathrm{C}$, sendo que houve redução dos ST e STV em todos os ensaios, exceto para o Lodo UASB/vinhaça, no qual foi observada maior concentração de $\mathrm{H}_{2}$.

As análises da variação de matéria orgânica, carboidratos e fenóis foram significativas $(p \geq 0,05)$ para todos os ensaios realizados. Em todos os ensaios a $37{ }^{\circ} \mathrm{C}$ verificou-se aumento da matéria orgânica, sendo que o maior aumento foi para o Lodo UASB/vinhaça, além de maior concentração de biogás. O aumento da matéria orgânica foi menor nos ensaios a $55{ }^{\circ} \mathrm{C}$. Nos ensaios com Lodo UASB/avícola e Lodo UASB/vinhaça à $55^{\circ} \mathrm{C}$ verificou-se redução da matéria orgânica $\left(10\right.$ para $6,8 \mathrm{mg} . \mathrm{L}^{-1}$ e de 7,2 para 5 g.L $\mathrm{L}^{-1}$, respectivamente). Apenas no ensaio com consórcio a $55{ }^{\circ} \mathrm{C}$ verificou-se aumento na concentração de carboidratos (de 2,7 para 3,2 g. $\mathrm{L}^{-1}$ ), enquanto, nos demais houve remoção, sendo que nos ensaios nos quais houve mais redução do teor de carboidratos (por faixa de temperatura), foi observada maior concentração de biogás, como no ensaio com Lodo 
UASB/vinhaça à $37^{\circ} \mathrm{C}$, no qual a concentração de carboidratos inicial foi reduzida de 1,0 g.L $\mathrm{L}^{-1}$ para 0,8 g.L $\mathrm{L}^{-1}$ ao final do período de incubação de $24 \mathrm{~h}$.

A oscilação no pH ocorreu devido a produção de ácidos orgânicos (Figura 5.6). O pH é uma das principais variáveis para a digestão anaeróbia, sendo que na faixa ácida $(\leq 4,5)$ pode inibir a atividade da enzima hidrogenase e consequentemente a produção de hidrogênio, favorecendo, além disso, a solvetogênese (SIVAGURUNATHAN et al., 2017b). Entre 4,5-6,0, a produção de HAc e HBu é favorecida, enquanto na neutralidade $(\geq 6,0)$ há maior produção de HPr e metano, e consumo de hidrogênio.

Por fim, notou-se que houve aumento na concentração de fenóis nos ensaios com consórcio autofermentativo a $37{ }^{\circ} \mathrm{C}\left(18,6\right.$ para $\left.19 \mathrm{mg} . \mathrm{L}^{-1}\right)$ e Lodo UASB/avícola a $55^{\circ} \mathrm{C}$ (18,1 para 19,3 mg. $\left.\mathrm{L}^{-1}\right)$. Nos ensaios com redução na concentração de fenóis (de 23,3 para 19,3 mg. $\mathrm{L}^{-1}$ ), como aquele a partir de Lodo UASB/vinhaça a $37{ }^{\circ} \mathrm{C}$ verificou-se melhor desempenho em relação à concentração de hidrogênio $\left(12,54 \mathrm{mmol} \mathrm{H}_{2} \cdot \mathrm{L}^{-1}\right)$.

Tabela 5.4. Parâmetros físico-químicos dos reatores anaeróbios com inóculos de diferentes origens.

\begin{tabular}{|c|c|c|c|c|c|c|}
\hline & \multicolumn{2}{|c|}{$\begin{array}{c}\text { Alóctone- } \\
\text { UASB/ } \\
\text { avícola }\end{array}$} & \multicolumn{2}{|c|}{$\begin{array}{c}\text { Alóctone- } \\
\text { UASB/ } \\
\text { vinhaça }\end{array}$} & \multicolumn{2}{|c|}{$\begin{array}{c}\text { Inóculo } \\
\text { autóctone }\end{array}$} \\
\hline & Inicial & Final & Inicial & Final & Inicial & Final \\
\hline Sólidos (mg.L-1) & \multicolumn{6}{|c|}{$37^{\circ} \mathbf{C}$} \\
\hline ST & 24,5 & 22,0 & 23,7 & 23,2 & 25,8 & 22,4 \\
\hline STV & 10,7 & 8,9 & 10,2 & 8,6 & 10,9 & 8,8 \\
\hline SS & 2,7 & 1,1 & 0,9 & 1,2 & 1,0 & 0,9 \\
\hline SSV & 2,1 & 1,3 & 0,6 & 0,9 & 0,6 & 0,8 \\
\hline DQOfiltrada $\left(\right.$ g. $\left.\mathbf{L}^{-1}\right)$ & 3,4 & 9,6 & 4,1 & 12,3 & 5,1 & 10,8 \\
\hline Carboidratos Totais (g.L $\left.L^{-1}\right)$ & 1,0 & 0,8 & 1,3 & 0,7 & 1,2 & 1,0 \\
\hline Fenóis Totais (mg.L-1) & 23,3 & 19,3 & 21,8 & 19,2 & 18,6 & 19,0 \\
\hline \multirow[t]{2}{*}{ pH } & 7,4 & 5,3 & 7,6 & 5,3 & 7,4 & 5,3 \\
\hline & \multicolumn{6}{|c|}{$55^{\circ} \mathrm{C}$} \\
\hline ST & 22,4 & 21,4 & 22,0 & 35,7 & 22,3 & 22,9 \\
\hline STV & 9,4 & 13,4 & 9,5 & 8,0 & 8,9 & 5,4 \\
\hline SS & 1,8 & 2,0 & 1,2 & 1,2 & 0,6 & 0,9 \\
\hline SSV & 1,2 & 1,3 & 0,8 & 1,0 & 0,4 & 0,4 \\
\hline DQO filtrada $\left._{(\text {g. }} \mathbf{L}^{-1}\right)$ & 10,0 & 6,8 & 7,2 & 5,0 & 2,5 & 5,1 \\
\hline Carboidratos Totais (g.L $\left.\mathrm{L}^{-1}\right)$ & 2,5 & 1,3 & 3,1 & 1,1 & 2,7 & 3,2 \\
\hline Fenóis Totais $\left(\mathrm{mg.L}^{-1}\right)$ & 18,1 & 19,3 & 19,2 & 17,6 & 19,0 & 18,6 \\
\hline pH & 7,8 & 7,0 & 7,6 & 7,5 & 7,7 & 5,0 \\
\hline
\end{tabular}

Notou-se relação entre a produção de ácidos orgânicos e/ou EtOH e valor de $P$ nos ensaios com inóculos de diferentes origens (Figura 5.6). A concentração de $\mathrm{H}_{2}$ foi diretamente proporcional à produção de HAc, ou seja, nos ensaios nos quais houve maior 
produção deste ácido (Lodo UASB/vinhaça- 3,35 g.L $\mathrm{L}^{-1}$ ), houve ainda maior concentração de hidrogênio (12,54 mmol H $\mathrm{H}_{2} \cdot \mathrm{L}^{-1}$ ), e nos ensaios com menor produção de HAc (Inóculo autóctone, 2,8 g. $\left.\mathrm{L}^{-1}\right)$, houve menor concentração de $\mathrm{H}_{2}\left(6,93 \mathrm{mmol} \mathrm{H}_{2} \cdot \mathrm{L}^{-1}\right)$.

Para todos os ensaios, além do HAc, verificou-se $\mathrm{HBu}$, HLac e EtOH, porém em menores proporções, após $24 \mathrm{~h}$ de incubação. Provavelmente, a via predominante foi a acetogênica, sendo o HAc o principal metabólito produzido durante a fermentação de bactérias do gênero Clostridium (VOS et al., 2009; GHIMIRE et al., 2015). Verificou-se produção de EtOH para os três inóculos analisados, sendo inversamente proporcional à concentração de $\mathrm{H}_{2}$; ou seja, nos ensaios com maior produção de EtOH (Inóculo autóctone, 0,64 g.. $\mathrm{L}^{-1}$ ) verificou-se menor concentração de $\mathrm{H}_{2}$.

A partir dos resultados obtidos nesta etapa, considerou-se que o lodo granular oriundo de reator UASB aplicado ao tratamento termofílico de vinhaça de cana-de-açúcar seria mais adequado como fonte de microrganismos para obtenção de $\mathrm{H}_{2}$ a partir de resíduo sólido de citros, tanto em condições mesofílicas quanto termofílicas. Sendo assim, optouse por utilizá-lo como inóculo alóctone nos ensaios subsequentes, junto ao inóculo autóctone previamente estabelecido no item 5.2.1. Desta forma, o lodo granular oriundo de reator UASB aplicado ao tratamento mesofílico de resíduos de avícola não foi utilizado nas demais etapas. 
Figura 5.6. Ácidos orgânicos é álcool no início e após $24 \mathrm{~h}$ dos ensaios em reator anaeróbio em batelada a $37{ }^{\circ} \mathrm{C}(\mathrm{A})$ e $55^{\circ} \mathrm{C}(\mathrm{B})$ com diferentes inóculos.
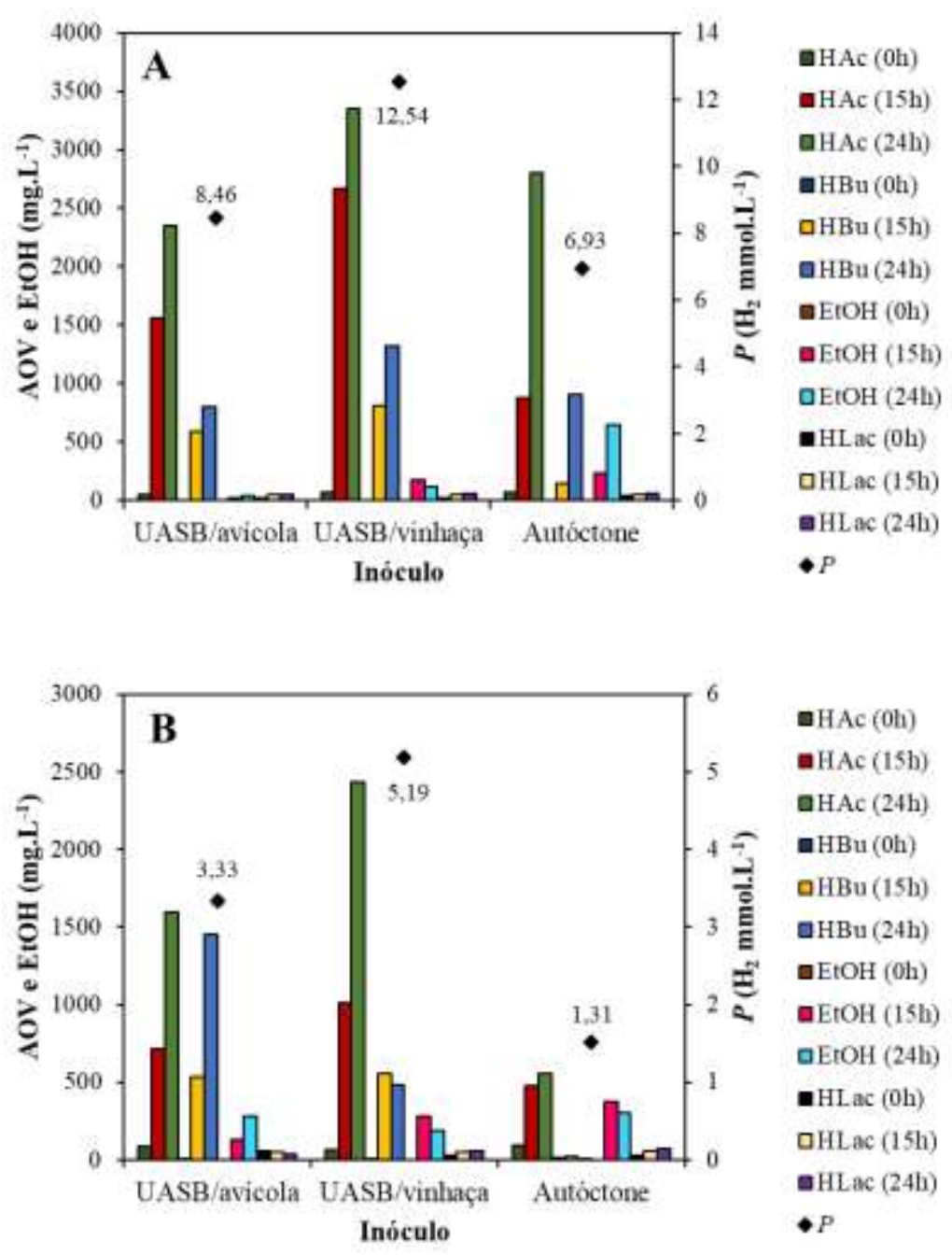

\subsection{PRÉ-TRATAMENTOS APLICADOS AO RESÍDUO SÓLIDO DE CITROS}

\subsubsection{Efeitos dos pré-tratamentos nas características físico-químicas e}

\section{morfológicas do substrato}

A partir da análise em MEV do bagaço de citros in natura (Figura 5.7 A-B) verificou-se diferenças estruturais entre a casca e bagaço. Para tanto, verificou-se superfície mais fibrosa no bagaço em relação às cascas, bem como diferenças em relação aos microrganismos aderidos à superfície do bagaço, com destaque para bacilos e endósporos autóctones desse resíduo.

$\mathrm{Na}$ análise comparativa entre as características morfológicas das cascas e bagaço após os pré-tratamentos por hidrotermólise (Figura 5.7 C-D) e deslignificação alcalina (Figura 5.7 E-F) verificou-se alteração na estrutura destes resíduos, sendo possível notar o 
aumento da fibrosidade das cascas e aplanamento do bagaço, após ambos os prétratamentos. Além disso, é possível inferir que houve eliminação dos microrganismos autóctones, uma vez que estruturas semelhantes à bactérias não foram observadas após os pré-tratamentos.

Figura 5.7. MEV da superfície do resíduo sólido de citros. Casca (A) e bagaço in natura (B), casca (C) e bagaço (D) após hidrotermólise e casca (E) e bagaço (F) após deslignificação alcalina. As setas indicam morfologias semelhantes a bactérias.

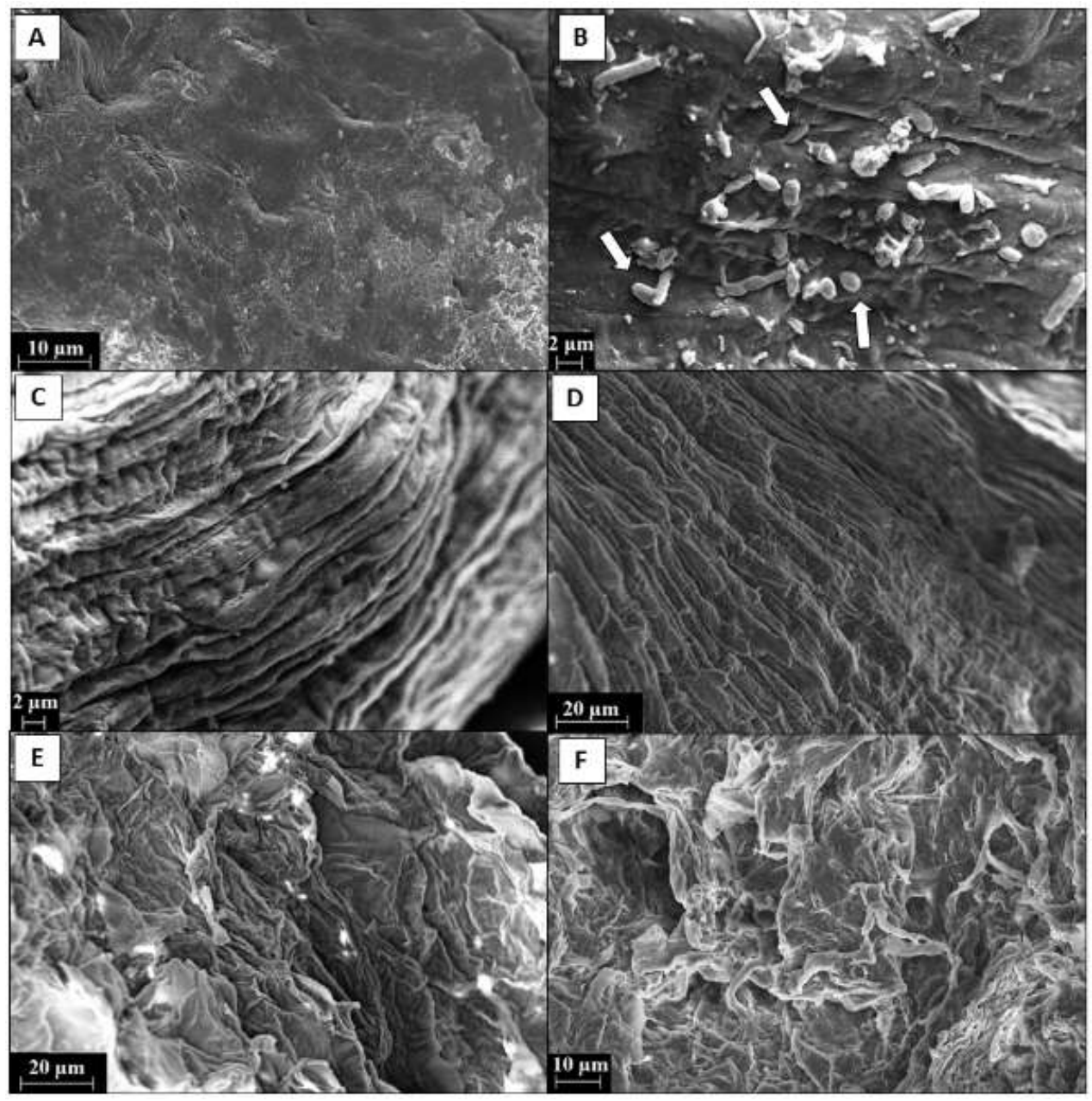

Após a aplicação da hidrotermólise e deslignificação alcalina foi possível observar mudança estrutural no resíduo sólido de citros por meio dos espectros de FT-IR, tanto nas cascas, quanto no bagaço, quando comparado aos espectros obtidos para este resíduo in natura. Após a hidrotermólise verificou-se diminuição na absorção na região entre 3.800 e $2.800 \mathrm{~cm}^{-1}$, além da região de $2.900 \mathrm{~cm}^{-1}$, provavelmente devido à redução dos grupos $\mathrm{OH}$, e do grupo $\mathrm{C}-\mathrm{H}$, respectivamente, com destaque para provável ruptura dos grupos metil e metileno da celulose da casca após este pré-tratamento. Em relação ao bagaço, não 
se verificou alterações na estrutura em relação à composição e intensidade dos grupos funcionais na análise comparativa desse material in natura e após ambos os pré-tratamentos avaliados (Figura 5.8).

Após a deslignificação alcalina foi possível notar modificações estruturais na zona de absorção entre 2.100 e $2.500 \mathrm{~cm}^{-1}$, com o surgimento de um pico de intensidade fraca, sendo que a absorção nesta região pode ser associada às vibrações de deformação axial de ligações duplas acumuladas (SILVERSTEIN; WEBSTER, 1981; HE et al., 2008). Além disso, também fica nítida a redução da absorção, tanto na região entre 3.800 e $2.800 \mathrm{~cm}^{-1}$, provavelmente devido à redução dos grupos $-\mathrm{OH}$ após o pré-tratamento, quanto na região em aproximadamente $2.900 \mathrm{~cm}^{-1}$, com redução do grupo $\mathrm{C}-\mathrm{H}$, e indicativo de ruptura dos grupos metil e metileno da celulose (HE et al., 2008).

He et al. (2008) observaram a redução de ligações de hidrogênio na estrutura da celulose, bem como a decomposição da cadeia lateral da lignina após deslignificação alcalina $(\mathrm{NaOH} 6 \%)$. Similarmente, no presente estudo, após o pré-tratamento de deslignificação alcalina, foi possível observar o desaparecimento de picos característicos de ligações $\mathrm{C}=\mathrm{O}$ de amidas na faixa de absorção entre $1.640-1.660 \mathrm{~cm}^{-1}$ para os espectros das cascas (Figura 5.8), indicando que em concentrações mais brandas de $\mathrm{NaOH}$, ainda ocorre remoção de lignina.

No presente estudo, a deslignificação alcalina foi conciliada ao uso de peróxido de hidrogênio (1\%), uma vez que este reagente é considerado efetivo na liberação de açúcares monoméricos e celulose de biomassa lignocelulósica, a partir da remoção da hemicelulose (MICHALSKA; LEDAKOWICZ, 2014). Ahmad et. al. (2020) modelaram a obtenção de $\mathrm{CH}_{4}$ em reatores em batelada a partir de bagaço de cana-de-açúcar pré-tratado via impregnação com $\mathrm{H}_{2} \mathrm{O}_{2}$ (2-6\%) seguida de hidrotermólise. Os autores observaram correlação positiva entre o aumento da concentração de $\mathrm{H}_{2} \mathrm{O}_{2}$ e a obtenção de $\mathrm{CH}_{4}$. Os autores concluíram que as condições ideais de pré-tratamento da biomassa lignocelulósica para uso como substrato para obtenção de $\mathrm{CH}_{4}$ foram com impregnação do resíduo sólido de citros com $\mathrm{H}_{2} \mathrm{O}_{2} 11 \%$ seguida de hidrotermólise a $138{ }^{\circ} \mathrm{C}, 14$ bar e 31,45 minutos. 
Figura 5.8. Espectrograma vibracional na região do infravermelho (FT-IR) do resíduo sólido de citros, cascas (A) e bagaço in natura (B), após hidrotermólise e deslignificação alcalina.

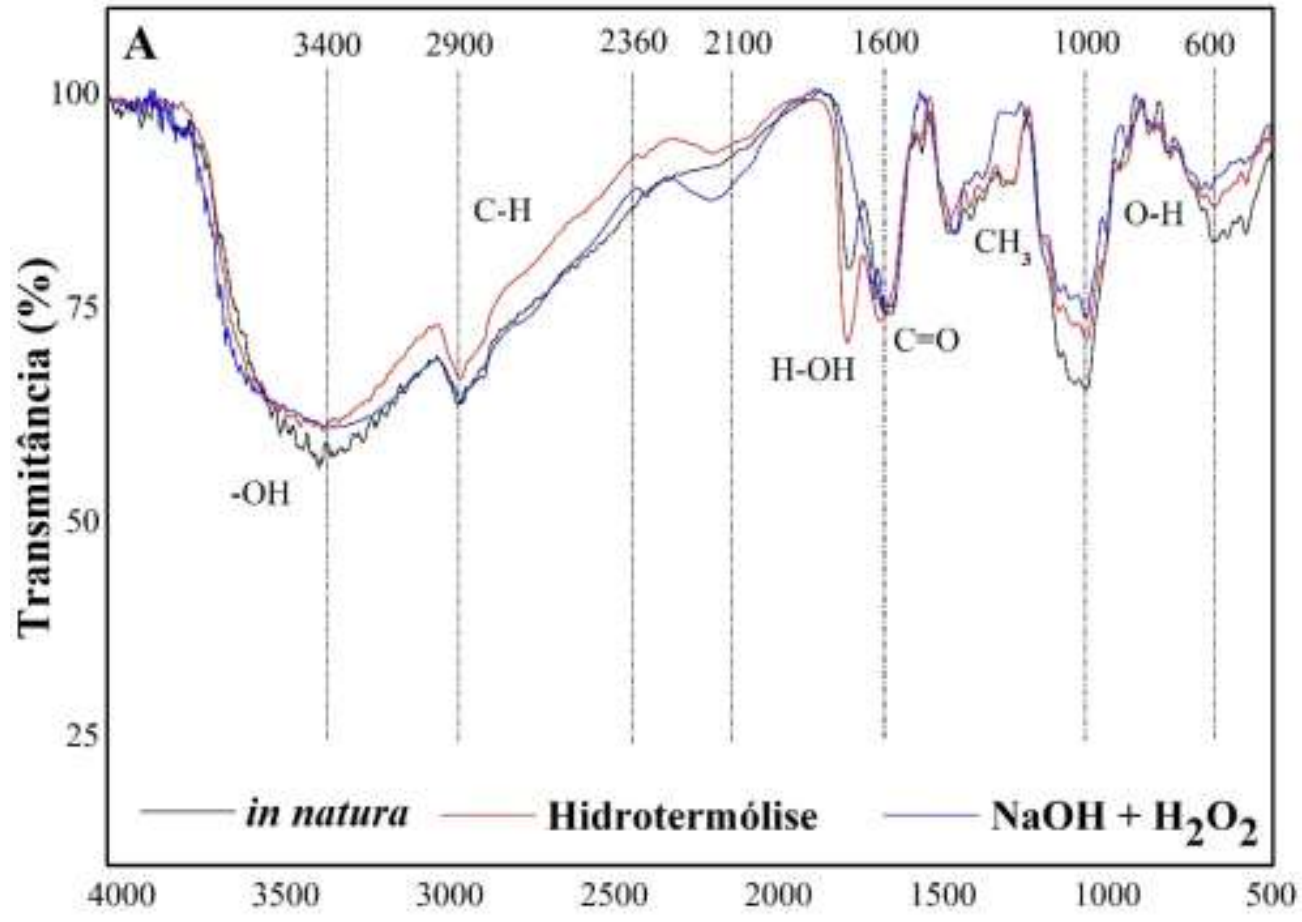

Número de ondas $\left(\mathrm{cm}^{-1}\right)$

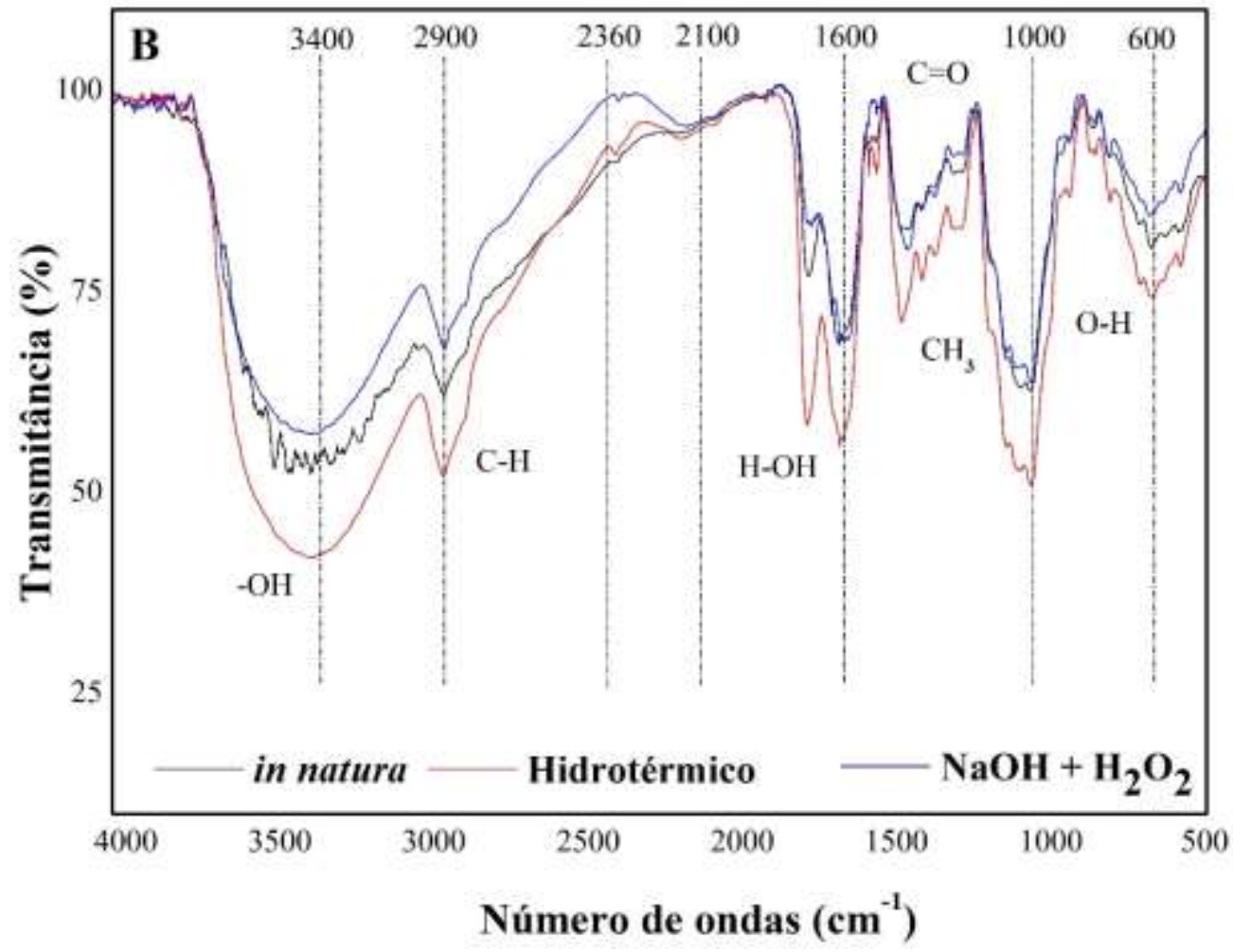


O percentual de lignina, teor de carboidratos totais e limoneno do resíduo sólido de citros (cascas e bagaço, separadamente) in natura e após os pré-tratamentos de hidrotermólise e deslignificação alcalina, estão apresentados na Figura 5.9.

Figura 5.9. Caracterização físico-química do resíduo sólido de citros (cascas e bagaço) antes e após diferentes pré-tratamentos.

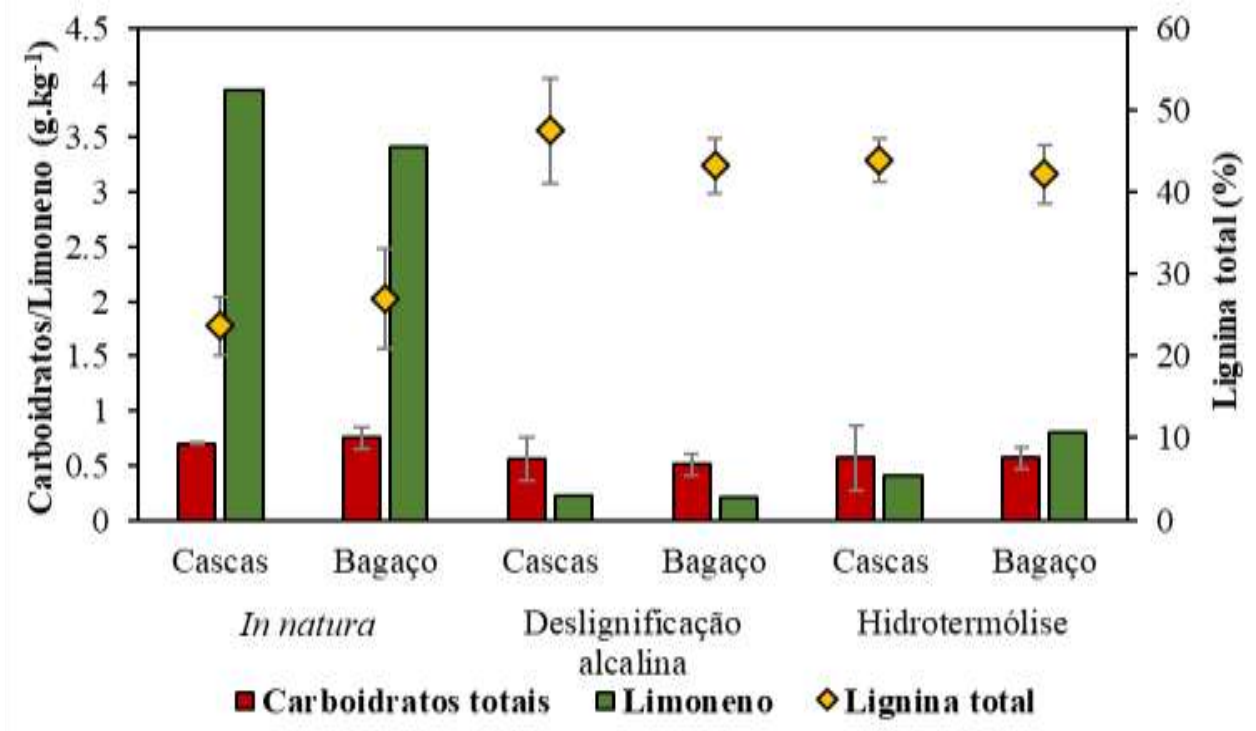

Foi possível observar menor teor de lignina no resíduo sólido de citros in natura (23,65 e $26,90 \%$ de ST para cascas e bagaço, respectivamente), quando comparado ao resíduo sólido de citros após hidrotermólise $(43,87 \%$ de ST para cascas e 42,17\% de ST para o bagaço) e deslignificação alcalina $(47,51 \%$ de ST para cascas e 43,20\% de ST para o bagaço). Com base nos resultados das análises por meio do teste de Kruskal-Wallis para 95\% de confiança, a diferença do teor de lignina entre o resíduo sólido de citros (cascas e bagaço) in natura e pré-tratados foi estatisticamente significativo $(\mathrm{p} \leq 0,05)$.

Em relação aos carboidratos totais quantificados para o resíduo sólido de citros, os valores foram similares entre as cascas e bagaços do resíduo sólido de citros in natura $(6,1$ e $\left.6,5 \mathrm{~g} \cdot \mathrm{kg}^{-1}\right)$, após hidrotermólise $\left(4,9\right.$ e $\left.4,9 \mathrm{~g} \cdot \mathrm{kg}^{-1}\right)$ e após deslignificação alcalina $(4,9$ e 4,4 $\left.\mathrm{g} \cdot \mathrm{kg}^{-1}\right)$. Entretanto, apenas a diferença entre o resíduo sólido de citros in natura (casca e bagaço) foi significativa quando comparada aos demais ensaios, isto é, $p \leq 0,05$. É possível inferir que devido a aplicação dos pré-tratamentos ocorreu redução do teor de carboidratos totais do resíduo sólido de citros, devido ao rompimento das fibras das cascas e bagaço e, ainda, à hidrólise dos monossacarídeos (glicose e xilose) no resíduo sólido de citros (WILKINS et al., 2007; CHOI et al., 2013, 2015). 
Por fim, em relação ao teor de limoneno do resíduo sólido de citros in natura, obtiveram-se os valores de 15,7 g. $\mathrm{kg}^{-1}$ para as cascas e 13,7 g.kg-1 para o bagaço. Após a aplicação dos pré-tratamentos, foi possível notar redução desta concentração, sendo 0,9 g. $\mathrm{kg}^{-1}$ para cascas e $0,8 \mathrm{~g} \cdot \mathrm{kg}^{-1}$ para o bagaço após a deslignificação alcalina, enquanto para o resíduo sólido de citros após hidrotermólise, foram obtidos 1,6 $\mathrm{g} \cdot \mathrm{kg}^{-1}$ para cascas e 3,2 para o bagaço.

A redução do teor de limoneno após a aplicação dos pré-tratamentos pode ser justificada devido ao caráter volátil deste composto (RUIZ; FLOTATS, 2014), ou, ainda, devido a sua transferência para a fração líquida após o pré-tratamento. Estudos anteriores indicam que a concentração inibitória mínima de limoneno é estimada em aproximadamente 0,2 mg. $\mathrm{kg}^{-1}$ de resíduo sólido de citros (CALABRÒ et al., 2016; RUIZ e FLOTATS, 2016).

\subsubsection{Efeitos dos pré-tratamentos na obtenção de $\mathrm{H}_{2} \mathrm{e} \mathrm{AOV}$}

Nos ensaios cinéticos em batelada contendo 15 g.L $\mathrm{L}^{-1}$ de resíduo sólido de citros (cascas + bagaço; 1:1), foi possível verificar a influência do substrato (in natura ou prétratado) na obtenção máxima de $\mathrm{H}_{2}(P)$, velocidade específica máxima $(R m)$ e tempo de início necessário para obtenção de $\mathrm{H}_{2}(\lambda)$ (Figura 5.10).

Foram observados maiores valores de $P\left(13,55 \mathrm{mmol} \mathrm{H}_{2} \cdot \mathrm{L}^{-1}\right), R m\left(3,11 \mathrm{mmol} \mathrm{H}_{2} \cdot \mathrm{h}^{-}\right.$ $\left.{ }^{1}\right)$ e $\lambda(4,85 \mathrm{~h})$ nos ensaios com resíduo sólido de citros in natura (Tabela 5.5). A partir das análises por meio do teste de Kruskal-Wallis para 95\% de confiança, foi possível inferir que a maior obtenção de $\mathrm{H}_{2}$ a partir do resíduo sólido de citros in natura foi significativa ( $p \leq 0,05)$ em comparação aos pré-tratados (hidrotermólise e deslignificação alcalina).

A partir dos parâmetros cinéticos obtidos nos ensaios com resíduo sólido de citros pré-tratado não se observou diferença significativa $(\mathrm{p} \geq 0,05)$ após hidrotermólise $\mathrm{e}$ deslignificação alcalina. Entretanto, com base nos valores médios observados, notou-se maior tempo de início necessário para obtenção de $\mathrm{H}_{2}$ no ensaio contendo resíduo sólido de citros após hidrotermólise (8,65 h), quando comparado ao resíduo sólido de citros após deslignificação alcalina (7,21 h). 
Figura 5.10. Concentração de $\mathrm{H}_{2}$ a partir do resíduo sólido de citros in natura (•), hidrotermólise (घ) e deslignificação alcalina ( $\boldsymbol{\Delta})$. Modelo de Gompertz modificado (----).

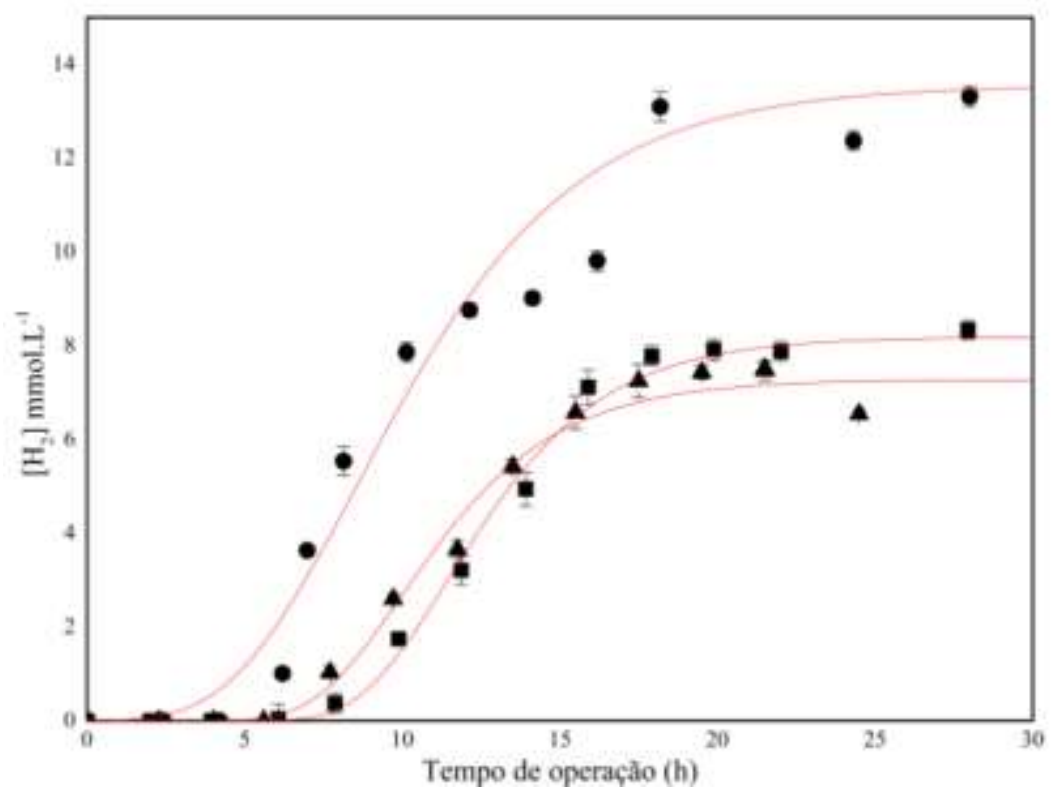

Tabela 5.5. Parâmetros de Gompertz modificado dos ensaios após diferentes pré-tratamentos do resíduo sólido de citros. Potencial máximo de concentração de $\mathrm{H}_{2}(P)$, velocidade específica máxima de obtenção de $\mathrm{H}_{2}(R m)$, tempo de início da obtenção de $\mathrm{H}_{2}(\lambda)$ e $\mathrm{R}^{2}$ obtidos da equação de Gompertz modificada.

\begin{tabular}{|c|c|c|c|}
\hline \multirow{2}{*}{ Parâmetros } & \multicolumn{3}{|c|}{ Substrato } \\
\hline & in natura & Deslignificação alcalina & Hidrotermólise \\
\hline$P\left(\mathrm{mmol} \mathrm{H}_{2} \cdot \mathrm{L}^{-1}\right)$ & 13,55 & 7,27 & 8,19 \\
\hline $\operatorname{Rm}\left(\mathrm{mmol} \mathrm{H}_{2} \cdot \mathrm{h}^{-1}\right)$ & 1,27 & 0,96 & 1,08 \\
\hline$\lambda(\mathrm{h})$ & 4,60 & 7,21 & 8,65 \\
\hline $\mathrm{R}^{2}$ & 0,94 & 0,98 & 0,99 \\
\hline
\end{tabular}

Nota: Potencial máximo de concentração de $\mathrm{H}_{2}(P)$, velocidade específica máxima de obtenção de $\mathrm{H}_{2}(R m)$, tempo de início da obtenção de $\mathrm{H}_{2}(\lambda)$ e $\mathrm{R}^{2}$ obtidos da equação de Gompertz modificada.

Apesar do maior $\lambda$, obtiveram-se no ensaio contendo resíduo sólido de citros após hidrotermólise valores superiores de $P\left(8,19 \mathrm{mmol} \mathrm{H} 2 . \mathrm{L}^{-1}\right)$ e $R m\left(1,08 \mathrm{mmol} \mathrm{H}_{2} \cdot \mathrm{h}^{-1}\right)$ em comparação com o resíduo sólido de citros após deslignificação alcalina. Nessa última condição, foram obtidos $P$ de 7,27 mmol $\mathrm{H}_{2} \cdot \mathrm{L}^{-1}$ e $R m$ de $0,96 \mathrm{mmol} \mathrm{H}_{2} \cdot \mathrm{h}^{-1}$. Provavelmente, ocorreu favorecimento da biodegradação deste substrato após hidrotermólise, entretanto, com aumento do tempo necessário de adaptação da biomassa antes do início da obtenção de $\mathrm{H}_{2}$, provavelmente em função da produção de inibidores após o rompimento das fibras do resíduo sólido de citros (QUÉMÉNEUR et al., 2012; CALABRÒ et al., 2016).

Soares et al. (2017) obtiveram resultados positivos para obtenção de $\mathrm{H}_{2}(17,7 \mathrm{mmol}$ $\left.\mathrm{H}_{2} \cdot \mathrm{L}^{-1}\right)$ a partir de bagaço de cana-de-açúcar pré-tratado via hidrotermólise em ensaios em batelada e em condições termofílicas $\left(60^{\circ} \mathrm{C}\right)$. Os autores conduziram o pré-tratamento a 
$200{ }^{\circ} \mathrm{C}$ e 16 bar por 10 minutos, em severidade de 3,94, relativamente próxima a aplicada no presente estudo $(3,53)$.

A maior severidade utilizada por Soares et al. (2017) pode ter contribuído para o rompimento das fibras do bagaço de cana-de-açúcar, aumentando sua biodegradabilidade, o que justifica a maior obtenção de $\mathrm{H}_{2}\left(17,7 \mathrm{mmol} \mathrm{H}\right.$. $\left.\mathrm{L}^{-1}\right)$ quando comparado ao presente estudo (8,19 mmol H$\left.\cdot \mathrm{L}^{-1}\right)$. De acordo com Ahmad et al. (2018), o aumento da severidade pode levar ao acúmulo de inibidores, como furfural e compostos fenólicos, tendo como consequência o aumento do tempo de adaptação da biomassa ao substrato (JACQUET et al., 2011; QUÉMÉNEUR et al., 2012; MONLAU et al., 2014).

Menor $P\left(7,27 \mathrm{mmol} \mathrm{H}_{2} \cdot \mathrm{L}^{-1}\right)$ foi obtido para resíduo pré-tratado por deslignificação alcalina. He et al. (2008) obtiveram aumento de até $64 \%$ da obtenção de biogás a partir de palha de arroz pré-tratada com $\mathrm{NaOH}(6 \%)$ como substrato, além de remoção de $28,4 \%$ de lignina, 36,8\% de hemicelulose e 16,4\% da celulose deste substrato. Chandra et al. (2012) compararam os efeitos da deslignificação alcalina conciliada à hidrotermólise a partir de palha de arroz em temperatura mesofílica $\left(37^{\circ} \mathrm{C}\right)$ na obtenção de metano. Os autores obtiveram 3,8 e 2,1 mmol CH $4 . \mathrm{L}^{-1}$ para os ensaios contendo o resíduo após deslignificação alcalina e hidrotermólise, respectivamente, comparados a $1,75 \mathrm{mmol} \mathrm{CH}_{4} \cdot \mathrm{L}^{-1}$ para o resíduo in natura.

Além dos parâmetros relacionados à obtenção de $\mathrm{H}_{2}$, verificou-se a produção de AOV e álcoois ao longo do período de incubação dos ensaios em batelada. A via acetogênica foi predominante, uma vez que o HAc foi o principal metabólito observado em resíduo sólido de citros in natura (4.355 mg.L $\left.\mathrm{L}^{-1}\right)$, pré-tratado por hidrotermólise $(2.375$ mg. $\left.\mathrm{L}^{-1}\right)$ e deslignificação alcalina (2.210 mg.L $\mathrm{L}^{-1}$ ) (Figura 5.11). HBu foi observado em todos os ensaios, sendo de $1.317 \mathrm{mg} . \mathrm{L}^{-1}$ resíduo de citros in natura, $1.329 \mathrm{mg} . \mathrm{L}^{-1}$ (hidrotermólise) e 1.219 mg.L $\mathrm{L}^{-1}$ (deslignificação alcalina). 
Figura 5.11. Ácidos orgânicos e etanol dos ensaios de diferentes pré-tratamentos. (A) ácido acético (HAc) e ácido butírico (HBu); (B) ácido lático (HLac) e etanol (EtOH).
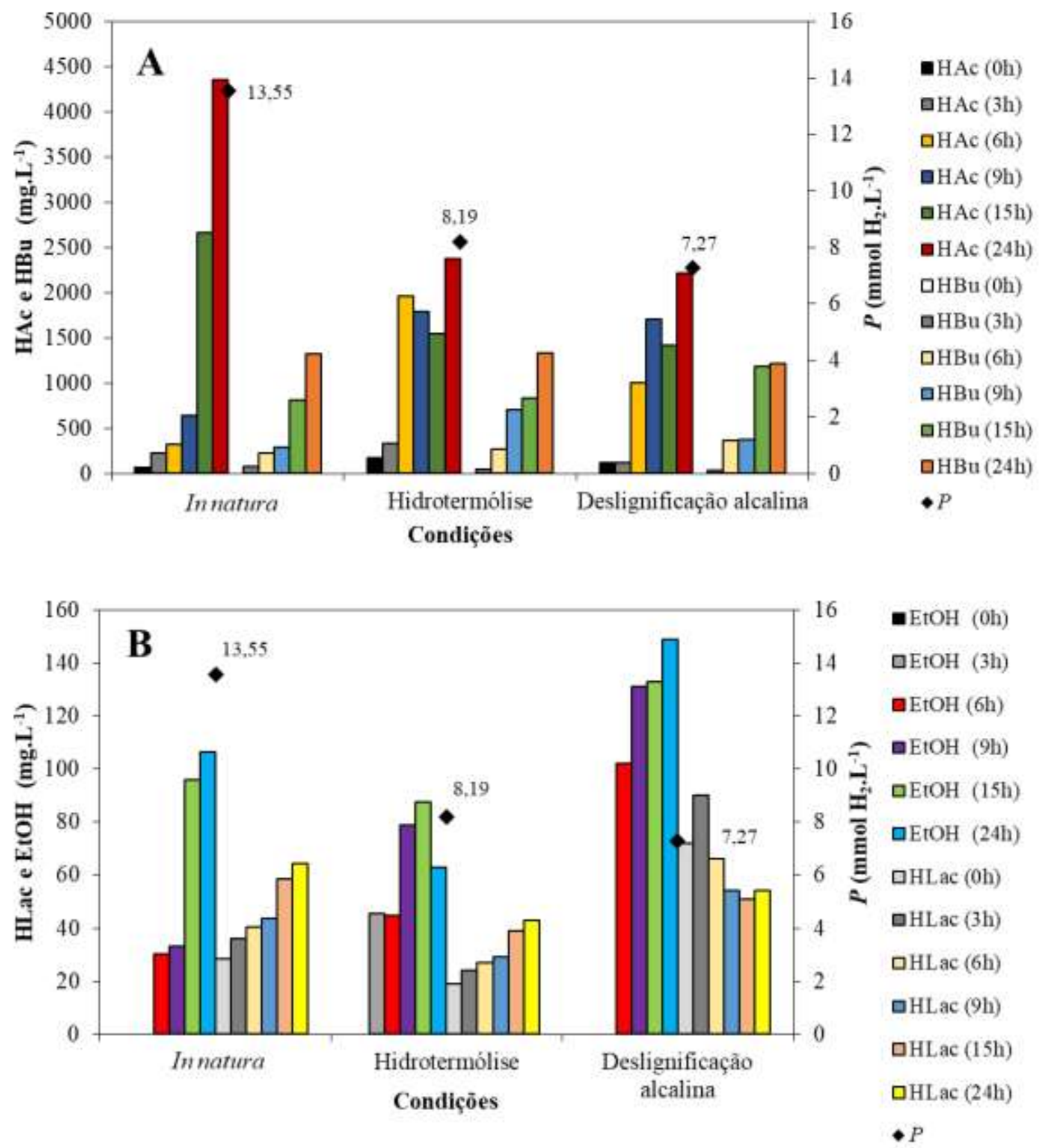

A partir da Figura 5.12, nota-se que houve consumo de carboidratos e acúmulo de fenóis significativas $(\mathrm{p} \leq 0,05)$ em todas as condições avaliadas (resíduo sólido de citros in natura ou pré-tratado). O maior consumo de carboidratos foi observado ao final do período de incubação do ensaio contendo resíduo de citros pré-tratado por deslignificação alcalina, de 0,26 g.L $\mathrm{L}^{-1}$ para $0,05 \mathrm{~g} . \mathrm{L}^{-1}$ ao final da incubação $(24 \mathrm{~h})$.

Em todos os ensaios houve acúmulo de fenóis, sendo que no ensaio contendo resíduo sólido de citros in natura verificou-se aumento da concentração de fenóis de 19,5 
para $23 \mathrm{mg} . \mathrm{L}^{-1}$, enquanto nos demais ensaios o aumento foi de 8,4 para $9,8 \mathrm{mg} . \mathrm{L}^{-1}$ após deslignificação alcalina e de 8,9 para 9,5 mg.L $\mathrm{L}^{-1}$ após hidrotermólise. Os resultados obtidos estão de acordo com o descrito por Ahmad et al. (2020), os quais indicam que a acúmulo de fenóis pode causar alterações no fluxo de troca de elétrons, causando o acúmulo de HAc, bem como a inibição da metanogênese. Na presente pesquisa, maiores concentrações de $\mathrm{H}_{2}$ $\left(13,55 \mathrm{mmol} \mathrm{H} \cdot \mathrm{L}^{-1}\right)$ e HAc $\left(4.355 \mathrm{mg} \mathrm{HAc.} \mathrm{L}^{-1}\right)$ foram relacionadas à condição de maior acúmulo de fenóis, no ensaio contendo resíduo in natura, provavelmente devido a maior biodegradação da biomassa lignocelulósica neste ensaio. De acordo com Monlau et al. (2014), o aumento na concentração de compostos fenólicos pode estar relacionado à biodegradação da lignina.

Quanto a concentração de ST e STV, tanto nos ensaios contendo resíduo sólidos de citros in natura, quanto nos ensaios contendo resíduo sólido de citros pré-tratado (hidrotermólise e deslignificação alcalina) a variação não foi significativa $(p \geq 0,05)$. 
Figura 5.12. Parâmetros físico-químicos dos ensaios de comparação entre (I) resíduo sólido de citros in natura, (II) após deslignificação alcalina e (III) após hidrotermólise. (A) carboidratos totais, (B) ST, (C) fenóis totais e (D) STV.
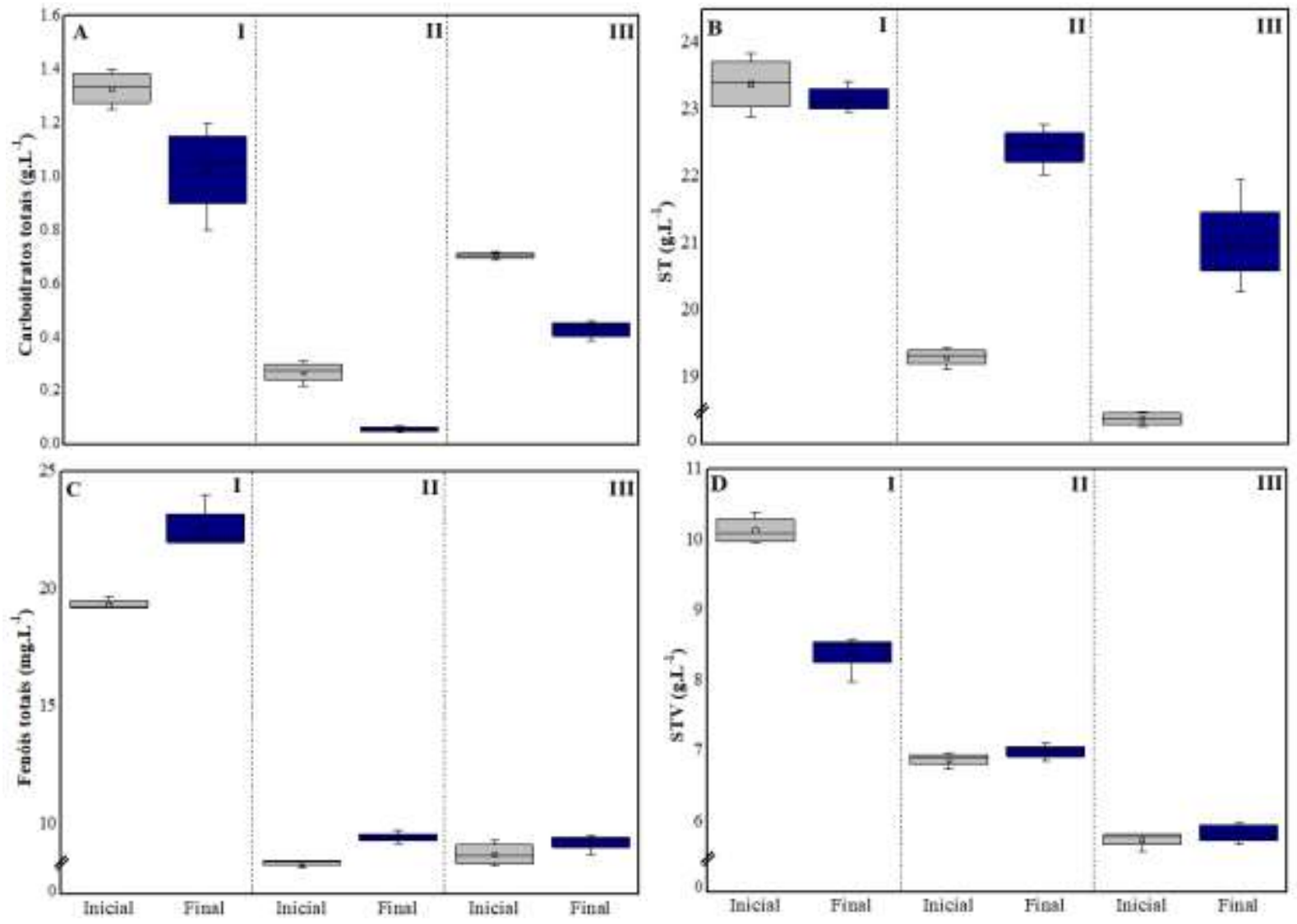

\subsubsection{Análise da comunidade microbiana}

A estrutura da comunidade microbiana (Domínio Bacteria) envolvida na digestão anaeróbia dos resíduos sólidos de citros (in natura e pré-tratados) foi verificada por meio do DGGE. A análise foi realizada nas amostras dos inóculos utilizados (inóculo autóctone e inóculo alóctone), bem como da biomassa dos reatores em batelada ao final do período de incubação (Figura 5.13). 
Figura 5.13. Dendrograma do coeficiente de similaridade (Correlação Pearson) a partir do perfil de bandas do DGGE para o Domínio Bacteria.

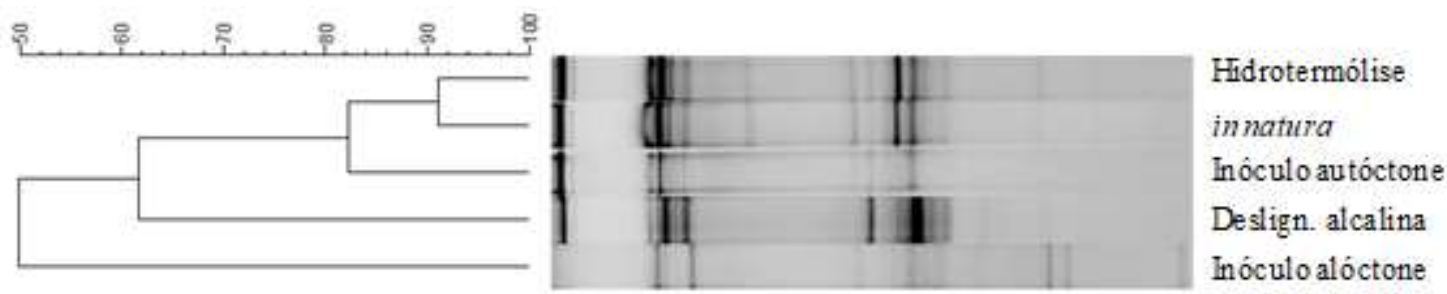

A similaridade entre as bandas das amostras de resíduo sólido de citros in natura e após hidrotermólise foi de $90 \%$. No entanto, a concentração de $\mathrm{H}_{2}$ foi maior no ensaio contendo resíduo sólido de citros in natura $\left(P=13,31 \mathrm{mmol} \mathrm{H}_{2} \cdot \mathrm{L}^{-1}\right)$ em relação ao resíduo sólido de citros após hidrotermólise $\left(P=8,19 \mathrm{mmol} \mathrm{H} \cdot \mathrm{L}^{-1}\right)$, bem como a produção de HAc, de $4.355 \mathrm{mg} . \mathrm{L}^{-1}$ e $2.375 \mathrm{mg} . \mathrm{L}^{-1}$, respectivamente.

A menor similaridade observada foi entre as populações do inóculo alóctone e as demais amostras (50\%). Provavelmente, ocorreu seleção das populações de bactérias após o processo fermentativo em todos os ensaios. Em relação ao inóculo autóctone, a similaridade observada quando comparado ao resíduo sólido de citros in natura foi de aproximadamente $80 \%$, o que pode indicar que as populações celulolíticas do próprio resíduo foram favorecidas neste ensaio.

As amostras foram comparadas a partir dos índices da diversidade de ShannonWiener e Dominância (Figura 5.14), sendo observado maior diversidade para o inóculo alóctone $(2,46)$, em relação as condições do resíduo sólido de citros in natura $(2,38)$ e prétratado (2,31 e 2,38 para hidrotermólise e deslignificação alcalina, respectivamente) e também quando comparada ao inóculo autóctone $(1,91)$.

Em relação à dominância, verificou-se menor valor para o inóculo alóctone $(0,10)$, quando comparado ao resíduo sólido de citros in natura $(0,12)$ e pré-tratado $(0,11$ e 0,12 para hidrotermólise e deslignificação alcalina, respectivamente). A maior dominância foi observada para o inóculo autóctone $(0,21)$. Desta forma, é possível notar que a relação entre diversidade e dominância foi inversamente proporcional. 
Figura 5.14. Variação dos índices de diversidade de Shannon-Wiener e Dominância para o Domínio Bacteria.

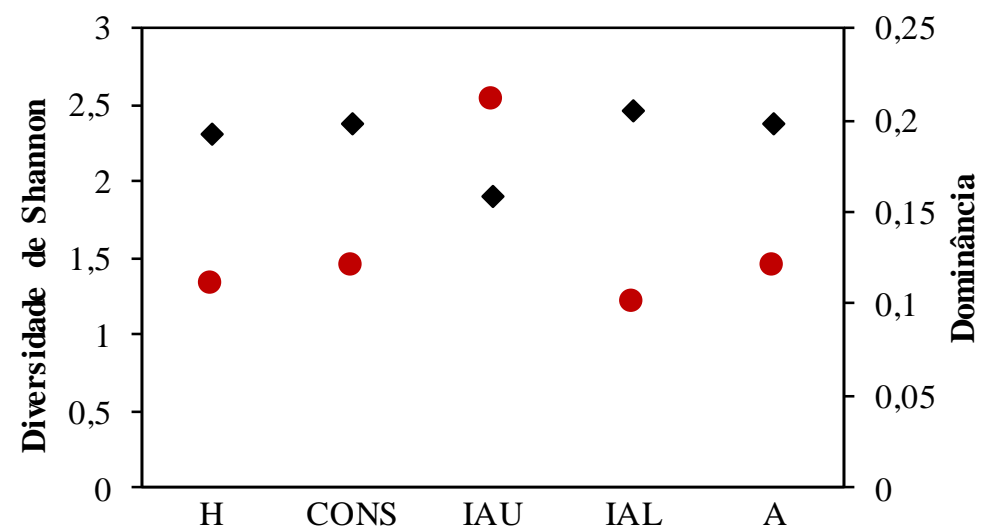

- Diversidade de Shannon

2,31

2,38

1,91

2,46

2,38

- Dominância

0,11

$0,12 \quad 0,21$

$0,1 \quad 0,12$

Nota: $\mathrm{H}=$ hidrotermólise; $\mathrm{CONS}=$ in natura; $\mathrm{IAU}=$ inóculo autóctone; $\mathrm{IAL}=$ inóculo alóctone; $\mathrm{A}=$ deslignificação alcalina.

$\mathrm{Na}$ análise de metabarcoding das amostras do resíduo sólido de citros in natura e pré-tratado por hidrotermólise, foi possível avaliar a composição da comunidade microbiana envolvida na biodegradação destes resíduos. Ao todo, foram obtidas 274.549 sequencias de genes do RNAr 16S com tamanho médio de 456 pb, sendo 133.445 sequências para a amostra do ensaio com resíduo sólido de citros in natura e 141.104 sequências para o ensaio com resíduo sólido de citros após hidrotermólise.

As Unidades Taxonômicas Operacionais (OTU) obtidas foram agrupadas considerando similaridade superior a $97 \%$ e, após a remoção de singletons, obtiveram-se 217 OTU para a amostra do ensaio contendo resíduo sólido de citros in natura e 225 OTU para o resíduo sólido de citros após hidrotermólise. Além disso, foram calculados os índices de diversidade ecológica para cada amostra (Tabela 5.6). 
Tabela 5.6. Índices ecológicos das sequencias obtidas a partir do sequenciamento massivo do gene RNAr 16S via Plataforma Illumina HiSeq para amostra (1) ensaio com resíduo in natura e (2) ensaio após hidrotermólise.

\begin{tabular}{|c|c|c|}
\hline & In natura & Hidrotermólise \\
\hline \multicolumn{3}{|c|}{ Parâmetros sequenciamento (RNAr 16S) } \\
\hline Cobertura $(\%)$ & 99,9 & 99,9 \\
\hline Numero total de sequências & 133.445 & 141.104 \\
\hline Total de OTUs & 217 & 225 \\
\hline \multicolumn{3}{|c|}{ Índices ecológicos } \\
\hline Diversidade de Shannon-Wiener & 3,21 & 3,03 \\
\hline Dominância & 0,08 & 0,10 \\
\hline Índice de riqueza (Chao-1) & 228,5 & 242,5 \\
\hline
\end{tabular}

A maior parte das populações microbianas foram acessadas e boa cobertura das amostras analisadas ( $\geq 99 \%$ ). A partir da estimativa dos índices ecológicos, foi possível notar redução da diversidade bacteriana após os pré-tratamentos do resíduo sólido de citros, de 3,21 para a amostra de resíduo sólido de citros in natura para 3,03 após hidrotermólise. É possível inferir que os microrganismos do filo Firmicutes, especialmente semelhantes a Clostridium, possuem afinidade com o resíduo sólido de citros (in natura e pré-tratado), uma vez que no presente estudo foi observada maior abundância relativa deste grupo. A composição da comunidade bacteriana para os filos e gêneros mais abundantes $(\geq 0,01 \%$ ) pode ser visualizada na Figura 5.15. 
Figura 5.15. Ideograma circular "Circos". Gêneros microbianos identificados nos resíduos in natura e após hidrotermólise. O círculo externo representa a abundância relativa em função do número de leituras. N.I= não identificado.

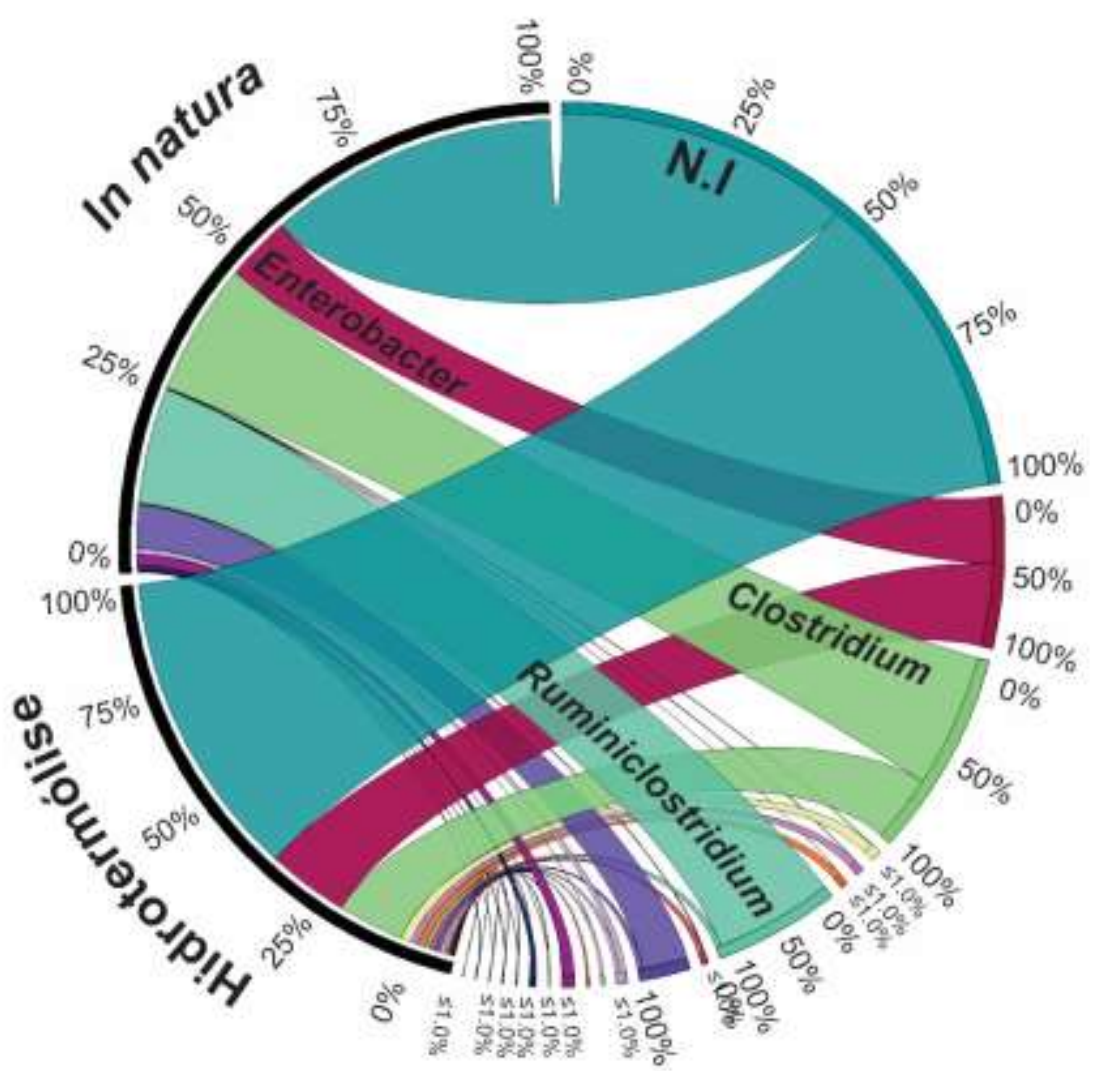
Blautia

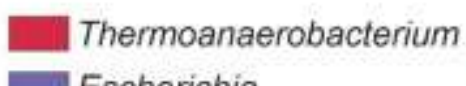
$\square$ Bifidobacterium

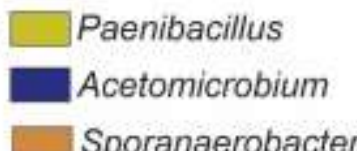
Lactobacillus
Escherichia
Pseudomonas
Thermohydrogenium
Lachnoclostridium
Enterococcus
Sporanaerobacter

Verificou-se que os filos mais abundantes para resíduo de citros in natura e após hidrotermólise foram Firmicutes (77,2 e 58,9\%, respectivamente) e Proteobacteria (17,40 e 40,2\%, respectivamente). Representantes pertencentes a Firmicutes são conhecidos especialmente por suas relações sintróficas em reatores anaeróbios, bem com à produção e degradação de ampla diversidade de AOV (VOS et al., 2009). Em relação à composição microbiana do inóculo alóctone, Soares et al. (2017) observaram abundância relativa de $78,24 \%$ para o filo Firmicutes e 21,53\% para o filo Synergistetes em reatores contendo bagaço de cana-de-açúcar, sendo que os principais gêneros identificados foram Coprothermobacter (41,73\%), Anaerobaculum (21,51\%), Clostridium (6,42\%), Symbiobacterium (6,20\%) e Thermoanaerobacterium (1,61\%).

Bactérias semelhantes a Clostridium (Firmicutes) foram identificadas em ambas as amostras analisadas, com 19,0\% de abundância relativa para o ensaio contendo resíduo 
sólido de citros in natura e 12,2\% após hidrotermólise. São bacilos Gram-positivos, possuem metabolismo diverso, produzem AOV e álcoois (HBu, HAc, HFor, HLac e HSuc e EtOH) a partir de carboidratos, peptonas e outros compostos orgânicos (VOS et al., 2009; GHIMIRE et al., 2015).

A faixa ótima de crescimento de Clostridium é entre $30-37{ }^{\circ} \mathrm{C}$ e pH 6,5-7,0 (VOS et al., 2009), o que condiz tanto com a temperatura $\left(30{ }^{\circ} \mathrm{C}\right)$ e $\mathrm{pH}(7,0)$ utilizados nesta pesquisa, quanto aos principais metabólitos ( $\mathrm{HAc}$ e $\mathrm{HBu}$ ) observados ao final da fermentação nos ensaios contendo resíduo in natura e pré-tratado por hidrotermólise.

Resultados similares foram obtidos por Rabelo et al. (2018), que identificaram diversas espécies da ordem Clostridiales em reatores anaeróbios aplicados à obtenção de $\mathrm{H}_{2}$ a partir de resíduo lignocelulósico (bagaço de cana-de-açúcar), como C. bifermentans (atual Paraclostridium bifermentans), C. cellobioparum (atual Ruminiclostridium cellobioparum), C. cellulolyticum (atual Ruminiclostridium cellulolyticum) e $C$. sartagoforme, sendo o principal metabólito observado foi o HAc, compreendendo $60 \%$ do total de ácidos orgânicos produzidos.

De acordo com Vos et al. (2009), a maior parte das espécies de Clostridium são capazes de hidrolisar a pectina, um dos principais componentes do resíduo sólido de citros, o que justifica a elevada abundância relativa deste grupo no substrato utilizado na presente pesquisa. Os autores afirmam que a biotina é a única vitamina requerida por Clostridium, sendo que produtos derivados de leveduras são ricos em biotina, como o extrato de levedura que compõe o meio PCS utilizado nesta pesquisa, favorecendo o crescimento de Clostridium.

Ruminiclostridium foi o segundo gênero identificado mais abundante, todavia, houve redução de sua abundância relativa, de $16,6 \%$ no ensaio contendo resíduo de citros in natura, para 1,0\% no ensaio contendo resíduo de citros após hidrotermólise. Da mesma forma, foi possível notar redução da abundância relativa de Paraclostridium (0,70 para $0,01 \%)$, Trichococcus $(0,15$ para $\leq 0,01 \%)$ e Clostridioides $(0,28$ para $0,01 \%)$ no ensaio contendo resíduo sólido de citros após hidrotermólise.

Ruminiclostridium é comum em rúmen e em resíduos lignocelulósicos, sendo de grande interesse para a biodegradação desta biomassa (KEGGI; DORAN-PETERSON, 2019). Os organismos deste gênero, anteriormente classificados em Clostridium, possuem diversas características morfológicas e metabólicas comuns a Clostridium. 
Diversas espécies de Ruminiclostridium hidrolisam pectina (VOS et al., 2009) e celulose, com produção de AOV (HAc e HLac) e álcoois (EtOH) (RAVACHOL et al., 2015; DUMITRACHE et al., 2016). Uma vez que a aplicação da hidrotermólise causa o rompimento das fibras e hidrólise dos polissacarídeos, como a pectina, é possível inferir que este gênero foi identificado em maior abundância no ensaio contendo resíduo sólido de citros in natura devido à maior disponibilidade de carboidratos totais $\left(6,3 \mathrm{~g} \cdot \mathrm{kg}^{-1}\right)$ em relação ao resíduo sólido de citros após hidrotermólise $\left(4,9\right.$ g. $\left.\mathrm{kg}^{-1}\right)$.

Houve redução da abundância relativa de Acetomicrobium (filo Bacteroidetes), de 0,71\% no resíduo de citros in natura, para $0,16 \%$ no resíduo de citros após hidrotermólise. Acetomicrobium são bactérias Gram-negativas, com faixa de crescimento ótima em pH 6,28,0 e temperaturas termofílicas $\left(58-73^{\circ} \mathrm{C}\right)$. Espécies deste gênero fermentam glicose em ácido acético, láctico, EtOH, $\mathrm{CO}_{2}$ e $\mathrm{H}_{2}$ (KRIEG et al., 2010). Desta forma, é possível inferir que este gênero contribuiu, tanto para a hidrólise do substrato, quanto para a maior concentração de $\mathrm{H}_{2}$ no ensaio contendo resíduo in natura $\left(P=13,31 \mathrm{mmol} \mathrm{H}_{2} \cdot \mathrm{L}^{-1}\right)$ em relação ao resíduo após hidrotermólise $\left(P=8,19 \mathrm{mmol} \mathrm{H}_{2} \cdot \mathrm{L}^{-1}\right)$.

De acordo com Kozianowski et al. (1997), Acetomicrobium não são capazes de assimilar substratos complexos, como pectinas, sendo possível inferir que os organismos deste gênero identificados nas amostras dos reatores em batelada são oriundos do inóculo alóctone utilizado (lodo de reator UASB), pois são comumente isoladas de lodos de tratamento de esgoto sanitário (KRIEG et al., 2010).

Os gêneros mais abundantes de Proteobacteria na amostra do ensaio contendo resíduo sólido de citros após hidrotermólise foram Pseudomonas e Enterobacter. De acordo com Heerden et al. (2002), bactérias semelhantes a Pseudomonas e Enterobacter são comuns em resíduo sólido de citros. Zhong et al. (2011), reportaram a degradação de celulose, hemicelulose e lignina por Pseudomonas, além de grupos bifenila (Bugg et al., 2011) e pectinas (GEETHA et al., 2012).

Em relação a Pseudomonas, houve aumento da abundância relativa de $\leq 0,01$ para 0,40\%, respectivamente, nos ensaios contendo resíduo sólido de citros in natura e prétratados por hidrotermólise. Apesar de Pseudomonas ser comum em resíduos de citros, Bakkali et al. (2008) apontam que concentrações de limoneno superiores a 0,2 mg.kg-1 podem ser tóxicas a organismos deste gênero. Sendo assim, é possível supor que o resíduo sólido de citros após hidrotermólise foi mais favorável a estas bactérias, uma vez que seu 
teor de limoneno foi inferior ao observado para o resíduo sólido de citros in natura (14,7 e 2,4 g.kg, respectivamente).

Enterobacter foi um dos gêneros com maior abundância relativa identificados na amostra de resíduo sólido de citros após hidrotermólise (15,74\% e 9,32\% no resíduo sólido de citros in natura). Organismos deste gênero são comumente identificados em amostras de água, solo, lodos de esgoto e também vegetais e frutas, e são capazes de fermentar carboidratos à AOV e gás, na estequiometria de $2 \mathrm{CO}_{2}: 1 \mathrm{H}_{2}$ (BRENNER; KRIEG; STALEY, 2005; MAINTINGUER et al., 2017). Desta forma, é possível inferior que a presença deste gênero e ambas as amostras analisadas contribuiu para a obtenção de $\mathrm{H}_{2}$ a partir dos resíduos sólidos de citros.

Park et al. (2003) isolaram uma cepa de Enterobacter aggromerans de citros (Citros junos) e observaram seu potencial de crescimento em meio de cultura contendo limoneno como única fonte de carbono, na faixa entre $0-5 \%$. Os autores concluíram que o aumento da concentração de limoneno foi diretamente proporcional ao efeito inibitório deste composto. Sendo assim, entende-se que o resíduo de citros após hidrotermólise foi menos tóxico aos organismos deste gênero, devido ao seu menor teor de limoneno $\left(2,4 \mathrm{~g}_{\mathrm{kg}} \mathrm{kg}^{-1}\right) \mathrm{em}$ comparação do resíduo de citros in natura $\left(14,7 \mathrm{~g}_{\mathrm{kg}} \mathrm{kg}^{-1}\right)$.

Apesar de menos abundantes, foi possível observar aumento da abundância relativa de outros gêneros identificados no ensaio contendo resíduo sólido de citros após hidrotermólise, como Thermoanaerobacterium (0,13 para 0,28\%). A identificação de organismos deste gênero em reatores fermentativos vem sendo relacionada, tanto às temperaturas termofílicas, quanto à degradação de compostos lignocelulósicos, como espiga de milho e palha de trigo (CAO et al., 2014).

Apesar de comuns, tanto em resíduos lignocelulósicos, quanto em lodo de esgoto anaeróbio, o baixo percentual observado para Thermoanaerobacterium pode estar relacionado à sua temperatura ótima de crescimento $\left(65^{\circ} \mathrm{C}\right)$ (KANOKSILAPATHAM et al., 2015), uma vez que no presente estudo aplicou-se a faixa mesofílica $\left(30{ }^{\circ} \mathrm{C}\right)$, provavelmente desfavorável ao estabelecimento de organismos deste gênero nos ensaios realizados.

Vale ressaltar que, tanto o resíduo sólido de citros in natura, quanto os pré-tratados utilizados nos ensaios em batelada possuem teor de limoneno na faixa de inibição indicada para este composto, de aproximadamente 0,2 g. $\mathrm{kg}^{-1}$ (POURBAFRANI et al., 2010; 
CALABRÒ et al., 2016; RUIZ; FLOTATS, 2016). A concentração de limoneno pode ser considerada como um dos causadores de pressão seletiva nas populações microbianas em reatores contendo resíduo sólido de citros, além de favorecer a acidogênese e o consequente acúmulo de AOV, acarretando na inibição da atividade metanogênica (BICAS; PASTORE, 2007).

Uma vez que se observou nos ensaios contendo resíduo sólido de citros in natura maior teor de carboidratos totais (solúveis), fenóis totais e limoneno, é possível inferir que os gêneros com maior abundância relativa no ensaio contendo resíduo sólido de citros após hidrotermólise, podem ser menos resistentes a este óleo essencial e aos compostos fenólicos (CHAPLEUR et al., 2016), devido às menores concentrações neste substrato $(2,4 \mathrm{~g}$ de limoneno. $\left.\mathrm{kg}^{-1}\right)$ quando comparado ao resíduo sólido de citros in natura $(14,7 \mathrm{~g}$ de limoneno. $\left.\mathrm{kg}^{-1}\right)$.

A redução da abundância relativa de Clostridium, Anaerobacterium e Ruminiclostridium, no ensaio contendo resíduo sólido de citros pré-tratado pode ter contribuído para a menor obtenção de $\mathrm{H}_{2}$ e AOV a partir deste resíduo (Figura 5.16), uma vez que todos os gêneros citados são conhecidamente produtores de HAc e $\mathrm{HBu}$ e, ainda, produtores de $\mathrm{H}_{2}$ em processos anaeróbios (VOS et al., 2009; KRIEG et al., 2010; KANOKSILAPATHAM et al., 2015; RABELO et al., 2018b).

Os gêneros Lactococcus, Caldicoprobacter, Bacillus, Thermacetogenium, Desulfotomaculum, Syntrophothermus, Fusobacterium, Thermobrachium, Tepidanaerobacter, Soehngenia, Oscillibacter, Dialister, Desulfotomaculum e Tepidimicrobium foram identificados com abundância relativa menor do que $0,1 \%$ em ambos os ensaios. Entretanto, estes gêneros podem ter contribuído para a obtenção de $\mathrm{H}_{2} \mathrm{e}$ AOV, como destacado por Benomar et al. (2015), que indicam a importância dos grupos menos abundantes em consórcios, ocasionando aumento significativo na obtenção de $\mathrm{H}_{2}$, não apenas devido à sintrofia mas, devido à interação célula-célula e à troca de metabólitos.

Em relação ao Domínio Archaea foram identificados microrganismos pertencentes apenas ao filo Euryarchaeota, com abundância relativa de 1,21\% no ensaio contendo resíduo in natura, e 0,03\% no ensaio contendo resíduo após hidrotermólise. A menor abundância relativa no resíduo pré-tratado pode indicar que esta biomassa pré-tratada pode ter sido desfavorável a estes microrganismos.

Os principais gêneros de arquéias identificados foram Methanosarcina, Methanothermobacter (0,68 e $\leq 0,01 \%)$, Methanoculleus $(0,12$ e 0,01\%) e Methanosaeta 
$(0,38$ e $\leq 0,01 \%)$, para os ensaios contendo resíduo de citros in natura e pré-tratado via hidrotermólise, respectivamente.

Todos os gêneros mencionados são capazes de produzir metano, entretanto, Methanothermobacter e Methanosarcina são capazes de produzir este biogás a partir, tanto do metabolismo acetoclástico, quanto hidrogenotrófico, enquanto Methanosaeta apresenta metabolismo estritamente acetoclástico. Além disso, Methanosaeta e Methanosarcina vem sendo relacionada à formação inicial de grânulos em reatores anaeróbios (SCHMIDT; AHRING, 1996). Vale ressaltar que não houve produção detectável de metano nos ensaios contendo resíduos de citros in natura ou pré-tratados.

A partir dos resultados obtidos nesta etapa considerou-se que os resíduos sólidos de citros in natura moídos foram mais favoráveis à obtenção de $\mathrm{H}_{2}$ em relação àqueles prétratados via hidrotermólise ou deslignificação alcalina. Desta forma, utilizou-se resíduos sem pré-tratamento nas etapas subsequentes, junto ao inóculo autóctone e alóctone previamente estabelecidos nos itens 5.2.1 e 5.2.2, respectivamente. 
Figura 5.16. Rotas de conversão do resíduo sólido de citros (RSC) a carboidratos, $\mathrm{AOV}, \mathrm{H}_{2}$ e $\mathrm{CH}_{4}$ e abundância relativa dos gêneros envolvidos nas diferentes etapas da digestão anaeróbia, sendo I= resíduo sólido de citros in natura e $\mathrm{H}=$ resíduo sólido de citros após hidrotermólise. $\mathrm{HAc}=$ Ácido acético; $\mathrm{HBu}=$ Ácido butírico; $\mathrm{HLac}=$ Ácido lático; EtOH= etanol. $(\diamond)$ Produtores de $\mathrm{H}_{2} ;(\diamond)$ Produtores de $\mathrm{CH}_{4}$.

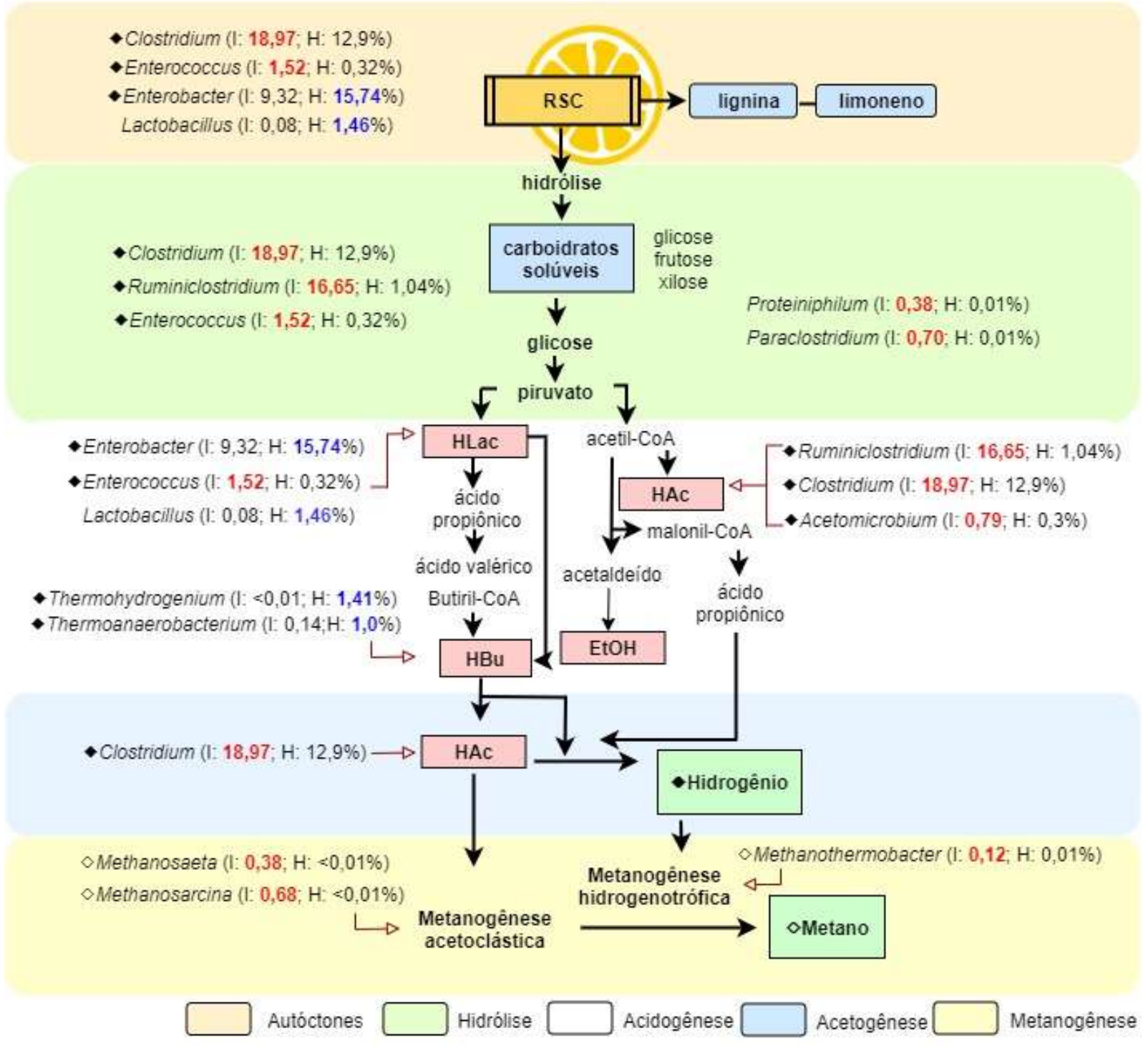

Fonte: Elaboração própria.

\subsection{SELEÇÃO DE VARIÁVEIS VIA PLACKETT \& BURMAN}

Os ensaios de screening design para seleção das variáveis operacionais mais significativas para obtenção de $\mathrm{H}_{2}$ foram realizados por meio do método de Plackett \& Burman (P\&B), utilizando o inóculo autóctone, inóculo alóctone (lodo UASB termofílico/vinhaça) e resíduo de citros in natura, conforme estabelecido nos ensaios preliminares descritos nos itens 5.2.1, 5.2.2 e 5.3.2, respectivamente. As variáveis analisadas foram $\mathrm{pH}\left(5,5,7,0\right.$ e 8,5), temperatura $\left(30,37\right.$ e $\left.44{ }^{\circ} \mathrm{C}\right)$, concentração de inóculo alóctone (1, 2 e 3 gSTV.L $\left.{ }^{-1}\right)$ e de substrato (5, 10 e 15 g.L $\left.\mathrm{L}^{-1}\right)$, volume do headspace (40, 50 
e $60 \%$ ) e concentrações de componentes do meio de cultura, sendo extrato de levedura ( 0 , 0,5 e 1 g.L $\left.\mathrm{L}^{-1}\right), \mathrm{CaCO}_{3}\left(0,2,5\right.$ e 5 g.L $\left.\mathrm{L}^{-1}\right), \mathrm{NaCl}\left(0,2,5\right.$ e 5 g.L $\left.\mathrm{L}^{-1}\right)$ e peptona $\left(0,2,5\right.$ e 5 g.L $\left.\mathrm{L}^{-1}\right)$.

Após a realização dos ensaios preditos pela matriz de Plackett \& Burman e cálculo dos parâmetros do modelo de Gompertz modificado ( $P, R m$ e $\lambda$ ) (Tabela 5.7), obtiveramse as curvas de concentração de hidrogênio (Figura 5.17) para cada condição. A significância de cada uma das respostas foi avaliada para o intervalo de confiança de $90 \%$, como recomendado em Rodrigues \& Iemma (2014), por meio da comparação dos efeitos e do p-valor (Tabela 5.8) e diagrama de Pareto (Figura 5.18).

Foram obtidos $P$ entre 13,29 e $0,03 \mathrm{mmol} \mathrm{H}_{2} \cdot \mathrm{L}^{-1}, R m$ entre 3,10 e $0,01 \mathrm{mmol} \mathrm{H}_{2} \mathrm{~h}^{-}$ ${ }^{1}$ e $\lambda$ entre 3,33 e 20,91 h. Em R5, maior $P\left(13,55 \mathrm{mmol} \mathrm{H}_{2} \cdot \mathrm{L}^{-1}\right)$ foi obtido nas condições de $30{ }^{\circ} \mathrm{C}$, pH 8,5, 2,25 gSTV.L ${ }^{-1}$ de inóculo autóctone, 3 gSTV.L $L^{-1}$ de inóculo alóctone, 15 g.L $\mathrm{L}^{-1}$ de resíduo sólido de citros, $40 \%$ de headspace, 5 g.L $\mathrm{L}^{-1}$ de $\mathrm{NaCl}$ e sem suplementação de extrato de levedura, carbonato de cálcio $\left(\mathrm{CaCO}_{3}\right)$ e peptona.

A curvatura dos resultados não foi significativa para as respostas $P$ e $R m$, o que indica que os pontos centrais estabelecidos estão entre os valores intermediários entre os pontos -1 e +1 adotados, ou seja, os dados obtidos foram ajustados ao modelo de $1^{\text {a }}$ ordem/linear, não havendo curvatura (RODRIGUES; IEMMA, 2014). Para a resposta do tempo de início da obtenção de $\mathrm{H}_{2}(\lambda)$, foi observado efeito positivo para curvatura, indicando que a resposta não se encaixa no modelo de $1^{\text {a }}$ ordem. Além disso, no ensaio R1 $\left(44{ }^{\circ} \mathrm{C}\right.$, pH 5,5, inóculo 1 gSTV.L ${ }^{-1}$, substrato 15 g.L $\mathrm{L}^{-1}$, headspace $40 \%, \mathrm{CaCO}_{3} 5$ g.L ${ }^{-1}$, $\mathrm{NaCl} 5$ g.L $\mathrm{L}^{-1}$ ) não se observou obtenção de $\mathrm{H}_{2}$ ao longo do período de incubação. 
Figura 5.17. Concentração acumulada de $\mathrm{H}_{2}$ dos ensaios de screening design para seleção de variáveis significativas por meio da matriz de Plackett \& Burman.

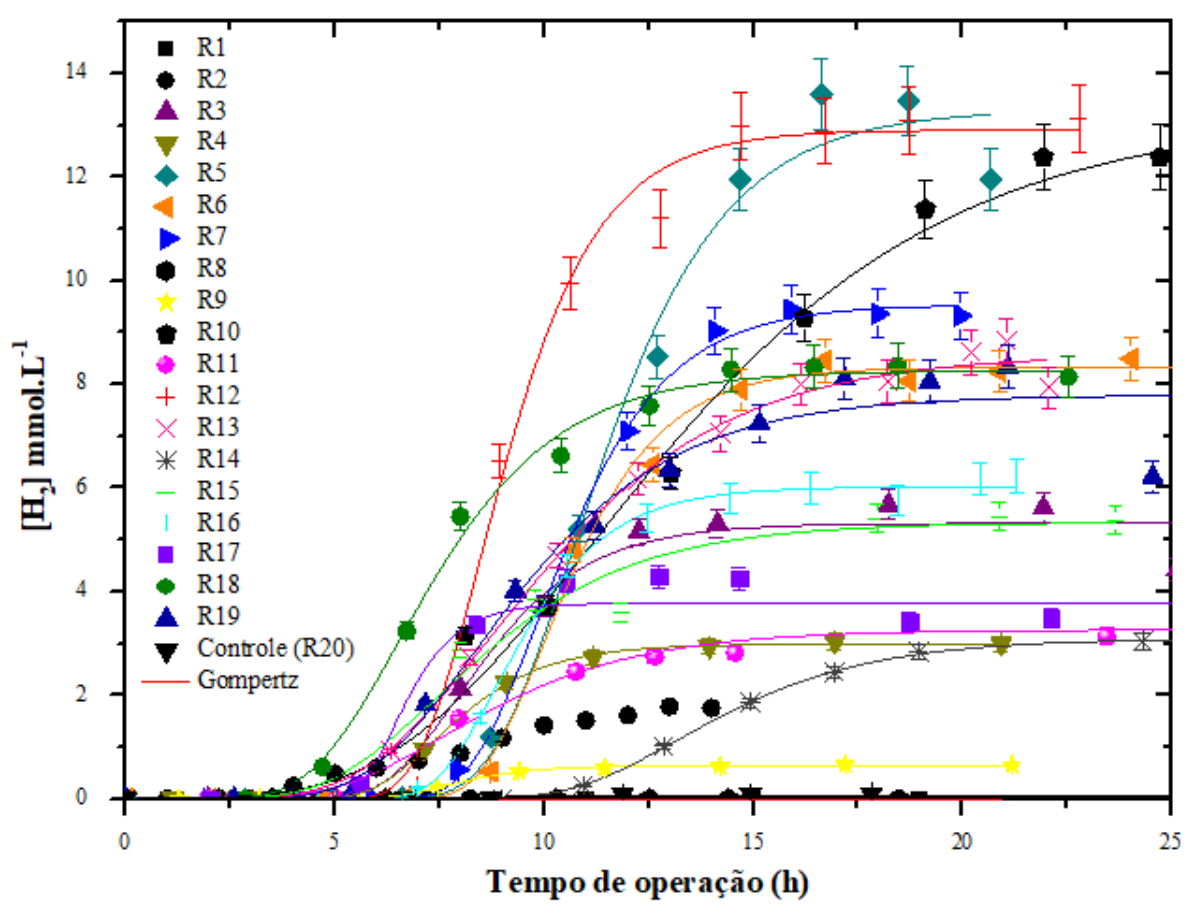

Tabela 5.7. Matriz de Plackett \& Burman codificada para o screening design com 16 condições experimentais e três repetições do ponto central $\left(\mathrm{x}_{1}-\mathrm{x}_{10}\right)$ e respostas obtidas para os ensaios cinéticos em batelada $\left(\mathrm{Y}_{1}-\mathrm{Y}_{4}\right)$.

\begin{tabular}{|c|c|c|c|c|c|c|c|c|c|c|c|c|c|c|c|}
\hline Ensaios & $\mathbf{X}_{1}$ & $\mathbf{X} 2$ & $\mathbf{X 3}$ & $\mathbf{X} 4$ & X5 & $\mathbf{X}_{6}$ & $\mathbf{X}_{7}$ & X8 & X9 & $\mathbf{X 1 0}$ & $\mathbf{R}^{2}$ & $Y_{1}$ & $\overline{Y_{2}}$ & $\mathbf{Y}_{3}$ & $Y_{4}$ \\
\hline $\mathrm{R} 1$ & +1 & -1 & -1 & -1 & 1 & -1 & -1 & +1 & +1 & -1 & $\overline{5}$ & - & - & 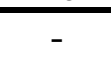 & 0 \\
\hline $\mathrm{R} 2$ & +1 & +1 & -1 & -1 & -1 & +1 & -1 & -1 & +1 & +1 & 0,99 & 2,07 & , & & 203 \\
\hline R3 & +1 & +1 & +1 & -1 & -1 & -1 & +1 & -1 & -1 & & & & & & 0 \\
\hline $\mathrm{R} 4$ & +1 & +1 & +1 & +1 & -1 & -1 & -1 & +1 & -1 & -1 & 00 & 9 & 76 & S & 0 \\
\hline R5 & -1 & +1 & +1 & +1 & +1 & -1 & -1 & -1 & +1 & -1 & 0,99 & 13,29 & 2,46 & 8,73 & 1.340 \\
\hline R6 & +1 & -1 & +1 & +1 & +1 & +1 & -1 & -1 & -1 & +1 & 0,99 & 33 & 2,00 & 8,49 & 113 \\
\hline R7 & -1 & +1 & -1 & +1 & +1 & +1 & +1 & -1 & -1 & -1 & 9 & 9,53 & 2,09 & 8,20 & .118 \\
\hline R8 & +1 & -1 & +1 & -1 & +1 & +1 & +1 & +1 & -1 & -1 & 0,99 & 0,03 &, 01 & 20,91 & 0 \\
\hline R9 & +1 & +1 & -1 & +1 & -1 & +1 & +1 & +1 & +1 & -1 & 0,99 & 0,65 & 0,20 & 6,34 & 93 \\
\hline R10 & -1 & +1 & +1 & -1 & +1 & -1 & +1 & +1 & +1 & +1 & 0,99 & 13,23 & 1,02 & 6,3 & 940 \\
\hline 1 & -1 & -1 & +1 & +1 & -1 & +1 & -1 & +1 & +1 & +1 & 0,97 & 6 & 0,46 & 4,9 & 140 \\
\hline R12 & +1 & -1 & -1 & +1 & +1 & -1 & +1 & -1 & +1 & +1 & 0,99 & 12,91 & 3,10 & 6,98 & 1.040 \\
\hline D 12 & -1 & +1 & -1 & -1 & +1 & +1 & -1 & +1 & -1 & +1 & 0,98 & 9 & 1,02 & 5,65 & 540 \\
\hline & -1 & -1 & +1 & -1 & -1 & +1 & +1 & -1 & +1 & -1 & 0,99 & 9 & 0,45 & 10,66 & 213 \\
\hline & -1 & -1 & -1 & +1 & -1 & -1 & +1 & +1 & -1 & +1 & 0,96 & 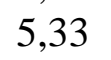 & 0,76 & 4,8 & 0 \\
\hline & -1 & -1 & -1 & -1 & -1 & -1 & -1 & -1 & -1 & -1 & 0,99 & 6,02 & 1,52 & 7,43 & 336 \\
\hline & 0 & 0 & 0 & 0 & 0 & 0 & 0 & 0 & 0 & 0 & 0,94 & 7,78 & 1,00 & 5,39 & 140 \\
\hline & 0 & 0 & 0 & 0 & 0 & 0 & 0 & 0 & 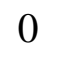 & 0 & 0,99 & 0,20 & 1,44 & 4,42 & 440 \\
\hline R19 & 0 & 0 & 0 & 0 & 0 & 0 & 0 & 0 & 0 & 0 & 0,97 & 7,79 & 1,09 & 5,73 & 130 \\
\hline
\end{tabular}

Nota: $\mathrm{x}_{1}=$ temperatura $\left({ }^{\circ} \mathrm{C}\right) ; \mathrm{x}_{2}=\mathrm{pH} ; \mathrm{x}_{3}=$ inóculo autóctone $\left(\mathrm{gSTV} . \mathrm{L}^{-1}\right) ; \mathrm{x}_{4}=$ inóculo alóctone $\left(\mathrm{gSTV} \cdot \mathrm{L}^{-1}\right) ; \mathrm{x}_{5}=$ substrato (g.L $\left.\mathrm{L}^{-1}\right) ; \mathrm{x}_{6}=$ headspace $(\%) ; \mathrm{x}_{7}=$ extrato de levedura $\left(\mathrm{g} . \mathrm{L}^{-1}\right) ; \mathrm{x}_{8}=\mathrm{CaCO}_{3}\left(\mathrm{~g} . \mathrm{L}^{-1}\right) ; \mathrm{x}_{9}=\mathrm{NaCl}\left(\mathrm{g} . \mathrm{L}^{-1}\right) ; \mathrm{x}_{10}=$ peptona $\left(\mathrm{g} \cdot \mathrm{L}^{-1}\right) . \mathrm{Y}_{1}=P\left(\mathrm{mmol} \mathrm{H} \cdot \mathrm{L}^{-1}\right), \mathrm{Y}_{2}=R m\left(\mathrm{mmol} \mathrm{H} \cdot \mathrm{h}^{-1}\right), \mathrm{Y}_{3}=\lambda(\mathrm{h}), \mathrm{Y}_{4}=\mathrm{HAc}\left(\mathrm{mg} \cdot \mathrm{L}^{-1}\right)$. 


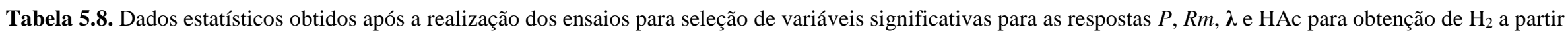
de resíduos sólidos de citros.

\begin{tabular}{|c|c|c|c|c|c|c|c|c|c|c|c|c|c|c|c|c|}
\hline \multirow{3}{*}{ Variável } & \multicolumn{16}{|c|}{ Parâmetros } \\
\hline & \multicolumn{4}{|c|}{$P\left(\mathbf{m m o l ~ H} \mathrm{H}_{2} \mathrm{~L}^{-1}\right)$} & \multicolumn{4}{|c|}{$R m\left(\mathrm{mmol} \mathrm{H}_{2} \cdot \mathrm{h}^{-1}\right)$} & \multicolumn{4}{|c|}{$\lambda(\mathbf{h})$} & \multicolumn{4}{|c|}{ HAc $\left(\mathrm{mg.L}^{-1}\right)$} \\
\hline & Efeito & $\begin{array}{c}\text { Erro } \\
\text { padrão }\end{array}$ & $\begin{array}{c}\mathbf{t} \\
\text { calculado }\end{array}$ & $\begin{array}{c}\text { p- } \\
\text { valor }\end{array}$ & Efeito & $\begin{array}{c}\text { Erro } \\
\text { padrão }\end{array}$ & $\begin{array}{c}\mathbf{t} \\
\text { calculado }\end{array}$ & $\begin{array}{c}\text { p- } \\
\text { valor }\end{array}$ & Efeito & $\begin{array}{c}\text { Erro } \\
\text { padrão }\end{array}$ & $\begin{array}{c}\mathbf{t} \\
\text { calculado }\end{array}$ & $\begin{array}{c}\text { p- } \\
\text { valor }\end{array}$ & Efeito & $\begin{array}{c}\text { Erro } \\
\text { padrão }\end{array}$ & $\begin{array}{c}\mathrm{t} \\
\text { calculado }\end{array}$ & $\begin{array}{c}\text { p- } \\
\text { valor }\end{array}$ \\
\hline Média & 5,92 & 0,45 & 13,11 & 0,0000 & 1,08 & 0,10 & 10,34 & 0,0000 & 8,37 & 0,47 & 17,92 & 0,0000 & 379,75 & 50,51 & 13,11 & 0,0000 \\
\hline Curvatura & 4,06 & 2,27 & 1,79 & 0,1173 & 0,20 & 0,52 & 0,39 & 0,7091 & $-6,38$ & 2,35 & $-2,71$ & 0,0300 & $-286,17$ & 254,22 & 1,79 & 0,1173 \\
\hline Temperatura & $-3,75$ & 0,90 & $-4,16$ & 0,0042 & $-0,30$ & 0,21 & $-1,42$ & 0,1988 & 2,54 & 0,93 & 2,72 & 0,0296 & $-397,25$ & 101,02 & $-4,16$ & 0,0042 \\
\hline $\mathrm{pH}$ & 2,09 & 0,90 & 2,31 & 0,0540 & 0,08 & 0,21 & 0,36 & 0,7289 & $-4,08$ & 0,93 & $-4,36$ & 0,0033 & 299 & 101,02 & 2,31 & 0,0540 \\
\hline $\begin{array}{l}\text { Consórcio } \\
\text { celulolítico }\end{array}$ & 0,56 & 0,90 & 0,61 & 0,5581 & $-0,07$ & 0,21 & $-0,36$ & 0,7289 & $-1,30$ & 0,93 & 1,39 & 0,2068 & -73 & 101,02 & 0,61 & 0,5581 \\
\hline Inóculo & 2,24 & 0,90 & 2,48 & 0,0419 & 0,81 & 0,21 & 3,88 & 0,0060 & $-3,13$ & 0,93 & $-3,35$ & 0,0122 & 201,5 & 101,02 & 2,48 & 0,0419 \\
\hline Substrato & 4,65 & 0,90 & 5,15 & 0,0013 & 0,78 & 0,21 & 3,73 & 0,0074 & 4,33 & 0,93 & 4,63 & 0,0024 & 513,25 & 101,02 & 5,15 & 0,0013 \\
\hline Headspace & $-2,94$ & 0,90 & $-3,26$ & 0,0139 & $-0,54$ & 0,21 & $-2,60$ & 0,0355 & 0,40 & 0,93 & 0,42 & 0,6852 & $-154,5$ & 101,02 & $-3,26$ & 0,0139 \\
\hline $\begin{array}{l}\text { Extrato de } \\
\text { levedura }\end{array}$ & 0,69 & 0,90 & 0,77 & 0,4681 & 0,04 & 0,21 & 0,20 & 0,8438 & 0,87 & 0,93 & 0,93 & 0,3829 & 91,5 & 101,02 & 0,77 & 0,4681 \\
\hline $\mathrm{CaCO}_{3}$ & $-3,31$ & 0,90 & $-3,67$ & 0,0080 & $-1,09$ & 0,21 & $-5,26$ & 0,0012 & 1,73 & 0,93 & 1,86 & 0,1058 & $-331,25$ & 101,02 & $-3,67$ & 0,0080 \\
\hline $\mathrm{NaCl}$ & 0,30 & 0,90 & 0,33 & 0,7534 & $-0,17$ & 0,21 & $-0,84$ & 0,4277 & $-0,16$ & 0,93 & $-0,17$ & 0,8669 & 232,75 & 101,02 & 0,33 & 0,7534 \\
\hline Peptona & 2,93 & 0,90 & 3,25 & 0,0141 & 0,28 & 0,21 & 1,33 & 0,2237 & $-5,05$ & 0,93 & $-5,40$ & 0,0010 & $-15,5$ & 101,02 & 3,25 & 0,0141 \\
\hline
\end{tabular}

Nota: (-) efeito negativo. Potencial máximo de concentração de $\mathrm{H}_{2}(P)$, velocidade específica máxima de obtenção de $\mathrm{H}_{2}(R m)$, tempo de início da obtenção de $\mathrm{H}_{2}(\lambda)$ e $\mathrm{R}^{2}$

obtidos da equação de Gompertz modificada. 
Figura 5.18. Diagramas de Pareto e significância das variáveis estudadas para o intervalo de confiança de $90 \%$. (A) $P$, (B) $R m,(\mathrm{C}) \lambda$ e (D) HAc.
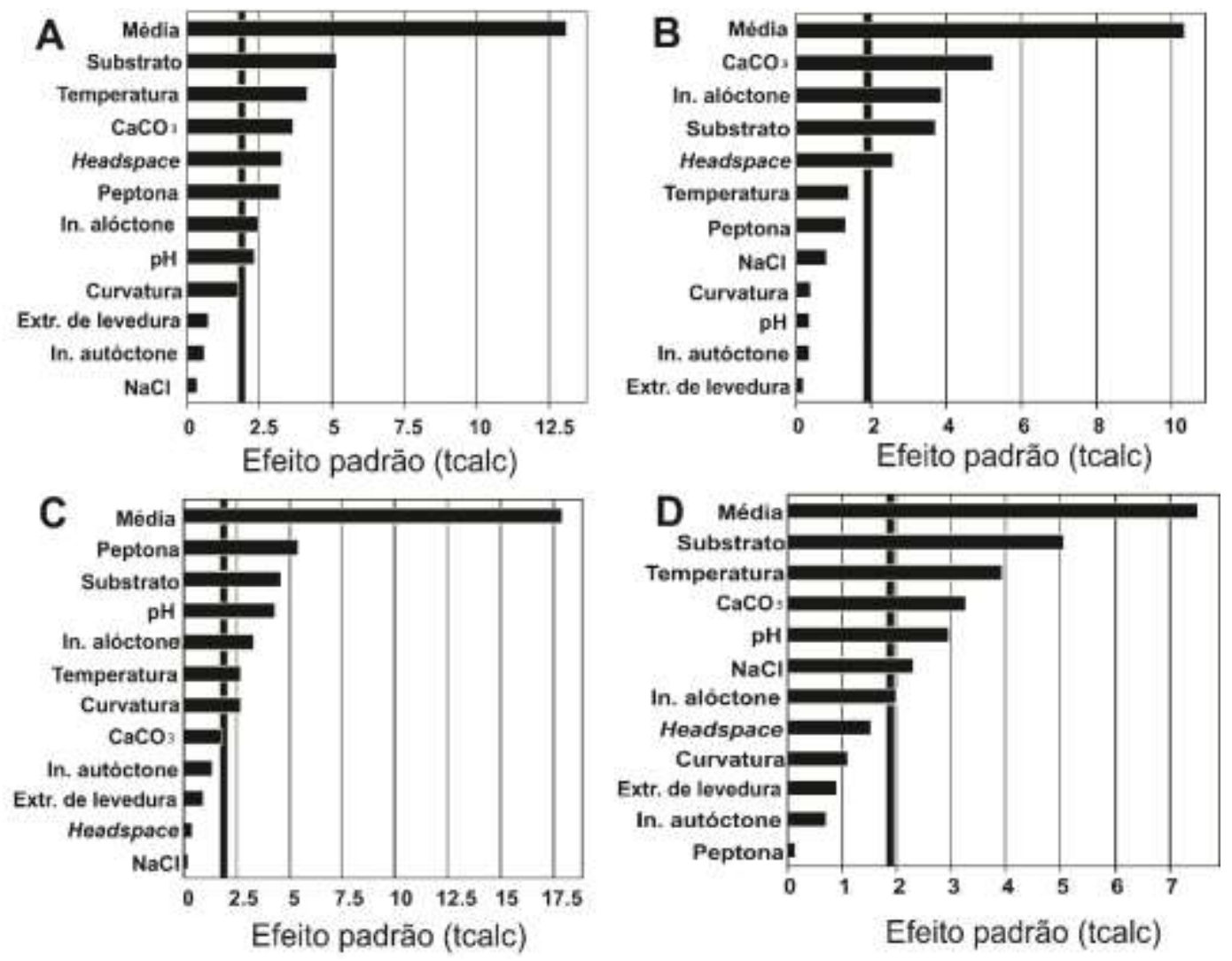

As variáveis $\mathrm{X}_{6}$ e $\mathrm{X}_{8}$ (volume do headspace e concentração de $\mathrm{CaCO}_{3}$, respectivamente) foram significativas, tanto para o parâmetro $P$ (potencial máximo de concentração de $\mathrm{H}_{2}$ ), quanto para $R m$ (velocidade específica máxima de obtenção de $\mathrm{H}_{2}$ ), sendo seu efeito negativo, ou seja, quanto menor o volume do headspace e menor a concentração de $\mathrm{CaCO}_{3}$, maior $P$ e $R m$ de $\mathrm{H}_{2}$.

De acordo com Liu et al. (2017), a pressão parcial de $\mathrm{H}_{2}$ está intimamente relacionada com a obtenção de $\mathrm{H}_{2}$ e HAc no processo de digestão anaeróbia. $\mathrm{O}$ volume do headspace está relacionado com a pressão parcial de $\mathrm{H}_{2}$ no meio reacional, uma vez que o seu acúmulo altera o fluxo de elétrons e, consequentemente, as reações bioquímicas catalisadas por microrganismos, reduzindo a concentração de $\mathrm{H}_{2}$ (CAZIER et al., 2015; VILLA MONTOYA et al., 2020). Desta forma, foi possível notar que os maiores valores de $P$ e $R m$ (R5, R10 e R12) foram obtidos nos reatores com menores volumes de headspace (40\%). Wang et al. (2017) verificaram que quanto maior a porcentagem inicial de $\mathrm{H}_{2}$ no headspace do reator, maior será a concentração de $\mathrm{H}_{2}$ durante o processo fermentativo a partir de glicose. Assim como no presente estudo, Villa-Montoya et al. (2019) observaram que menores volumes de headspace favoreceram maior obtenção de $\mathrm{H}_{2}$ a partir de resíduos 
do processamento de café, sendo obtido $29,46 \mathrm{mmol} \mathrm{H}_{2} \cdot \mathrm{L}^{-1}$ em reatores operados com $40 \%$ de headspace, mesmo volume considerado ótimo no presente estudo.

Concentração de peptona $\left(\mathrm{X}_{10}\right), \mathrm{pH}\left(\mathrm{X}_{2}\right)$ e concentração de inóculo $\left(\mathrm{X}_{4}\right)$ foram significativas, tanto para $P$, quanto para a duração do tempo de início da obtenção de $\mathrm{H}_{2}$, com efeito positivo para $P$ e negativo para $\lambda$. Neste estudo, o tempo de início da obtenção de $\mathrm{H}_{2}$ foi entre 1,02-3,10 h, para os mesmos ensaios em que houve maior $P$ de $\mathrm{H}_{2}$ (R5, R10 e R12). Resultados similares foram observados por Hwang et al. (2011), sendo que o tempo de início da obtenção de $\mathrm{H}_{2}$ observado foi entre 3-4 h para reatores operados com resíduos do processamento de uva e $\mathrm{pH}$ inicial de 5,5.

Resultados similares foram observados por Villa-Montoya (2019), que avaliaram via delineamento de Plackett \& Burman diversos fatores para a obtenção de $\mathrm{H}_{2}$ a partir de resíduos do processamento de café. Assim como na presente pesquisa, os fatores considerados como mais significativos para obtenção de $\mathrm{H}_{2}$ foram $\mathrm{pH}(7,0)$, temperatura $\left(30{ }^{\circ} \mathrm{C}\right)$, volume de headspace $(50 \%)$ e concentração de substrato (30 gDQO.L ${ }^{-1}$ de agua residuária e 6 g.L -1 $^{-1}$ de cascas de café). Nestas condições ótimas, os autores observaram concentração máxima de 29,46 mmol $\mathrm{H}_{2} . \mathrm{L}^{-1}$ e $1.956 \mathrm{mg} . \mathrm{L}^{-1}$ de HAc. Semelhante ao presente estudo com resíduo sólido de citros também foi observado 13,29 mmol $\mathrm{H}_{2} . \mathrm{L}^{-1} \mathrm{e}$ $\left.1.340 \mathrm{mg} \mathrm{HAc} . \mathrm{L}^{-1}\right)$, em pH $(8,5)$, temperatura $\left(30{ }^{\circ} \mathrm{C}\right)$, volume de headspace $(40 \%) \mathrm{e}$ concentração de resíduo sólido de citros (15 gDQO.L $\left.\mathrm{L}^{-1}\right)$.

Cahyari et al. (2019) observaram que a faixa de temperatura termofílica $\left(55^{\circ} \mathrm{C}\right)$ pode ser vantajosa em relação à mesofílica para obtenção de $\mathrm{H}_{2}$ a partir de resíduos de alimentos, uma vez que pode reduzir compostos voláteis potencialmente tóxicos, como o limoneno. Entretanto, na presente pesquisa o aumento da temperatura $\left(\mathrm{x}_{1}\right)$ teve efeito negativo em $P\left(3,75 \mathrm{mmol} \mathrm{H}_{2} \cdot \mathrm{L}^{-1}\right)$, o que pode justificar as menores valores nos ensaios $\mathrm{R} 1$ $\left(\leq 0,01 \mathrm{mmol} \mathrm{H}_{2} \cdot \mathrm{L}^{-1}\right)$ e $\mathrm{R} 8\left(0,03 \mathrm{mmol} \mathrm{H} 2 \cdot \mathrm{L}^{-1}\right)$, ambos em $\mathrm{pH}$ inicial de 5,5 e operados a 44 ${ }^{\circ} \mathrm{C}$. Nota-se ainda que os maiores valores de $P$ foram observados nos reatores operados a $30{ }^{\circ} \mathrm{C}$, como R5 $\left(13,29 \mathrm{mmol} \mathrm{H} \cdot \mathrm{L}^{-1}\right)$ e R10 $\left(13,23 \mathrm{mmol} \mathrm{H} \cdot \mathrm{L}^{-1}\right)$.

Em temperaturas elevadas, há maior gasto de energia associada às vias catabólicas para manutenção do $\mathrm{pH}$ intracelular, levando a menor síntese de biomassa (SSV) (INFANTES et al., 2011; MAZARELI et al., 2019). Além disso, temperaturas elevadas podem ser associadas ao aumento na permeabilidade da membrana celular aos ácidos orgânicos, acarretando em inibição das bactérias produtoras de hidrogênio (INFANTES et 
al., 2011). Nos ensaios $\mathrm{R} 1$ e R8, houve menor tempo de início da obtenção de $\mathrm{H}_{2}$, provavelmente devido às maiores temperaturas do processo $\left(44^{\circ} \mathrm{C}\right)$, que podem favorecer a atividade da enzima Fe-hidrogenase (INFANTES et al., 2011; MAZARELI et al., 2019). Assim como na presente pesquisa, Villa-Montoya et al. (2019) observaram que a elevação da temperatura, de $30{ }^{\circ} \mathrm{C}$ para $50{ }^{\circ} \mathrm{C}$ teve efeito negativo no potencial máximo de concentração de $\mathrm{H}_{2}$.

A resposta adotada como de maior relevância para a presente pesquisa foi o valor de $P$ (potencial máximo de concentração de $\mathrm{H}_{2}$ ), as variáveis escolhidas como mais relevantes para o processo foram consideradas de acordo com os resultados de significância para esta resposta. Efeito significativo e positivo foi observado para concentração de substrato ( $\left.\mathrm{x}_{5}\right)$, enquanto concentração de $\mathrm{NaCl}\left(\mathrm{x}_{9}\right)$ e extrato de levedura $\left(\mathrm{x}_{7}\right)$ não foram significativas. Desta forma, considerou-se que as variáveis significativas mais indicadas para otimização da obtenção de $\mathrm{H}_{2}$ a partir dos resíduos de citros foram concentração de substrato, inóculo e pH inicial do meio.

A suplementação com peptona teve efeito positivo e significativo no processo $(2,93$ mmol $\left.\mathrm{H}_{2} \cdot \mathrm{L}^{-1}\right)$, provavelmente, aumentou a disponibilidade de aminoácidos e peptídeos. Em R10 e R12, ensaios em que houve suplementação de 5 g.L $\mathrm{L}^{-1}$ de peptona, foram obtidos 13,23 e 12,91 mmol $\mathrm{H}_{2} \cdot \mathrm{L}^{-1}$, enquanto nos reatores $\mathrm{R} 1 \mathrm{e} \mathrm{R} 8$, foram observadas concentrações $\leq 0,03 \mathrm{mmol} \mathrm{H}_{2} \cdot \mathrm{L}^{-1}$, sem adição de peptona.

O extrato de levedura é rico em biotina, um dos principais nutrientes requeridos por bactérias semelhantes a Clostridium (VOS et al., 2009). Todavia, ao contrário do observado para peptona, o aumento da concentração de extrato de levedura não foi significativo $(\mathrm{p}=$ 0,4681) para $P$. Entretanto, observou-se efeito positivo significativo para $R m$, ou seja, até $1 \mathrm{~g} . \mathrm{L}^{-1}$ de extrato de levedura foi favorável para ligeiro aumento de $P\left(0,04 \mathrm{mmol} \mathrm{H}_{2} \cdot \mathrm{h}^{-1}\right)$. Nos ensaios dos pontos centrais (R17, 18 e 19), a suplementação com extrato de levedura foi de $0,5 \mathrm{~g} . \mathrm{L}^{-1}$, e o $R m$ médio de $1,17 \mathrm{mmol} \mathrm{H}_{2} \cdot \mathrm{h}^{-1}$, enquanto em R12, observou-se maior $\operatorname{Rm}\left(3,10 \mathrm{mmol} \mathrm{H}_{2} \cdot \mathrm{h}^{-1}\right)$ e houve suplementação de 1 g.L $\mathrm{L}^{-1}$ de extrato de levedura. VillaMontoya et al. (2019) verificaram efeito não significativo da suplementação com extrato de levedura para a obtenção de $\mathrm{H}_{2}$ a partir de resíduos de café, tanto para $P$, quanto para $R m$.

A fim de estabelecer possíveis relações entre os parâmetros físico-químicos analisados (concentração de carboidratos e fenóis totais, pH inicial e SSV) (Figura 5.19), 
realizou-se a Análise de Componente Principal (PCA) entre estes parâmetros e as respostas do modelo de Gompertz modificado ( $P, R m$ e $\lambda$ ) (Figura 5.20).

Figura 5.19. Parâmetros físico-químicos de carboidratos, $\mathrm{SSV}$ e pH, obtidos para os ensaios screening design baseado na matriz de Plackett \& Burman (P\&B).

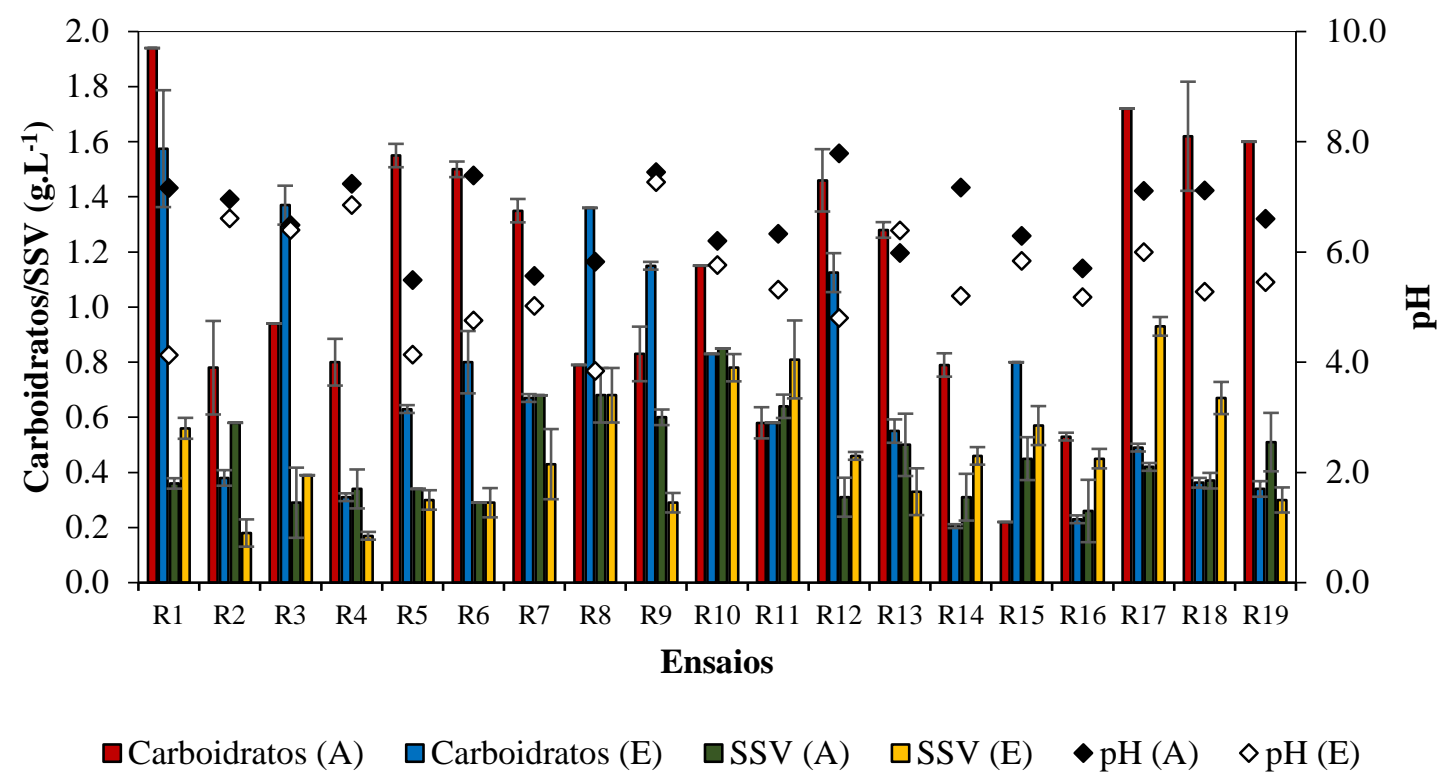

Os maiores $P$ de $\mathrm{H}_{2}$ ocorreram nos reatores com $\mathrm{pH}$ inicial acima de 8,0 , sendo de 13,29 mmol H $2 . L^{-1}$ (R5), 9,53 mmol H2.L ${ }^{-1}$ (R7), 13,23 mmol H2.L $\mathrm{L}^{-1}$ (R10) e 8,59 mmol $\mathrm{H}_{2} \cdot \mathrm{L}^{-1}$ (R13). Todavia, ressalta-se que em pH inicial de 5,5 (R12) também foi observado $P$ de $12,91 \mathrm{mmol} \mathrm{H}_{2} \cdot \mathrm{L}^{-1}$. Além disso, maiores valores de $R m$ também foram associados a estes reatores, sendo de 2,46, 2,09, 1,02, 1,02 e 3,10 $\mathrm{mmol} \mathrm{H}_{2} \cdot \mathrm{h}^{-1}$, respectivamente. VillaMontoya et al. (2019) observaram maior $P\left(29,46 \mathrm{mmol} \mathrm{H}_{2} \cdot \mathrm{L}^{-1} \mathrm{em} \mathrm{pH} \geq 7,0\right.$, em reatores em batelada operados com resíduos do processamento de café como substrato. Além disso, os autores observaram que o aumento do $\mathrm{pH}$ na faixa de 4,0 a 7,0 teve efeito positivo em $P$ e $R m$, de $22,67 \mathrm{mmol} \mathrm{H}_{2} \cdot \mathrm{L}^{-1}$ e $1,18 \mathrm{mmol} \mathrm{H}_{2} \cdot \mathrm{h}^{-1}$, respectivamente.

Entretanto, em pH inicial de 5,5 (R8) e 60\% de headspace, obteve-se menor $P(0,03$ mmol $\left.\mathrm{H}_{2} \cdot \mathrm{L}^{-1}\right)$, bem como maior tempo de início da obtenção de $\mathrm{H}_{2}(20,91 \mathrm{~h})$. Em R5, R10 e R12 com 40\% de headspace e pH de 8,5 (em R5 e R10) e 5,5 (em R12) foram obtidos maiores valores de $P$ e $R m$. 
Figura 5.20. Análise de Componente Principal (PCA) dos parâmetros físico-químicos iniciais (concentração de fenol e carboidratos, SSV e pH) e respostas do modelo de Gompertz (modificado) para os ensaios de screening design. A primeira dimensão (eixo $\mathrm{x} ; 33 \%$ ), está relacionada às variáveis SSV e $\lambda$, enquanto a segunda dimensão (eixo y; 24,3\%) está relacionada as variáveis $P$, concentração de fenóis e carboidratos, $R m$ e pH, totalizando $57,3 \%$ da variância das análises.

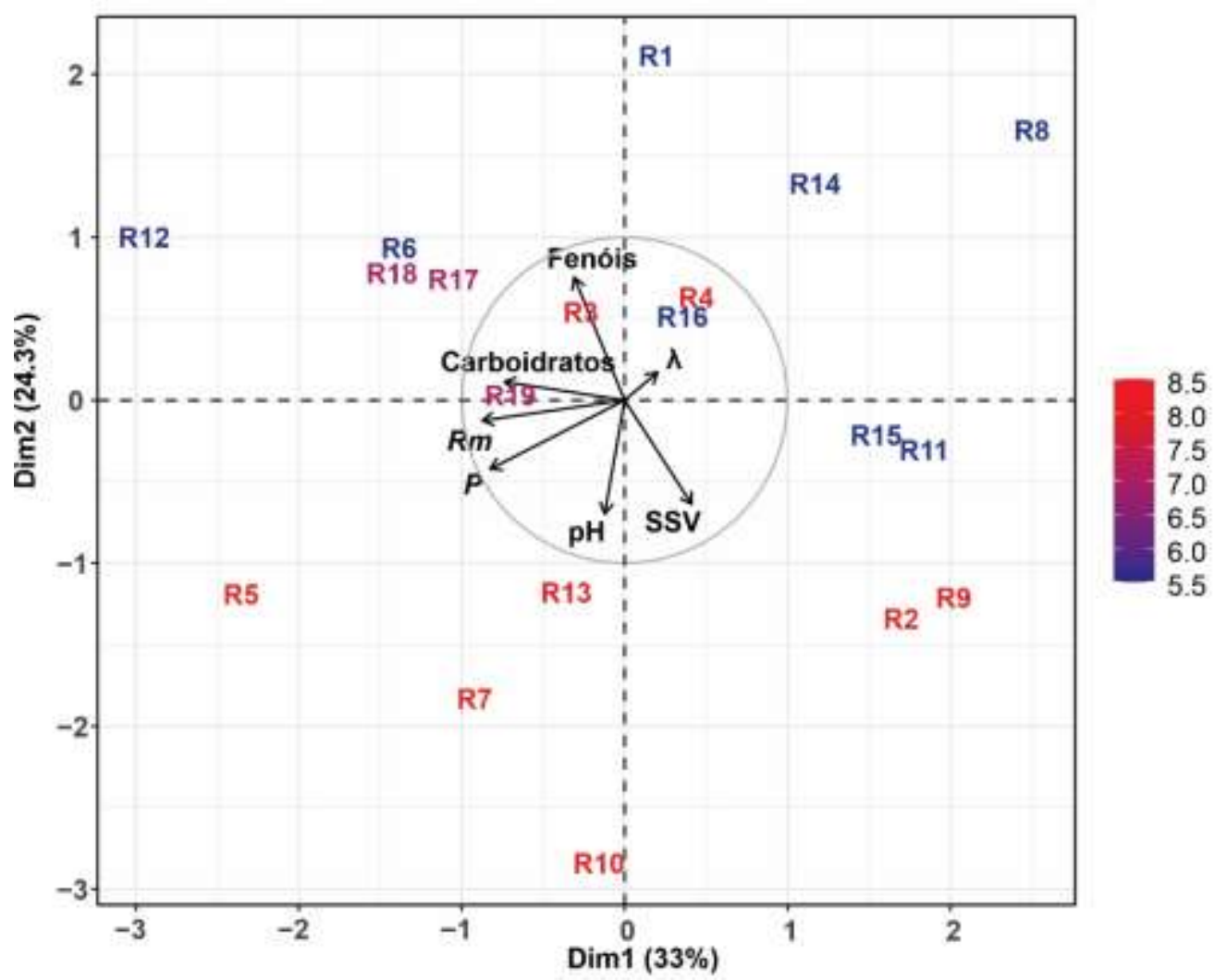

Nota: A escala de cores representa o $\mathrm{pH}$ inicial dos diferentes ensaios. O primeiro e o segundo eixo do PCA representam $57,3 \%$ da variância total.

Os menores valores de $P$ foram observados nos reatores com maiores valores de fenóis, como por exemplo, em R8, de 0,03 mmol $\mathrm{H}_{2} \cdot \mathrm{L}^{-1}$ para 0,82 mg.L $\mathrm{L}^{-1}$ de fenóis. Em R12, com $P$ de 12,91 mmol $\mathrm{H}_{2} \cdot \mathrm{L}^{-1}$, não foi observado acúmulo de compostos fenólicos acima do limite de quantificação de $\leq 0,3 \mathrm{mg} . \mathrm{L}^{-1}$. Além disso, para o aumento da concentração de compostos fenólicos, verificou-se efeito significativo para a variável temperatura $(\mathrm{p}=0,0265)$, sendo que o efeito de sua elevação é positivo $\left(2,58 \mathrm{mg} . \mathrm{L}^{-1} \mathrm{de}\right.$ fenóis totais), ou seja, quanto maior a temperatura de incubação maior será a geração de compostos fenólicos.

De acordo com Monlau et al. (2014), o aumento na concentração de compostos fenólicos pode estar relacionado à biodegradação da lignina. Além disso, de acordo com Sawatdeenarunat et al. (2015), temperaturas termofílicas podem favorecer a biodegradação de resíduos lignocelulósicos. Soares et al. (2017) observaram que a temperatura foi um dos 
fatores mais influentes na obtenção de $\mathrm{H}_{2}$ a partir de bagaço de cana-de-açúcar (pré-tratado via hidrotermólise), sendo que a concentração máxima de $\mathrm{H}_{2}\left(17,7 \mathrm{mmol} \mathrm{H}_{2} \cdot \mathrm{L}^{-1}\right)$ ocorreu a $60{ }^{\circ} \mathrm{C}$, enquanto a menor concentração de $\mathrm{H}_{2}\left(3,5 \mathrm{mmol} \mathrm{H}_{2} \cdot \mathrm{L}^{-1}\right)$ foi observada a $35,8{ }^{\circ} \mathrm{C}$.

Para as variáveis $P, R m$ e $\lambda$, foi possível quantificar os ácidos orgânicos e álcoois ao longo do processo fermentativo. A significância dos resultados foi avaliada para o intervalo de confiança de 90\%, como recomendado em Rodrigues \& Iemma (2014), por meio da comparação dos efeitos e do p-valor e Diagrama de Pareto (Figura 5.18). Entre os compostos orgânicos analisados (HAc, $\mathrm{HBu}, \mathrm{HPr}, \mathrm{HLac}, \mathrm{EtOH})$, apenas a produção de HAc foi significativa (Figura 5.21 A), portanto, foi considerado como resposta do screening design realizado, junto aos demais parâmetros de obtenção de $\mathrm{H}_{2}$ obtidos via modelo de Gompertz (modificado).

Mesmo com resposta não significativa ( $p \geq 0,1$ ), entre os demais compostos mencionados apenas HBu foi observado ao longo do período de incubação (Figura 5.21 B), com concentração máxima em R10 e R12 (528 e 347 mg.L ${ }^{-1}$, respectivamente). Stein et al. (2017) compararam a produção de $\mathrm{HBu}$ em condições mesofílicas $\left(37^{\circ} \mathrm{C}\right) \mathrm{em} \mathrm{pH}$ ácido $(5,5)$ e alcalino $(9,0)$, e concluíram que as condições alcalinas são mais favoráveis à produção de $\mathrm{HBu}$, possivelmente devido a menor solubilização do substrato. Sendo assim, é possível inferir que as condições avaliadas no presente estudo em R10 favoreceram a produção de $\mathrm{HBu}$, possivelmente devido ao $\mathrm{pH}$ mais alcalino deste reator $(8,5) \mathrm{em}$ comparação ao R12 $(5,5)$. 
Figura 5.21. Concentração de HAc (A) e HBu (B) e potencial máximo de concentração de $\mathrm{H}_{2}$ dos ensaios de delineamento de Plackett \& Burman.
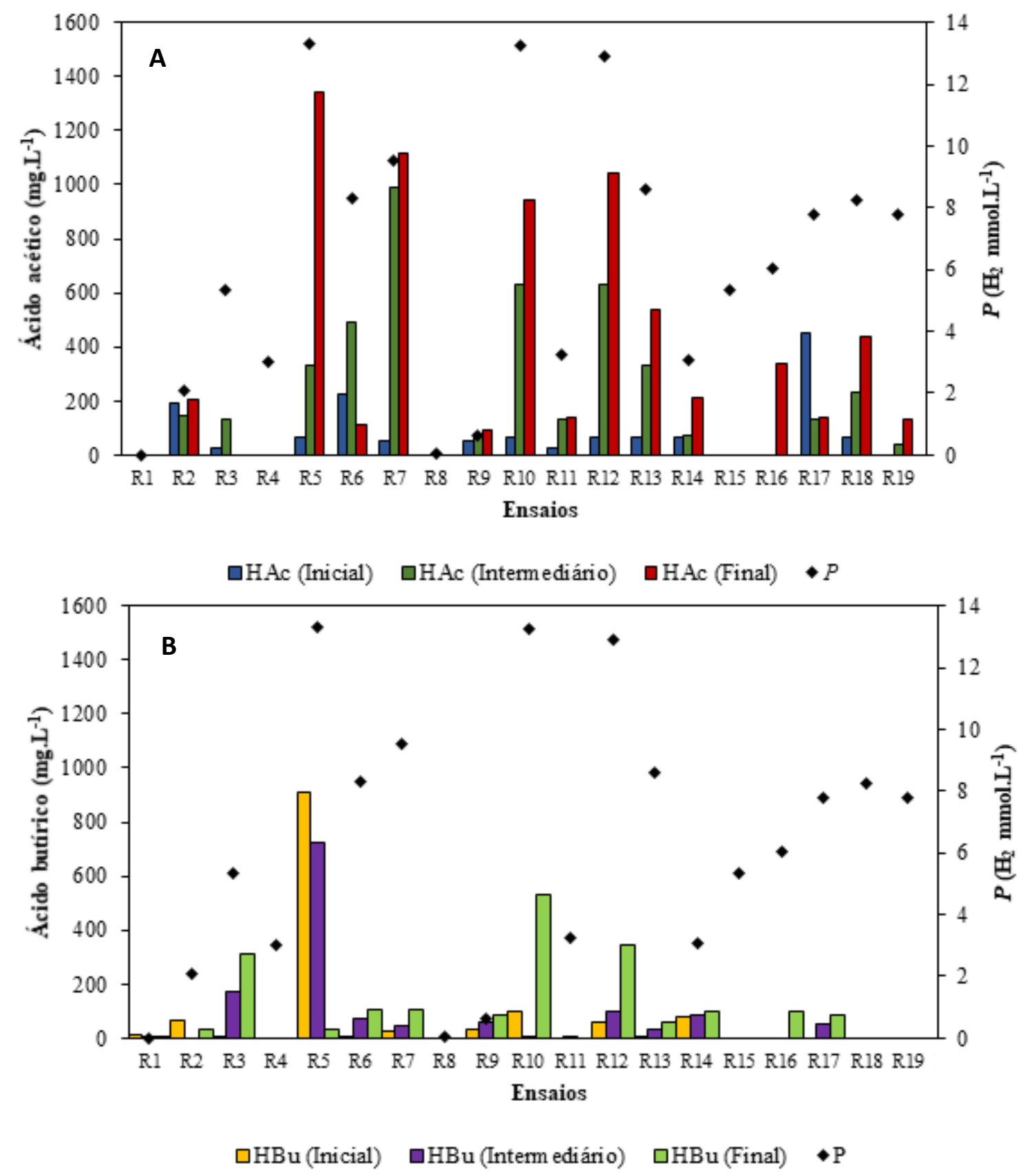

As variáveis significativas para produção de HAc foram as mesmas para $P, R m$ e $\lambda$ de $\mathrm{H}_{2}$. Foi possível observar efeito significativo $(\mathrm{p} \leq 0,1)$ para concentração de substrato, temperatura, $\mathrm{pH}$ e concentração de $\mathrm{CaCO}_{3}$ em relação à produção de $\mathrm{HAc}$. As variáveis relativas à concentração de inóculo, $\mathrm{NaCl}$, extrato de levedura, consórcio autofermentativo, peptona e volume do headspace não foram consideradas significativas para produção de HAc ( $\mathrm{p} \geq 0,1)$. Ainda, foi possível observar efeito positivo da concentração de substrato e pH do meio reacional, em relação ao HAc. Por outro lado, para as variáveis concentração 
de $\mathrm{CaCO}_{3}$ e temperatura, efeito negativo em relação ao HAc foi observado, ou seja, quanto maior a concentração de $\mathrm{CaCO}_{3}$ e maior a temperatura de incubação, menor a concentração de HAc, possivelmente devido ao efeito tamponante do sistema reacional.

Nota-se que a menor produção de HAc foi relacionada aos ensaios de menor concentração de $\mathrm{H}_{2}\left(\mathrm{R} 1\right.$ e R8) de $\leq 0,01$ e $0,07 \mathrm{mmol} \mathrm{H}_{2} . \mathrm{L}^{-1}$, respectivamente. Da mesma forma, nos ensaios com maior produção de HAc foram relacionados com o maior valor de $P$, sendo de 13,29 mmol H $2 . \mathrm{L}^{-1}$ (R5), 9,53 mmol H $2 . \mathrm{L}^{-1}$ (R7), 13,23 mmol H $2 . \mathrm{L}^{-1}$ (R10) e 12,91 $\mathrm{mmol} \mathrm{H} \cdot \mathrm{L}^{-1}$ (R12).

Em relação ao HBu foi possível notar que houve maior concentração em R10 e R12 (528 e 347 mg.L $\mathrm{L}^{-1}$, respectivamente). Em R5, foram obtidos $700 \mathrm{mg} . \mathrm{L}^{-1}$ de $\mathrm{HBu}$ ao longo de $10 \mathrm{~h}$ de operação, entretanto, no final do processo ( $25 \mathrm{~h}$ de operação), esta concentração foi reduzida para apenas $31 \mathrm{mg} . \mathrm{L}^{-1}$. Soares et al. (2019a) também observaram esse mesmo padrão a partir de bagaço de cana-de-açúcar em condições termofílicas $\left(50-70{ }^{\circ} \mathrm{C}\right)$. Entretanto, na presente pesquisa nenhuma das variáveis estudadas teve efeito significativo na produção de $\mathrm{HBu}(\mathrm{p} \geq 0,1)$.

Sabe-se que as vias metabólicas de produção de HAc e $\mathrm{HBu}$ estão intimamente relacionadas à obtenção de $\mathrm{H}_{2}$; ou seja, a partir da glicose tem-se a formação de 4 mols (Equação 3.3) e 2 mols (Equação 3.4), respectivamente.

Além da glicose, a xilose é outro monômero abundante em resíduos sólidos de citros (WILKINS et al., 2007; CHOI et al., 2013, 2015) e a formação de $\mathrm{H}_{2}$ é de 3,33 mol via HAc (Equação 5.1) e 1,67 mol via HBu (Equação 5.2) (MÄKINEN; NISSILÄ; PUHAKKA, 2012).

$$
\begin{aligned}
& \mathrm{C}_{5} \mathrm{H}_{10} \mathrm{O}_{5}+1,67 \mathrm{H}_{2} \mathrm{O} \rightarrow 1,67 \mathrm{C}_{2} \mathrm{H}_{3} \mathrm{O}_{2}^{-}+1,67 \mathrm{H}^{+}+1,67 \mathrm{CO}_{2}+3,33 \mathrm{H}_{2} \\
& \mathrm{C}_{5} \mathrm{H}_{10} \mathrm{O}_{5} \rightarrow 0,83 \mathrm{C}_{4} \mathrm{H}_{7} \mathrm{O}_{2}^{-}+0,83 \mathrm{H}^{+}+1,67 \mathrm{CO}_{2}+1,67 \mathrm{H}_{2}
\end{aligned}
$$

Os efeitos dos diferentes parâmetros analisados sobre as respostas físico-químicas envolvidas no processo encontram-se resumidos na Tabela 5.9. 
Tabela 5.9. Efeito dos diferentes parâmetros na obtenção de $\mathrm{H}_{2}, \mathrm{AOV}$ em reatores em batelada com resíduo sólido de citros.

\begin{tabular}{|c|c|c|c|c|c|c|c|}
\hline \multirow[b]{2}{*}{ Variáveis } & \multicolumn{3}{|c|}{ Obtenção de $\mathbf{H}_{2}$} & \multicolumn{2}{|c|}{ AOV } & \multicolumn{2}{|c|}{ Parâmetros físico-químicos } \\
\hline & $P$ & $R m$ & $\lambda$ & HAc & HBu & $\begin{array}{l}\text { Acúmulo } \\
\text { de Fenóis }\end{array}$ & $\begin{array}{l}\text { Consumo de } \\
\text { carboidratos }\end{array}$ \\
\hline $\mathrm{x}_{1}$ (Temperatura) & $\downarrow \mathrm{x}_{1} \uparrow P$ & $\mathrm{NS}$ & $\widehat{\uparrow \mathrm{x}_{1} \uparrow \lambda}$ & $\downarrow \mathrm{x}_{1} \uparrow \mathrm{HAc}$ & $\mathrm{NS}$ & $\widehat{\uparrow \mathrm{x}_{1} \uparrow p h e}$ & $\mathrm{NS}$ \\
\hline $\mathrm{x}_{2}(\mathrm{pH})$ & $\uparrow \mathrm{x}_{2} \uparrow P$ & NS & $\downarrow \mathrm{x}_{2} \uparrow \lambda$ & $\uparrow \mathrm{x}_{2} \uparrow \mathrm{HAc}$ & NS & NS & NS \\
\hline $\mathrm{x}_{3}$ (Consórcio) & NS & NS & NS & NS & NS & NS & NS \\
\hline $\mathrm{X}_{4}($ Lodo $)$ & $\uparrow \mathrm{x}_{4} \uparrow P$ & $\uparrow \mathrm{x}_{4} \uparrow R m$ & $\downarrow \mathrm{x}_{4} \uparrow \lambda$ & $\uparrow \mathrm{x}_{4} \uparrow \mathrm{HAc}$ & NS & NS & NS \\
\hline $\mathrm{x}_{5}$ (Substrato) & $\uparrow \mathrm{x}_{5} \uparrow P$ & $\uparrow \mathrm{x}_{5} \uparrow R m$ & $\uparrow x_{5} \uparrow \lambda$ & $\uparrow \mathrm{x}_{5} \uparrow \mathrm{HAc}$ & NS & NS & $\uparrow \mathrm{x}_{5} \uparrow c a r b s$ \\
\hline $\mathrm{x}_{6}($ Headspace $)$ & $\downarrow \mathrm{x}_{6} \uparrow P$ & $\downarrow \mathrm{x}_{6} \uparrow R m$ & NS & NS & NS & NS & NS \\
\hline $\mathrm{x}_{7}(\mathrm{YE})$ & NS & $\uparrow \mathrm{x}_{7} \uparrow R m$ & NS & NS & NS & NS & $\downarrow \mathrm{x}_{7} \uparrow c a r b s$ \\
\hline $\mathrm{x}_{8}\left(\mathrm{CaCO}_{3}\right)$ & $\downarrow \mathrm{x}_{8} \uparrow P$ & $\downarrow \mathrm{x}_{8} \uparrow R m$ & NS & $\downarrow \mathrm{X}_{8} \uparrow \mathrm{HAc}$ & NS & NS & $\downarrow \mathrm{x}_{8} \uparrow \operatorname{carbs}$ \\
\hline $\mathrm{X}_{9}(\mathrm{NaCl})$ & NS & NS & NS & $\uparrow \mathrm{X}_{9} \uparrow \mathrm{HAc}$ & NS & NS & NS \\
\hline $\mathrm{x}_{10}$ (Peptona) & $\uparrow \mathrm{x}_{10} \uparrow P$ & NS & $\downarrow \mathrm{x}_{10} \uparrow \lambda$ & NS & NS & NS & NS \\
\hline
\end{tabular}

Nota: $Y E=$ extrato de levedura; acúmulo de fenóis $=p h e$; consume de carboidratos $=$ carbs. $\uparrow=$ aumento devido ao efeito positivo; $\downarrow=$ diminuição devido ao efeito negativo. Apenas o efeito das respostas significativas $(\mathrm{p} \leq 0,1)$ foram considerados, enquanto as demais foram representadas como não significativas (NS). Potencial máximo de concentração de $\mathrm{H}_{2}(P)$, velocidade específica máxima de obtenção de $\mathrm{H}_{2}(R m)$, tempo de início da obtenção de $\mathrm{H}_{2}(\lambda)$ e $\mathrm{R}^{2}$ obtidos da equação de Gompertz modificada.

A partir dos resultados obtidos nesta etapa, considerou-se as amostras dos reatores R5 e R12 para sequenciamento e análise da comunidade microbiana, uma vez que foram as condições nas quais observaram-se maiores concentrações de $\mathrm{H}_{2}$ (R5-13,29 e R12-12,91 mmol H $\mathrm{H}_{2} \mathrm{~L}^{-1}$ ) e maiores concentrações de HAc (R5-1340 e R12-1.040 mg.L $\mathrm{L}^{-1}$ ).

\subsubsection{Análise da comunidade microbiana}

A partir das análises via metabarcoding (RNAr 16S), foi possível caracterizar e comparar a estrutura da comunidade microbiana (Domínio Bacteria) envolvida na fermentação do resíduo de citros, para os ensaios nos quais foram obtidos maiores $P$ (R513,29 e R12-12,91 mmol H2.L $\mathrm{L}^{-1}$ ) e HAc (R5-1340 e R12-1.040 mg.L $\mathrm{L}^{-1}$ ) (Figura 5.22). 
Figura 5.22. Ideograma circular "Circos" representando os gêneros bacterianos identificados nos reatores R5 e R12 dos ensaios de screening design via delineamento de Plackett \& Burman.

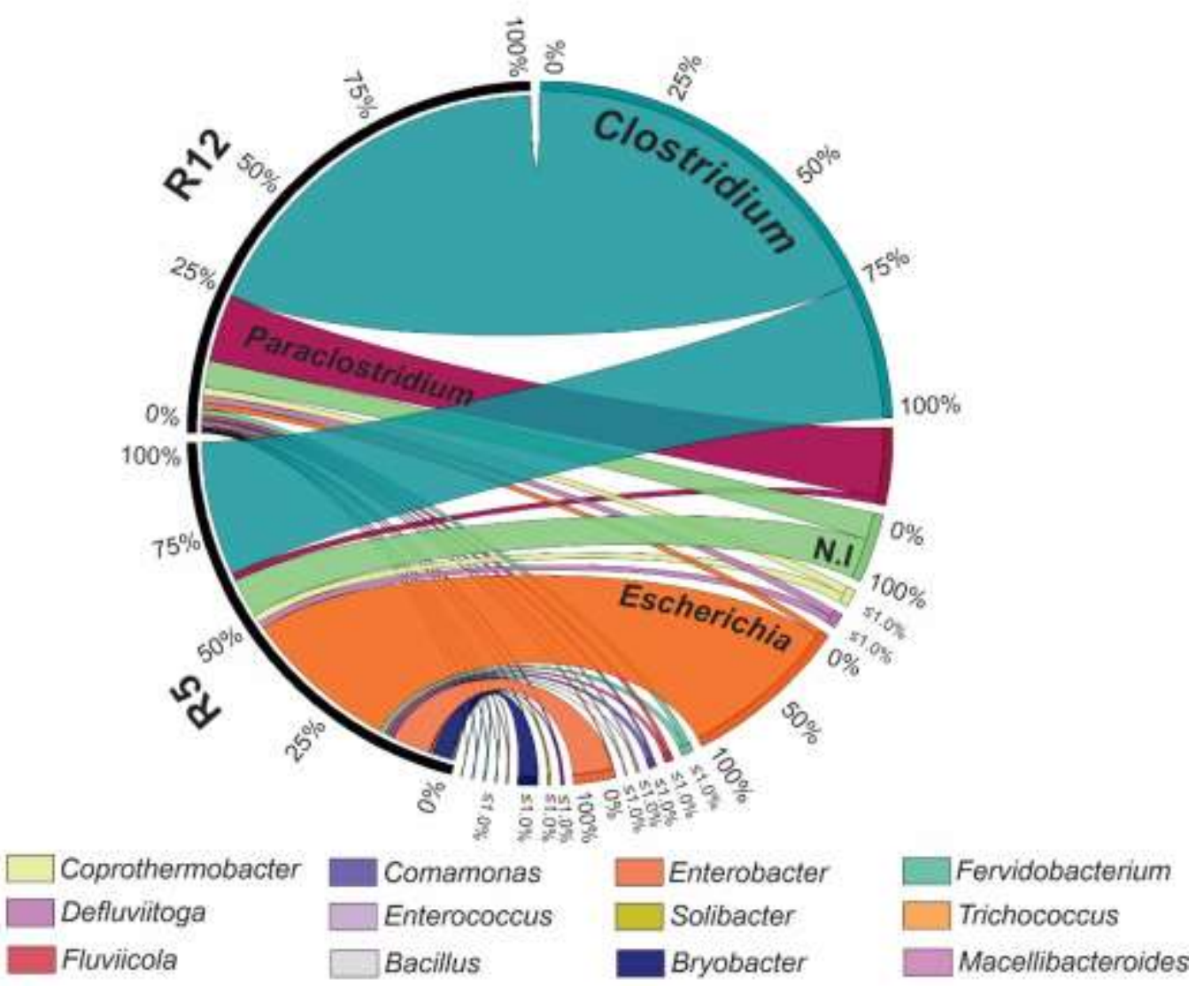

Nota: O círculo exterior representa a abundância relativa em função do número de leituras. N.I= não identificado.

No total, foram obtidas 76.929 sequencias de RNAr 16S com tamanho médio de 412 pb (pares de base), sendo 35.485 sequências para R5 e 41.444 sequências para R12. As OTUs obtidas foram agrupadas considerando-se similaridade $\geq 97 \%$ e, remoção de singletons, sendo 648 para R5 e 581 OTUs para R12. Além disso, os índices de diversidade ecológica foram calculados para cada amostra (Tabela 5.10). A partir dos valores de cobertura ( $\geq 99 \%)$ referentes à proporção de sequências representativas, foi possível notar que a maioria das populações microbianas foi acessada, indicando boa cobertura (Figura $5.23)$. 
Tabela 5.10. Índices ecológicos para as sequencias do RNAr $16 \mathrm{~S}$ via plataforma Illumina dos ensaios R5 e R12.

\begin{tabular}{ccc}
\hline & \multicolumn{2}{c}{ Reatores Anaeróbios } \\
\cline { 2 - 3 } & Parâmetros sequenciamento (RNAr 16S) & R12 \\
\hline Cobertura (\%) & 99,6 & 99,4 \\
Numero total de sequências & 35.485 & 41.444 \\
Comprimento medio (nt) & 418 & 406 \\
GC (\%) & 55,12 & 53,24 \\
Total de OTUs & 648 & 581 \\
& Índices ecológicos & \\
\hline Shannon & 3,936 & 2,789 \\
Simpson & 0,809 & 0,635 \\
Chao-1 & 643,138 & 585,484 \\
\hline
\end{tabular}

Figura 5.23. Curvas de rarefação do RNAr $16 \mathrm{~S}$ via plataforma Illumina HiSeq para os reatores R5 e R12.

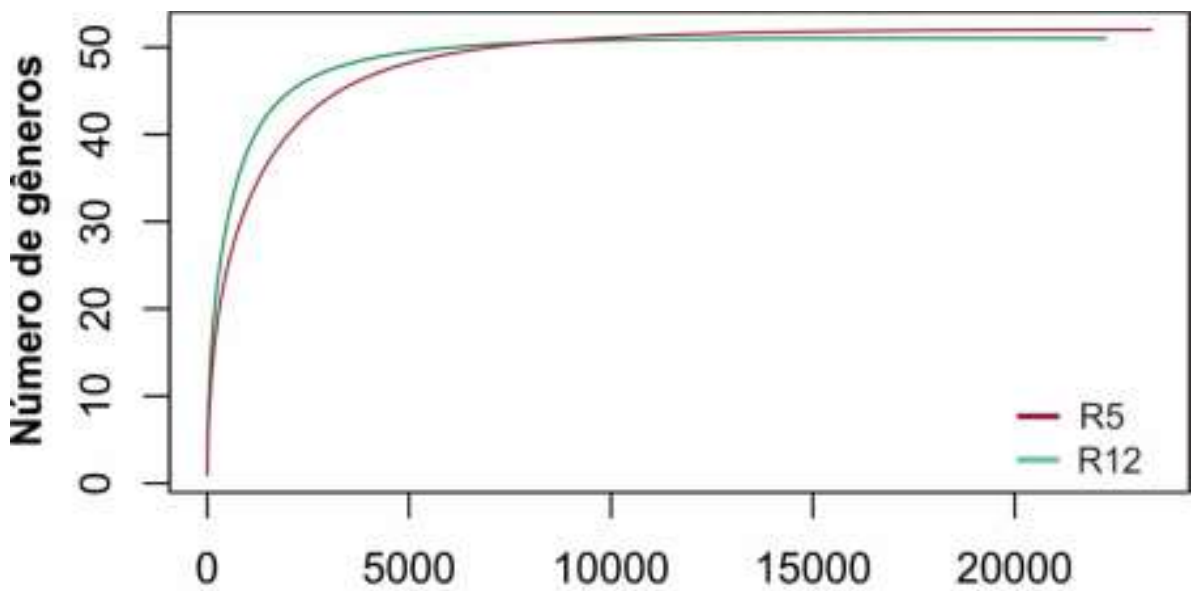

Tamanho da amostra

Os reatores R5 e R12 foram inoculados com a mesma quantidade de inóculo alóctone (3 gSTV.L $\left.{ }^{-1}\right)$ e 0,75 e 2,25 g.L $\mathrm{L}^{-1}$ de inóculo autóctone, respectivamente. Apesar disso, maior diversidade de Shannon foi observada em R5 (2,01), quando comparado a R12 $(1,49)$, bem como para o índice de Simpson (0,76 e 0,59, respectivamente). Entretanto, como mencionado anteriormente, o aumento da concentração de biomassa autóctone nos reatores não foi considerado significativo para nenhum dos parâmetros avaliados no processo fermentativo $(\mathrm{p} \geq 0,1)$.

Os filos mais abundantes foram Firmicutes $(88,87$ e 40,69\% para R5 e R12, respectivamente) e Proteobacteria (4,11 e 47,93\% para R5 e R12, respectivamente). Organismos do filo Firmicutes são abundantes em reatores anaeróbios, comumente associados as interações sintróficas e produção de diversos AOV, como HAc e HBu (VOS 
et al., 2009), condizente com os principais metabolitos obtidos na presente pesquisa (HAc $1.340 \mathrm{mg} . \mathrm{L}^{-1}$ e $\left.\mathrm{HBu} 528 \mathrm{mg} . \mathrm{L}^{-1}\right)$.

Clostridium foi identificado em ambos os reatores, sendo mais abundante em R12 (70,87\%) em relação ao R5 (29,93\%). De acordo com Vos et al. (2009), a biotina é uma das principais vitaminas requeridas por Clostridium. Desta forma, a maior abundância relativa de Clostridium em R12 quando comparado a R5 pode ser justificada pela composição do meio reacional, uma vez que em R5 não houve suplementação com extrato de levedura, rico em biotina (SATO et al., 1992). Entretanto, a partir dos dados operacionais, constatou-se que a concentração de $\mathrm{H}_{2}$ foi similar em ambos os ensaios $(12,91$ e 13,29 mmol $\mathrm{H}_{2} \cdot \mathrm{L}^{-1}$, respectivamente), indicando que a influência deste componente no meio de cultura não foi significativa para $P$. Desse modo, com a finalidade de tornar o processo fermentativo mais vantajoso a ausência de suplementação com extrato de levedura poderá favorecer a redução dos custos, tornando atrativa sua ampliação à escala real (GROOTSCHOLTEN et al., 2013).

Na caracterização do inóculo bruto, Soares et al. (2017) observaram apenas 6,42\% de abundância relativa para Clostridium em lodo de reator UASB aplicado ao processamento termofílico de vinhaça, semelhante ao utilizado no presente estudo. Provavelmente, as condições reacionais de $\mathrm{R} 12\left(44{ }^{\circ} \mathrm{C}, 40 \%\right.$ de headspace, $\mathrm{pH}$ 5,5 e 15 g.L $\mathrm{L}^{-1}$ de substrato) foram favoráveis para tais bactérias. De acordo com Valentín-Reyes (2018), bactérias deste gênero são comumente resistentes à elevada pressão parcial de $\mathrm{H}_{2}$. Desta forma, é possível inferir que menor volume de headspace (40\%) utilizado na presente pesquisa pode ter contribuído para a prevalência de Clostridium nestes reatores (R12 e R5).

Resultados similares foram observados também por Rabelo et al. (2018a), uma vez que Clostridium foi o gênero mais abundante em reatores anaeróbios aplicados a fermentação mesofílica de bagaço de cana-de-açúcar. Da mesma forma, Villa-Montoya et al. (2019) observaram maior abundância relativa de Clostridium em pH superior a 7,0 e temperatura mesofílica $\left(30^{\circ} \mathrm{C}\right)$ a partir de resíduos do processamento de café.

Paraclostridum foi o segundo gênero identificado em maior abundância relativa no ensaio R12 (12,89\%), enquanto em R5, este gênero foi observado em apenas 1,52\% de abundância relativa. Uma vez que, ao contrário de R5, no ensaio R12 houve suplementação com 1 g. $\mathrm{L}^{-1}$ de extrato de levedura. Provavelmente, a composição do meio pode ter favorecido estas bactérias em R12. Rabelo et al. (2020) isolaram uma cepa de 
Paraclostridium CR4 a partir de bagaço de cana-de-açúcar, e indicaram sua recorrência em resíduos lignocelulósicos e seu potencial para obtenção de $\mathrm{H}_{2}$ a partir deste tipo de substrato. Além disso, os autores supracitados suplementaram o meio de cultura utilizado para isolamento desta cepa com 1 g.L $\mathrm{L}^{-1}$ de extrato de levedura, mesma concentração utilizada na presente pesquisa em R12. De acordo com Yang et al. (2019), além de Paraclostridium ser um dos gêneros mais dominantes em lodo anaeróbio de esgoto doméstico, a dominância deste gênero pode ser comumente associada à elevada obtenção de $\mathrm{H}_{2}$ em reatores anaeróbios, com concomitante produção de HAc.

Escherichia é bactéria resistente ao limoneno, um dos principais inibidores presentes em resíduo sólido de citros (CALABRÒ et al., 2016), sendo identificada em maior abundância relativa em R5 (34,5\%), enquanto em R12 a abundância foi de apenas 1,18\%. Da mesma forma, a abundância relativa observada para Enterobacter nos ensaios R5 e R12 foi de 8,55 e 0,26\%, respectivamente, ambos do filo Proteobacteria (família Enterobacteriaceae) e geralmente crescem em temperatura ótima na faixa mesofílica (22$37{ }^{\circ} \mathrm{C}$ ) e pH 7,0 (BRENNER; KRIEG; STALEY, 2005). Provavelmente, as condições operacionais em $\mathrm{R} 12\left(44^{\circ} \mathrm{C}, \mathrm{pH} 8,5\right)$ não foram favoráveis a estas bactérias. Além disso, é importante salientar que HAc é o principal metabolito produzido por estes gêneros, o que condiz com o observado ao final do período de incubação em R5 (1.340 mg.L $\left.\mathrm{L}^{-1}\right)$, superior ao observado em R12 (1.040 mg.L $\left.\mathrm{L}^{-1}\right)$.

Coprothermobacter, foi identificado com abundância relativa de 1,89\% em R5 e 1,63\% em R12. Soares et al. (2017) também identificaram esse gênero com abundância relativa de $41,73 \%$ no inóculo de mesma origem, possivelmente devido à sua afinidade às condições termofílicas $\left(50-70{ }^{\circ} \mathrm{C}\right.$ ) (GAGLIANO et al., 2015), como o reator UASB aplicado ao processamento termofílico de vinhaça de cana-de-açúcar. Além das menores temperaturas utilizadas no presente estudo $\left(30-44{ }^{\circ} \mathrm{C}\right)$, a menor abundância relativa observada em reatores aplicados à obtenção de $\mathrm{H}_{2}$ pode ser justificada porque bactérias deste gênero são conhecidas por estabelecer relações sintróficas com arqueias hidrogenotróficas, as quais foram identificadas em abundância relativa $\leq 0,01 \%$.

As bactérias anaeróbias termofílicas da família Thermotogae (Defluviitoga e Fervidobacterium) são comumente identificadas em reatores aplicados à digestão anaeróbia de resíduos lignocelulósicos, como silagem de milho e cevada (MAUS et al., 2015). Apesar de sua faixa ótima de crescimento a $55^{\circ} \mathrm{C}$ (HANIA et al., 2012) foram identificadas em maior abundância em R5 (1,57 e 1,19\%) quando comparado a R12 (1,33 
e $1,12 \%$ ) operados a 30 e $44{ }^{\circ} \mathrm{C}$, respectivamente. Maus et al. (2015) observaram que o principal metabolito acumulado a partir da fermentação de carboidratos complexos (xilano e celulose) por cepa de D. tunisiensis L3 foi HAc, com concomitante obtenção de $\mathrm{H}_{2}$. Da mesma forma, no presente estudo foi observada maior produção de HAc em R5 (1.340 mg. $\mathrm{L}^{-1}$ ), bem como maior abundância relativa destes gêneros.

Os demais gêneros identificados com abundância relativa superior a 1,0\% foram Trichococcus (4,19 e 0,11\%) e Comamonas (1,04 e 0,49\%) para os ensaios R5 e R12, respectivamente. Membros do gênero Trichococcus são comumente identificados em lodos de esgoto, sendo que sua temperatura ótima é entre 25-30 ${ }^{\circ} \mathrm{C}$ (PARSHINA et al., 2019), o que pode explicar sua maior abundância relativa em $\mathrm{R} 5$, operado a $30{ }^{\circ} \mathrm{C}$, quando comparado a R12, operado a $44{ }^{\circ} \mathrm{C}$. Da mesma forma, Anaerobaculum, Symbiobacterium e Thermoanaerobacterium, relatados por Soares et al. (2017) com abundância relativa de $21,51 \%, 6,20 \%$ e $1,61 \%$ em lodo de reator UASB aplicado ao processamento termofílico de vinhaça de cana-de-açúcar, foram identificados abaixo de $0,01 \%$, tanto para $\mathrm{R} 5$, quanto para R12 no presente estudo, no qual utilizou-se o mesmo inóculo. Entretanto, como enfatizado por Benomar et al. (2015), mesmo gêneros pouco abundantes em determinado sistema podem contribuir significativamente para a obtenção de $\mathrm{H}_{2}$ e demais metabolitos, devido a sua importância para reações sintróficas e, ainda, interações célula-célula.

$\mathrm{Na}$ Figura 5.24, é possível resumir a relação entre a comunidade microbiana observada nas amostras nas quais houve maior potencial máximo de concentração de $\mathrm{H}_{2}$ (R5, 13,29 mmol $\left.\mathrm{H}_{2} \cdot \mathrm{L}^{-1}\right)$ e maior velocidade específica máxima de obtenção de $\mathrm{H}_{2}(3,10$ mmol $\left.\mathrm{H}_{2} \cdot \mathrm{h}^{-1}\right)$. Os gêneros associados ao inóculo alóctone utilizado foram Clostridium, Coprothermobacter, Enterobacter, Escherichia e Defluviitoga (SOARES et al., 2017).

Além disso, foi possível estabelecer relação direta entre o aumento de 1 para 2 gSTV.L ${ }^{-1}$ de inóculo alóctone $\left(\mathrm{x}_{4}\right)$ com o aumento de $P, R m$ e produção de HAc, possivelmente porque, com exceção de Escherichia, os demais gêneros mencionados estão relacionados com a obtenção de $\mathrm{H}_{2}$ e HAc durante o processo de fermentação (VOS et al., 2009; HANIA et al., 2012; GAGLIANO et al., 2015; MAUS et al., 2015; RABELO et al., 2018a; SOARES et al., 2019b). Não foi possível estabelecer o mesmo tipo de relação para o inóculo autóctone $\left(\mathrm{x}_{3}\right)$, uma vez que este parâmetro não foi considerado como significativo, entretanto, com base em trabalhos anteriores (BAKKALI et al., 2008; 
CALABRÒ et al., 2016; MUBARAK; SORAYA, 2018), os gêneros identificados no inóculo autóctone foram Clostridium, Paraclostridium, Enterobacter e Escherichia.

Foi possível relacionar as concentrações de substrato $\left(\mathrm{x}_{5}\right)$, extrato de levedura $\left(\mathrm{x}_{7}\right)$ e $\mathrm{CaCO}_{3}\left(\mathrm{x}_{8}\right)$ com o consumo de carboidratos solúveis. Os principais gêneros relacionados com a etapa de hidrólise na presente pesquisa foram Clostridium e Paraclostridium, ambos em maior abundância relativa em R12 (70,87 e 12,89\%) quando comparados a R5 (29,93 e $1,52 \%$, respectivamente). A maior abundância relativa de grupos hidrolíticos em R12 pode ser um dos fatores responsáveis pelo maior $R m$ em R12 (3,10 mmol $\left.\mathrm{H}_{2} \cdot \mathrm{h}^{-1}\right)$ em relação a R5 $\left(2,46 \mathrm{mmol} \mathrm{H}_{2} \cdot \mathrm{h}^{-1}\right)$.

Por fim, os principais gêneros envolvidos com a produção de HAc e concomitante obtenção de $\mathrm{H}_{2}$ observados foram Paraclostridium, Clostridium, Enterobacter e Defluviitoga (VOS et al., 2009; HANIA et al., 2012; GAGLIANO et al., 2015; MAUS et al., 2015; RABELO et al., 2018a; SOARES et al., 2019b). Em relação à hidrólise, a maior abundância de Clostridium e Paraclostridium em R12 pode ter favorecido a maior velocidade específica máxima de obtenção de $\mathrm{H}_{2}$ neste ensaio $\left(3,10 \mathrm{mmol} \mathrm{H}_{2} \cdot \mathrm{h}^{-1}\right)$, apesar de concentrações similares de $\mathrm{H}_{2}$ em R5 e R12 (13,29 e 12,91 mmol H2.L $\mathrm{L}^{-1}$, respectivamente). 
Figura 5.24. Possíveis vias de conversão de resíduos sólidos de citros (RSC) em carboidratos, AOV e $\mathrm{H}_{2}$ e abundância relativa de gêneros relacionados aos inóculos alóctone e autóctone, hidrólise e acidogênese. Os valores entre parênteses representam abundância relativa nos ensaios R5 e R12, respectivamente. As setas vermelhas representam o efeito positivo $(\uparrow)$ ou negativo $(\downarrow)$ em cada variável (x1-x10) em diferentes respostas $(P, R m, \lambda, \mathrm{HAc})$.

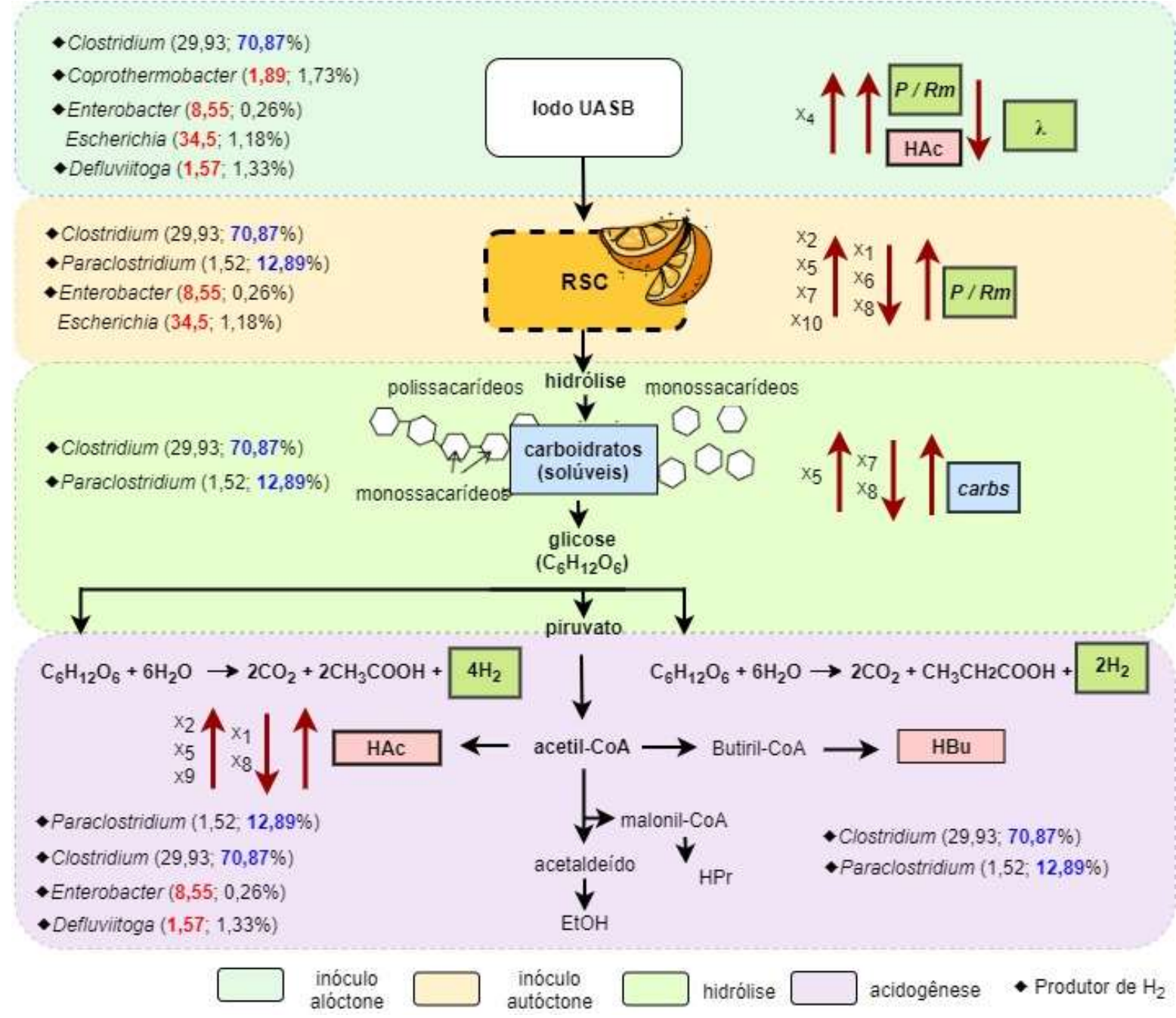

Fonte: Elaboração própria.

A partir dos resultados obtidos nesta etapa, considerou-se o $\mathrm{pH}$, concentração de inóculo alóctone e concentração de substrato como variáveis significativas para obtenção de $\mathrm{H}_{2}$ a partir de resíduos sólidos de citros. Além disso, uma vez que foi possível estabelecer entre os componentes do meio PCS (peptona, $\mathrm{NaCl}$, extrato de levedura e $\mathrm{CaCO}_{3}$ ), apenas efeito significativo da peptona na obtenção de $\mathrm{H}_{2}$, os demais componentes não foram considerados nos ensaios realizados nas demais etapas. 
Desta forma, considerou-se como variáveis independentes para os ensaios de otimização via DCCR a concentração de inóculo ( $x_{1} ; 2,32-5,68$ gSTV.L $\left.{ }^{-1}\right)$, concentração de substrato $\left(\mathrm{x}_{2} ; 1,55-28,45\right.$ g.L.-1) e $\mathrm{pH}\left(\mathrm{x}_{3} ; 4,32-7,68\right)$.

\subsection{OTIMIZAÇÃO DA OBTENÇÃO DE $\mathrm{H}_{2}$ VIA DELINEAMENTO} COMPOSTO CENTRAL ROTACIONAL

\subsubsection{Delineamento Composto Central Rotacional (DCCR)}

O Delineamento Composto Central Rotacional (DCCR) foi realizado de acordo com os resultados obtidos no screening design via delineamento de Plackett \& Burman, cujas condições fixadas foram as seguintes: concentração de consórcio autóctone fermentativocelulolítico $(5 \%)$, temperatura $\left(30{ }^{\circ} \mathrm{C}\right)$, volume do headspace $(40 \%)$ e concentração de peptona $\left(5 \mathrm{~g} . \mathrm{L}^{-1}\right)$.

A fim de avaliar a influência das variáveis independentes de concentração de inóculo $\left(\mathrm{x}_{1} ; 2,32-5,68\right.$ gSTV.L $\left.{ }^{-1}\right)$, concentração de substrato $\left(\mathrm{x}_{2} ; 1,55-28,45\right.$ g.L.-1 $)$ e $\mathrm{pH}$ $\left(\mathrm{X}_{3} ; 4,32-7,68\right)$, realizou-se o delineamento fatorial completo de $2^{3}$, incluindo 6 pontos axiais e 3 repetições no ponto central, totalizando 17 ensaios em triplicata (Figura 5.25).

Figura 5.25. Variação da concentração de hidrogênio dos ensaios de DCCR.

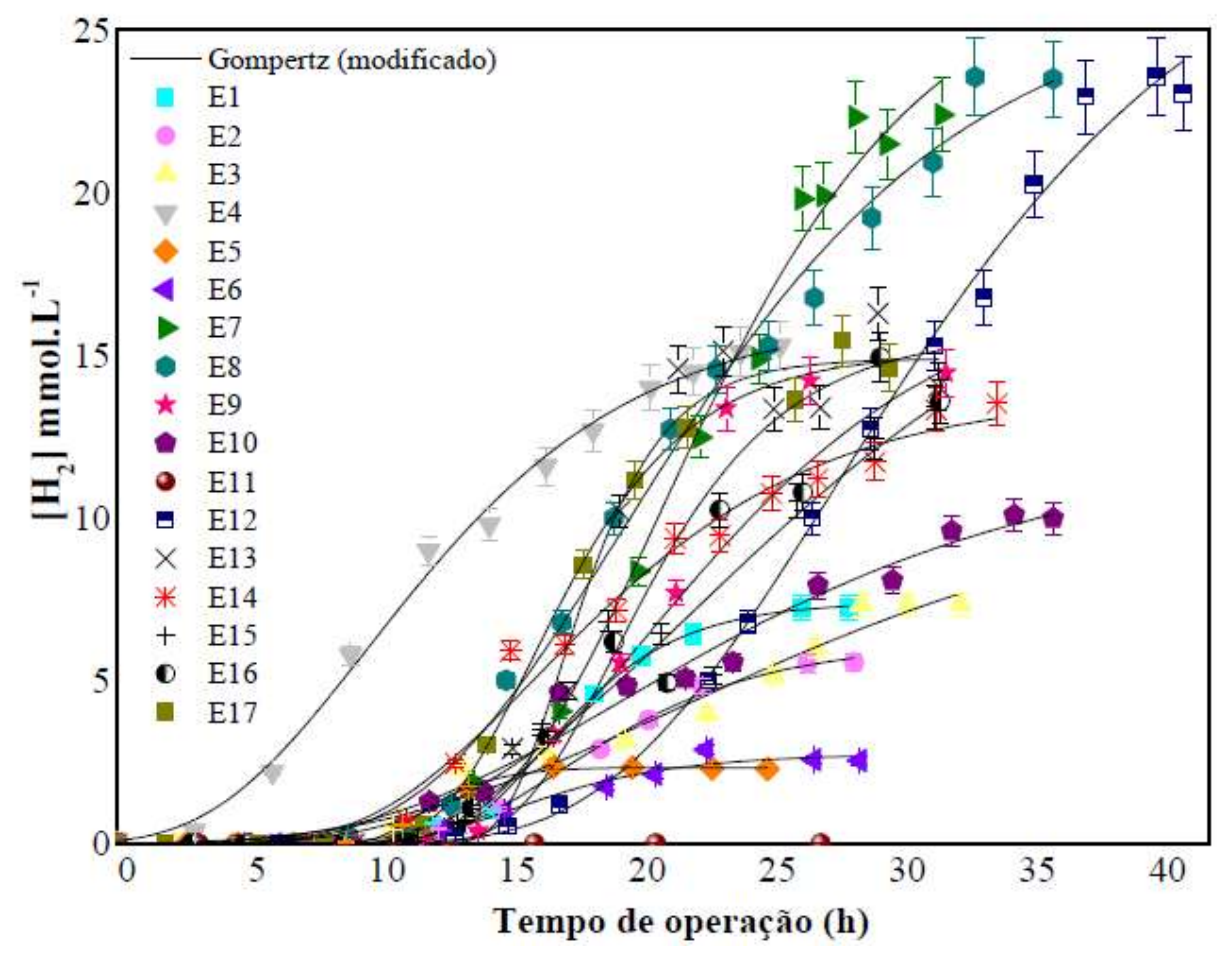

As condições experimentais e os resultados obtidos para as respostas $P\left(\mathrm{Y}_{1}\right), R m$ $\left(\mathrm{Y}_{2}\right)$ e $\lambda\left(\mathrm{Y}_{3}\right)$ e valores de significância para estas respostas e suas interações encontram-se resumidas na Tabela 5.11 e Tabela 5.12, respectivamente. Conforme as condições 
estabelecidas para cada ensaio, foram obtidos $P$ entre 0,01 (E11) e $29,26 \mathrm{mmol} \mathrm{H}_{2} \cdot \mathrm{L}^{-1}$ (E8), $R m$ entre 0,01 (E11) e 2,48 mmol $\mathrm{H}_{2} \cdot \mathrm{h}^{-1}$ (E13) e $\lambda$ entre 3,74 (E4) e $20 \mathrm{~h}(\mathrm{E} 8$ ).

Tabela 5.11. Respostas relativas à obtenção de hidrogênio nos ensaios de DCCR.

\begin{tabular}{|c|c|c|c|c|c|c|c|}
\hline \multirow[b]{2}{*}{ Ensaios } & \multicolumn{3}{|c|}{ Variáveis } & \multicolumn{3}{|c|}{ Respostas } & \multirow[b]{2}{*}{$\mathbf{R}^{2}$} \\
\hline & $\begin{array}{c}\text { Inóculo } \\
\left.\text { (gSTV.L }^{-1}\right)\end{array}$ & $\begin{array}{c}\text { Substrato } \\
\left(\text { g. } \mathrm{L}^{-1}\right)\end{array}$ & $\mathbf{p H}$ & 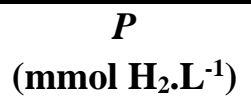 & $\begin{array}{c}R m \\
\left(\mathbf{m m o l ~ H}_{2} \cdot \mathbf{h}^{-1}\right)\end{array}$ & $\begin{array}{c}\lambda \\
\text { (h) }\end{array}$ & \\
\hline E1 & 3,0 & 7,0 & 4,5 & $7,44 \pm 0,1$ & $0,91 \pm 0,1$ & $13,22 \pm 0,3$ & 0,98 \\
\hline E2 & 5,0 & 7,0 & 4,5 & $6,17 \pm 0,2$ & $0,52 \pm 0,0$ & $12,70 \pm 0,3$ & 0,99 \\
\hline E3 & 3,0 & 23,0 & 4,5 & $11,24 \pm 2,6$ & $0,37 \pm 0,0$ & $10,21 \pm 1,1$ & 0,97 \\
\hline E4 & 5,0 & 23,0 & 4,5 & $16,29 \pm 0,5$ & $1,02 \pm 0,1$ & $3,74 \pm 0,4$ & 0,99 \\
\hline E5 & 3,0 & 7,0 & 7,5 & $2,35 \pm 0,0$ & $0,52 \pm 0,0$ & $9,88 \pm 0,2$ & 0,98 \\
\hline E6 & 5,0 & 7,0 & 7,5 & $2,75 \pm 0,2$ & $0,28 \pm 0,0$ & $11,43 \pm 0,8$ & 0,98 \\
\hline E7 & 3,0 & 23,0 & 7,5 & $27,39 \pm 1,2$ & $1,72 \pm 1,1$ & $15,0 \pm 0,5$ & 0,99 \\
\hline E8 & 5,0 & 23,0 & 7,5 & $29,26 \pm 1,4$ & $1,20 \pm 0,1$ & $20,0 \pm 0,5$ & 0,96 \\
\hline E9 & 2,3 & 15,0 & 6,0 & $15,66 \pm 1,1$ & $1,56 \pm 0,3$ & $15,41 \pm 0,8$ & 0,98 \\
\hline E10 & 5,7 & 15,0 & 6,0 & $12,10 \pm 1,3$ & $0,47 \pm 0,0$ & $9,99 \pm 1,0$ & 0,98 \\
\hline E11 & 4,0 & 1,5 & 6,0 & $0,01 \pm 5,2$ & $0,01 \pm 0,0$ & $8,52 \pm 0,3$ & 0,98 \\
\hline E12 & 4,0 & 28,5 & 6,0 & $20,75 \pm 1,7$ & $1,46 \pm 0,1$ & $19,61 \pm 0,4$ & 0,96 \\
\hline E13 & 4,0 & 15,0 & 3,5 & $14,90 \pm 0,6$ & $2,48 \pm 0,5$ & $14,89 \pm 0,6$ & 0,97 \\
\hline E14 & 4,0 & 15,0 & 8,5 & $13,85 \pm 0,7$ & $0,82 \pm 0,0$ & $9,86 \pm 0,7$ & 0,98 \\
\hline E15 & 4,0 & 15,0 & 6,0 & $19,69 \pm 6,9$ & $0,76 \pm 0,1$ & $12,80 \pm 1,3$ & 0,95 \\
\hline E16 & 4,0 & 15,0 & 6,0 & $17,51 \pm 3,0$ & $0,95 \pm 0,5$ & $13,69 \pm 1,1$ & 0,96 \\
\hline E17 & 4,0 & 15,0 & 6,0 & $15,69 \pm 0,3$ & $1,63 \pm 0,1$ & $12,47 \pm 0,3$ & 0,99 \\
\hline Otimizado & 4,0 & 29,8 & 8,98 & $48,47 \pm 2,2$ & $4,69 \pm 0,6$ & $17,35 \pm 0,6$ & 0,97 \\
\hline Não otimizado & 2,0 & 15 & 7,0 & $13,31 \pm 0,7$ & $1,27 \pm 0,2$ & $4,60 \pm 1,0$ & 0,94 \\
\hline
\end{tabular}

Nota: Os erros apresentados ( \pm ) correspondem ao desvio padrão calculado em cada condição para os resultados obtidos por meio do modelo de Gompertz. Potencial máximo de concentração de $\mathrm{H}_{2}(P)$, velocidade específica máxima de obtenção de $\mathrm{H}_{2}(R m)$, tempo de início da obtenção de $\mathrm{H}_{2}(\lambda)$ e $\mathrm{R}^{2}$ obtidos da equação de Gompertz modificada. 
Tabela 5.12. Valores de significância para o intervalo de confiança de $10 \%$ das respostas para as variáveis dos ensaios de DCCR.

\begin{tabular}{cccc}
\hline & \multicolumn{3}{c}{ p-valor } \\
\hline Interações & $P$ & $R m$ & $\lambda$ \\
\hline $\mathrm{x}_{1}$ & 0,0000 & 0,0132 & 0,0005 \\
$\mathrm{x}_{1}{ }^{2}$ & 0,9956 & 0,3256 & 0,5086 \\
$\mathrm{x}_{2}$ & 0,2003 & 0,5730 & 0,7743 \\
$\mathrm{x}_{2}{ }^{2}$ & 0,0000 & 0,0799 & 0,1812 \\
$\mathrm{x}_{3}$ & 0,0267 & 0,2888 & 0,8938 \\
$\mathrm{x}_{3}{ }^{2}$ & 0,1336 & 0,4198 & 0,5790 \\
$\mathrm{x}_{1} \cdot \mathrm{x}_{2}$ & 0,2626 & 0,5238 & 0,6997 \\
$\mathrm{x}_{1} \cdot \mathrm{x}_{3}$ & 0,3900 & 0,6664 & 0,8186 \\
$\mathrm{x}_{2} \cdot \mathrm{x}_{3}$ & 0,8641 & 0,5650 & 0,2382 \\
\hline
\end{tabular}

Nota: $\mathrm{x}_{1}=$ Concentração de inóculo $\left(\mathrm{gSTV} . \mathrm{L}^{-1}\right) ; \mathrm{x}_{2}=$ Concentração de substrato $\left(\mathrm{g} . \mathrm{L}^{-1}\right) ; \mathrm{x}_{3}=\mathrm{pH}$. Potencial máximo de concentração de $\mathrm{H}_{2}(P)$, velocidade específica máxima de obtenção de $\mathrm{H}_{2}(R m)$, tempo de início da obtenção de $\mathrm{H}_{2}(\lambda)$ e $\mathrm{R}^{2}$ obtidos da equação de Gompertz modificada.

Estudos envolvendo a variação de único fator por vez acabam não sendo totalmente representativos, uma vez que a partir dessa possibilidade, não se tem análise da influência entre os diferentes fatores (JUNG et al., 2011). O aumento da temperatura, por exemplo, está relacionado com o aumento do metabolismo celular (INFANTES et al., 2011). Entretanto, seu aumento também está relacionado ao aumento da permeabilidade celular em função da inibição por AOV não dissociados, o que justifica o estabelecimento de uma faixa ótima para cada processo, uma vez que há maior gasto de energia para manter o $\mathrm{pH}$ intracelular e menor síntese de biomassa.

O modelo de regressão (reparametrizado) obtido para a resposta $P\left(\mathrm{Y}_{1}\right)$ ao nível de significância de $10 \%$, conta apenas com os termos estatisticamente significativos $(p \leq 0,1)$, sendo dois termos lineares $\left(\mathrm{x}_{2}\right.$ e $\left.\mathrm{x}_{3}\right)$, um termo quadrático $\left(\mathrm{x}_{2}^{2}\right)$ e uma interação $\left(\mathrm{x}_{2} \cdot \mathrm{x}_{3}\right)$, referentes às variáveis de $\mathrm{pH}\left(\mathrm{x}_{2}\right)$ e concentração de substrato e $\mathrm{pH}\left(\mathrm{x}_{3}\right)$ (Equação 5.3). Para a referida resposta, a variável de concentração de inóculo $\left(\mathrm{x}_{1}\right)$ não foi considerada como significativa $(\mathrm{p}=0,9972)$ dentro do intervalo de confiança de $10 \%$, bem como sua interação com as demais variáveis (Figura 5.26).

$$
Y_{1}=15,29+7,35 x_{2}-1,97 x_{2}^{2}+1,38 x_{3}+4,70 x_{2} x_{3}
$$

sendo,

$\mathrm{Y}_{1}=P$, concentração máxima predita de $\mathrm{H}_{2}$;

$\mathrm{x}_{2}=\mathrm{pH}$, efeito linear;

$\mathrm{x}_{2}{ }^{2}=\mathrm{pH}$, efeito quadrático; 
$\mathrm{X}_{3}=$ concentração de substrato $\left(\mathrm{g} \cdot \mathrm{L}^{-1}\right)$, efeito linear;

$\mathrm{X}_{2} \mathrm{X}_{3}=$ interação entre $\mathrm{x}_{2} \mathrm{e} \mathrm{X}_{3}$.

Figura 5.26. Diagrama de Pareto ilustrando a significância dos resultados obtidos para a resposta $P$ para $o$ intervalo de confiança de $90 \%$.

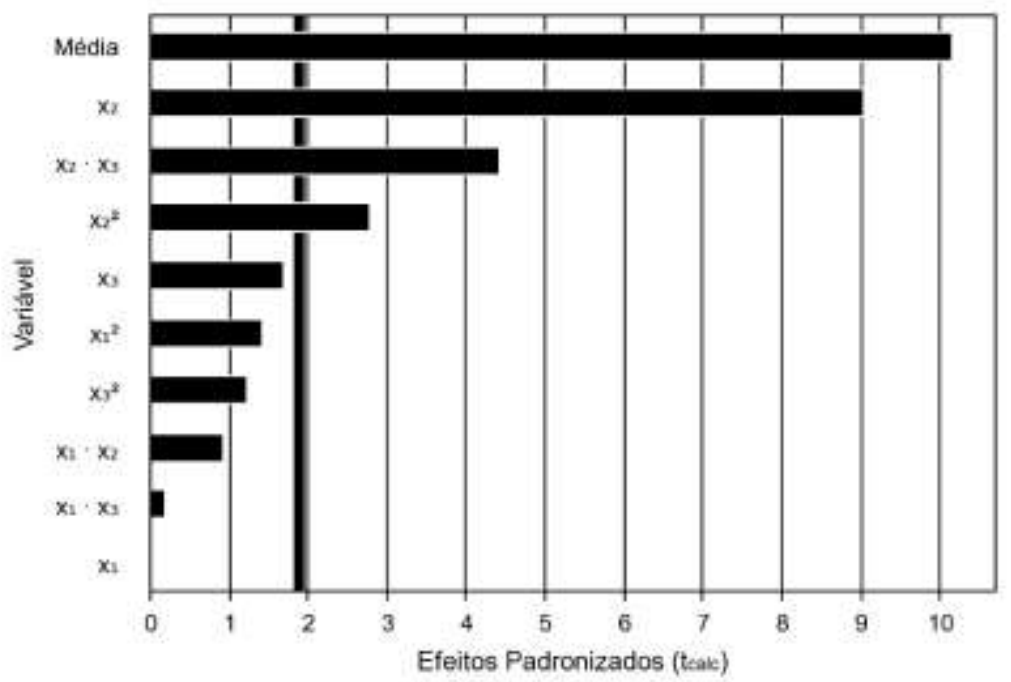

Nota: $\mathrm{x}_{1}=$ Concentração de inóculo $\left(\mathrm{g}\right.$ STV.L $\left.\mathrm{L}^{-1}\right) ; \mathrm{x}_{2}=$ Concentração de substrato $\left(\mathrm{g} \cdot \mathrm{L}^{-1}\right) ; \mathrm{x}_{3}=\mathrm{pH} ; \mathrm{Y}_{1}=P ; \mathrm{Y}_{2}=$ $R m ; \mathrm{Y}_{3}=\lambda$. Potencial de concentração de $\mathrm{H}_{2}(P)$, velocidade máxima de obtenção de $\mathrm{H}_{2}(R m)$, tempo de início da obtenção de $\mathrm{H}_{2}(\lambda)$ e $\mathrm{R}^{2}$ obtidos da equação de Gompertz modificada.

A partir do teste ANOVA (Tabela 5.13) observa-se que o modelo obtido é estatisticamente significativo, uma vez que a porcentagem de variação explicada $\left(R^{2}\right)$ foi de 91,21\% (Figura 5.27). O valor de F calculado para regressão/resíduos é aproximadamente 12,5 vezes superior ao $\mathrm{F}$ tabelado $(2,48)$ para experimentos com intervalo de confiança de $10 \%$ e com 4 graus de liberdade de regressão e 12 graus de liberdade de resíduos.

O F calculado da falta de ajuste/erro puro $(1,3)$ é menor do que o $\mathrm{F}$ tabelado para os experimentos com 10 graus de liberdade para falta de ajuste e 2 graus de liberdade para erro puro $(9,39)$ no mesmo intervalo de confiança, sugerindo um bom ajuste do modelo.

Além disso, observa-se que o p-valor da falta de ajuste $(0,5053)$ não foi considerado como significativo, enquanto o p-valor da regressão foi considerado como altamente significativo $(\mathrm{p} \leq 0,00001)$. 
Figura 5.27. Relação entre os valores experimentais e valores preditos obtidos para a resposta $P$.

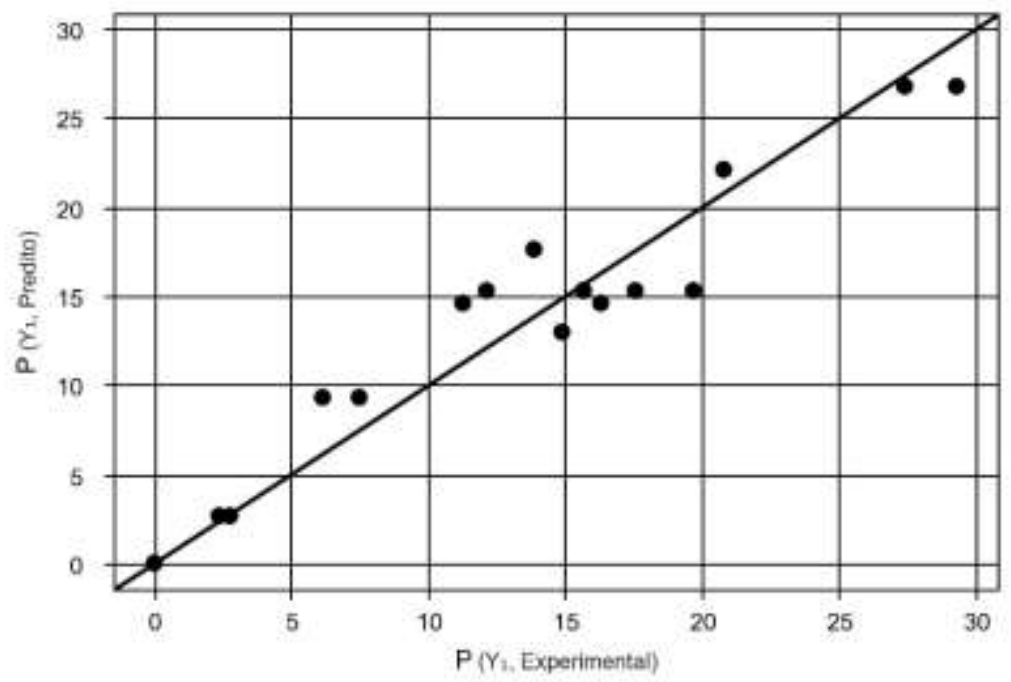

Nota: $P=$ Potencial de concentração de $\mathrm{H}_{2}\left(\mathrm{Y}_{1}\right)$.

Tabela 5.13. Dados estatísticos (ANOVA) obtidos para os ensaios de DCCR, para a resposta $P$ e intervalo de confiança de $90 \%$.

\begin{tabular}{cccccc}
\hline $\begin{array}{c}\text { Fonte de } \\
\text { variação }\end{array}$ & $\begin{array}{c}\text { Soma dos } \\
\text { quadrados }\end{array}$ & $\begin{array}{c}\text { Graus de } \\
\text { liberdade }\end{array}$ & $\begin{array}{c}\text { Quadrado } \\
\text { médio }\end{array}$ & F calculado & p-valor \\
\hline Regressão & 990,7 & 4 & 247,7 & 31,1 & 0,00000 \\
Resíduos & 95,5 & 12 & 8,0 & & \\
Falta de & 87,5 & 10 & 8,7 & 2,2 & 0,35505 \\
ajuste & 8,0 & 2 & 4,0 & & \\
Erro puro & $1.086,2$ & 16 & 246,79 & 30,93 & \\
Total & & &
\end{tabular}

Uma vez que foi possível considerar o modelo de regressão obtido como significativo, foi possível avaliar a superfície de resposta (Figura 5.28) para $\mathrm{Y}_{1}$. De acordo com a superfície e com a derivação da função do modelo considerou-se para a validação experimental como condição ótima para obtenção de $\mathrm{H}_{2}(P)$ as condições de 4 g.L $\mathrm{L}^{-1}$ de inóculo, pH inicial do meio reacional de 8,98 e 29,8 g.L $\mathrm{L}^{-1}$ de resíduo de citros como substrato. 
Figura 5.28. Superfície de resposta (A) e superfície de contorno (B) obtida para a interação entre as variáveis substrato $\left(g . L^{-1}\right)$ e $\mathrm{pH}$.

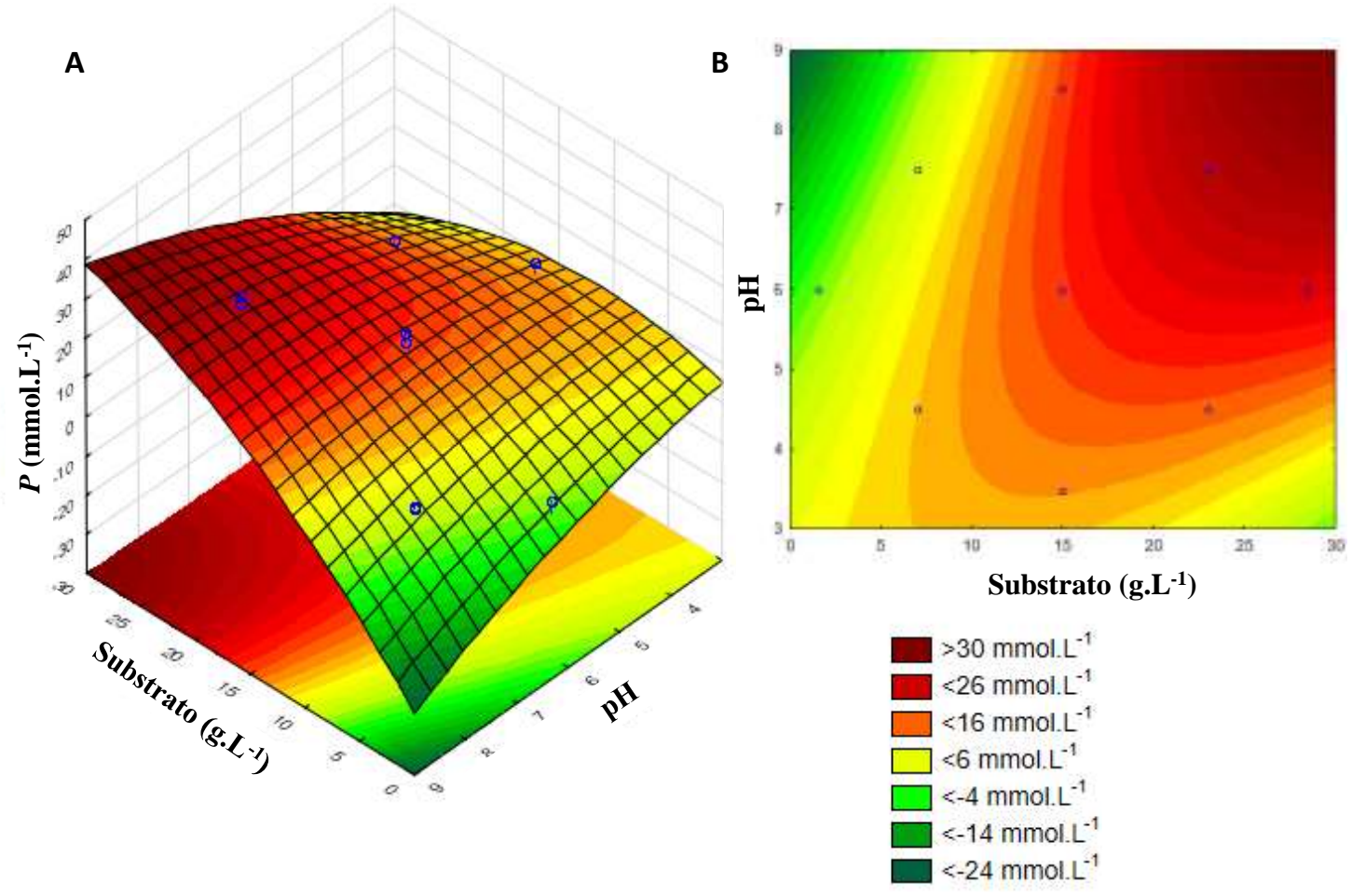

Nota: $P=$ Potencial de concentração de $\mathrm{H}_{2}\left(\mathrm{Y}_{1}\right)$.

Para a resposta $R m\left(\mathrm{Y}_{2}\right)$, apenas um termo linear $\left(\mathrm{x}_{2}\right)$ referente à concentração de substrato foi considerado como estatisticamente significativo ao nível de significância adotado (10\%) (Figura 5.29). De acordo com a ANOVA (Tabela 5.14) obtida para esta resposta, considera-se que a regressão foi estatisticamente significativa $(p \leq 0,1)$ (Equação 5.4), ao contrário da falta de ajuste observada $(\mathrm{p} \geq 0,1)$.

O F calculado para regressão/resíduos $(4,6)$ foi 1,5 vez maior do que o F tabelado para experimentos com 1 grau de liberdade de regressão e 15 graus de liberdade de resíduos $(3,07)$.

$$
Y_{2}=0,98+0,33 x_{2}
$$

sendo,

$\mathrm{Y}_{2}=R m$, velocidade máxima da obtenção de $\mathrm{H}_{2}\left(\mathrm{mmol} \mathrm{H}_{2} \cdot \mathrm{h}^{-1}\right)$;

$\mathrm{x}_{2}=\mathrm{pH}$, efeito linear. 
Figura 5.29. Diagrama de Pareto para a resposta $R m$ para o intervalo de confiança de $90 \%$.

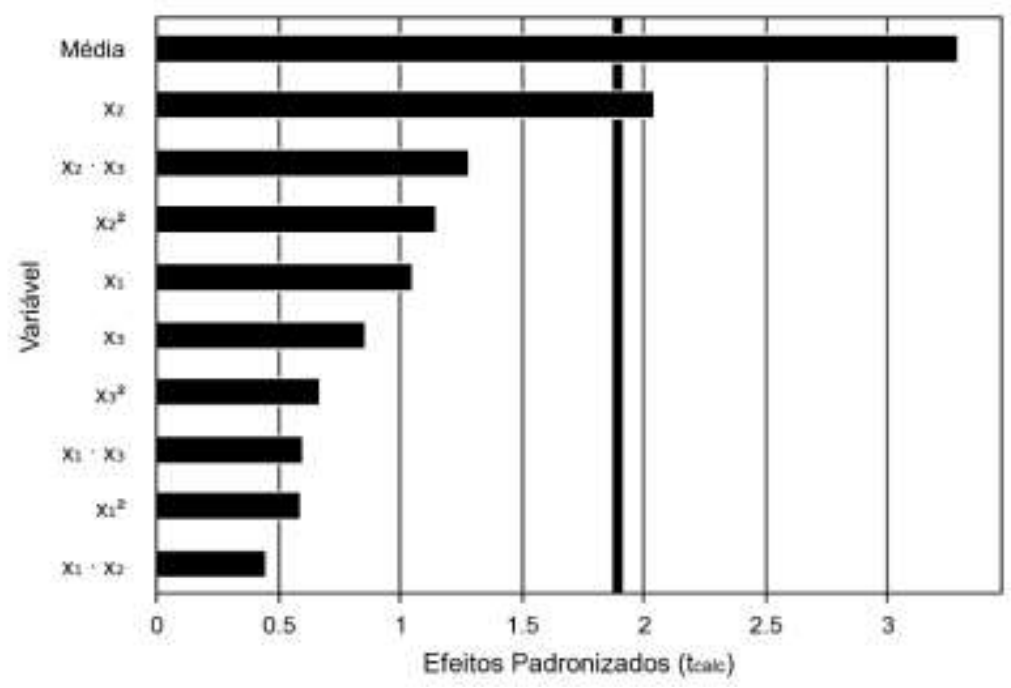

Nota: $\mathrm{x}_{1}=$ Concentração de inóculo $\left(\mathrm{g} \mathrm{STV} . \mathrm{L}^{-1}\right) ; \mathrm{x}_{2}=$ Concentração de substrato $\left(\mathrm{g} . \mathrm{L}^{-1}\right) ; \mathrm{x}_{3}=\mathrm{pH} ; \mathrm{Y}_{1}=P ; \mathrm{Y}_{2}=$ $R m ; \mathrm{Y}_{3}=\lambda$. Potencial máximo de concentração de $\mathrm{H}_{2}(P)$, velocidade máxima de obtenção de $\mathrm{H}_{2}(R m)$, tempo de início da obtenção de $\mathrm{H}_{2}(\lambda)$ e $\mathrm{R}^{2}$ obtidos da equação de Gompertz modificada.

Tabela 5.14. Dados estatísticos (ANOVA) dos ensaios de DCCR para a resposta $R m$ e intervalo de confiança de $90 \%$.

\begin{tabular}{cccccc}
\hline $\begin{array}{c}\text { Fonte de } \\
\text { variação }\end{array}$ & $\begin{array}{c}\text { Soma dos } \\
\text { quadrados }\end{array}$ & $\begin{array}{c}\text { Graus de } \\
\text { liberdade }\end{array}$ & $\begin{array}{c}\text { Quadrado } \\
\text { médio }\end{array}$ & F calculado & p-valor \\
\hline Regressão & 1,5 & 1 & 1,5 & 4,57 & 0,0494 \\
Resíduos & 4,9 & 15 & 0,3 & & \\
Falta de & & & & & \\
ajuste & 4,5 & 13 & 0,3 & 1,65 & 0,4397 \\
Erro puro & 0,4 & 2 & 0,2 & & \\
Total & 6,4 & 16 & & & \\
\hline
\end{tabular}

Para o erro puro, que conta com 13 graus de liberdade para falta de ajuste e 2 graus de liberdade para o erro puro, o $\mathrm{F}$ calculado $(1,7)$ foi menor que o $\mathrm{F}$ tabelado $(9,41)$. Entretanto, o percentual de variação obtido $\left(\mathrm{R}^{2}\right)$ para esta resposta foi demasiadamente baixo, de apenas $61 \%$ (Figura 5.30), ou seja, pouca variação foi observada dentro do erro experimental de medição da análise.

Para a faixa estudada no DCCR não se verificou efeito das variáveis estabelecidas referente a resposta $R m$. Ainda assim, foi possível notar que as condições experimentais ótimas em relação à $\mathrm{x}_{2}$ para otimização desta resposta seriam próximas às obtidas para a resposta $P$, com 28,45 g. $\mathrm{L}^{-1}$ de substrato para $R m$ máximo de $1,54 \mathrm{mmol} \mathrm{H}_{2} \cdot \mathrm{h}^{-1}$. 
Figura 5.30. Relação entre os valores experimentais e valores preditos obtidos para a resposta $R m$.

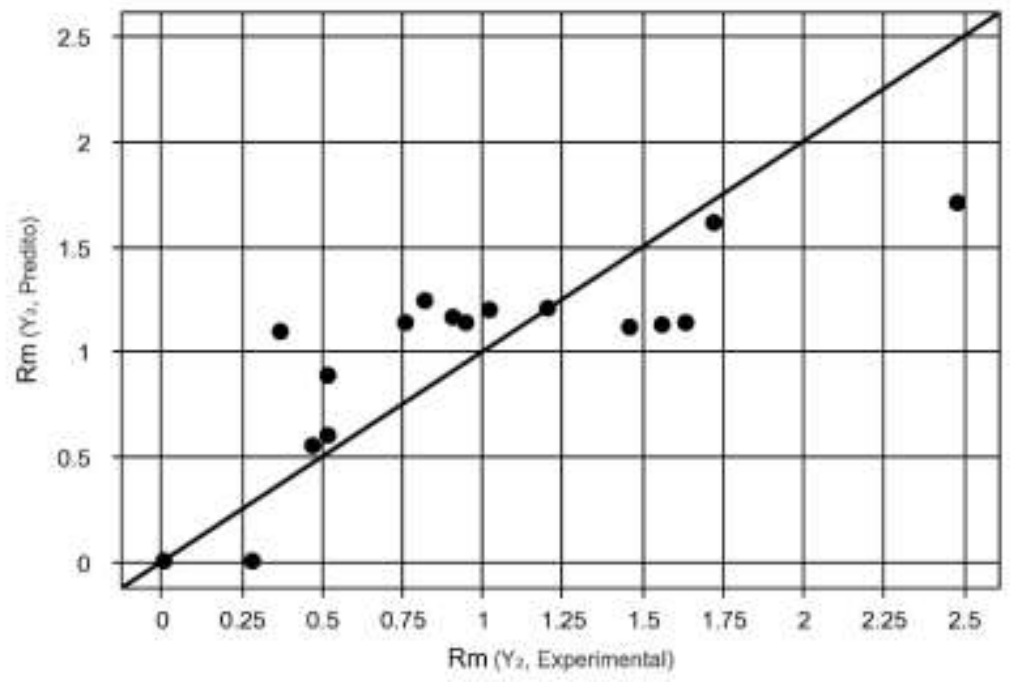

Nota: $R m=$ velocidade máxima de obtenção de $\mathrm{H}_{2}\left(\mathrm{Y}_{2}\right)$.

Por fim, para a resposta $\lambda\left(\mathrm{Y}_{3}\right)$, apenas a interação entre $\mathrm{x}_{2}$ e $\mathrm{x}_{3}$ (concentração de substrato e $\mathrm{pH}$ ) verificou-se efeito significativo $(\mathrm{p} \leq 0,1)$ (Figura 5.31). Apesar disso, para os demais parâmetros da ANOVA (Tabela 5.15) calculada para esta resposta, foi observado baixo percentual de variação explicada $\left(\mathrm{R}^{2}=33,14 \%\right.$ ) (Figura 5.32). Ainda, a falta de ajuste observada foi significativa $(\mathrm{p} \leq 0,1)$ e demasiadamente alta $(165,2)$.

Tabela 5.15. Dados estatísticos (ANOVA) dos ensaios de DCCR, para a resposta $\lambda$ e intervalo de confiança de $90 \%$.

\begin{tabular}{cccccc}
\hline $\begin{array}{c}\text { Fonte de } \\
\text { variação }\end{array}$ & $\begin{array}{c}\text { Soma dos } \\
\text { quadrados }\end{array}$ & $\begin{array}{c}\text { Graus de } \\
\text { liberdade }\end{array}$ & $\begin{array}{c}\text { Quadrado } \\
\text { médio }\end{array}$ & F calculado & p-valor \\
\hline Regressão & 82,3 & 1 & 82,3 & 7,44 & 0,0156 \\
Resíduos & 166,0 & 15 & 11,1 & & \\
Falta de & & & & & \\
ajuste & 165,2 & 13 & 12,7 & 31,92 & 0,0308 \\
Erro puro & 0,8 & 2 & 0,4 & & \\
Total & 248,3 & 16 & & & \\
\hline
\end{tabular}


Figura 5.31. Diagrama de Pareto para a resposta $\lambda$ e intervalo de confiança de $90 \%$.

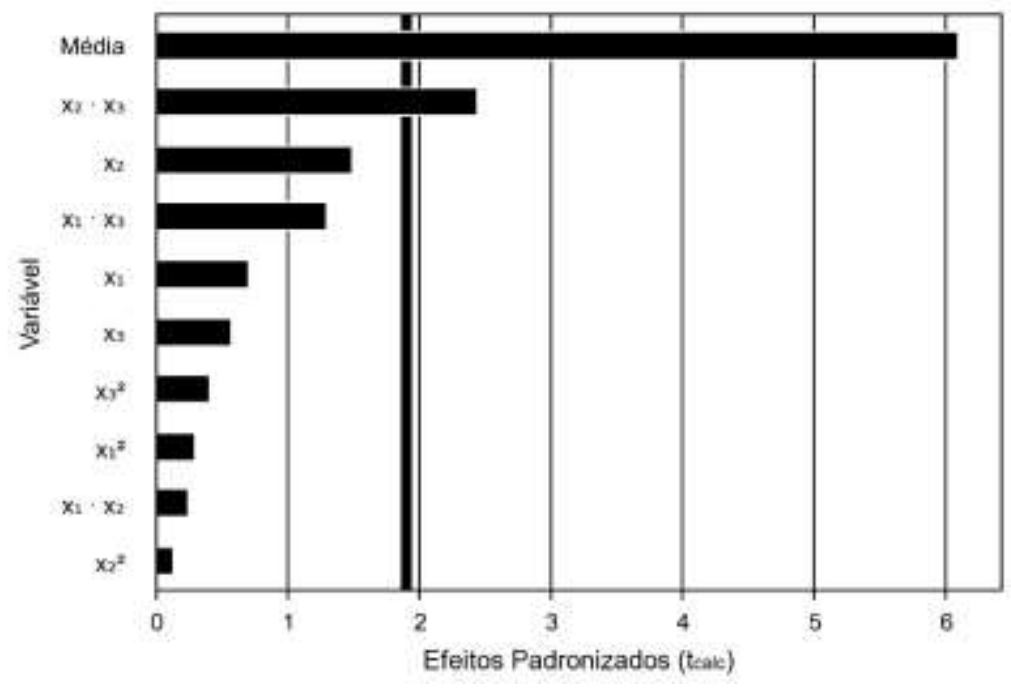

Nota: $\mathrm{x}_{1}=$ Concentração de inóculo $\left(\mathrm{g} \mathrm{STV} . \mathrm{L}^{-1}\right) ; \mathrm{x}_{2}=$ Concentração de substrato $\left(\mathrm{g} . \mathrm{L}^{-1}\right) ; \mathrm{x}_{3}=\mathrm{pH} ; \mathrm{Y}_{1}=P ; \mathrm{Y}_{2}=$ $R m ; \mathrm{Y}_{3}=\lambda$. Potencial máximo de concentração de $\mathrm{H}_{2}(P)$, velocidade máxima de obtenção de $\mathrm{H}_{2}(R m)$, tempo de início da obtenção de $\mathrm{H}_{2}(\lambda)$ e $\mathrm{R}^{2}$ obtidos da equação de Gompertz modificada.

Figura 5.32. Relação entre os valores experimentais e valores preditos obtidos para a resposta $\lambda$.

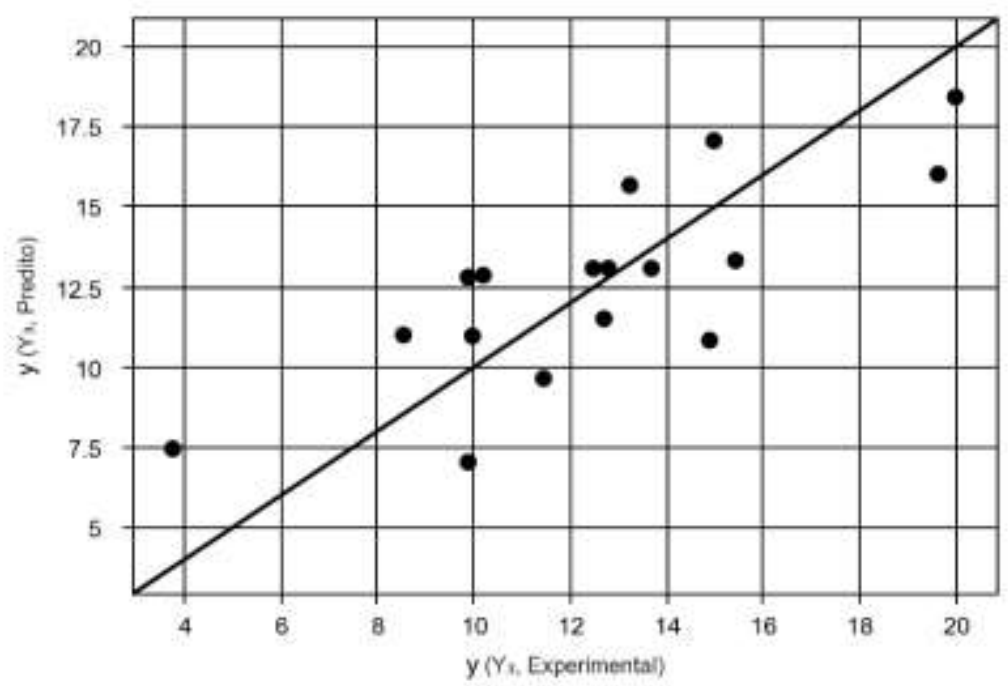

Nota: $\lambda=$ tempo de início da obtenção de $\mathrm{H}_{2}\left(\mathrm{Y}_{3}\right)$.

De acordo com o modelo de regressão (Equação 5.5) obtido para a resposta $Y_{3}(\lambda)$, estimou-se que o pH ideal do meio reacional para que o tempo necessário para a produção de $\mathrm{H}_{2}$ seja reduzido seria em torno de 3,0. Entretanto, verificou-se que este modelo não foi estatisticamente significativo e optou-se por manter o pH em torno de 8,0, na condição otimizada indicada pelos modelos de regressão obtidos para as respostas $\mathrm{Y}_{1}(P)$ e $\mathrm{Y}_{2}(R m)$.

$$
Y_{3}=12,55+3,21 x_{2} x_{3}
$$

sendo, 
$\mathrm{Y}_{3}=\lambda$, tempo necessário para início da obtenção de $\mathrm{H}_{2}(\mathrm{~h})$;

$\mathrm{x}_{2}=\mathrm{pH}$, efeito linear;

$\mathrm{X}_{3}=$ concentração de substrato $\left(\mathrm{g} . \mathrm{L}^{-1}\right)$, efeito linear.

\subsubsection{Validação experimental}

A partir da superfície de resposta obtida para a resposta $\mathrm{Y}_{1}(P)$ foi possível avaliar as regiões ótimas para aumento da concentração de $\mathrm{H}_{2}$ e optar pela região na qual seria possível obter o maior valor de $P$ e, ainda, maior $R m$, sendo tais condições apresentadas na Tabela 5.16.

Tabela 5.16. Teste ANOVA e valores ótimos para as respostas $P$ e $R m$ dos ensaios de DCCR.

\begin{tabular}{cccc}
\hline Variável independente & $\mathbf{Y}_{\mathbf{1}}$ & $\mathbf{Y}_{\mathbf{2}}$ & $\mathbf{Y}_{\mathbf{3}}$ \\
\hline Inóculo $\left(\mathrm{gSTV} . \mathrm{L}^{-1}\right)$ & Indiferente & Indiferente & Indiferente \\
Substrato $\left(\mathrm{g} . \mathrm{L}^{-1}\right)$ & $+\alpha(28,45)$ & $+\alpha(28,45)$ & Indiferente \\
$\mathrm{pH}$ & $+\alpha(8,52)$ & Indiferente & Indiferente
\end{tabular}

Nota: $\mathrm{x}_{1}=$ Concentração de inóculo $\left(\mathrm{g}\right.$ STV.L $\left.\mathrm{L}^{-1}\right) ; \mathrm{x}_{2}=$ Concentração de substrato $\left(\mathrm{g} . \mathrm{L}^{-1}\right) ; \mathrm{x}_{3}=\mathrm{pH} ; \mathrm{Y}_{1}=P$; $\mathrm{Y}_{2}=$ $R m ; \mathrm{Y}_{3}=\lambda$. Potencial máximo de concentração de $\mathrm{H}_{2}(P)$, velocidade máxima de obtenção de $\mathrm{H}_{2}(R m)$, tempo de início da obtenção de $\mathrm{H}_{2}(\lambda)$ e $\mathrm{R}^{2}$ obtidos da equação de Gompertz modificada.

A condição adotada para o ensaio experimental de validação (Figura 5.33) foi de 4 gSTV.L ${ }^{-1}$ de inóculo, 29,8 g.L $\mathrm{L}^{-1}$ de substrato e $\mathrm{pH}$ inicial do meio reacional de 8,98, além de $5 \%$ de consórcio autofermentativo, 5 g. $\mathrm{L}^{-1}$ de peptona, $40 \%$ de headspace e temperatura de incubação de $30{ }^{\circ} \mathrm{C}$, como definido no delineamento preliminar de Plackett \& Burman. $\mathrm{Na}$ Tabela 5.17 encontram-se resumidos os valores experimentais obtidos em comparação com os valores preditos pelos modelos.

Os resultados obtidos no ensaio de comparação entre diferentes pré-tratamentos utilizando resíduo de citros in natura foram usados como base comparativa, sendo considerado como ensaio não otimizado. Assim, as condições não otimizadas foram: 15 g.L $\mathrm{L}^{-1}$ de resíduo de citros in natura, 2 gSTV.L $\mathrm{L}^{-1}$ de inóculo alóctone, $\mathrm{pH}$ 7,0, $30{ }^{\circ} \mathrm{C}$ e meio de cultura PCS (HARUTA et al., 2002), onde se obteve 13,31 mmol H2. $\mathrm{L}^{-1}$. 
Figura 5.33. Concentração acumulada de $\mathrm{H}_{2}$ no ensaio de validação. Otimizado ( $\bullet$; Não otimizado (•). Os desvios padrão foram calculados em cada condição para os resultados obtidos por meio do modelo de Gompertz.

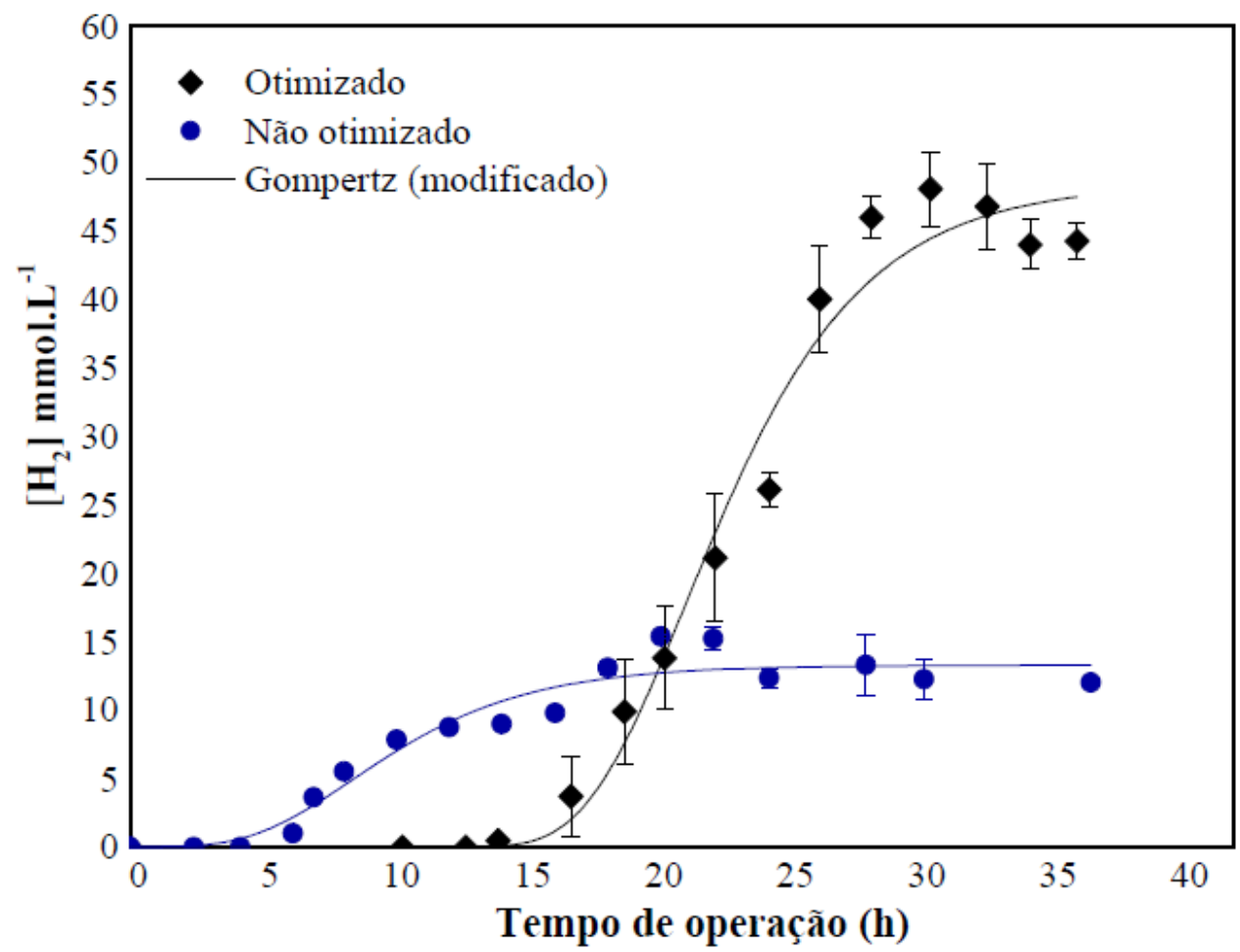

Tabela 5.17. Comparação entre os resultados para concentração de $\mathrm{H}_{2}(P)$ preditos pelo modelo obtido por meio de DCCR e os resultados experimentais obtidos.

\begin{tabular}{ccc}
\hline Resposta & $\begin{array}{c}\boldsymbol{P} \text { experimental } \\
\left(\mathbf{m m o l} \mathbf{H}_{2} \cdot \mathbf{L}^{-\mathbf{1}}\right)\end{array}$ & $\begin{array}{c}\boldsymbol{P} \text { predito } \\
\left(\mathbf{m m o l} \mathbf{H}_{2} . \mathbf{L}^{-\mathbf{1}}\right)\end{array}$ \\
\hline $\mathrm{Y}_{1}$ & $48,47 \pm 2,2$ & $42,18 \pm 5,1$ \\
\hline
\end{tabular}

Nota: $\mathrm{Y}_{1}=P$.

A partir do ensaio experimental de validação é possível afirmar que a obtenção de $\mathrm{H}_{2}$ foi otimizada, uma vez que o valor de $P$ obtido $\left(48,47 \mathrm{mmol}_{2} \cdot \mathrm{L}^{-1}\right)$ foi 3,87 vezes superior ao valor de $P$ obtido antes de sua otimização $\left(12,54 \mathrm{mmol} \mathrm{H}_{2} \cdot \mathrm{L}^{-1}\right)$. Além disso, o valor de $R m$ obtido $\left(4,70 \mathrm{mmol} \mathrm{H} 2 . \mathrm{h}^{-1}\right)$ também foi superior nos ensaios anteriores, nos quais o $R m$ máximo observado foi de 2,64 $\mathrm{mmol} \mathrm{H}_{2} \cdot \mathrm{h}^{-1}$.

O balanço de massa de fase solúvel (BMS) da condição otimizada foi realizado em

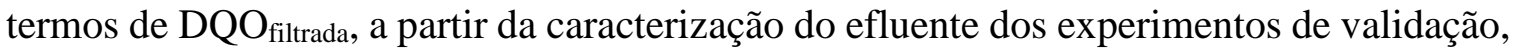
de acordo com a Equação 4.3. Os valores obtidos para as condições iniciais e finais foram 
22 e 63\%, respectivamente. Os percentuais de acidificação dos metabólitos considerados para o BMS encontram-se resumidos na Figura 5.34.

Figura 5.34. Balanço de Massa da fase Solúvel (BMS) do reator em batelada nas condições otimizadas aplicadas à obtenção de $\mathrm{H}_{2}$ a partir de resíduos sólidos de citros.

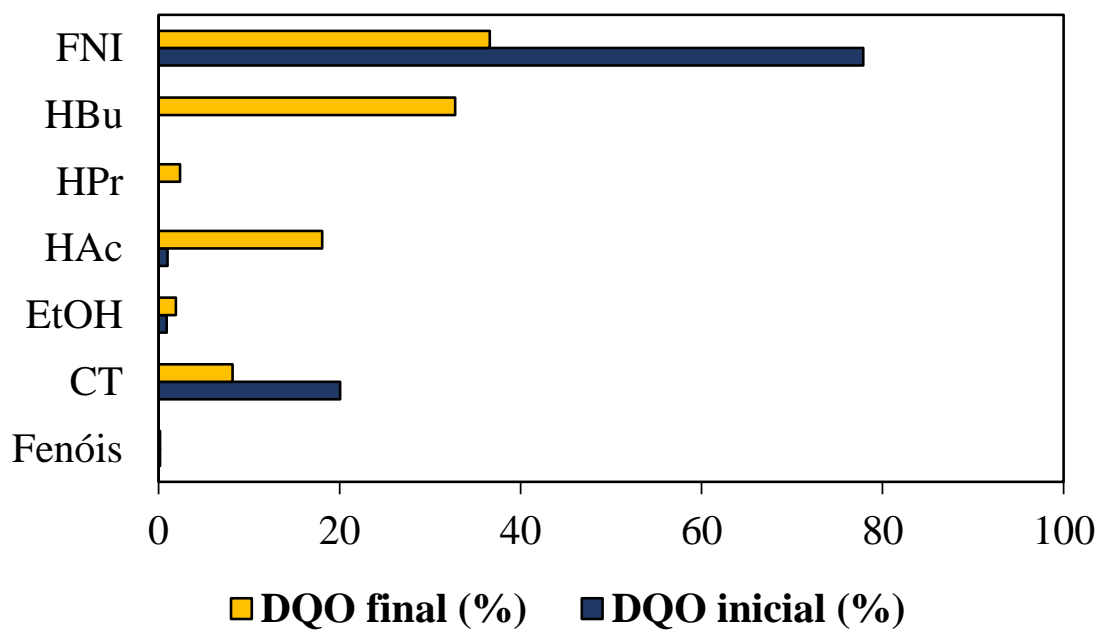

Nota: $\mathrm{FNI}=$ fração não identificada, $\mathrm{HBu}=$ ácido butírico, $\mathrm{HPr}=$ Ácido propiônico, $\mathrm{HAc}=$ ácido acético, EtOH=etanol, $\mathrm{CT}=$ carboidratos totais.

Por meio da comparação da contribuição relativa de cada composto, nota-se que $\mathrm{HBu}$ e HAc foram os compostos identificados que mais contribuíram para o aumento da matéria orgânica em termos de DQO $_{\text {filtrada }}$ no ensaio de validação (33 e 18\%, respectivamente). Destaca-se ainda contribuição considerável da fração não identificada (FNI) para a BMS (78 e 37\%, respectivamente), sendo, tanto para os compostos do início da reação do resíduo sólido de citros e/ou inóculo, quanto os compostos produzidos ao longo da reação, como ácido cítrico, ácido gálico, ácido vanílico, entre outros (KANDASAMY; ARADHYA, 2014).

\subsubsection{Parâmetros físico-químicos e AOV}

Os resultados das analises referêntes aos diferentes parâmetros cinéticos $(P, R m$ e ג) e físico-químicos ( $\mathrm{pH}$, concentração de carboidratos e fenóis totais) encontram-se resumidos na Tabela 5.18, tanto para os ensaios em diferentes condições de DCCR, quanto para comparação entre o reator em condições otimizadas no ensaio de validação.

$\mathrm{O}$ pH é um fator influente na obtenção de $\mathrm{H}_{2}$ e, concomitantemente, na produção de AOV na digestão anaeróbia, especialmente devido ao seu efeito na enzima hidrogenase, 
uma vez que, em condições ácidas, o ATP é usado para garantir a neutralidade celular ao invés de produzir hidrogênio (CHUENCHART et al., 2020). Além disso, o pH pode ter influência na resistência de microrganismos ao limoneno, devido ao mecanismo de defesa conhecido como adaptação homeoviscosa, onde as células tendem a manter a fluidez da membrana constante, independentemente das condições, por meio de alterações no conteúdo e comprimento das cadeias de ácidos graxos (RUIZ; FLOTATS, 2014). Neste estudo, foi observada relação entre o pH e a concentração de substrato, uma vez que a interação entre estes parâmetros foi significativa para $P(\mathrm{p} \leq 0,1)$.

Resultados similares foram observados por Mu, Wang e Yu (2006), que otimizaram $P$ e $R m$, indicando como condições ótimas o pH 5,5, 34,8 ${ }^{\circ} \mathrm{C}$ e 24,8 g. $\mathrm{L}^{-1}$ de sacarose, onde obtiveram $P$ de 139,5 mmol $\mathrm{H}_{2} . \mathrm{L}^{-1}$. Vale ressaltar que, assim como no presente estudo, os autores supracitados indicaram as variáveis $\mathrm{pH}$ e concentração de substrato como interdependentes $\left(\mathrm{x}_{2} \mathrm{x}_{3}\right)$, onde 29,8 g.L $\mathrm{L}^{-1}$ de resíduo de citros e $\mathrm{Rm}$ de $4,17 \mathrm{mmol} \mathrm{H}_{2} \cdot \mathrm{h}^{-1}$ foram obtidos ao final do tempo operacional em condições otimizadas.

Nos ensaios de DCCR, os ensaios para os quais foram observados os menores valores finais de $\mathrm{pH}$, como E3 $(4,51)$ e E7 $(4,96)$, podem estar relacionados com maior $\lambda$ ( $\geq 10$ h) e maiores concentrações de substrato (23 g.L. $\left.\mathrm{L}^{-1}\right)$. Todavia, elevadas concentrações de $\mathrm{H}_{2}$ foram observadas nesses ensaios (11,24 e 27,39 mmol $\mathrm{H}_{2} \cdot \mathrm{L}^{-1}$, respectivamente). Sendo assim, é possível inferir que mesmo com maior período de adaptação necessário devido ao acúmulo de $\mathrm{AOV}$ e $\mathrm{pH}$ ácido ocasionado pelo aumento da concentração do substrato, essa limitação foi superada pelo consórcio microbiano. Da mesma forma, menor concentração de $\mathrm{H}_{2}$ foi observada nos ensaios em que $\mathrm{pH} \geq 6,0$ foi alcançado ao final da operação, como E6 $\left(2,75 \mathrm{mmol} \mathrm{H}_{2} \cdot \mathrm{L}^{-1}\right)$ e E11 $\left(\leq 0,01 \mathrm{mmol} \mathrm{H}_{2} \cdot \mathrm{L}^{-1}\right)$, onde foram avaliadas menores concentrações de substrato $\left(7,0\right.$ e 1,5 g. $\left.\mathrm{L}^{-1}\right)$.

Em suma, a concentração de compostos fenólicos e a remoção de carboidratos dissolvidos também foram quantificados nos ensaios de DCCR, no entanto, nenhum padrão foi observado para os parâmetros de $\operatorname{Gompertz}(P, R m$ ou $\lambda)$ para as concentrações iniciais e finais. Resultados similares foram observados por Villa-Montoya et al. (2020), uma vez que nenhum aumento na concentração $(P)$ foi observado para os mesmos parâmetros, usando resíduos do processamento de café como substrato. Uma possível explicação para os resultados obtidos é a relação entre as diferentes proporções entre o inóculo (2,0-5,7 gSTV.L $\left.{ }^{-1}\right)$ e o substrato $\left(1,5-29,8\right.$ g. $\left.\mathrm{L}^{-1}\right)$ com diferentes $\mathrm{pH}$ iniciais $(3,5-8,9)$ utilizados na presente pesquisa, o que pode alterar a disponibilidade e a interação entre os diferentes 
components da biomassa lignocelulósicas (celulose, hemicelulose, lignina, monômeros dissolvidos, ácidos e álcoois).

Ao comparar apenas as condições otimizadas e não otimizadas, é possível inferir que a maior remoção de carboidratos dissolvidos (51 e 42\%) esteve relacionada às maiores concentrações de $\mathrm{H}_{2}$ (8,8 e 3,9 mmol $\mathrm{H}_{2} \cdot \mathrm{g}^{-1} \mathrm{STV}$ de inóculo) nos mesmos ensaios, devido à bioconversão de carboidratos em $\mathrm{AOV}$, como $\mathrm{HAc}$ e $\mathrm{HBu}$, com concomitante obtenção de $\mathrm{H}_{2}$. Além disso, nota-se que mesmo com $\mathrm{pH}$ inicial mais elevado nas condições otimizadas $(8,98)$ em comparação com as não otimizadas $(7,0)$, o pH final no primeiro caso foi menor do que no segundo (4,80 e 5,30, respectivamente), o que pode estar relacionado com a maior bioconversão de carboidratos devido à sua maior disponibilidade (SHEN et al., 2018).

Em relação às variações observadas na concentração de fenóis nos ensaios do DCCR, constatou-se que nos reatores em que houve menor acúmulo de fenóis após a fermentação (0,5-1,7 mg.L $\left.\mathrm{L}^{-1}\right)$, maiores valores de $P$ foram observados (E4, E8 , E9, E10, Otimizado e Não otimizado, de 12,10-48,47 mmol $\mathrm{H}_{2} \cdot \mathrm{L}^{-1}$ ). Contudo, foi possível observar que na maioria dos ensaios verificou-se aumento da concentração de fenóis, o que pode ser atribuído à despolimerização da lignocelulose durante a hidrólise, gerando compostos derivados da lignocelulose (ou seja, derivados de furano, compostos fenólicos e lignina), e pode afetar o crescimento microbiano, danificando suas membranas celulares (QUÉMÉNEUR et al., 2012). No presente estudo, as concentrações de fenol foram de 16,69 a 22,82 mg.L $\mathrm{L}^{-1}$, o que sugere que esse parâmetro provavelmente não teve efeito significativo nas condições aplicadas (BUITRÓN; CARVAJAL, 2010; TAI et al., 2010). 
Tabela 5.18. Parâmetros cinéticos e físico-químicos dos ensaios de DCCR e ensaio de validação (otimizado).

\begin{tabular}{|c|c|c|c|c|c|c|c|c|c|c|c|c|c|c|}
\hline \multirow{3}{*}{ Reator } & \multicolumn{3}{|c|}{ Variáveis } & \multicolumn{5}{|c|}{ Resultados } & \multirow{3}{*}{$\begin{array}{l}\text { Produção } \\
\text { específica }\end{array}$} & \multirow{2}{*}{\multicolumn{3}{|c|}{ Carboiratos totais }} & \multirow{2}{*}{\multicolumn{2}{|c|}{ Fenóis $\left(\mathrm{mg} . \mathrm{L}^{-1}\right)$}} \\
\hline & Inóculo & & pH & & & & & & & & & & & \\
\hline & $\begin{array}{c}\text { alóctone } \\
\left.\text { (gSTV.L }^{-1}\right)\end{array}$ & (g.L $\left.\mathbf{L}^{-1}\right)$ & inicial & $P$ & $R m$ & $\lambda$ & $\mathbf{R}^{2}$ & final & & Inicial & Final & $\begin{array}{c}\text { Remoção } \\
(\%)\end{array}$ & Inicial & Final \\
\hline E1 & 3,0 & 7,0 & 4,5 & $7,44 \pm 0,1$ & $0,91 \pm 0,1$ & $13,22 \pm 0,3$ & 0,98 & 5,51 & 1,7 & $2,13 \pm 0,3$ & $1,39 \pm 0,2$ & 35 & $\overline{17,09 \pm 0,2}$ & $\overline{17,72 \pm 0,4}$ \\
\hline E2 & 5,0 & 7,0 & 4,5 & $6,17 \pm 0,2$ & $0,52 \pm 0,0$ & $12,70 \pm 0,3$ & 0,99 & 6,14 & 0,9 & $0,96 \pm 0,3$ & $0,51 \pm 0,1$ & 47 & $16,81 \pm 0,2$ & $18,90 \pm 1,3$ \\
\hline E3 & 3,0 & 23 & 4,5 & $11,24 \pm 2,6$ & $0,37 \pm 0,0$ & $10,21 \pm 1,1$ & 0,97 & 4,51 & 2,5 & $0,96 \pm 0,1$ & $0,74 \pm 0,4$ & 23 & $19,77 \pm 0,3$ & $20,86 \pm 0,3$ \\
\hline E4 & 5,0 & 23 & 4,5 & $16,29 \pm 0,5$ & $1,02 \pm 0,1$ & $3,74 \pm 0,4$ & 0,99 & 5,34 & 2,5 & $2,11 \pm 0,3$ & $1,03 \pm 0,4$ & 51 & $21,61 \pm 3,1$ & $20,03 \pm 0,2$ \\
\hline E5 & 3,0 & 7,0 & 7,5 & $2,35 \pm 0,0$ & $0,52 \pm 0,0$ & $9,88 \pm 0,2$ & 0,98 & 5,73 & 0,5 & $1,09 \pm 0,1$ & $0,54 \pm 0,1$ & 50 & $17,06 \pm 1,2$ & $17,37 \pm 0,1$ \\
\hline E6 & 5,0 & 7,0 & 7,5 & $2,75 \pm 0,2$ & $0,28 \pm 0,0$ & $11,43 \pm 0,8$ & 0,98 & 6,63 & 0,4 & $2,11 \pm 0,1$ & $1,03 \pm 0,2$ & 51 & $16,69 \pm 2,1$ & $18,48 \pm 0,1$ \\
\hline E7 & 3,0 & 23 & 7,5 & $27,39 \pm 1,2$ & $1,72 \pm 1,1$ & $15,0 \pm 0,5$ & 0,99 & 4,96 & 6,1 & $0,89 \pm 0,1$ & $0,49 \pm 0,3$ & 45 & $19,67 \pm 0,4$ & $20,88 \pm 0,4$ \\
\hline E8 & 5,0 & 23 & 7,5 & $29,26 \pm 1,4$ & $1,20 \pm 0,1$ & $20,0 \pm 0,5$ & 0,96 & 5,58 & 4,5 & $2,30 \pm 0,6$ & $1,09 \pm 0,3$ & 53 & $21,13 \pm 3,4$ & $20,63 \pm 3,2$ \\
\hline E9 & 2,3 & 15 & 6,0 & $15,66 \pm 1,1$ & $1,56 \pm 0,3$ & $15,41 \pm 0,8$ & 0,98 & 5,53 & 4,1 & $1,39 \pm 0,8$ & $0,74 \pm 0,5$ & 47 & $20,35 \pm 3,0$ & $18,64 \pm 0,5$ \\
\hline E10 & 5,7 & 15 & 6,0 & $12,10 \pm 1,3$ & $0,47 \pm 0,0$ & $9,99 \pm 1,0$ & 0,98 & 6,18 & 1,7 & $1,10 \pm 0,1$ & $0,44 \pm 0,2$ & 60 & $21,50 \pm 0,2$ & $19,07 \pm 1,3$ \\
\hline E11 & 4,0 & 1,5 & 6,0 & $0,01 \pm 5,2$ & $0,01 \pm 0,0$ & $8,52 \pm 0,3$ & 0,98 & 7,34 & 0,0 & $0,30 \pm 0,1$ & $0,25 \pm 0,1$ & 17 & $16,37 \pm 1,2$ & $17,25 \pm 0,3$ \\
\hline E12 & 4,0 & 28,5 & 6,0 & $20,75 \pm 1,7$ & $1,46 \pm 0,1$ & $19,61 \pm 0,4$ & 0,96 & 5,10 & 3,8 & $3,43 \pm 0,8$ & $1,13 \pm 0,1$ & 67 & $20,91 \pm 0,8$ & $32,82 \pm 0,3$ \\
\hline E13 & 4,0 & 15 & 3,5 & $14,90 \pm 0,6$ & $2,48 \pm 0,5$ & $14,89 \pm 0,6$ & 0,97 & 5,05 & 2,7 & $1,99 \pm 0,4$ & $0,88 \pm 0,5$ & 56 & $18,55 \pm 0,8$ & $19,14 \pm 1,1$ \\
\hline E14 & 4,0 & 15 & 8,5 & $13,85 \pm 0,7$ & $0,82 \pm 0,0$ & $9,86 \pm 0,7$ & 0,98 & 5,37 & 2,5 & $1,68 \pm 0,2$ & $0,94 \pm 0,4$ & 44 & $18,63 \pm 1,3$ & $20,44 \pm 0,5$ \\
\hline E15 & 4,0 & 15 & 6,0 & $19,69 \pm 6,9$ & $0,76 \pm 0,1$ & $12,80 \pm 1,3$ & 0,95 & 5,43 & 3,6 & $1,60 \pm 0,3$ & $0,80 \pm 0,4$ & 50 & $17,73 \pm 1,4$ & $18,90 \pm 0,4$ \\
\hline E16 & 4,0 & 15 & 6,0 & $17,51 \pm 3,0$ & $0,95 \pm 0,5$ & $13,69 \pm 1,1$ & 0,96 & 5,43 & 3,2 & $1,60 \pm 0,3$ & $0,80 \pm 0,4$ & 50 & $17,73 \pm 1,4$ & $18,90 \pm 0,4$ \\
\hline E17 & 4,0 & 15 & 6,0 & $15,69 \pm 0,3$ & $1,63 \pm 0,1$ & $12,47 \pm 0,3$ & 0,99 & 5,43 & 2,9 & $1,60 \pm 0,3$ & $0,80 \pm 0,4$ & 50 & $17,73 \pm 1,4$ & $18,90 \pm 0,4$ \\
\hline Validação & 4,0 & 29,8 & 8,98 & $48,47 \pm 2,2$ & $4,69 \pm 0,6$ & $17,35 \pm 0,6$ & 0,97 & 4,80 & 8,8 & $3,25 \pm 0,2$ & $1,58 \pm 0,3$ & 51 & $22,82 \pm 0,0$ & $22,16 \pm 0,0$ \\
\hline Não-otim. & 2,0 & 15 & 7,0 & $13,31 \pm 0,7$ & $1,27 \pm 0,2$ & $4,60 \pm 1,0$ & 0,94 & 5,30 & 3,9 & $1,25 \pm 0,1$ & $0,73 \pm 0,1$ & 42 & $21,76 \pm 0,1$ & $19,21 \pm 0,1$ \\
\hline
\end{tabular}

Nota: Potencial máximo de concentração de $\mathrm{H}_{2}\left(P, \mathrm{mmol} \mathrm{H}_{2} \cdot \mathrm{L}^{-1}\right)$, Produção específica= mmol $\mathrm{H}_{2} \cdot \mathrm{g}^{-1} \mathrm{STV}$ (inóculo autóctone + alóctone), velocidade específica máxima

de obtenção de $\mathrm{H}_{2}\left(R m, \mathrm{mmol} \mathrm{H}_{2} \cdot \mathrm{h}^{-1}\right)$, tempo de início da obtenção de $\mathrm{H}_{2}(\lambda, \mathrm{h})$. As barras de erros ( \pm ) correspondem ao desvio padrão calculado em cada condição. 
Em relação à concentração de substrato, Desvaux (2005) indica que este parâmetro é relevante para a fermentação da biomassa lignocelulósica, uma vez que microrganismos celulolíticos devem aderir ao substrato para poder hidrolisá-lo, o que justifica as altas concentrações de resíduos sólidos de citros nas condições otimizadas $\left(29,8\right.$ g.L $\left.L^{-1}\right)$. Além disso, altas concentrações de substrato tem como consequência o aumento da concentração de carboidratos solúveis prontamente assimiláveis, resultando em rápida hidrólise e maior acúmulo de AOV (JIANG et al., 2018).

Sabe-se que altas concentrações de AOV ionizados no ambiente podem levar ao acúmulo excessivo de ânions no citoplasma, e a acidificação pode ocorrer devido aos AOV que atravessam livremente a membrana cellular e se dissociam dentro da célula, diminuindo a força motriz de prótons através da membrana, afetando o metabolismo celular e reduzindo seu potencial de crescimento (JIANG et al., 2018). A maior produção de AOV ao longo do tempo de operação teve como consequência diminuição do $\mathrm{pH}$ no final do período de operação e também o maior $\lambda$ observado no ensaio otimizado (17,35 h, $\mathrm{pH} 4,80)$, quando comparado com o ensaio não otimizado (4,60 h, pH 5,30). Provavelmente, seja necessário tempo maior de adaptação para as bactérias consumidoras de $\mathrm{AOV}$ e produtoras de $\mathrm{H}_{2}$ (JIANG et al., 2018); além disso, a elevada recalcitrância da celulose e a toxicidade da lignina e seus derivados podem afetar a atividade hidrolítica, uma vez que as enzimas celulolíticas podem ficar adsorvidas irreversivelmente na lignina dissolvida (MASIH-DAS; TAO, 2018).

A partir da análise dos AOV produzidos ao longo das diferentes condições operacionais estudadas nos ensaios de DCCR (Figura 5.35), é possível notar que os principais metabólitos produzidos foram HAc e $\mathrm{HBu}$. Nas condições operacionais do raetor $\mathrm{R} 8$ reator foram observadas as maiores concentrações destes compostos, sendo $2.244 \mathrm{mg}$. $\mathrm{L}^{-}$ ${ }^{1}$ de HAc e $1.683 \mathrm{mg} . \mathrm{L}^{-1}$ de $\mathrm{HBu}$ ao final do período operacional (35 h). Vale ressaltar que, no mesmo ensaio, foi observada a maior concentração de $\mathrm{H}_{2}\left(29,26 \mathrm{mmol} \mathrm{H} \mathrm{H}_{2} \cdot \mathrm{L}^{-1}\right)$. Da mesma forma, os principais AOV observados nos demais reatores com maior concentração de $\mathrm{H}_{2}\left(P \geq 20 \mathrm{mmol} \mathrm{H}_{2} \cdot \mathrm{L}^{-1}\right)$ foram HAc e HBu, como em R12 (20,75 mmol H $\mathrm{H}_{2} \cdot \mathrm{L}^{-1}$, $797 \mathrm{mg}$

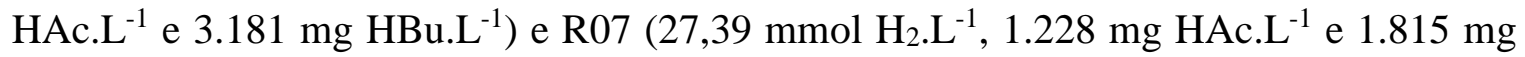
HBu. $\left.\mathrm{L}^{-1}\right)$. Todos os ensaios mencionados foram operados com resíduo sólido de citros acima de 20 g.L. $\mathrm{L}^{-1}$ e $\mathrm{pH}$ acima de 7,0. 
As maiores concentrações de HPr e HVal foram observadas em R3 (1.353 e 691 mg. $\mathrm{L}^{-1}$, respectivamente). Sob tais condições, foram obtidas concentrações máximas de $P=$ 11,24 mmol H $\mathrm{H}_{2} \cdot \mathrm{L}^{-1}$, devido à produção concomitante de HAc (2.713 mg.L $\left.\mathrm{L}^{-1}\right)$. É possível inferir que a elevada produção de AOV tenha ocorrido devido ao menor $\mathrm{pH}$ deste ensaio $(4,5)$ e maior concentração de substrato utilizada $\left(23\right.$ g.L $\left.\mathrm{L}^{-1}\right)$. Além disso, foi possível observar produção de EtOH em R4, onde foi aplicada a mesma concentração de substrato e mesmo $\mathrm{pH}$, sendo observada $P$ de $16,29 \mathrm{mmol} \mathrm{H}_{2} \cdot \mathrm{L}^{-1}$ para essas condições.

O reator R5 foi operado com maior $\mathrm{pH}(7,5)$ e menor concentração de substrato $(7$ g. $\mathrm{L}^{-1}$ ), sendo que o principal composto orgânico produzido ao longo do tempo operacional foi o EtOH (2.777 mg. $\mathrm{L}^{-1}$ ). Neste ensaio, foi observada uma das menores produções de $\mathrm{H}_{2}$ $\left(P=2,35 \mathrm{mmol} \mathrm{H}_{2} \cdot \mathrm{L}^{-1}\right)$, provavelmente devido ao predomínio da via solvetogênica (ŁUKAJTIS et al., 2018).

No ensaio de otimização, os principais metabólitos observados foram $\mathrm{HBu}$ (3.731 mg. $\mathrm{L}^{-1}$ ) e HAc (3.516 mg. $\left.\mathrm{L}^{-1}\right)$. A concentração de $\mathrm{HBu}$ em condições otimizadas foi superior à observada no reator não otimizado $\left(1.317 \mathrm{mg} . \mathrm{L}^{-1}\right)$. Além disso, as concentrações de EtOH e HPr foram sutilmente superiores no reator otimizado (188 e $324 \mathrm{mg} . \mathrm{L}^{-1}$ ) quando comparado com o não otimizado (116 e 209 mg. $\mathrm{L}^{-1}$ ).

Sabe-se que a produção de HPr não é favorável à obtenção de $\mathrm{H}_{2}$, sendo inclusive um indicador de inibição da digestão anaeróbia (XING et al., 2020). Entretanto, em nenhum dos experimentos foram obtidas concentrações superiores ao limite inibitório, de 1.000 mg.L - $^{-1}$ (SHEN et al., 2018). Além disso, o HPr pode ser convertido em HAc, com concomitante obtenção de $\mathrm{H}_{2}$ (Equação 5.6) (MAZARELI et al., 2019).

$$
\mathrm{CH}_{3} \mathrm{CH}_{2} \mathrm{COOH}+3 \mathrm{H}_{2} \mathrm{O} \rightarrow \mathrm{CH}_{3} \mathrm{COOH}+7 \mathrm{HCO}_{3}^{-}+\mathrm{H}^{+}+3 \mathrm{H}_{2}
$$

Woo, Charles e Kwonsu (2015) otimizaram a produção de AOV a partir de palha de arroz como substrato em reatores em batelada. Os autores concluíram a partir da superfície de resposta obtida que as variáveis temperatura, concentração de substrato e pH inicial foram significativas no processo de fermentação, com produção máxima de AOV de 12,37 g. $\mathrm{L}^{-1}$ a $39,23{ }^{\circ} \mathrm{C}, 52,23$ g. $\mathrm{L}^{-1}$ de substrato e $\mathrm{pH} 10$. Assim como no presente estudo, os autores observaram que a interação entre as variáveis temperatura e concentração de substrato não foi significativa $(\mathrm{p} \geq 0,05)$. 
Figura 5.35. Concentração de AOV e alcoois ao longo do período operacional nos ensaios de DCCR (R01-R15), validação (Otim) e não otimizado (Não-Otim). As amostras foram coletadas entre $0-35 \mathrm{~h}$ periodicamente $(\sim 6 \mathrm{~h})$ ao longo do período operacional.

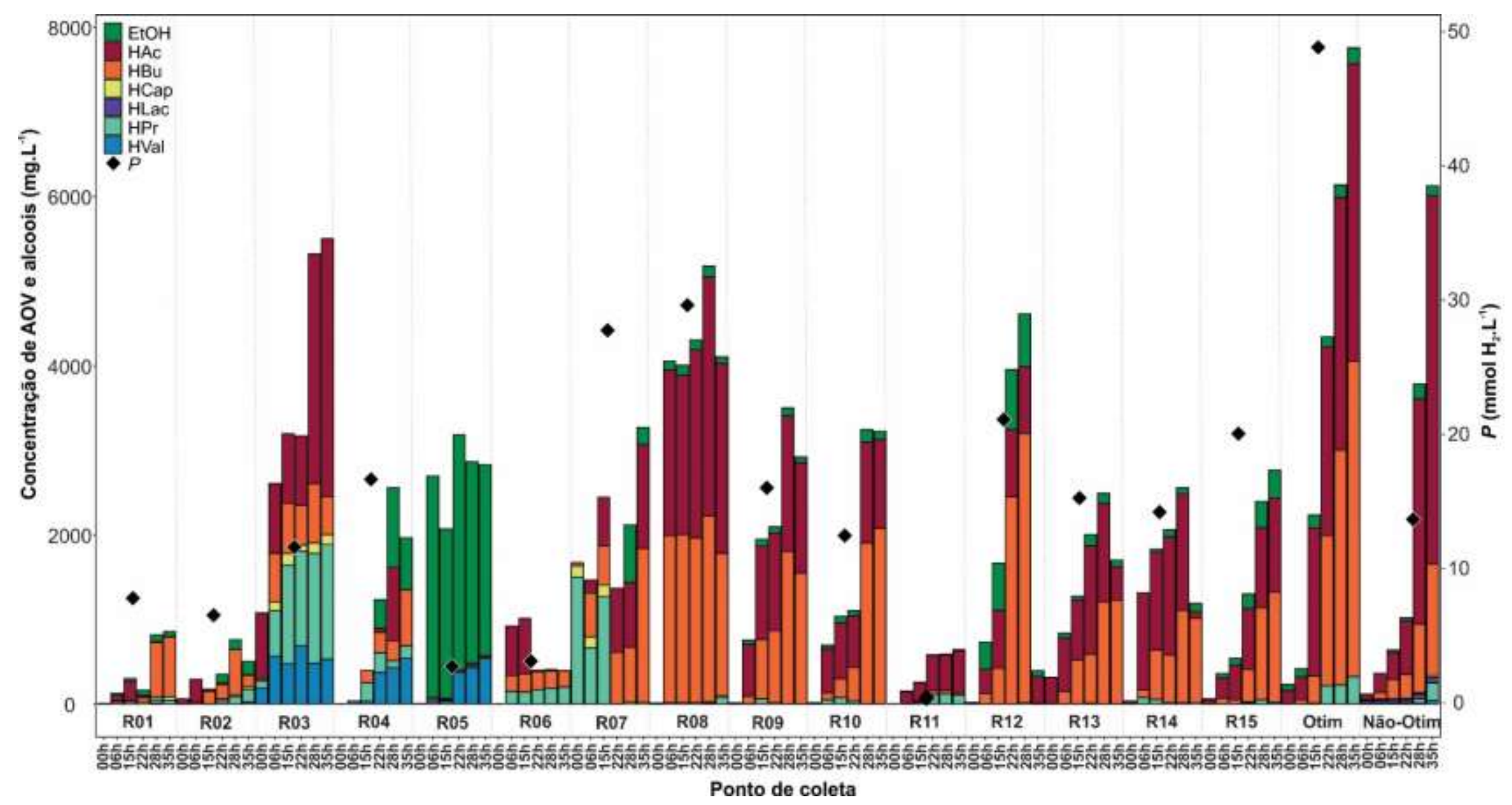




\subsubsection{Caracterização microbiana}

Ao final do periodo de incubação em condições otimizadas, a comunidade microbiana foi comparada com amostras do inóculo alóctone utilizado, a partir da técnica de metagenômica shotgun. Esta abordagem teve como objetivo obter informações sobre os mecanismos de fermentação do resíduo sólido de citros e obtenção de $\mathrm{H}_{2}$, identificando os microrganismos e as vias metabólicas envolvidas no processo. As anotações taxonômicas e funcionais foram atribuídas a cada gene detectado, permitindo uma análise taxofuncional das comunidades microbianas.

Após a análise das leituras via fastp e ordenação via fast $Q C$ foi possível obter análise estatística global das sequências (Tabela 5.19). O tamanho médio das sequências foi de 150 pares de bases (pb), conforme esperado via aplicação da plataforma Illumina HiSeq. Nota-se que a proporção entre os quatro pares de bases foi satisfatória, ou seja, manteve-se proporcionalidade. Além disso, nenhuma cauda de PoliG ou PoliX, comum neste tipo de sequenciamento foi detectada (CHEN et al., 2018).

Para evitar que a abundancia de determinadas sequencias seja superestimada, espera-se que a taxa de duplicação seja baixa, em uma biblioteca diversificada e sem qualquer tipo de contaminação ou viés (EWELS et al., 2016). Vale ressaltar que a análise em fastQC não suporta dados emparelhados, sendo que a detecção é feita a partir de cada leitura individual, o que pode resultar em superestimativa da taxa de duplicação. Assim, esse parâmetro foi considerado satisfatório para todas as amostras analisadas, uma vez que ocorreram apenas leituras $\geq 85 \%$ em todas as amostras. Além disso, é possível notar que a maioria das sequências apresenta baixo índice de duplicação.

O número de bases "N" é outro parâmetro importante para a análise da qualidade das sequências, ou seja, posições com bases desconhecidas e substituídas por N, que podem comprometer a confiabilidade dos dados gerados. A quantidade esperada de bases $\mathrm{N}$ em uma amostra foi abaixo de 5\% (EWELS et al., 2016), e todas as amostras analisadas foram consideradas dentro da faixa esperada, e para apenas uma amostra bruta (Amostra 2) verificou-se $0,22 \%$ de bases $\mathrm{N}$, enquanto nas demais amostras, não foram observadas. Além disso, as sequências brutas foram filtradas usando a ferramenta fastp. O conteúdo dos adaptadores das sequências obtido foi considerado de boa qualidade, ou seja, representam menos de $5 \%$ do total das sequências.

Em suma, é possível concluir que as sequências obtidas estão dentro dos padrões considerados nas etapas de controle de qualidade, como por qualidade de sequência de base, 
por score de qualidade de sequência, conteúdo de sequência de base, conteúdo de base citosina-guanina (GC), conteúdo GC, conteúdo por base $\mathrm{N}$, distribuição de comprimento de sequência, nível de duplicação de sequência, sequências super-representadas e conteúdo do adaptador.

Por meio da análise dos índices ecológicos (Tabela 5.20), foi possível comparar os valores obtidos para amostras de biomassa em condições otimizadas e inóculo. O índice de diversidade de Shannon-Wiener $\left(\mathrm{H}^{\prime}\right)$ leva em consideração o número de taxons e sua dominância, indicando maior diversidade nas amostras de inóculo $\left(\mathrm{H}^{\prime}=6,0\right) \mathrm{em}$ comparação aquelas do ensaio otimizado $\left(\mathrm{H}^{\prime}=2,7\right)$. A partir do índice de Simpson, foi possível observar que menor dominância ocorreu nas amostras do ensaio otimizado $(0,8)$, em relação à biomassa do inóculo $(1,0)$, provavelmente devido à seleção das populações após a aplicação das condições otimizadas, o que levou ao aumento da dominância e consequentemente diminuição da diversidade.

A riqueza das amostras foi comparada por meio do índice Chao-1 e número observado de táxons, sendo possível observar maior riqueza e número de táxons para a amostra de inóculo (10.204,6 e 10.202, respectivamente) em comparação às amostras das condições otimizadas ( $9.222,7$ e 8.216 , respectivamente). Vale salientar que a diferença entre os valores de riqueza calculados via Chao-1 e o número Observado refere-se à correção da variância adotado no cálculo do primeiro índice, uma vez que se assume que o número de observações para um táxon tem uma distribuição de Poisson (distribuição de probabilidade de variável aleatória discreta) e corrige sua variância. Desta forma, os valores de Chao-1 são ligeiramente maiores em relação ao número observado de táxons, uma vez que este índice é calculado como Chao- $1=\mathrm{S}_{0}+\mathrm{a}_{0}$, onde $\mathrm{S}_{0}$ é o número de táxons observados ao menos uma vez em na amostra, e an é a inferência do número desconhecido de táxons presente na comunidade, mas que não foi observado nas amostras (HUGHES et al., 2001). Além disso, para a variação estimada por meio do erro padrão (Chao-1 se), verificou-se boa reprodutibilidade, tanto para as amostras de inóculo ( $s e=3.2,10.198,10.199$ e 10.209), quanto para as amostras do ensaio otimizado ( $s e=84,5,7.708,8.140$ e 8.800). 
Tabela 5.19. Parâmetros estatísticos e de qualidade para as sequências brutas e filtradas obtidas a partir do inóculo (Amostras 1-3) e do ensaio otimizado (Amostra 4-6).

\begin{tabular}{|c|c|c|c|c|c|c|}
\hline \multirow[t]{4}{*}{ Parâmetros } & \multicolumn{6}{|c|}{ Amostras } \\
\hline & \multicolumn{3}{|c|}{ Inóculo } & \multicolumn{3}{|c|}{ Otimizado } \\
\hline & Amostra 1 & Amostra 2 & Amostra 3 & Amostra 4 & Amostra 5 & Amostra 6 \\
\hline & \multicolumn{6}{|c|}{ reads brutos } \\
\hline Total reads & 17.290 .172 & 12.526 .754 & 19.814 .318 & 10.345 .642 & 9.309 .040 & 16.350 .010 \\
\hline Tamanho médio (pb) & 150 & 150 & 150 & 150 & 150 & 150 \\
\hline Duplicação foward (\%) & 9,0 & 12,0 & 11,2 & 12,7 & 12,4 & 14,4 \\
\hline Duplicação reverse (\%) & 7,7 & 11,5 & 6,4 & 12,1 & 11,9 & 12,9 \\
\hline GC foward $(\%)$ & 43 & 44 & 43 & 32 & 32 & 32 \\
\hline GC reverse $(\%)$ & 43 & 44 & 43 & 32 & 32 & 33 \\
\hline Falha foward (\%) & 8 & 9 & 8 & 9 & 9 & 17 \\
\hline Falha reverse (\%) & 17 & 9 & 17 & 9 & 9 & 17 \\
\hline \multirow[t]{2}{*}{ Total de sequencias (milhões) } & 8,6 & 6,3 & 9,95 & 5,2 & 4,7 & 8,2 \\
\hline & \multicolumn{6}{|c|}{ reads filtrados } \\
\hline Total & 16.921 .042 & 12.473 .842 & 19.084.252 & 10.314 .652 & 9.288 .216 & 15.850 .520 \\
\hline Mapeadas & 12.254 .406 & 8.801 .212 & 13.999 .335 & 7.176 .259 & 6.406 .724 & 10.980 .601 \\
\hline Filtradas & 11.533 .978 & 8.223 .774 & 13.178 .577 & 7.015 .467 & 6.250 .879 & 10.701 .743 \\
\hline Duplicação (\%) & 8,2 & 13,3 & 8,0 & 11,7 & 12,3 & 16,2 \\
\hline $\mathrm{GC}(\%)$ & 43,3 & 44,3 & 43,7 & 32,0 & 32,8 & 32,8 \\
\hline reads filtrados $(\%)$ & 97,9 & 99,6 & 96,3 & 99,7 & 99,8 & 96,9 \\
\hline \multirow[t]{10}{*}{ Adaptadores removidos $(\%)$} & 0,4 & 0,4 & 0,4 & 1,0 & 0,7 & 0,9 \\
\hline & \multicolumn{6}{|c|}{ Montagem } \\
\hline & contigs (total) & 78.123 & Comprimento total & 289.363 .813 & N50 & 6.819 \\
\hline & contigs $(\geq 0 \mathrm{pb})$ & 78.123 & $\geq 0 \mathrm{pb}$ & 289.363 .813 & N75 & 2.191 \\
\hline & contigs $(\geq 1.000 \mathrm{pb})$ & 78.123 & $\geq 1.000 \mathrm{pb}$ & 289.363 .813 & L50 & 6.406 \\
\hline & contigs $(\geq 5.000 \mathrm{pb})$ & 9.331 & $\geq 5.000 \mathrm{pb}$ & 161.611 .757 & L75 & 26.860 \\
\hline & contigs $(\geq 1.0000 \mathrm{pb})$ & 3.949 & $\geq 10.000 \mathrm{pb}$ & 124.512 .722 & $\mathrm{GC}(\%)$ & 46,52 \\
\hline & contigs $(\geq 25.000 \mathrm{pb})$ & 1.250 & $\geq 25.000 \mathrm{pb}$ & 83.880 .261 & $\mathrm{~N}$ & 0 \\
\hline & contigs $(\geq 50.000 \mathrm{pb})$ & 478 & $\geq 50.000 \mathrm{pb}$ & 57.094 .463 & N's/100 kpb & 0 \\
\hline & Maior contig & 932.907 & & & & \\
\hline
\end{tabular}


Tabela 5.20. Índices ecológicos (Observado, Chao-1, Shannon-Wiener e Simpson) para sequências filtradas obtidas a partir do inóculo (Amostras 1-3) e ensaio otimizado (Amostras 4-6). se = Erro Padrão calculado a partir de triplicatas.

\begin{tabular}{ccc}
\hline & \multicolumn{2}{c}{ Amostras } \\
\cline { 2 - 3 } Índice ecológico & Inóculo & Otimizado \\
\cline { 2 - 3 } Observado & 10.202 & 8.216 \\
Chao-1 & $10.204,6$ & $9.222,7$ \\
Chao-1 $(\mathrm{se})$ & 3,2 & 84,5 \\
Shannon-Wiener & 6,0 & 2,7 \\
Simpson & 1,0 & 0,8 \\
\hline
\end{tabular}

As variações na comunidade microbiana após a otimização foram analisadas para diferentes níveis taxonômicos. O conjunto de dados foi associado a 3 domínios diferentes (Archaea, Bacteria, Eukaryota) e Vírus, 163 filos, 466 ordens, 423 classes, 848 famílias e 2581 gêneros. Proteobacteria (40,51\%), Bacterioidetes (21,24\%), Firmicutes $(9,76 \%)$ e Thermotogae $(8,04 \%)$ foram os filos mais abundantes no inóculo. Nas amostras do ensaio otimizado verificou aumento da dominância de Firmicutes (89,54\%), enquanto a abundância dos demais filos citados diminuiu drasticamente (4,78; 0,55 e 1,57\%, respectivamente) (Figura 5.36).

As bactérias do filo Firmicutes são conhecidas principalmente por suas relações sintróficas em reatores anaeróbios, bem como pela produção e degradação de ampla diversidade de AOV, como HAc e HBu (YUTIN; GALPERIN, 2013). Os principais metabólitos obtidos nos reatores otimizados foram HAc (3516 mg.L $\left.\mathrm{L}^{-1}\right)$ e HBu (3731 mg.L$\left.{ }^{1}\right)$. Woo, Charles e Kwonsu (2015) aplicaram DCCR a fim de otimizar a produção de AOV a partir da palha de arroz, e verificaram que as variáveis temperatura $\left(39,23{ }^{\circ} \mathrm{C}\right)$, concentração de substrato $\left(52,23\right.$ g. $\left.\mathrm{L}^{-1}\right)$ e pH inicial (10) foram significativas na obtenção da concentração máxima de $\operatorname{AOV}\left(12370 \mathrm{mg} . \mathrm{L}^{-1}\right)$. Assim como no presente estudo, os autores relataram Firmicutes como o filo mais dominante nestas condições. 
Figura 5.36. Abundância relativa dos filos (A) e gêneros (B) de bactérias mais abundantes no inóculo (Amostras 1-3) e amostras otimizadas (Amostras 4-6). NA = não identificado. As abundâncias relativas foram calculadas considerando o número total de leituras pré-processadas nas amostras.

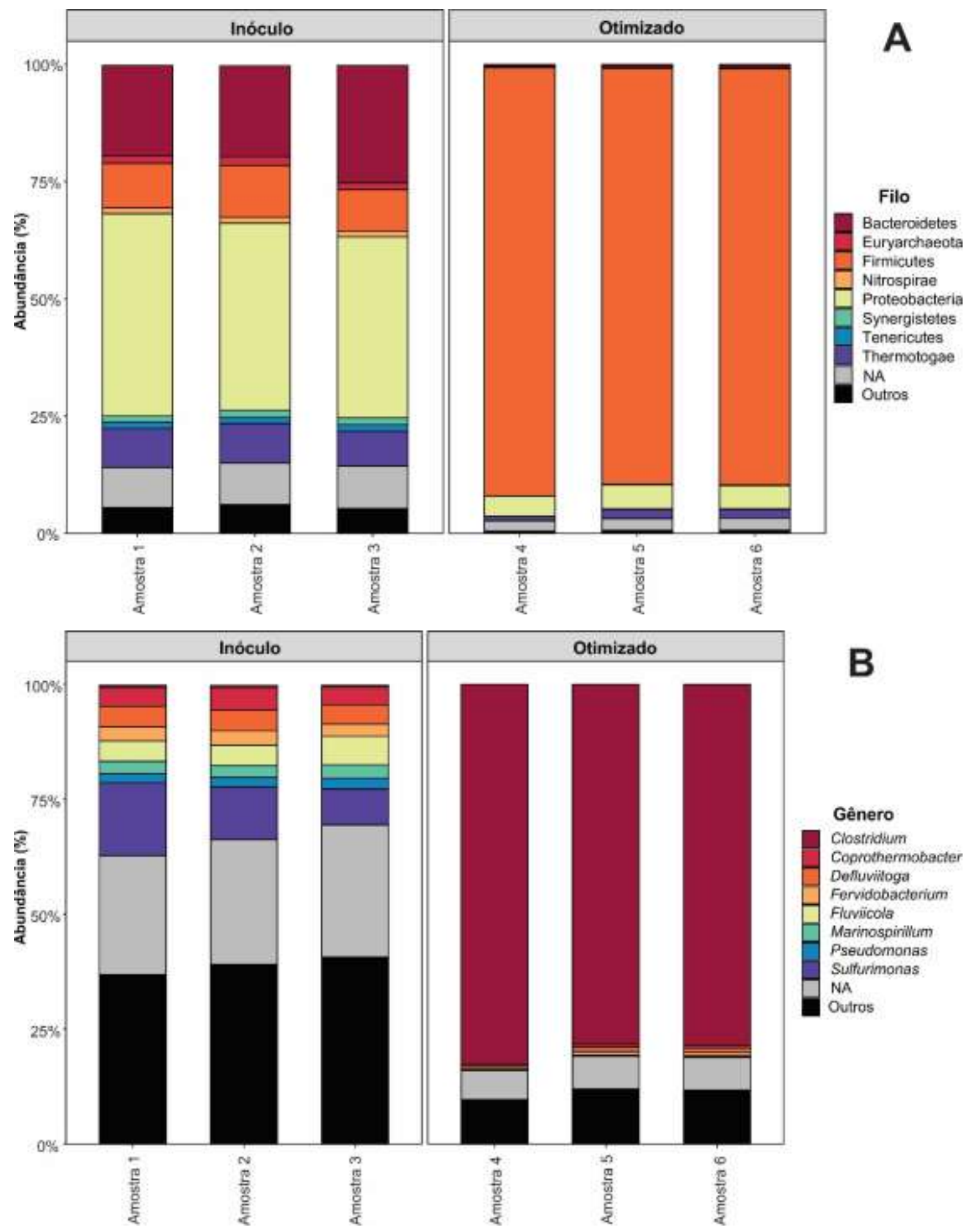

Consistente com os valores do índice ecológico, maior diversidade foi observada nas amostras de inóculo em comparação com aquelas obtidas do ensaio de otimização.

Vários gêneros foram identificados no inóculo em abundâncias médias semelhantes, como Coprothermobacter (4,32\%), Defluviitoga (4,36\%), Fervidobacterium (2,93\%), Fluviicola 
(5,01\%), Marinospirilum (2,75\%), Pseudomonas (2,14\%) e Sulfirimonas (11,68\%). Em relação ao ensaio de otimização ficou evidente forte seleção do gênero Clostridium, cuja abundância relativa foi de $0,43 \%$ no inóculo a 79,78\% nas amostras dos reatores otimizados. Além disso, foi observado ligeiro aumento na abundância relativa de Paraclostridium, de $\leq 0,01 \%$ no inóculo para 1,93\% nos reatores otimizados.

Organismos do gênero Clostridium são bacilos Gram-positivos que possuem metabolismos diversos, produzem AOV e álcoois ( $\mathrm{HBu}, \mathrm{HAc}, \mathrm{HLac}, \mathrm{HFor} \mathrm{e} \mathrm{EtOH})$ a partir de carboidratos, peptonas e outros compostos orgânicos (YUTIN; GALPERIN, 2013). Rabelo et al. (2018), identificaram várias espécies da ordem Clostidiales em reatores anaeróbios aplicados na obtenção de $\mathrm{H}_{2}$ a partir de resíduo lignocelulósico (bagaço de canade-açúcar). As espécies identificadas pelos autores supracitados foram Paraclostridium bifermentans (anteriormente $C$. bifermentans), Ruminiclostridium celobioparum (anteriormente C. cellobioparum), $R$. cellulolyticum (anteriormente $C$. cellulolyticum) e $C$. sartagoforme.

C. beijerinckii, uma das espécies frequentemente identificada em reatores anaeróbios, tem sua fisiologia ainda pouco compreendida, mas sabe-se que é capaz de produzir $\mathrm{HAc}, \mathrm{HBu}, \mathrm{EtOH}$, isopropanol e acetona em diferentes condições operacionais (FONSECA et al., 2019). Esta espécie pode consumir diversos açúcares, como glicose, amido, xilose, celobiose, e não apresenta preferência entre glicose e xilose como substrato, podendo consumi-los simultaneamente (CEBREIROS; FERRARI; LAREO, 2019), o que é relevante para a presente pesquisa, uma vez que a xilose é um dos principais monômeros em resíduos sólidos de citros (CHOI et al., 2015).

De acordo com Gomez-Flores et al. (2017), C. beijerinckii não é capaz de hidrolisar celulose. No entanto, Cebreiros et al. (2019) relataram produtos de hidrólise de celulose levando à produção de butanol (4,2 g.L $\left.\mathrm{L}^{-1}\right)$, usando uma cepa $C$. beijerinckii DSM6423 após pré-tratamento enzimático de serragem de eucalipto como substrato principal. No presente estudo, não foi observada produção de butanol, provavelmente devido às diferentes condições operacionais aplicadas. Deve-se destacar que Cebreiros et al. (2019) utilizaram uma cepa isolada, ou seja, sem interações sintróficas, importantes uma vez que essas interações podem determinar as principais vias de fermentação de $C$. beijerinckii (GOMEZFLORES; NAKHLA; HAFEZ, 2017), levando à acetogênese em vez de solvetogênese. 
A despeito dos poucos estudos relacionando a capacidade de $C$. beijerinckii em produzir $\mathrm{H}_{2}$ (GOMEZ-FLORES; NAKHLA; HAFEZ, 2017; WU et al., 2019), $C$. butyricum, é amplamente conhecida por ser produtora de $\mathrm{H}_{2}$ em reatores anaeróbios pela conversão de açúcares em HBu, pela via glicolítica, ou alternativamente, HLac e HAc também podem ser convertidos em HBu (DETMAN et al., 2019). Neste estudo foram observadas concentrações de $\mathrm{HBu}$ de $3.731 \mathrm{mg} . \mathrm{L}^{-1}$ ao longo do tempo operacional, provavelmente devido à conversão de monômeros solúveis.

A maioria das espécies de Clostridium são capazes de hidrolisar pectina (YUTIN; GALPERIN, 2013), um dos componentes dos resíduos de citros, ressaltando a sua alta abundância relativa no ensaio otimizado. Além disso, a biotina é a única vitamina exigida por Clostridium (YUTIN; GALPERIN, 2013), e os produtos derivados da levedura são ricos em biotina, como o extrato de levedura, componente do meio PCS utilizado nesta pesquisa, favorecendo o crescimento de Clostridium.

Resultados semelhantes foram observados por Villa-Montoya (2019), com maior abundância de Clostridium (88\%) em pH $\geq 7,0$ e $30{ }^{\circ} \mathrm{C}$, durante a obtenção de $\mathrm{H}_{2}$ a partir dos resíduos do processamento do café. Soares et al. (2018) também indicaram a partir do bagaço da cana-de-açúcar a predominância de Clostridium (33\%) nas condições otimizadas (2,77 g.L $\mathrm{L}^{-1}$ de extrato de levedura e 5,84 g.L $\mathrm{L}^{-1}$ de cana-de-açúcar). Rabelo et al. (2018) identificaram Paraclostridium bifermentats $(62,69 \%)$ como um dos principais gêneros em reatores otimizados $\left(7,0\right.$ g. $\mathrm{L}^{-1}$ de bagaço de cana-de-açúcar e $\left.\mathrm{pH} 7,2\right)$ e concentração de 23,10 $\mathrm{mmol} \mathrm{H}_{2} \cdot \mathrm{L}^{-1}$. No presente estudo, houve abundância relativa de Clostridium de até $79,78 \%$ nas condições otimizadas.

Nas condições não otimizadas ( 15 g. $\mathrm{L}^{-1}$ de resíduo in natura, 2 gSTV.L ${ }^{-1}$ de inóculo alóctone, $\mathrm{pH} 7,0,30^{\circ} \mathrm{C}$ e meio de cultura PCS), foi possível observar menor abundância relativa de Clostridium (18,67\%) com 15 g.L. $\mathrm{L}^{-1}$ de resíduo sólido de citros in natura, 2 g.L $\mathrm{L}^{-}$ ${ }^{1}$ de inóculo alóctone, $37{ }^{\circ} \mathrm{C}$ e meio de crescimento PCS em pH inicial de 7,0. Nestas condições, 13,31 mmol H $2 . \mathrm{L}^{-1}$ e $4.355 \mathrm{mg} . \mathrm{L}^{-1}$ de HAc foram obtidos. Provavelmente, as condições aplicadas aos reatores otimizados (4 gSTV.L ${ }^{-1}$ de inóculo, 29,8 gL $\mathrm{gL}^{-1}$ de substrato e $\mathrm{pH}$ 8,98) foram favoráveis para este gênero cuja abundânica relativa observada foi de $79,78 \%$.

Coprothermobacter foi identificada em abundância relativa de 4,32\% no inóculo e $\leq 0,01 \%$ para as amostras otimizadas. Soares et al. (2017) usaram inóculo semelhante (lodo de reatores UASB aplicado ao processamento termofílico da vinhaça de cana-de-açúcar) 
do presente estudo e observaram 41,73\% de abundância relativa para o inóculo. Da mesma forma, a abundância relativa de Defluviitoga foi reduzida (4,36 para $\leq 0,01 \%$, respectivamente), nas amostras do inóculo e reator otimizado, respectivamente. Tais gêneros são identificados em reatores aplicados à digestão anaeróbia de resíduos lignocelulósicos, como silagem de milho e cevada, mas tem afinidade com temperaturas termofílicas $\left(55^{\circ} \mathrm{C}\right)$ (MAUS et al., 2015).

Coprothermobacter é comumente associada à atividade hidrolítica devido à produção de proteases extracelulares, com concomitante obtenção de $\mathrm{H}_{2}$, majoritariamente via acetogênese, que atua como um dos principais responsáveis pela transferência de elétrons entre estas bactérias e arqueias metanogênicas hidrogenotróficas (TANDISHABO et al., 2012; GAGLIANO et al., 2015). Entretanto, de acordo com Tandishabo et al. (2012), a abundância deste gênero em reatores não está associada apenas à termodinâmica de produção de $\mathrm{H}_{2}$ no sistema, mas principalmente com as características do resíduo utilizado como substrato. Desta forma, é possível inferir, que além da faixa de temperatura aplicada na presente pesquisa $\left(30^{\circ} \mathrm{C}\right)$ destoar da faixa ótima de crescimento deste gênero $\left(55^{\circ} \mathrm{C}\right)$, provavelmente um dos motivos para a redução de sua abundância relativa nos ensaios otimizados foi o maior teor de carboidratos e menor teor de proteínas (58 g. $\mathrm{kg}^{-1}$ ) nos resíduos sólidos de citros, por se tratar de biomassa lignocelulósica (MAMMA; CHRISTAKOPOULOS, 2014).

Defluviitoga, apesar de também ser considerada como um gênero majoritariamente proteolítico, pode consumir diferentes carboidratos na ausência de proteínas, como arabinose, celobiose, frutose, galactose, glicose, sacarose, xilose, celulose, entre outros, sendo $\mathrm{H}_{2}, \mathrm{CO}_{2}$, HAc e EtOH os principais produtos finais de sua atividade fermentativa (HANIA et al., 2012; MAUS et al., 2016). Desta forma, é possível inferir que, neste caso, os reatores em condições otimizadas não foram favoráveis aos organismos deste gênero quando comparados ao inóculo, principalmente, senão unicamente, devido à temperatura utilizada, uma vez que Hania et al. (2012) indicam que não há crescimento de Defluviitoga a $30{ }^{\circ} \mathrm{C}$, enquanto o inóculo provém de reator operado a $55{ }^{\circ} \mathrm{C}$, dentro da faixa de crescimento ótima deste gênero. 


\subsubsection{Anotação funcional e mapeamento de vias metabólicas}

Após a anotação de genes e comparação entre as diferentes amostras, foi possível observar boa reprodutibilidade entre as repetições biológicas, uma vez que houve agrupamento entre as amostras de inóculo (8.884 genes em comum) e as amostras de biomassa dos reatores otimizados (25.388 genes em comum) (Figura 5.37).

Vale ressaltar que, devido à homologia, diferentes genes podem expressar os mesmos número KO, especialmente quando se trata de amostra composta/consórcio. Além disso, existem mais genes em comum entre as amostras do reator otimizado devido ao maior domínio e maior Chao-1 tornando-se mais distintos em relação as amostras do inóculo (genes mais exclusivos).

Figura 5.37. Visão geral do número de genes para todos os níveis metabólicos entre as amostras analisadas e suas interseções por meio do gráfico Upset.

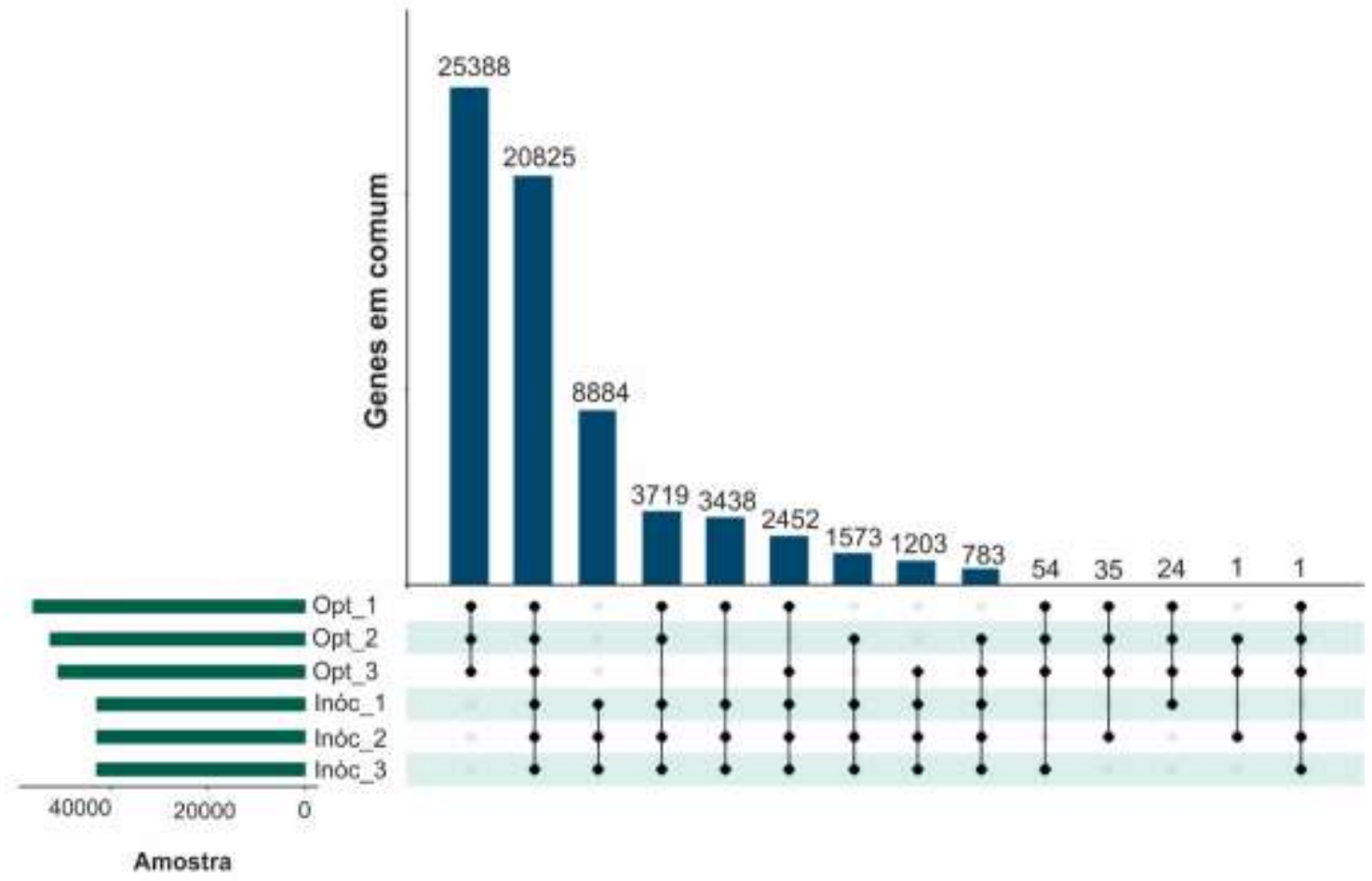

Metabolismo foi o primeiro nível mais abundante (12,15 e 13,70\%) (Figura 5.38) entre as categorias de KEGG, às quais os genes identificados puderam ser atribuídos, tanto para o inóculo, quanto para as amostras do ensaio otimizado, respectivamente. Nenhuma categoria KEGG foi atribuída para 78,90\% das amostras do inóculo e 83,50\% das amostras do ensaio otimizado. Vale ressaltar que a impossibilidade de aumentar a porcentagem de genes anotados com sucesso é uma limitação atual da metagenômica, uma vez que baixos 
percentuais podem levar ao entendimento incompleto da taxonomia e do potencial funcional da comunidade microbiana.

Figura 5.38. Abundância relativa das vias metabólicas predominantes nas amostras de inóculo (Amostras 13) e do ensaio otimizado (Amostras 4-6) para os níveis de KEGG.

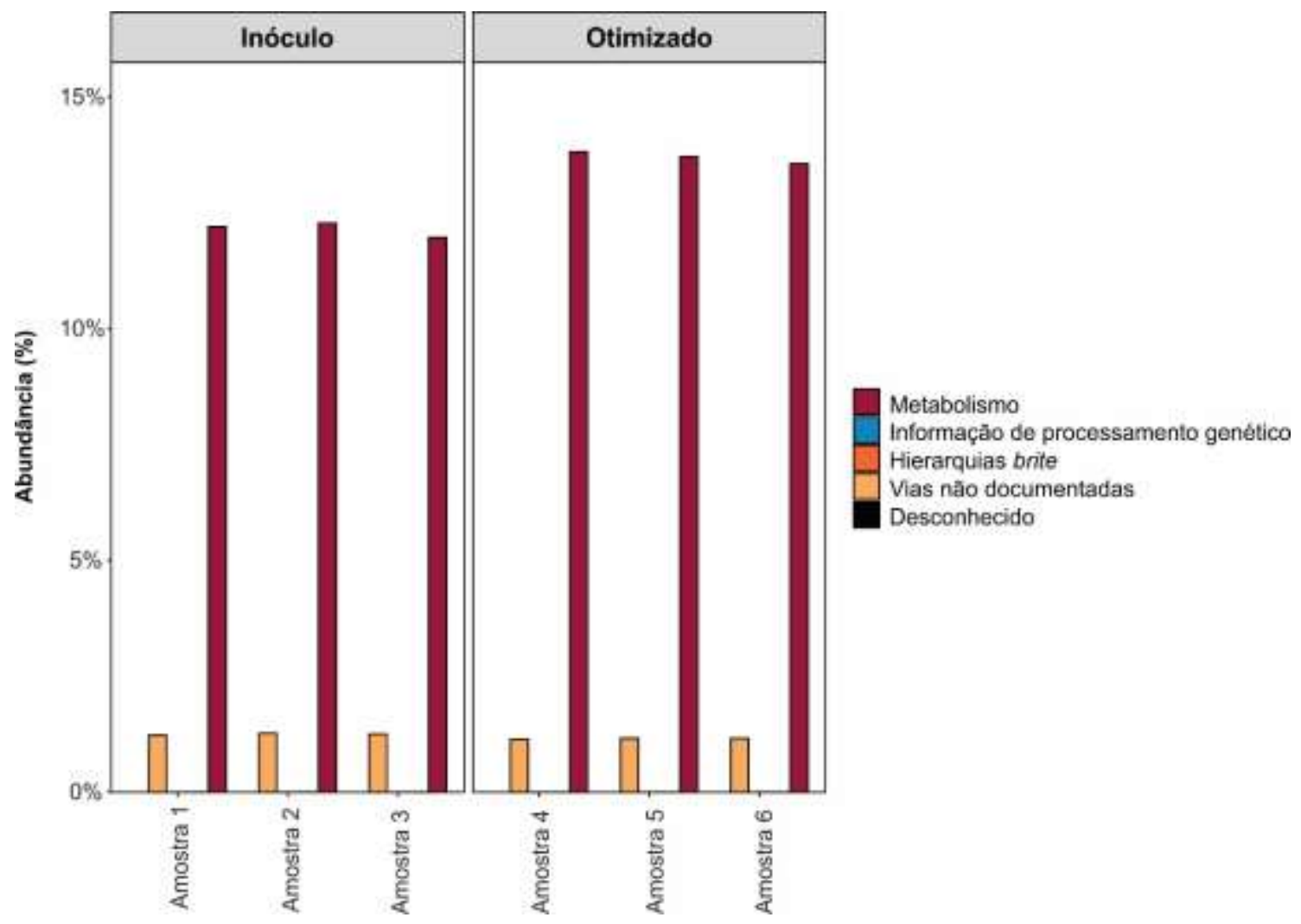

$\mathrm{Na}$ categoria Metabolismo, as principais vias observadas foram relacionadas a carboidratos (5,64 e 8,14\%), nucleotídeos (0,66 e 0,74\%), aminoácidos (1,87 e 1,71\%), biossíntese de glicano (1,29 e 0,99\%), vitaminas e cofatores (1,84 e 1,54\%), terpenóides e policetídeos (0,40 e 0,28\%), metabólitos secundários (0,39 e 0,28\%), entre outros $(0,012$ e 0,04\%), para o inóculo e ensaio de otimização, respectivamente (Figura 5.39).

Uma vez que houve aumento apenas de genes relacionados ao metabolismo de carboidratos, apenas as vias metabólicas relacionadas a essa categoria foram consideradas para análises posteriores. Entre as principais vias, destacam-se glicólise e gliconeogênese (0,50 e 0,56\%), ciclo de Krebs (0,55 e 0,19\%), pentose fosfato $(0,52$ e $0,61 \%)$, galactose $(0,32$ e $0,99 \%)$, amido e sacarose $(0,42$ e 1,78 \%), aminoaçúcares e nucleotídeo $(0,45$ e $0,57 \%)$, piruvato $(0,83$ e $1,11 \%)$, glioxilato e dicarboxilato $(0,70$ e $0,43 \%)$, butanoato $(0,45$ e 0,49\%), entre outros (0,91 e 1,41\%), para o inóculo e as amostras do ensaio de otimização, respectivamente. 
Figura 5.39. Abundância relativa das vias metabólicas predominantes nas amostras do inóculo (Amostras 13) e do ensaio de otimização (Amostras 4-6) para todos os níveis metabólicos (A) e filtradas para metabolismo de carboidratos $(\mathrm{B})$.
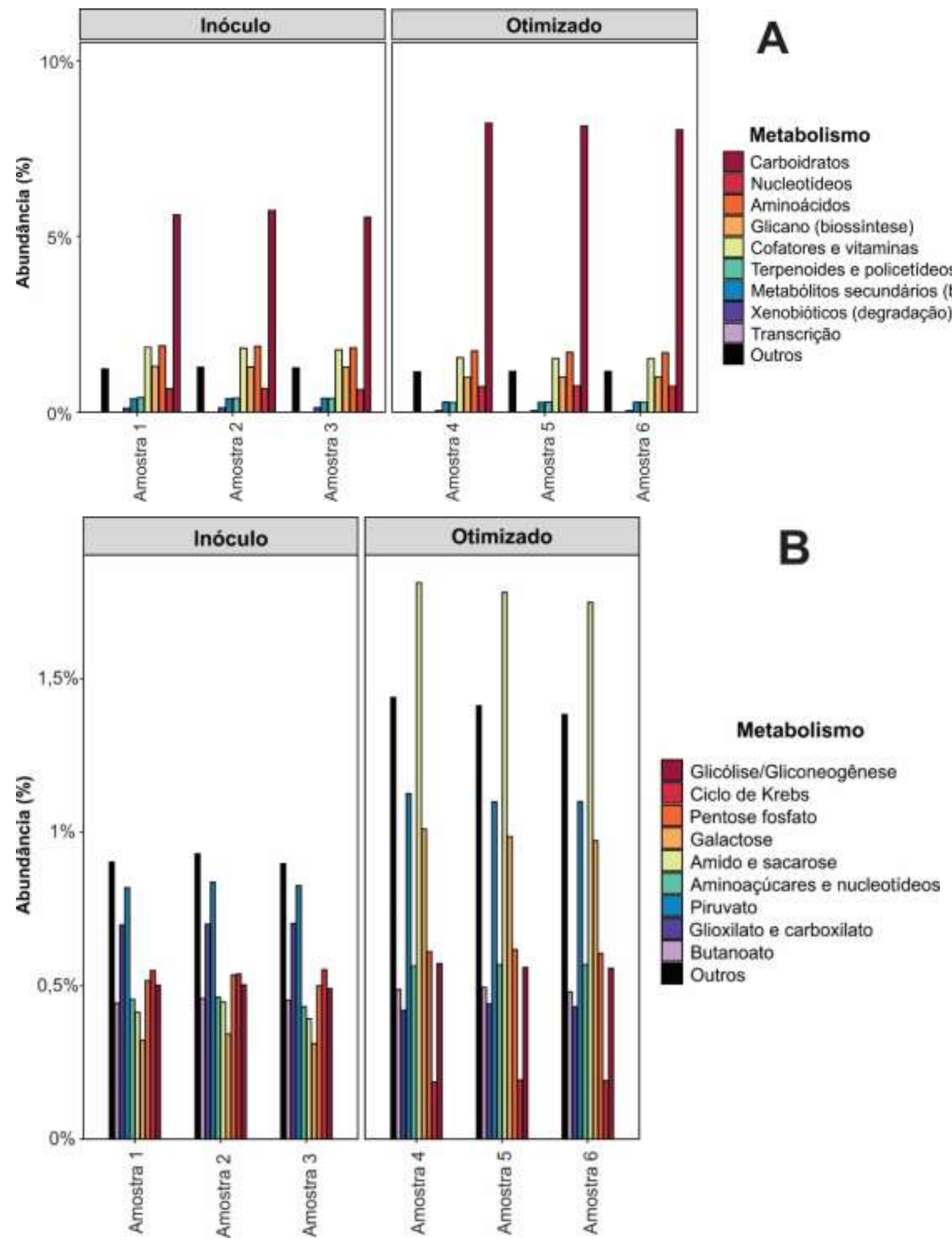

Visivelmente, Clostridium foi o principal gênero associado ao aumento de genes relacionados ao metabolismo de carboidratos. De fato, seu aumento foi observado na glicólise e gliconeogênese $(0,18$ a 83,93\%), pentose fosfato $(0,33$ a 77,05\%), galactose 
$(0,10$ a $86,87 \%)$, piruvato $(0,90$ a $84,68 \%)$ e, principalmente, metabolismos de amido e sacarose (1,69 a 86,52\%) (Figura 5.40).

Figura 5.40. Abundância relativa das vias metabólicas predominantes nas amostras de inóculo (A) e do ensaio de otimização (B) para a categoria de metabolismo de carboidratos, com as contribuições dos 10 gêneros mais abundantes. As proporções foram calculadas considerando as médias do número total de leituras pré-processadas em triplicata.

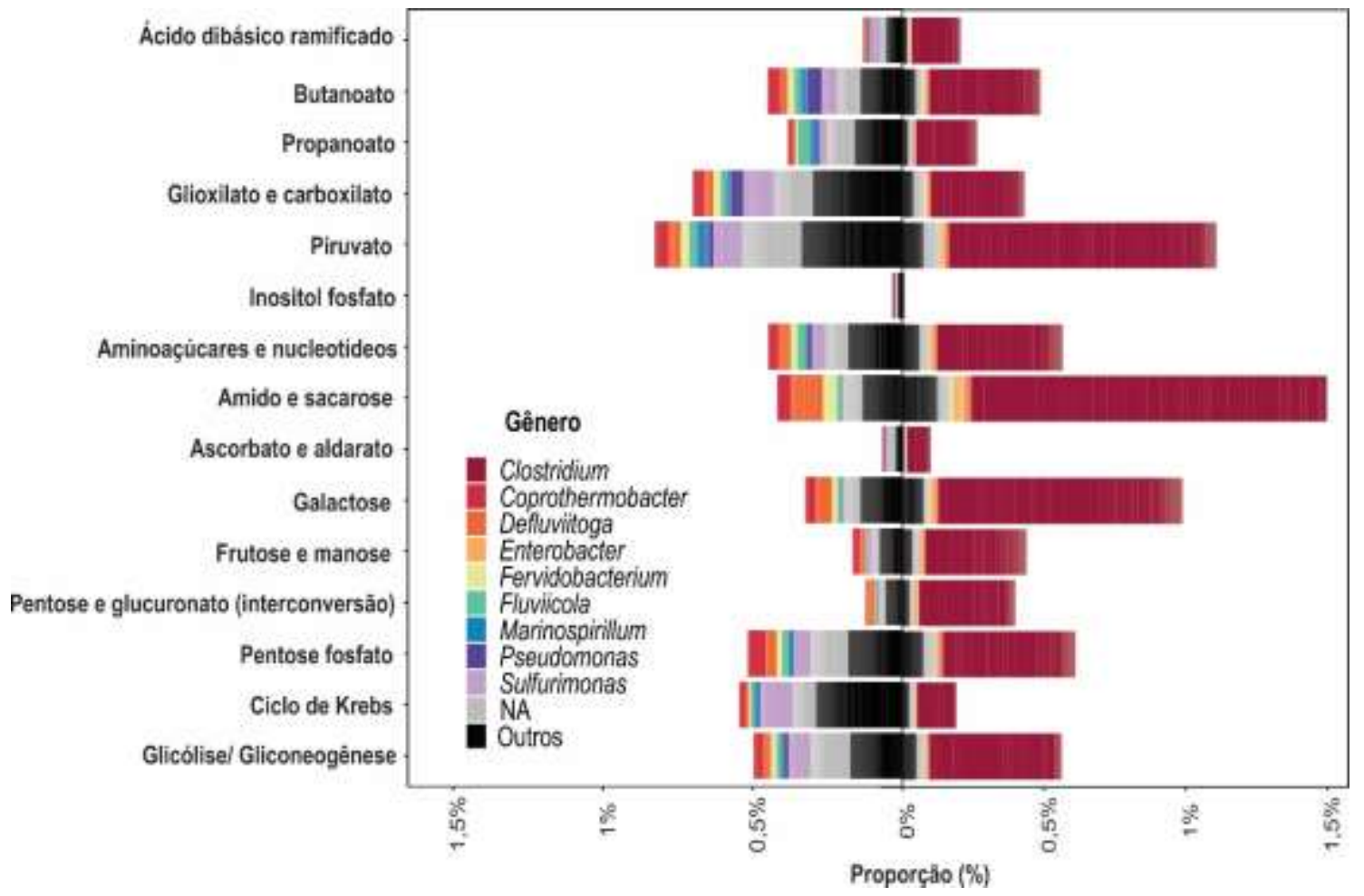

Da mesma forma, foram verificados os $\mathrm{KO}$ mais abundantes na categoria metabolismo de carboidratos (Figura 5.41), bem como os principais gêneros relacionados com cada um deles, principalmente aquelas com maiores proporções nas amostras do ensaio de otimização em relação ao inóculo. É possível notar que Clostridium foi o principal gênero relacionado a estas alterações nas condições otimizadas. K00615, uma transcetolase [EC: 2.2.1.1] envolvida na via da pentose fosfato, teve proporções de cerca de $0,10 \%$ no inóculo e $0,17 \%$ nas amostras do ensaio de otimização. 
Figura 5.41. Proporção dos $30 \mathrm{KO}$ mais abundantes nas amostras de inóculo (A) e do ensaio de otimização (B) para o metabolismo de carboidratos, com os 10 gêneros mais abundantes associados a estes KO. As proporções foram calculadas considerando o número total de leituras em triplicata.

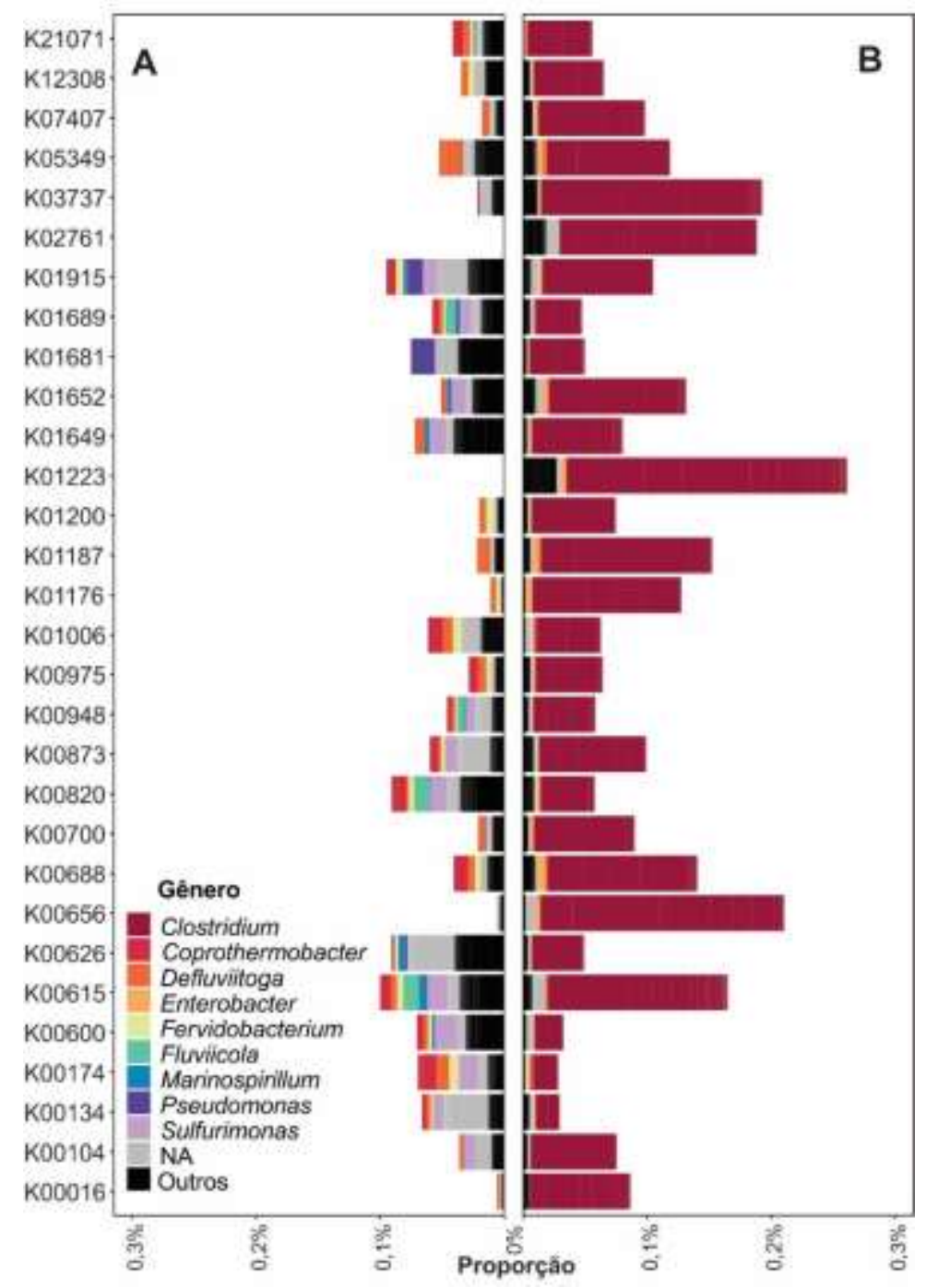

Nota: $\mathrm{K} 21071=$ fosfofrutoquinase dependente de ATP/fosfofrutoquinase dependente de difosfato, K12308= $\beta$-galactosidase, $\quad \mathrm{K} 07407=\alpha$-galactosidase, $\quad \mathrm{K} 05349=\quad \beta$-glicosidase, $\quad \mathrm{K} 03737=\quad$ piruvatoferredoxina/flavodoxina oxidoredutase, K02761= componente EIIC do sistema PTS de celobiose, K01915= glutamina sintetase, K01689= enolase, K01681 = aconitato hidratase, K01652= acetolactato sintase I/II/III, $\mathrm{K} 01649=2$-isopropilmalato sintase, K01223 $=6$-fosfo- $\beta$-glicosidase, $\mathrm{K} 01200=$ pululanase, $\mathrm{K} 01187=\alpha-$ glicosidase, K01176= $\alpha$-glicosidase, K01006= piruvato, ortofosfato diquinase, K00948= ribose-fosfato pirofosfoquinase, $\mathrm{K} 00873=$ piruvato quinase, $\mathrm{K} 00820=$ frutose- 6 -fosfato transaminase, $\mathrm{K} 00700=$ enzima de ramificação de 1,4- $\alpha$-glicano, K00686= glicogênio fosforilase, K00686= glicogênio fosforilase Cacetiltransferase, K00615 $=$ transcetolase, $\mathrm{K} 00600=$ glicina hidroximetiltransferase, K00174= 2oxoglutarato/2-oxoácido ferredoxina oxidoredutase subunidade $\alpha$, K00134= gliceraldeído 3-fosfato desidrogenase, K00104= glicolato desidrogenase, K00104= lactolato desidrogenase. 
O K00656, formiato C-acetiltransferase [EC: 2.3.1.54] envolvido no metabolismo de piruvato (piruvato formiato liase), também foi observado em proporções mais altas nas amostras do ensaio de otimização $(0,21 \%)$ do que no inóculo $(0,01 \%)$. Esta enzima é importante na catálise da conversão da coenzima A em formiato e acetil-CoA em condições anaeróbias (SRIVASTAVA et al., 2017). A reação envolvendo K00656 é uma etapa intermediária na produção de ácido acético a partir de acetil-CoA, com produção concomitante de $\mathrm{H}_{2}$ (SRIVASTAVA et al., 2017); geralmente associada a várias espécies de Clostridium (LEVIN et al., 2006). Nesta reação reversível, piruvato e CoA são convertidos em formiato e acetil-CoA que por sua vez, pode ser convertido pela formiato desidrogenase em $\mathrm{H}_{2}$ e $\mathrm{CO}_{2}$ (JIA et al., 2017) (Figura 5.42).

Figura 5.42. Ação da piruvato formiato liase na clivagem do piruvato em formiato e acetil-CoA.

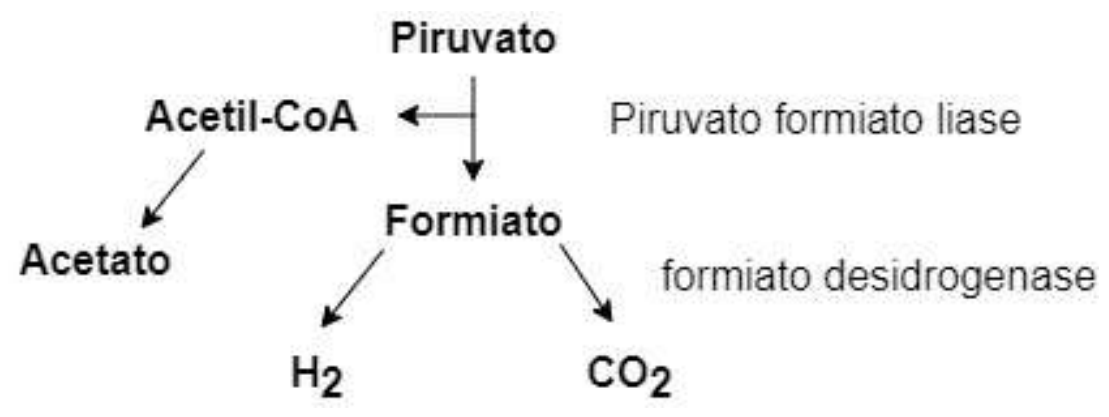

Fonte: Modificado de Jia et al. (2017).

O K01223 foi um dos mais abundantes $(\leq 0,001 \%$ e $0,26 \%$, respectivamente no inóculo e ensaio de otimização). Este KO refere-se a uma hidrolase 6 -fosfo- $\beta$-glicosidase [EC: 3.2.1.86] envolvida na glicólise (Equação 5.7). Esta enzima catalisa a hidrólise do monofosfato de celobiose (6-fosfo- $\beta$-D-glicosil-1,4-D-glicose) em D-glicose + D-glicose 6-fosfato. $\mathrm{O}$ mesmo $\mathrm{KO}$ foi observado em reatores em batelada aplicados à obtenção de $\mathrm{H}_{2}$ a partir de substrato lignocelulósico (resíduo de processamento de café) por Villa-Montoya et al. (2020) e em condições operacionais semelhantes (reatores em batelada operadas a 30 ${ }^{\circ} \mathrm{C}$ em $\left.\mathrm{pH} 7,0\right)$.

$$
6 \text { fosfo } \beta \text { Dglicosil }(1,4) \text { Dglicose }+H_{2} \leftrightarrow \text { D glicose }+D \text { glicose } 6 \text { fosfato }
$$

O K02761 é uma enzima do sistema de fosfotransferase (PTS) dependente de fosfoenolpiruvato de celobiose, relacionada com o metabolismo do amido e sacarose, e catalisa a fosforilação de açúcar com sua translocação através da membrana celular 
(KEYHANI; BACIA; ROSEMAN, 2000). Este KO foi observado em porcentagens $\leq 0,001 \%$ no inóculo e $0,19 \%$ nas amostras do ensaio de otimização.

K03737 é uma piruvato-ferredoxina/flavodoxina oxidoredutase [EC: 1.2.7.1, 1.2.7.] e catalisa a interconversão entre piruvato e acetil-CoA. Esta enzima pode estar relacionada com o metabolismo de piruvato, propanoato e também butanoato (NAKAYAMA et al., 2013). Este KO foi observado em 0,02\% nas amostras de inóculo e 0,19\% nas amostras do ensaio de otimização. Além disso, ao analisar apenas os $\mathrm{KO}$ envolvidos em vias conhecidamente relacionadas à obtenção de $\mathrm{H}_{2}$ (VILLA MONTOYA et al., 2020) (Figura 5.43), ficou claro que K03737 foi mais abundante e verificado em maior porcentagem nas amostras do ensaio de otimização.

Outros $\mathrm{KO}$ relacionados com a produção de $\mathrm{H}_{2}$ foram observados em maiores proporções nas amostras do ensaio de otimização, a saber: K04072 (0,1\%) e K00016 (0,08\%). K04072 é uma acetaldeído desidrogenase/álcool desidrogenase [EC: 1.2.1.10, 1.1.1.1] envolvida em diversas vias, como glicólise, degradação de ácidos graxos, degradação de compostos aromáticos, metabolismo de piruvato e butanoato, entre outras. Estas desidrogenases podem catalisar a conversão de acetaldeído em ácido acético (Equação 5.8), além da fermentação de glicose em etanol e $\mathrm{CO}_{2}$ (Equação 5.9) (GOODLOVE et al., 1989).

$$
\begin{aligned}
& \text { Acetaldeído }+\mathrm{NAD}^{+}+\text {Coenzima } \mathrm{A} \leftrightarrow \text { AcetilCoA }+\mathrm{NADH}+\mathrm{H}^{+} \\
& \text {Glicose }+2 \mathrm{ADP}+2 \mathrm{Pi} \rightarrow 2 \mathrm{EtOH}+2 \mathrm{CO}_{2}+2 \mathrm{ATP}+2 \mathrm{H}_{2} \mathrm{O}
\end{aligned}
$$

Finalmente, K00016 é uma L-lactato desidrogenase [EC: 1.1.1.27] que ativa as vias da glicólise/gliconeogênese e usual em todos os seres vivos. Segundo Villa-Montoya (2020), essa enzima poderia estar envolvida, tanto na síntese de ácido lático e álcoois, quanto na rota inversa, que permite a obtenção de $\mathrm{H}_{2}$ a partir dos mesmos metabólitos. Nessa via, o ácido lático pode ser convertido em ácido pirúvico após redução do $\mathrm{NAD}^{+}$ (Equação 5.10), que pode ser convertido em $\mathrm{H}_{2}, \mathrm{CO}_{2}$ e $\mathrm{HBu}$.

$$
(S)-\text { lactato }+\mathrm{NAD}^{+} \rightarrow \text { piruvato }+\mathrm{NADH}+\mathrm{H}^{+}
$$


Figura 5.43. Proporções de $\mathrm{KO}$ relacionadas com a obtenção de $\mathrm{H}_{2}$ nas amostras de inóculo (A) e do ensaio de otimização (B), com os 10 gêneros associados mais abundantes. As proporções foram calculadas considerando o número total de leituras processadas em triplicata.

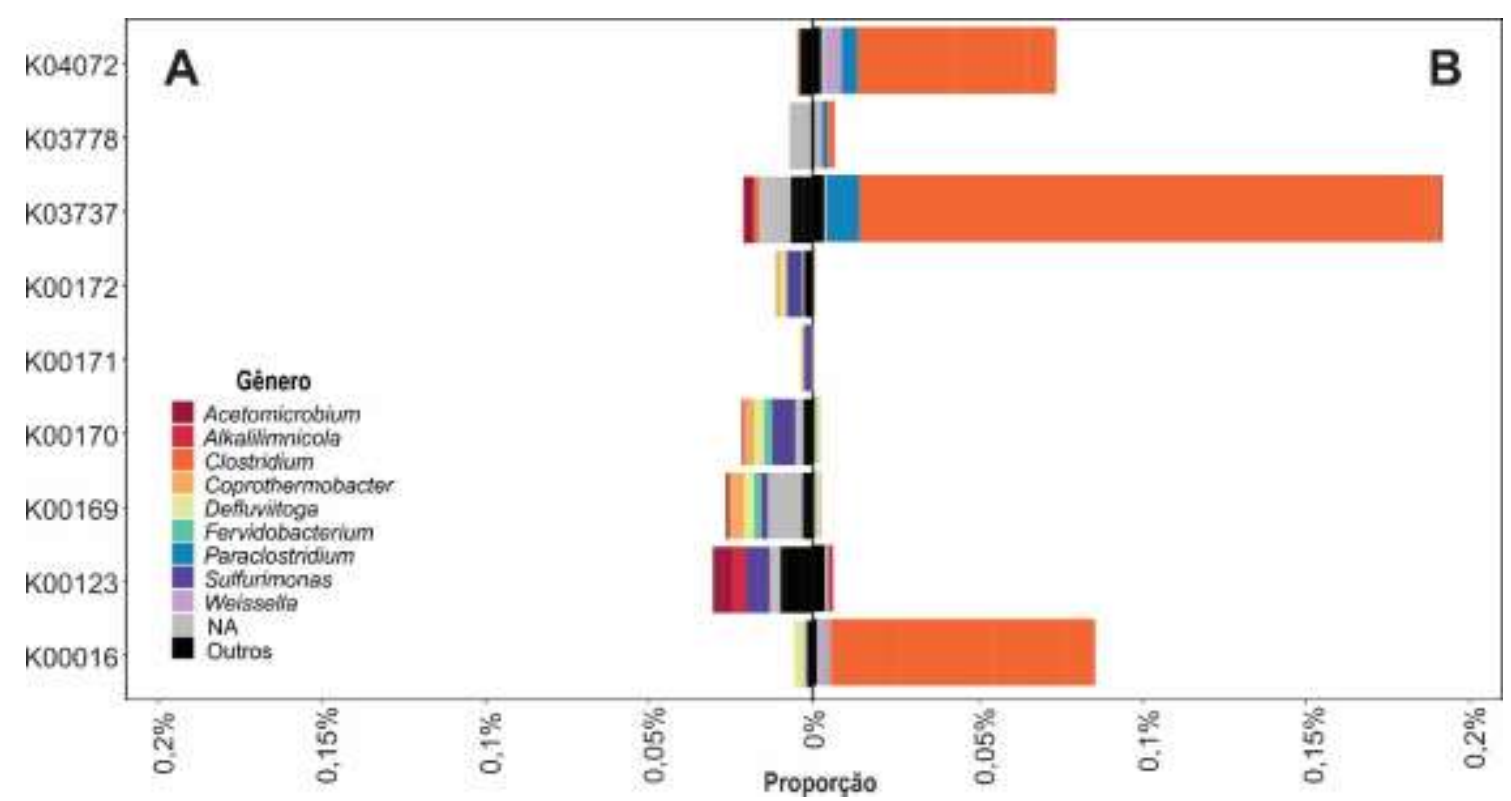

Nota: K04072= acetaldeído desidrogenase/álcool desidrogenase, K03778= D-lactato desidrogenase, K03737 $=$ piruvato-ferredoxina/flavodoxina oxidoredutase, $\mathrm{K} 00172=$ piruvato ferredoxina oxidoredutase $\gamma$ subunidade, $\mathrm{K} 00171=$ piruvato-ferredoxina subunidade $\beta-16001$ piruvato oxidoredutase, K00171= subunidade deluvato de oxidoreduto-subunitase, K00171= subunidade de oxidoreduto-oxidato-K0016701 piruvato ferredoxina oxidoredutase $\alpha$ subunidade, K00123= subunidade principal formato desidrogenase, K00016 = L-lactato desidrogenase.

Visivelmente, diversos $\mathrm{KO}$ relacionados à obtenção de $\mathrm{H}_{2}$ foram observados em menores proporções nas amostras do ensaio de otimização em relação ao inóculo, como K00172, K00171, K00170, K00169 e K00123. A maioria destes KO foi relacionada a Coprothermobacter, Defluviitoga, Helicobacter e Sulfirimonas. Pode-se supor que as condições operacionais utilizadas nos ensaios de otimização não foram favoráveis a estas bactérias, uma vez que a maioria delas são termofilicas (GAGLIANO et al., 2015; MAUS et al., 2015) e os ensaios no presente estudo foram realizados a $30{ }^{\circ} \mathrm{C}$.

As enzimas ativas de carboidratos (CAZymes) no inóculo e nas amostras do ensaio de otimização foram analisadas, com enfoque naquelas diretamente relacionadas com a degradação de celulose/hemicelulose ou lignina (XIA et al., 2014; JANUSZ et al., 2017). Além de quantificadas, foram relacionadas aos 10 gêneros mais abundantes associadas a cada CAZy (Figura 5.44). Vale ressaltar que as CAZymes foram definidas de acordo com a 
homologia de proteínas, ou seja, a mesma CAZy pode representar enzimas distintas com atividades distintas (YIN et al., 2012).

O grupo liguinolítico das Atividades Auxiliares (AA) não corresponde adequadamente às enzimas ativas dos carboidratos, mas por ser composto por enzimas redox que atuam de forma complementar são consideradas em conjunto. A lignina, por exemplo, não é um carboidrato, mas está invariavelmente associada a polissacarídeos na parede celular da planta, na qual as fibras de celulose são incorporadas em uma matriz de lignina (JANUSZ et al., 2017). Neste estudo, alguns genes AA foram identificados, mas um aumento entre a amostra do ensaio de otimização e o inóculo foi observado para apenas dois deles: AA7 (de $\leq 0,001$ a $0,04 \%$, respectivamente) e AA4 (de $\leq 0,01$ a $0,02 \%$, respectivamente). De acordo com Li et al. (2019), a maioria das enzimas relacionadas à despolimerização da lignina, como as peroxidases e lacases liguinolíticas, são produzidas por fungos e poucas bactérias aeróbias, as quais oxidam os polímeros heterogêneos a pequenas moléculas aromáticas, sendo as cepas e mecanismos envolvidos em sua degradação em anaerobiose ainda pouco conhecido.

A família lignolítica AA7 está associada às atividades de glicoligossacarídeos e quitoligossacarídeos oxidase [EC 1.1.3.-], reduzindo os resíduos de glicosila finais de oligossacarídeos ligados por ligações $\alpha$ ou $\beta$-1,4-glicose. AA4 é um grupo álcool vanílico oxidase [EC 1.1.3.38] cujas enzimas podem catalisar a conversão de compostos fenólicos com cadeias laterais em seus anéis aromáticos em aldeídos.

É importante ressaltar que o grupo AA3, principalmente relacionado à atividade da celobiose desidrogenase [EC 1.1.99.18] foi observado em menor proporção nas amostras do ensaio de otimização $(0,001 \%)$, quando comparado ao inóculo $(0,054 \%)$. No inóculo, os principais gêneros relacionados com este grupo foram Aureimonas (24,07\%) e Burkholderia (22,22\%). Zámocký et al. (2004) e Melo-Nascimento et al. (2018) relacionaram o gênero Burkholderia à produção extracelular de celobiose desidrogenase. Nas amostras do inóculo, o gênero Burkholderia foi altamente relacionado (22,22\%) com AA3 (celobiose desidrogenase), sendo importante mencionar a capacidade metabólica dessas bactérias em degradar lignina (AKITA et al., 2017), porém, foram obtidos 0,14 e 0,046\% de abundância relativa nas amostras do ensaio de otimização e inóculo, respectivamente, provavelmente devido ao ambiente anaeróbio das condições experimentais. 
Figura 5.44. Proporções das Enzimas Ativas por Carboidrato (CAZymes) das classes Atividades Auxiliares (AA) ou Hidrólise Glicosídica (GH) nas amostras de inóculo (A) e do ensaio de otimização (B), com os 10 gêneros mais abundantes associados. As proporções foram calculadas considerando o número total de leituras processadas em triplicata.

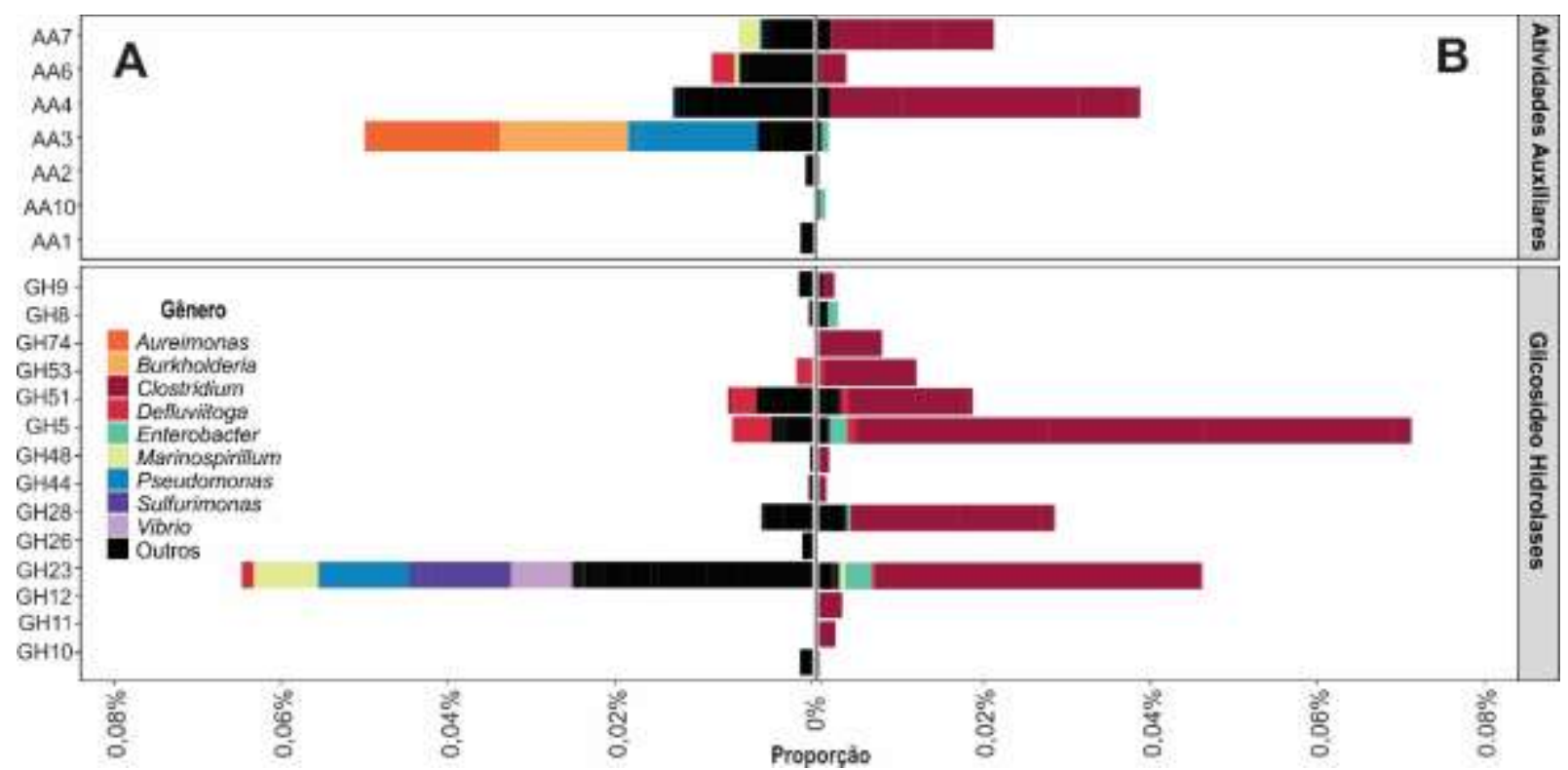

Nota: $\mathrm{AA} 7=$ glicoligossacarídeo/quitoligossacarídeo oxidase, AA6= 1,4-benzoquinona redutase, AA4= vanilil-álcool oxidase, AA3 $=$ celobiose desidrogenase, AA2 = lignina peroxidase, AA10 $=$ celulose monoxigenase, $\mathrm{AA} 1=$ lacase, GH9= celulase GH74= endoglicanase, GH53= endo- $\beta-1,4$-galactanase, GH51= endoglicanase $/ \beta$-xilosidase, GH5= exocelulase, GH48= endocelulase, GH44= endoglicanase/xiloglicanase, $\mathrm{GH} 28=$ poligalacturonase, $\beta$-mananase/ $\beta$-GH26 1,3-xilanase, GH23= lisozima, GH10= endo-1,4- $\beta$-xilanase.

Os grupos AA e GH atuam de forma sinérgica, visto que ambos atuam nas estruturas lignocelulósicas (MELO-NASCIMENTO et al., 2018). As Glicosídeo Hidrolases (GH) [EC 3.2.1.-] estão incluídas no grupo das enzimas que hidrolizam a ligação glicosídica entre dois ou mais carboidratos. A família da celulase GH5 foi aquela que foi observado maior aumento nas amostras otimizadas quando comparadas ao inóculo $(0,071$ a 0,015\%, respectivamente). De acordo com Xia et al. (2014), GH5 é uma exocelulase e membros da ordem Clostridiales são conhecidos por desempenhar papel essencial na quebra da cadeia da celulose, expressando essas enzimas como um complexo enzimático extracelular (celulossomas) ou CAZymes livres não celulossomais, que degradam a celulose cristalina.

Entre as muitas funções relacionadas com a família de enzimas $\mathrm{GH}$, é possível destacar endo- $\beta$-1,4-glicanase/celulase [EC 3.2.1.4], endo- $\beta$-1,4-xilanase [EC 3.2.1.8], $\beta$ glicosidase [EC 3.2.1.21], $\beta$-manosidase [EC 3.2.1.25] e celulose $\beta$-1,4-celobiosidase [EC 3.2.1.91]. De acordo com Aspeborg et al. (2012), muitas enzimas neste grupo são 
componentes celulossomais de bactérias, como Ruminiclostridium (e.g., R. cellulolyticum, anteriormente $C$. celulolyticum) e sua faixa de temperatura ótima está em condições mesófilas (YUTIN; GALPERIN, 2013). Dessa forma, é possível afirmar que a temperatura utilizada neste estudo $\left(30^{\circ} \mathrm{C}\right)$ pode ter sido favorável para a expressão desses genes relacionados a tais enzaimas.

Outras famílias relacionadas com a atividade celulase/hemicelulase cujo aumento foi observado em pequenas proporções de $\leq 0,001 \%$ no inóculo a cerca de $0,01 \%$ nas amostras do ensaio de otimização, como GH74, GH28, GH8 e GH48. Dentre essas famílias, GH74 merece destaque, pois possui atividades de endoglicanase [EC 3.2.1.4], oligoxiloglicano redutor de celobiohidrolase [EC 3.2.1.150] e xiloglicanase [EC 3.2.1.151].

GH48 é uma endocelulase conhecida, com atividade celobiohidrolase [EC 3.2.1.176], endo- $\beta$-1,4-glicanase [EC 3.2.1.4] e atividade da quitinase [EC 3.2.1.14], sendo geralmente relacionada com membros da ordem Clostridiales (XIA et al., 2014). Vale ressaltar que algumas espécies da ordem Clostridiales, como $C$. beijerinckii, mesmo não sendo produtores de celulase (GOMEZ-FLORES; NAKHLA; HAFEZ, 2017), podem estar indiretamente relacionadas a esta função devido a sua capacidade de hidrolisar em subprodutos de celulose e hemicelulose, como glicose, celobiose e xilose (CEBREIROS; FERRARI; LAREO, 2019).

Após sequenciar o genoma completo de $C$. beijerinckii isolado de uma planta de processamento de vinhaça de cana-de-açúcar, Fonseca et al. (2019) identificaram diversas classes enzimáticas funcionais do grupo GH [EC 3.2.1.-], especialmente relacionadas à atividade de $\beta$-glicosidase, como $\beta$-D-glicosídeo e glicohidrolases [EC 3.2.1.21], que possibilitam a hidrólise da celulose, uma vez que completam sua etapa final de degradação. Além disso, os autores supracitados identificaram enzimas que codificam genes que estão diretamente envolvidas na obtenção de $\mathrm{H}_{2}$, como os genes que codificam o portador de elétrons ferredoxina, piruvato-flavodoxina oxidoredutase [EC 1.2.7.-] e Fe-hidrogenase [EC 1.12.7.2]. No presente estudo, o principal KO relacionado com os números EC mencionados para a atividade da $\beta$-glicosidase foi $\mathrm{K} 05349$ (55\%), e com a obtenção de $\mathrm{H}_{2}$ foi K03737 (27,89\%) no ensaio de otimização.

Vale ressaltar que a família GH23 foi visivelmente reduzida nas amostras otimizadas, quando comparadas com o inóculo, de 0,11\% para 0,01\%. Esta lisozima também é conhecida como peptidoglicano transglicosilase lítica [3.2.1.17]. Uma possível explicação é que as condições utilizadas no ensaio otimizado não foram favoráveis à 
Sulfurimonas, gênero mais abundante relacionada a este CAZyme no inóculo (16,36\%). A atividade da $\beta$-1,3-endoglicanase nesta espécie foi observada por Villa e Veiga-Crespo (2009).

A ferramenta DESeq2 foi usada para identicar genes diferencialmente abundantes. O total de 76.061 genes diferencialmente abundantes foi identificado, representando $52 \%$ do total de 147.274 genes. Genes diferencialmente abundantes foram considerados como aqueles com p-valor $\leq 0,005$, e mais abundantes nas amostras de biomassa do ensaio de otimização do que nas amostras de inóculo. Estes resultados foram utilizados para analisar as potenciais vias metabólicas do processo, por meio da ferramenta Pathview.

Encontra-se em resumo na Figura 5.45 as possíveis vias de conversão de resíduos sólidos de citros em $\mathrm{H}_{2}$, bem como os principais compostos orgânicos acumulados durante sua fermentação nas condições otimizadas $\left(30^{\circ} \mathrm{C}, \mathrm{pH}\right.$ 8,98 e 29,8 g. $\mathrm{L}^{-1}$ de substrato). De maneira geral, é possível afirmar que as condições aplicadas nos ensaios otimizados foram favoráveis ao estabelecimento, tanto de bactérias degradadoras dos principais componentes da biomassa lignocelulósica, como de bactérias produtoras de $\mathrm{H}_{2}$, como Clostridium e Paraclostridium. 
Figura 5.45. Possíveis vias de conversão de resíduos sólidos de citros em $\mathrm{H}_{2}$ e $\mathrm{AOV}$ em condições otimizadas. Os números EC mostrados entre colchetes representam apenas os genes significativamente superabundantes nos reatores otimizados $(\mathrm{p} \leq 0,005)$. Os valores entre parenteses representam a abundância relativa dos principais gêneros observados nos reatores otimizados.

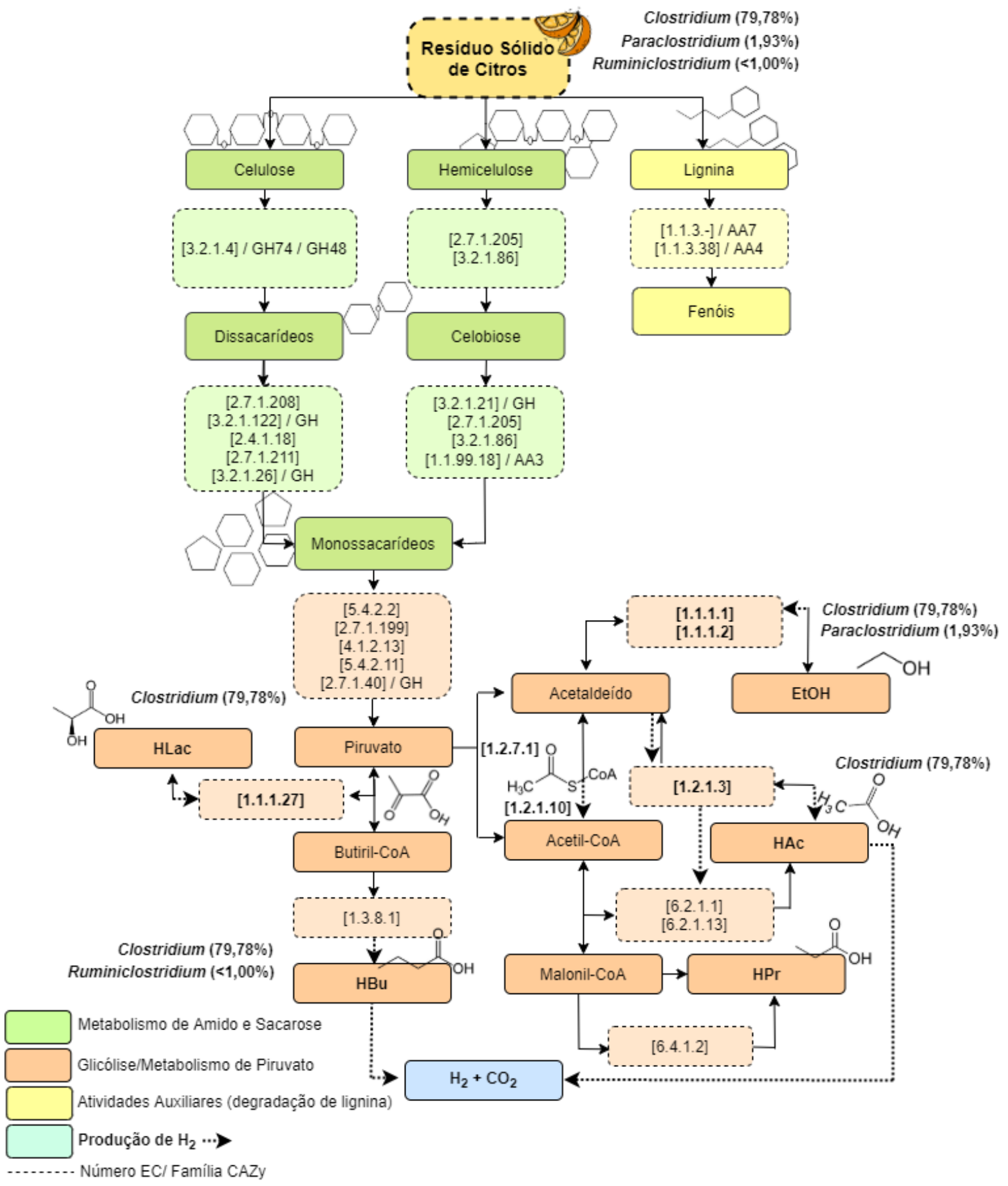

Fonte: Elaboração própria. 


\subsection{OBTENÇÃO DE BACTÉRIAS ANAERÓBIAS CELULOLÍTICAS}

\subsubsection{Atividade celulolítica, isolamento e identificação}

Após a autofermentação das cascas e bagaços de citros (1:1) em reatores em batelada, operados durante $48 \mathrm{~h}$, com glicose como fonte de carbono e pH 7,0, foi possível isolar 12 colônias de bactérias anaeróbias, sendo observada produção de $\mathrm{H}_{2}$ em apenas 3 destas cepas. Em relação ao isolamento da cepa, foi possível observar em placas de Petri suas características macromorfológicas, com colônias pequenas $(\leq 2 \mathrm{~mm})$, de forma irregular, superfície planoconvexa, com bordas inteiras e lisas.

Morfologias semelhantes a bacilos de microrganismos autóctones aderidos a superfície do bagaço de citros in natura foram observados por MEV. Além disso, por meio de microscopia óptica (Figura 5.46), foi possível observar a prevalência de bacilos Grampositivos, além de diversas estruturas similares a endósporos e bacilos em fase de esporulação, com endósporos ovais e terminais.

Figura 5.46. Características micromorfológicas do consórcio celulolítico autóctone das cascas e bagaço de laranja in natura, após diluição seriada $\left(10^{-26}\right)$ em microscopia de contraste de fase.

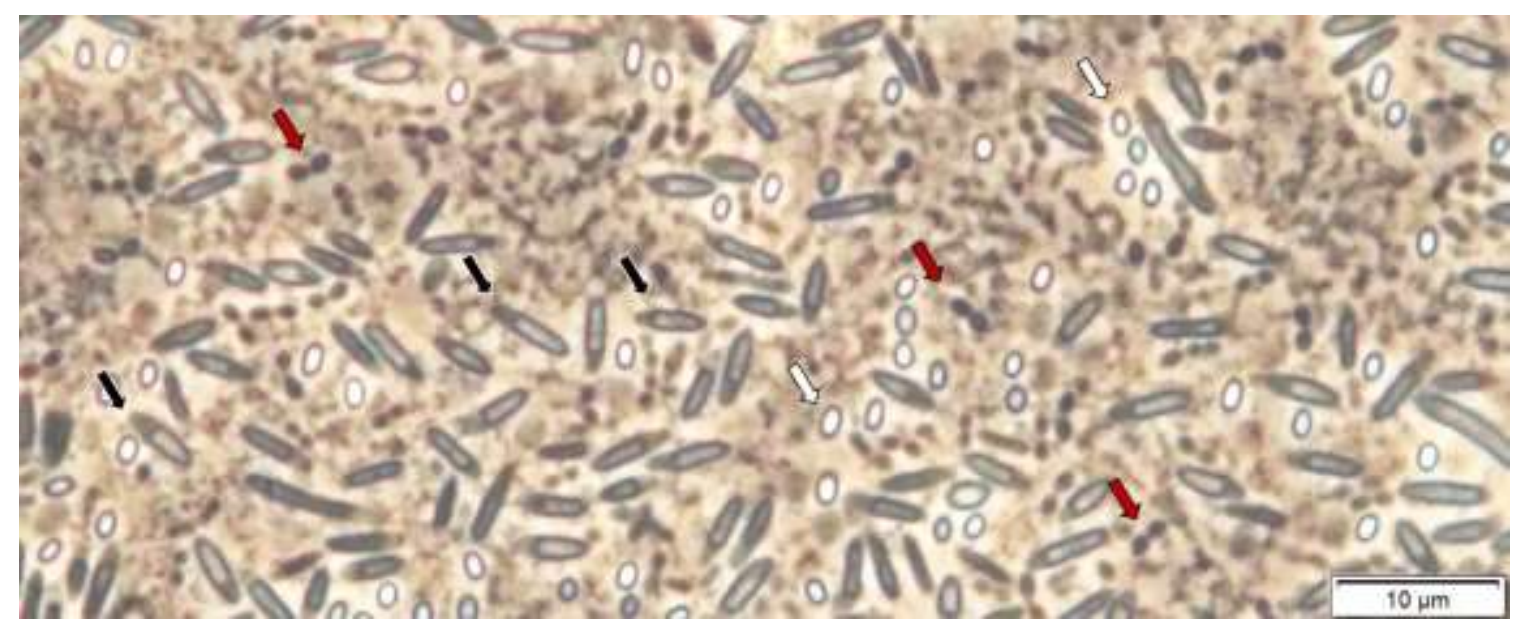

Nota: As setas vermelhas indicam as células de diplococos, as setas pretas indicam os bacilos contendo endósporos e as setas brancas indicam os esporos. Aumento total de 1600X.

A cepa isolada (IS_2) para a qual foi observada maior obtenção de $\mathrm{H}_{2}$ foi identificada como 99\% similar à Enterococcus casseliflavus (Figura 5.47). Bactérias semelhantes a Enterococcus podem ser entéricas, endofíticas e epifíticas. Bactérias deste gênero são anaeróbias facultativas, Gram-positivas, formadoras de células ovóides, que 
ocorrem individualmente ou em duplas, com crescimento ótimo entre $30-37{ }^{\circ} \mathrm{C}$ (VOS et al., 2009), como a temperatura utilizada neste estudo $\left(37^{\circ} \mathrm{C}\right)$.

Apesar de seu $\mathrm{pH}$ ótimo de crescimento ser 7,5, bactérias semelhantes a Enterococcus possuem membrana celular impermeável à ácidos orgânicos, o que confere resistência a ampla faixa de pH (4,5 a 10,0) (JOHN; CARVALHO, 2011). Na presente pesquisa, o pH inicial dos reatores em batelada foi ajustado para 7,0. De acordo com Huycke (2002), a via metabólica predominante em Enterococcus pode variar de acordo com suas condições de crescimento, com produção de HLac, HFor, HAc ou EtOH como principais produtos finais da fermentação.

A presença de Enterococcus no consórcio autofermentativo obtido a partir do resíduo sólido de citros se justifica devido à característica epifítica deste gênero, bem como sua resistência a ambientes ácidos. Cibis et al. (2016) observaram bactérias semelhantes à Enterococcus casseliflavus, em sistemas mesofílicos de biogás alimentados com silagem de milho, o que pode indicar afinidade destes organismos aos resíduos lignocelulósicos. Além disso, Mubarak e Soraya (2018) observaram resistência significativa $(p \leq 0,05)$ de Enterococcus sp. em diferentes concentrações de extrato de lima (Citrus aurantiifolia) (6,25-100\%), em pH mínimo de 2,89, em temperatura mesofílica $\left(37^{\circ} \mathrm{C}\right)$ por período de incubação de $72 \mathrm{~h}$.

Nos testes de atividade celulolítica para a cultura IS_2, foi possível observar atividade significativa ( $\mathrm{p} \leq 0,05)$ quando comparada ao ensaio controle (sem inóculo) (Tabela 5.21). Após o isolamento, a taxa de degradação de celulose para a cepa obtida (IS_2) foi de $61,3 \pm 0,1 \%$, aproximadamente 4,6 vezes maior em relação ao consórcio autóctone. Além disso, houve mudança de coloração das fibras de papel após o período de incubação, uma vez que as fibras nos ensaios controle mantiveram-se com a coloração original (brancas), e as fibras dos ensaios contendo o consórcio celulolítico tornaram-se amareladas, como descrito por Wang et al. (2011). Desta forma, é possível inferir que a cepa isolada seja celulolítica. De acordo com Herdian et al. (2018), diversas espécies de Enterococcus podem apresentar atividade celulolítica.

Nas mesmas condições de $\mathrm{pH}(7,0)$ e meio de cultivo (PCS) do presente estudo, Wang et al. (2011) caracterizaram consórcio autóctone obtido a partir da autofermentação de palha de arroz, e observaram a predominância de bactérias semelhantes à Clostridium. A atividade celulolítica do consórcio em fibra de papel filtro foi de 99,0 $\pm 0,7 \%$. A maior eficiência na degradação de celulose observada por estes autores pode ser atribuída à maior 
temperatura de incubação $\left(50^{\circ} \mathrm{C}\right)$, favorecendo o crescimento de bactérias conhecidamente celulolíticas neste consórcio, como Clostridium thermobutyricum e Clostridium thermosuccinogenes (atual Ruminiclostridium thermosuccinogenes) (YUTIN; GALPERIN, 2013). No caso específico com resíduos de citros, todos os ensaios foram feitos a $37^{\circ} \mathrm{C}$.

Figura 5.47. Dendrograma de distância genética do gene RNAr $16 \mathrm{~S}$ de bactérias anaeróbias isoladas de resíduo sólido de citros in natura. A barra de escala representa o número de substituições por posição de nucleotídeo para cada dendrograma. Os números de acesso de cada sequência estão representados entre parênteses. Os valores dos nós representam os valores de bootstrap (1000 réplicas). Utilizou-se a sequência do gene RNAr 16S de E. coli (X80725.1) como grupo externo ( $)$.

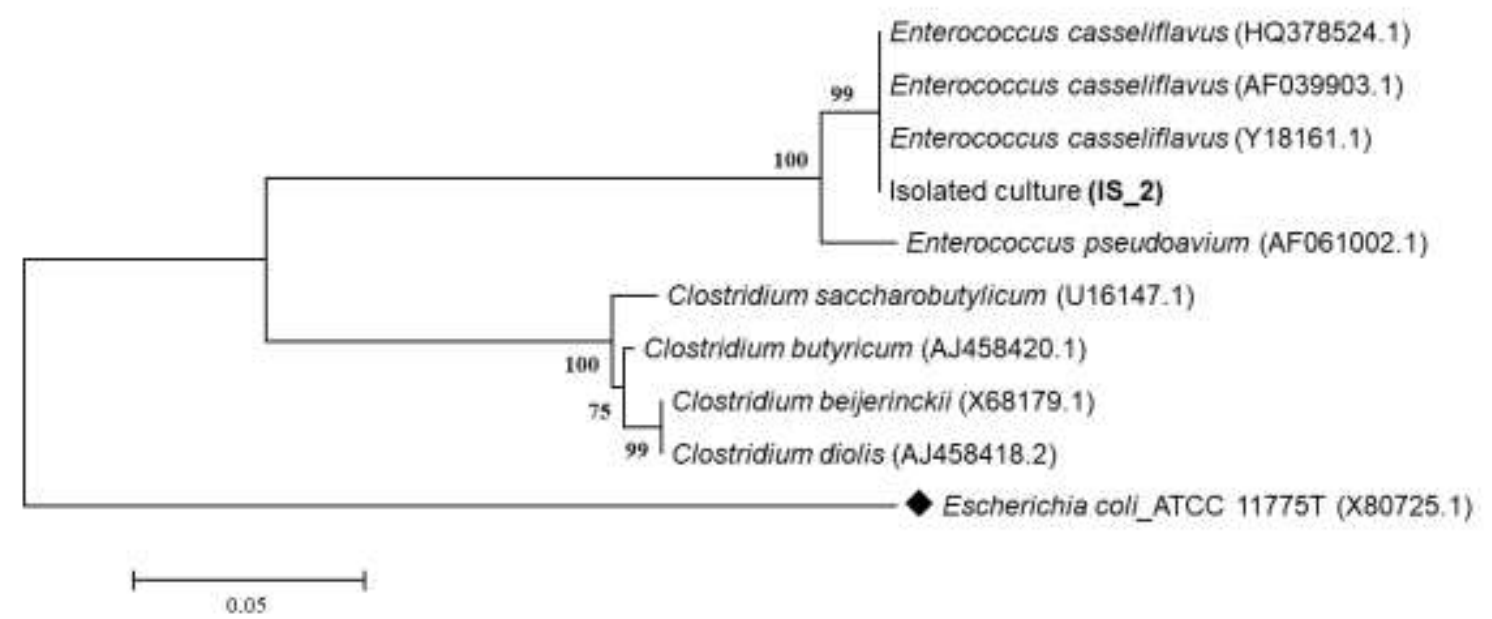

Tabela 5.21. Remoção da fibra de papel filtro e $p$ valor obtido ${ }^{a}$ para a cepa isolada (IS_2), consórcio autofermentativo e ensaio controle (sem inóculo).

\begin{tabular}{cccc}
\hline & $\begin{array}{c}\text { Remoção } \\
(\boldsymbol{\%})\end{array}$ & $\boldsymbol{p}$ valor & $\begin{array}{c}\text { Significância } \\
(\mathbf{9 5 \%})\end{array}$ \\
\hline IS_2 & $61,3 \pm 0,1^{\mathrm{a}}$ & 0,0216 & Significativo \\
Consórcio & $13,4 \pm 0,3^{\mathrm{b}}$ & 0,0397 & Significativo \\
Controle & $3,3 \pm 0,1^{\mathrm{c}}$ & - & - \\
\hline
\end{tabular}

${ }^{a} \mathrm{p}$ valor obtido em comparação ao ensaio controle. Médias seguidas da mesma letra não diferem entre si para o intervalo de confiança de 95\% via Teste de Tukey. 


\subsubsection{Parâmetros cinéticos}

A massa seca celular (MSC) observada para a cepa (IS_2) nas condições de isolamento $\left(37^{\circ} \mathrm{C}, \mathrm{pH} 7,0,2 \mathrm{~g}\right.$ de glicose por litro) foi proporcional à absorbância de 600

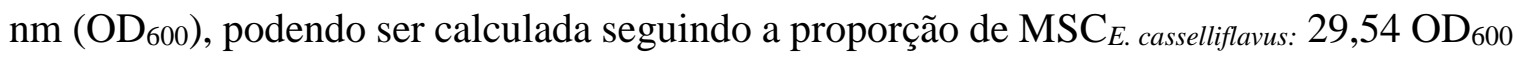
(Figura 5.48). A velocidade de crescimento específico obtida neste estudo, em 2 g.L $\mathrm{L}^{-1}$ de glicose e pH 7,0 $\left(\mu=0,35 \mathrm{~h}^{-1}\right)$, foi inferior à obtida por Parente et al. $(1997)\left(\mu=1,85 \mathrm{~h}^{-1}\right)$ para E. faecium em pH 5,5 e 5 g.L $\mathrm{L}^{-1}$ de glicose a $37^{\circ} \mathrm{C}$. Além disso, o tempo de geração $(\mathrm{Tg})$ calculado para IS_2 foi de 1,98 $\mathrm{h}$.

Uma das possíveis explicações para a menor velocidade de crescimento específico obtida no presente estudo, além de se tratar de espécie diferente, é que Parente et al. (1997) utilizaram uma cepa padrão de Enterococcus (E. faecium DPC1146), enquanto no presente estudo, utilizou-se uma cepa selvagem, nativa de resíduos sólidos de citros, que poderia estar menos adaptada às condições de cultivo laboratorial. Até o momento, não há dados para comparação de caracterização de E. casseliflavus na literatura.

Para outras espécies de Enterococcus, é possível observar valores de $T g$ similares aqueles obtidos para a cepa isolada (IS_2). Orandi et al. (2005) obtiveram $T g$ de 1,21 h para Enterococcus faecium isolada de soro de queijo de reatores em batelada, operados com meio de cultivo MRS (Sharlau Microbiology, Spain) a $37^{\circ} \mathrm{C}, \mathrm{pH}$ 6,5 e condições estáticas, durante $16 \mathrm{~h}$. Martínez et al. (2003) obtiveram $\mathrm{Tg}$ de $1,5 \mathrm{~h}$ em reatores operados a $37^{\circ} \mathrm{C}$ e pH 7,0 durante 48 h em Brain Heart Infusion (BHI), também para E. faecium (ATCC 49624. A partir destes resultados é possível inferir que o $T g$ (1,98 h) da cepa isolada (IS_2) foi similar ao de E. faecium nas mesmas condições operacionais. 
Figura 5.48. Tempo de geração (b) e relação entre massa seca e absorbância (b) para a cepa isolada (IS_2).
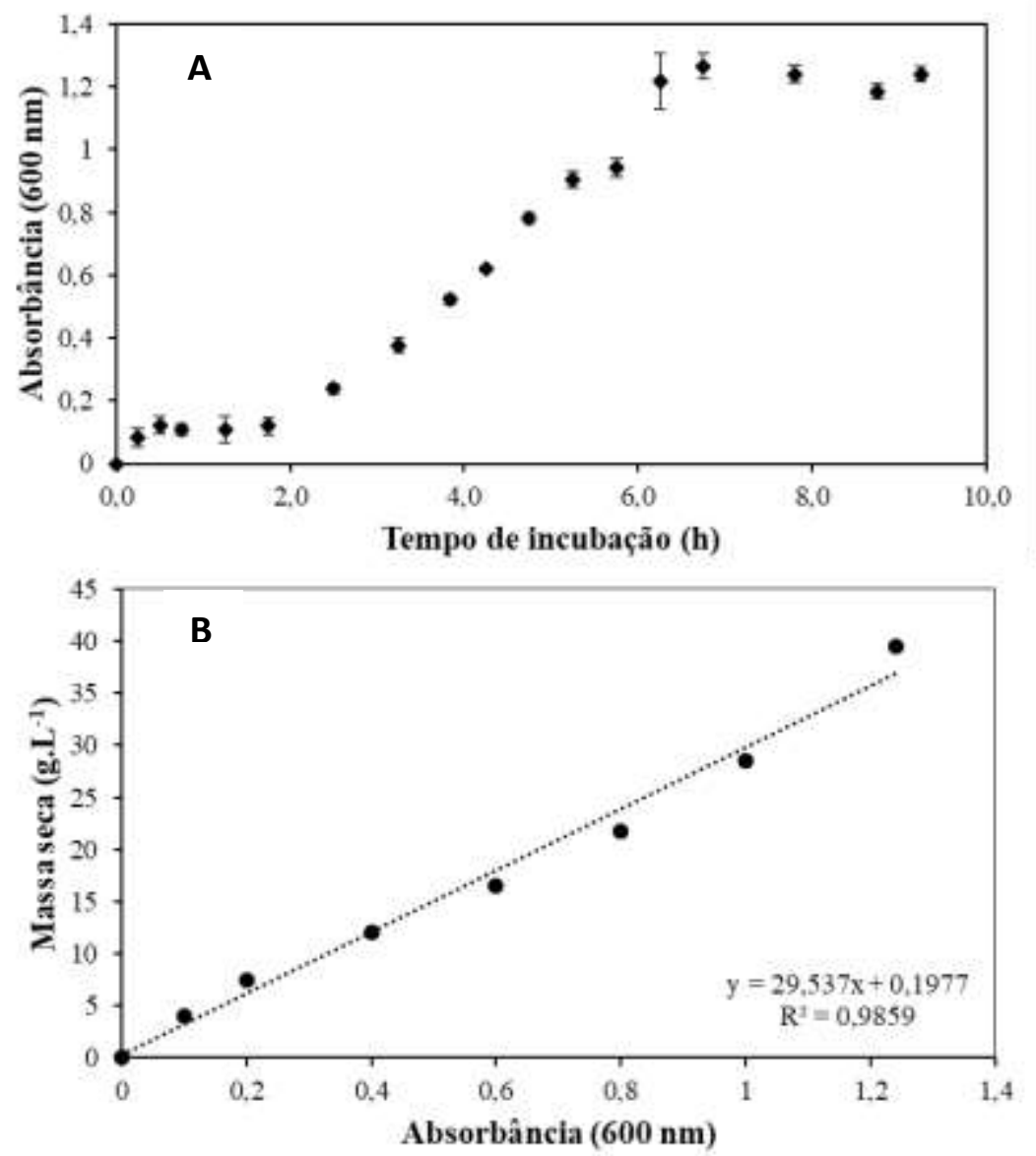

\subsubsection{Vias fermentativas e metabolitos da cepa isolada}

A cepa isolada filogeneticamente semelhante à E. casseliflavus (IS_2) foi caracterizada quanto a utilização de diferentes fontes de carbono (2 g. $\mathrm{L}^{-1}$ de amido, celobiose, celulose, frutose, glicose, lactose, sacarose, xilose e resíduo sólido de citros). Após período de incubação de aproximadamente $30 \mathrm{~h}$ verificou-se produção de $\mathrm{H}_{2} \mathrm{em}$ todas as condições, para as diferentes fontes de carbono testadas. Os principais metabólitos observados foram ácido acético (HAc, $\left.365 \mathrm{mg} . \mathrm{L}^{-1}\right)$ a partir de xilose; etanol (EtOH, 345 mg. $\mathrm{L}^{-1}$ ) a partir de glicose; ácido lático (HLac, $178 \mathrm{mg} . \mathrm{L}^{-1}$ ) a partir da glicose; ácido propiônico (HPr, $\left.184 \mathrm{mg} . \mathrm{L}^{-1}\right)$ a partir do resíduo sólido de citros e ácido butírico (HBu, 70 mg. $\mathrm{L}^{-1}$ ) a partir de lactose (Figura 5.49). 
Figura 5.49. Produção de AOV e etanol a partir de diferentes fontes de carbono e potencial máximo de concentração de $\mathrm{H}_{2}(\diamond)$ pela cepa isolada (IS_2).

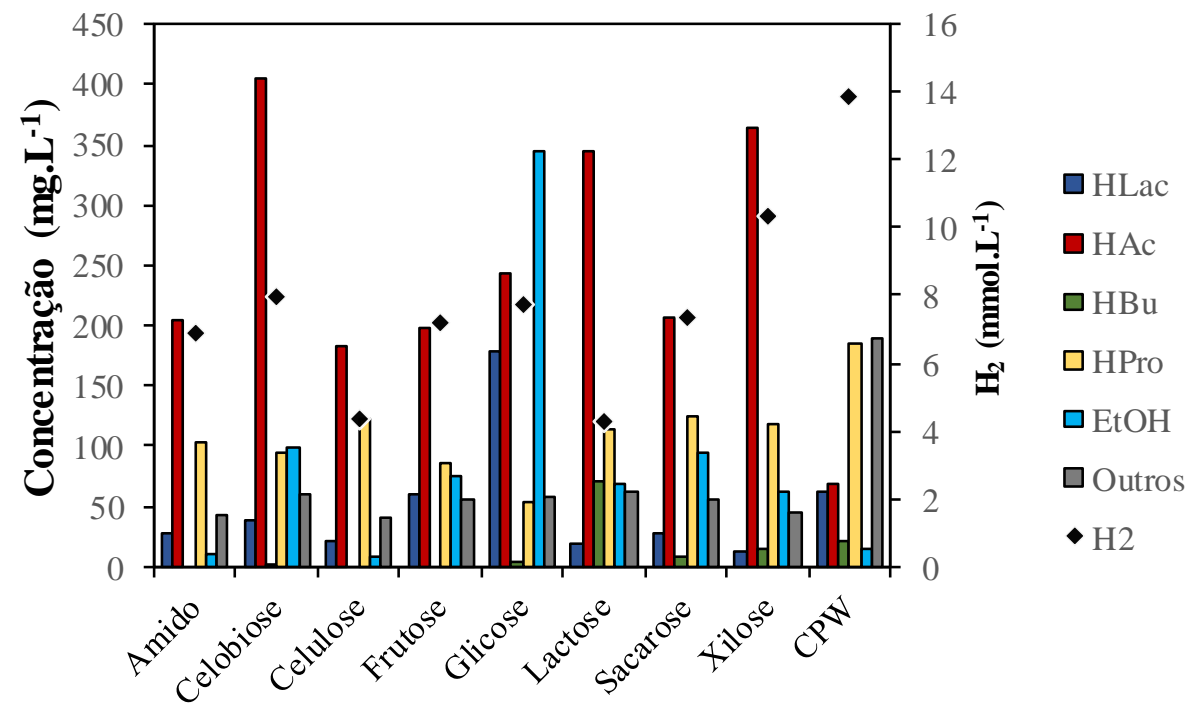

A partir das fontes complexas de carbono (polissacarídeos amido e celulose) e biomassa lignocelulósica (resíduo de citros), a maior concentração de $\mathrm{H}_{2}$ foi a partir do resíduo sólido de citros $\left(13,9 \mathrm{mmol} \mathrm{H}_{2} \cdot \mathrm{L}^{-1}\right)$. Apesar de sua composição lignocelulósica, o resíduo sólido de citros é rico em monômeros prontamente assimiláveis, especialmente glicose e xilose (CHOI et al., 2015), o que pode ter contribuído para maior obtenção de $\mathrm{H}_{2}$ a partir deste substrato. Em relação à concentração de $\mathrm{H}_{2}$ observada a partir de celulose (4,3 $\left.\mathrm{mmol} \mathrm{H} \mathrm{H}_{2} \mathrm{~L}^{-1}\right)$, é possível inferir que a cepa isolada (IS_2) não é eficiente em sintetizar as enzimas necessárias para hidrólise das ligações $\beta$ entre as moléculas de glicose que compõe este polissacarídeo, como apontado em Ács et al. (2015).

Wang et al. (2009) avaliaram o potencial de Enterococcus gallinarum, isolada de rúmem, na bioconversão de celulose em $\mathrm{H}_{2}$ em condições mesofílicas $\left(37^{\circ} \mathrm{C}\right)$ e $\mathrm{pH}$ inicial de 6,5. Após período de $5 \mathrm{~h}$ a conversão foi de aproximadamente $2,4 \mathrm{mmol} \mathrm{de} \mathrm{H}_{2} \cdot \mathrm{g}^{-1}$ de celulose, sendo que os principais AOV produzidos foram HAc (971 mg.L $\left.\mathrm{L}^{-1}\right)$, HPr (623 $\left.\mathrm{mg} . \mathrm{L}^{-1}\right)$ e $\mathrm{HBu}\left(450 \mathrm{mg} \cdot \mathrm{L}^{-1}\right)$. Na presente pesquisa, o rendimento foi de $0,34 \mathrm{mmol} \mathrm{de} \mathrm{H}_{2} \cdot \mathrm{g}^{-}$ ${ }^{1}$ de celulose, além de predominância de HAc (182 mg.L $\left.\mathrm{L}^{-1}\right)$ e HPr $\left(121 \mathrm{mg} . \mathrm{L}^{-1}\right)$, o que pode indicar menor afinidade da cepa isolada (IS_2) com esta fonte de carbono, quando comparada à E. gallinarum.

A concentração de $\mathrm{H}_{2}$ a partir de dissacarídeos e polissacarídeos foi similar aos ensaios contendo glicose, amido e celobiose, respectivamente, de 7,7, 6,9 e 8,0 mmol H $\mathrm{m}_{2} \mathrm{~L}^{-}$ ${ }^{1}$. Da mesma forma, foram obtidas concentrações de $\mathrm{H}_{2}$ semelhantes para as condições com frutose $\left(7,2 \mathrm{mmol} \mathrm{H}_{2} \cdot \mathrm{L}^{-1}\right)$ e sacarose $\left(7,3 \mathrm{mmol} \mathrm{H}_{2} \cdot \mathrm{L}^{-1}\right)$. Sabe-se que a sacarose é um 
dissacarídeo de ligações $\alpha$ entre uma molécula de glicose e uma molécula de frutose (AN et al., 2014).

Dentre os monossacarídeos a maior concentração observada foi a partir da xilose (10,3 mmol $\left.\mathrm{H}_{2} \cdot \mathrm{L}^{-1}\right)$, bem como a maior produção de HAc $\left(365 \mathrm{mg} \cdot \mathrm{L}^{-1}\right)$. A xilose é um dos principais monômeros encontrados em resíduos de citros (WILKINS et al., 2007; CHOI et al., 2013, 2015), o que pode justificar a maior assimilação por microrganismos autóctones deste tipo de substrato. A xilose tem estrutura com menos átomos de carbono $\left(\mathrm{C}_{5} \mathrm{H}_{10} \mathrm{O}_{5}\right)$, quando comparado à glicose e frutose $\left(\mathrm{C}_{6} \mathrm{H}_{12} \mathrm{O}_{6}\right)$, além da sacarose $\left(\mathrm{C}_{12} \mathrm{H}_{22} \mathrm{O}_{11}\right)$ e demais substratos utilizados, como os dissacarídeos lactose $\left(\mathrm{C}_{12} \mathrm{H}_{22} \mathrm{O}_{11}\right)$ e celobiose $\left(\mathrm{C}_{12} \mathrm{H}_{22} \mathrm{O}_{11}\right)$, os polissacarídeos celulose e amido $\left[\left(\mathrm{C}_{6} \mathrm{H}_{10} \mathrm{O}_{5}\right)_{n}\right]$.

A partir da xilose, via rota do HAc a produção teórica é de 3,33 mol de $\mathrm{H}_{2}$ (Equação 5.1) e 1,67 mol de $\mathrm{H}_{2}$ quando há formação de HBu (Equação 5.2) (MÄKINEN; NISSILÄ; PUHAKKA, 2012). A partir da cepa isolada (IS_2), o rendimento foi de 1,0 mol de $\mathrm{H}_{2}$ por mol de xilose nos ensaios em $\mathrm{pH}$ 7,0.

Apesar do rendimento teórico de $\mathrm{H}_{2}$ a partir da glicose ser maior em relação à xilose, de 4 mols de $\mathrm{H}_{2}$ na via HAc e 2 mols de $\mathrm{H}_{2}$ via $\mathrm{HBu}$ (Equações 5.1 e 5.2, respectivamente) verificou-se menor rendimento nos ensaios contendo glicose $\left(0,91 \mathrm{~mol} \mathrm{de} \mathrm{H}_{2} \cdot \mathrm{mol}^{-1}\right.$ de glicose) (MÄKINEN; NISSILÄ; PUHAKKA, 2012; ŁUKAJTIS et al., 2018). Resultados similares foram obtidos por Yin e Wang (2016), que utilizaram como inóculo uma cepa de E. faecium, obtendo 1,69 mol de $\mathrm{H}_{2} \cdot \mathrm{mol}^{-1}$ de glicose em reatores em batelada. Além disso, os autores avaliaram diferentes $\mathrm{pH}$ iniciais (5-10) do meio reacional, sendo que o maior rendimento de $\mathrm{H}_{2}$ ocorreu em $\mathrm{pH}$ 7,0, mesmo $\mathrm{pH}$ utilizado no presente estudo.

Nos ensaios contendo glicose como fonte de carbono, houve acúmulo de EtOH ao final da operação (345 mg. $\mathrm{L}^{-1}$ ), enquanto nos ensaios a partir de xilose, houve menor produção deste álcool (61 mg. $\left.\mathrm{L}^{-1}\right)$. Sabe-se que a predominância da via solvetogênica em reatores pode resultar em baixa obtenção de $\mathrm{H}_{2}$, uma vez que há produção de $\mathrm{EtOH}$ a partir de HAc, ao invés de $\mathrm{H}_{2}$ (Equação 5.11) (MÄKINEN; NISSILÄ; PUHAKKA, 2012; ŁUKAJTIS et al., 2018). Provavelmente, a variação da via metabólica predominante acarretou em menor concentração de $\mathrm{H}_{2}$ a partir da glicose $\left(7,7 \mathrm{mmol} \mathrm{H}_{2} \cdot \mathrm{L}^{-1}\right)$ em relação à xilose $\left(10,3 \mathrm{mmol} \mathrm{H}_{2} \cdot \mathrm{L}^{-1}\right)$.

$\mathrm{CH}_{3} \mathrm{COOH}+2 \mathrm{H}_{2} \rightarrow \mathrm{CH}_{3} \mathrm{CH}_{2} \mathrm{OH}+4 \mathrm{H}_{2} \mathrm{O}$ 
Mäkinen et al. (2012), avaliaram a obtenção de $\mathrm{H}_{2}$ a partir de diferentes fontes de carbono por cultura mista de Clostridium acetobutulyticum e Citrobacter freundii, em reatores batelada operados a $45{ }^{\circ} \mathrm{C}$. Estes autores observaram que o rendimento de $\mathrm{H}_{2}$ foi maior a partir de pentoses do que a partir de hexoses, ou seja, de $0,71 \mathrm{~mol} \mathrm{H}_{2} \cdot \mathrm{mol}^{-1}$ de xilose e $0,61 \mathrm{~mol} \mathrm{H}_{2} \cdot \mathrm{mol}^{-1}$ de arabinose em relação à glicose $\left(0,54 \mathrm{~mol} \mathrm{H}_{2} \cdot \mathrm{mol}^{-1}\right.$ de glicose). Além disso, os autores indicam que a fermentação de pentoses (xilose e arabinose) resulta em maior obtenção de $\mathrm{H}_{2}$ e HAc, enquanto a fermentação de hexoses (glicose) favorece a produção de HLac.

Na presente pesquisa, foi possível observar que houve maior produção de HLac a partir da glicose $\left(178 \mathrm{mg} . \mathrm{L}^{-1}\right)$ em relação à xilose $\left(12 \mathrm{mg} . \mathrm{L}^{-1}\right)$. O mesmo não ocorreu nos ensaios contendo polissacarídeos de glicose, como amido (27 mg HLac. $\left.\mathrm{L}^{-1}\right)$ e celulose (21 mg HLac. $\mathrm{L}^{-1}$ ), provavelmente porque o produto final predominante a partir da fermentação de glicose por Enterococcus é o HLac (VOS et al., 2009).

Em relação à produção de AOV e álcoois a partir de glicose e xilose, utilizando a cepa isolada (IS_2), os principais metabólitos obtidos foram HAc, $\mathrm{HBu}, \mathrm{HPr}$ e EtOH (Figura 5.50). Foram obtidos $880 \mathrm{mg} . \mathrm{L}^{-1}$ e $619 \mathrm{mg} . \mathrm{L}^{-1}$ de AOV nos ensaios contendo glicose e xilose, respectivamente. O acúmulo de AOV pode acarretar na inibição da produção de $\mathrm{H}_{2}$ devido ao aumento da permeabilidade de ácidos orgânicos não dissociados na membrana celular, e consequente gasto de energia, a fim de excretar os prótons via transporte ativo contra o gradiente de concentração da membrana celular (INFANTES et al., 2011). O acúmulo de AOV resultou em menor $\mathrm{pH}$ final a partir da glicose ( $\mathrm{pH} 5,7) \mathrm{em}$ relação à xilose $(\mathrm{pH} 6,4)$, o que pode ter contribuído para a inibição da produção de $\mathrm{H}_{2}$ da cepa de E. casseliflavus (IS_2) (MÄKINEN; NISSILÄ; PUHAKKA, 2012). 
Figura 5.50. Ácidos orgânicos e álcool ao longo do período de incubação com glicose (a) e xilose (b) para a cepa isolada (IS_2).
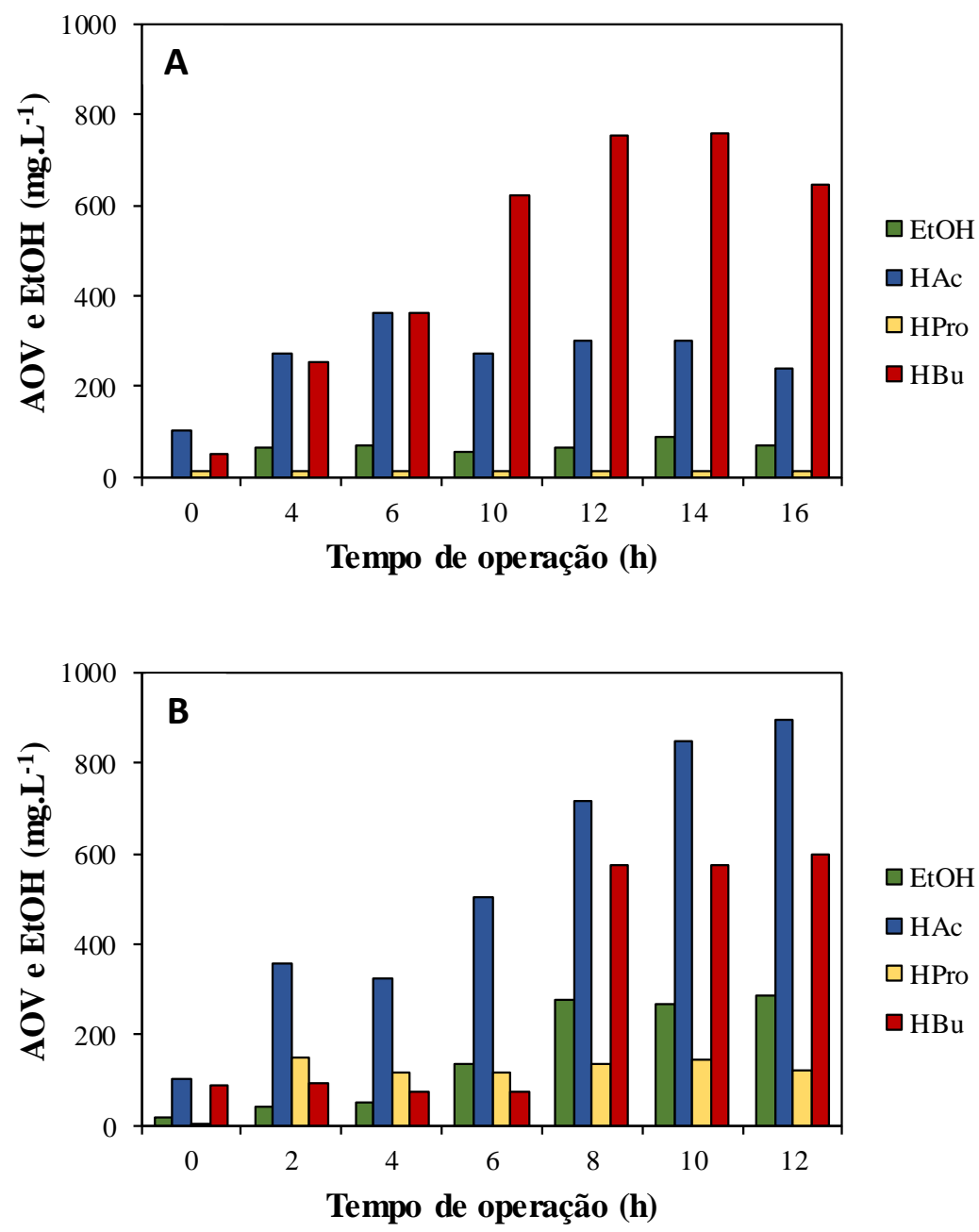

Yun, Wee e Ryu (2003) observaram que a fonte de carbono pode afetar diretamente a rota metabólica prevalente para cepa de Enterococcus faecalis. A partir de glicose, frutose e maltose houve maior rendimento de HLac (0,96 g de HLac. $\mathrm{g}^{-1}$ de carboidrato), enquanto a partir de galactose, amido e xilose houve maior produção dos ácidos fórmico e HAc.

Da mesma forma, no presente estudo, houve diferença entre os metabólitos a partir de diferentes fontes de carbono. O ácido em menor concentração ao longo de ambos os ensaios foi HPr, com produção máxima de $14 \mathrm{mg} . \mathrm{L}^{-1}$ e $151 \mathrm{mg} . \mathrm{L}^{-1}$ a partir de glicose e xilose, respectivamente. Na via metabólica de formação do HPr, há consumo de 2 mols de $\mathrm{H}_{2}$ a cada mol de glicose consumida (Equação 3.5) (LI; FANG, 2007; GHIMIRE et al., 2015). 
Apesar da desvantagem da produção de $\mathrm{HPr}$ em processos de obtenção de $\mathrm{H}_{2}$, houve maior produção deste ácido (119 mg HPr.L $\left.\mathrm{L}^{-1}\right)$ no reator contendo xilose, no qual houve maior produção de $\mathrm{H}_{2}$, em relação à glicose $\left(53 \mathrm{mg} \mathrm{HPr.L}{ }^{-1}\right)$. Entretanto, maior acúmulo de HAc a partir da xilose (365 mg HAc. $\left.\mathrm{L}^{-1}\right)$ foi observado em relação à glicose $(243 \mathrm{mg}$ HAc. $L^{-1}$ ), o que pode justificar a maior obtenção de $\mathrm{H}_{2}$ a partir da xilose, mesmo com maior acúmulo de HPr.

De acordo com Infantes et al. (2011), a acidificação do meio reacional pode levar à retenção de prótons $\left(\mathrm{H}^{+}\right)$e à formação de $\mathrm{HPr}$. $\mathrm{O}$ pH final do meio reacional após a fermentação de xilose e glicose foram de 5,4 e 5,7, respectivamente. Desta forma, é possível inferir que o favorecimento da produção de HAc ocasionou maior acúmulo de AOV e consequente acidificação do meio reacional, levando a mudança na via metabólica e produção de HPr.

No ensaio contendo glicose, HBu e HAc foram os principais metabólitos (758 mg.L1 e 362 mg. $\mathrm{L}^{-1}$, respectivamente), enquanto a partir da xilose, houve mudança de rota metabólica, uma vez que o principal metabólito observado foi HAc (897 mg.L $\left.\mathrm{L}^{-1}\right)$. Resultados similares foram obtidos por Mäkinen (2012), com consórcio misto de Clostridium acetobutulyticum e Citrobacter freundii, sendo que $\mathrm{HBu}$ foi o principal produto metabólico a partir de glicose.

Em relação a remoção de carboidratos (Tabela 5.22), não foi verificada diferença significativa para o intervalo de confiança de $95 \%$, sendo que houve consumo máximo de 94\% a partir de frutose. Resultados similares foram observados por Maintinguer et al. (2017) na caracterização nutricional de uma cepa de Enterobacter sp. isolada de resíduos de cervejaria, com 85,6\% de consumo de glicose após 8,8 h de incubação. O maior percentual de remoção de carboidratos observado no presente estudo pode ter ocorrido devido ao maior tempo de incubação dos reatores $(30 \mathrm{~h})$.

Nos ensaios contendo resíduo de citros como substrato, verificou-se variação significativa $(\mathrm{p} \leq 0,05)$ do $\mathrm{pH}$, sendo o menor valor $(\mathrm{pH} 5,3)$ ao final do período de incubação de 12 h. É possível inferir que a redução do $\mathrm{pH}$ inicial $(7,0)$ ocorreu devido à produção de AOV ao final do processo fermentativo. Além disso, no ensaio contendo resíduo sólido de citros, houve conversão total dos carboidratos solúveis disponíveis no início do processo e, ainda, a maior concentração de $\mathrm{H}_{2}\left(13,9\right.$ mmol $\left.\mathrm{H}_{2} \cdot \mathrm{L}^{-1}\right)$.

A menor obtenção de $\mathrm{H}_{2}$ ocorreu a partir de lactose $\left(4,3 \mathrm{mmol} \mathrm{H}_{2} \cdot \mathrm{L}^{-1}\right)$ e celulose (4,3 mmol $\left.\mathrm{H}_{2} \cdot \mathrm{L}^{-1}\right)$, além de menor variação de $\mathrm{pH}(6,4$ e 6,6, respectivamente). De acordo 
com Ács et al. (2015), polissacarídeos podem não ser ideais como substrato para Enterococcus, que não possuem aparato enzimático para clivagem destes polímeros. Sendo assim, é possível inferir que a obtenção de $\mathrm{H}_{2}$ a partir de resíduo sólido de citros foi favorecida devido à presença de glicose e xilose como principais componentes deste resíduo (CHOI et al., 2015).

Foram observados 2,90 mg. $\mathrm{L}^{-1}$ de fenóis no ensaio contendo resíduo sólido de citros, provavelmente devido à degradação de componentes de resíduos lignocelulósicos, como a lignina e a hemicelulose (AHMAD; SILVA; VARESCHE, 2018).

Tabela 5.22. Remoção de carboidratos e pH final dos reatores em batelada, operados com diferentes fontes de carbono para a cepa isolada (IS_2).

\begin{tabular}{ccc}
\hline Fonte de Carbono & Remoção de carboidratos (\%) & pH \\
\hline Amido & $94 \pm 2,1$ & $6,62 \pm 0,0$ \\
Celobiose & $94 \pm 0,7$ & $6,45 \pm 0,0$ \\
Celulose & $94 \pm 1,4$ & $6,61 \pm 0,1$ \\
Frutose & $95 \pm 2,5$ & $6,44 \pm 0,0$ \\
Glicose & $94 \pm 2,1$ & $5,73 \pm 0,0$ \\
Lactose & $94 \pm 1,4$ & $6,44 \pm 0,0$ \\
Sacarose & $93 \pm 0,7$ & $6,49 \pm 0,0$ \\
Xilose & $94 \pm 4,9$ & $5,38 \pm 0,0$ \\
Resíduo sólido de citros & $94 \pm 5,4$ & $5,30 \pm 0,1$ \\
\hline
\end{tabular}

\subsubsection{Efeito da concentração de xilose}

Uma vez que a xilose é um dos principais monômeros que compõe os resíduos do processamento de citros, informações acerca de sua faixa ótima de concentração para uso em processos anaeróbios tornam-se desejáveis. A xilose foi o monômero a partir do qual houve maior obtenção de $\mathrm{H}_{2}\left(10,3 \mathrm{mmol} \mathrm{H} \mathrm{H}_{2} \mathrm{~L}^{-1}\right)$ e HAc $\left(365 \mathrm{mg} \cdot \mathrm{L}^{-1}\right)$, portanto, realizou-se a caracterização da concentração de $\mathrm{H}_{2}$ obtida a partir de diferentes concentrações desta pentose $\left(0,53\right.$ a $\left.6,47 \mathrm{~g} . \mathrm{L}^{-1}\right)$, sendo de 3,0 a $12,9 \mathrm{mmol} \mathrm{H} \cdot \mathrm{L}^{-1}$.

Nos ensaios com menor concentração de substrato $\left(0,53\right.$ e 1,0 g xilose. $\left.\mathrm{L}^{-1}\right)$, houve estabilização da concentração de $\mathrm{H}_{2}$ em menor tempo quando comparados aos ensaios com maior concentração $\left(3,5 ; 6,0\right.$ e $6,45 \mathrm{~g}$ de xilose. $\left.\mathrm{L}^{-1}\right)$. No ensaio com $0,53 \mathrm{~g}$ de xilose. $\mathrm{L}^{-1}$, a estabilização da concentração de $\mathrm{H}_{2}$ ocorreu em aproximadamente $10 \mathrm{~h}$, enquanto no ensaio contendo 6,45 g de xilose por litro, a estabilização ocorreu em aproximadamente $40 \mathrm{~h}$ de operação (Figura 5.51). 
Figura 5.51. Concentração de $\mathrm{H}_{2}$ pela cepa isolada (IS_2) em função do tempo com diferentes concentrações de xilose.

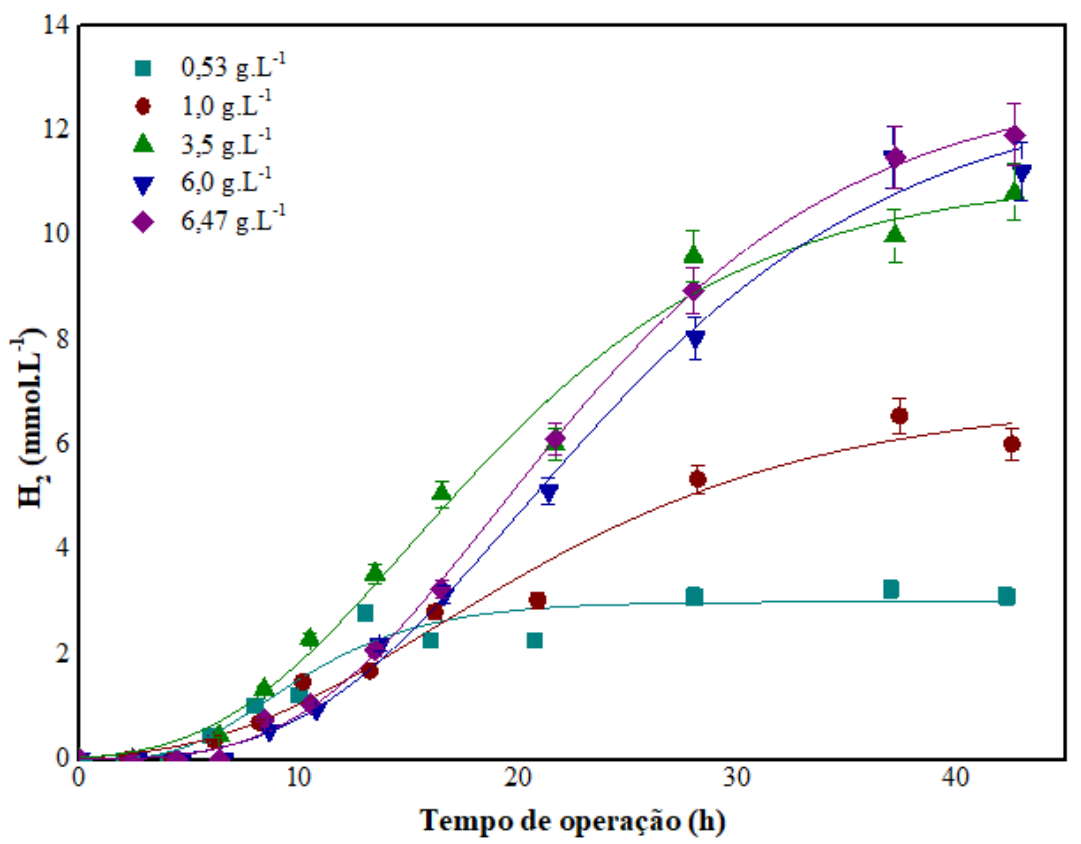

Quanto maior a concentração de xilose, maiores velocidade específica máxima de obtenção de $\mathrm{H}_{2}$ foram observados, sendo a maior de $0,53 \mathrm{mmol} \mathrm{H}_{2} \cdot \mathrm{h}^{-1}$ para $6,47 \mathrm{~g} . \mathrm{L}^{-1}$ de xilose e a mínima de $0,28 \mathrm{mmol}_{2} \cdot \mathrm{h}^{-1}$ para $0,53 \mathrm{~g} . \mathrm{L}^{-1}$ de xilose. Da mesma forma, maiores $\lambda\left(10,02 \mathrm{~h}^{-1}\right)$ foram observados para maior concentração de xilose $\left(6,47 \mathrm{~g}\right.$ de xilose. $\left.\mathrm{L}^{-1}\right) \mathrm{e}$ o menor de 4,49 $\mathrm{h}^{-1}$ em $0,53 \mathrm{~g}$ de xilose. $\mathrm{L}^{-1}$ (Tabela 5.23).

Tabela 5.23. Parâmetros de Gompertz modificado e densidade óptica da cepa isolada (IS_1) obtidos a partir de diferentes concentrações de xilose.

\begin{tabular}{|c|c|c|c|c|c|c|c|}
\hline $\begin{array}{l}\text { Xilose } \\
\left(\text { g. L } L^{-1}\right)\end{array}$ & 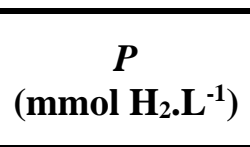 & $\begin{array}{c}R m \\
\left(\mathbf{m m o l ~ H}_{2} \cdot \mathbf{h}^{-1}\right)\end{array}$ & $\begin{array}{c}\lambda \\
\left(\mathbf{h}^{-1}\right)\end{array}$ & $\mathbf{R}^{2}$ & pH & $\begin{array}{c}\text { OD }_{600} \\
(\mathbf{n m})\end{array}$ & $\begin{array}{l}\text { Consumo de } \\
\text { carboidratos } \\
(\%)\end{array}$ \\
\hline 0,53 & 3,0 & 0,28 & 4,49 & 0,93 & 6,77 & 0,29 & 92,73 \\
\hline 1,0 & 6,9 & 0,26 & 6,30 & 0,98 & 6,18 & 0,32 & 94,70 \\
\hline 3,5 & 11,5 & 0,46 & 6,45 & 0,99 & 6,00 & 0,65 & 98,70 \\
\hline 6,0 & 12,9 & 0,48 & 10,26 & 0,99 & 5,54 & 1,09 & 92,10 \\
\hline 6,47 & 12,9 & 0,53 & 10,02 & 0,98 & 5,57 & 1,17 & 92,07 \\
\hline
\end{tabular}

Nota: Potencial máximo de concentração de $\mathrm{H}_{2}(P)$, velocidade específica máxima de obtenção de $\mathrm{H}_{2}(R m)$, tempo de início da obtenção de $\mathrm{H}_{2}(\lambda)$ e $\mathrm{R}^{2}$ obtidos da equação de Gompertz modificada.

A remoção de carboidratos foi superior a $90 \%$ em todas as condições avaliadas, entretanto, o maior valor observado foi para o ensaio com 3,5 g de xilose. $\mathrm{L}^{-1}$, seguido do ensaio contendo $0,53 \mathrm{~g}$ de xilose. $\mathrm{L}^{-1}$ (98,70 e 92,73\%, respectivamente). A menor remoção de carboidratos $(92,07 \%)$ foi observado no ensaio com $6,47 \mathrm{~g}$ de xilose. $\mathrm{L}^{-1}$. Para avaliação das respostas $P, R m, \lambda, \mathrm{pH}, \mathrm{OD}_{600}$ e remoção de carboidratos considerou-se a significância 
da regressão, resíduos, a falta de ajuste e erro puro a partir da Análise de Variância (ANOVA), no intervalo de confiança de $95 \%$ (Tabela 5.24). Em relação à $P$, considerouse que a concentração de substrato teve efeito positivo $\left(3,7 \mathrm{mmol} \mathrm{H}_{2} \cdot \mathrm{L}^{-1}\right)$ para potencial máximo de concentração de $\mathrm{H}_{2}$. $\mathrm{O}$ valor máximo de $P$ previsto via modelo de regressão foi de $13,1 \pm 0,9 \mathrm{mmol} \mathrm{H} \cdot \mathrm{L}^{-1}$, com 5,68 g. $\mathrm{L}^{-1}$ de xilose. Concentrações similares de substrato ( $5 \mathrm{~g}$ de glicose. $\mathrm{L}^{-1}$ ) foram avaliadas por Yin e Wang (YIN; WANG, 2016), que obtiveram $6,1 \mathrm{mmol} \mathrm{H} \cdot \mathrm{L}^{-1}$, utilizando E. faecium, em reatores em batelada operados a $35^{\circ} \mathrm{C}$ e $\mathrm{pH}$ 7,0. Desta forma, é possível inferir maior afinidade de Enterococcus à xilose em relação à glicose.

Em relação a $R m$, o aumento da concentração de substrato foi proporcional ao aumento deste parâmetro, ou seja, teve efeito positivo $\left(0,11 \mathrm{mmol} \mathrm{H}_{2} \cdot \mathrm{h}^{-1}\right)$. Desta forma, o $R m$ previsto foi de $0,54 \pm 0,03 \mathrm{mmol} \mathrm{H}_{2} \cdot \mathrm{h}^{-1}$ para $5 \mathrm{~g}$ de xilose. $\mathrm{L}^{-1}$. Para $\lambda$, foram obtidos $9,92 \pm 0,64 \mathrm{~h}^{-1}$ para $6,47 \mathrm{~g}$ de xilose. $\mathrm{L}^{-1}$. Entretanto, sabe-se que o aumento de $\lambda$ não é desejável para o processo, uma vez que há aumento do tempo necessário de reação.

Para o pH, foi observado efeito negativo, ou seja, quanto maior a concentração de substrato, menor o $\mathrm{pH}$ da reação $(5,52 \pm 0,13)$, provavelmente devido à produção de $\mathrm{AOV}$ oriundos da fermentação (ŁUKAJTIS et al., 2018). O acúmulo de AOV pode levar à diminuição do pH, o que pode acarretar em inibição da biomassa fermentativa e, consequentemente, menor obtenção de $\mathrm{H}_{2}$ (ROSA; SILVA, 2017; FONSECA; SCHMIDELL; REGINATTO, 2018).

A $\mathrm{OD}_{600}$ foi proporcional ao aumento da concentração de substrato, uma vez que quanto maior a concentração inicial de xilose, maior a absorbância (efeito positivo de $1,12 \pm 0,09$ ), devido ao crescimento celular. Por fim, para o consumo de carboidratos, observou-se efeito negativo, sendo possível inferir que quanto maior a concentração de substrato, maior o consumo de carboidratos. Entretanto, a partir de 3,5 g.L $\mathrm{L}^{-1}$, este aumento não foi significativo. Apesar do aumento da concentração de substrato ter efeito positivo na concentração de $\mathrm{H}_{2}$, e no aumento da biomassa, a partir de determinada concentração de xilose (3,5 g.L $\left.\mathrm{L}^{-1}\right)$, sua adição não foi mais significativa tanto para o aumento da concentração de $\mathrm{H}_{2}$ quanto para o consumo de carboidratos.

Rabelo et al. (2018a) avaliaram a influência de diferentes concentrações de substrato (2,0; 5,0 e 10,0 g de celulose. $\left.\mathrm{L}^{-1}\right)$ na obtenção de $\mathrm{H}_{2}$, partir de consórcio composto por Clostridium sp., Klebsiella sp., Routella sp. e Desulfovibrio sp., sendo obtido 14,77; 
39,25 e 22,53 mmol $\mathrm{H}_{2} \cdot \mathrm{L}^{-1}$, respectivamente. Os autores observaram que o aumento da concentração de substrato de 5,0 g.L $\mathrm{L}^{-1}$ para 10 g.L $\mathrm{L}^{-1}$ causou maior acúmulo de AOV e redução do pH, o que justifica a menor concentração de $\mathrm{H}_{2}$ nos ensaios com 10 g.L L $^{-1}$ (22,5 mmol $\left.\mathrm{H}_{2} \cdot \mathrm{L}^{-1}\right)$, em comparação a 5 g. $\mathrm{L}^{-1}\left(39,2 \mathrm{mmol} \mathrm{H} \mathrm{H}_{2} \mathrm{~L}^{-1}\right)$ de celulose. Na presente pesquisa, foi observada maior concentração de $\mathrm{H}_{2}$ proporcional ao aumento da concentração de substrato de 0,53 para 3,5 g de xilose. $\mathrm{L}^{-1}$, obtendo-se 13,0 e 11,5 mmol $\mathrm{H}_{2} . \mathrm{L}^{-1}$, respectivamente.

Tabela 5.24. Modelo de regressão e ANOVA para as respostas potencial máximo de concentração de $\mathrm{H}_{2}(P)$, velocidade específica máxima de obtenção de $\mathrm{H}_{2}(R m)$, tempo de início da obtenção de $\mathrm{H}_{2}(\lambda), \mathrm{pH}$, densidade óptica $\left(\mathrm{OD}_{600}\right)$ e consumo de carboidratos nos ensaios em diferentes concentrações de xilose $(0,53$ a 6,47 g.L. 1) pela cepa isolada (IS_2).

\begin{tabular}{|c|c|c|c|c|c|c|}
\hline Modelo & $\begin{array}{l}\text { Fonte de } \\
\text { Variação } \\
\end{array}$ & $\begin{array}{c}\text { Soma de } \\
\text { quadrados }\end{array}$ & $\begin{array}{l}\text { Quadrados } \\
\text { médios }\end{array}$ & $\mathbf{R}^{2}$ & $\begin{array}{c}\text { F } \\
\text { calculado }\end{array}$ & p valor \\
\hline \multirow{4}{*}{$\begin{array}{c}P\left(\text { mmol. } L^{-1}\right) \\
11,71+3,69 \mathrm{x}_{1}-2,37 \mathrm{x}_{1}^{2}\end{array}$} & Regressão & 77,5 & 38,8 & 96,44 & 40,6 & 0,0067 \\
\hline & Resíduo & 2,9 & 1,0 & & \multirow{3}{*}{4,0} & \multirow{3}{*}{0,3318} \\
\hline & $\begin{array}{c}\text { Falta de } \\
\text { ajuste }\end{array}$ & 2,5 & 1,3 & & & \\
\hline & Erro puro & 0,3 & 0,3 & & & \\
\hline \multirow{4}{*}{$\begin{array}{c}R m\left(m m o l . h^{-1}\right) \\
0,41+0,11 \mathrm{x}_{1}\end{array}$} & Regressão & 0,1 & 0,0 & 94,35 & 25,1 & 0,0134 \\
\hline & Resíduo & 0,0 & 0,0 & & \multirow{3}{*}{8,7} & \multirow{3}{*}{0,2331} \\
\hline & $\begin{array}{c}\text { Falta de } \\
\text { ajuste }\end{array}$ & 0,0 & 0,0 & & & \\
\hline & Erro puro & 0,0 & 0,0 & & & \\
\hline \multirow{4}{*}{$\begin{array}{c}\lambda(h) \\
7,33+2,18 \mathrm{x}_{1}\end{array}$} & Regressão & 24,4 & 12,2 & 91,91 & 17,0 & 0,0230 \\
\hline & Resíduo & 2,1 & 0,7 & & \multirow{3}{*}{214,2} & \multirow{3}{*}{0,0482} \\
\hline & $\begin{array}{l}\text { Falta de } \\
\text { ajuste }\end{array}$ & 2,1 & 1,1 & & & \\
\hline & Erro puro & 0,0 & 0,0 & & & \\
\hline \multirow{4}{*}{$\begin{array}{c}\mathrm{pH}= \\
6,03-0,43 \mathrm{x}_{1}\end{array}$} & Regressão & 0,9 & 0,0 & 85,96 & 9,2 & 0,0526 \\
\hline & Resíduo & 0,1 & 0,1 & & \multirow{3}{*}{6,9} & \multirow{3}{*}{0,2600} \\
\hline & $\begin{array}{c}\text { Falta de } \\
\text { ajuste }\end{array}$ & 0,1 & 0,0 & & & \\
\hline & Erro puro & 0,0 & 0,0 & & & \\
\hline \multirow{4}{*}{$\begin{array}{c}\mathrm{OD}_{600} \\
0,68+0,38 \mathrm{x}_{1}\end{array}$} & Regressão & 0,7 & 0,3 & 93,67 & 22,2 & 0,0159 \\
\hline & Resíduo & 0,0 & 0,0 & & \multirow{3}{*}{0,0} & \multirow{3}{*}{0,9938} \\
\hline & $\begin{array}{c}\text { Falta de } \\
\text { aiuste }\end{array}$ & 0,0 & 0,0 & & & \\
\hline & Erro puro & 0,0 & 0,0 & & & \\
\hline \multirow{4}{*}{$\begin{array}{l}\text { Consumo de carboidratos } \\
\qquad 98,40-4,50 \mathrm{x}_{1}^{2}\end{array}$} & Regressão & 45,1 & 22,6 & 94,94 & 22,8 & 0,0113 \\
\hline & Resíduo & 2,4 & 0,8 & & \multirow{3}{*}{2,8} & \multirow{3}{*}{0,3921} \\
\hline & $\begin{array}{l}\text { Falta de } \\
\text { aiuste }\end{array}$ & 2,0 & 1,0 & & & \\
\hline & Erro puro & 0,4 & 0,4 & & & \\
\hline
\end{tabular}

Nota: Potencial máximo de concentração de $\mathrm{H}_{2}(P)$, velocidade específica máxima de obtenção de $\mathrm{H}_{2}(R m)$, tempo de início da obtenção de $\mathrm{H}_{2}(\lambda)$ e $\mathrm{R}^{2}$ obtidos da equação de Gompertz modificada. 


\subsubsection{Aplicação em resíduo sólido de citros e bioaumentação}

Apesar do resíduo sólido de citros se tratar de resíduo lignocelulósico, contém elevadas concentrações de carboidratos prontamente disponíveis, como os monômeros glicose (35,5\% da massa seca) e xilose (2,2\% da massa seca) (CHOI et al., 2015). Esta composição pode ser conveniente para uso deste resíduo como substrato fermentativo.

A partir da glicose como fonte de carbono, foram obtidos potencial máximo de concentração de $\mathrm{H}_{2}(P)$, velocidade específica máxima de obtenção de $\mathrm{H}_{2}(R m)$ e $\lambda$ de 9,1 mmol H $\mathrm{H}_{2} \cdot \mathrm{L}^{-1}, 0,14 \mathrm{mmol} \mathrm{H}_{2} \cdot \mathrm{h}^{-1} \mathrm{e} 4,08 \mathrm{~h}$, respectivamente. Foi possível constatar que houve maior concentração de $\mathrm{H}_{2}$ no ensaio de bioaumentação com E. casseliflavus (13,9 mmol $\mathrm{H}_{2} . \mathrm{L}^{-1}$ ) com resíduo sólido de citros (Tabela 5.25) (Figura 5.52).

Maiores $R m$ foram obtidos em ensaios contendo glicose $\left(1,99 \mathrm{mmol} \mathrm{H}_{2} \cdot \mathrm{h}^{-1}\right)$, quando comparado ao ensaio de autofermentação $\left(1,03 \mathrm{mmol} \mathrm{H}_{2} \cdot \mathrm{h}^{-1}\right)$ e bioaumentação $(1,01 \mathrm{mmol}$ $\left.\mathrm{H}_{2} \cdot \mathrm{h}^{-1}\right)$, provavelmente devido à facilidade de assimilação da glicose quando comparado a substratos complexos, como resíduo sólido de citros. Além disso, o acúmulo de fenóis a partir do resíduo sólido de citros $\left(2,90 \mathrm{mg} . \mathrm{L}^{-1}\right)$ pode ter contribuído para menor $\mathrm{Rm}$ nestes ensaios.

Tabela 5.25. Parâmetros referentes ao modelo de Gompertz modificado a , para concentração de $\mathrm{H}_{2}$ para os ensaios com diferentes substratos (glicose e resíduo sólido de citros), bioaumentação e autofermentação.

\begin{tabular}{cccc}
\hline \multirow{2}{*}{ Parâmetros } & \multicolumn{3}{c}{ Ensaios } \\
\cline { 2 - 4 } & Glicose & Bioaumentação & $\begin{array}{c}\text { Autofermentação } \\
\text { + bioaumentação }\end{array}$ \\
\hline$P\left(\mathrm{mmol} \mathrm{H}_{2} \cdot \mathrm{L}^{-1}\right)$ & 9,1 & 7,5 & 13,9 \\
$R m\left(\mathrm{mmol} \mathrm{H}_{2} \cdot \mathrm{h}^{-1}\right)$ & 1,99 & 1,03 & 1,01 \\
$\lambda(\mathrm{h})$ & 4,08 & 5,27 & 2,12 \\
$\mathrm{R}^{2}$ & 0,99 & 0,96 & 0,97 \\
\hline
\end{tabular}

a potencial máximo de concentração de $\mathrm{H}_{2}(P)$, velocidade específica máxima de obtenção de $\mathrm{H}_{2}(R m)$, tempo de início da obtenção de $\mathrm{H}_{2}(\lambda)$ e $\mathrm{R}^{2}$ obtidos da equação de Gompertz modificada.

Uma vez que a xilose é o principal monômero em resíduos de citros (WILKINS et al., 2007; CHOI et al., 2015), e a maior concentração de $\mathrm{H}_{2}$ ocorreu nos ensaios contendo xilose como única fonte de carbono $\left(10,3 \mathrm{mmol} \mathrm{H}_{2} \cdot \mathrm{L}^{-1}\right)$, é possível inferir que o resíduo sólido de citros foi favorável à obtenção de $\mathrm{H}_{2}$. Além disso, a presença de microrganismos autóctones presentes no bagaço de citros pode ter contribuído para o aumento da disponibilidade de açúcares fermentáveis no meio reacional (HARUTA et al., 2002). 
É possível inferir que o aumento da biomassa da cepa isolada (IS_2) conciliada à comunidade autóctone do resíduo sólido de citros (autofermentação + bioaumentação) afetou positivamente a obtenção de $\mathrm{H}_{2}$. De acordo com Lin et al. (2017) e Valdez-Vazquez et al. (2015), as bactérias autóctones tem maior afinidade ao seu resíduo de origem do que quando aplicadas em outros substratos, o que justifica a importância do estudo da microbiota específica do resíduo sólido de citros.

Figura 5.52. Remoção de carboidratos totais $(\bullet)$ e potencial máximo de concentração de $\mathrm{H}_{2}$ do ensaio contendo glicose (匹), bioaumentação (resíduo sólido de citros + IS_2) ( $\bullet$ ) e autofermentação + bioaumentação (apenas resíduo sólido de citros) ( $\boldsymbol{\Delta})$ nos reatores em batelada inoculados com a cepa (IS_2) isolada de resíduo sólido de citros.

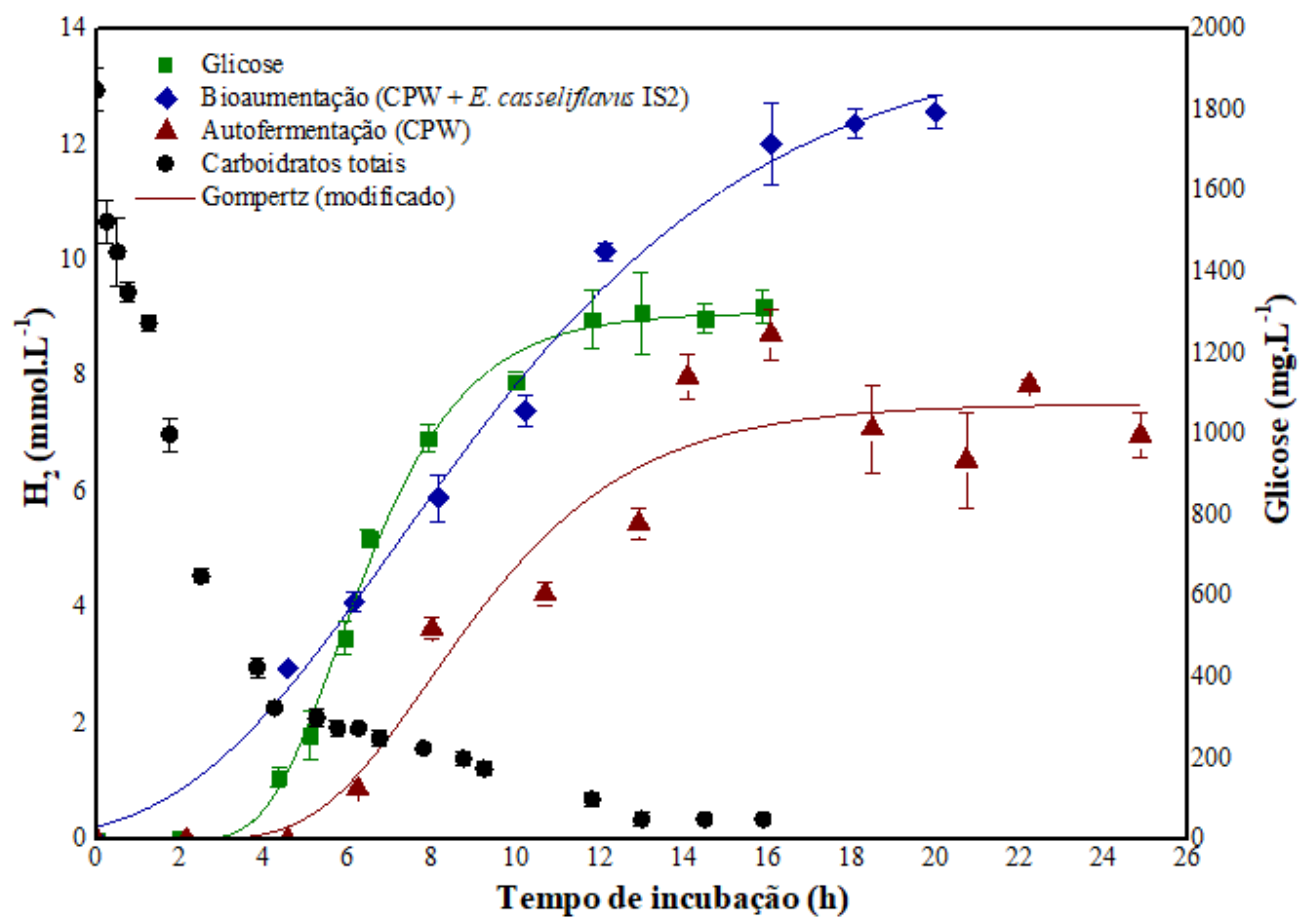

A obtenção de $\mathrm{H}_{2}$ utilizando a cepa isolada (IS_2) pode ser comparada ao uso de consórcios com predominância de Clostridium a partir de diferentes resíduos, como xilose (MÄKINEN; NISSILÄ; PUHAKKA, 2012), resíduos lignocelulósicos (BRAGA et al., 2017; LIN et al., 2017; VALDEZ-VAZQUEZ et al., 2019) e celulose (RABELO et al., 2018b), e em condições operacionais similares ( $\mathrm{pH}$ neutro e temperatura mesofílica) (Tabela 5.26).

Yin e Wang (2016) obtiveram $116 \mathrm{mmol} \mathrm{H}_{2} \cdot \mathrm{L}^{-1}$ a partir da fermentação de glicose com E. faecium, o que pode indicar maior afinidade desta cepa com a glicose em comparação à cepa isolada (IS_2). Entretanto, estes autores utilizaram maiores concentrações de glicose (15 g.L $\left.\mathrm{L}^{-1}\right)$ do que no presente estudo $\left(2\right.$ g. $\left.\mathrm{L}^{-1}\right)$. A partir destes 
resultados, é possível inferir que novos estudos acerca das condições ótimas para obtenção de $\mathrm{H}_{2}$ por meio de cepas isoladas são necessários para o estabelecimento das condições operacionais mais indicadas para cada organismo em diferentes substratos.

Tabela 5.26. Concentração de $\mathrm{H}_{2}$ a partir de diferentes substratos e inóculos.

\begin{tabular}{|c|c|c|c|c|c|c|}
\hline Inóculo & Substrato & Reator & $\mathrm{pH}$ & $\mathbf{t}^{\circ} \mathrm{C}$ & mmol H2. $\mathrm{L}^{-1}$ & Referência \\
\hline $\begin{array}{l}\text { C. acetobutulyticum }+ \\
\text { Citrobacter freundii }\end{array}$ & Xilose & $\mathrm{CSTR}^{*}$ & 6,8 & 45 & 7,3 & $\begin{array}{l}\text { Mäkinen et al. } \\
\text { (2012) }\end{array}$ \\
\hline Consórcio autóctone & $\begin{array}{c}\text { Resíduos } \\
\text { de } \\
\text { cogumelos }\end{array}$ & Batelada & 8,0 & 55 & 6,4 & Lin et al. (2017) \\
\hline Consórcio misto & Celulose & Batelada & 6,8 & 37 & 39,2 & $\begin{array}{l}\text { Rabelo et al. } \\
\qquad(2018 \mathrm{a})\end{array}$ \\
\hline $\begin{array}{c}\text { C. acetobutylicum }+C . \\
\text { cellulovorans }\end{array}$ & $\begin{array}{l}\text { Palha de } \\
\text { trigo }\end{array}$ & Batelada & 5,5 & 37 & 17,6 & $\begin{array}{c}\text { Valdez-Vazquez et } \\
\text { al. (2019) }\end{array}$ \\
\hline $\begin{array}{c}\text { C. cellulolyticum } \\
\text { (atual } R \text {. cellulolyticum) }\end{array}$ & $\begin{array}{l}\text { Bagaço de } \\
\text { cana-de- } \\
\text { açúcar }\end{array}$ & Batelada & 7,0 & 37 & 7,6 & Braga et al. (2017) \\
\hline Enterococcus faecium & Glicose & Batelada & 7,0 & 35 & 116 & Yin e Wang (2016) \\
\hline $\begin{array}{l}\text { Enterococcus } \\
\text { casseliflavus }\end{array}$ & $\begin{array}{l}\text { residuo } \\
\text { sólido de } \\
\text { citros }\end{array}$ & Batelada & 7,0 & 37 & 13,9 & Presente pesquisa \\
\hline
\end{tabular}

* continuous stirred-tank reactor.

A partir do monitoramento da produção de AOV ao longo do período de incubação (Figura 5.53), é possível notar que HAc e HBu foram os principais metabólitos tanto a partir de glicose quanto a partir de resíduo sólido de citros. Entretanto, a partir de resíduo sólido de citros, houve maior produção de $\mathrm{HPr}$, de $284 \mathrm{mg} . \mathrm{L}^{-1}$ no ensaio de autofermentação + bioaumentação e 95 mg.L $\mathrm{L}^{-1}$ no ensaio de bioaumentação, comparados a apenas de 14 mg. $\mathrm{L}^{-1}$ a partir da glicose. 
Figura 5.53. Compostos orgânicos a partir da glicose (A), autofermentação do resíduo sólido de citros + bioaumentação (B) e bioaumentação (C) ao longo do tempo de operação dos reatores em batelada.

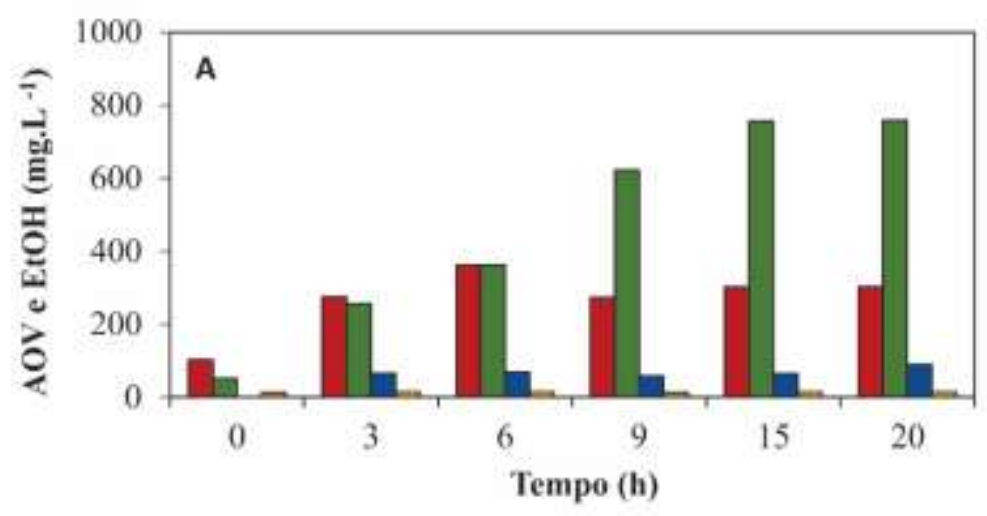

- $\mathrm{HAc}=\mathrm{HBu}=\mathrm{EtOH}$ 口 $\mathrm{HPr}$

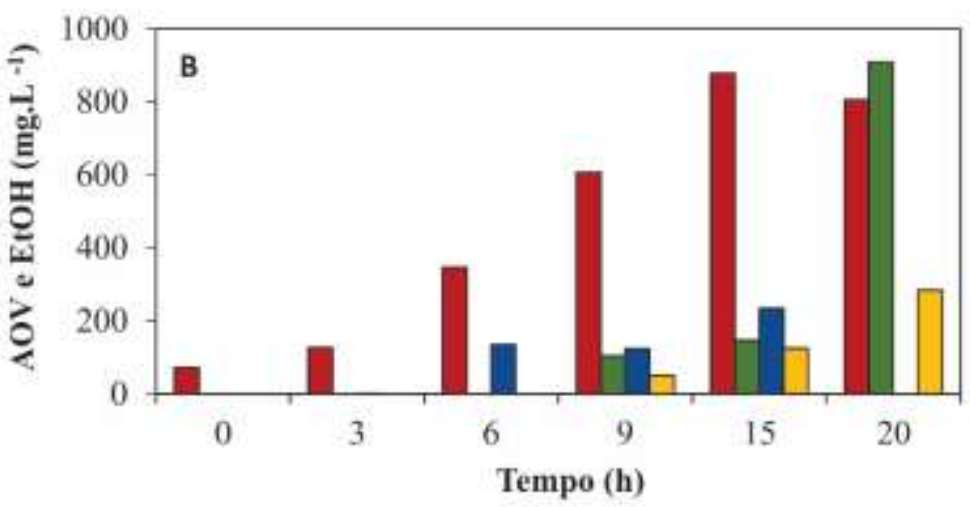

घAc $\square \mathrm{HBu}=\mathrm{EtOH}$ 口 $\mathrm{HPr}$

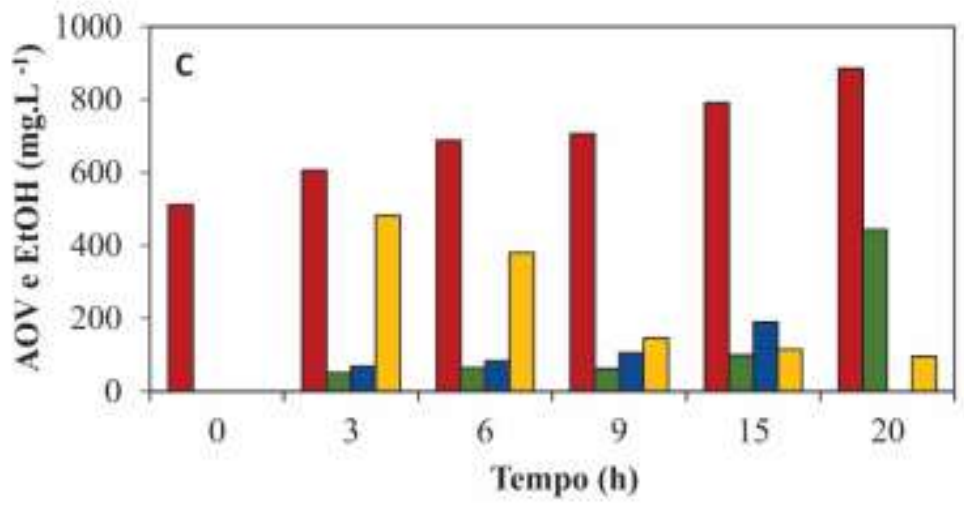

: $\mathrm{HAc}=\mathrm{HBu}=\mathrm{EtOH}$ 口 $\mathrm{HPr}$

De acordo com Ruiz e Flotats (2016), quanto maior a concentração de limoneno, maior o acúmulo de AOV, especialmente HPr. Os principais metabólitos observados a partir da autofermentação do resíduo sólido de citros foram HAc (805 mg.L $\left.\mathrm{L}^{-1}\right), \mathrm{HBu}(909$ mg. $\left.\mathrm{L}^{-1}\right)$ e HPr (284 mg.L $\left.\mathrm{L}^{-1}\right)$. A produção de HPr foi crescente no ensaio de autofermentação do resíduo sólido de citros, sendo que foram obtidos $50 \mathrm{mg} . \mathrm{L}^{-1} \mathrm{em} 9 \mathrm{~h}$ de incubação e 284 mg.L $\mathrm{L}^{-1}$ ao final da fermentação. No ensaio de bioaumentação, foram obtidos $482 \mathrm{mg} . \mathrm{L}^{-1}$ de 
HPr após 3 h, sendo que a concentração deste composto ao final do processo fermentativo foi reduzida para $95 \mathrm{mg} \cdot \mathrm{L}^{-1}$. Desta forma, é possível inferir que a bioaumentação da cepa isolada (IS_2) favoreceu a produção de HAc a partir do resíduo sólido de citros e, consequentemente, a obtenção de $\mathrm{H}_{2}$.

Apesar da produção de HPr não ser favorável à obtenção de $\mathrm{H}_{2}$, destaca-se que a produção de HAc foi superior no ensaio de bioaumentação $\left(886 \mathrm{mg} \cdot \mathrm{L}^{-1}\right)$ quando comparado à glicose $\left(303 \mathrm{mg} . \mathrm{L}^{-1}\right)$, o que justifica a maior obtenção de $\mathrm{H}_{2}$ a partir da bioaumentação, uma vez que a via acetogênica é favorável à produção deste composto (ŁUKAJTIS et al., 2018). Da mesma forma, Su et al. (2016) observaram que após 30 dias de fermentação em reatores em batelada operados com esterco suíno como inóculo, os principais AOV produzidos a partir de resíduo de citros foram HAc $\left(2610,7 \mathrm{mg} . \mathrm{L}^{-1}\right), \operatorname{HPr}\left(56,2 \mathrm{mg} . \mathrm{L}^{-1}\right) \mathrm{e}$ $\mathrm{HBu}\left(27,5 \mathrm{mg} \cdot \mathrm{L}^{-1}\right)$.

Wang et al. (2009) relataram o potencial de E. gallinarum para obtenção de $\mathrm{H}_{2}$ a partir de celulose (Avicel; 5 g. $\mathrm{L}^{-1}$ ), obtendo 2,38 mmol de $\mathrm{H}_{2} \cdot \mathrm{g}^{-1}$ de substrato, com coprodução HAc, HPr e HBu ao final do período de incubação. Yin e Wang (2016) obtiveram 1,69 mol de $\mathrm{H}_{2} \cdot \mathrm{mol}^{-1}$ de glicose utilizando E. faecium como inóculo, com prevalência da via acetogênica ao longo do processo. Desta forma, é possível inferir que a degradação de substratos complexos pode favorecer a produção de HPr, ao contrário dos substratos simples, tais como os monômeros.

Encontram-se resumidas na Figura 5.54 as possíveis vias de conversão dos resíduos sólidos de citros e diferentes carboidratos (poli, di e monossacarídeos) em $\mathrm{H}_{2}$, bem como os principais compostos orgânicos acumulados durante a fermentação pela cepa isolada de E. casseliflavus (IS_2). É importante salientar que diferentes compostos podem ser produzidos de acordo com cada substrato utilizado, devido às suas características e às etapas necessárias à sua fermentação (MÄKINEN; NISSILÄ; PUHAKKA, 2012; SINHA; PANDEY, 2014; ŁUKAJTIS et al., 2018; MAZARELI et al., 2019). Outro fator importante é o pH, uma vez que o piruvato pode ser convertido em HLac em pH entre 5,0-6,0, mas em pH neutro ou ligeiramente alcalino os principais metabólitos são EtOH e HAc, como pode ser observado no presente estudo a partir de glicose a $\mathrm{pH} 7,0$, sendo obtidos 345 e 243 mg. $\mathrm{L}^{-1}$ de EtOH e HAc, respectivamente. O esquema foi proposto de acordo com Vos et al. (2009) e os resultados a partir de diferentes substratos descritos no presente estudo. 
Figura 5.54. Possíveis vias de conversão de resíduo sólido de citros (RSC), polissacarídeos e monossacarídeos aos principais metabólitos observados na fermentação de E. casseliflavus. HAc = ácido acético; $\mathrm{HBu}=$ ácido butírico; $\mathrm{HPr}=$ ácido propiônico; $\mathrm{HLac}=$ ácido lático; $\mathrm{EtOH}=$ etanol.
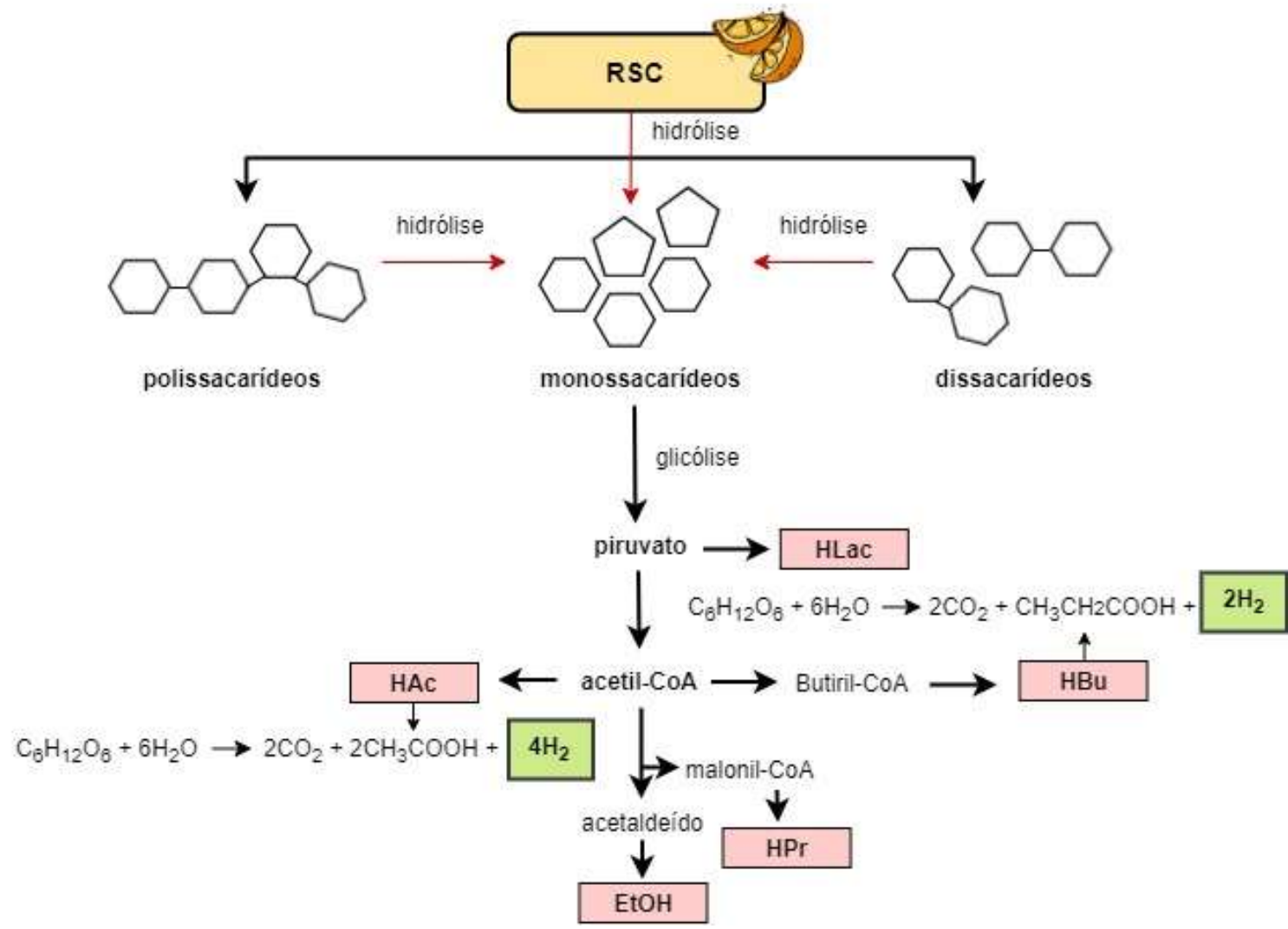

Fonte: Elaboração própria.

\subsection{POTENCIAL METANOGÊNICO}

\subsubsection{Obtenção de biogás e AOV}

Após o período de incubação de aproximadamente $22 \mathrm{~h}$, foram obtidos $P$ de 13,29 mmol $\mathrm{H}_{2} \cdot \mathrm{L}^{-1}, R m$ de $2,46 \mathrm{mmol} \mathrm{H}_{2} \cdot \mathrm{h}^{-1}$ e $\lambda$ de $8,76 \mathrm{~h}$ na Fase I, nas condições de $30{ }^{\circ} \mathrm{C}, \mathrm{pH}$ 8,5, 2,25 gSTV.L ${ }^{-1}$ de inóculo autóctone, 3 gSTV.L ${ }^{-1}$ de inóculo alóctone, 5 g.L $\mathrm{L}^{-1}$ de resíduo sólido de citros, $40 \%$ de headspace e 5 g.L $\mathrm{L}^{-1}$ de $\mathrm{NaCl}$. Neste estágio, não foi possível detectar produção de metano $\left(\leq 1,17 \mathrm{mmol} \mathrm{CH}_{4} \cdot \mathrm{L}^{-1}\right)$.

Após descarte da fração sólida, a fração líquida do reator fermentativo obtido na Fase I (reator acidogênico) foi utilizado como substrato da Fase II (reator metanogênico), que teve como principal objetivo a obtenção de $\mathrm{CH}_{4}$, a fim de simular um sistema de duas fases (fase acidogênica a partir de resíduos sólidos de citros e fase metanogênica a partir da fração líquida do primeiro reator).

Os reatores foram monitorados por período de aproximadamente $700 \mathrm{~h}$ (Figura 5.55). De acordo com os dados obtidos (Tabela 5.27), estima-se que o $P$ calculado para 
concentração de $\mathrm{CH}_{4}$ foi de $50,2 \mathrm{mmol} \mathrm{CH}_{4} \cdot \mathrm{L}^{-1}$, a velocidade máxima da reação foi de 0,2 mmol $\mathrm{CH}_{4} \cdot \mathrm{h}^{-1}$ e o tempo de início da obtenção de $\mathrm{CH}_{4}$ foi de $281,4 \mathrm{~h}$. Além disso, é possível observar que o aumento da velocidade teve início em aproximadamente $240 \mathrm{~h}$ de incubação, coincidindo com o momento no qual a produção de hidrogênio cessou, possivelmente devido à atividade de bactérias homoacetogênicas e/ou arqueias metanogênicas hidrogenotróficas.

Figura 5.55. Concentração de $\mathrm{H}_{2}$ na Fase I e obtenção de $\mathrm{H}_{2}$ e $\mathrm{CH}_{4}$ na Fase II.

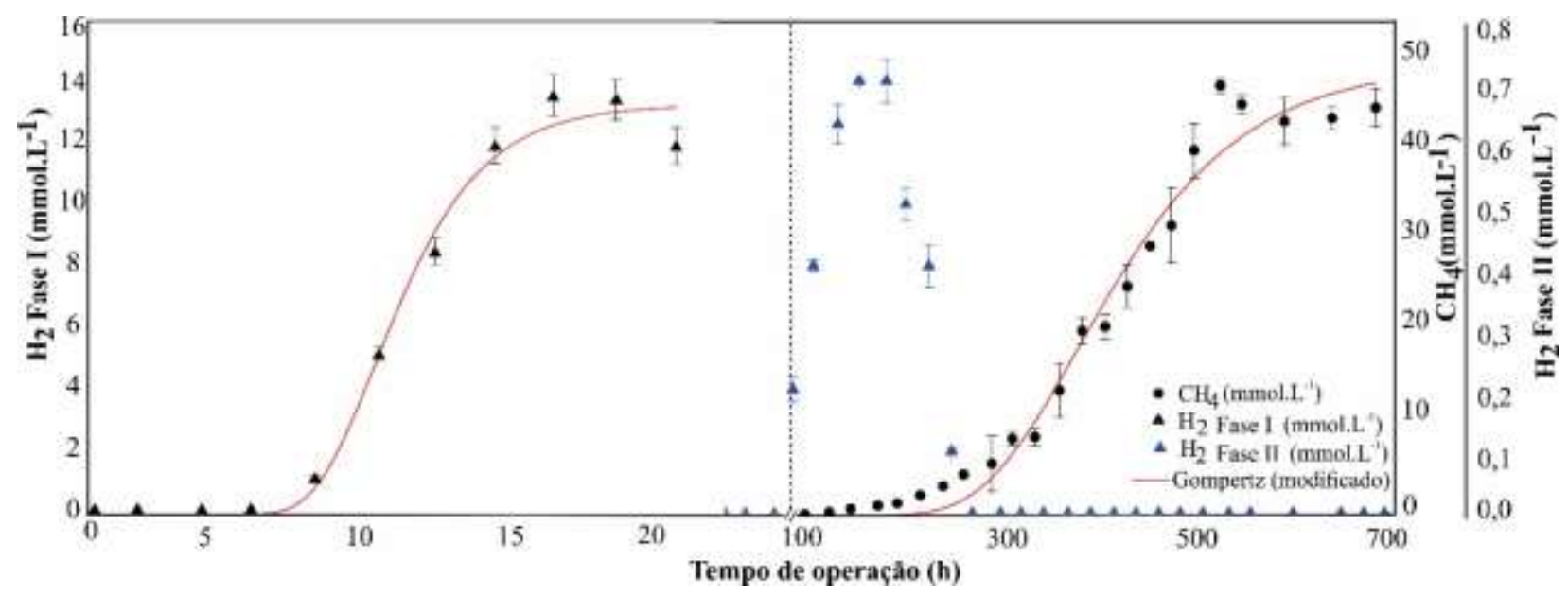

Tabela 5.27. Parâmetros cinéticos de obtenção de $\mathrm{H}_{2}$ e $\mathrm{CH}_{4}$ nas fases I e II, respectivamente.

\begin{tabular}{ccc}
\hline Parâmetros & Fase I $\left(\mathbf{H}_{2}\right)$ & Fase II $\left(\mathbf{C H}_{4}\right)$ \\
\hline$P\left(\mathrm{mmol}_{\mathbf{L}} \mathrm{L}^{-1}\right)$ & $13,29 \pm 0,48$ & $50,2 \pm 2,3$ \\
$R m\left(\mathrm{mmol}_{\mathrm{h}}{ }^{-1}\right)$ & $2,46 \pm 0,35$ & $0,2 \pm 0,01$ \\
$\lambda(\mathrm{h})$ & $8,73 \pm 0,40$ & $281,4 \pm 10,42$ \\
$\mathrm{R}^{2}$ & 0,99 & 0,98 \\
Produção específica & 39.7 & 187.4
\end{tabular}

Nota: (-) Não detectado. Produção específica $=$ mL.gTVS ${ }_{\text {RSC. }}$ L $^{-1}$. Potencial máximo de concentração de $\mathrm{H}_{2}$ $(P)$, velocidade específica máxima de obtenção de $\mathrm{H}_{2}(R m)$, tempo de início da obtenção de $\mathrm{H}_{2}(\lambda)$ e $\mathrm{R}^{2}$ obtidos da equação de Gompertz modificada.

Forgàcs et al. (2012) obtiveram concentração máxima de $247,7 \mathrm{mmol} \mathrm{CH} 4 . \mathrm{L}^{-1}$ utilizando resíduo de citros tratado por explosão a vapor com inóculo de reator de planta de produção de biogás. Calabrò et al. (2016) utilizaram diversos inóculos para a obtenção de metano a partir de resíduos de citros, tais como resíduos industriais e resíduos 
agroindustriais, sendo obtidos os melhores resultados em experimentos em condição mesófila em reatores em batelada, com concentração de $33 \mathrm{mmol} \mathrm{CH}_{4} \cdot \mathrm{L}^{-1}$. Destaca-se ainda a obtenção de $0,01 \mathrm{mmol} \mathrm{CH}_{4} \cdot \mathrm{L}^{-1}$ utilizando resíduo pré-tratado de citros com inóculo de estrume suíno e lodo de esgoto (SU; TAN; XU, 2016). Quando comparados aos trabalhos mencionados, é possível concluir que a obtenção de metano observada na presente pesquisa foi satisfatória $\left(50,2 \mathrm{mmol} \mathrm{CH} 4 \cdot \mathrm{L}^{-1}\right)$, especialmente considerando-se que não foi necessário pré-tratamento inicial dos resíduos sólidos de citros, uma das etapas mais onerosas do processo.

Tendo em vista que altas concentrações de compostos orgânicos são inibitórias aos microrganismos metanogênicos, é a faixa ideal para processos metanogênicos é entre 6,57,5 , tem-se investido em sistemas de duas fases, a fim de favorecer os microrganismos específicos de cada etapa do processo fermentativo a partir do ajuste das variáveis operacionais ótimas para cada estágio - hidrólise/acidogênese (Fase I) e metanogênese (Fase II). Liu et al. (2006) apontam que a obtenção de metano a partir de resíduos sólidos chega a ser até $21 \%$ maior em processos de duas fases quando comparado a uma única fase, provavelmente devido à hidrólise avançada do substrato durante a primeira etapa, na qual há obtenção de hidrogênio e ácidos orgânicos, enquanto a obtenção de hidrogênio pode aumentar em até $88 \%$.

$\mathrm{Na}$ presente pesquisa, o acúmulo de AOV ao final da fase acidogênica, especialmente HAc, favoreceu a obtenção de $\mathrm{H}_{2}$ na Fase II devido a presença de arqueias metanogênicas acetoclásticas. Neste estudo, os valores de $P$ para $\mathrm{H}_{2}$ na Fase 1 e metano na Fase 2 foram de 13,29 mmol $\mathrm{H}_{2} \cdot \mathrm{L}^{-1}$ e 50,2 $\mathrm{mmol} \mathrm{CH}_{4} \cdot \mathrm{L}^{-1}$, respectivamente. Da mesma forma, Braga et al. (2018) avaliaram o potencial do efluente do processo fermentativo em batelada de bagaço de cana-de-açúcar, a partir de lodo de reator UASB como inóculo, utilizando bateladas em duas fases. Os autores obtiveram concentração máxima de 7,6 mmol $\mathrm{CH}_{4} \cdot \mathrm{L}^{-1}$ na Fase II.

Cremonez et al. (2020) avaliaram a separação das fases acidogênica e metanogênica em reatores alimentados com polímero à base de amido de mandioca em reatores semicontínuos de fluxo ascendente, e obtiveram 26,69 mmol H $2 . \mathrm{L}^{-1}$ and 528,2 $\mathrm{mmol} \mathrm{CH}_{4} \cdot \mathrm{L}^{-1}$. Provavelmente, os maiores valores obtidos por Cremonez et al. (2020) estejam relacionados a configuração reacional e características do resíduo usado como substrato, bastante diferente dos valores obtidos na presente pesquisa. 
Os resultados referentes às análises físico-químicas dos reatores do ensaio de potencial metanogênico encontram-se resumidos na Tabela 5.28. A partir das análises estatísticas para o intervalo de confiança de 95\%, foi possível observar diferença significativa $(\mathrm{p} \leq 0,05)$ quando comparados os dados de SST ( $\mathrm{p}=0,01067), \operatorname{SSV}(\mathrm{p}=$ 0,1199), carboidratos totais ( $\mathrm{p}=0,01547), \mathrm{DQO}_{\text {filtrada }}(\mathrm{p}=0,04405)$ e concentração de fenóis totais $(\mathrm{p}=0,006931)$ das fases I e II. Da mesma forma, a variação do $\mathrm{pH}$ foi considerada como estatisticamente não significativa $(\mathrm{p}=0,05614)$.

A concentração inicial de limoneno no resíduo sólido de citros bruto foi de 14.700 mg.kg ${ }^{-1}$. Sendo assim, entende-se que a concentração inicial desse composto na Etapa I foi de aproximadamente 220,5 mg. $\mathrm{kg}^{-1}$. Uma vez que Calabró et al. (2016) estabeleceram que valores acima de $200 \mathrm{mg} \cdot \mathrm{kg}^{-1}$ de limoneno são inibitórias à metanogênese, é possível inferir que a presença desse composto foi um dos motivos para a ausencia de concentrações significativas de $\mathrm{CH}_{4}$ no biogás no Estágio I.

Neste estudo, o pH inicial na Fase I foi ajustado para 8,5, atingindo 6,7 após a fermentação, enquanto na Fase II o pH inicial foi ajustado para 7,0, com pH final de 7,4, o que pode ter potencializado o efeito inibitório do limoneno na Fase I. Sabe-se que o pH ideal para acidogênese e metanogênese são distintos, ou seja, ácido e neutro, respectivamente. Provavelmente, na condição da Fase 1 (reator acidogênico) a ação antimicrobiana do limoneno pode ter sido potencializada inviabilizando a obtenção de metano, uma vez que sua concentração inicial na Fase I foi de 220,5 mg.L $\mathrm{L}^{-1}$, ou seja, acima do limite inibitório de $200 \mathrm{mg} . \mathrm{L}^{-1}$ estabelecido por Calabrò et al. (2016). Burt (2004) descreveu que vários parâmetros podem afetar a toxicidade do limoneno e outros óleos essenciais, sendo o $\mathrm{pH}$ um deles, que em condições ácidas pode aumentar sua toxicidade.

A concentração inicial de limoneno na Fase II foi de $0,58 \mathrm{mg} \cdot \mathrm{kg}^{-1}$. Uma vez que a concentração inibitória mínima de limoneno é estimada em aproximadamente $200 \mathrm{mg} \cdot \mathrm{kg}^{-1}$ (CALABRÒ et al., 2016; RUIZ; FLOTATS, 2016). Sob tais condições, é possível inferir que não houve inibição da metanogênese na Fase II em função da concentração de limoneno. Entretanto, este composto não foi observado ao final do período de operação da Fase II, que pode indicar sua volatilização para o headspace ou degradação em $p$-cimeno, um composto menos tóxico comumente gerado a partir da degradação do limoneno em anaerobiose. 
Tabela 5.28. Parâmetros físico-químicos dos reatores do ensaio de potencial metanogênico ao final do período de operação da Fase I e Fase II.

\begin{tabular}{|c|c|c|}
\hline Sólidos (g.L $\left.\mathrm{L}^{-1}\right)$ & Fase I & Fase II \\
\hline SST & $1,71 \pm 0,2$ & $0,58 \pm 0,1$ \\
\hline SSV & $1,11 \pm 0,1$ & $0,40 \pm 0,1$ \\
\hline DQO filtrada $\left(\right.$ g. $\left.\mathbf{L}^{-1}\right)$ & $18,85 \pm 0,2$ & $9,38 \pm 0,4$ \\
\hline Carboidratos totais $\left(\right.$ g. $\left.\mathrm{L}^{-1}\right)$ & $1,09 \pm 0,1$ & $0,30 \pm 0,1$ \\
\hline Fenóis totais (mg.L $\left.\mathrm{L}^{-1}\right)$ & $20,09 \pm 0,5$ & $19,43 \pm 0,3$ \\
\hline Limoneno (mg.L $\left.{ }^{-1}\right)$ & 0,58 & - \\
\hline Lignina (\%) & 25,27 & - \\
\hline pH (inicial) & 8,5 & 7,0 \\
\hline pH (final) & $6,86 \pm 0,0$ & $7,37 \pm 0,0$ \\
\hline
\end{tabular}

Nota: (-) Não detectado.

Foi possível observar maior concentração de matéria orgânica e acúmulo de ácidos orgânicos ao final da fase acidogênica (Fase I). A partir destes resultados, é possível inferir que a combinação da obtenção de $\mathrm{H}_{2}$ com a obtenção de metano acaba por favorecer a recuperação de energia (LU et al., 2009; BRAGA et al., 2018).

Apesar da importância da produção de AOV como intermediários para o processo de digestão anaeróbia, o acúmulo destes compostos pode levar à inibição do processo. Esta inibição pode ocorrer devido à competição por substrato em vias nas quais não há produção de biogás e quando estas moléculas penetram pela membrana celular e ocorre sua dissociação no interior da célula, levando à acidificação do citoplasma devido ao acúmulo de ânions e redução da força próton motiva, do potencial de crescimento e metabolismo celular (JIANG et al., 2018).

De acordo com Yusof et al., (2019), estima-se que concentrações acima de 900 $\mathrm{mg} . \mathrm{L}^{-1}$ de $\mathrm{AOV}$ podem ser inibitórias para a metanogênese, uma vez que podem acarretar em acidificação do meio. Na Fase I, foram obtidos $1.498 \mathrm{mg} \cdot \mathrm{L}^{-1}$ de AOV ao final do período de operação, além de valores $\geq 900 \mathrm{mg} . \mathrm{L}^{-1}$ ao longo de todo o processo fermentativo. Na Fase II, apesar de $1.439 \mathrm{mg} . \mathrm{L}^{-1}$ de AOV iniciais ocorreu o seu consumo ao longo do processo, consequentemente refletindo em maior período de adaptação da biomassa $(\lambda=281,4 \mathrm{~h})$ para a obtenção de $\mathrm{CH}_{4}$.

Foram observadas concentrações crescentes de HAc ao longo do período de operação da Fase I, sendo de $63 \mathrm{mg} . \mathrm{L}^{-1}$ no início da incubação e $1340 \mathrm{mg} . \mathrm{L}^{-1}$ ao final do processo (Figura 5.56). Além disso, $907 \mathrm{mg} . \mathrm{L}^{-1}$ de $\mathrm{HBu}$ foram produzidos no início da operação da Fase I, $723 \mathrm{mg} . \mathrm{L}^{-1}$ durante o processo e $31 \mathrm{mg} . \mathrm{L}^{-1}$ ao final do processo, sendo 
possível inferir que houve conversão do HBu em HAc ao longo do período de incubação (Equação 5.12).

$\mathrm{C}_{6} \mathrm{H}_{6} \mathrm{O}+5 \mathrm{H}_{2} \mathrm{O} \rightarrow 3 \mathrm{CH}_{3} \mathrm{COOH}+2 \mathrm{H}_{2}$

A predominância da via acetoclástica pode ter contribuído para a concentração elevada de $\mathrm{H}_{2}$ na Fase I, uma vez que há rendimento de 4 mols de $\mathrm{H}_{2}$ para cada mol de glicose consumidos nesta via (Equação 3.3), enquanto na produção de HBu há rendimento de apenas 2 mols de $\mathrm{H}_{2}$ para cada mol de glicose (Equação 3.4) (MÄKINEN; NISSILÄ; PUHAKKA, 2012; ŁUKAJTIS et al., 2018). Além disso, o HBu não pode ser utilizado como substrato direto para a metanogênese, sendo necessária, portanto, a sua conversão à HAc, que por sua vez pode ser consumido como substrato na metanogênese acetoclástica. Na Fase II, houve redução da concentração de HAc (1317 a $\left.\leq 10 \mathrm{mg} . \mathrm{L}^{-1}\right)$, que pode ser atribuída ao seu consumo na via acetoclástica (Equação 3.7) (NESHAT et al., 2017).

Ao final da Fase I, foram obtidos 85 mg.L $\mathrm{L}^{-1}$ de HPr e $40 \mathrm{mg} . \mathrm{L}^{-1}$ de EtOH. Uma vez que na via metabólica de produção de $\mathrm{HPr}$, há consumo de 2 mols de $\mathrm{H}_{2}$ para cada mol de glicose oxidado (Equação 3.5) (LI; FANG, 2007; GHIMIRE et al., 2015), sabe-se que concentração elevada deste ácido é desvantajosa para o processo. Da mesma forma, na via solvetogênica há consumo de HAc para a produção de EtOH (Equação 5.13). Assim como o HBu, o HPr não pode ser diretamente consumido por arqueias metanogênicas, sendo necessária sua conversão à HAc (Equação 5.8).

$$
A T P+\text { acetato }+ \text { Coenzima } A \rightarrow A M P+\operatorname{difosfato}+\text { AcetilCoA }
$$

Nota-se que na conversão dos compostos mencionados em HAc há concomitante obtenção de $\mathrm{H}_{2}$, que por sua vez pode ser consumido por arqueias hidrogenotróficas para a redução do $\mathrm{CO}_{2}$ a $\mathrm{CH}_{4}$ (Equação 3.8).

Dentre os metabólitos observados, o HPr vem sendo reportado como o mais tóxico para o processo de digestão anaeróbia devido a sua dificuldade de assimilação (NESHAT et al., 2017; XING et al., 2020). De acordo com Shen et al. (2018), o HPr pode ser inibitório para a metanogênese acima de $1.000 \mathrm{mg} . \mathrm{L}^{-1}$. Desta forma, considerou-se que a concentração de HPr observada ao final da Fase I ( $\left.85 \mathrm{mg} . \mathrm{L}^{-1}\right)$ não foi inibitória para a metanogênese na Fase II. 
Figura 5.56. Ácidos orgânicos e etanol ao longo do período de incubação na Fase I (A) e Fase II (B) em diferentes amostrais temporais (CP1-3). Para as condições otimizadas, os pontos amostrais foram coletados no período entre 0-22 h, enquanto para as condições não otimizadas as amostras foram coletadas entre 0-700 h. Ácido acético (HAc), ácido butírico (HBu), ácido propiônico (HPr) e etanol (EtOH).

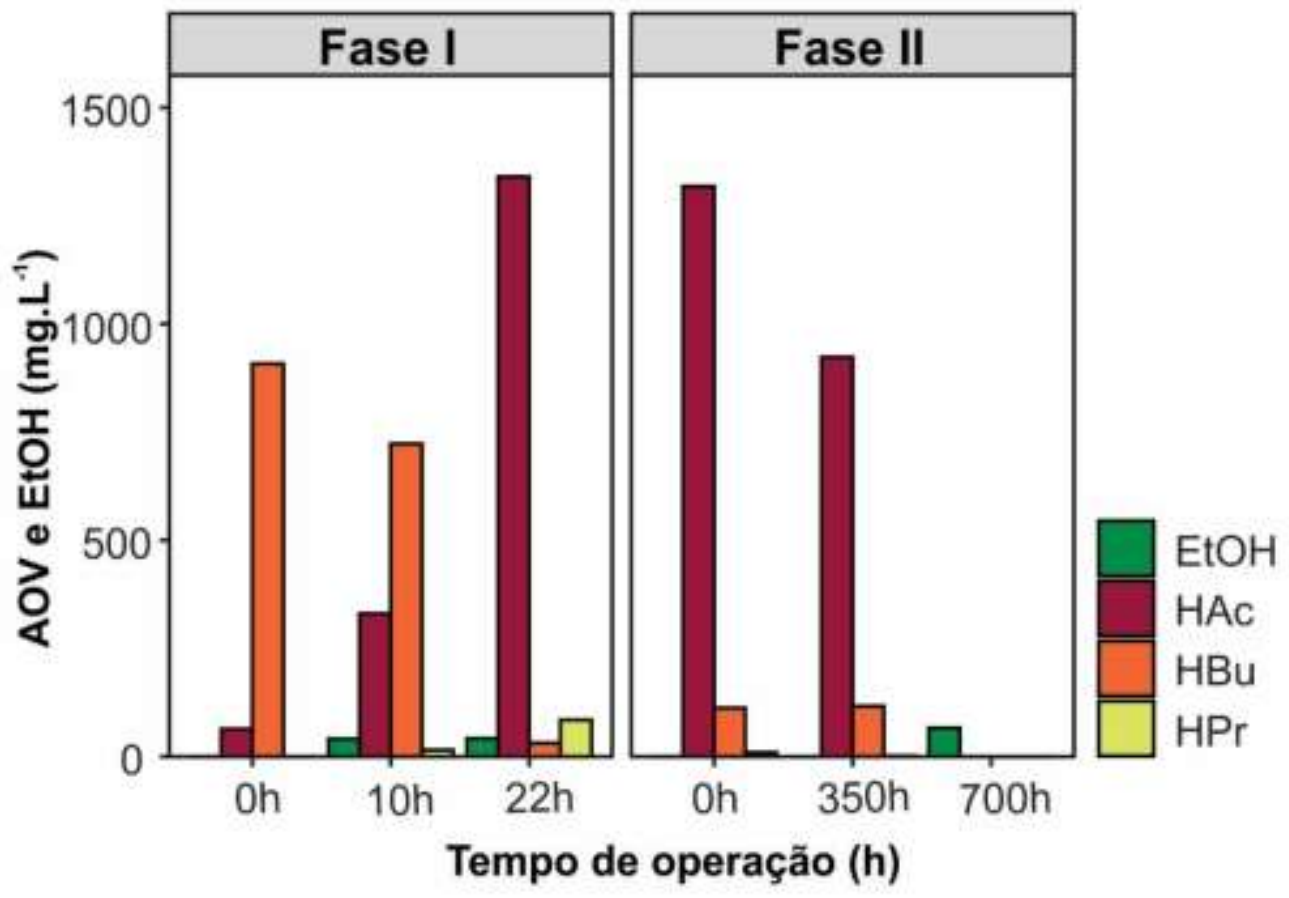

\subsubsection{Caracterização da comunidade microbiana}

As análises micromorfológicas da biomassa após o término da operação dos reatores acidogênicos (Fase I) e metanogênicos (Fase II) foram avaliados, sendo verificado no primeiro caso bacilos e endósporos (Figura 5.57). Além disso, foi possível observar sarcinas e bacilos fluorescentes, característica comum em arqueias metanogênicas semelhantes a Methanosarcina e Methanobacterium, devido à presença da coenzima carreadora de elétrons $\mathrm{F}_{420}$, que absorve luz na faixa de $420 \mathrm{~nm}$ e fluoresce na forma verdeazulada (MADIGAN, 2016). 
Figura 5.57. Características micromorfológicas da biomassa da Fase II ao final do período de incubação. As setas vermelhas indicam os bacilos e as setas pretas indicam os endósporos. Aumento total de 1600X.

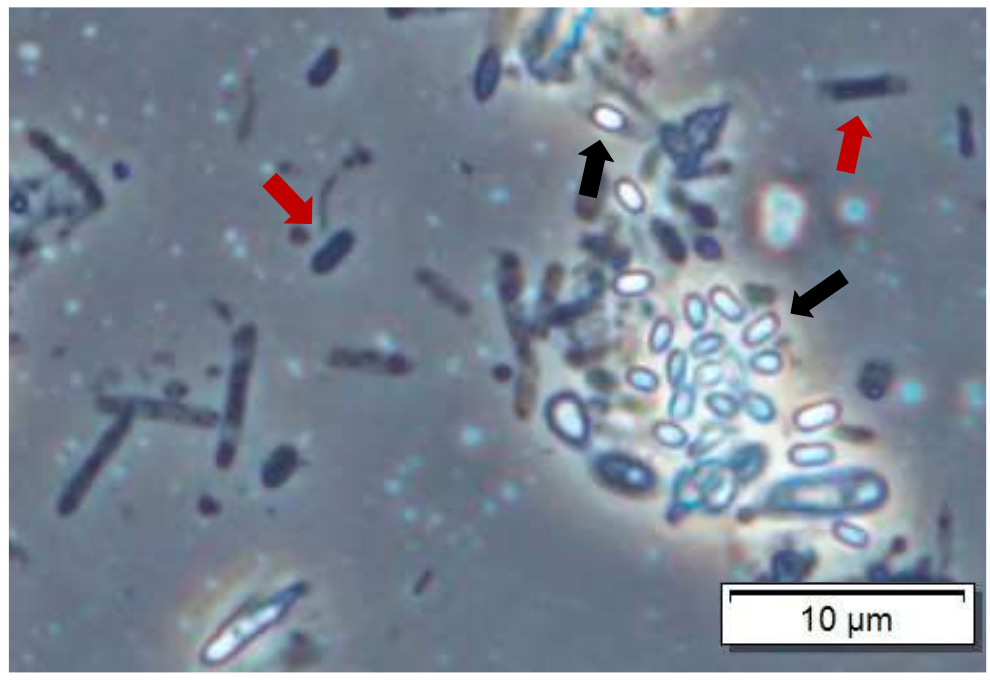

Após as análises de metabarcoding da biomassa do ensaio de potencial metanogênico do efluente foi possível comparar os resultados desta etapa (Fase II) com os resultados obtidos para a Fase I. Foram obtidas 35.485 sequências de genes do RNAr 16S para a amostra da Fase I e 33.761 para a Fase II. As Unidades Taxonômicas Operacionais (OTU) obtidas foram agrupadas considerando similaridade superior a 97\% e, após a remoção de singletons foram obtidas 600 OTU para a Fase I e 646 OTU para a Fase II. Em relação aos valores de cobertura ( $\geq 99 \%$ ), referentes à proporção de sequencias representativas, foi possível notar que a maior parte das populações foram acessadas, indicando boa cobertura das amostras analisadas (Figura 5.58).

Os índices ecológicos avaliados encontram-se resumidos na Tabela 5.29. Os valores obtidos para a amostra da biomassa da Fase I e Fase II foram comparados, sendo que houve maior diversidade na Fase I $(3,9)$, em relação à Fase II $(2,9)$. Esta diversidade foi inferida por meio do índice de diversidade de Shannon-Wiener ( $\left.\mathrm{H}^{\prime}\right)$, que leva em consideração o número de taxons e sua dominância na amostra. Entretanto, com base no índice de Simpson, estimou-se dominância similar em ambas as amostras $(0,8)$. Uma possível explicação para estes valores similares, em contraste aos valores distintos de diversidade, é que a separação dos reatores em fases distintas favoreceu as condições ótimas para os organismos envolvidos tanto na etapa acidogênica (Fase I), quanto na etapa metanogênica (Fase II) (BRAGA et al., 2018; CREMONEZ et al., 2020). 
A riqueza das amostras foi comparada por meio do índice Chao-1, sendo possível observar maior riqueza, relativa ao maior número de OTUs observado, na amostra da Fase II $(643,4)$ em relação à Fase I $(643,1)$. Vale ressaltar que os valores obtidos para o índice de Chao-1 são ligeiramente maiores que o número real de OTUs observado, uma vez que este índice assume que o número de observações para um táxon tem uma distribuição de Poisson (distribuição de probabilidade de variável aleatória discreta) e corrige sua variância por meio da soma de um valor a 0 , referente ao número desconhecido de táxons presente na comunidade, mas que não foi observado nas amostras (HUGHES et al., 2001). Os valores próximos observados podem estar relacionados à utilização da mesma fonte de inóculo em ambas as fases (lodo UASB oriundo do tratamento termofílico de vinhaça de cana-deaçúcar), bem como ao ajuste das condições mais favoráveis a cada etapa.

Tabela 5.29. Índices ecológicos do gene RNAr $16 \mathrm{~S}$ para as fases I e II do ensaio acidogênico e metanogênico de resíduo sólido de citros.

\begin{tabular}{|c|c|c|}
\hline & & \\
\hline & FASE I & FASE II \\
\hline \multicolumn{3}{|c|}{ Parâmetros sequenciamento (16S RNAr) } \\
\hline Cobertura $(\%)$ & 99,6 & 99,9 \\
\hline Número total de sequências & 35.485 & 33.761 \\
\hline Comprimento médio & 418 & 422 \\
\hline $\mathrm{GC}(\%)$ & 55,12 & 54,42 \\
\hline Total de OTUs & 600 & 646 \\
\hline \multicolumn{3}{|c|}{ Índices ecológicos } \\
\hline Shannon-Wiener $\left(\mathrm{H}^{\prime}\right)$ & 3,9 & 2,9 \\
\hline Simpson & 0,8 & 0,8 \\
\hline Chao-1 & 643,1 & 643,4 \\
\hline
\end{tabular}


Figura 5.58. Curvas de rarefação obtidas para as sequencias obtidas após sequenciamento massivo do gene RNAr 16S via plataforma Illumina HiSeq para as amostras das fases I e II.

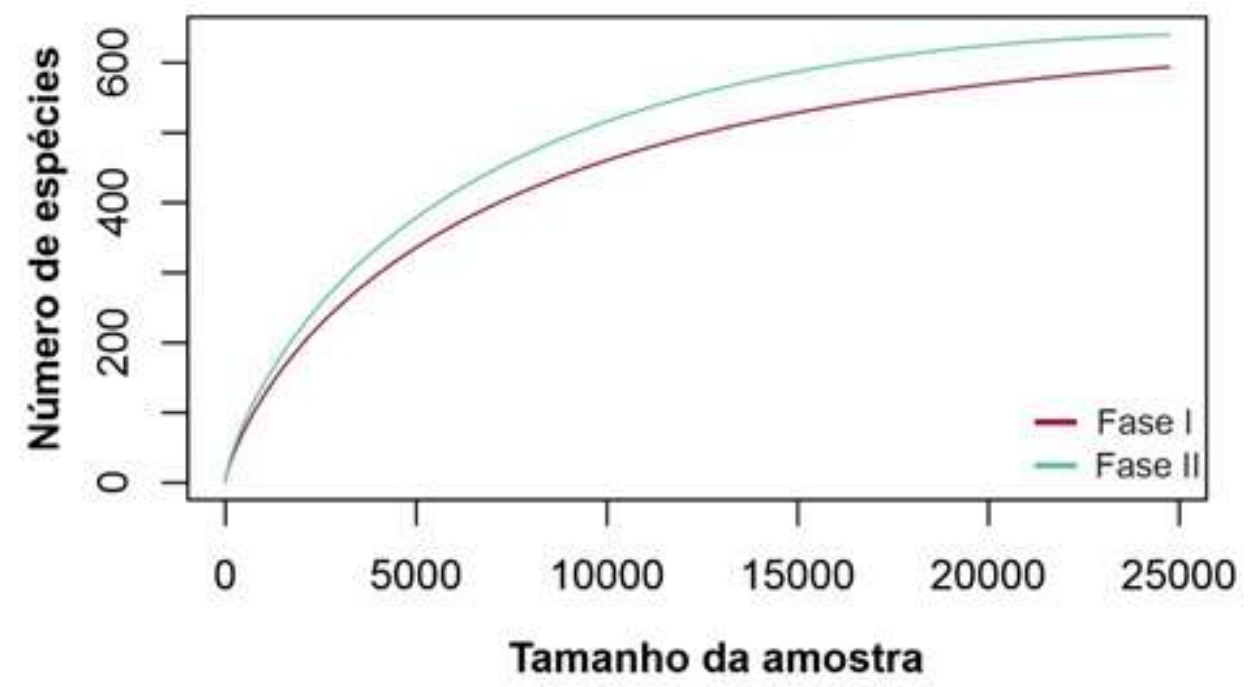

Os filos identificados em maior abundância relativa, tanto na Fase I, quanto na Fase II para o Domínio Bacteria foram Proteobacteria (47,83 e 42,34\%) Firmicutes (40,55 e $48,32 \%)$, Thermotogae (3,04 e 0,72\%) e Acidobacteria (2,45 e 2,15\%), respectivamente. Outros filos observados em menores proporções $(\leq 1,5 \%)$ foram Bacteroidetes, Nitrospirae, Chloroflexi, Spirochaetes, Tenericutes, entre outros. A maior abundância de Proteobacteria e Firmicutes pode ser relacionada aos principais metabólitos observados na Fase I, na qual houve acúmulo de HAc (1340 mg.L $\left.\mathrm{L}^{-1}\right)$ e $\mathrm{HBu}\left(723 \mathrm{mg} . \mathrm{L}^{-1}\right)$, os principais metabólitos produzidos por bactérias pertencentes a estes filos (VOS et al., 2009).

Os principais gêneros identificados na Fase I (Figura 5.59), etapa na qual ocorreu a fermentação dos resíduos sólidos de citros e consequente produção de compostos orgânicos e $\mathrm{H}_{2}$, foram Escherichia (34,39\%), Clostridium (29,83\%), Enterobacter (8,52\%), Trichococcus $(4,18 \%)$ e Coprothermobacter $(1,89 \%)$. Entre os gêneros mencionados, vale ressaltar a importância de Clostridium nas diferentes etapas que envolvem a obtenção de hidrogênio a partir da biodegradação de resíduos sólidos de citros, uma vez que diversas espécies deste gênero são conhecidamente celulolíticas, além de produtoras de compostos orgânicos e $\mathrm{H}_{2}$ via acetogênese. Rabelo et al. (2018a) e Villa-Montoya et al. (2019) observaram maior abundância relativa de Clostridium em reatores anaeróbios aplicados a fermentação mesofílica de bagaço de cana-de-açúcar e resíduos do processamento de café, respectivamente. 
A identificação de Escherichia e Enterobacter na Fase I pode ser justificada devido a sua afinidade com temperaturas mesofílicas e pH neutro (BRENNER; KRIEG; STALEY, 2005), além da resistência ao limoneno, um dos principais inibidores dos resíduos de citros (CALABRÒ et al., 2016). Estas bactérias do filo Proteobacteria podem ter contribuído para o acúmulo de HAc na Fase I, uma vez que este ácido é o principal metabólito produzido por estes organismos (VOS et al., 2009).

O gênero Coprothermobacter está relacionado com a origem do inóculo utilizado, uma vez que possuem afinidade com temperaturas termofílicas (GAGLIANO et al., 2015) utilizadas na operação do reator UASB aplicado ao processamento de vinhaça de cana-deaçúcar $\left(55^{\circ} \mathrm{C}\right)$. Além disso, o gênero mencionado foi identificado por Soares et al. (2017) com abundância relativa de 41,73\% em inóculo de mesma origem. Trichococcus são comuns em lodos de esgoto, sendo que sua temperatura ótima é entre $25-30{ }^{\circ} \mathrm{C}$ (PARSHINA et al., 2019), temperatura de operação da Fase I.

$\mathrm{Na}$ Fase II, os principais gêneros do domínio Bacteria identificados foram Comamonas (36,54\%), Clostridium (6,30\%), Coprothermobacter (4,0\%), Tissierella (1,89\%), Escherichia (1,81\%), Sporosarcina (1,40\%), Anaerobaculum (1,36\%), Lysinibacillus (1,18\%) Paraclostridium (1,14\%) e Enterococcus (0,93\%). Os organismos do gênero Comamonas são aeróbios e já foram relatados em reatores anaeróbios (DELFORNO et al., 2017, 2019). Além disso, Comamonas pode estar relacionado à hidrólise de HAc (WILLEMS; GILLIS, 2015).

Entre os gêneros de bactérias identificado na Fase II, destaca-se Clostridium (6,30\%), Eubacterium (0,00089\%) e Thermoanaerobacter (0,000162\%), que podem ser associados à homoacetogênese, processo no qual o $\mathrm{H}_{2}$ é consumido e convertido em ácido acético. Uma vez que não houve aumento na concentração deste ácido ao longo do período de operação, é possível inferir que este processo não foi predominante nos ensaios realizados. Além disso, a cinética de crescimento dos organismos homoacetogênicos é inferior a das arqueias hidrogenotróficas (BRAGA et al., 2018). 
Figura 5.59. Ideograma circular "Circos" representando os gêneros de bactérias identificados nas fases I e II.

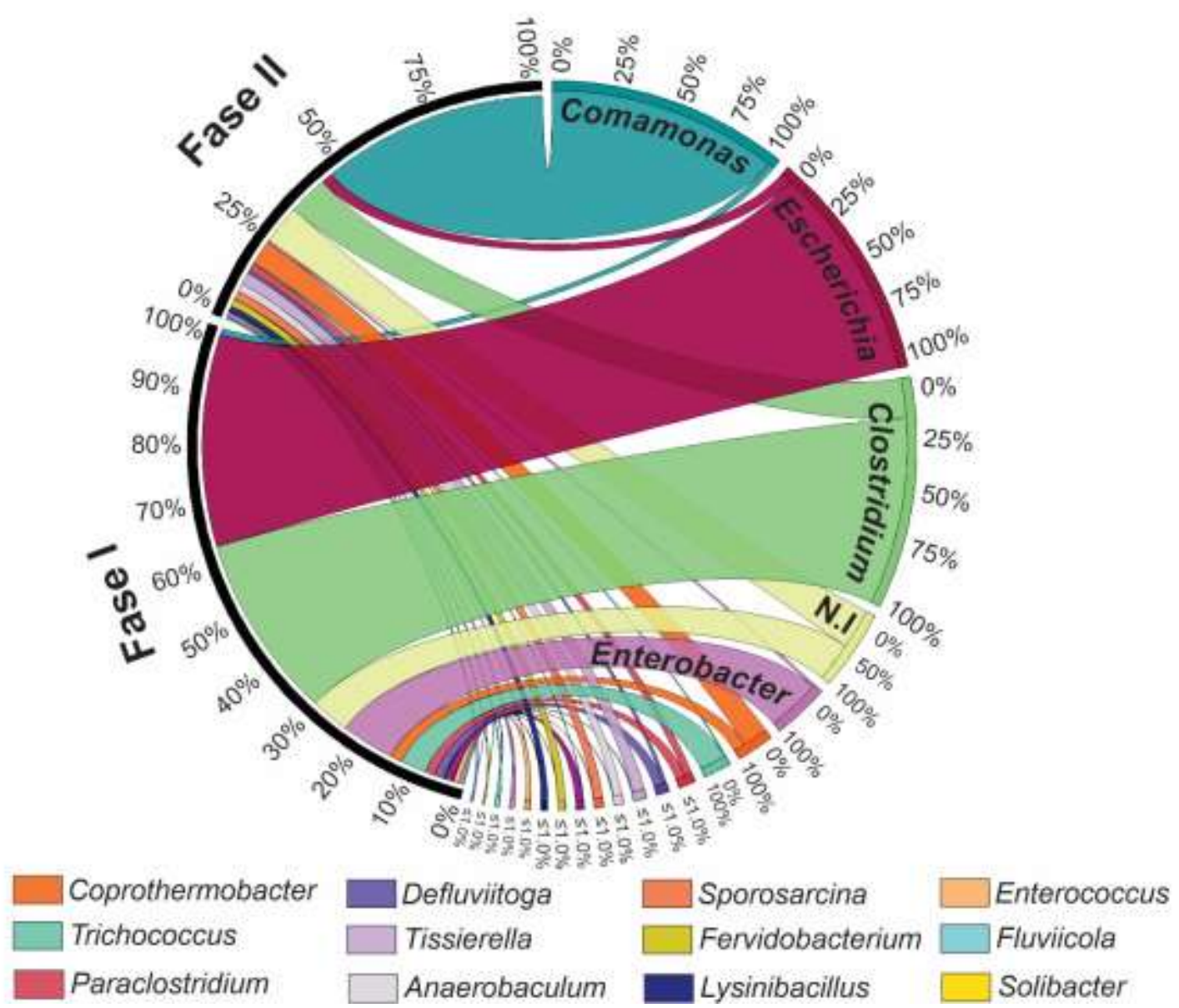

Não se observou produção de metano ao longo do período de operação da Fase I, entretanto, arqueias metanogênicas dos gêneros Methanosarcina, Methanothermobacter e Methanoculleus foram identificadas com abundância relativa de 0,16\%,0,08\% e 0,02\%, respectivamente. A inibição da metanogênese na Fase I pode estar relacionada com a concentração de limoneno, um dos principais inibidores presentes em resíduos sólidos de citros, uma vez que sua concentração observada foi de $0,58 \mathrm{mg} \cdot \mathrm{kg}^{-1}$, enquanto na Fase II este composto não foi observado.

Maior abundância relativa de arqueias foi observada na Fase II (Figura 5.60), uma vez que nesta etapa objetivou-se à obtenção de $\mathrm{CH}_{4}$ a partir do fração líquida acidificada da Fase I. Os gêneros metanogênicos (filo Euryarchaeota) identificados foram Methanoplasma (0,26\%), Methanoculleus (0,25\%), Methanosarcina (0,20\%), Methanomassiliicoccus (0,15\%) e Methanothermobacter (0,083\%). 
Arqueias do gênero Methanoculleus podem produzir $\mathrm{CH}_{4}$ a partir de $\mathrm{CO}_{2}$ e $\mathrm{H}_{2}$. Apesar de não serem capazes de utilizar ácido acético, estes organismos são mais tolerantes às elevadas concentrações de compostos orgânicos, como HAc e HPr, quando comparadas às outras arqueias metanogênicas (JIANG et al., 2019). De acordo com Zhang et al. (2017), aproximadamente $30 \%$ do metano formado em reatores anaeróbios provém da via hidrogenotrófica, o que contribui para a manutenção da pressão parcial do reator e estabelecimento de bactérias sintróficas.

Exceto pelo gênero Methanosarcina, que pode ser versátil e apresentar metabolismo acetoclástico, os demais gêneros identificados podem ser considerados hidrogenotróficos (LANG et al., 2015). Desta forma, a identificação destas arqueias hidrogenotróficas pode estar relacionada ao consumo de $\mathrm{H}_{2}$ no início do período de operação da Fase II. Apesar de apresentar metabolismo preferencialmente metilotrófico, Methanoplasma e Methanomassiliicoccus são associados à metanogênese hidrogenotrófica (KOO; YULISA; HWANG, 2019), possivelmente devido à sua dependência de $\mathrm{H}_{2}$ para regeneração da coenzima M no metabolismo metilotrófico, por meio da redução do $\mathrm{CO}_{2}(\mathrm{OZBAYRAM}$ et al., 2018).

Koo, Yulisa e Hwang (2019) relataram favorecimento da via hidrogenotrófica em reatores anaeróbios operados com resíduos de alimentos como substrato e resíduo animal como inóculo. O gênero identificado em maior abundância relativa foi Methanoculleus, além de Methanoplasma e Methanomassiliicoccus. Em Ghosh et al. (2020), os autores realizaram a caracterização metataxonômica do consórcio microbiano envolvido na biodegradação de resíduo sólido municipal e lodo de esgoto. Os autores verificaram que Methanosarcina foi o gênero mais abundante, provavelmente devido à sua maior tolerância às elevadas concentrações de HAc produzidas na fase acidogênica e variações no $\mathrm{pH}$. Na presente pesquisa, o $\mathrm{pH}$ foi mantido próximo à neutralidade na Fase II $(\sim 7,0)$ e as concentrações iniciais de HAc foram de (1.340 mg.L $\left.\mathrm{L}^{-1}\right)$.

Methanosarcina é um gênero multifuncional, capaz de produzir metano a partir de diferentes vias metabólicas (acetoclástica, hidrogenotrófica e metilotrófica). Desta forma, a identificação dessas arqueias em reatores anaeróbios pode favorecer a obtenção de $\mathrm{H}_{2}$ devido ao consumo de metabólitos intermediários da digestão anaeróbia, como os ácidos acético e butírico, e contribuindo para a manutenção do pH do reator (NESHAT et al., 2017; ZHANG et al., 2017). 
Figura 5.60. Ideograma circular "Circos" representando os gêneros de arqueias nas fases I e II.

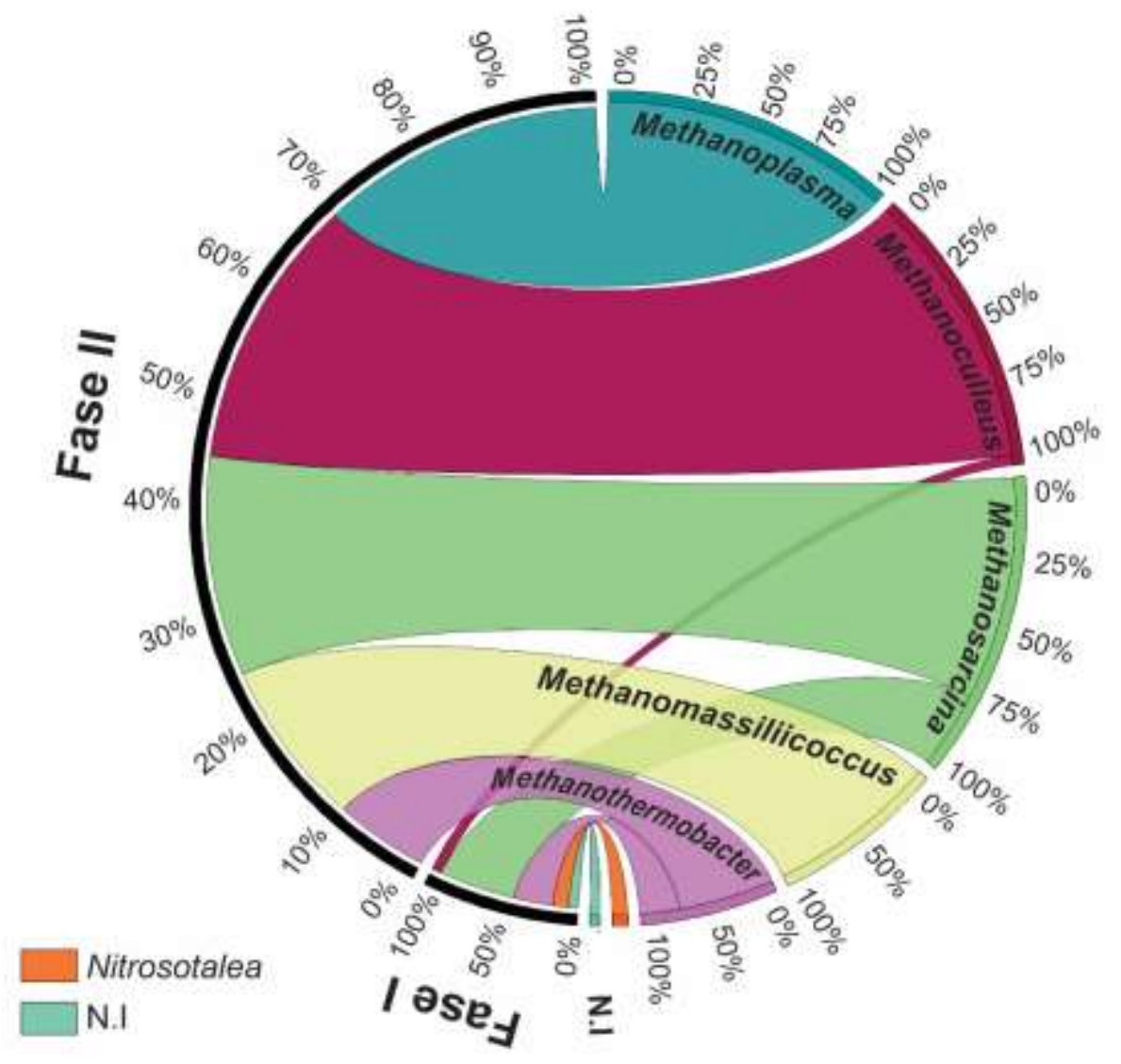

\subsubsection{Caracterização funcional}

Por meio da predição dos perfis funcionais dos dados de metabarcoding (16S RNAr), foi possível obter o total de 7.035 diferentes objetos KO para a Fase I e 6.917 KO para a Fase II. A quantificação de cada KO por amostra foi realizada conforme descrito em Iwai et al. (2016), totalizando 6.844.289 na Fase I e 22.234.364 na Fase II. A partir da observação entre o número de correspondências entre os $\mathrm{KO}$ obtidos foi possível prever as principais vias metabólicas descritas na plataforma Kyoto Encyclopedia of Genes and Genomes (KEGG) para a categoria "Metabolismo" (24,75 e 22,59\%, respectivamente). As vias de Processamento de Informação Genética, Processamento de informações ambientais, Processos Celulares, Sistemas Organizacionais e Doenças Humanas não foram consideradas, uma vez que não são diretamente relevantes para o tema de estudo.

De acordo com a Figura 5.61, nota-se que as principais correspondências se referem às vias de metabolismo de carboidratos (12,70 e 11,48\%) e energia (4,66 e 4,71\%). Em relação ao metabolismo de carboidratos, as principais subcategorias observadas foram 
metabolismo de frutose e manose (1,61 e 1,59\%), metabolismo de piruvato (1,60 e 1,58\%), glicólise/gliconeogênese (1,57\%), metabolismo de propanoato (1,59 e 0,47\%) e butanoato $(1,52$ e $1,51 \%)$ e metabolismo de amido e sacarose (0,49 e 0,45\%), para Fase I e Fase II, respectivamente. Para o metabolismo energético, destaca-se como principal subcategoria o metabolismo de metano, no qual foram observadas 2,10\% das correspondências para a Fase I e 2,20\% para a Fase II.

$\mathrm{Na}$ Figura 5.62 é possível observar os $\mathrm{KO}$ mais abundantes que puderam ser inferidos para as amostras analisadas (Fase I e Fase II). Na Fase I, os KO mais abundantes foram K14230 (0,06\%), K14230 (0,06\%) e K14225, referentes à Biossíntese de aminoacilRNAt $(0,05 \%)$, K14255- 4-amino-anidrotetraciclina N4-metiltransferase $(0,06 \%)$ e K03088- Fator de RNA polimerase sigma-70 (0,05\%).

Os KO mais abundantes na Fase II foram K03088- Fator de RNA polimerase sigma70 (0,44\%), K01999- proteína de ligação ao substrato do sistema de transporte de aminoácidos de cadeia ramificada $(0,39 \%)$, K02014- proteína receptora da membrana externa do complexo de ferro (0,34\%), K01997 e K01998- proteína do sistema de transporte de aminoácidos de cadeia ramificada permease $(0,26 \%)$. Tanto, os KO mencionados, quanto os demais KO observados em maior abundância nas Fases I e II estão majoritariamente relacionados às subcategorias do Processamento de Informação Genética, como tradução e transcrição e transporte de membrana. 
Figura 5.61. Principais vias metabólicas inferidas para os diferentes níveis KEGG. Os percentuais apresentados foram calculados com base no número de correspondências para cada objeto KO observados para cada amostra (Fase I e Fase II).

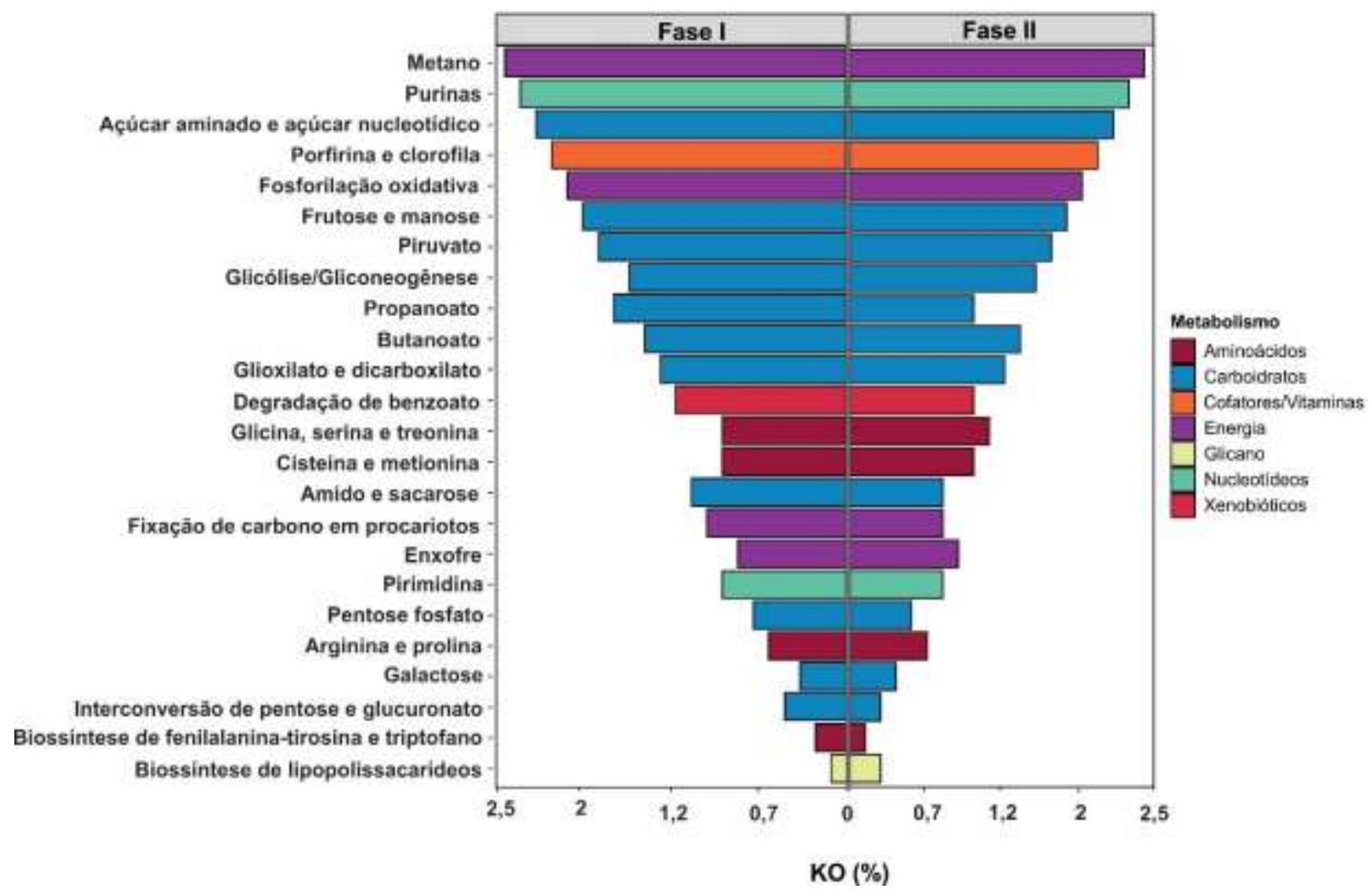

Encontram-se resumidas na Figura 5.63 os principais KO envolvidos na Fase I, especialmente nas etapas de hidrólise, glicólise, acidogênese e acetogênese. Nota-se que maiores proporções destes KO foram relacionados à Fase I, quando comparados à Fase II, especialmente para componente EIIB e EIIA do sistema PTS de celobiose K02760 (0,03\%) e K02759 (0,02\%) [EC:2.7.1.196 2.7.1.205], envolvidos no metabolismo de amido e sacarose, na conversão de celobiose em celobiose 6-fosfato. Entre os principais microrganismos relacionados à síntese desta enzima estão as bactérias do gênero Escherichia (KEYHANI et al., 2000), observadas em abundância relativa de 34,39\% na Fase I. Da mesma forma, a 6-fosfo- $\beta$-glicosidase K01223 [EC:3.2.1.86] também esta relacionada ao metabolismo de amido e sacarose, além da glicólise. Esta hidrolase é responsável pela conversão da celobiose 6-fosfato em D-glicose. Escherichia é o principal gênero observado na Fase I e relacionado à síntese desta enzima. 
Figura 5.62. KO mais abundantes inferidos para as amostras da Fase I e Fase II, relacionadas às etapas de hidrólise, acidogênese, acetogênese e concomitante obtenção de $\mathrm{H}_{2}$. Os percentuais foram calculados com base no número total de $\mathrm{KO}$ em cada amostra.

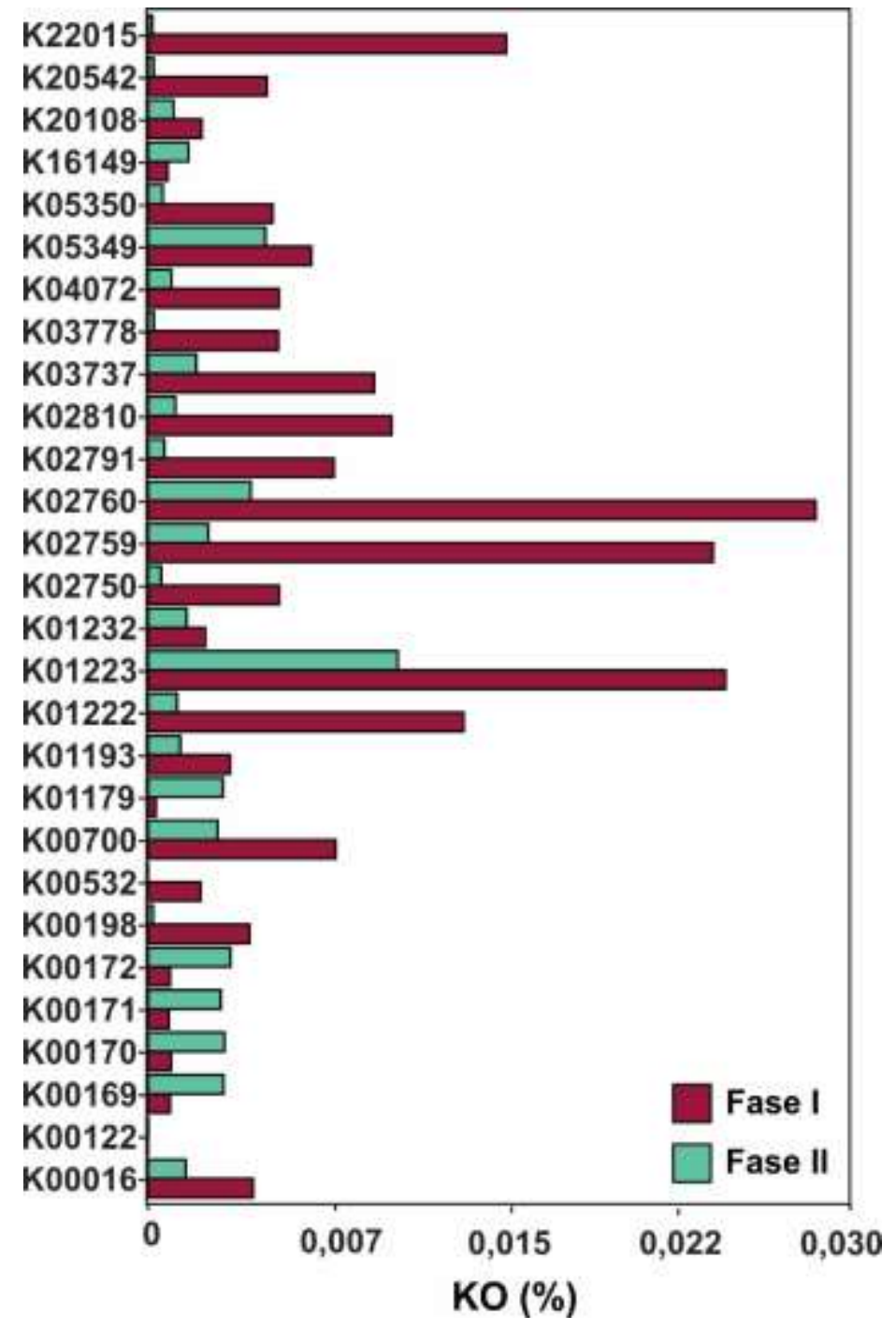

Foram observadas em menores proporções $\mathrm{KO}$ relacionados à hidrólise (endoglicanase, K01179 [EC:3.2.1.4] e componente EIIA e EIIB do sistema PTS de celobiose, K02759 e K02760 [EC: 2.7.1.205]), glicólise (fosfoglicomutase, K01835 [EC: 5.4.2.2], componentes do sistema PTS de glicose, K02778 [EC: 2.7.1.199]), acidogênese e acetogênese (acetil-CoA sinthetase e acetato/butirato ligase, K01895 e K01913 [EC: 6.2.1.1]). Entre as principais vias nas quais estas enzimas estão envolvidas, estão o metabolismo de carboidratos, metabolismo de piruvato e glicólise. Além disso, vale ressaltar a presença de $\mathrm{KO}$ relacionados à obtenção de hidrogênio, como piruvato sintase (K00169, K00170, K00171 [EC: 1.2.7.1]) e álcool desidrogenase (K04072, K13954, K00001 [EC: 1.1.1.1]). 
Estima-se que os gêneros Clostridium, Escherichia (34,5\%) e Paraclostridium $(1,52 \%)$ estejam intimamente relacionados às etapas de hidrólise e glicólise na Fase I, enquanto na acidogênese, além dos gêneros mencionados também estariam envolvidos os gêneros Enterobacter (8,55\%) e Defluviitoga (1,57\%).

Foram observadas KO relacionados à degradação de lignina e limoneno, ambos presentes no resíduo sólido de citros. A hidrolase de limoneno-1,2-epóxido K10533 [EC: 3.3.2.8] e a limoneno 1,2- monoxigenase K14733 foram observadas na Fase I (0,000012 e 0,00004\%, respectivamente). A vanilil-álcool oxidase (K20153, [EC 1.1.3.38]) está relacionada às atividades auxiliares para degradação da lignina, sendo que este grupo de enzimas pode catalisar a conversão de compostos fenólicos com cadeias laterais do anel aromático, e foram observados em proporções de 0,00005\% na Fase I.

Figura 5.63. Principais KO inferidos e relacionados à metanogênese. Os percentuais foram calculados com base no número total de KO em cada amostra (Fase I e Fase II).

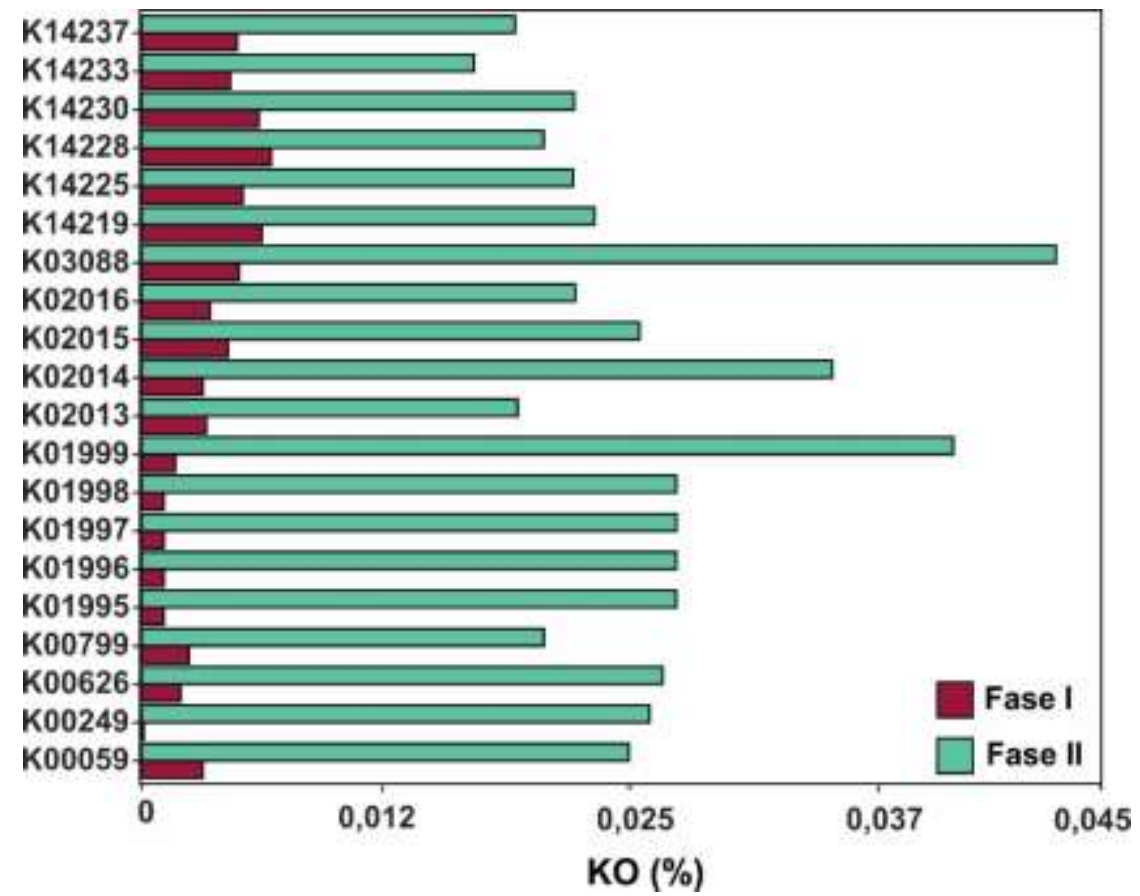

Os principais $\mathrm{KO}$ relacionados à metanogênese foram filtrados de acordo com Macedo et al. (2020), e encontram-se resumidos na Figura 5.64. Como esperado, maiores proporções de todos os $\mathrm{KO}$ envolvidos em diferentes etapas da obtenção de metano foram observados em maiores proporções na Fase II quando comparadas à Fase I. O KO observado em maior proporção foi ligase K01895 (0,04\%) acetil-CoA sintetase [EC:6.2.1.1], enzima envolvida na conversão de acetato em acetil-CoA (Equação 5.13) na 
via acetogênica, sendo o gênero Methanosarcina a principal arqueia associada à esta reação (BARNHART et al., 2015).

Figura 5.64. Principais KO inferidos e relacionados à hidrólise, glicólise, acidogênese, acetogênese e obtenção de $\mathrm{H}_{2}$. Os percentuais foram calculados com base no número total de $\mathrm{KO}$ em cada amostra.

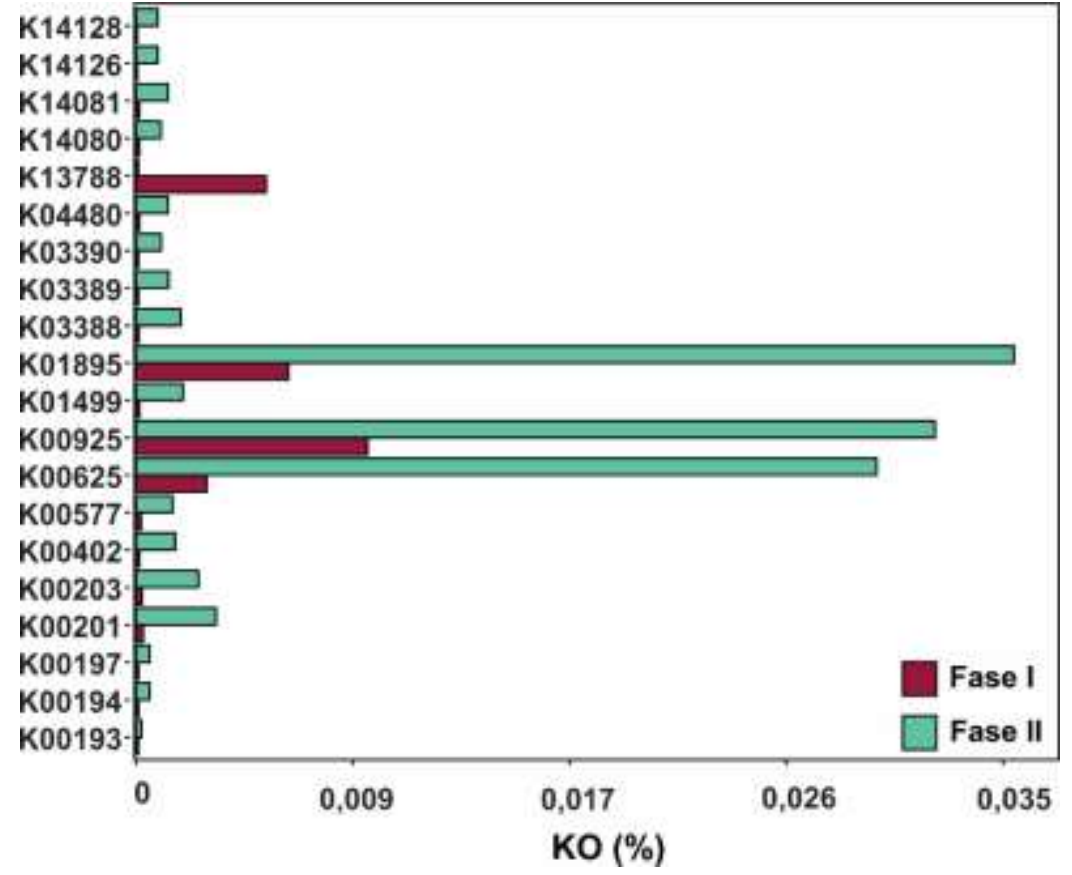

O segundo KO observado em maior abundância na Fase II (0,03\%) foi K00925 [EC: 2.7.2.1], relacionado a uma transferase com atividade acetato quinase. Este KO também foi observado na Fase I $(0,01 \%)$. A acetato quinase está envolvida na metanogênese devido ao seu papel fundamental na conversão de acetato a acetil-CoA, entretanto, ao contrário da acetil-CoA sintetase, que pode ser sintetizada por diversos organismos, apenas o gênero Methanosarcina é capaz de assimilar o acetato a partir da atividade da acetato quinase (BARNHART et al., 2015). A fosfato acetiltransferase K00625 [EC:2.3.1.8] foi observada na Fase II e Fase I na proporção de 0,03\% e 0,003\%, respectivamente. Esta transferase relacionada à regeneração da coenzima A pode ser relacionada, tanto ao metabolismo de Clostridium, quanto Methanosarcina, sendo importante para o metabolismo do acetato (NÉMETI; GREGUS, 2009).

Apenas a fosfato acetiltransferase K13788 [EC:2.3.1.8] foi observada em maiores proporções na Fase I em comparação à Fase II (0,01\% e 0,0001\%, respectivamente). Esta enzima está relacionada com a fermentação de acetato, na reação reversível entre síntese de acetil-CoA e regeneração da coenzima A (Equação 5.14), tanto no metabolismo de metano (acetoclástico), quanto no metabolismo de piruvato. Os principais gêneros associados à síntese desta enzima são Escherichia e Clostridium (NÉMETI; GREGUS, 
2009; CAMPOS-BERMUDEZ et al., 2010), identificados em abundância relativa de 34,39 e $29,83 \%$ na Fase I, respectivamente.

$$
\text { AcetilCoA }+ \text { fosfato } \leftrightarrow \text { CoA }+ \text { acetil fosfato }
$$

Entre os $\mathrm{KO}$ relacionados à metanogênese e observados em menores proporções, destaca-se a subunidade gama de metil-coenzima M redutase K00402 [EC: 2.8.4.1], observada em 0,002\% na Fase II e 0,0001\% na Fase I. Esta transferase é responsável pela catálise da etapa final da metanogênese, na qual ocorre efetivamente a obtenção biológica de metano. Diversos gêneros de arqueias metanogênicas são associados à esta enzima, sendo encontrada em alguns dos gêneros observados na Fase II, como Methanosarcina $(0,20 \%)$ e Methanothermobacter (0,083\%) (WREDE et al., 2013; GRÄWERT et al., 2014; WAGNER et al., 2016).

O K00193 [EC: 2.3.1.169] esta relacionado à síntese de proteína corrinóide Fe-S de metil-Co(III) $\left(\mathrm{CH}_{3}-\mathrm{CO}(\mathrm{III}) \mathrm{FeSP}\right)$ a partir da proteína $\mathrm{Co}(\mathrm{I})$ corrinóide $\mathrm{Fe}-\mathrm{S}$ e Acetil-CoA. A $\mathrm{CH}_{3}-\mathrm{CO}(\mathrm{III}) \mathrm{FeSP}$ é convertida a proteína $\mathrm{Co}(\mathrm{I})$ corrinóide $\mathrm{Fe}-\mathrm{S}$ e 5- metil-tetrahidrossarcinapterina (5-Metil-H4SPT) pelas enzimas relacionadas à acetil-CoA decarbonilase/sintase [K00194 e K00197, EC: 2.1.1.245].

Apesar dos $\mathrm{KO}$ observados em maior abundância estarem relacionados ao metabolismo acetoclástico, destaca-se a importância de KO observados em menores proporções e envolvidas na via metanogênica hidrogenotrófica. Entre estes, destaca-se o K14128 [EC:1.12.99.-], referente à atividade oxidorredutase da subunidade de hidrogenase não redutora de F420, que está interligada com a metanogênese hidrogenotrófica na etapa de redução da coenzima F420 utilizando $\mathrm{H}_{2}$.

Encontra-se resumida na Figura 5.65 possíveis vias metabólicas e gêneros envolvidos no processo. Com base nos resultados apresentados, é possível inferir que a principal via envolvida na obtenção de metano a partir da fração líquida acidificada após a fermentação de resíduos sólidos de citros é a via acetogênica, uma vez que maior proporção de genes que codificam enzimas envolvidas nesta via foram inferidos na Fase II, além de maior abundância relativa de arqueias conhecidamente acetoclásticas, como Methanosarcina $(0,20 \%)$. 
Figura 5.65. Possíveis vias de conversão de resíduos sólidos de citros à $\mathrm{CH}_{4}$ em reatores em batelada operados em duas diferentes fases, sendo a Fase I referente às etapas de hidrólise, glicólise, acidogênese e acetogênese, e a Fase II majoritariamente referente à metanogênese. Os colchetes representam os números EC (Enzyme Commission Numbers) referentes aos KOs inferidos nas amostras. Os valores entre parenteses referem-se à abundância relativa dos principais gêneros observados nas fases I e II.

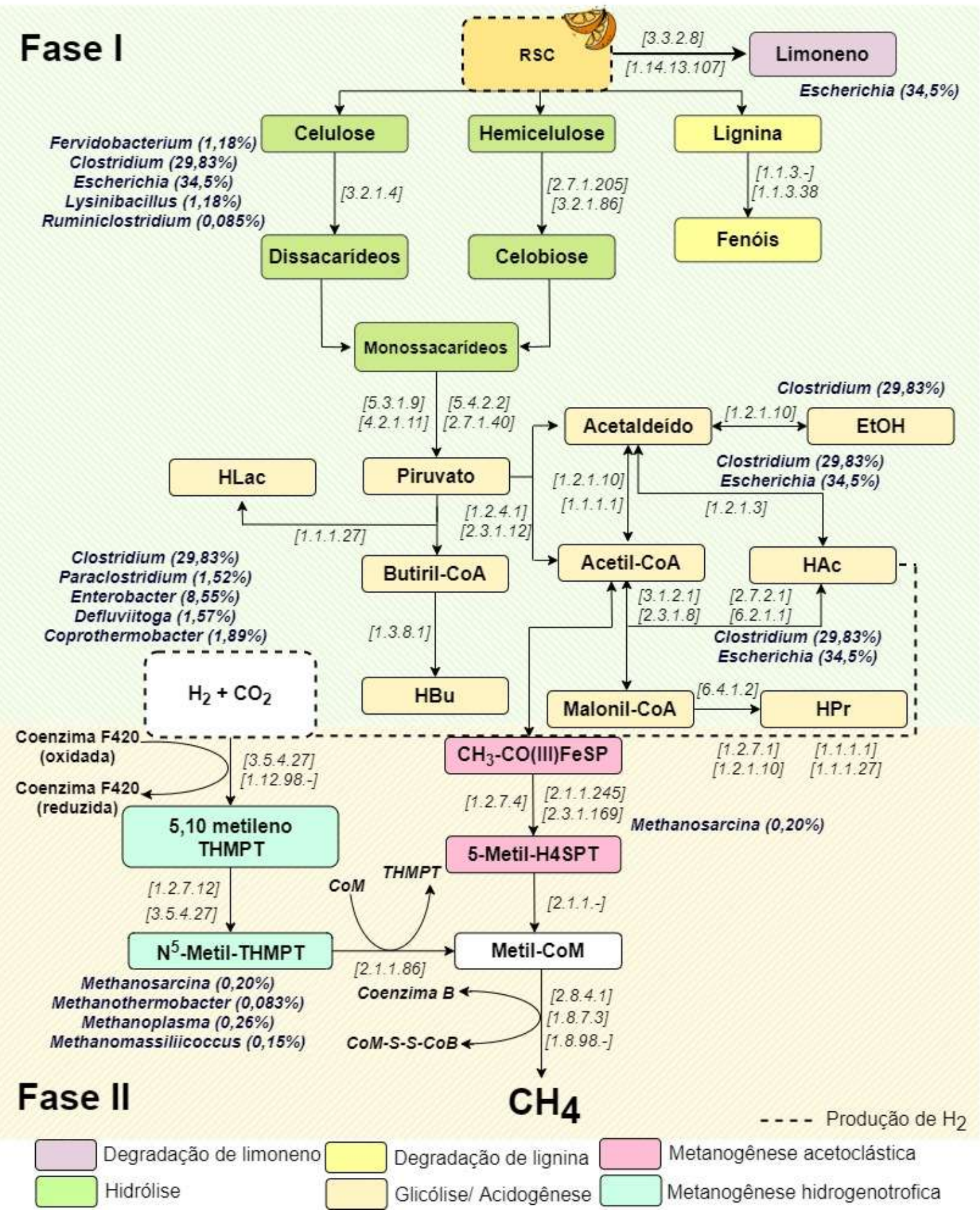

Fonte: Elaboração própria. 


\subsection{DETERMINAÇÃO DO TEOR DE LIMONENO VIA GC-MS}

\subsubsection{Equipamentos e condições}

O teor de limoneno foi determinado por Cromatografia a Gás modelo 7890B, utilizando o software MassHunter acoplado ao Espectrômetro de Massa (GC-MS Agilent), modelo MS 5977A. Foram injtados $250 \mu \mathrm{L}$ de amostra do headspace e utilizando os parâmetros resumidos na Tabela 5.30. A condição cromatográfica foi definida por análise de resolução de pico.

Tabela 5.30. Especificações de operação do GC-MS.

\begin{tabular}{cc}
\hline & Cromatógrafo de gás \\
Coluna analítica & Agilent HP 5 MS $(30 \mathrm{~m} \times 0,25 \mathrm{~mm} \times 0,25 \mu \mathrm{m})$ \\
Injetor & Split: $10: 1$ \\
$230{ }^{\circ} \mathrm{C}$ & $\mathrm{He}$ \\
Temperatura da entrada & $250 \mu \mathrm{L}$ \\
Gás de arraste & Injetor automático \\
Volume de injeção & PAL RSI 85 \\
Modelo & $100{ }^{\circ} \mathrm{C}$ \\
Temperatura de incubação & $10 \mathrm{~min}$ \\
Tempo de incubação & Programa de Forno \\
Temperatura & $40{ }^{\circ} \mathrm{C}$ \\
Tempo de retenção & $3 \mathrm{~min}$ \\
Taxa & $10{ }^{\circ} \mathrm{C}$ \\
Temperatura & $100{ }^{\circ} \mathrm{C}$ \\
Taxa & $60{ }^{\circ} \mathrm{C}$ \\
Temperatura & $220^{\circ} \mathrm{C}$ \\
\hline & Espectrômetro de Massa \\
Temperatura auxiliar & $240{ }^{\circ} \mathrm{C}$ \\
Faixa de massa & $\mathrm{m} / \mathrm{z} 50 \mathrm{a} 550$ \\
\hline
\end{tabular}

Fonte: Elaboração própria.

\subsubsection{Curva de calibração e validação de parâmetros}

O método foi considerado linear para a faixa de concentração estudada (3 a 20 mg.L

${ }^{1}$ de limoneno). Em relação a curva de calibração, obteve-se boa linearidade, uma vez que o coeficiente de correlação $\left(\mathrm{R}^{2}\right)$ foi de 0,979 (Figura 5.66). Os desvios padrão observados para a curva de calibração foram entre 0,5 e $1,8 \mathrm{mg} . \mathrm{L}^{-1}$. 
Figura 5.66. Curva de calibração do limoneno para 3,0; 6,0; 9,0; 12,0;15,0;18,0 e 20,0 mg.L de limoneno.

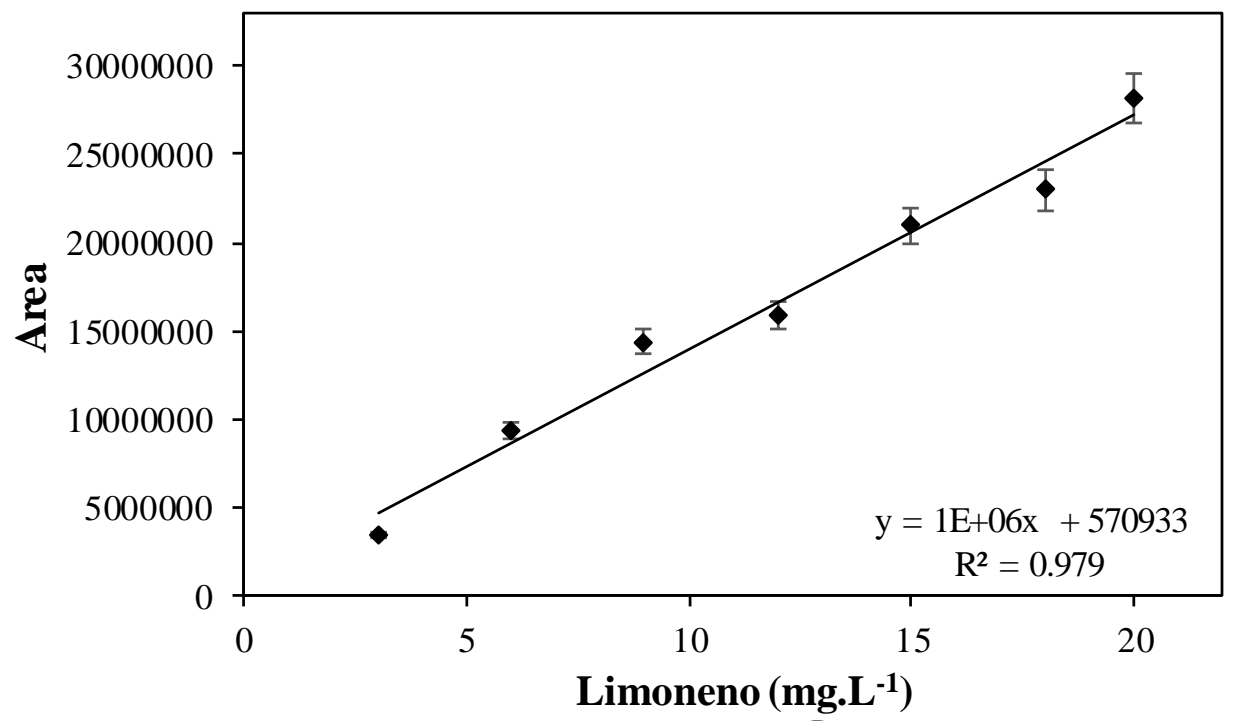

A área do pico correspondente ao limoneno foi determinada por cromatograma e análise em espectrometro de massa de uma solução padrão de concentração conhecida de limoneno. Na Figura 5.67 A, é possível observar o cromatograma obtido para o padrão com $15 \mathrm{mg} . \mathrm{L}^{-1}$ de limoneno, que corresponde a $15,3 \mathrm{mg} . \mathrm{L}^{-1}$ de limoneno de acordo com a curva de calibração. Na Figura 5.67 B, é possível observar o cromatograma para ensaios com 17 mg. $\mathrm{L}^{-1}$ de limoneno. Além disso, o resultado pode ser confirmado por meio de comparações com a base de dados do Instituto Nacional de Padrões e Tecnologia (NIST).

Por meio da precisão instrumental estimada em 0,1 (CV\%), LD e LQ (1,7 e 4,2 $\mathrm{mg} . \mathrm{L}^{-1}$, respectivamente) pode-se inferir sobre a confiabilidade do método desenvolvido. O valor de F tabulado, obtido via ANOVA, foi de 2,6, enquanto o valor de F calculado foi de 233,51. Desta forma, considera-se que os valores calculados superiores aos valores tabelados são evidência da linearidade do método, ao nível de significância de 95\%. Os parâmetros de validação avaliados estão de acordo com a Resolução-Re n. 899 (ANVISA, 2003), bem como com o Relatório Técnico da IUPAC (THOMPSON; ELLISON; WOOD, 2002). 
Figura 5.67. Cromatograma típico de solução padrão de limoneno (15 mg. $\left.\mathrm{L}^{-1}\right)$ (A) e cromatograma obtido para ensaios com $17 \mathrm{mg} . \mathrm{L}^{-1}$ de limoneno (B).
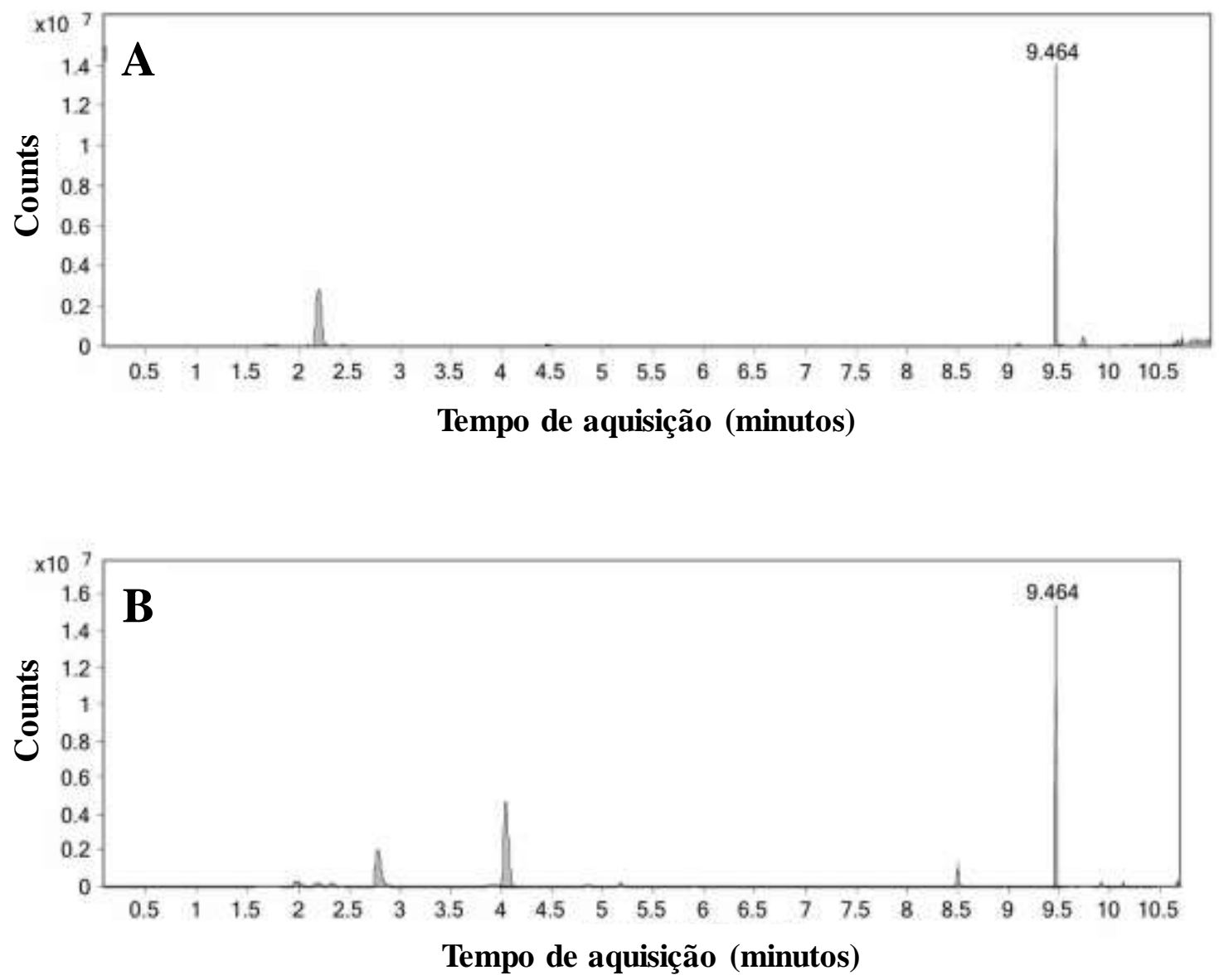

Em comparação com Davidowski e DiMarco (2009), o método desenvolvido no presente estudo é vantajoso em relação à temperatura do injetor do cromatógrafo gasoso $\left(230{ }^{\circ} \mathrm{C}\right)$ e à temperatura do programa do forno $\left(40^{\circ} \mathrm{C}\right)$, enquanto no estudo mencionado, a faixa de temperatura para os mesmos parâmetros foi de 250 e $80{ }^{\circ} \mathrm{C}$, respectivamente. Além disso, o método apresentado na presente pesquisa permite a análise de amostras líquidas de reatores anaeróbios, inoculadas com materiais impuros, como lodo de esgoto, enquanto em Davidowski e DiMarco (2009), os autores utilizaram GC-MS para quantificação de limoneno em extrato de laranja.

\subsubsection{Ensaio de adsorção}

A recuperação de limoneno nos ensaios controle (sem lodo de esgoto) foi de $106,1 \pm 13 \%$ do valor teórico (2000 mg. $\left.\mathrm{L}^{-1}\right)$, enquanto nos ensaios com lodo de esgoto, 
$92,3 \pm 0,4 \%$ foi recuperado. No entanto, essa diferença não foi estatisticamente significativa $(\mathrm{p}=0,179)$ para o intervalo de confiança de $95 \%$.

\subsubsection{Aplicabilidade}

O método GC-MS proposto foi aplicado para determinação da concentração de limoneno no início $(\mathrm{pI})$ e final $(\mathrm{pF})$ do processo de fermentação dos reatores anaeróbios em batelada (Figura 5.68). Não houve diferença significativa $(p \geq 0,05)$ entre o conteúdo de limoneno de $\mathrm{pI}$ e pF. Pode-se inferir que não houve degradação significativa do limoneno ao longo do processo de fermentação, bem como não houve adsorção significativa de limoneno no lodo de esgoto usado como inóculo, como observado no ensaio de adsorção. Além disso, pode-se concluir que o método desenvolvido foi eficaz para a determinação da análise de conteúdo de limoneno em reatores anaeróbios.

O equilíbrio de sorção/dessorção entre limoneno e matéria orgânica afeta o processo de degradação desta molécula (CALABRÒ et al., 2016). Em Calabrò et al. (2016), os autores observaram que aproximadamente $76 \%$ do limoneno adicionado foi adsorvido na fase sólida dos resíduos de citros. No entanto, na presente pesquisa, houve $97 \%$ de recuperação do composto adicionado, sem diferença significativa entre o controle (2123 mg. $\left.\mathrm{L}^{-1}\right)$ e os ensaios com lodo de esgoto (1746 mg. $\left.\mathrm{L}^{-1}\right)$. Esta diferença pode ter ocorrido devido à composição do substrato utilizada pelos autores mencionados, uma vez que os resíduos de citros são ricos em lipídeos de cadeia longa, que possuem forte afinidade com o D-limoneno hidrofóbico. 
Figura 5.68. Teor de limoneno inicial (pI) e final (pF) do processo de fermentação de reatores anaeróbios em batelada operados com diferentes concentrações de limoneno (sem adição de limoneno a $2000 \mathrm{mg} . \mathrm{L}^{-1}$ ) por cerca de 160 h. Adsorção (AD) e potencial máximo de concentração de $\mathrm{H}_{2}(P)$.

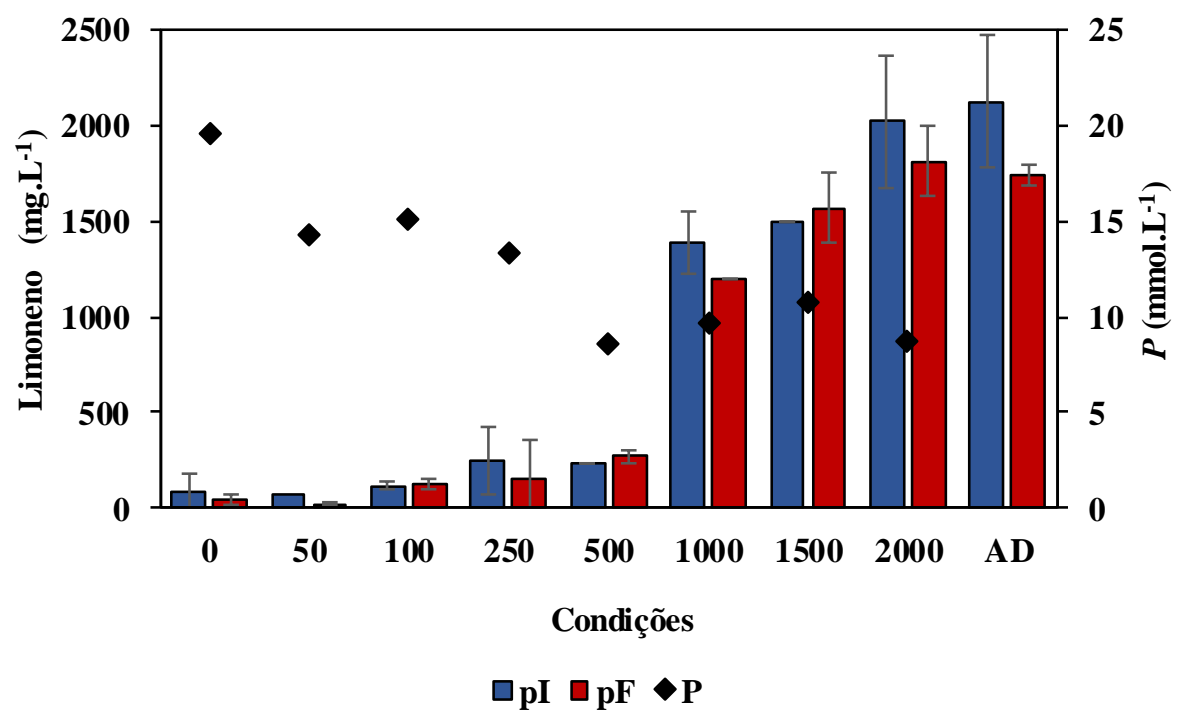

O efeito de diferentes concentrações de limoneno (até $2.000 \mathrm{mg} \cdot \mathrm{L}^{-1}$ ) em ensaios em reatores em batelada e reatores controle sem esse composto foi avaliado em relação ao potencial de concentração de $\mathrm{H}_{2}\left(P \mathrm{mmol} \mathrm{H}_{2} \cdot \mathrm{L}^{-1}\right)$, velocidade específica máxima de obtenção de $\mathrm{H}_{2}\left(R m\right.$ mmol H $\left.\mathrm{H}_{2} \cdot \mathrm{h}^{-1}\right)$ e tempo de início da obtenção de $\mathrm{H}_{2}$ ( $\lambda$ h) (Figura 5.69). A concentração máxima de $\mathrm{H}_{2}$ foi de $19,5 \mathrm{mmol} \mathrm{H}_{2} \cdot \mathrm{L}^{-1}$ nos ensaios controle, enquanto a concentração mínima foi de $8,6 \mathrm{mmol} \mathrm{H} \mathrm{H}_{2} \mathrm{~L}^{-1}$ nos ensaios contendo $2.000 \mathrm{mg} . \mathrm{L}^{-1} \mathrm{de}$ limoneno. Para o intervalo de confiança de $95 \%$, pode-se afirmar que o aumento do limoneno para $50 \mathrm{mg} . \mathrm{L}^{-1}$ e de 50 a $100 \mathrm{mg} . \mathrm{L}^{-1}$ não foi significativo, ou seja, não foi observado efeito inibitório por esse composto. Entretanto, o aumento de 100 para 2.000 mg. $L^{-1}$ causou efeito inibitório significativo $(\mathrm{p} \geq 0,05)$ na obtenção de $\mathrm{H}_{2}$ (Tabela 5.31).

Resultados similares foram observados para a resposta $R m$, ou seja, a adição de 50 mg. $\mathrm{L}^{-1}$ de limoneno não foi significativa $\left(R m=0,5 \mathrm{mmol} \mathrm{H}_{2} \cdot \mathrm{h}^{-1}\right)$, enquanto a adição nos intervalos entre 100 e $2000 \mathrm{mg} . \mathrm{L}^{-1}$ de limoneno ocasionou diminuição de $R m$ em todos os demais ensaios. O Rm máximo observado foi de $1,6 \mathrm{mmol} \mathrm{H}_{2} \cdot \mathrm{h}^{-1}$ nos ensaios controle, enquanto o $R m$ mínimo foi de $0,1 \mathrm{mmol} \mathrm{H} \cdot \mathrm{h}^{-1}$ com $2000 \mathrm{mg} \cdot \mathrm{L}^{-1}$ de limoneno.

Aumento proporcional no tempo de início da obtenção de $\mathrm{H}_{2}(\lambda)$ foi observado proporcionalmente ao aumento das concentrações de limoneno, sendo que o mínimo $\lambda$ foi observado nos ensaios controle $(17,1 \mathrm{~h})$ e o máximo $\lambda(37,9 \mathrm{~h})$ para $2000 \mathrm{mg} . \mathrm{L}^{-1} \mathrm{de}$ limoneno. Entretanto, apenas nos ensaios em que houve aumento de 50 para $100 \mathrm{mg} . \mathrm{L}^{-1} \mathrm{de}$ 
limoneno, houve diferença significativa para $\lambda$, sendo $11,6 \mathrm{~h}$ em $50 \mathrm{mg} . \mathrm{L}^{-1}$ e $10,8 \mathrm{~h}$ em 100 mg.L $\mathrm{L}^{-1}$. Este padrão pode ser explicado com base nos maiores desvios padrão observados para este parâmetro (CALABRÒ et al., 2016).

Figura 5.69. Concentração de $\mathrm{H}_{2}$ nos reatores anaeróbios controle e com diferentes concentrações de limoneno.

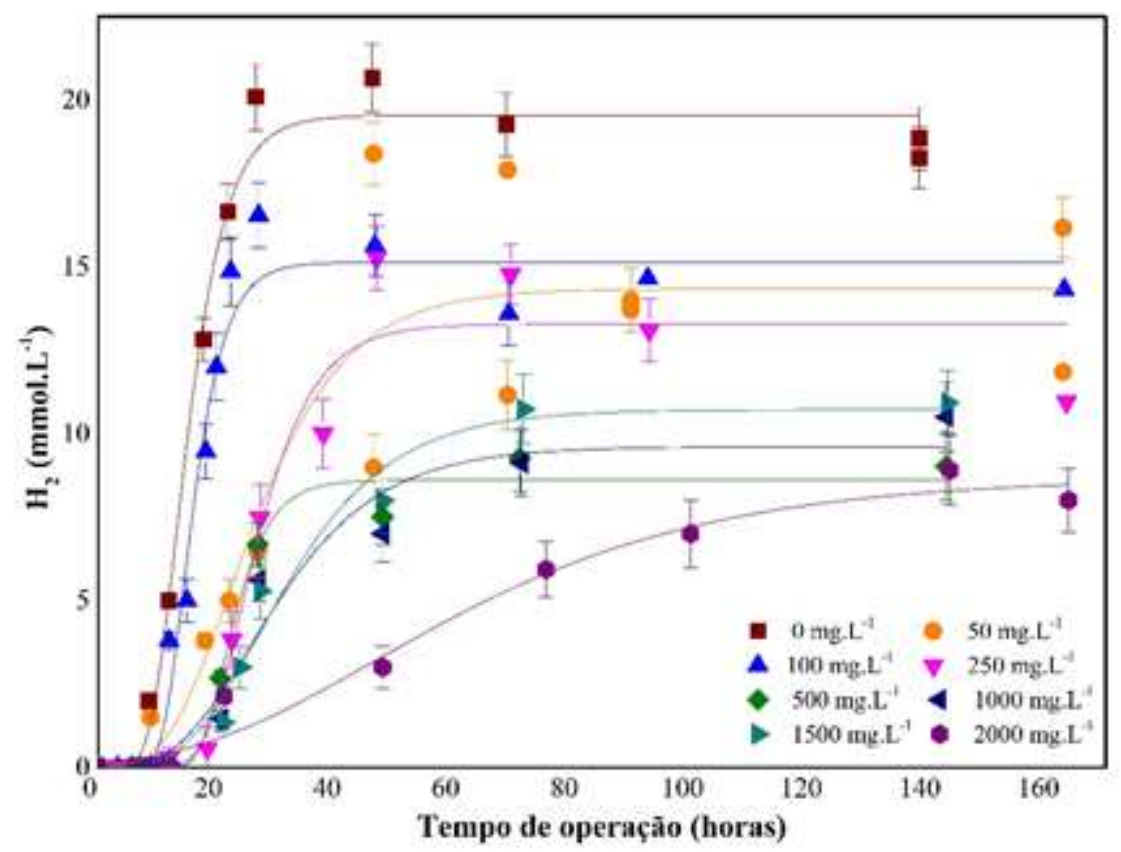

Tabela 5.31. Parâmetros cinéticos de obtenção de $\mathrm{H}_{2}$ dos reatores anaeróbios controle e com diferentes concentrações de limoneno. Médias seguidas pela mesma letra não diferem entre si para o intervalo de confiança de $95 \%$ no teste de Kruskal-Wallis.

\begin{tabular}{|c|c|c|c|c|}
\hline \multirow{2}{*}{$\begin{array}{c}\text { Limoneno } \\
\left(\mathrm{mg}^{-L^{-1}}\right)\end{array}$} & \multicolumn{4}{|c|}{ Parâmetros } \\
\hline & $P\left(\mathrm{mmol} \mathrm{H}_{2} . \mathrm{L}^{-1}\right)$ & $R m\left(\mathrm{mmol} \mathrm{H}_{2} \cdot \mathrm{h}^{-1}\right)$ & $\lambda(\mathbf{h})$ & $\mathbf{R}^{2}$ \\
\hline sem limoneno & $19,5 \pm 0,4^{\mathrm{a}}$ & $1,7 \pm 0,2^{\mathrm{a}}$ & $8,7 \pm 0,7^{\mathrm{a}}$ & 0,99 \\
\hline 50 & $14,3 \pm 1,1^{\mathrm{a}}$ & $0,5 \pm 0,2^{\mathrm{a}}$ & $11,6 \pm 5,9^{\mathrm{a}}$ & 0,97 \\
\hline 100 & $15,1 \pm 0,5^{\mathrm{ab}}$ & $1,5 \pm 0,2^{b}$ & $10,8 \pm 0,9^{b}$ & 0,97 \\
\hline 250 & $13,3 \pm 0,7^{\mathrm{c}}$ & $0,7 \pm 0,2^{\mathrm{c}}$ & $17,8 \pm 2,1^{\mathrm{b}}$ & 0,96 \\
\hline 500 & $8,6 \pm 0,3^{\mathrm{d}}$ & $0,7 \pm 0,2^{\mathrm{d}}$ & $17,0 \pm 1,3^{\mathrm{b}}$ & 0,98 \\
\hline 1000 & $9,6 \pm 0,7^{\mathrm{e}}$ & $0,3 \pm 0,1^{\mathrm{e}}$ & $13,1 \pm 3,5^{\mathrm{b}}$ & 0,95 \\
\hline 1500 & $10,7 \pm 0,5^{\mathrm{c}}$ & $0,3 \pm 0,1^{\mathrm{f}}$ & $14,7 \pm 2,1^{b}$ & 0,98 \\
\hline 2000 & $8,7 \pm 0,5^{\mathrm{f}}$ & $0,1 \pm 0,1^{\mathrm{g}}$ & $15,0 \pm 2,3^{b}$ & 0,97 \\
\hline
\end{tabular}

Nota: Potencial máximo de concentração de $\mathrm{H}_{2}(P)$, velocidade específica máxima de obtenção de $\mathrm{H}_{2}(R m)$, tempo de início da obtenção de $\mathrm{H}_{2}(\lambda)$ e $\mathrm{R}^{2}$ obtidos da equação de Gompertz modificada.

Calabrò et al. (2016), observaram que concentrações acima de $200 \mathrm{mg} . \mathrm{L}^{-1} \mathrm{de}$ limoneno refletiram em efeito inibidor na obtenção de $\mathrm{CH}_{4}$ a partir de resíduos sólidos de 
citros. Estes autores observaram aumento de $\lambda$ proporcional ao aumento da concentração de limoneno, como observado na presente pesquisa.

Os autores supracitados observaram redução significativa em $\lambda$ após o período de adaptação da biomassa; no entanto, a concentração de metano final $\left(33 \mathrm{mmol} \mathrm{CH} 4 . \mathrm{L}^{-1}\right)$ foi semelhante aos ensaios de controle. Maior adaptabilidade dos organismos metanogênicos após certo período pode ter ocorrido devido à sua camada superficial cristalina, que confere maior resistência a compostos lipofílicos, como o limoneno (RUIZ; FLOTATS, 2014). Tal possibilidade pode ter ocorrido devido ao maior tempo de reação para a obtenção de metano (cerca de 4 dias) quando comparado ao $\mathrm{H}_{2}$, que na presente pesquisa foi de cerca de $17,1 \mathrm{~h}$ nos ensaios controle. No entanto, este composto não foi detectado no final da Fase II, o que pode indicar sua volatilização para o headspace ou degradação em $p$-cimeno, um composto menos tóxico comumente gerado a partir da degradação do limoneno em ambientes anaeróbios (CALABRÒ et al., 2016).

Srilatha et al. (1995) estudaram o efeito da concentração de limoneno nos resíduos de citros à temperatura mesofílica $\left(30{ }^{\circ} \mathrm{C}\right)$, concluindo que a dosagem diária máxima de limoneno seria $24 \mathrm{mg} . \mathrm{L}^{-1}$, correspondendo a $2,5 \mathrm{kgSTV} \mathrm{m}^{3} \mathrm{~d}^{-1}$ de resíduo por digestor. A dosagem máxima descrita por estes autores foi menor quando comparada ao presente estudo; no entanto, deve-se notar que os autores usaram resíduo sólido de citros, contendo aproximadamente $8,9 \mathrm{~g} \cdot \mathrm{kg}^{-1}$ de limoneno, enquanto na presente pesquisa, os reatores foram avaliados pela adição de limoneno (PA) em reatores em batelada. Sendo assim, é importante considerar o efeito inibitório de outros óleos essenciais nos resíduos de citros, não apenas o limoneno (2014).

A produção de ST não foi significativa ( $\mathrm{p} \geq 0,05)$, bem como a variação do conteúdo dos STV. A variação de outros parâmetros (fenóis, $\mathrm{pH}$ e carboidratos) foi considerada significativa $(\mathrm{p} \leq 0,05)$, e houve acúmulo de compostos fenólicos em todos os ensaios, de aproximadamente $2 \mathrm{mg} . \mathrm{L}^{-1}$, independentemente da concentração inicial de limoneno. A remoção de carboidratos foi estatisticamente significativa em todos os ensaios, com aproximadamente $80 \%$ da concentração inicial de carboidratos (cerca de 5 g. $\mathrm{L}^{-1}$ ), também independente da concentração inicial de limoneno.

A variação do $\mathrm{pH}$ em diferentes ensaios foi significativa $(\mathrm{p} \leq 0,05)$. Além disso, foi observada uma relação inversamente proporcional entre a concentração inicial de limoneno e a redução do $\mathrm{pH}$, uma vez que nos ensaios controle o pH foi 5,9 e nos ensaios com 2.000 
mg. $\mathrm{L}^{-1}$ de limoneno, o pH foi 6,3 ao final do periodo de incubação. Este resultado pode estar relacionado à produção de $\mathrm{AOV}$ e $\mathrm{H}_{2}$, uma vez que em ensaios com menor concentração de limoneno (50 mg. $\left.\mathrm{L}^{-1}\right)$ foi observado maior optencial máximo de concentração de $\mathrm{H}_{2}\left(14,45 \mathrm{mmol} \mathrm{H} \mathrm{H}_{2} \mathrm{~L}^{-1}\right)$ quando comparada às concentrações mais altas de limoneno (2.000 mg. $\mathrm{L}^{-1}$ de limoneno; $8,7 \mathrm{mmol} \mathrm{H} \cdot \mathrm{L}^{-1}$ ) (Tabela 5.32).

Tabela 5.32. Parâmetros físico-químicos dos reatores em batelada controle e com diferentes concentrações de limoneno no início $(\mathrm{pI})$ e final $(\mathrm{pF})$.

\begin{tabular}{|c|c|c|c|c|c|c|c|c|}
\hline \multirow{2}{*}{$\begin{array}{c}\text { Limoneno } \\
\left(\mathrm{mg} . \mathrm{L}^{-1}\right)\end{array}$} & \multicolumn{2}{|c|}{$\begin{array}{c}\text { Carboidratos } \\
\left(\text { g.L } \mathrm{L}^{-1}\right)\end{array}$} & \multicolumn{2}{|c|}{$\begin{array}{c}\text { Fenóis } \\
\left(\text { mg.L }^{-1}\right)\end{array}$} & \multicolumn{2}{|c|}{ pH } & \multicolumn{2}{|c|}{$\begin{array}{c}\text { STV } \\
\left(\mathrm{mg.L}^{-1}\right)\end{array}$} \\
\hline & $\mathrm{pI}$ & $\mathrm{pF}$ & $\mathrm{pI}$ & $\mathrm{pF}$ & $\mathrm{pI}$ & $\mathrm{pF}$ & $\mathrm{pI}$ & $\mathrm{pF}$ \\
\hline 0 & $4,9 \pm 0,4$ & $0,3 \pm 0,0$ & $8,0 \pm 0,0$ & $9,1 \pm 0,1$ & $7,2 \pm 0,1$ & $5,9 \pm 0,2$ & $33 \pm 7$ & $42 \pm 5$ \\
\hline 50 & $5,2 \pm 0,1$ & $0,2 \pm 0,0$ & $8,0 \pm 0,0$ & $8,9 \pm 0,1$ & $7,4 \pm 0,1$ & $5,8 \pm 0,3$ & $35 \pm 2$ & $34 \pm 5$ \\
\hline 100 & $5,2 \pm 0,1$ & $0,2 \pm 0,0$ & $8,1 \pm 0,1$ & $9,6 \pm 0,2$ & $7,4 \pm 0,2$ & $6,3 \pm 0,1$ & $49 \pm 13$ & $28 \pm 12$ \\
\hline 250 & $3,2 \pm 0,3$ & $0,1 \pm 0,0$ & $8,3 \pm 0,1$ & $9,8 \pm 0,0$ & $7,1 \pm 0,1$ & $6,1 \pm 0,1$ & $11 \pm 8$ & $23 \pm 15$ \\
\hline 500 & $4,9 \pm 0,6$ & $0,2 \pm 0,0$ & $8,9 \pm 0,1$ & $9,4 \pm 0,0$ & $7,0 \pm 0,1$ & $6,0 \pm 0,2$ & $54 \pm 6$ & $35 \pm 7$ \\
\hline 1000 & $3,5 \pm 0,2$ & $0,1 \pm 0,0$ & $7,8 \pm 0,0$ & $9,3 \pm 0,1$ & $7,3 \pm 0,3$ & $6,4 \pm 0,2$ & $56 \pm 6$ & $47 \pm 11$ \\
\hline 1500 & $3,8 \pm 0,1$ & $0,2 \pm 0,0$ & $7,8 \pm 0,0$ & $9,1 \pm 0,0$ & $7,3 \pm 0,1$ & $6,3 \pm 0,1$ & $42 \pm 6$ & $37 \pm 7$ \\
\hline 2000 & $3,5 \pm 0,1$ & $0,1 \pm 0,0$ & $7,8 \pm 0,0$ & $9,5 \pm 0,3$ & $7,2 \pm 0,1$ & $6,3 \pm 0,1$ & $95 \pm 2$ & $49 \pm 22$ \\
\hline
\end{tabular}

A partir do monitoramento de AOV e álcoois no final do período de incubação, foi possível observar diferenças entre os metabólitos produzidos em diferentes concentrações de limoneno (Figura 5.70). Não foi observada produção de HBu nos ensaios controle e em ensaios contendo $50 \mathrm{mg} . \mathrm{L}^{-1}$ de limoneno. No entanto, a diferença na concentração de $\mathrm{H}_{2}$ entre esses ensaios não foi significativa. A produção máxima de $\mathrm{HBu}$ foi de $886 \mathrm{mg} . \mathrm{L}^{-1} \mathrm{em}$ ensaios com $100 \mathrm{mg} . \mathrm{L}^{-1}$ de limoneno.

A HAc foi o principal metabólito observado em todas as condições, com maior produção no ensaio controle $\left(1.771 \mathrm{mg} . \mathrm{L}^{-1}\right)$ e menor produção no ensaio a $2000 \mathrm{mg} . \mathrm{L}^{-1} \mathrm{de}$ limoneno (1.024 mg. $\left.\mathrm{L}^{-1}\right)$. A produção de HAc foi proporcional à concentração de $\mathrm{H}_{2}$, uma vez que nos ensaios controle foram obtidos 19,5 mmol $\mathrm{H}_{2} \cdot \mathrm{L}^{-1}$ e nos ensaios com 2.000 mg. $\mathrm{L}^{-1}$ de limoneno, $8,68 \mathrm{mmol} \mathrm{H}_{2} \cdot \mathrm{L}^{-1}$. 
Figura 5.70. Ácidos orgânicos e álcoois dos reatores em batelada controle e com diferentes concentrações de limoneno. Ácido acético (HAc), ácido butírico (HBu), ácido propiônico (HPr) e etanol (EtOH).

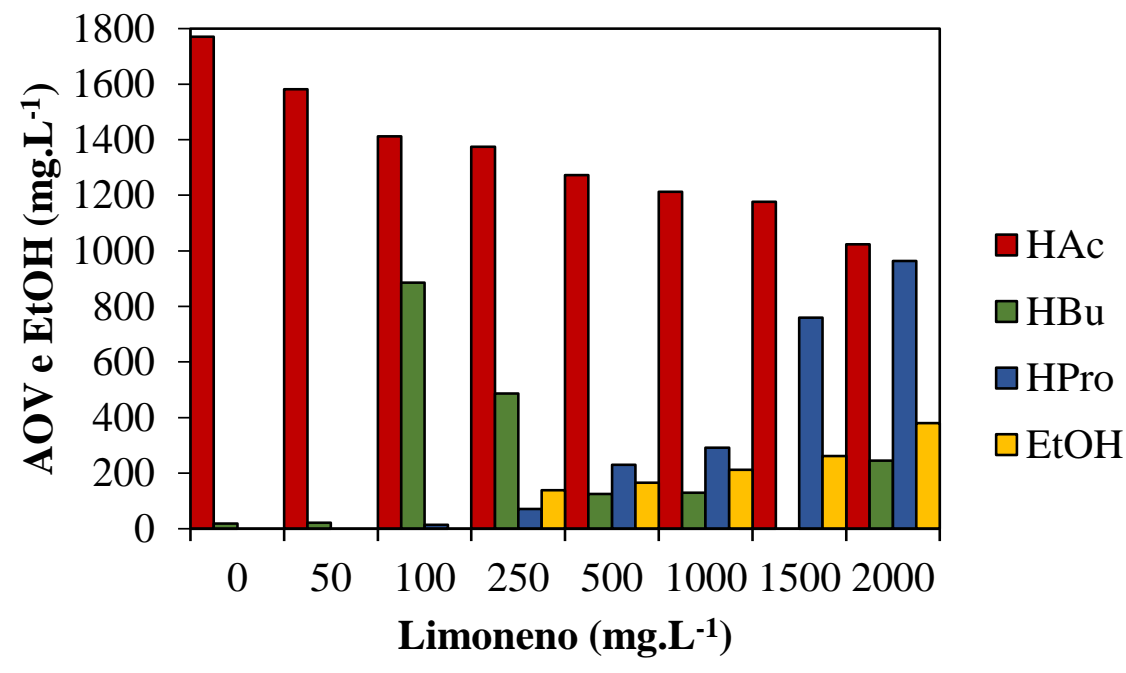

Sabe-se que a via acetogênica é mais vantajosa para a obtenção de $\mathrm{H}_{2}$ em relação à via de produção de $\mathrm{HBu}$, pois no primeiro caso, o rendimento de $\mathrm{H}_{2}$ é de cerca de 4 mols por mol de glicose (Equação 3.3), enquanto no segundo caso, o rendimento de $\mathrm{H}_{2}$ é de cerca de 2 mols de $\mathrm{H}_{2}$ por mol de glicose (Equação 3.4) (MÄKINEN; NISSILÄ; PUHAKKA, 2012; ŁUKAJTIS et al., 2018). Neste estudo, foram obtidos $0,70 \mathrm{~mol} \mathrm{de} \mathrm{H}_{2}$ por mol de glicose nos ensaios controle, enquanto nos ensaios com $2.000 \mathrm{mg} . \mathrm{L}^{-1}$ de limoneno avaliada o rendimento foi de apenas $0,3 \mathrm{~mol} \mathrm{de} \mathrm{H}_{2}$ por mol de glicose.

Da mesma forma, foi possível notar aumento proporcional na produção de HPr ao aumento da concentração de limoneno, sendo de $14 \mathrm{mg}$ HPr. $\mathrm{L}^{-1}$ observados nos ensaios com 100 mg. $\mathrm{L}^{-1}$ de limoneno e $964 \mathrm{mg}$ HPr.L $\mathrm{L}^{-1}$ nos ensaios com $2.000 \mathrm{mg} . \mathrm{L}^{-1}$ de limoneno. Na via metabólica de produção de $\mathrm{HPr}$, há consumo de 2 mols de $\mathrm{H}_{2}$ para cada mol de glicose oxidado (Equação 3.5) (LI; FANG, 2007; GHIMIRE et al., 2015).

Ruiz e Flotats (2016) apontam uma relação proporcional entre a concentração de limoneno e a produção de HPr. Estes autores obtiveram $284 \mathrm{mg}$ HPr.L ${ }^{-1}$ após a autofermentação de resíduos de citros, além de $805 \mathrm{mg}$ HAc.L $\mathrm{L}^{-1}$ e $909 \mathrm{mg} \mathrm{HBu.L^{-1 }}$. Resultados similares foram obtidos por $\mathrm{Su}$ et al. (2016), sendo que em 30 dias de fermentação com bateladas operadas com esterco de suíno como inóculo, os principais AOV produzidos a partir de resíduos sólidos de citros foram HAc (2.610 mg. $\left.\mathrm{L}^{-1}\right), \mathrm{HPr}$ (56 mg. $\left.\mathrm{L}^{-1}\right)$ e $\mathrm{HBu}\left(27,5 \mathrm{mg} . \mathrm{L}^{-1}\right)$. Neste estudo, embora a acetogênese tenha sido a principal 
via, foi possível observar uma relação proporcional entre a concentração de limoneno e a produção de $\mathrm{HPr}$, com redução concomitante da concentração de $\mathrm{H}_{2}$.

O mesmo padrão foi observado para a produção de EtOH, uma vez que $139 \mathrm{mg}$ EtOH.L ${ }^{-1}$ foram obtidos em ensaios com $250 \mathrm{mg} . \mathrm{L}^{-1}$ de limoneno e $380 \mathrm{mg} . \mathrm{L}^{-1}$ de EtOH em ensaios com $2.000 \mathrm{mg} . \mathrm{L}^{-1}$ de limoneno. A via solvetogênica não é desejável em processos cujo objetivo principal é a obtenção de $\mathrm{H}_{2}$, pois existe produção de EtOH a partir de HAc, em vez de $\mathrm{H}_{2}$ (Equação 5.13) (MÄKINEN; NISSILÄ; PUHAKKA, 2012; ŁUKAJTIS et al., 2018).

Em relação aos resultados da obtenção de $\mathrm{H}_{2}$ e AOV, pode-se inferir que a presença de limoneno causou alterações substanciais nas vias metabólicas predominantes durante a fermentação em reatores anaeróbios. 


\section{CONSIDERAÇÕES FINAIS}

A hipótese de que os resíduos de citros in natura são fonte de microrganismos autóctones celulolíticos e fermentativos (Hipótese 1) foi aceita, uma vez que foi possível obter, tanto um consórcio fermentativo autóctone a partir de cascas e bagaço in natura, quanto isolar bactérias anaeróbias celulolíticas a partir deste consórcio. É possível considerar que o consórcio autóctone obtido após autofermentação do resíduo de citros possui atividade celulolítica, uma vez que o resultado obtido para o teste de degradação de fibra de papel filtro $(13,44 \%)$ foi considerado significativo $(p \geq 0,05)$. Além disso, foi possível isolar e caracterizar uma bactéria autóctone de resíduos de citros (in natura) similar à Enterococcus casseliflavus (98\% similar), sendo que a aplicação da cepa isolada favoreceu a obtenção de $\mathrm{H}_{2}\left(10,32 \mathrm{mmol} \mathrm{H} \cdot \mathrm{L}^{-1}\right)$ a partir de resíduos de citros.

Considerou-se aceita a hipótese de que os grânulos de reator UASB podem ser considerados fonte de microrganismos fermentativos para obtenção de $\mathrm{H}_{2}$ a partir da fermentação de resíduo de citros (Hipótese 2). Nos ensaios contendo Lodo UASB/vinhaça, a concentração de $\mathrm{H}_{2}$ foi significativamente maior em relação ao Lodo UASB/avícola (12,54 e 8,46 mmol H2. $\mathrm{L}^{-1}$, respectivamente), assim como $R m\left(1,07\right.$ e 2,64 mmol H $2 . \mathrm{h}^{-1}$, respectivamente). Além disso, considerou-se que a faixa ideal para dar continuidade aos ensaios seria a faixa mesofílica, uma vez que a concentração de $\mathrm{H}_{2}$ foi superior aos ensaios conduzidos na faixa termofílica ( $P$ Lodo UASB/vinhaça $=12,54 \mathrm{mmol} \mathrm{H}_{2} \cdot \mathrm{L}^{-1}$ a $37{ }^{\circ} \mathrm{C}$ e $5,19 \mathrm{mmol} \mathrm{H} 2 \cdot \mathrm{L}^{-1}$ a $55^{\circ} \mathrm{C}$ ).

Em relação à avaliação do efeito de diferentes pré-tratamentos, buscou-se compreender em que medida o aumento da concentração de $\mathrm{H}_{2}$ foi possível por meio da aplicação dos pré-tratamentos de hidrotermólise e deslignificação alcalina com a finalidade de romper a estrutura lignocelulósica dos resíduos de citros (Hipótese 3). Entretanto, esta hipótese não foi aceita, uma vez que apesar de haver produção de $\mathrm{H}_{2}$ nos ensaios contendo resíduo de citros após hidrotermólise $\left(P=8,19 \mathrm{mmol} \mathrm{H} \mathrm{H}_{2} \mathrm{~L}^{-1}\right)$ e deslignificação alcalina $(P=$ $7,27 \mathrm{mmol} \mathrm{H}_{2} \cdot \mathrm{L}^{-1}$ ), sua concentração foi significativamente inferior quando comparados aos ensaios sem pré-tratamento $\left(P=13,55 \mathrm{mmol} \mathrm{H}_{2} \cdot \mathrm{L}^{-1}\right)$. Uma das causas para a diminuição da concentração de $\mathrm{H}_{2}$ pode ser atribuída à formação de subprodutos potencialmente tóxicos após o pré-tratamento, como compostos fenólicos. Entretanto, a partir da caracterização destes resíduos, notou-se que houve alteração em sua composição físicoquímica e morfológica, observadas, tanto após a análise em FT-IR, quanto em MEV. A 
despeito de a hipótese inicial ter sido rejeitada, vale salientar que este resultado foi considerado positivo para o processo geral, uma vez que a etapa de pré-tratamento é considerada a mais onerosa do processo de conversão de biomassa em açúcares fermentáveis para a obtenção de produtos de interesse biotecnológico.

A partir dos resultados obtidos nos ensaios referentes às hipóteses 1-3 foram estabelecidas as faixas de estudo do planejamento sequencial, para o qual buscou-se otimizar a obtenção de biogás e outros produtos de interesse biotecnológico a partir de resíduos de citros por meio do método estatístico de Planejamento Experimental (Hipótese 4). O screening design via delineamento de Plackett-Burman foi útil na seleção de variáveis significativas para continuidade dos ensaios de otimização da obtenção de biogás a partir de resíduos de citros. As variáveis consideradas para as etapas subsequentes foram o $\mathrm{pH}$ inicial do meio, com efeito positivo de 2,09 $\mathrm{mmol} \mathrm{H}_{2} \cdot \mathrm{L}^{-1}$, concentração de inóculo, com efeito positivo de $2,24 \mathrm{mmol} \mathrm{H}_{2} \cdot \mathrm{L}^{-1}$ e concentração de substrato, também com efeito positivo, de 4,65 mmol $\mathrm{H}_{2} \cdot \mathrm{L}^{-1}$. A obtenção de $\mathrm{H}_{2}$ foi otimizada a partir do método de Delineamento Composto Central Rotacional (DCCR), sendo que as condições consideradas ótimas para o processo foram de $4 \mathrm{gSTV}^{-1}$ de inóculo (lodo de reator UASB/vinhaça), 29,8 g. $\mathrm{L}^{-1}$ de resíduo sólido de citros e $\mathrm{pH}$ inicial do meio reacional de 8,98. A concentração máxima obtida $\left(48,47 \mathrm{mmol} \mathrm{H}_{2} \cdot \mathrm{L}^{-1}\right)$ foi 3,87 vezes superior ao valor de $P$ obtido antes de sua otimização $\left(12,54 \mathrm{mmol} \mathrm{H}\right.$. $\left.\mathrm{L}^{-1}\right)$. Desta forma, a hipótese foi aceita.

Uma vez que não foi possível observar produção de $\mathrm{CH}_{4}$ nos ensaios em que utilizou-se resíduo sólido de citros como substrato, utilizou-se o efluente acidificado obtido após a fermentação do ensaio R5 (15 g.L $\mathrm{L}^{-1}$ de substrato, 2,25 gSTV.L $\mathrm{L}^{-1}$ de consórcio autóctone 3 gSTV.L ${ }^{-1}$ de lodo, 5 g.L $\mathrm{L}^{-1}$ de $\mathrm{NaCl}, 40 \%$ de headspace e $\mathrm{pH}$ 8,5), no qual houve maior $P\left(13,29 \mathrm{mmol} \mathrm{H} \mathrm{H}_{2} \cdot \mathrm{L}^{-1}\right)$ como substrato para metanogênese, a fim de simular um sistema de duas fases (Hipótese 5). A hipótese foi aceita, uma vez que os metabólitos produzidos na Fase I, especialmente HAc $\left(1.340 \mathrm{mg} . \mathrm{L}^{-1}\right)$, contribuíram para a obtenção de $\mathrm{CH}_{4}$ na Fase II, uma vez que foram produzidos 50,2 $\mathrm{mmol} \mathrm{CH}_{4} \cdot \mathrm{L}^{-1}$.

Tendo em vista que o limoneno é um dos principais limitantes da reutilização de resíduos sólidos de citros em reatores anaeróbios para recuperação de produtos de interesse biotecnológico ( do teor de limoneno em amostras líquidas via Cromatografia Gasosa acoplada à Espectrometria de Massas (GC-MS), além de aplicar o método desenvolvido no monitoramento de reatores do tipo batelada operados em temperatura mesofílica $\left(30{ }^{\circ} \mathrm{C}\right)$ 
para obtenção de $\mathrm{H}_{2}$. Em relação à aplicação do método para monitoramento de reatores anaeróbios, foi possível notar efeito inibitório na produção de $\mathrm{H}_{2}$ e HAc após a adição de limoneno nos reatores. Este efeito inibitório foi significativamente proporcional ao aumento das concentrações de limoneno, possivelmente devido às alterações na via metabólica, estimulando a produção de EtOH e HPr. A presença de limoneno afetou significativamente o tempo de início da obtenção de $\mathrm{H}_{2}$, uma vez que nos ensaios controle $\lambda=8,7 \mathrm{~h}$ foram observados e nos ensaios com $2.000 \mathrm{mg}$. $\mathrm{L}^{-1}$ de limoneno, $\lambda$ foi de $15,0 \mathrm{~h}$. Por fim, a hipótese foi aceita, uma vez que por meio do desenvolvimento do método foi possível a determinação de limoneno em amostras líquidas de reatores em batelada, com potencial de aplicação na caracterização e controle de reatores anaeróbios e águas residuárias.

Na Hipótese 7, presumiu-se que as diferentes condições operacionais aplicadas em diferentes etapas da presente pesquisa influenciam diretamente a comunidade microbiana envolvida no processo, bem como as vias metabólicas predominantes. A hipótese foi considerada como verdadeira, uma vez que a partir da aplicação de técnicas de biologia molecular (16S metabarcoding e metagenômica shotgun) via Plataforma Illumina, foi possível observar a predominância de diferentes populações nas diferentes etapas descritas do presente estudo, de acordo com as variáveis operacionais utilizadas. Destaca-se que Clostridium foi o principal gênero identificado e relacionado à obtenção de $\mathrm{H}_{2}$ nas diferentes etapas, além de Ruminiclostridium, Paraclostridium e Enterococcus., enquanto na fase metanogênica foram observadas arqueias dos gêneros Methanoplasma, Methanothermobacter, Methanomassiliicoccus e Methanosarcina.

Após a caracterização funcional da validação das condições otimizadas via DCCR, foi possível identificar diversos genes relacionados à obtenção de $\mathrm{H}_{2}$, como piruvatoferredoxina/flavodoxina oxidoredutase, formiato de piruvato-liase, formiato desidrogenase, acetaldeído desidrogenase, álcool desidrogenase e L-lactato desidrogenase. Além disso, os gêneros mais relacionados à produção destes genes foram Clostridium e Paraclostridium. Além disso, foi possível confirmar por análise diferencial da expressão gênica que, entre outras, as vias de degradação da celulose e produção de HAc foram significativamente mais abundantes nas condições otimizadas, e.g., endo- $\beta-1,4-$ glicanase/celulase, endo- $\beta$-1,4-xilanase, $\beta$-glicosidase, $\beta$-manosidase, celulose $\beta$-1,4- 
celobiosidase, celobio-hidrolase, entre outras funções que podem ser relacionadas à degradação da biomassa lignocelulósica.

Por fim, foi possível concluir que os resíduos sólidos de citros (cascas e bagaço in natura) podem ser considerados como potencial substrato na digestão anaeróbia em batelada, especialmente para obtenção de $\mathrm{H}_{2}$ e AOV, como HAc e $\mathrm{HBu}$. A comparação entre os resultados obtidos nas diferentes etapas realizadas e os objetivos e hipóteses iniciais da presente pesquisa encontra-se resumida na Tabela 6.1. 
Tabela 6.1. Conclusões sobre as hipóteses iniciais da pesquisa e resumo sobre as principais condições operacionais e resultados de cada etapa.

\begin{tabular}{|c|c|c|c|c|c|}
\hline Objetivo & Condições experimentais & $\begin{array}{c}P \\
\left(\mathrm{mmol} \mathrm{H}_{2} \cdot \mathrm{L}^{-1}\right) \\
\end{array}$ & $\begin{array}{c}\text { Principais } \\
\text { microrganismos }\end{array}$ & Técnica & $\begin{array}{l}\text { Aceitação da } \\
\text { hipótese }\end{array}$ \\
\hline $\begin{array}{l}\text { 1- Avaliar consórcio fermentativo de bactérias anaeróbias celulolíticas a } \\
\text { partir de resíduos de citros in natura em relação à obtenção de produtos de } \\
\text { interesse biotecnológico }\end{array}$ & $\begin{array}{c}\text { meio PCS + RSC } 15{\mathrm{~g} . \mathrm{L}^{-1}} \\
\mathrm{pH} 7,0 ; 37^{\circ} \mathrm{C} \\
\text { Headspace } 50 \%\end{array}$ & 7,78 & - & - & $\checkmark$ \\
\hline $\begin{array}{l}\text { 2- Caracterizar bactérias anaeróbias potencialmente celulolíticas a partir do } \\
\text { consórcio do resíduo de citros }\end{array}$ & $\begin{array}{c}\text { meio PCS + xilose } 5 \text { g.L.- } \\
\text { pH } 7,0 ; 37{ }^{\circ} \mathrm{C} \\
\text { Headspace } 50 \%\end{array}$ & 10,32 & $\begin{array}{l}\text { Enterococcus, } \\
\text { Clostridium }\end{array}$ & Sanger & $\checkmark$ \\
\hline $\begin{array}{l}\text { 3- Comparar o efeito da adição de lodo termófilico e mesofílico de reator } \\
\text { UASB como fonte de biomassa anaeróbia na obtenção de produtos de } \\
\text { interesse biotecnológico a partir de resíduos de citros }\end{array}$ & $\begin{array}{l}\text { lodo UASB } 2 \text { gSTV.L } \mathrm{L}^{-1} \\
\text { meio PCS + RSC } 15 \mathrm{~g} \cdot \mathrm{L}^{-1} \\
\text { pH } 7,0 ; 37^{\circ} \mathrm{C} \\
\text { Headspace } 50 \%\end{array}$ & 12,54 & $\begin{array}{l}\text { Coprothermobacter, } \\
\text { Defluviitoga, } \\
\text { Sulfirimonas }\end{array}$ & shotgun & $\checkmark$ \\
\hline $\begin{array}{l}\text { 4- Comparar e caracterizar os resíduos de citros após diferentes pré- } \\
\text { tratamentos }\end{array}$ & $\begin{array}{l}\text { lodo UASB } 2 \text { gSTV.L. }{ }^{-1} \\
\text { meio PCS + RSC } 15 \mathrm{~g} . \mathrm{L}^{-1} \\
\text { pH } 7,0 ; 37{ }^{\circ} \mathrm{C} \\
\text { Headspace } 50 \%\end{array}$ & 13,31 & $\begin{array}{l}\text { Clostridium, } \\
\text { Ruminiclostridium }\end{array}$ & $\begin{array}{l}\text { metabarcoding, } \\
\text { DGGE }\end{array}$ & $x$ \\
\hline $\begin{array}{l}\text { 5- Avaliar as melhores condições para obtenção de produtos de interesse } \\
\text { biotecnológico a partir de resíduos de citros via Plackett \& Burman }\end{array}$ & $\begin{array}{l}\text { lodo UASB } 3 \text { gSTV.L }{ }^{-1} \\
\text { RSC } 15 \text { g.L } .^{-1} \\
\text { pH } 8,5 ; 30{ }^{\circ} \mathrm{C} \\
\text { Headspace } 40 \%\end{array}$ & 13,29 & $\begin{array}{l}\text { Escherichia, } \\
\text { Clostridium }\end{array}$ & metabarcoding & $\checkmark$ \\
\hline 5- Otimizar a obtenção de $\mathrm{H}_{2}$ por meio de DCCR e superfície de resposta & $\begin{array}{l}\text { lodo UASB } 4 \text { gSTV.L }{ }^{-1} \\
\text { RSC } 29,8 \text { g.L.-1 } \\
\text { pH 8,98; } 30^{\circ} \text { C; Pep. } 5 \text { g.L } \text { - }^{-1} \\
\text { Headspace } 60 \%\end{array}$ & 48,47 & $\begin{array}{c}\text { Clostridium } \\
\text { Paraclostridium }\end{array}$ & shotgun & $\checkmark$ \\
\hline $\begin{array}{l}\text { 6- Avaliar o potencial metanogênico de fração líquida após a fermentação } \\
\text { dos resídos de citros em batelada }\end{array}$ & $\begin{array}{c}\text { efluente acidificado* } \\
\text { pH } 7,0 ; 30{ }^{\circ} \mathrm{C} \\
\text { Headspace } 50 \%\end{array}$ & $50,2 * *$ & $\begin{array}{l}\text { Methanoplasma, } \\
\text { Methanoculleus, } \\
\text { Methanosarcina }\end{array}$ & metabarcoding & $\checkmark$ \\
\hline $\begin{array}{l}\text { 7- Desenvolver um método de determinação de limoneno em amostras } \\
\text { líquidas via GC-MS, e aplicar o método desenvolvido no monitoramento de } \\
\text { reatores em batelada }\end{array}$ & $\begin{array}{c}\text { limoneno } 100 \text { mg.L }{ }^{-1} \\
\text { lodo UASB } 3 \text { gSTV.L } \text { - }^{-1} \\
\text { meio PCS + glicose } 5 \text { g.L } \mathrm{L}^{-1} \\
\text { pH 7,0; } 30{ }^{\circ} \mathrm{C} \\
\text { Headspace } 50 \%\end{array}$ & 15,10 & - & - & $\checkmark$ \\
\hline
\end{tabular}

Nota: (-) Não se aplica, $\checkmark$ = hipótese aceita, $X=$ hipótese não aceita, PCS= Peptone Cellulose Solution (peptona 5 g.L $\mathrm{L}^{-1}$, extrato de levedura $1 \mathrm{~g} . \mathrm{L}^{-1}$, NaCl 5 g.L $\mathrm{L}^{-1}$, $\mathrm{CaCO}_{3} 5$ g.L-1 $), \mathrm{RSC}=$ resíduo sólido de citros, (*) efluente acidificado resultante da de otimização da obtenção de $\mathrm{H}_{2}+$ meio Zinder, $(* *) \mathrm{CH}_{4}\left(\mathrm{mmol} \mathrm{CH}_{4} \cdot \mathrm{L}^{-1}\right) . \mathrm{Pep}^{-1}$ peptona. 


\section{CONCLUSÕES}

- A partir do consórcio fermentativo autóctone obtido a partir de resíduos de citros in natura, foi possível isolar e caracterizar uma bactéria anaeróbia celulolítica produtora de $\mathrm{H}_{2}$, similar a Enterococcus casseliflavus $(98 \%)$;

- A mistura do consórcio autóctone e inóculo alóctone foi favorável à obtenção de $\mathrm{H}_{2}$ a partir de resíduos sólidos de citros, sendo a maior concentração de $\mathrm{H}_{2}$ observada a partir de lodo de reator UASB aplicado ao processamento termofílico de vinhaça de canade-açúcar $\left(12,54 \mathrm{mmol} \mathrm{H}\right.$. $\left.\mathrm{L}^{-1}\right)$ em condições mesofílicas $\left(30^{\circ} \mathrm{C}\right)$;

- A utilização de resíduos de citros in natura foi mais vantajosa para obtenção de $\mathrm{H}_{2}$ em comparação ao resíduo pré-tratado via hidrotermólise ou deslignificação alcalina, uma vez que foram obtidos, respectivamente, 13,55, 8,19 e 7,27 $\mathrm{mmol} \mathrm{H}_{2} \cdot \mathrm{L}^{-1}$;

- Foi possível otimizar a obtenção de $\mathrm{H}_{2}$ a partir de resíduos sólidos de citros em aproximadamente 3,87 vezes por meio da aplicação de planejamento estatístico sequencial (Plackett \& Burman + DCCR), sendo que as condições consideradas ótimas para o processo foram de 4 gSTV.L ${ }^{-1}$ de inóculo (lodo de reator UASB/vinhaça), 29,8 g.L - $^{-1}$ de resíduo sólido de citros e pH inicial do meio reacional de 8,98;

- Confirmou-se por meio de sequenciamento metagenômico shotgun e análise diferencial da expressão gênica que, entre outras, as vias de degradação da celulose e produção de HAc foram significativamente mais abundantes nas condições otimizadas, com favorecimento do gênero Clostridium;

- A partir do uso da fração líquida do ensaio acidogênico (Fase I) dos resíduos sólidos de citros em reatores em batelada foi possível obter no reator metanogênico (Fase II) 50,2 mmol $\mathrm{CH}_{4} \cdot \mathrm{L}^{-1}$. As arqueias identificadas neste processo foram Methanoplasma, Methanothermobacter, Methanomassiliicoccus e Methanosarcina;

- O efeito inibitório do limoneno na metanogênese pode ser superado na abordagem de duas fases, uma vez que concentração acima dos limites inibitórios (200 mg. $\mathrm{kg}^{-1}$ ) foram observados na Fase I (220,5 mg.kg $\left.{ }^{-1}\right)$, enquanto na Fase II este composto foi observado abaixo deste limite $\left(\leq 0,58 \mathrm{mg} \cdot \mathrm{kg}^{-1}\right)$;

- Efeito inibitório na obtenção de $\mathrm{H}_{2}$ e HAc foi observado após adição de limoneno nos reatores. Este efeito inibitório foi significativamente proporcional ao aumento das concentrações de limoneno, possivelmente devido às alterações nas vias metabólicas, estimulando a produção de EtOH e HPr. 


\section{RECOMENDAÇÕES}

- Aplicar as condições otimizadas em processos contínuos e reatores em escala ampliada;

- Avaliar a possibilidade de substituição da água potável por água residuária, como água residuária da citricultura, água de prensagem de resíduos sólidos de citros ou esgoto doméstico;

- Avaliar a reproducibilidade das condições otimizadas em outros resíduos sólidos lignocelulósicos;

- Novos experimentos devem ser realizados, por meio de Delineamento Composto Central Rotacional, a fim de estabelecer as condições operacionais mais favoráveis à bactéria isolada a partir de resíduo de citros in natura (E. casseliflavus), a fim de utiliza-la como inóculo em processos de digestão anaeróbia de resíduos lignocelulósicos. 


\section{REFERÊNCIAS}

ABID, M. et al. Characterization of pectins extracted from pomegranate peel and their gelling properties. Food Chemistry, v. 215, p. 318-325, 2017. Disponível em: <http://dx.doi.org/10.1016/j.foodchem.2016.07.181>.

ABNT, A. B. de N. T. Classificação De Resíduos Sólidos, Norma ABNT NBR 10.004:2004, 2004. . Disponível em: <www.abetre.org.br>.

ACD, S. E. ChemSketch version 2018.1 Advanced Chemistry Development, Inc., Toronto, ON, Canada, 2019. . Disponível em: <www.acdlabs.com>.

ÁCS, N. et al. Bioaugmentation of biogas production by a hydrogen-producing bacterium. Bioresource Technology, v. 186, p. 286-293, 2015. Disponível em: <http://dx.doi.org/10.1016/j.biortech.2015.02.098>.

ADORNO, M. A. T.; HIRASAWA, J. S.; VARESCHE, M. B. A. Development and Validation of Two Methods to Quantify Volatile Acids (C2-C6) by GC/FID: Headspace (Automatic and Manual) and Liquid-Liquid Extraction (LLE). American Journal of Analytical Chemistry, v. 05, n. 07, p. 406-414, 2014. Disponível em: <http://www.scirp.org/journal/doi.aspx?DOI=10.4236/ajac.2014.57049>.

AHMAD, F. et al. Methane Production from Hydrogen Peroxide Assisted Hydrothermal Pretreatment of Solid Fraction Sugarcane Bagasse. Waste and Biomass Valorization, p. 1-20, 2018. Disponível em: 〈http://dx.doi.org/10.1007/s12649-018-0452-1〉.

AHMAD, F. et al. Methane Production from Hydrogen Peroxide Assisted Hydrothermal Pretreatment of Solid Fraction Sugarcane Bagasse. Waste and Biomass Valorization, v. 11, n. 1, p. 31-50, 2020.

AHMAD, F.; SILVA, E. L.; VARESCHE, M. B. A. Hydrothermal processing of biomass for anaerobic digestion - A review. Renewable and Sustainable Energy Reviews, v. 98, p. 108-124, 2018. Disponível em: 〈https://doi.org/10.1016/j.rser.2018.09.008>.

AHRO, M. et al. Low-Resolution Gas-Phase FT-IR Method for the Determination of the Limonene/Carvone Ratio in Supercritical CO2 -Extracted Caraway Fruit Oils. Journal of Agricultural and Food Chemistry, v. 49, p. 3140-3144, 2001.

AKITA, H. et al. Identification and characterization of Burkholderia multivorans CCA53. BMC Research Notes, v. 10, n. 1, p. 249, 6 dez. 2017. Disponível em: <http://bmcresnotes.biomedcentral.com/articles/10.1186/s13104-017-2565-1>.

AN, D. et al. Characterization on hydrogen production performance of a newly isolated Clostridium beijerinckii YA001 using xylose. International Journal of Hydrogen Energy, v. 39, n. 35, p. 19928-19936, 2014. Disponível em: <http://dx.doi.org/10.1016/j.ijhydene.2014.10.014>. 
ANJUM, M. et al. Synergistic effect of co-digestion to enhance anaerobic degradation of catering waste and orange peel for biogas production. Waste Management and Research, v. 35, n. 9, p. 967-977, 2017.

APHA/AWWA/WEF. Standard Methods for the Examination of Water and Wastewater. 22. ed. [s.l: s.n.]

AQUINO, S. F. de; CHERNICHARO, C. A. L. Acúmulo de ácidos graxos voláteis (AGVs) em reatores anaeróbios sob estresse: causas e estratégias de controle. Engenharia Sanitaria e Ambiental, v. 10, n. 2, p. 152-161, 2005. Disponível em: $<$ http://www.scielo.br/scielo.php?script=sci_arttext\&pid=S1413$41522005000200009 \& \operatorname{lng}=\mathrm{pt} \& \operatorname{tng}=\mathrm{pt}>$.

ASPEBORG, H. et al. Evolution, substrate specificity and subfamily classification of glycoside hydrolase family 5 (GH5). BMC Evolutionary Biology, v. 12, n. 1, 2012.

ATALlA, R. H.; VANDERHART, D. L. Native Cellulose: A Composite of Two DistinctCrystalline Forms. Science, v. 223, n. 4633, p. 283-285, 1984.

AZMAN, S. et al. Presence and role of anaerobic hydrolytic microbes in conversion of lignocellulosic biomass for biogas production. Critical Reviews of Environmental Science and Technology, v. 45, n. 23, p. 2523-2564, 2015.

BAKKALI, F. et al. Biological effects of essential oils - A review. Food and Chemical Toxicology, v. 46, n. 2, p. 446-475, 2008.

BALAT, M. Production of bioethanol from lignocellulosic materials via the biochemical pathway: A review. Energy Conversion and Management, v. 52, n. 2, p. 858-875, 2011.

BARNHART, E. P. et al. Potential Role of Acetyl-CoA Synthetase (acs) and Malate Dehydrogenase (mae) in the Evolution of the Acetate Switch in Bacteria and Archaea. Scientific Reports, v. 5, n. 1, p. 12498, 3 dez. 2015. Disponível em: <http://www.nature.com/articles/srep12498>.

BENOMAR, $S$. et al. Nutritional stress induces exchange of cell material and energetic coupling between bacterial species. Nature Comunications, v. 6, n. 6883, p. 1-10, 2015.

BICAS, J. L. et al. Characterization of monoterpene biotransformation in two pseudomonads. Journal of Applied Microbiology, v. 105, n. 6, p. 1991-2001, 2008.

BICAS, J. L.; PASTORE, G. M. Isolation and screening of D-limonene-resistant microorganisms. Brazilian Journal of Microbiology, v. 38, p. 563-567, 2007.

BLANCH, G. P.; NICHOLSON, G. J. Determination of the Enantiomeric Composition of Limonene and Limonene-1, 2-epoxide in Lemon Peel by Multidimensional Gas Chromatography with Flame-lonization Detection and Selected Ion Monitoring Mass Spectrometry. Journal of Chromatographic Science, v. 36, p. 19-22, 1998.

BLUNDI, C.; GARDÊLHA, R. Método para determinação de matéria orgânica específica em águas 
residuárias. In: CHERNICHARO, C. A. L. (COORD. (Ed.). Pós tratamento de efluentes de reatores anaeróbios: aspectos metodológicos. PROSAB. p. 9-17.

BORGES, A. C. G.; COSTA, V. M. H. D. M. A evolução do agronegócio citrícola paulista e o perfil da intervenção do estado. Revista Uniara, n. 17/18, p. 101-124, 2006.

BOTTA, L. S. et al. Bioconversion of waste office paper to hydrogen using pretreated rumen fluid inoculum. Bioprocess and Biosystems Engineering, v. 39, n. 12, p. 1887-1897, 2016.

BRAGA, J. K. et al. Hydrogen Production by Clostridium cellulolyticum a Cellulolytic and Hydrogen-Producing Bacteria Using Sugarcane Bagasse. Waste and Biomass Valorization, v. 0, n. 0, p. 1-11, 2017. Disponível em: <http://dx.doi.org/10.1007/s12649017-0105-9>.

BRAGA, J. K. et al. Bacterial and archaeal community structure involved in biofuels production using hydrothermal- and enzymatic-pretreated sugarcane bagasse for an improvement in hydrogen and methane production. Sustainable Energy \& Fuels, 2018. Disponível em: <http://xlink.rsc.org/?DOI=C8SE00312B >.

BRENNER, D. J.; KRIEG, N. R.; STALEY, J. T. The Proteobacteria- Part B: The Gammaproteobacteria. In: GARRITY, G. M. (Ed.). Bergey's Manual of Systematic Bacteriology. 2 ed. New York: Springer, 2005. 2p. 1136.

BRUCE, T. et al. Bacterial community diversity in the brazilian atlantic forest soils. Microbial Ecology, v. 60, n. 4, p. 840-849, 2010.

BUCHANAN, I. D.; NICELL, J. A. Model development for horseradish peroxidase catalyzed removal of aqueous phenol. Biotechnology and Bioengineering, v. 54, n. 3, p. 251-261, 1997.

BUGG, T. D. H. et al. The emerging role for bacteria in lignin degradation and bio-product formation. Current Opinion in Biotechnology, v. 22, n. 3, p. 394-400, 2011. Disponível em: 〈http://dx.doi.org/10.1016/j.copbio.2010.10.009>.

BUITRÓN, G.; CARVAJAL, C. Biohydrogen production from Tequila vinasses in an anaerobic sequencing batch reactor: Effect of initial substrate concentration, temperature and hydraulic retention time. Bioresource Technology, v. 101, n. 23, p. 9071-9077, dez. 2010. Disponível em: <https://linkinghub.elsevier.com/retrieve/pii/S0960852410011302>.

BURT, S. Essential oils: their antibacterial properties and potential applications in foods - a review. International Journal of Food Microbiology, v. 94, p. 223-253, 2004.

CABRERA, E. et al. Alkaline and alkaline peroxide pretreatments at mild temperature to enhance enzymatic hydrolysis of rice hulls and straw. Bioresource Technology, v. 167, p. 1-7, 2014. Disponível em: <http://dx.doi.org/10.1016/j.biortech.2014.05.103>.

CAHYARI, K. et al. Optimization of hydrogen production from fruit waste through mesophilic and 
thermophilic dark fermentation: Effect of substrate-to-inoculum ratio. Malaysian Journal of Analytical Sciences, v. 23, n. 1, p. 116-123, 2019.

CALABRÒ, P. S. et al. Effect of the concentration of essential oil on orange peel waste biomethanization: Preliminary batch results. Waste Management, v. 48, p. 440-447, 2016.

CAMPOS-BERMUDEZ, V. A. et al. Functional dissection of Escherichia coli phosphotransacetylase structural domains and analysis of key compounds involved in activity regulation. FEBS Journal, v. 277, n. 8, p. 1957-1966, abr. 2010. Disponível em: <http://doi.wiley.com/10.1111/j.1742-4658.2010.07617.x>.

CAO, G. et al. Single-step bioconversion of lignocellulose to hydrogen using novel moderately thermophilic bacteria. Biotechnology for Biofuels, v. 7, n. 82, p. 1-13, 2014.

CAPORASO, J. G. et al. QIIME allows analysis of high-throughput community sequencing data. Nature methods, v. 7, n. 5, p. 335-336, 2010. Disponível em: <http://dx.doi.org/10.1038/nmeth0510-335>.

CAZIER, E. A. et al. Biomass hydrolysis inhibition at high hydrogen partial pressure in solid-state anaerobic digestion. Bioresource Technology, v. 190, p. 106-113, 2015. Disponível em: <http://dx.doi.org/10.1016/j.biortech.2015.04.055>.

CEBREIROS, F.; FERRARI, M. D.; LAREO, C. Cellulose hydrolysis and IBE fermentation of eucalyptus sawdust for enhanced biobutanol production by Clostridium beijerinckii DSM 6423. Industrial Crops and Products, v. 134, p. 50-61, ago. 2019. Disponível em: <https://linkinghub.elsevier.com/retrieve/pii/S0926669019302250>.

CECILIA, J. A. et al. Industrial Food Waste Valorization : A General Overview. In: BASTIDASOYANEDEL, J. R.; SCHMIDT, J. (Ed.). Biorefinery. Springer, 2019. p. 25 p.

CEPEA- CENTRO DE ESTUdOS AVANÇADOS EM ECONOMIA APLICADA. PIB do Agronegócio. Disponível em: <http://www.cepea.esalq.usp.br/pib/>.

CHANDRA, R. et al. Improving biodegradability and biogas production of wheat straw substrates using sodium hydroxide and hydrothermal pretreatments. Energy, v. 43, n. 1, p. 273-282, 2012. Disponível em: 〈http://dx.doi.org/10.1016/j.energy.2012.04.029〉.

CHANDRA, R.; TAKEUCHI, H.; HASEGAWA, T. Hydrothermal pretreatment of rice straw biomass: A potential and promising method for enhanced methane production. Applied Energy, v. 94, p. 129-140, 2012. Disponível em: <http://dx.doi.org/10.1016/j.apenergy.2012.01.027>.

CHAPLEUR, O. et al. Asymmetrical response of anaerobic digestion microbiota to temperature changes. Applied Microbiology and Biotechnology, v. 100, n. 3, p. 1445-1457, 2016.

CHEN, S. et al. Fastp: An ultra-fast all-in-one FASTQ preprocessor. Bioinformatics, v. 34, n. 17, p. i884-i890, 2018.

CHOI, I. S. et al. Bioethanol production from mandarin (Citrus unshiu) peel waste using popping 
pretreatment. Applied Energy, v. 102, p. 204-210, 2013.

CHOI, I. S. et al. A low-energy, cost-effective approach to fruit and citrus peel waste processing for bioethanol production. Applied Energy, v. 140, p. 65-74, 2015.

CHUENCHART, W. et al. Enhancement of food waste thermophilic anaerobic digestion through synergistic effect with chicken manure. Biomass and Bioenergy, v. 136, n. March, p. 105541, 2020. Disponível em: 〈https://doi.org/10.1016/j.biombioe.2020.105541〉.

CIBIS, K. G.; GNEIPEL, A.; KÖNIG, H. Isolation of acetic , propionic and butyric acid-forming bacteria from biogas plants. Journal of Biotechnology, v. 220, p. 51-63, 2016.

CITROSUCO. Relatório de sustentabilidade: Safra 2015-2016. [s.l: s.n.].

COLOMBO, L. T. et al. Applying functional metagenomics to search for novel lignocellulosic enzymes in a microbial consortium derived from a thermophilic composting phase of sugarcane bagasse and cow manure. Antonie van Leeuwenhoek, International Journal of General and Molecular Microbiology, v. 109, n. 9, p. 1217-1233, 2016.

CONVERTI, A.; PEREGO, P. Use of carbon and energy balances in the study of the anaerobic metabolism of Enterobacter aerogenes at variable starting glucose concentrations. Applied Microbiology and Biotechnology, v. 59, n. 2-3, p. 303-309, 2002.

CORRÊA, A. da S. Avaliação da microbiota endofítica de citros com potencial antagônico no controle biológico de Guignardia citricarpa. 2008. Universidade Federal do Rio Grande do Sul, 2008.

CREMONEZ, P. A. et al. Effect of substrate concentrations on methane and hydrogen biogas production by anaerobic digestion of a cassava starch-based polymer. Industrial Crops and Products, v. 151, p. 112471, 2020. Disponível em: <https://doi.org/10.1016/j.indcrop.2020.112471>.

DANIEL, R. The metagenomics of soil. Nature Reviews Microbiology, v. 3, n. 6, p. 470-478, 2005.

DAS, D.; VEZIROGLU, T. N. Hydrogen production by biological processes: a survey of literature. International Journal of Hydrogen Energy, v. 26, n. 1, p. 13-28, 2001.

DATAR, R. et al. Hydrogen production from the fermentation of corn stover biomass pretreated with a steam-explosion process. International Journal of Hydrogen Energy, v. 32, n. 8, p. 932-939, 2007.

DAVIDOWSKI, S.; DIMARCO, B. The Extraction and Quantification of Limonene from Citrus Rinds Using GC/MS. PerkinElmer Application Note, p. 1-4, 2009. Disponível em: $<$ http://perkinelmer.cl/assets/the-extraction-and-quantification-of-limonene-from-citrusby-gcms.pdf>.

DE LA RUBIA, M. A. et al. Influence of particle size and chemical composition on the performance 
and kinetics of anaerobic digestion process of sunflower oil cake in batch mode. Biochemical Engineering Journal, v. 58-59, n. 1, p. 162-167, 2011. Disponível em: <http://dx.doi.org/10.1016/j.bej.2011.09.010>.

DELFORNO, T. P. et al. Metagenomic analysis of the microbiome in three different bioreactor configurations applied to commercial laundry wastewater treatment. Science of the Total Environment, v. 587-588, p. 389-398, 2017. Disponível em: <http://dx.doi.org/10.1016/j.scitotenv.2017.02.170>.

DELFORNO, T. P. et al. Comparative metatranscriptomic analysis of anaerobic digesters treating anionic surfactant contaminated wastewater. Science of the Total Environment, v. 649, p. 482-494, 2019. Disponível em: <https://doi.org/10.1016/j.scitotenv.2018.08.328>.

DEMÍRBAS, A. Bioethanol from cellulosic materials: a renewable motor fuel from biomass. Energy Source, v. 27, n. 4, p. 327-237, 2005.

DEPPENMEIER, U. The unique biochemistry of methanogenesis. Progress in Nucleic Acid Research and Molecular Biology, v. 71, p. 223-283, 2002. Disponível em: <http://linkinghub.elsevier.com/retrieve/pii/S0079660302710453>.

DESVAUX, M. Clostridium cellulolyticum: Model organism of mesophilic cellulolytic clostridia. FEMS Microbiology Reviews, v. 29, n. 4, p. 741-764, 2005.

DETMAN, A. et al. Cell factories converting lactate and acetate to butyrate: Clostridium butyricum and microbial communities from dark fermentation bioreactors. Microbial Cell Factories, v. 18, n. $1, \quad$ p. 36,13 dez. 2019. Disponível em: <https://microbialcellfactories.biomedcentral.com/articles/10.1186/s12934-019-1085-1>.

DORMAN, H. J. D.; DEANS, S. G. Antimicrobial agents from plants: antibacterial activity of plant volatile oils. Journal of Applied Microbiology, v. 88, p. 308-316, 2000.

DUARTE, I. C. S. et al. Development of a Method by HPLC to Determine LAS and its Application in Anaerobic Reactors. Journal of Brazilian Chemical Society, v. 17, n. 7, p. 1360-1367, 2006.

DUBOIS, M. et al. Colorimetris method for determination of sugars and related substances. Analytical Chemistry, v. 28, n. 3, p. 350-356, 1956.

DUMITRACHE, A. et al. Consolidated bioprocessing of Populus using Clostridium (Ruminiclostridium) thermocellum: A case study on the impact of lignin composition and structure. Biotechnology for Biofuels, v. 9, n. 1, p. 1-14, 2016.

DÜRRE, P. New insights and novel developments in clostridial acetone/butanol/isopropanol fermentation. Applied Microbiology and Biotechnology, v. 49, n. 6, p. 639-648, 1998.

ESCUDIÉ, F. et al. FROGS: Find, Rapidly, OTUs with Galaxy Solution. Bioinformatics, v. 34, n. 8, p. 1287-1294, 2018.

EWELS, P. et al. MultiQC: Summarize analysis results for multiple tools and samples in a single 
report. Bioinformatics, v. 32, n. 19, p. 3047-3048, 2016.

FAOSTAT. Statistical Database of the Food and Agriculture Organization of the United Nations. Disponível em: <http://faostat.fao.org>. Acesso em: 8 ago. 2016.

FITZGERALD, J. A. et al. Trace element supplementation is associated with increases in fermenting bacteria in biogas mono-digestion of grass silage. Renewable Energy, v. 138, p. 980-986, 2019. Disponível em: 〈https://doi.org/10.1016/j.renene.2019.02.051〉.

FONSECA, B. C. Produção de hidrogênio por fermentação por um novo isolado de Clostridium beijerinckii. 2016. Universidade de São Paulo, 2016.

FONSECA, B. C. et al. Genome sequence of the $\mathrm{H}_{2}$-producing Clostridium beijerinckii strain $\mathrm{Br} 21$ isolated from a sugarcane vinasse treatment plant. Genetics and Molecular Biology, v. 42, n. $1, \quad$ p. $2019 . \quad$ Disponível em: <http://www.scielo.br/scielo.php?script=sci_arttext\&pid=S141547572019000100139\&tlng=en>.

FONSECA, B. C.; SCHMIDELL, W.; REGINATTO, V. Impact of Glucose Concentration on Productivity and Yield of Hydrogen Production by the New Isolate Clostridium beijerinckii Br21. The Canadian Journal of Chemical Engineering, v. 9999, p. 1-8, 2018.

FORGÁCS, G. et al. Methane production from citrus wastes: Process development and cost estimation. Journal of Chemical Technology and Biotechnology, v. 87, n. 2, p. 250-255, 2012.

FORSTER-CARNEIRO, T.; PÉREZ, M.; ROMERO, L. I. Influence of total solid and inoculum contents on performance of anaerobic reactors treating food waste. Bioresource Technology, v. 99, n. 15, p. 6994-7002, 2008.

FRUNZO, L. P. G. d'Antonio G. E. M. F. L.; PIROZZI, F. Thermal pretreatment of olive mill wastewater for efficient methane production: control of aromatic substances degradation by monitoring cyclohexane carboxylic acid. Environmental Technology, v. 36, n. 14, p. 1785-1794, 2015.

GAGLIANO, M. C. et al. Ecology and biotechnological potential of the thermophilic fermentative Coprothermobacter spp. FEMS Microbiology Ecology, v. 91, n. 5, p. 1-12, 2015.

GALPERIN, M. Y. Genome Diversity of Spore-Forming Firmicutes. Microbiology spectrum, v. 1, n. 2, p. 1-15, 2013. Disponível em: <http://www.pubmedcentral.nih.gov/articlerender.fcgi?artid=4306282\&tool=pmcentrez\& rendertype $=$ abstract $>$.

GEETHA, M. et al. Screening of pectinase producing bacteria and fungi for its pectinolytic activity using fruit wastes. International Journal of Biochemistry \& Biotech Science, v. 1, p. 30-42, 2012. 
GHIMIRE, A. et al. A review on dark fermentative biohydrogen production from organic biomass: Process parameters and use of by-products. Applied Energy, v. 144, p. 73-95, 2015. Disponível em: <http://dx.doi.org/10.1016/j.apenergy.2015.01.045>.

GHOSH, P. et al. Enhanced biogas production from municipal solid waste via co-digestion with sewage sludge and metabolic pathway analysis. Bioresource Technology, v. 296, p. 122275, jan. 2020. Disponível em: <https://linkinghub.elsevier.com/retrieve/pii/S0960852419315056>.

GOMEZ-FLORES, M.; NAKHLA, G.; HAFEZ, H. Hydrogen production and microbial kinetics of Clostridium termitidis in mono-culture and co-culture with Clostridium beijerinckii on cellulose. AMB Express, v. 7, n. 1, p. 84, 20 dez. 2017. Disponível em: <http://ambexpress.springeropen.com/articles/10.1186/s13568-016-0256-2>.

GONZALES, R. R. et al. Enhancement of hydrogen production by optimization of $\mathrm{pH}$ adjustment and separation conditions following dilute acid pretreatment of lignocellulosic biomass. International Journal of Hydrogen Energy, v. 42, n. 45, p. 27502-27511, 2017. Disponível em: <https://doi.org/10.1016/j.ijhydene.2017.05.021>.

GOODLOVE, P. E. et al. Cloning and sequence analysis of the fermentative alcoholdehydrogenase-encoding gene of Escherichia coli. Gene, v. 85, n. 1, p. 209-214, 1989.

GRABBER, J. H. How do lignin composition, structure, and cross-linking affect degradability? A review of cell wall model studies. Crop Science, v. 45, n. 3, p. 820-831, 2005.

GRÄWERT, T. et al. Inhibition of Methyl-CoM Reductase from Methanobrevibacter ruminantium by 2-Bromoethanesulfonate. Journal of Agricultural and Food Chemistry, v. 62, n. 52, p. 12487-12490, 31 dez. 2014. Disponível em: <https://pubs.acs.org/doi/10.1021/jf505056g>.

GREEN, M. R.; SAMBROOK, J. Molecular Cloning: A Laboratory Manual. 4th. ed. New York: Cold Spring Harbor Laboratory Press, 2012. v. 1

GROOTSCHOLTEN, T. I. M. et al. Chain elongation of acetate and ethanol in an upflow anaerobic filter for high rate MCFA production. Bioresource Technology, v. 135, p. 440-445, 2013. Disponível em: 〈http://dx.doi.org/10.1016/j.biortech.2012.10.165>.

GUEDON, E.; PETITDEMANGE, H.; POINCARE, H. Improvement of Cellulolytic Properties of Clostridium cellulolyticum by Metabolic Engineering. v. 68, n. 1, p. 53-58, 2002.

GUO, J. et al. Dissecting microbial community structure and methane-producing pathways of a full-scale anaerobic reactor digesting activated sludge from wastewater treatment by metagenomic sequencing. Microbial Cell Factories, v. 14, n. 1, p. 1-11, 2015.

GUO, X. M. et al. Predictive and explicative models of fermentative hydrogen production from solid organic waste: Role of butyrate and lactate pathways. International Journal of Hydrogen Energy, v. 39, n. 14, p. 7476-7485, 2014. 
GUREVICH, A. et al. QUAST: Quality assessment tool for genome assemblies. Bioinformatics, v. 29, n. 8, p. 1072-1075, 2013.

HAMMER; HARPER, D.; RYAN, P. PAST: paleontological statistics software package for education and data analysis. Palaeontologia Electronica, , 2001. .

HANIA, W. Ben et al. Defluviitoga tunisiensis gen. nov., sp. nov., a thermophilic bacterium isolated from a mesothermic and anaerobic whey digester. International Journal of Systematic and Evolutionary Microbiology, v. 62, n. 6, p. 1377-1382, 2012.

HARADA, H. et al. Anaerobic treatment of a recalcitrant distillery wastewater by a thermophilic UASB reactor. Bioresource Technology, v. 55, p. 215-221, 1996.

HARUTA, S. et al. Construction of a stable microbial community with high cellulose-degradation ability. Applied Microbiology and Biotechnology, v. 59, n. 4-5, p. 529-534, 2002.

HAWKES, F. R. et al. Sustainable fermentative hydrogen production: Challenges for process optimisation. International Journal of Hydrogen Energy, v. 27, n. 11-12, p. 1339-1347, 2002.

HE, Y. et al. Physicochemical Characterization of Rice Straw Pretreated with Sodium Hydroxide in the Solid State for Enhancing Biogas Production. Energy \& Fuels, v. 22, n. 4, p. 27752781, 2008. Disponível em: 〈http://pubs.acs.org/doi/abs/10.1021/ef8000967〉.

HEERDEN, I. van et al. Microbial, chemical and physical aspects of citrus waste composting. Bioresource Technology, v. 81, p. 71-76, 2002.

HERDIAN, H. et al. Isolation of Cellulolytic Lactic-Acid Bacteria from Mentok (Anas moschata) Gastro-Intestinal Tract. Tropical Animal Science Journal, v. 41, n. 3, p. 200-206, 2018. HIRASAWA, J. S. Avaliação da metanogênese e sulfetogênese na presença de oxigênio, sob diferentes relações etanol/sulfato, utilizando técnicas de biologia molecular. 2007. Universidade de São Paulo (USP), 2007.

HJORTH, M. et al. Extrusion as a pretreatment to increase biogas production. Bioresource Technology, v. 102, n. 8, p. 4989-4994, 2011. Disponível em: <http://dx.doi.org/10.1016/j.biortech.2010.11.128>.

HUGHES, J. B. et al. Counting the Uncountable: Statistical Approaches to Estimating Microbial Diversity. Applied and Environmental Microbiology, v. 67, n. 10, p. 4399-4406, 2001. Disponível em: 〈https://aem.asm.org/content/67/10/4399>.

HUYCKE, M. M. Physiology of Enterococci. In: AL., M. S. G. ET (Ed.). The Enterococci: Pathogenesis, Molecular Biology, and Antibiotic Resist. Washington: ASM Press, 2002. p. $133-175$.

HWANG, J. H. et al. Feasibility of hydrogen production from ripened fruits by a combined twostage (dark/dark) fermentation system. Bioresource Technology, v. 102, n. 2, p. 1051- 
1058, 2011. Disponível em: 〈http://dx.doi.org/10.1016/j.biortech.2010.08.047>.

IBEKWE, A. M. et al. Functional relationships between aboveground and belowground spinach (Spinacia oleracea L., cv. Racoon) microbiomes impacted by salinity and drought. Science of The Total Environment, v. 717, p. 137207, maio 2020. Disponível em: <https://linkinghub.elsevier.com/retrieve/pii/S0048969720307178>.

ILGI KAPDAN, K.; KARGI, F. Bio-hydrogen production from waste materials. Enzyme and Microbial Technology, v. 38, n. 5, p. 569-582, 2006.

INFANTES, D. et al. Influence of $\mathrm{pH}$, temperature and volatile fatty acids on hydrogen production by acidogenic fermentation. International Journal of Hydrogen Energy, v. 6, p. 1559515601, 2011.

IWAI, S. et al. Piphillin: Improved Prediction of Metagenomic Content by Direct Inference from Human Microbiomes. PLOS ONE, v. 11, n. 11, p. e0166104, 7 nov. 2016. Disponível em: <https://dx.plos.org/10.1371/journal.pone.0166104>.

JACKOWIAK, D. et al. Optimisation of a microwave pretreatment of wheat straw for methane production. Bioresource Technology, v. 102, n. 12, p. 6750-6756, 2011. Disponível em: <http://dx.doi.org/10.1016/j.biortech.2011.03.107>.

JACQUET, N. et al. Influence of steam explosion on the thermal stability of cellulose fibres. Polymer Degradation and Stability, v. 96, n. 9, p. 1582-1588, 2011.

JANUSZ, G. et al. Lignin degradation: Microorganisms, enzymes involved, genomes analysis and evolution. FEMS Microbiology Reviews, v. 41, n. 6, p. 941-962, 2017.

JIA, X. et al. Metaproteomic analysis of the relationship between microbial community phylogeny, function and metabolic activity during biohydrogen-methane coproduction under shortterm hydrothermal pretreatment from food waste. Bioresource Technology, v. 245, n. September, p. 1030-1039, 2017. Disponível em: <https://doi.org/10.1016/j.biortech.2017.08.180>.

JIANG, Y. et al. Inhibition of volatile fatty acids on methane production kinetics during dry codigestion of food waste and pig manure. Waste Management, v. 79, p. 302-311, 2018. Disponível em: <https://doi.org/10.1016/j.wasman.2018.07.049>.

JIANG, Y. et al. Exploring the roles of and interactions among microbes in dry co-digestion of food waste and pig manure using high-throughput 16S rRNA gene amplicon sequencing 06 Biological Sciences 0605 Microbiology 09 Engineering 0907 Environmental Engineering. Biotechnology for Biofuels, v. 12, n. 1, p. 1-16, 2019. Disponível em: <https://doi.org/10.1186/s13068-018-1344-0>.

JOHN, U. V.; CARVALHO, J. Enterococcus: Review of its physiology, pathogenesis, diseases and the challenges it poses for clinical microbiology. Frontiers in Biology, v. 6, n. 5, p. 357366, 2011. 
JUNG, K. et al. Optimization of combined ( acid D thermal ) pretreatment for fermentative hydrogen production from Laminaria japonica using response surface methodology ( RSM

). International Journal of Hydrogen Energy, v. 36, n. 16, p. 9626-9631, 2011. Disponível em: <http://dx.doi.org/10.1016/j.ijhydene.2011.05.050>.

JUSTINO DE ARAÚJO, A. C. et al. GC-MS-FID characterization and antibacterial activity of the Mikania cordifolia essential oil and limonene against MDR strains. Food and Chemical Toxicology, v. 136, p. 111023, 2020. Disponível em: <https://doi.org/10.1016/j.fct.2019.111023>.

KANDASAMY, S.; ARADHYA, S. M. Polyphenolic profile and antioxidant properties of rhizome of commercial banana cultivars grown in India. Food Bioscience, v. 8, p. 22-32, dez. 2014. Disponível em: <https://linkinghub.elsevier.com/retrieve/pii/S2212429214000443>.

KANEHISA, M. KEGG: Kyoto Encyclopedia of Genes and Genomes. Nucleic Acids Research, v. $28, \quad$ n. $1, \quad$ p. 27-30, 2000. Disponível em: <http://doi.wiley.com/10.1002/0471250953.bi1107s32>.

KANEHISA, M.; SATO, Y.; MORISHIMA, K. BlastKOALA and GhostKOALA: KEGG Tools for Functional Characterization of Genome and Metagenome Sequences. Journal of Molecular Biology, v. 428, n. 4, p. 726-731, 2016. Disponível em: <http://dx.doi.org/10.1016/j.jmb.2015.11.006>.

KANOKSILAPATHAM, W. et al. Isolation, characterization, and survival strategies of Thermotoga sp . strain PD524, a hyperthermophile from a hot spring in Northern Thailand. Extremophiles, 2015.

KEGGI, C.; DORAN-PETERSON, J. Paenibacillus amylolyticus 27C64 has a diverse set of carbohydrate-active enzymes and complete pectin deconstruction system. Journal of Industrial Microbiology and Biotechnology, v. 46, n. 1, p. 1-11, 2019. Disponível em: <https://doi.org/10.1007/s10295-018-2098-1>.

KESKIN, T. et al. Determining the effect of trace elements on biohydrogen production from fruit and vegetable wastes. International Journal of Hydrogen Energy, v. 43, n. 23, p. 1066610677, 2018. Disponível em: <https://doi.org/10.1016/j.ijhydene.2018.01.028>.

KEYHANI, N. O. et al. The Chitin Disaccharide, N, N' -Diacetylchitobiose, Is Catabolized by Escherichia coli and Is Transported/Phosphorylated by the Phosphoenolpyruvate:Glycose Phosphotransferase System. Journal of Biological Chemistry, v. 275, n. 42, p. 3308433090, 2000. Disponível em: 〈http://www.jbc.org/lookup/doi/10.1074/jbc.M001043200>.

KEYHANI, N. O.; BACIA, K.; ROSEMAN, S. The transport/phosphorylation of N,N'diacetylchitobiose in Escherichia coli: Characterization of phospho-IIB(Chb) and of a potential transition state analogue in the phosphotransfer reaction between the proteins 
IIA(Chb) and IIB(Chb). Journal of Biological Chemistry, v. 275, n. 42, p. 33102-33109, 2000.

KHANNA, N. et al. Improvement of biohydrogen production by Enterobacter cloacae IIT-BT 08 under regulated pH. Journal of Biotechnology, v. 152, n. 1-2, p. 9-15, 2011. Disponível em: <http://dx.doi.org/10.1016/j.jbiotec.2010.12.014>.

KIM, I.; HAN, J. I. Optimization of alkaline pretreatment conditions for enhancing glucose yield of rice straw by response surface methodology. Biomass and Bioenergy, v. 46, p. 210217, 2012. Disponível em: 〈http://dx.doi.org/10.1016/j.biombioe.2012.08.024>.

KIRAN, E. U. et al. Bioconversion of food waste to energy: A review. Fuel, v. 134, p. 389-399, 2014.

KIVAISI, A. K.; ELIAPENDA, S. Pretreatment of bagasse and coconut fibres for enhanced anaerobic degradation by rumen microorganisms. Renewable Energy, v. 5, n. 5-8, p. 791795, 1994.

KOBAYASHI, H. et al. Hydrolysis of woody biomass by a biomass-derived reusable heterogeneous catalyst. Chemical Science, v. 7, n. 1, p. 692-696, 2016. Disponível em: <http://xlink.rsc.org/?DOI=C5SC03377B>.

KOO, T.; YULISA, A.; HWANG, S. Microbial community structure in full scale anaerobic monoand co-digesters treating food waste and animal waste. Bioresource Technology, v. 282, p. 439-446, jun. 2019. Disponível em: <https://linkinghub.elsevier.com/retrieve/pii/S0960852419303992>.

KOPPAR, A.; PULLAMMANAPPALLIL, P. Anaerobic digestion of peel waste and wastewater for on site energy generation in a citrus processing facility. Energy, v. 60, p. 62-68, 2013. Disponível em: 〈http://dx.doi.org/10.1016/j.energy.2013.08.007>.

KOPYLOVA, E.; NOÉ, L.; TOUZET, H. SortMeRNA: Fast and accurate filtering of ribosomal RNAs in metatranscriptomic data. Bioinformatics, v. 28, n. 24, p. 3211-3217, 2012.

KORAYEM, A. S. et al. Optimization of biosurfactant production by Streptomyces isolated from Egyptian arid soil using Plackett-Burman design. Annals of Agricultural Sciences, v. 60, n. 2, p. 209-217, 2015. Disponível em: <http://dx.doi.org/10.1016/j.aoas.2015.09.001>.

KOTAY, S. M.; DAS, D. Microbial hydrogen production with Bacillus coagulans IIT-BT S1 isolated from anaerobic sewage sludge. Bioresource Technology, v. 98, n. 6, p. 11831190, 2007.

KOZIANOWSKI, G. et al. Purification and characterization of thermostable pectate-lyases from a newly isolated thermophilic bacterium, Thermoanaerobacter italicus sp. nov. Extremophiles, v. 1, n. 4, p. 171-182, 1997.

KRIEG, N. R. et al. The Bacteroidetes, Spirochaetes, Tenericutes (Mollicutes), Acidobacteria, Fibrobacteres, Fusobacteria, Dictyoglomi, Gemmatimonadetes, Lentisphaerae, 
Verrucomicrobia, Chlamydiae, and Planctomycetes. In: WHITMAN, W. B. (Ed.). Bergey's Manual of Systematic Bacteriology. 2 ed. ed. New York: Springer, 2010. 4p. 976.

LACAVA, P. T. et al. Caracterização da comunidade bacteriana endofítica de citros por isolamento , PCR específico e DGGE. Pesquisa Agropecuária Brasileira, v. 41, n. 4, p. 637-642, 2006.

LANG, K. et al. New Mode of Energy Metabolism in the Seventh Order of Methanogens as Revealed by Comparative Genome Analysis of "Candidatus Methanoplasma termitum". Applied and Environmental Microbiology, v. 81, n. 4, p. 1338-1352, 15 fev. 2015. Disponível em: <http://aem.asm.org/lookup/doi/10.1128/AEM.03389-14>.

LANGMEAD, B. Aligning Short Sequencing Reads with Bowtie. In: Current Protocols in Bioinformatics. Hoboken, NJ, USA: John Wiley \& Sons, Inc., 2010. p. 1-24.

LAZARO, C. Z. et al. Sugarcane vinasse as substrate for fermentative hydrogen production: The effects of temperature and substrate concentration. International Journal of Hydrogen Energy, v. 39, n. 12, p. 6407-6418, 2014.

LEE, D. Y. et al. Effect of iron concentration on continuous $\mathrm{H}_{2}$ production using membrane bioreactor. International Journal of Hydrogen Energy, v. 34, n. 3, p. 1244-1252, 2009. Disponível em: <http://dx.doi.org/10.1016/j.ijhydene.2008.11.093>.

LEITÃO, R. C. et al. Biodegradabilidade Anaeróbia dos Resíduos Provenientes das Cadeias Produtivas dos Biocombustíveis: Bagaço de Cana-de-açúcar. Embrapa Agroindústria Tropical, n. December 2013, p. 1-41, 2013.

LEVIN, D. B. et al. Hydrogen production by Clostridium thermocellum 27405 from cellulosic biomass substrates. International Journal of Hydrogen Energy, v. 31, n. 11, p. 14961503, 2006.

LI, C. et al. Recent advancement in lignin biorefinery: With special focus on enzymatic degradation and valorization. Bioresource Technology, v. 291, p. 121898, nov. 2019. Disponível em: <https://linkinghub.elsevier.com/retrieve/pii/S0960852419311289>.

LI, C.; FANG, H. H. P. Fermentative hydrogen production from wastewater and solid wastes by mixed cultures. Critical Reviews in Environmental Science and Technology, v. 37, n. 1, p. 1-39, 2007.

LI, Q.; SILES, J. A.; THOMPSON, I. P. Succinic acid production from orange peel and wheat straw by batch fermentations of Fibrobacter succinogenes S85. Applied Microbiology and Biotechnology, v. 88, n. 3, p. 671-678, 2010.

LIN, C. et al. Anaerobic hydrogen production from unhydrolyzed mushroom farm waste by indigenous microbiota. Journal of Bioscience and Bioengineering, v. 124, n. 4, p. 425- 
429, 2017. Disponível em: 〈http://dx.doi.org/10.1016/j.jbiosc.2017.05.001〉.

LIN, C. Y.; SHEI, S. H. Heavy metal effects on fermentative hydrogen production using natural mixed microflora. International Journal of Hydrogen Energy, v. 33, n. 2, p. 587-593, 2008.

LIN, P. Y. et al. Biological hydrogen production of the genus Clostridium: Metabolic study and mathematical model simulation. International Journal of Hydrogen Energy, v. 32, n. 12, p. 1728-1735, 2007.

LIU, D. et al. Hydrogen and methane production from household solid waste in the two-stage fermentation process. Water Research, v. 40, n. 11, p. 2230-2236, 2006.

LIU, Y.; WANG, Y. Directional enhancement of fermentative coproduction of hydrogen and acetic acid from glucose via control of headspace pressure. International Journal of Hydrogen Energy, v. 42, n. 7, p. 4095-4101, 2017. Disponível em: <http://dx.doi.org/10.1016/j.ijhydene.2016.09.083>.

LÓPEZ, J. Á. S.; LI, Q.; THOMPSON, I. P. Biorefinery of waste orange peel. Critical Reviews in Biotechnology, v. 30, n. 1, p. 63-69, 2010.

LOPRESTO. A non-conventional method to extract D- limonene from waste lemon peels and comparison with ... Separation and Purification Technology, v. 137, n. February, p. 1320, 2015. Disponível em: 〈http://dx.doi.org/10.1016/j.seppur.2014.09.015>.

LOTITO, A. M. et al. Biomethanization of citrus waste: Effect of waste characteristics and of storage on treatability and evaluation of limonene degradation. Journal of Environmental Management, v. 215, p. 366-376, 2018. Disponível em: <https://doi.org/10.1016/j.jenvman.2018.03.057>.

LOVE, M. I.; HUBER, W.; ANDERS, S. Moderated estimation of fold change and dispersion for RNA-seq data with DESeq2. Genome Biology, v. 15, n. 12, p. 1-21, 2014.

LU, Y. et al. Characteristics of hydrogen and methane production from cornstalks by an augmented two- or three-stage anaerobic fermentation process Yuan. Bioresource Technology, v. 100, p. 2009. 2889-2895, Disponível em: <http://dx.doi.org/10.1016/j.biortech.2009.01.023>.

ŁUKAJTIS, R. et al. Hydrogen production from biomass using dark fermentation. Renewable and Sustainable Energy Reviews, v. 91, n. April 2017, p. 665-694, 2018.

LUO, W.; BROUWER, C. Pathview: An R/Bioconductor package for pathway-based data integration and visualization. Bioinformatics, v. 29, n. 14, p. 1830-1831, 2013.

MACEDO, T. Z. et al. The influence of upflow velocity and hydraulic retention time changes on taxonomic and functional characterization in Fluidized Bed Reactor treating commercial laundry wastewater in co-digestion with domestic sewage. Biodegradation, v. 31, n. 1-2, p. 73-89, 2020. 
MADIGAN, M. T. Microbiologia de Brock. 14. ed. Porto Alegre: Artmed, 2016.

MAINTINGUER, S. I. et al. Hydrogen bioproduction with Enterobacter sp. isolated from brewery wastewater. International Journal of Hydrogen Energy, v. 42, n. 1, p. 152-160, 2017.

MÄKINEN, A. E.; NISSILÄ, M. E.; PUHAKKA, J. A. Dark fermentative hydrogen production from xylose by a hot spring enrichment culture. International Journal of Hydrogen Energy, v. 37, n. 17, p. 12234-12240, 2012.

MAMMA, D.; CHRISTAKOPOULOS, P. Biotransformation of Citrus By-Products into Value Added Products. Waste and Biomass Valorization, v. 5, n. 4, p. 529-549, 2014.

MARINE, S. S.; CLEMONS, J. Determination of Limonene Oxidation Products Using SPME and GC - MS. Journal of Chromatographic Science, v. 41, p. 31-35, 2003.

MARQUES, S. S. I. et al. Growth of Chlorella vulgaris on sugarcane vinasse: The effect of anaerobic digestion pretreatment. Applied Biochemistry and Biotechnology, v. 171, n. 8, p. 1933-1943, 2013.

MARTíN, M. A. et al. Biomethanization of orange peel waste. Bioresource Technology, v. 101, n. 23, p. 8993-8999, 2010.

MARTÍNEZ, S.; LÓPEZ, M.; BERNARDO, A. Thermal inactivation of Enterococcus faecium: effect of growth temperature and physiological state of microbial cells. Letters in Applied Microbiology, v. 37, p. 475-481, 2003.

MASIH-DAS, J.; TAO, W. Anaerobic co-digestion of foodwaste with liquid dairy manure or manure digestate: Co-substrate limitation and inhibition. Journal of Environmental Management, v. 223, n. July, p. 917-924, 2018. Disponível em: <https://doi.org/10.1016/j.jenvman.2018.07.016>.

MATHUR, G. et al. Enhanced production of laccase from Coriolus sp. using Plackett-Burman design. Journal of Pharmacy Research, v. 6, n. 1, p. 151-154, 2013. Disponível em: <http://dx.doi.org/10.1016/j.jopr.2012.11.031>.

MAUS, I. et al. Complete genome sequence of the strain Defluviitoga tunisiensis L3, isolated from a thermophilic, production-scale biogas plant. Journal of Biotechnology, v. 203, p. 17-18, 2015. Disponível em: 〈http://dx.doi.org/10.1016/j.jbiotec.2015.03.006>.

MAUS, I. et al. Genomic characterization of Defluviitoga tunisiensis L3, a key hydrolytic bacterium in a thermophilic biogas plant and its abundance as determined by metagenome fragment recruitment. Journal of Biotechnology, v. 232, p. 50-60, ago. 2016. Disponível em: <https://linkinghub.elsevier.com/retrieve/pii/S0168165616302565>.

MAZARELI, R. C. d. S. et al. Metagenomic analysis of autochthonous microbial biomass from banana waste: Screening design of factors that affect hydrogen production. Biomass and Bioenergy, v. 138, n. April, 2020. 
MAZARELI, R. C. da S. et al. Bacillus sp. isolated from banana waste and analysis of metabolic pathways in acidogenic systems in hydrogen production. Journal of Environmental Management, v. 247, n. December 2018, p. 178-186, 2019. Disponível em: <https://doi.org/10.1016/j.jenvman.2019.06.040>.

MAZARELI, R. C. da S. Otimização da produção de hidrogênio a partir de resíduos de banana: avaliação da diversidade de bactérias autóctones e distribuição funcional. 2019. Universidade de São Paulo, 2019.

MCMURDIE, P. J.; HOLMES, S. Phyloseq: An R Package for Reproducible Interactive Analysis and Graphics of Microbiome Census Data. PLoS ONE, v. 8, n. 4, 2013.

MELO-NASCIMENTO, A. O. do. S. et al. Functional characterization of ligninolytic Klebsiella spp. strains associated with soil and freshwater. Archives of Microbiology, v. 200, n. 8, p. 1267-1278, 2018. Disponível em: 〈http://dx.doi.org/10.1007/s00203-018-1532-0〉.

MENZEL, P.; NG, K. L.; KROGH, A. Fast and sensitive taxonomic classification for metagenomics with Kaiju. Nature Communications, v. 7, p. 1-9, 2016. Disponível em: <http://dx.doi.org/10.1038/ncomms11257>.

MERLIN CHRISTY, P.; GOPINATH, L. R.; DIVYA, D. A review on anaerobic decomposition and enhancement of biogas production through enzymes and microorganisms. Renewable and Sustainable Energy Reviews, v. 34, p. 167-173, 2014. Disponível em: <http://dx.doi.org/10.1016/j.rser.2014.03.010>.

MICELI, J. F.; TORRES, C. I.; KRAJMALNIK-BROWN, R. Shifting the balance of fermentation products between hydrogen and volatile fatty acids: microbial community structure and function. FEMS microbiology ecology, v. 92, 2016, p. 1-8, 2016. Disponível em: <http://femsec.oxfordjournals.org/content/91/4/fiv011.abstract>.

MICHALSKA, K.; LEDAKOWICZ, S. Alkaline hydrogen peroxide pretreatment of energy crops for biogas production. Chemical Papers, v. 68, p. 913-922, 2014.

MILLATI, R. et al. Anaerobic digestion of citrus waste using two-stage membrane bioreactor. IOP Conference Series: Materials Science and Engineering, v. 316, p. 012063, 2018. Disponível em: <http://stacks.iop.org/1757$899 X / 316 / \mathrm{i}=1 / \mathrm{a}=012063$ ?key=crossref.77f0ad27c09db5bf062443846b8dacdc $>$.

MILLER, J. A. et al. Determination of d -limonene in adipose tissue by gas chromatography - mass spectrometry. Journal of Chromatographic B, v. 870, p. 68-73, 2008.

MONLAU, F. et al. Do furanic and phenolic compounds of lignocellulosic and algae biomass hydrolyzate inhibit anaerobic mixed cultures? A comprehensive review. Biotechnology Advances, v. 32 , n. 5, p. 934-951, 2014. Disponível em: <http://dx.doi.org/10.1016/j.biotechadv.2014.04.007>.

MOSEY, F. E. Mathematical modelling of the anaerobic digestion process: Regulatory mechanisms 
for the formation of short-chain volatile acids from glucose. Water Science and Technology, v. 15, n. 8-9, p. 209-232, 1983.

MOSIER, N. et al. Features of promising technologies for pretreatment of lignocellulosic biomass.

Bioresource Technology, v. 96, n. 6, p. 673-686, 2005.

MU, Y.; WANG, G.; YU, H. Response surface methodological analysis on biohydrogen production by enriched anaerobic cultures. Enzyme and Microbial Technology, v. 38, p. 905-913, 2006.

MUBARAK, Z.; SORAYA, C. The acid tolerance response and $\mathrm{pH}$ adaptation of Enterococcus faecalis in extract of lime Citrus aurantiifolia from Aceh Indonesia. F1000Research, v. 7, p. 287, 2018.

MUYZER, G.; WAAL, E. C. D. E.; UITIERLINDEN, A. G. Profiling of Complex Microbial Populations by Denaturing Gradient Gel Electrophoresis Analysis of Polymerase Chain Reaction-Amplified Genes Coding for 16S rRNA. Applied and Environmental Microbiology, v. 59, n. 3, p. 695-700, 1993.

NAKAYAMA, T. et al. Escherichia coli pyruvate: Flavodoxin oxidoreductase, YdbK - Regulation of expression and biological roles in protection against oxidative stress. Genes and Genetic Systems, v. 88, n. 3, p. 175-188, 2013.

NANDA, S. et al. Gasification of fruit wastes and agro-food residues in supercritical water. Energy Conversion and Management, v. 110, p. 296-306, 2016.

NATION, J. L. A new method using hexamethyldisilazane for preparation of soft insect tissues for scanning electron microscopy. Stain technology, v. 58., n. 6, p. 347-351, 1983.

NAVEENA, B. J. et al. Selection of medium components by Plackett-Burman design for production of $\mathrm{L}(+)$ lactic acid by Lactobacillus amylophilus GV6 in SSF using wheat bran. Bioresource Technology, v. 96, n. 4, p. 485-490, 2005.

NEGRO, V. et al. Life cycle assessment of orange peel waste management. Resources, Conservation and Recycling, v. 127, n. August, p. 148-158, 2017. Disponível em: <https://doi.org/10.1016/j.resconrec.2017.08.014>.

NELSON, D. L.; COX, M. M. Princípios de Bioquímica de Lehninger. 5. ed. Porto Alegre: Artmed, 2011.

NÉMETI, B.; GREGUS, Z. Mechanism of Thiol-Supported Arsenate Reduction Mediated by Phosphorolytic-Arsenolytic Enzymes. Toxicological Sciences, v. 110, n. 2, p. 270-281, ago. 2009. Disponível em: <https://academic.oup.com/toxsci/articlelookup/doi/10.1093/toxsci/kfp112>.

NESHAT, S. A. et al. Anaerobic co-digestion of animal manures and lignocellulosic residues as a potent approach for sustainable biogas production. Renewable and Sustainable Energy 
Reviews, v. 79, p. 308-322, 2017. Disponível em: <http://dx.doi.org/10.1016/j.rser.2017.05.137>.

NIKOLAIDIS, P.; POULLIKKAS, A. A comparative overview of hydrogen production processes. Renewable and Sustainable Energy Reviews, v. 67, p. 597-611, 2017. Disponível em: <http://dx.doi.org/10.1016/j.rser.2016.09.044>.

NURK, S. et al. metaSPAdes: a new versatile metagenomic assembler. Genome research, v. 27, n. $5, \quad$ p. $824-834, \quad 2017 . \quad$ Disponível em: <http://www.ncbi.nlm.nih.gov/pubmed/28298430\%0Ahttp://www.pubmedcentral.nih.gov /articlerender.fcgi?artid=PMC5411777> .

ORANDI, S. M. et al. Original article Influence of $\mathrm{pH}$ and temperature on the growth of Enterococcus faecium and Enterococcus faecalis. Le Lait, v. 85, n. 3, p. 181-192, 2005.

OZBAYRAM, E. et al. Comparison of Rumen and Manure Microbiomes and Implications for the Inoculation of Anaerobic Digesters. Microorganisms, v. 6, n. 1, p. 15, 2018.

PAL, P.; NAYAK, J. Acetic Acid Production and Purification: Critical Review Towards Process Intensification. Separation and Purification Reviews, v. 46, n. 1, p. 44-61, 2017.

PARENTE, E. et al. Growth and bacteriocin production by Enterococcus faecium DPC1146 in batch and continuous culture. Journal of Industrial Microbiology \& Biotechnology, v. 18, p. 62-67, 1997.

PARK, Y. J.; KIM, I. C.; CHANG, H. C. Microbial conversion of (+)-Limonene by an Enterobacter agglomerans isolate. Journal of Microbiology and Biotechnology, v. 13, n. 4, p. 636639, 2003.

PARSHINA, S. N. et al. Trichococcus shcherbakoviae sp. nov., isolated from a laboratory-scale anaerobic EGSB bioreactor operated at low temperature. International Journal of Systematic and Evolutionary Microbiology, v. 69, n. 2, p. 529-534, 2019.

PLACKETT, R. L.; BURMAN J.P. The design of optimum multifactorial experiments. Biometrika, v. 33, p. 305-325, 1946.

POURBAFRANI, M. et al. Production of biofuels, limonene and pectin from citrus wastes. Bioresource Technology, v. 101, n. 11, p. 4246-4250, 2010. Disponível em: <http://dx.doi.org/10.1016/j.biortech.2010.01.077>.

QUÉMÉNEUR, M. et al. Inhibition of fermentative hydrogen production by lignocellulose-derived compounds in mixed cultures. International Journal of Hydrogen Energy, v. 37, n. 4, p. 3150-3159, 2012.

RABELO, C. A. B. S. et al. Optimization of hydrogen and organic acids productions with autochthonous and allochthonous bacteria from sugarcane bagasse in batch reactors. Journal of Environmental Management, v. 223, n. July, p. 952-963, 2018a. Disponível em: 〈https://doi.org/10.1016/j.jenvman.2018.07.015>. 
RABELO, C. A. B. S. et al. Bioconversion of cellulose into hydrogen, biogas and organic acids using microbial consortium from pulp and paper mill wastewater treatment plant. Quimica Nova, v. 41, n. 2, p. 169-175, 2018b.

RABELO, C. A. B. S. et al. Isolation of Paraclostridium CR4 from sugarcane bagasse and its evaluation in the bioconversion of lignocellulosic feedstock into hydrogen by monitoring cellulase gene expression. Science of the Total Environment, v. 715, p. 136868, 2020. Disponível em: <https://doi.org/10.1016/j.scitotenv.2020.136868>.

RAJENDHRAN, J.; GUNASEKARAN, P. Strategies for accessing soil metagenome for desired applications. Biotechnology Advances, v. 26, n. 6, p. 576-590, 2008.

RASPOR, P.; GORANOVIČ, D. Biotechnological applications of acetic acid bacteria. Critical Reviews in Biotechnology, v. 28, n. 2, p. 101-124, 2008.

RATTANAPAN, C. et al. Biogas production by co-digestion of canteen food waste and domestic wastewater under organic loading rate and temperature optimization. Environments MDPI, v. 6, n. 2, 2019.

RATTI, R. P. et al. Thermophilic hydrogen production from sugarcane bagasse pretreated by steam explosion and alkaline delignification. International Journal of Hydrogen Energy, v. 40, n. 19 , p. 6296-6306, 2015.

RAVACHOL, J. et al. Combining free and aggregated cellulolytic systems in the cellulosomeproducing bacterium Ruminiclostridium cellulolyticum. Biotechnology for Biofuels, v. 8, n. 1, p. 1-14, 2015.

REN, N. Q. et al. Effects of different pretreatment methods on fermentation types and dominant bacteria for hydrogen production. International Journal of Hydrogen Energy, v. 33, n. 16, p. 4318-4324, 2008.

RHO, M.; TANG, H.; YE, Y. FragGeneScan: Predicting genes in short and error-prone reads. Nucleic Acids Research, v. 38, n. 20, p. 1-12, 2010.

RIBANI, M. et al. Validação em métodos cromatográficos e eletroforéticos. Química Nova, v. 27, n. 5, p. 771-780, 2004.

RODRIGUES, C. V. et al. Bioconversion of crude glycerol from waste cooking oils into hydrogen by sub-tropical mixed and pure cultures. International Journal of Hydrogen Energy, v. 4, p. 144-154, 2019.

RODRIGUES, M. I.; IEMMA, A. F. Planejamento de Experimentos e Otimização de Processos. 3. ed. Campinas, São Paulo: Casa do Espírito Amigo Fraternidade Fé e Amor, 2014.

ROSA, P. R. F.; SILVA, E. L. Review of Continuous Fermentative Hydrogen- Producing Bioreactors from Complex Wastewater. Frontiers in Bioenergy and Biofuels Hydrogen, p. 257-284, 2017. 
RUGGERI, B.; TOMMASI, T.; SANFILIPPO, S. $\mathbf{B i o H}_{2} \& \mathbf{B i o C H}_{4}$ Through anaerobic digestion. New York: Springer London, 2015.

RUIZ, B.; FLOTATS, X. Citrus essential oils and their influence on the anaerobic digestion process: An overview. Waste Management, v. 34, n. 11, p. 2063-2079, 2014. Disponível em: <http://dx.doi.org/10.1016/j.wasman.2014.06.026>.

RUIZ, B.; FLOTATS, X. Effect of limonene on batch anaerobic digestion of citrus peel waste. Biochemical Engineering Journal, v. 109, p. 9-18, 2016.

SADHU, S.; MAITI, T. K. Cellulase Production by Bacteria : A Review. British Microbiology Research Journal, v. 3, n. 3, p. 235-258, 2013. Disponível em: $\langle$ www.sciencedomain.org $>$.

SAIDI, R. et al. Biohydrogen production from hyperthermophilic anaerobic digestion of fruit and vegetable wastes in seawater: Simplification of the culture medium of Thermotoga maritima. Waste Management, v. 71, p. 474-484, 2018. Disponível em: <https://doi.org/10.1016/j.wasman.2017.09.042>.

SANGER, F.; COULSON, A. R. A rapid method for determining sequences in DNA by primed synthesis with DNA polymerase. Journal of Molecular Biology, v. 94, n. 3, p. 441-448, 1975.

SARATALE, G. D. et al. Outlook of biohydrogen production from lignocellulosic feedstock using dark fermentation - A review. Journal of Scientific and Industrial Research, v. 67, n. 11, p. 962-979, 2008.

SATO, K. et al. Effect of yeast extract and vitamin B12 on ethanol production from cellulose by Clostridium thermocellum I-1-B. Applied and Environmental Microbiology, v. 58, n. 2, p. 734-736, 1992.

SAWATDEENARUNAT, C. et al. Anaerobic digestion of lignocellulosic biomass: Challenges and opportunities. Bioresource Technology, v. 178, p. 178-186, 2015. Disponível em: <http://dx.doi.org/10.1016/j.biortech.2014.09.103>.

SCHLEIFER, K. H. Classification of Bacteria and Archaea: Past, present and future. Systematic and Applied Microbiology, v. 32, n. 8, p. 533-542, 2009. Disponível em: <http://dx.doi.org/10.1016/j.syapm.2009.09.002>.

SCHMIDT, J. E.; AHRING, B. K. Granular Sludge Formation in Upflow Anaerobic Sludge Blanket (UASB) Reactors. Biotechnology and Bioengineering, v. 49, n. 4, p. 229-246, 1996.

SCHNEIDER, V. E. et al. Diagnóstico dos Resíduos Orgânicos do Setor Agrossilvopastoril e Agroindústrias Associadas. Instituto de Pesquisa Econômica Aplicada - IPEA, p. 134, 2012.

SCHROYEN, M. et al. Effect of enzymatic pretreatment of various lignocellulosic substrates on 
production of phenolic compounds and biomethane potential. Bioresource Technology, v. 192, p. 696-702, 2015. Disponível em: <http://dx.doi.org/10.1016/j.biortech.2015.06.051>.

SHARMA, S.; MADAN, M.; VASUDEVAN, P. Biomethane Production from Fermented Substrates. Journal of Fermentation and Bioengineering, v. 68, n. 4, p. 296-297, 1989.

SHEN, F. et al. Effect of organic loading rate on anaerobic co-digestion of rice straw and pig manure with or without biological pretreatment. Bioresource Technology, v. 250, p. 155162, 2018. Disponível em: 〈https://doi.org/10.1016/j.biortech.2017.11.037〉.

SHEN, L. et al. Interspecies electron transfer in syntrophic methanogenic consortia: From cultures to bioreactors. Renewable and Sustainable Energy Reviews, v. 54, p. 1358-1367, 2016. Disponível em: <http://dx.doi.org/10.1016/j.rser.2015.10.102>.

SILVERSTEIN, R.; WEBSTER, F. Spectrometric Identification of Organic Compounds. 4. ed. SINHA, P.; PANDEY, A. Biohydrogen production from various feedstocks by Bacillus firmus NMBL-03. International Journal of Hydrogen Energy, v. 39, n. 14, p. 7518-7525, 2014. Disponível em: <http://dx.doi.org/10.1016/j.ijhydene.2013.08.134>.

SITTHIKITPANYA, S.; REUNGSANG, A.; PRASERTSAN, P. Two-stage thermophilic biohydrogen and methane production from lime-pretreated oil palm trunk by simultaneous saccharification and fermentation. International Journal of Hydrogen Energy, v. 43, n. 9, p. 4284-4293, 2018. Disponível em: <https://doi.org/10.1016/j.ijhydene.2018.01.063>.

SIVAGURUNATHAN, P. et al. Fermentative hydrogen production using lignocellulose biomass: An overview of pre-treatment method, inhibitor effects and detoxification experiences. Renewable and Sustainable Energy Reviews, v. 77, n. March 2016, p. 28-42, 2017.

SOARES, L. A. et al. Design and optimization of hydrogen production from sugarcane bagasse hydrothermally pretreated using response surface methodology. Water Science \& Technology, v. 76, n. (1-2), p. 95-105, 2017.

SOARES, L. A. et al. Metagenomic analysis and optimization of hydrogen production from sugarcane bagasse. Biomass and Bioenergy, v. 117, p. 78-85, 2018. Disponível em: $<$ https://doi.org/10.1016/j.biombioe.2018.07.018>.

SOARES, L. A. Bioconversão anaeróbia do bagaço de cana-de-açúcar em produtos de valor biotecnológico em condição termofílica e mesofílica. 2018. Universidade de São Paulo, 2018.

SOARES, L. A. et al. Bioconversion of Sugarcane Bagasse into Value-Added Products by Bioaugmentation of Endogenous Cellulolytic and Fermentative Communities. Waste and Biomass Valorization, v. 7, n. 10, p. 1899-1912, 2019a. Disponível em: <http://link.springer.com/10.1007/s12649-018-0201-5>. 
SOARES, L. A. et al. Experimental design and syntrophic microbial pathways for biofuel production from sugarcane bagasse under thermophilic condition. Renewable Energy, v. 140, p. 852-861, 2019b. Disponível em: 〈https://doi.org/10.1016/j.renene.2019.03.103〉.

SOARES, L. A. et al. Screening and Bioprospecting of Anaerobic Consortia for Biofuel Production Enhancement from Sugarcane Bagasse. Applied Biochemistry and Biotechnology, v. 190, n. 1, p. 232-251, 2020.

SOLLI, L. et al. A metagenomic study of the microbial communities in four parallel biogas reactors. Biotechnology for biofuels, v. 7, n. 1, p. 146, 2014. Disponível em: <http://www.biotechnologyforbiofuels.com/content/7/1/146>.

SONG, H. S. et al. Quantitative determination and characteristic flavour of Citrus junos (yuzu) peel oil. Flavour and Fragrance Journal, v. 15, p. 245-250, 2000.

SONG, S. K.; LEE, Y. Y. Acid hydrolysis of wood cellulose under low water condition. Biomass, v. 6, n. 1-2, p. 93-100, 1984.

SPADOTTO, C. A.; RIBEIRO, W. Gestão de resíduos na agricultura e agroindústria. [s.l.] Fundação de Estudos e Pesquisas Agrícolas e Florestais - FEFAP, 2007.

SRILATHA, H. R. et al. Fungal pretreatment of orange processing waste by solid-state fermentation for improved production of methane. Process Biochemistry, v. 30, n. 4, p. 327-331, 1995.

SRIVASTAVA, S. et al. Intensification of hydrogen production by B. licheniformis using kitchen waste as substrate. International Journal of Hydrogen Energy, v. 42, n. 34, p. 21659 21666, 2017. Disponível em: <http://dx.doi.org/10.1016/j.ijhydene.2017.06.140>.

STEIN, U. H. et al. Maximizing the production of butyric acid from food waste as a precursor for ABE-fermentation. Science of the Total Environment, v. 598, n. 2017, p. 993-1000, 2017. Disponível em: <http://dx.doi.org/10.1016/j.scitotenv.2017.04.139>.

SU, H.; TAN, F.; XU, Y. Enhancement of biogas and methanization of citrus waste via biodegradation pretreatment and subsequent optimized fermentation. Fuel, v. 181, p. 843851, 2016. Disponível em: <http://dx.doi.org/10.1016/j.fuel.2016.05.055>.

SUNDBERG, M. Pretreatment of Biomass Investigation of suitable pretreatment of Icelandic biomass for biofuel production. n. October, p. 30, 2010.

TAI, J. et al. Biological hydrogen production from phenol-containing wastewater using Clostridium butyricum. International Journal of Hydrogen Energy, v. 35, n. 24, p. 13345-13349, dez. $2010 . \quad$ Disponível em: <https://linkinghub.elsevier.com/retrieve/pii/S0360319909019442>.

TANDISHABO, K. et al. Distribution and role of Coprothermobacter spp. in anaerobic digesters. Journal of Bioscience and Bioengineering, v. 114, n. 5, p. 518-520, nov. 2012. Disponível em: <https://linkinghub.elsevier.com/retrieve/pii/S1389172312002423>. 
TAYLOR, K. A. C. . A simple colorimetric assay for muramic acid and lactic acid. Applied Biochemistry and Biotechnology, v. 56, p. 49-58, 1996.

USEPA. Method 6010D - Inductively Coupled Plasma-Optical Emission Spectrometry. In: Method. p. 1-35.

VALDEZ-VAZQUEZ, I. et al. Hydrogen and butanol production from native wheat straw by synthetic microbial consortia integrated by species of Enterococcus and Clostridium. Fuel, v. 159, p. 214-222, 2015. Disponível em: <http://dx.doi.org/10.1016/j.fuel.2015.06.052〉.

VALDEZ-VAZQUEZ, I. et al. Enhanced hydrogen production from lignocellulosic substrates via bioaugmentation with Clostridium strains. Industrial Crops \& Products, v. 137, p. 105111, 2019. Disponível em: 〈https://doi.org/10.1016/j.indcrop.2019.05.023>.

VALENTÍN-REYES, J. et al. Mathematical modelling for biohydrogen production by Clostridium beijerinckii. International Journal of Hydrogen Energy, v. 43, n. 37, p. 17602-17610, 2018.

VAUTZ, W.; SIELEMANN, S.; BAUMBACH, J. I. Determination of terpenes in humid ambient air using ultraviolet ion mobility spectrometry. Analytica Chimica Acta, v. 513, p. 393399, 2004.

VILLA, C. et al. High-performance liquid chromatographic method for the simultaneous determination of 24 fragrance allergens to study scented products. Journal of Pharmaceutical and Biomedical Analysis, v. 44, p. 755-762, 2007.

VILLA MONTOYA, A. C. et al. Hydrogen, alcohols and volatile fatty acids from the co-digestion of coffee waste (coffee pulp, husk, and processing wastewater) by applying autochthonous microorganisms. International Journal of Hydrogen Energy, v. 44, n. 39, p. 2143421450, 2019.

VILLA MONTOYA, A. C. et al. Optimization of key factors affecting hydrogen production from coffee waste using factorial design and metagenomic analysis of the microbial community. International Journal of Hydrogen Energy, v. 45, n. 7, p. 4205-4222, 2020.

VILLA, T. G.; VEIGA-CRESPO, P. Enzybiotics: Antibiotic enzymes as drugs and therapeutics.

VOGEL, T. M. Bioaugmentation as a soil bioremediation approach. Current Opinion in Biotechnology, v. 7, n. 3, p. 311-316, 1996.

VOS, P. De et al. The Firmicutes. In: WHITMAN, W. B. (Ed.). Bergey's Manual of Systematic Bacteriology. 2. ed. Athens: Springer, 2009. p. 1450.

WAGNER, T. et al. Didehydroaspartate Modification in Methyl-Coenzyme M Reductase Catalyzing Methane Formation. Angewandte Chemie International Edition, v. 55, n. 36, p. 10630-10633, 26 ago. 2016. Disponível em: <https://onlinelibrary.wiley.com/doi/abs/10.1002/anie.201603882>. 
WALTER, A. et al. Biomethane potential of industrial paper wastes and investigation of the methanogenic communities involved. Biotechnology for Biofuels, v. 9, p. 1-21, 2016.

WANG, A. et al. Bio-hydrogen production from cellulose by sequential co-culture of cellulosic hydrogen bacteria of Enterococcus gallinarum G1 and Ethanoigenens harbinense B49. Biotechnology Letters, v. 31, n. 9, p. 1321-1326, 2009.

WANG, W. et al. Characterization of a microbial consortium capable of degrading lignocellulose. Bioresource Technology, v. 102, n. 19, p. 9321-9324, 2011. Disponível em: <http://dx.doi.org/10.1016/j.biortech.2011.07.065>.

WANG, Y. et al. The Influence of Hydrogen Concentration in Sparging Gas on Hydrogen Production and Consumption via Anaerobic Fermentation. Transactions of the ASABE, v. 60, n. 3, p. 607-612, 2017.

WEI, L.; GENG, P. A review on natural gas/diesel dual fuel combustion, emissions and performance. Fuel Processing Technology, v. 142, p. 264-278, 2016. Disponível em: <http://dx.doi.org/10.1016/j.fuproc.2015.09.018>.

WICKHAM, H. ggplot2: Elegant Graphics for Data Analysis. 1. ed. New York, NY: Springer New York, 2009.

WILKINS, M. R. et al. Hydrolysis of grapefruit peel waste with cellulase and pectinase enzymes. Bioresource Technology, v. 98, n. 8, p. 1596-1601, 2007.

WILLEMS, A.; GILLIS, M. Comamonas. In: Bergey's Manual of Systematics of Archaea and Bacteria. Chichester, UK: John Wiley \& Sons, Ltd, 2015. p. 1-17.

WILSON, D. B. Microbial diversity of cellulose hydrolysis. Current Opinion in Microbiology, v. 14, n. 3, p. 259-263, 2011.

WOO, G.; CHARLES, P.; KWONSU, S. A comprehensive study on volatile fatty acids production from rice straw coupled with microbial community analysis. Bioprocess and Biosystems Engineering, v. 38, n. 6, p. 1157-1166, 2015.

WREDE, C. et al. Localization of Methyl-Coenzyme M Reductase as Metabolic Marker for Diverse Methanogenic Archaea. Archaea, v. 2013, p. 1-7, 2013. Disponível em: <http://www.hindawi.com/journals/archaea/2013/920241/>.

WU, J. et al. Enhanced butanol-hydrogen coproduction by Clostridium beijerinckii with biochar as cell's carrier. Bioresource Technology, v. 294, p. 122141, dez. 2019. Disponível em: <https://linkinghub.elsevier.com/retrieve/pii/S0960852419313719>.

WU, S. Y.; CHU, C. Y.; SHEN, Y. C. Effect of calcium ions on biohydrogen production performance in a fluidized bed bioreactor with activated carbon-immobilized cells. International Journal of Hydrogen Energy, v. 37, n. 20, p. 15496-15502, 2012. Disponível em: <http://dx.doi.org/10.1016/j.ijhydene.2012.04.119>.

WU, X. et al. Optimization of Fermentation Process Parameters for Ginsenoside Re Bioconversion 
by Plackett-Burman and Box-Benhnken Design. MATEC Web of Conferences, v. 238, p. 04001, 2018.

XIA, Y. et al. Thermophilic microbial cellulose decomposition and methanogenesis pathways recharacterized by metatranscriptomic and metagenomic analysis. Scientific Reports, v. 4 , p. 1-9, 2014.

XING, B. S. et al. Stable and high-rate anaerobic co-digestion of food waste and cow manure: Optimisation of start-up conditions. Bioresource Technology, v. 307, p. 123195, 2020. Disponível em: <https://doi.org/10.1016/j.biortech.2020.123195>.

YAMADA, Y.; HOSHINO, K.; ISHIKAWA, T. The Phylogeny of Acetic Acid Bacteria Based on the Partial Sequences of 16S Ribosomal RNA: The Elevation of the Subgenus Gluconoacetobacter to the Generic Level. Bioscience, Biotechnology, and Biochemistry, v. 61, n. $8, \quad$ p. 1244-1251, 1997. Disponível em: <http://www.tandfonline.com/doi/full/10.1271/bbb.61.1244>.

YANG, G.; YIN, Y.; WANG, J. Microbial community diversity during fermentative hydrogen production inoculating various pretreated cultures. International Journal of Hydrogen Energy, v. 44, n. 26, p. 13147-13156, 2019. Disponível em: <https://doi.org/10.1016/j.ijhydene.2019.03.216>.

YIN, Y. et al. DbCAN: A web resource for automated carbohydrate-active enzyme annotation. Nucleic Acids Research, v. 40, n. W1, p. 445-451, 2012.

YIN, Y.; WANG, J. Characterization and hydrogen production performance of a novel strain Enterococcus faecium INET2 isolated from gamma irradiated sludge. International Journal of Hydrogen Energy, v. 41, n. 48, p. 22793-22801, 2016. Disponível em: <https://linkinghub.elsevier.com/retrieve/pii/S0360319916330828>.

YUN, J. S.; WEE, Y. J.; RYU, H. W. Production of optically pure L(+)-lactic acid from various carbohydrates by batch fermentation of Enterococcus faecalis RKY1. Enzyme and Microbial Technology, v. 33, n. 4, p. 416-423, 2003.

YUSOF, T. R. T. et al. Evaluation of hydrogen and methane production from co-digestion of chicken manure and food waste. Polish Journal of Environmental Studies, v. 28, n. 4, p. 3003-3014, 2019.

YUTIN, N.; GALPERIN, M. Y. A genomic update on clostridial phylogeny: Gram-negative spore formers and other misplaced clostridia. Environmental Microbiology, 2013. Disponível em: <http://doi.wiley.com/10.1111/1462-2920.12173>.

ZÁMOCKÝ, M. et al. Ancestral gene fusion in cellobiose dehydrogenases reflects a specific evolution of GMC oxidoreductases in fungi. Gene, v. 338, n. 1, p. 1-14, 2004.

ZHANG, J. et al. Three-stage anaerobic co-digestion of food waste and horse manure. Scientific 
Reports, v. 7, n. 1, p. 1-10, 2017. Disponível em: <http://dx.doi.org/10.1038/s41598-01701408-w>.

ZHANG, Q. et al. Enhancement of methane production from cassava residues by biological pretreatment using a constructed microbial consortium. Bioresource Technology, v. 102, n. $19, \quad$ p. $8899-8906, \quad 2011 . \quad$ Disponível em: <http://dx.doi.org/10.1016/j.biortech.2011.06.061>.

ZHAO, L. et al. Fungal pretreatment of cornstalk with Phanerochaete chrysosporium for enhancing enzymatic saccharification and hydrogen production. Bioresource Technology, v. 114, p. 365-369, 2012. Disponível em: 〈http://dx.doi.org/10.1016/j.biortech.2012.03.076>.

ZHENG, X. J.; YU, H. Q. Biological Hydrogen Production by Enriched Anaerobic Cultures in the Presence of Copper and Zinc. Journal of Environmental Science and Health - Part A Toxic/Hazardous Substances and Environmental Engineering, v. 39, n. 1, p. 89-101, 2004.

ZHENG, Y. et al. Pretreatment of lignocellulosic biomass for enhanced biogas production. Progress in Energy and Combustion Science, v. 42, n. 1, p. 35-53, 2014. Disponível em: <http://dx.doi.org/10.1016/j.pecs.2014.01.001>.

ZHONG, W. et al. Bioresource Technology Effect of biological pretreatments in enhancing corn straw biogas production. Bioresource Technology, v. 102, n. 24, p. 11177-11182, 2011. Disponível em: 〈http://dx.doi.org/10.1016/j.biortech.2011.09.077〉.

ZINDER, S. H.; KOCH, M. Non-aceticlastic methanogenesis from acetate: acetate oxidation by a thermophilic syntrophic coculture. Archives of Microbiology, v. 138, n. 3, p. 263-272, 1984.

ZVERLOV, V. V.; SCHWARZ, W. H. Bacterial cellulose hydrolysis in anaerobic environmental subsystems - Clostridium thermocellum and Clostridium stercorarium, thermophilic plantfiber degraders. Annals of the New York Academy of Sciences, v. 1125, p. 298-307, 2008.

ZWIETERING, M. H. et al. Modeling of bacterial growth with shifts in temperature. Applied and Environmental Microbiology, v. 60, n. 1, p. 204-213, 1994. 


\section{GLOSSÁRIO}

16S (16S RNAr) - Subunidade dos ribossomos procarióticos com baixas taxas de evolução, o que a torna adequada para reconstrução filogenética e analise metataxonômica, especialmente no Domínio Bacteria.

Acetogênese - Produção microbiológica de acetato a partir de diferentes substratos.

Alinhamento - Método de bioinformática aplicado à comparação entre duas ou mais sequências, com a finalidade de estabelecer relações de similaridade.

Alóctone - Em caso de inoculo alóctone, trata-se de um inoculo de origem externa ao processo, adicionado como fonte de microrganismos.

Autóctone - Em caso de inoculo autóctone (ou inoculo indígeno), trata-se de inoculo obtido a partir do próprio substrato utilizado no processo, e.g., a partir de autofermentação.

Batelada - Processo descontínuo.

Consórcio - Fonte mista de microrganismos.

Contig - sequências de DNA montadas por meio de sobreposição de reads.

Dendrograma - Representação gráfica de resultados de cluster hierárquico, que pode ser calculado a partir de diferentes distâncias estatisticas para representar a afinidade entre grupos. Um dendrogramas filogenético tem como diferencial a apresentação de relações filogenéticas entre diferentes taxons.

Endósporo - estrutura microbiológica comum em bactérias anaeróbias, especialmente do filo Firmicutes, formada geralmente em condições de estresse.

E-value - "Valor Esperado" ou "Aleatoriedade Implícita", parâmetro de análise da plataforma NCBI referente ao numero esperado de sequencias ao acaso em determinado banco de dados. Quanto menor o E-value, maior a significância da correspondência.

FASTA - Formato de arquivos baseado em texto (.txt) comum em bioinformática, no qual são representados sequencias de nucleotídeos por meio de códigos de uma letra (e.g., A, T, C, G).

FASTAQ - Arquivo similar ao format FASTA, contendo informações sobre seus índices de qualidade, codificados por meio de caracteres ASCII (código binário).

Grupo externo - Grupo filogenéticamente mais distânte, geralmente utilizado como referência para o cálculo das relações evolutivas entre os grupos internos. 
HiSeq - Técnica de sequenciamento via Plataforma Illumina, no qual há menor tamanho de leitura, menor velocidade e maior quantidade de dados em relação à técnica MiSeq, da mesma plataforma.

Identificador KO - "Número KO" ou "Número K", referente ao Banco de Dados KO de Funções Moleculares, provenientes de genes e proteínas caracterizados experimentalmente em organismos específicos que são usados para encontrar ortólogos em outros organismos.

Illumina - Plataforma de análise genômica, baseada na técnica de sequenciamento por síntese.

Inóculo - Fonte de microrganismos.

Metabarcoding - Sequências curtas de DNA ou RNA que podem ser utilizadas para caracterização microbiana, e.g., $16 \mathrm{~S}$.

Metabólitos - Produto do metabolismo de determinada molécula ou substâncias por meio de reações bioquímicas.

Metataxonômica - Técnica de caracterização da comunidade microbiana a partir de sequenciamento massivo de DNA, a partir da qual torna-se possível inferir as relações filogenéticas entre as sequencias obtidas.

Nucleotídeo - Únidade minima do material genético, ácido ribonucleico (RNA) ou desoxirribonucleico (DNA), constituida por uma base nitrogenada, um açúcar (ribose) e um grupo fosfato.

Número de acesso - Identificador das sequencias depositadas em determinado banco de dados.

Número E.C - Do inglês "Enzyme Commission Numbers". Sistema de classificação numérica aplicado às enzimas, composto por até cinco números em ordem hierárquica, referentes às reações químicas catalizadas por tais enzimas.

Ortólogo - Genes com funções similares e mesma origem evolutiva, mas que divergiram por especiação.

OTU - Abreviação de Unidade Taxonômica Operacional. Menor unidade taxonômica utilizada em um estudo.

Paired-end - Sequenciamento tanto da região alvo quanto de sua fita correspondente, resultando em duas sequencias complementares.

PCR - Reação em Cadeia da Polimerase, técnica utilizada para amplificação exponencial de uma região genômica específica. 
Pipeline - cadeia de processos.

Ponto central - Replicas verdadeiras utilizadas para estimativa do erro puro.

Pontos axiais - Níveis extremos de um determinado experimento na metodologia de superfície de resposta.

Primer ou Iniciador - Fragmentos curtos de RNA (oligonucleotídeo) utilizados para amplificação de uma região-alvo por meio da técnica de PCR, por meio de uma hidroxila livre em sua extremidade 3'.

Read - Pequena sequência de pares de base, obtida como resultado do sequenciamento do genôma a partir da técnica shotgun.

Shotgun - Técnica de sequenciamento aleatório de alto desempenho aplicado à posterior reconstrução do genoma completo de determinado organismo ou amostra.

Single-end - Sequenciamento apenas da região alvo do material genético, não incluindo sua sequência complementar e resultando em apenas uma sequencia. Contrário de paired-end.

Solvetogênese - Via metabólica de produção microbiológica/fermentativa de etanol.

Táxon - Unidade taxonômica, referente a qualquer nível de classificação filogenético, e.g., gênero.

Químera - Em bioinformática, uma sequência quimérica é o produto da concatenação acidental de duas ou mais sequências de DNA, resultando em uma sequência artificial (químera) que pode levar a erros durante o tratamento e análise das sequências.

Lignocelulose - Biomassa composta principalmente por fibras de celulóse e hemicelulose revestidas por lignina.

Bioaumentação - Aumento da população microbiana em uma determinada amostra por meio da adição de cepas específicas ou fortalecimento da comunidade autóctone da propria amostra.

Hidrotermólise - Pré-tratamento físico baseado na pressurização de água em elevadas temperaturas $\left(\sim 200{ }^{\circ} \mathrm{C}\right)$, seguida de rápida despressurização e resfriamento, a fim de romper as fibras de lignocelulose de diferentes biomassas.

Hidrólise - Reação em que há quebra da ligação química em uma molécula ocasionada por uma molécula de água. 


\section{LISTA DE PUBLICAÇÕES}

A presente pesquisa é baseada principalmente nos resultados apresentados nos seguintes artigos:

I. CAMARGO, F. P., SAKAMOTO, I. K., DUARTE, I. C. S., VARESCHE, M. B. A. Influence of alkaline peroxide assisted and hydrothermal pretreatment on biodegradability and bio-hydrogen formation from citrus peel waste. International Journal of Hydrogen Energy, v. 44, n. 41, p. 22888-22903, 2019. (DOI: 10.1016/j.ijhydene.2019.07.011).

II. CAMARgo, F. P., SAKAmoto, I. K., Silva, E. L., DUARTE, I. C. S., VARESCHE, M. B. A. Bioaugmentation with Enterococcus casseliflavus- a hydrogen-producing strain isolated from Citrus Peel Waste. Waste and Biomass Valorization, 2020. (DOI: 10.1007/s12649-020-01049-7).

III. CAMARGO, F. P., SARTI, A., SABATINI, C., ADORNO; M. A. T., DUARTE, I. C. S., VARESCHE, M. B. A. Development and validation of new method for limonene quantification by gas chromatography mass spectrometry (GC-MS) and its application in anaerobic reactor. Química Nova, 2020. (DOI: 10.21577/01004042.20170557).

IV. CAMARGO, F. P., SAKAMOTO, I. K., BIZE, A., DUARTE, I. C. S., SILVA, E. L., VARESCHE, M. B. A. Screening design of nutritional and physicochemical parameters on bio-hydrogen and volatile fatty acids production from Citrus Peel Waste in batch reactors. International Journal of Hydrogen Energy, 2020. (DOI: 10.1016/j.ijhydene.2020.06.084).

V. CAMARGO, F. P., SAKAMOTO, I. K., DELFORNO, T. P., MARIADASSOU, M., LOUX, V., MidouX, C., DUARTE, I. C. S., SILVA, E. L., BIZE, A., VARESCHE, M. B. A. Microbial characterization of a consortium involved in an optimized batch reactor applied to biohydrogen production from Citrus Peel Waste as lignocellulosic substrate. Journal of Environmental Management, 2021.

VI. CAmargo, F. P., SAKAmoto, I. K., DUARTE, I. C. S., Silva, E. L., VARESCHE, M. B. A. Metataxonomic characterization of bacterial and archaeal community involved in hydrogen and methane production from Citrus Peel Waste in batch reactors. Biomass \& Bioenergy, 2021. 


\section{ÍNDICE REMISSIVO}

16S, 31, 70, 76, 77, 78, 79, 83, 106, 107, 108, 109, 138, 139, 158, 159, 160, 207, 232, 233, 234, 238, 259, 276, 283, 291 , 295, 296

acetogênese, 73, 189, 191, 234, 240, 241, $243,245,254$

alóctone, 83, 84, 90, 91, 92, 94, 95, 98, 99, 106, 107, 121, 122, 125, 136, 137, $138,140,142,145,146,147,160,163$, $165,175,180,184,190,225,263,295$ amido, 39, 40, 96, 189, 193, 195, 197, 209, 210, 211, 212, 213, 227, 239, 240 autofermentação, XV, 88, 89, 90, 95, $107,117,118,119,120,121,205,206$, 220, 221, 222, 223, 254, 257, 295

bioaumentação, 30, 219, 220, 221, 222, 223, 224

C. beijerinckii, 64, 189, 190, 202

CAZymes, 111, 199, 201

celobiose, 39, 40, 68, 69, 96, 189, 191, 196, 197, 200, 201, 202, 209, 210, 211, 240, 241

celulolítico, 40, 69, 70, 89, 90, 94, 95, 96, 120, 121, 149, 166, 205, 206

celulose, 29, 34, 39, 40, 43, 47, 49, 54, $57,58,59,60,61,62,67,68,69,70$, 72, 89, 96, 115, 117, 121, 127, 128, 133, 142, 163, 178, 181, 189, 191, 199, 200, 201, 202, 206, 209, 210, 211, 212, $214,218,221,224,259,263$

comunidade microbiana, 30, 31, 35, 71, 74, 77, 78, 84, 96, 106, 107, 136, 138, 158, 163, 184, 187, 193, 231, 259, 296 consórcio autóctone, 91, 120, 166, 206, 257, 258, 263

deslignificação alcalina, 34, 50, 58, 62 , $74,86,87,91,106,126,127,128,129$, $130,131,132,133,134,135,136,137$, $138,145,257,263$

E. casseliflavus, 208, 209, 212, 220, 224, 225, 265

endósporos, 119, 120, 126, 205, 231, 232 EtOH, 72, 101, 118, 124, 125, 134, 141, 142, 146, 155, 177, 182, 189, 191, 206,
209, 211, 212, 224, 225, 230, 231, 254, $255,259,263$

fenóis, $79,84,97,101,123,124,134$, $135,136,144,152,154,158,177,179$, $215,220,228,252$

frutose, 96, 117, 191, 196, 209, 210, 211, $213,214,239$

glicólise, 193, 194, 197, 198, 239, 240, 241, 242, 243, 245

hemicelulose, $34,39,40,43,47,48,50$, $57,58,60,61,62,68,115,116,117$, 128, 133, 142, 178, 199, 202, 215, 297

hidrotermólise, 34, 49, 50, 51, 55, 59, $60,61,62,83,84,86,91,106,126$, $127,128,129,130,131,132,133,135$, $136,137,138,139,140,141,142,143$, $144,145,146,155,257,263$

HLac, 72, 118, 125, 134, 141, 142, 146, $155,189,190,206,209,212,213,224$, 225

HPr, 101, 124, 155, 177, 182, 209, 210, $212,213,214,222,223,224,225,230$, 231, 237, 254, 259, 263

Illumina, 31, 32, 77, 78, 80, 106, 107, 109, 110, 139, 160, 184, 234, 259, 296 índices ecológicos, 77, 139, 185, 232

KEGG, 81, 109, 111, 192, 193, 238, 240, 277

lactose, 96, 209, 211, 214

lignina, 29, 39, 41, 43, 47, 48, 54, 56, 57, $58,60,61,62,79,116,117,128,130$, $133,135,142,154,178,179,181,199$, 200, 201, 215, 242, 297

limoneno, 30, 35, 43, 44, 45, 46, 60, 71, 72, 84, 104, 105, 106, 130, 131, 142, $143,144,151,162,177,223,228,235$, 236, 242, 246, 247, 248, 249, 250, 251, 252, 253, 254, 255, 258, 261, 263

metabarcoding, 31, 32, 77, 80, 81, 82, 83, $107,138,158,232,238,259,261$

metabolismo de carboidratos, 193, 194, 195, 196, 238, 241

metagenômica, 31, 32, 77, 79, 81, 84, $107,109,184,192,259$ 
metanogênese, $64,68,72,73,74,135$, 227, 228, 229, 230, 231, 236, 237, 242, $243,244,245,258,263,275$

metataxonômica, 237, 295

peptona, $83,92,147,151,152,156,165$, 166,175

Plackett \& Burman, 31, 32, 34, 83, 91, 92, 93, 95, 98, 107, 146, 147, 148, 151, $153,156,159,166,175,261,263$

pré-tratamento, $41,47,48,50,51,57$, $58,59,60,61,62,80,82,83,86,91$, $122,127,128,133,145,189,227,257$ sacarose, 63, 96, 117, 178, 191, 193, 195, $197,209,210,211,239,240$ screening design, 34, 93, 94, 109, 146, $148,153,154,155,159,166,258$

shotgun, IX, XV, 31, 32, 77, 78, 80, 81, $82,84,107,110,184,259,261,263$, 297

superfície de resposta, $34,83,94,170$, 175, 178, 182, 261, 297

vias metabólicas, $35,65,78,81,82,84$, 111, 157, 184, 192, 193, 194, 195, 203, 237, 238, 240, 244, 255, 259, 263

xilose, 41, 48, 50, 54, 56, 79, 96, 130, 157, 189, 191, 202, 209, 210, 211, 212, 213, 214, 215, 216, 217, 218, 219, 220, 221,261 